\title{
Complexiteit en contingentie : een kritische inleiding tot de sociologie van Niklas Luhmann
}

Citation for published version (APA):

Blom, C. (1997). Complexiteit en contingentie : een kritische inleiding tot de sociologie van Niklas Luhmann. [Doctoral Thesis, Maastricht University]. Kok Agora. https://doi.org/10.26481/dis.19970530cb

Document status and date:

Published: 01/01/1997

DOI:

10.26481/dis.19970530cb

Document Version:

Publisher's PDF, also known as Version of record

\section{Please check the document version of this publication:}

- A submitted manuscript is the version of the article upon submission and before peer-review. There can be important differences between the submitted version and the official published version of record.

People interested in the research are advised to contact the author for the final version of the publication, or visit the DOI to the publisher's website.

- The final author version and the galley proof are versions of the publication after peer review.

- The final published version features the final layout of the paper including the volume, issue and page numbers.

Link to publication

\footnotetext{
General rights rights.

- You may freely distribute the URL identifying the publication in the public portal. please follow below link for the End User Agreement:

www.umlib.nl/taverne-license

Take down policy

If you believe that this document breaches copyright please contact us at:

repository@maastrichtuniversity.nl

providing details and we will investigate your claim.
}

Copyright and moral rights for the publications made accessible in the public portal are retained by the authors and/or other copyright owners and it is a condition of accessing publications that users recognise and abide by the legal requirements associated with these

- Users may download and print one copy of any publication from the public portal for the purpose of private study or research.

- You may not further distribute the material or use it for any profit-making activity or commercial gain

If the publication is distributed under the terms of Article $25 \mathrm{fa}$ of the Dutch Copyright Act, indicated by the "Taverne" license above, 


\section{COMPLEXITEIT EN CONTINGENTIE}

EEN KRITISCHE INLEIDING TOT DE SOCIOLOGIE VAN

NIKIAS LUHMANN 
In herinnering aan Gijs Blom van wie ik in ieder geval zeker weet dat ik hem nooit goed heb begrepen 


\section{COMPLEXITEIT EN CONTINGENTIE}

Een kritische inleiding tot de sociologie van Niklas Luhmann

\section{Proefschrift}

ter verkrijging van de graad van doctor aan de Universiteit Maastricht

op gezag van de Rector Magnificus, Prof.mr. M.J. Cohen ingevolge het besluit van het College van Decanen in het openbaar te verdedigen op vrijdag 30 mei 1997 om 14.00 uur

door

Christiaan Blom

geboren op 21 september 1954

te Lagos 


\section{PROMOTOR}

Prof.dr.ir. G.H. de Vries

\section{BEOORDELINGSCOMMISSIE}

Prof dr. A. Labrie (voorzitter)

Prof dr. H.P. Kunneman (Universiteit voor Humanistiek, Utrecht)

Dr. W.P.M Martens (Katholieke Universiteit Nijmegen)

Prof dr H. Philipsen

Prof mr. N.H.M Roos

(C) 1997 Kok Agora, Kampen

Alle rechten voorbehouden. Niets uit deze uitgave mag worden verveelvou-
digd, opgeslagen in gemaakt, in enige vorm, of op enige door fotokopieën, opnamen, of enig wijze, hetzij elektronisch, mechanisch, schriftelijke toestemming van de uitgever.

Omslagontwerp: Rob Lucas Omslagillustratie: Fuga in rood grote terts door Tannelie (foto: Paul
Mellaart) 
INHOUD

Woord vooraf vii

Inleiding 1

Hoofdstuk I. Systeem en complexiteit 9

$\$ 1$ Inleiding 9

$\$ 2$ De vroegere fase: het "functioneel structuralisme" 11

$\$ 3$ De kritiek op het 'structureel functionalsme' 13

$\$ 4$ De problematiek van de 'open systeem'-theorie 16

$\$ 5$ Zelfreferentiele systemen $\quad 20$

\$6 De autonomie van zelfreferentiële systemen: geslotenheid en

$\$ 7$ Voorbij structuur $\quad 28$

$\$ 8 \quad$ Observeren en onderscheiden $\quad 31$

$\$ 9$ Het probleem "complexiteit" $\quad 40$

$\$ 10$ Ter afsiuiting $\quad 49$

Methodologisch Excurs: Het 'equivalentie-functionalisme' 56

Hoofdstuk II. Zin en Contingentie : $\quad 68$

$\$ 1$ Inleiding 68

$\$ 2$ Vertrekpunt Husserl $\quad \cdots \quad 70$

$\$ 3$ Negatie, actualiteit en potentialiteit $\quad 73$

$\$ 4$ Identiteit 76

$\$ 5$ Verwachting, Structuur en Informatie 81

$\$ 6$ Objectiviteit en drie-dimensionaliteit $\quad 85$

$\$ 7$ Zin en complexiteit $\quad 91$

\$8 Beleven en handelen 95

89 Zin, Systeem en Wereld $\quad 97$

$\$ 10$ Ter afsluiting $\quad 99$

Hoofdstuk III. Een onwaarschijnlijke waarschujnlijkheid: Communicatie 107

$\begin{array}{lll}\$ 1 \text { Inleiding } & 107\end{array}$

$\$ 2$ Dubbele Contingentie 109

$\$ 3$ Het begrip "communicatie"; een statische analyse 122

$\$ 4$ De autopoiesis van communicatie: een dynamische analyse 131

$\$ 5$ Reflexiviteit en reflexie 135

\$6 Ter afsluiting: de complexe relatie tussen bewustzijn en communicatie 
Hoofdstuk IV. Handeling, Structuur, Conflict 162

$\$ 1$ Inleiding 162

\$2 De handeling 162

\$2.1 Instrumentaliteit en doelrationaliteit 166

$\$ 2.2$ Voorbij Weber, voorbij Schutz. 171

$\S 3$ Structuur 173

$\$ 4$ Conflict 182

$\$ 5$ Ter afsluiting 193

Hoofdstuk V. Evolutie en Differentiatie: Grondslagen van de Maatschappijtheorie

$\$ 1$ Inleiding

$\$ 2$ Interactie, organisatie, maatschappij 203

\$2.1 Interactie 203

$\$ 2.2$ Organisatie 206

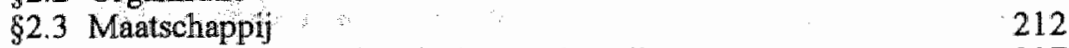

$\$ 2.4$ Problemen met het begrip 'maatschappij' 217

§3 Maatschappij en Evolutie 220

\$4 Grondstructuren van de moderne, functioneel gedifferentieerde maatschappij $\quad 237$

$\$ 4.1$ Codering $\quad 240$

$\$ 4.2$ Programmering 245

$\$ 4.3$ Codering en programmering 246

$\$ 5$ Ter afsluiting: de sociologische beschrijving van zelfbeschrijving 249

Họofdstuk VI. De Moderne Maatschappij: Diagnose en Kritiek 254

$\$ 1$ Inleiding 254

$\$ 2$ De diagnose van de moderne maatschappij: redundantieverlies, positivering en heterarchie $\quad 257$

$\$ 2.1$ Redundantieverlies $\quad 257$

$\$ 2.2$ Positivering 259

$\$ 2.3$ Heterarchie 263

$\$ 2.4$ Redundantieverlies, positivering, heterarchie $\quad 265$

$\$ 3$ Kritiek (I): de sturingsdiscussie 268

$\$ 4$ Kritiek (II): de demarcatie van functiesystemen $\quad 282$

$\$ 5$ Ter afsluiting $\quad 293$

Hoofdstuk VII. Tot besluit $\quad 295$

$\$ 1$ Inleiding $\quad 295$

$\$ 2$ Verlichting van Verlichting 298

$\$ 3$ Complexiteit en normativiteit: de 'politiek' van Luhmanns project 304

$\$ 4$ Seculiere Romantiek $\quad 310$

$\$ 5$ Ter afsluiting: "Vernunftige Sociologie"

$\begin{array}{ll}\text { Literatunurlijst } & 325\end{array}$

Summary $\quad: \quad 334$ 
niet aflatende hulpvaardigheid.

Gebruikelijk of niet -, ik zou bij deze tevens de leden van mijn beoordelingscommissie willen bedanken voor de inspanningen die zij zich hebben getroost. Het toch al wat pedante argument dat zij dit aan hun academische status verplicht zouden zijn, weegt bij lange na niet op tegen de aanslag die ik met dit proefschrift op hun spaarzame tijd heb gepleegd. Twee van hen will ik in het bijzonder noemen, zij het om redenen die niet direkt samenhangen met hun beoordelaarschap. Prof. Nico Roos wil ik nogmaals bedanken voor de enthousiaste en stimulerende discussies die wij over vrijwel alle facetten van Niklas Luhmann's werk (en dus over de hele wereld) gevoerd hebben. Mogen zijn intellectuele nieuwschierigheid en flair voor altijd ongetemd blijwen. Met mijn erkentelijkheid jegens Prof. Harry Kunneman keer ik terug naar een verder verleden, naar mijn studie aan de Centrale Interfaculteit te Amsterdam. Zijn zowel uiterst gedreven als gedegen manier van doceren en schrijven vormen voor mij nog steeds - en, vreemd genoeg, als bijna vanzelfsprekend - een bron van inspiratie. Het is bovendien niet waarschijnlijk, dat ik zonder die indringende confrontatie met het werk van Jurgen Habermas, waar Prof. Kunneman borg voor stond, ooit een boek van Niklas Luhmann zou hebben ingekeken, laat staan dat ik over de intellectuele vaardigheden en middelen zou hebben beschikt om er iets van te begrijpen.

Helaas staat de ruimte het niet toe, om hier, op een enigszins persoonlijke wijze, ook al die mensen te bedanken die de afgelopen jaren de universitaire leefwereld voor mij draaglijk hebben weten te houden. Ik denk dan aan Wemer Callebaut, Paul de Bruine, Maarten Doorman, Arnold Labrie, Joke Spruyt, aan alle hulp die ik van Sabine Kuipers, Maaike Luxembourg en Elleen Schelling heb gehad - en weet dat ik nu velen ten onrechte niet noem.

En tenslotte dank ik jou Frederiek - ik dank je voor de onverzettelijkheid van jouw vriendschap en voor het feit dat je mij, in het moeras van alle ernst, de vaste bodem van de dwaasheid hebt terug gegeven. 


\section{INLEIDING}

'A general sociollogioal theory could be viowed as an antonomous work of art. But first of all this theory is necessary in order to consirtict a theory of society. ${ }^{1}$

Dit is een boek over de sociologie van Niklas Luhmann, met bijzondere aandacht voor de grondslagen daarvan en zijn maatschappijtheorie -

'Over Luhmann?l - maar dat is toch kritiekloze apologie van het bestaande", de 'Hochform eines technokratischen Bewußsseins'; dat is toch de als theorie verklede ideologische legitimatie van een 'auf Entpolitisierung einer mobilisierten Bevölkerung angewiesenen politischen System '?'

Dat is inderdaad wat Jürgen Habermas zijn lezers altijd heeft voorgehouden. ${ }^{2}$ En dat schijnt voor het merendeel van de sociologen en filosofen hier ten lande ook de uitkomst te zijn geweest van de discussie die hij begin jaren zeventig met Luhmann voerde. De behoefte om bij die conclusie langer stil te staan, daarover publiekelijk met elkaar in debat te treden, moet bovendien gering zijn geweest, getuige althans het aantal aan Luhmanns sociologie gewijde artikelen dat gedu-rende de jaren zeventig en tachtig in Nederlandse tijdschriften is verschenen. ${ }^{3}$ De officiele, reguliere curricula van de universitaire sociologie- en filosofieopleidingen uit deze periode bevestigen dat beeld. Voor studenten werd het een overbodige lixe geacht om zich in de achtergrond en aard van Luhmanns werk te verdiepen.

Eigenlijk is het onbegrijpelijk, dat Luhmann er ooit mee heeft ingestemd, zijn discussie met Habermas te laten uitbrengen onder de titel Theorie der Ge-

1. N. Luhmann, "The Theory of Social Systems and its Epistemology: Reply to Danilo Zolo's Critical Comments', in: Philosophy of the Sacial Sciences 16 (1986)ip. 133.

2. Verg. o.a. J. Habermas, "Theorie der Gesellschaft oder Sozialtechnologie? Eine Auseinandersetzung mit Niklas Luhmann', in: J.Habermas/N.Luhmann, Theorie der Gesellschaft oder Sozial.

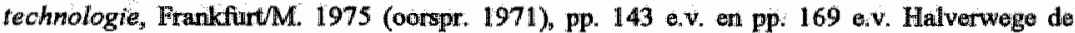
jaren tachitig weet Habermas nog steeds zeker dat de systeemtheorie op grond van haar immanente functionalisme naadloos is opgenomen "in die Funktionszusammenhänge der systemischen Selbstbehauptung - ohne die Absicht und die Kraft diese Zusammenhänge irgend za transzendieren'. (J.Habermas, Der philosophische Diskurs der Moderne, Frankfurt/M. 1985, p.430)

3. Zelf heb ik, mijn eigen bescheiden bijdrage niet mee gerekend, slechtss 4 in Nederlandse tilidschriften gepubliceerde artikelen over of rondom Luhmann kunnen vinden, die uit de periode $1970 \mathrm{t} / \mathrm{m} 1990$ stammen. Die zijn van de hand van A. Foefnagel (Men: em Maatschappij, 46 $(1971,4))$, P. Schnabel (Sociologische Gids 20 (1973, 3)), H. Jolles (Somiologische Gidis 22 $(1975,3$ en 5$)$ ). In diezelfde periode verschenem, voor zover ik heb kunnen nagain, 9 artikelen in het Japans. 
sellschaft oder Sozialtechnologie - Was leistet die Systemforschung? De rollen waren al bij voorbaat verdeeld. "Maatschappijtheorie" - dat was het geestelijk eigendom van de Frankfurterschule; daar had de roemrijke 'Positivismusstreit' geen twijfel over laten bestaan. "Maatschappijtheoretici" - dat waren natuurlijk Adorno en Habermas. Voor Luhmann resteerde Sozialtechnologie. Aan het einde van zijn 'Entgegnung auf Jürgen Habermas' kon Luhmann over de titel van hun gezamenlijke boek dan nog wel opmerken: 'Ich lese das 'oder' nicht im Sinne des "aut", sondern im Sinne des "vel' und nehme das Fragezeichen als Symbol fur Unsicherheit". Weinigen zullen echter de, vaak zeer gecondenseerde, niet bepaald lichtverteerbare discussie tussen beide heren tot het einde toe hebben uitgezeten - en voor het overige valt te betwijfelen, of een dergelijke humor tot enige distantie had kunnen verleiden binnen een intellectueel klimaat dat eerder rijp was voor de receptie van Louis Althusser en Elmer Altvater. Onbegrijpelijk vooral ook, deze buiging voor een zo opzichtig retorisch juk, aangezien Luhmann er in zijn geschriften blijk van had gegeven wel degelijk te hebben nagedacht over de 'politiek' van het wetenschapsbedrijf, over het mechanisme van 'wetenschappelijke reputatie', de financiěle en organisatorische mogelijkheden die dat biedt, over citatiestrategieën, over met wie je wel en niet in een adem genoemd moet worden, etc. ${ }^{5}$ Maar misschien ging Luhmann op dat moment er simpelweg vanuit, dat ze alles over en rondom hem mochten schrijven, zolang ze zijn naam maar goed spelden - en naamsbekendheid heeft hij aan zijn discussie met Habermas zeker over gehouden. Of misschien dacht hij toen al, wat hij later expliciet over zichzelf zou zeggen: "Ich denke primär historisch' - en had hij het geduld dat wel vaker gepaard gaat aan historisch besef.

De tijden zijn inmiddels veranderd. De universiteit van Bielefeld is onder de aegis van Luhmann tot een van de belangrijkste centra van sociologiebeoefening in Europa geworden en zijn eigen werk staat bovenaan de ranglijst van Duitslands intellectuele exportprodukten. Van degenen die zich ooit als 'marxistisch socioloog" afficheerden, haasten velen zich nu om Luhmann tegen Habermas cum suis in bescherming te nemen. Zo wist Johannes Berger al vrij spoedig na de publikatie van Luhmanns opus magnum Soziale Systeme (1984) dat het onzin is om Luhmanns werk met technocratieverwijten te bestoken, of als 'Herrschaftskonform' te bestempelen -

'Die Idee eines 'stummen Zwangs der Verhăltnisse' ist fur Luhmanns Systemkonzept so wenig pragend wie die Anlehnung an Vorstellungen vom 'Gehäuse der Hörigkeit" und ähnliche

4. N. Luhmann, 'Systemtheoretische Argumentationen. Eine Entgegnung auf Jurgen Habermas", in: J.Habermas/N Luhmann, op oit, p. 398.

5. Vergelijk bijv. een vroeg artikel als 'Selbststewerung der Wissenschaft', opgenomen in: $\mathbb{N}$. Luhmann, Soziologische Aufklärung (D), Oplladen 1970, pp. 232-252. 


\begin{abstract}
'Zwangsbegrifflichkeiten' [-] Hinter der "Theorie sozialer Systeme" lauert auch keine aus der Diskussion der funfziger Jahre in die Gegenwart transponierte und entsprechend "aufgeputzte' Technokratiethese. Sie ist nicht konzipient um zu bestreiten daß die Menschen ihre Geschichte aus freien Stücke machen. Vielmehr ist diese Freiheit als doppelte Freiheit gerade das Grundproblem dieser Theorie: ${ }^{26}$
\end{abstract}

Sighard Neckel en Jurgen Wolf die Luhmann bekritiseren vanwege een vermeende vrijage met het postmodernisme, voegden daar vrij recentelijk aan toe: "The times when systems theory could be brushed aside with one hand as social technology are definitively over. ${ }^{\text {? }}$

Ook het intellectuele klimaat in Nederland is stilaan veranderd - en dat geldt in nog sterkere mate wanneer we i.p.v. over 'Nederland' over 'Nederlandstalig' spreken, om expliciet de sociologie en filosofie van onze zuiderburen erbij te betrekken. De golf van Postmodernisme die over de Lage Landen heen is gespoeld, mag dan de zelfverzekerdheid van het filosofisch moralisme geen goed hebben gedaan, ironie en speelse distantie varen er wel bij. Klaarblijkelijk zijn dat omstandigheden die ook Luhmann gunstig gezind zijn. Aan het toenemend aantal publicaties en aan de vraag naar Luhmanns lijfelijke aanwezigheid op symposia en congressen laten zich in ieder geval een groeiende belangstelling voor zijn werk aflezen, waarbij met name organisatiedeskundigen, literatuurwetenschappers en rechtstheoretici kunnen claimen daaraan al in een vroeg stadium te hebben bijgedragen.

Maar daarmee wordt ook een typisch probleem manifest. Een jarenlange verwaarlozing van een traditie die zelf volop in ontwikkeling is gebleven, laat zich niet op stel en sprong repareren. Vooral niet wanneer de fakkeldrager en theoretische innovator Luhmann heet, hetgeen synoniem is met de bijna onhebbelijke gewoonte artikel na artikel, essay na essay, en gemiddeld een boek per jaar te publiceren. ${ }^{8}$ Natuurlijk kenmerkt ook Luhmanns werk zich door een herhaling van denkmotieven, analyse-modellen en beschrijvingskaders. Daar staat tegenover, dat zich gedurende zijn wetenschappelijke carrière diepgaande theoretische verschuivingen hebben voorgedaan, zo zelfs, dat een specifieke instantie daarvan door Luhmann zelf wordt begrepen als een heuse

6. J. Berger, "Autopolesis: Wie "systemisch" ist die Theorie sozialer Systeme", in: H.Haferkamp/* M.Schmid (Elisg.), Simn, Kommunikation und soziale Differenzierung - Beiträge zu Luhmanns Theorie sozialer Systeme, Frankfurt/M. 1987, p. 130/131.

7. S.Neckel/J. Wolf, "The Fascination of Amorality: Luhmanins Theory of Morality and its Resonance among Gierman Intellectuals", in: Theory, Culture and Society, Vol. 11 (1994), p. 70 .

8. De tot nog toe meest complete Luhmiann-bibliografie (1131 items) is onder de titel 'Gesamtverzeichnis der Veroffentlichungen Niklas Luhmanns 1958-1992' te vinden in: K.Damman/D.Grunow/K.Japp (Hrs.g.), Die Verwaltung des politischen Systems Opladen 1994, pp. $282-382$. 
paradigmawisseling. Voeg daar aan toe, dat hij in de loop van de tijd, en met name vanaf het begin van de jaren tachtig een publiek van meer dan de 'kritische massa' heeft opgebouwd dat inmiddels vertrouwd is geraakt met zijn uiterst complexe begrippenapparaat, hetgeen op zijn beurt Luhmann heeft bevrijd van de dwang om ook zijn meest basale theoretische vooronderstellingen telkens weer toe te lichten, en het probleem van een Luhmann-receptie in Nederland wordt enigszins duidelijk: vrijwel iedere eerste kennismaking met het origineel doet de lezer(es) ernstig twijfelen tussen Luhmann en zichzelf. Klassiek is, wat dat betreft, het al eerder genoemde Soziale Systeme waarin Luhmann nota bene de algemene grondslagen van zijn (tot nog toe) definitieve versie van een systeemtheoretische sociologie uiteen zet. In feite veronderstelt dit boek al zoveel kennis omtrent zijn eerdere werk, dat het misschien wel de slechtst denkbare inleiding tot Luhmanns intellectuele project vormt. De aanvankelijk geinteresseerde lezer(es) die bij het tweede hoofdstuk gekomen, Soziale Systeme met een zucht naar de stoffigste plank van de boekenkast verbant; kan weinig worden verweten.

Deze constatering dat de receptie van Luhmanns werk in Nederland op hindernissen stuit die al snel onoverkomelijk worden, heeft voor een niet onbelangrijk deel tot het schrijven van het nu voorliggende boek geïnspireerd. Ik hoop hiermee althans op zijn minst Luhmanns denkwereld toegankelijker te maken, een brugfunctie te vervullen voor diegenen die uit hoofde van hun wetenschappelijke interesse, of simpelweg uit nieuwsgierigheid willen weten wat Luhmann te melden heeft, maar niet over de tijd beschikken om zich door gestaag leeswerk het voorland en de achtergronden van Luhmanns huidige opvattingen eigen te maken. Misschien zou 'brugfunctie' onderstreept moeten worden want het is geenszins de pretentie van dit boek, dat het de bestudering van Luhmanns eigen geschriften overbodig zou maken. In tegendeel -, om te beginnen is het al niet opgezet als een encyclopedisch overzicht of omvattend compendium van alles waar Luhmann zich tot nog toe mee bezig heeft gehouden. Dit boek concentreert zich eerst en vooral op de grondslagen van Luhmanns project van een systeemtheoretische sociologie - op de uitgangspunten en vooronderstellingen van de algemene systeemtheorie die het overkoepelende kader van zijn theoretische inspanningen vormen (Hfst. I), vervolgens op de begrippen en modellen die tezamen het 'Kategoriensystem', d.w.z. het voor Luhmanns conceptie van de 'sociale werkelijkheid' constitutieve beschrijvingsapparaat uitmaken (Hfst. II $t / m$ IV) en tenslotte op zijn maatschappijtheorie (met nadruk op zijn theorie van de 'moderne' maatschappij) die binnen de architectuur van zijn theoretisch bouwwerk eveneens fungeert als een algemeen raamwerk en wel ten behoeve van sociologische deeldisciplines zoals 
religie- of kunstsociologie (Hfst. V en VD) ${ }^{9}$. De komende hoofdstukken hebben m.a.w. een overwegend theoretische en filosofische inslag en laten de door Luhmann en zijn leerlingen/medewerkers uitgevoerde empirische en historischsociologische studies (noodgedwongen) terzijde. Het wil de navigatie-instrumenten warmee Luhmann zijn 'Hohenflug vaber den Wolken' uitvoert, reconstrueren en inzichtelijk maken, in de wetenschap dat ijle lucht euforisch maakt, maar de zinnen begoochelt -

'Gelegentlich sind Durchblicke nach unten möglich - ein Blick auf Gelände mit Wegen, Siedlungen, Flüssen oder Küstenstreifen, die an Vertrautes erinnern.. Aber niemand sollte der fllusion zum Opfer fallen, daß diese wenigen Anhaltspunkte genügen, um den Flug zu steuern. ${ }^{\prime 10}$

Met dit boek heb ik bovendien een kritische inleiding tot Luhmanns werk willen schrijven en daarmee mijzelf - en de lezer - uitgeleverd aan alle retorischdidaktische problemen die dat met zich mee brengt. Een ieder zal uit eigen ervaring vertrouwd zijn met de spanning tussen het 'positieve', opbouwende karakter van een uiteenzetting van iemands gedachtengoed en het al gauw afbrekende, 'negatieve' karakter van (met name: fundamentele) kritiek, een spanning tussen "geven" en 'terugnemen' die bij een tekst ter omvang van een boek gemakkelijk te hoog oploopt. Om deze te minderen heb ik niet gekozen voor het beproefde recept, alle meer fundamentele discussies en kritieken op te sparen voor een kritisch-evaluerend 'Slothoofdstuk' - daarvoor zijn sommige kritische argumenten mi te dwingend én te vruchtbaar. Voor zover mogelijk, heb ik wel geprobeerd de discussie en kritiek telkens an het slot van de per hoofdstuk, soms zelfs per 'dubbel-hoofdstuk' behandelde thematiek op te voeren. Ook in deze is de belangrijkste remedie echter die van de beperking geweest. Alhoewel dankbaar gebruik (en misbruik) is gemaakt van het onmetelijke werk dat door anderen is verricht, pretendeert dit boek niet een systematisch overzicht te geven van alle mogelijke vormen van kritiek op Luhmanns project. In deze beperking heb ik mij overigens niet laten leiden door de faam van de critici of door de luidruchtigheid van sommige debatten, maar bovenal door wat mij, gegeven de verschillende claims van Luhmanns sociologie en maatschappijtheorie (ook in theorie-vergelijkend opzicht) intrinsiek belangrijke problemen leken. Binnen het daarmee afgestoken veld kan natuurlijk nog worden onderscheiden tussen meer en minder zwaarwichtige problemen en kritieken, met als definitief ijkpunt die gevallen die zich niet meer laten repareren, althans niet binnen het

9. Zie voor deze functie van 'maatschappijtheorie' als 'frame of reference', als 'mothodisch konstru-iertes Sprachspiel' waarbinnem deelsociologieẽn ontwikkeld en geơvalueerd kunnen worden; o.a. H. Wilke, Systemihearie entwickelter Gesellschaffem, Munchen 1989, pp. 17 e.v.

10. N. Luhmann, Soziale Systeme, Frankfurt/M.1985, p.13. 
Luhmanniaanse raamwerk in zijn authentieke vorm. Een voorbeeld van dit laatste is de mi. uiterst problematische status van Luhmanns maatschappijconcept en de kritiek die, in samenhang daarmee, op belangrijke delen van zijn theorie van de moderne maatschappij kan worden gegeven.

Op dit punt aanbeland, dringt zich de misschien wat banale vraag op, waarom ubberhaupt een 'Inleiding' tot Luhmanns werk geschreven: waarom al die moeite, als het uitmondt in de afwijzing van een centraal leerstuk, in casu zijn maatschappijtheorie! Het antwoord hierop is zowel simpel als buitensporig ingewikkeld. Voor het ingewikkelde antwoord mogen de nog komende hoofdstukken instaan; laat ik het hier bij het simpele houden. In een volzin gegoten, zou dat kunnen luiden: Met zijn conceptie van de sociale werkelijkheid als 'eine freischwebend konsolidierte Realität, ein sich selbst gründendes Unternehmen"ll, plaatst Luhmann niet alleen een aantal klassieke, inmiddels uitgesleten methodologische en theoretische tegenstellingen (zoals die tussen methodologisch individualisme en methodologisch collectivisme, tussen structurele en dynamische analyse, of die tussen 'conflict' en 'consensus') in een volledig nieuw daglicht, maar bovendien committeert Luhmanns sociologie zich "van meet af aan', d.w.z. al op het niveau van haar meest elementaire grondslagen, aan een problematiek die voor iedere hedendaagse maatschappijtheorie van beslissende betekenis zou moeten zijn - welke kritiek men vervolgens ook op Luhmanns specifieke uitwerking daarvan mag hebben. Ik doel hier op het probleem 'complexiteit', op de overmatige complexiteit van de moderne maatschappij.

Daarmee verkrijgt deze "Kritische inleiding tot de sociologie van Niklas Luhmann' bewust het karakter van een programmatisch 'statement', of zo men wil: van een 'zet' binnen het (theoretisch) discours over de eigenaard en de problematiek van de moderne, Westerse maatschappij. Laat ik, zonder nu alsnog te bezwijken voor de verleiding het "buitensporig ingewikkelde" antwoord te willen geven, toch proberen dit programmatische kader kort toe te lichten.

Als vertrekpunt zou de constatering kunnen dienen, dat alle invloedrijke maatschappijtheorieen zich behalve door hun cognitieve eigenschappen en integratieve functies, ook altijd hebben gekenmerkt door hun engagement met een specifieke problematiek. ${ }^{12}$ Voor Marx was dat de 19 de eeuwse 'sociale

11. Soziale Systeme, op, cit, pi 173.

12. Over de 'integratieve functies' wan maatschappijtheoriegr hebben we, onder verwijzing naar Willke (noot 8), al eerder opgemerkt, dat deze onder meer betnekking hebben op de integratie. en synthese wan verspreid tot stand gebrachte sociologische kennis. De belangrijkste cognitieve functie varu maatschappijtheorieên bestaat misschien nog wel daarin, dat zij een brug vormen. tussen de meest algemene, a-historische grondbegrippen wan een sociologisch paradigma (begrippen als 'handeling', "interactie!, 'structuur', "actor', "groep', etc.) en het onderzoek naar concrete, altijd in een historische context geplatste sociale fenomenen Een mantschappijtheorie dient m.aw. de struoturele kenmerken wan een historische fase (of socianluvolutionair ontwikkelingsstadium) to benoemen, kenmerken die geacht worden de randvoorwaarden te 


\section{WOORD VOORAF}

Zou ik dit Woord vooraf hebben mogen trommelen, op echt blik, dan had ik de wereld naderhand nog wijs kunnen maken dat de val in het diepe in feite een weloverwogen sprong is geweest. Maar ik kan niet trommelen, in ieder geval niet zoals Oskar, en het droog hakkelend geluid dat mijn toetsenbord voortbrengt, laat slechts ruimte voor prozaïsch, en aan de intervallen te horen: zo nu en dan reflexief, realisme. Het diepere inzicht dat een schrijv(st)er van een proefschrift zelf aan al zijn/haar inspanningen overhoudt, lijkt mij dan ook te zijn, dat alle goede (en minder goede) bedoelingen uiteindelijk de weg plaveien naar een nooit gepland of verwacht eindresultaat. Dat mag al diegenen die dagelijks in de weer zijn met het 'stroomlijnen' en efficienter maken van het wetenschappelijk onderzoek in Nederland somber stemmen, ik zelf kan daarin slechts de heimelijke (en soms pijnlijke) glimlach ontdekken van een academische levensvorm die haar autonomie als het moet ook achter de rug van haar dragers om bevecht. En laat ik eerlijk zijn: iemand die, met Luhmann, 'contingentie' voor een fundamenteel kenmerk van de werkelijkheid houdt en "doelrationaliteit" toch vooral beschouwt als de gipsen kraag die het onze planners mogelijk maakt met opgeheven hoofd door het leven te gaan, zo iemand kan uiteindelijk niet anders dan met een diepe buiging de ironie welkom heten.

Bovendien is onbedoeld en niet-gepland niet per definitie 'ongewenst'. Mijn promotor Prof. Gerard de Vries heeft mij er althans ooit van kunnen overtuigen dat een stevige 'Inleiding' op het werk van Niklas Luhmann wel eens op een groter lezerspubliek zou kunnen rekenen, dan het oorspronkelijk door mij voorbereidde proefschrift over de taalfilosofische, kentheoretische en ontologische interpretaties van het relationalisme dat aan de opkomst van de moderne wetenschap, de sociologie incluis, ten grondslag ligt - zoals hij mij er ook van heeft weten te overtuigen dat het verstandiger is om het filosofisch wereldraadsel pas na mijn promotie op te lossen. Daarvoor ben ik hem nu dankbaar. In het licht van Gerards naderende vertrek naar Amsterdam zou ik hem middels dit Woord vooraf bovendien willen bedanken voor zijn niet te overschatten bijdrage aan het academisch werkklimaat hier op de Faculteit der Cultuurwetenschappen. Als lid van "zijn" vakgroep Wijsbegeerte heb ik daar in het bijzonder van mogen profiteren.

Daarmee spreek ik natuurlijk ook mijn erkentelijkheid uit jegens al mijn collega's, zij het alleen al voor het geduld waarmee ze de afgelopen jaren 'zelfreferentiële systeemtheorie' en 'Niklas Luhmann' hebben doorstaan. Een van hen will ik in het bijzonder bedanken, zij het dat de term 'collega' mij onwennig en, in zekere zin, ongepast in de oren klinkt. Als het om de kwaliteit van zijn raad gaat, hoef ik Ton Nijhuis nauwelijks meer voor het voetlicht te halen - zijn wetenschappelijke en bestuurlijke capaciteiten zijn inmiddels wijd en zijd bekend. Laat ik daarenboven de daad roemen waarmee Ton mij altijd terzijde heeft gestaan, naast zijn intellectuele, ook zijn praktische solidariteit en 
kwestie', door hem geformuleerd in termen van de 'tegenstelling tussen loonarbeid en kapitaal'. Max Webers analyses van het 'westers rationaliseringsproces' stonden daarentegen in het teken van zijn worsteling met, en verzet tegen de hegemonie van het doelrationele denken dat in de vorm van een overal om zich heen grijpende bureaucratisering aan de menselijke zinverlening haar veelvormigheid en rijkdom ontneemt. Jürgen Habermas concentreert zich op zijn beurt op de emancipatie- en ontplooiingskansen van het individu wiens leefwereld dreigt te worden uitgehold door een oprukkende systeemrationaliteit. Dit engagement met een kemprobleem is geen bijkomstigheid; het is niet alleen van belang in termen van de motivatie van een individuele wetenschapper of filosoof om zoveel tijd en energie te steken in een, op zichzelf beschouwd, abstracte intellectuele ondememing. Of een maatschappijtheorie adequat is, indien het gaat om de analyse van de huidige samenleving en haar problemen, hangt voor een belangrijk deel precies af van de centrale problematiek waarmee de theorie zich engageert:

Zonder te willen afdingen op de historische waarde en betekenis van theoretici als Marx of Weber, en meer in het algemeen van het emancipatieperspectief, bestaan er toch zwaarwegende redenen om af te stappen van het soort problemen die de drijfveer vormden van de inmiddels 'klassieke' maatschappijtheorieën. De afgelopen decennia hebben zich problemen aangediend, die binnen het kader van een, aan vraagstukken als sociale ongelijkheid of persoonlijke emancipatie gecommitteerde maatschappijtheorie niet meer systematisch kunnen worden behandeld. We hoeven in dit verband slechts aan het milieu-vraagstuk te denken, of anders aan de op hol geslagen ontwikkeling van een 'massavernietiging'-technologie, aan de sturingsproblemen waar de politiek op stuit, aan de problemen van informatisering en globalisering etc. Tegen deze achtergrond begint het vermoeden te rijzen dat een maatschappijtheorie die over voldoende analytische capaciteit wil kunnen beschikken, de problematiek die haar drijfveer vormt vandaag de dag abstracter moet vatten dan in formuleringen als "loonarbeid versus kapital', 'emancipatie van het individu', etc. Een beschouwing van de moderne maatschappij onder het gezichtspunt van haar complexiteit (en, zoals we nog zullen zien, 'dus' ook van haar contingentie en polycontextualiteit) voldoet in ieder geval aan deze eis van voldoende abstractie/afdoende omvattendheid.

Maar kan 'complexiteit' uberhaupt wel als een probleem worden begrepen en dan nog wel als een maatschappelijk probleem waarmee de sociologie of sociale filosofie, zich werkelijk zou kunnen engageren?! De 'programmatische' bewering van dit boek is in ieder geval dat Luhmanns theorie van sociale systemen een voldoende grondslag biedt om op deze en soortgelijke vragen een

vormen waaronder sociale processen zich afspelen en die hun onderlinge verwevenheid conditioneren. 
bevestigend antwoord te geven - hoe men verder ook over zijn maatschappijtheorie, als de bijzondere invulling die Luhmann daaraan geeft, mag oordelen. Voor een nadere toelichting op deze bewering kan ik hier slechts naar de rest van dit boek verwijzen. Laat ik echter, een blik werpend op het slothoofdstuk, nu al vaststellen dat een engagement met 'het probleem complexiteit', de normatieve dimensie die kenmerkend is voor de 'grote' maatschappijtheorieen, beslist niet laat verdampen. Hoe huiverig Luhmann zelf ook tegenover moral en ethiek mag staan, het complexiteitsprobleem is niet een 'slechts' technischtechnologisch probleem. We kunnen hooguit observeren, dat met het abstracter worden van het maatschappijtheoretische 'engagement', ook de normatieve dimensie naar ijlere lagen is uitgeweken. De normativiteit van Luhmanns project laat zich niet meer betrappen op het niveau van inhoudelijke uitspraken over de sociale werkelijkheid, maar gaat schuil in de systematiek van het beschrijvingsapparaat met behulp waarvan empirisch inhoudsvolle uitspraken worden gegenereerd. Vanuit dat bas-relieff, zo zullen we in het slothoofdstuk zien, dringt Luhmanns sociologie aan op een verzoening met het differente en uitgeslotene, op een rehabilitatie van het deviante als een voor de moderne, hoog-complexe maatschappij onmisbare bron van dynamiek en ontwikkeling. Dan zal ook duidelijk worden wat een goede verstaander misschien al had begrepen, maar door velen op het eerste gezicht voor onwaarschijnlijk zal zijn gehouden: terwijl 'systeemtheorie' vaak wordt geassocieerd met een eenzijdig ontwikkeld Verlichtingsdenken, met 'sciëntisme'en door Habermas zelfs met technocratie, is Luhmanns denkwereld veeleer verankerd in 19 de eeuwse Romantiek Luhmann? - dat is 'halbierte', geseculariseerde Romantiek; dat is Romantiek die afscheid heeft genomen van alle 'Sehnsucht', maar zich vastklampt aan het complement daarvan: de ironie. 


\section{Hoofdstuk I}

\section{SYSTEEM EN COMPLEXITEIT}

\section{$\S 1$. Inleiding}

Als opmaat van een langer lopend onderzoek naar de inhoud en consequenties van Niklas Luhmanns 'systeemtheoretische' sociologie ligt het enigszins voor de hand om de vraag te stellen, wat Luhmann zelf zich voorstelt bij het etiket 'systeemtheorie'. Er zijn echter ook minder 'brave' redenen voor een dergelijk begin aan te voeren. Deze vraag confronteert ons namelijk direct met de kenmerkende stijl van Luhmann, met zijn eigenzinnig mengsel van filosofische ironie en sociologische ernst, van spottende distantie en plechtstatige passie. Want leg je Luhmann de vraag voor waar systeemtheorie zoal over gaat, dan is zijn reactie, inclusief de interpunctie, vrijwel voorspelbaar: niet over het zo (niet!), maar over het $a l$ - over alles, over het gehele universum, over Welt. ${ }^{13}$ 'Systeemtheorie' houdt voor Luhmann m.a.w. een aanspraak op universaliteit in, de pretentie alles wat zich in de wereld voordoet theoretisch te kunnen beschrijven en reconstrueren. En alleen voor zover de algemene systeemtheorie aan die pretentie vasthoudt en daar een invulling aan weet te geven, kan ze zichzelf met recht presenteren als een 'supra-disciplinair', unificerend wetenschapsprogramma, de status van 'Supertheorie' verwerven, op éen lijn te stellen met bijvoorbeeld de darwinistische evolutietheorie. ${ }^{14}$

De universaliteitsaanspraak van de systeemtheorie houdt overigens nog niet de 'totalitaire' claim in de enig mogelijk ware, correcte of plausibele theorie te zijn. ${ }^{15}$ Dat kan eigenlijk ook moeilijk volgens Luhmann. Met de aanspraak op universaliteit is namelijk tegelijk een probleem in huis gehaald dat vervolgens iedere uitgewerkte theorie als een specifieke keuze doet verschijnen, als éen van de mogelijkheden om de wereld te beschrijven. Iedere aanspraak op universali-

13. Verg. N. Luhmann, Neuere Entwicklungen in der Systemtheorie', in: Merkur 42 (1988), p.292.

14. Zie voor de zowel synchroon als diachroon - "die Differenz von Kontimuität und Diskontinuität in der wissenschaftlichen Entwicklang aberbrackende" - unificenende functie van "Supertheow rieên": N. Luhmann, "Soziologie der Moral', opgenomen in: N. Luhmann/St.H.Pfurtner, Theorietechmik und Moral, Frankfurt 1978, p. 9 e.v. Luhmann voegt darar 0.a. aan toe, dat. "Supertheorien ... eine eigenständige Funktion im Wissenschaftssystem [haben], die eigene Rechte und eigene Mittel erfordert: Sie sind innerhalb des Wissenschaftssystems die Auffangund Abwehrebene fur moralische ebenso wie für erkenntnistheoretische (im Wissenschaftssystem sellbst generierte) Ansproliche." Idem, p. 9.

15. Varg. o.a. N. Luhmann, 'Systemtheoretische Argumentationen. Eine Entgegnung auf Jurgen Habermas', in: J.Habermas/N.Luhmann, Theorie der Gesellschaft oder Sozialtechnologie, Frankfurt 1975 (le dr. 1971), p.379 e.y. 
teit, iedere pretentie een theorie op te stellen die "Welt-adăquat" is, stuit onvermijdelijk op het probleem dat niemand het 'al', de wereld in zijn totaliteit, kan obserweren of bevatten. Alleen een god die boven en buiten het universum staat, zou het universum op zichzelf, als eenheid, kunnen observeren, het onderscheiden van iets dat er niet toe behoort (bijv. van hemzelf). Wij stervelingen zijn echter onvermijdelijk een deel van de wereld, kunnen alleen binnen de wereld observeren. En aangezien observerenl ook altijd het maken en benutten van een onderscheid inhoudt - anders zouden we niets onderscheidens observeren wordt met iedere observatie of beschrijving de eenheid van de wereld doorbroken. In principe zou de wereld dan nog als de eenheid van het onderscheid dat in en door een observatie wordt geactualiseerd, kunnen worden opgevat. Maar iedere observatie van die eenheid veronderstelt weer de invoering van een nieuwe differentie, al was het alleen maar om de geobserveerde eenheid van alle andere mogelijke eenheden te kunnen onderscheiden. We blijven de wereld molesteren.

Het wordt dus van het grootste belang met welk onderscheid we van start gaan, welke differentie, om met Luhmann te spreken, als 'Leitdifferenz' aan de opbouw van een omvattende theorie ten grondslag wordt gelegd. Hier kan en moet men kiezen tussen verschillende mogelijkheden en wel in de wetenschap dat iedere volgende stap door die initielle keuze wordt geconditioneerd en gedirigeerd: Zo kunnen we met Marx het onderscheid 'arbeid/kapitaal' voor het meest fundamentele onderscheid aanzien en dit als de overkoepelende, richtinggevende differentie voor een analyse van de moderne maatschappij benutten. De beschrijving (van een deel) van de wereld die daaruit resulteert, verschilt op belangrijke punten van een maatschappijtheorie die als 'Leitdifferenz' Habermas onderscheid tussen communicatief handelen en instrumenteel handelen hanteert Beide benaderingen verschillen niet alleen inhoudelijk, maar ook wat betreft het sóort verschijnselen dat het meest geschilkt is om het probleemoplossend vermogen van de theorie te demonstreren.

Op zoek naar een basisonderscheid dat algemeen en abstract genoeg is om niet meteen al in 'blinde' empirie te verzanden, heef Luhmann van meet af aan zijn zinnen gezet op het onderscheid systeem/omgeving.

'Für meine Zwecke genugte es, von einer Unterscheidung auszugehen, namlich von der Unterscheidung von System und Umweit. Das ist eine sehr wichtige, stark einschrânkende Ausgangsstellung. Danach befaßt sich die Systemtheorie nicht einfach mit besonderen Objekten, nähmlich Systeme, im Unterschied zur irgendwelchen anderen Objekten. Sie befaßit sich mit der Welt, gesehen mit Hilfe einer spezifischen Differenz, nähmlich der von System und Umwelt. Es wird also alles, was vorkommt, erfaßt; 
aber nur unter der Bedingung, daß man angibt, ob es jeweils System ist oder Umwelt. ${ }^{16}$

Met de systeem/omgeving-differentie, zo meent Luhmann, beschikken we over een uitgangspunt dat voldoende algemeen en abstract is om een, in vergelijking, zeer complexe theorie op te bouwen - door veel van zijn lezers verwenst als te complex, door Luhmann echter begrepen als een noodzakelijke eigenschap van iedere 'supertheorie' die, vis-à-vis de diffuse complexiteit van de wereld der verschijnselen, voldoende analytische, 'oplossende" capaciteit wil aanleveren.

In dit hoofdstuk zullen we in grote lijnen nagaan, wat de implicaties zijn van deze keuze voor het systeem/omgeving-onderscheid. Daarbij zullen we bijzondere aandacht schenken aan de door hem zelf als een paradigmawisseling' betitelde overgang binnen zijn werk, namelijk van de zogeheten 'open' systeem(/omgevings)theorie naar de theorie van 'autopoietische', of zo men wil, 'zelfreferentiële' systemen. Daarbij zullen we ons overigens beperken tot de algemene systeemmodellen die Luhmann telkens voor ogen hebben gestaan en slechts bij wijze van voorbeeld (en dan nog zeer beperkt) ingaan op zijn "sociologie $^{y}$ in de meer strikte zin van het woord.

\section{§ 2. De vroegere fase: het 'functioneel structuralisme"}

Systeemtheorie, als een algemene, supra-disciplinaire wetenschap, staat of valt dus, volgens Luhmann, met de keuze voor het systeem/omgevings-onderscheid als de 'Leitdifferenz' die aan alle verdergaande theoretische ontwikkelingen ten grondslag wordt gelegd. Maar ook als we dit specifieke uitgangspunt overnemen en op geleide hiervan bereid zijn alles wat we in de wereld tegenkomen, iedere entiteit of samenhang; als een systeem in een omgeving te beschouwen, kunnen we nog steeds verschillende kanten op. Zo kunnen we de kant 'systeem" kiezen en ons vervolgens concentreren op de vraag, hoe we in concreto een bepaald systeem moeten beschrijven, wat de elementen van dat systeem zijn, welke relaties er tussen de elementen bestaan, welke 'structuren' d.w.z. welke relaties tussen de relaties, etc.

Binnen de systeemtheorie heeft Luhmann echter die theoretische inspanningen altijd het meest vruchtbaar gevonden, die 'boundary maintenance'-problemen centraal stellen, die zich ma.w. richten op de vraag hoe systemen het onderscheid tussen zichzelf en hun omgeving, tussen een 'binnen' en een 'buiten' handhaven, welke processen en mechanismen daar een rol in spelen, etc. Theoretische benaderingen die worden geïnspireerd door dergelijke problemen van grensafbakening en -behoud worden binnen de systeerntheoretische traditie meestal als 'systeem-omgevingstheorieën" aangeduid. Tot dit cluster kan ook

16. N. Luhmann, "Neuere Entwicklungen in der Systemtheorie", in Merkur 42 (1988), p. 292. 
het vroegere werk van Luhmann worden gerekend. ${ }^{17}$ Om zijn eigen versie van een systeem-omgevingstheorie expliciet van andere te onderscheiden, betitelde Luhmann zijn aanpak als 'functioneel structuralisme'. Met deze benaming wilde hij onder meer tot uitdrukking brengen, dat het binnen de klassieke systeemtheorie gangbare type van 'functionele analyse' geradicaliseerd diende te worden. In plaats van halt te houden bij de analyse van de bijdragen die systeeminterne processen leveren aan de instandhouding van telkens cruciaal geachte structuren, moest de functionele analyse zich uitbreiden tot structuren, ja zelfs tot systeemvorming op zich. Nu veronderstelt iedere functionele analyse de isolatie van een 'probleem', in referentie waaraan processen en eventueel ook structuren en systemen als (een bijdrage aan) een 'oplossing' kunnen worden begrepen. Binnen de context van een systeem/orngevingstheorie lag het voor de hand, aldus Luhmann, om de 'omgeving" en in laatste instantie de 'wereld' uit te roepen tot het overkoepelende referentieprobleem van een geradicaliseerd functionalisme.

'Alle funktionale Analyse setzt einen Bezugspunkt voraus, auf den hin eine Funktion erfullt wird. $(-)$ Geht man won [einem] Systembegriff aus, der in einer Differenzienung von Innen und Außen sein konstituierendes Prinzip hat, und sucht man ihn zu transzendieren, dann fragt man nach einer Bezugseinheit, die keine Grenzen mehr hat. Man fragt nach der Welt. Die Welt kann nicht als System begriffen werden, weil sie kein 'Außen' hat, gegen das sie sich abgrenzt. ${ }^{18}$

'Wereld' staat voor alles wat het geval is, voor alle mogelijke dingen of standen van zaken. We weten inmiddels echter, dat 'wereld' voor een totaliteit staat die niet als zodanig kan worden geobserveerd, die met iedere observatie wordt 'gemolesteerd'. Zo beschouwd kan 'Welt' geen term kan zijn die in descriptieve zin naar de empirisch waameembare wereld verwijst. De term "wereld" is bij Luhmann eerder de aanduiding van een probleem en wel van het 'eerste', meest algemene, alles overkoepelende probleem: het probleem 'complexiteit'.

'Weil die Welt kein Umwelt hat, kann sie auch nicht bedroht werden. Anders als in Falle von Systemen ișt ihr Bestand nie gefahrdet und daher auch nicht problematisch. Solange uberhaupt etwas ist, ist auch die Welt. Alle Bestandsgefăhrdung muß daher

17. Dit voegere werk, Luhmanns "eerste fase", beslaat nuwweg de periode tussen de publikatie van Punktionen und Folgen formaler Organisation in 1964 en het einde van de zeventiger jaren. Met do publikatie in 1980 van het eerste deel van Gesellschaftsstruktur und Semantik is Luhmanns vroegere fase in ieder geval definitief afgesloten.

18. N. Luhmann, 'Soziologie als Theorie sozialer Systeme', in: Soziologische Aufklaraing I, Opladen 1984, p.114-115. 
als Moglichkeit in der Welt gedacht werden, alle Bestandsvernichtung ereignet sich in der Welt. Zum Problem wird die Welt nicht unter dem Gesichtspunkt ihres Seins, sondern unter dem Gesichtspunikt ihrer Komplexität. ${ }^{19}$

Met 'wereld' als aanduiding voor het ultieme referentieprobleem van alle functionele analyse wordt in feite gepostuleerd, dat alles waarvan op een of andere manier gezegd kan worden dat het 'bestaat', altijd bestaat als een vorm van gereduceerde complexiteit. In de woorden van Luhmann:

'Systeme sind Weltausschnitte, sind also von geringerer Komplexität als die Welt selbst. Ihr Verhaltnis zur Welt kann daher als Selektion beschrieben werden... Diese Selektion kann nicht beliebig erfolgen (selbst wenn Welt als unendlich und voll kontingent gedacht wird), weil sie zur Konstitution einer Differenz von System und Umwelt fuhrt, die problematisch ist und nicht beliebig geordnet sein kann. Jedes System hat nicht nur relativ zur Welt, sondern auch im Verhalltnis zu seiner Umwelt geringere Komplexität. Die Umwelt kann mehr mögliche Zustände annehmen als das System selbst. ${ }^{.20}$

In dit perspectief verschijnt de functie van systeemvorming, van 'systemen op zich' als reductie van complexiteit, een reductie die tot stand komt door het trekken van een grens, door de stabillisering van een 'binnen/buiten' -differentie. Deze complexiteitsreductie is principieel problematisch en het is aan de systeemtheorie om te onderzoeken, hoe systemen er desondanks telkens in slagen de contingente reductie van wereldcomplexiteit die ze zelf zijn, overeind te houden, welke processen en structuren ze daarbij benutten en hoe ze omgaan met het risico van hun eigen selectiviteit. Uiteindelijk kunnen zowel de dynámische als structurele kenmerken van systemen functioneel geanalyseerd worden als een reductie van complexiteit, als een voortgezette, zich verder vertakkende behandeling van het probleem "wereld".

\section{§3. De kritiek op het 'structureel functionalisme'}

19. Idem, p.115.

Verg. aok N. Luhmann, 'Systemtheoretische Argumentationen', op. cit. waar hij op paginat 380 opmerkt. 'Der Welithegriff bezeichnet nicht mehr den Grund, sondern die Kontingenz alles Seienden', en voorts: "Die Welt gibt micht mehr Geltungen vor, sondern nur das Problem der Geltung."

20. N. Luhmann, "Gesellschatt", in: Soziologische Aufktärung I, op. cit, p.143.

21. Verg. N. Luhmann, "Moderne Systemtheorien als Form gesamtgesellschafticher Analyse', in: J. Habermas/N. Luhmann, Theorie der Gesellschaft oder Sozialtechnologie, Frankfurt/M. 1971, p.11 
Met de vorige paragraaf lijken we allengs verzeild te zijn geraakt bij een exercitie in hedendaagse metafysica. Dat is het in zeker opzicht ook. Maar misschien krijgt het geheel wat meer cachet; wanneer we het in zijn ideeênhistorische context plaatsen en het tevens zien als een kritische reactie op de systeemtheoretische sociologie van de vijftiger en zestiger jaren en dan met name op het 'structureel functionalisme' van Talcott Parsons: ${ }^{n 2}$ Dit 'structureel functionalisme' ging uit van de veronderstelling dat sociale systemen en i.h.b. maatschappijen slechts stabiliteit en duurzaamheid konden verkrijgen op voorwaarde van een voldoende ontwikkeld normen- en waardenstelsel dat niet alleen door een minimale interne consistentie wordt gekenmerkt, maar bovendien door de leden van het collectief algemeen geaccepteerd wordt. "[T] he primary integration of the social system", zo heet het in Toward a General Theory of Action, "is based on an integrated system of generalized patterns of value-orientation'. ${ }^{23}$ En nog in The Evolution of Societies schrijft Parsons: 'Societal order requires integration in the sense of normative coherence and of societal coordination. Moreover, normatively-defined obligations must be accepted while conversely, collectivities must have normative sanction in performing their fuinctions and promoting their legitimate interests. ${ }^{.24}$

In een meer methodologisch perspectief zou men kunnen zeggen, dat het structureel-functionalisme sociale processen analyseerde in termen van hun bijdrage aan het voortbestaan van een 'normative order', opgevat als de structurele invariant van sociale systemen. Het is precies deze concentratie op wat Habermas het probleem van de "Bestandserhaltung' genoemd heef, in combinatie met de aanname dat normatieve structuren de 'hard core' van dat ' $\mathrm{Be}$ stand' vormen, die een niet aflatende stroom van kritiek op Parsons' werk heeft uitgelokt. ${ }^{25}$ Niet alleen werd hem een 'oversocialized conception of man verweten, maar bovendien zou achter de schromelijke overdrijving van zowel de structurele als empirische betekenis van normatieve consensus een ideologische verdediging van de nu eenmaal gegeven maatschappelijke orde

22. Verg. in deze o.fi. H. Willke, Systemtheorie, Stuttgart 1991, p.3 e.v.

Parsons heeft zich overigens eerder laten inspireren door het werk van Henderson, dandoor de General System Theory die, onder aanvoering van Von Bertalanify, in de jaren vijfig opgang begint te maken.

23. T.Parsons/E.Shills (ed), Toward a General Theory of Action, New York 1962, $\mathrm{p}, 203$.

24. T.Parsons, The Evolution of Societies (ed. J.Toby), Englewood Cliffs 1977, p.135.

25. Zile o.al. J. Habermas, "Theorie der Gesellschaft oder Sozialtechnologie', in: J.Habermas/N.Luhmann, op.cit, p. 143. 
uitgaan ${ }^{26}$ Parsons als conservatief, Parsons als apologeet van de Westerse, kapitalistische samenleving. ${ }^{27}$

Zonder zich overigens veel van politiek-ideologische overwegingen aan te trekken, accepteerde Luhmann in grote lijnen deze, inmiddels gangbaar geworden kritiek op Parsons. ${ }^{28}$ Het eigenlijke probleem van Parsons' sociologie school voor hem echter niet zozeer in de uitkomsten ervan, als wel in de meest algemene theoretische uitgangspunten van het structureel functionalisme:

'Der Grund für die Mangel der strukturell-funktionalen Systemtheorie liegt in ihrem Prinzip selbst, darin nämlich, daß sie den Strukturbegriff dem Funktionsbegriff vorordnet. Dadurch nimmt die strukturell-funktionale Theorie sich die Möglichkeit, Strukturen schlechthin zu problematisieren und nach dem Sinn von Strukturbildung, ja nach dem Sinn von Systembildung aberhaupt zu fragen. Eine solche Möglichkeit ergibt sich jedoch, wenn man das Verhältnis dieser Grundbegriffe umkehrt, also den Funktionsbegriff dem Strukturbegriff vorordnet. Eine funktionalstrukturelle Theorie vermag nach der Funktion von Systemstrukturen zu fragen, ohne dabei eine umfassende Systemstruktur als Bezugspunkt der Frage voraussetzen zu müssen. ${ }^{29}$

Terugblikkend kan Luhmanns vroegere werk voor een belangrijk deel worden begrepen als een poging om de problemen van de Parsoniaanse systeemsociologie te overwinnen Luhmanns tegenbod, het "functioneelstructuralisme', kwam in feite neer op het inruilen van het bestandsprobleem voor het probleem van de reductie van complexiteit met, zoals we gezien hebben, "wereld" als het ultieme referentieprobleem. Deze radicalisering van het

26. De uitdrukking "owersocialized conception of man' is, alls kritische 'statement", van Dennis Wrong afkomstig. Wrong had daarmee niet exclusief Parsons op het oog matar meer in het algemeen al die sociologieên die hat hobbesiaanse ordeprobleem centraal stellen - wanrwoor Parsons theorie natuurlijk well emblematisch was. Wrong: "Much of our cuirrent theory offers an oversocialized. view of man in answering the Hobbesian question...' (D. Wrong, 'The Oversociallized Conception of Man in Modem Sociology', in: American Sociological Review $26(1961)$, p. 184.)

27. Exemplarisch voor deze, binnen de context van de zestiger jaren onvermijdelijke kritiek is nog steeds Alvin Gouldners The Coming Crisis of Western Soclology, London 1971, met name 'Part II'. Zie van hem ook: A. Gouldner, 'Reciprocity and Autonomy in Funictional Theory", opgenomen in: Llewellyn Grosz (ed.), Symposium on Socialagical Theory, New York 1995, p. $241-270$.

28. Verg. 0.a. N. Luhmanim, "Moderne Systemtheorien als Form gesamtgesellschaftlicher Analyse", in: J.Habermas/N.Luhmann; op.cit., p.13-15. Zie voor zijn meer algemene analyse en kritiek op het denken in termen van "bestandsproblemen" $0 . a$ : $N$. Luhmann, "Funktion und Kausalitat", opgenomen in Soziologische A.uflidrung $I$, op, cit.y p. $18 \mathrm{ev}$.

29. N. Luhmann, 'Soziologie alls Theorie sozialer Systeme', in: Soziologisahe Amfklarung I, op.cit., p.114. 
functionele perspectief kon vervolgens niet anders dan tot een heroverweging van de verhouding tussen "structuur' en 'proces" leiden. En al vroeg in Luhmanns werk kunnen we zie hoe de traditionele asymmetrie tussen het structuur- en het procesbegrip wordt opgeheven en beide op gelijk niveau worden geplaatst als weliswaar verschillende, maar desalniettemin equivalente vormen van complexiteitsreductie. 'Structuur' staat dan niet meer als het vaste of constante tegenover 'proces' als het vliedende - wezenlijk is weeleer dat beide selectiviteit belichamen en dat ze tezamen een getrapte omgang met complexiteit mogelijk maken:

'Die funktional-strukturelle Theorie kann...auch den Unterschied von Struktur und Prozeß noch unter einen funktionalen Gesichtpunkt bringen, ihnen als funktional-sinnvolle Differenzienung der Wirklichkeit ansehen und auf das Problem der Komplexität beziehen. Sie sieht die Funktion der Differenzierung von Struktur und Prozeß in der Reduktion von Komplexität durch doppeite Selektivitöt. ${ }^{30}$

Het onderscheid structuur/proces wordt hier niet als een ontologisch onderscheid opgevat - het gaat niet om een verschil in wrezensbepaling -, maar als een strategisch principe dat (bepaalde) systemen benutten in hun omgang met complexiteit. Het maakt een gefaseerde, d.w.z. temporeel gespreide, reductie van complexiteit mogelijk. Door structuur en proces te differentiëren wordt het m.a.w. mogelijk een deel van het complexiteitsprobleem op de dimensie 'tijd' af te wentelen, het 'na elkaar' te gebruiken om de selectielast te verlichten. Structuur fungeert dan als preselectie, als een voor-ontwerp van ordening 'ins Ungewisse'; processen verschijnen daarentegen als de stapsgewijze verwerking van de dan nog resterende, "voorgestructureerde' complexiteit. Luhmann: 'Das Risiko in der Welt zu Leben wird so geteilt: Es wird im wesentlichen durch Strukturen absorbiert, im ubrigen fallweise abgearbeitet. ${ }^{.31}$

\section{§ 4. De problematiek van de 'open systeem'-theorie}

Een onmiskenbaar voordeel van Luhmanns functioneel-structurele benadering boven het structureel-functionalisme van Parsons - ja boven iedere systeemtheorie die zich op de bestendigheid van structuren fixeert, ligt in de mogelijkheid die Luhmanns aanpak biedt om systemen als wezenlijk dynamische, veranderlijke entiteiten te analyseren. Met 'wereld' als enig vaste 
referentiepunt, verschijnen nu centrale concepten zoals 'structuur' en 'systeem" als termen die naar veranderlijke zaken verwijzen. De invariantie van systemen kan als een relatieve invariantie worden beschouwd en de identiteit van systemen worden losgekoppeld van cruciaal geachte 'kernstructuren' om te worden gelokaliseerd in de aard van de relaties tussen systeemelementen chemische, fysische, semantische, etc - en de op basis daarvan gerealiseerde selectiviteit t.o.v. een telkens 'overcomplexe' omgeving.

Het zou de systeemtheoretische traditie echter onrecht aandoen, wanneer hier niet tevens wordt gewezen op alle inspanningen die, nog vóor Luhmann ten tonele verscheen, al gaande waren om een aanvankelijk statische conceptie van structuren te vervangen door een veel dynamischer opvatting. En ook binnen de systeemtheoretische sociologie stond Luhmann geenszins alleen in zijn kritiek op het statisch karakter van het Parsoniaanse paradigma, dat tot lang in de jaren zestig de systeemsociologie domineerde. Zo maakte halverwege de zestiger jaren Walter Buckley naam binnen de sociologie met zijn voorstel, maatschappijen te beschouwen als 'complex-adaptieve' systemen. Dergelijke systemen zouden zich kenmerken door 'feed-back'-mechanismen en door het feit dat ze zich aan hun omgeving kunnen aanpassen middels structuurveranderingen. ${ }^{32}$

Tegelijk moet echter worden vastgesteld, dat precies de pogingen om een model van dynamische structuren te ontwikkelen, een fundamenteel probleem binnen de grondslagen van de na-oorlogse systeemtheorie aan het licht brachten. De algemene systeemtheorie die vanaf het begin van de jaren vijftig onder leiding van o.a. Bertalanffy, Ackoff, Ahsby en Boulding opkwam met de pretentie een supra-disciplinaire, 'meta-science' voor te stellen - 'its subjectmatter is the formulation and derivation of those principles which are valid for 'systems' in general' - werd geïnspireerd door het zogeheten 'open systeem'-model. In algemene zin kon een 'systeem' worden gedefinieerd als 'a set of elements standing in interrelation among themselves and with the environment'. ${ }^{33}$ Typisch voor 'open' systemen is nu, dat ze zich niet simpelweg in een omgeving bevinden - dat geldt ook voor een 'gesloten' systeem als een klok -, maar dat ze actief contact met hun omgeving onderhouden, daarmee in een uitwisselingsrelatie staan: Als exemplarische voorbeelden van open systemen golden voor Bertalanffy c.s. cellen, planten, dieren, etc. en met het oog daarop kunnen we ook spreken van 'stofwisselingsrelaties' tussen open systemen en hun omgeving, om te benadrukken, dat voor dit type systemen de omgang met de omgeving een cruciale factor voorstelt waarvan hun voorbestaan afhankelijk is. Dit omgevingscontact is voor open systemen echter niet alleen een

32. Buckley's meest bekende boek is ongetwijfeld: Sociology and Moderm Systems Theory, Englewood Cliffs 1967; meer samenvattend: W. Buckley, 'Gesellschaft als komplexes adaptieves System", in: K. Türk (hrsg.), Handlungssysteme, Opladen 1978.

33. L. won Bertalanffy, "The History and Status of General System Theory", in: G.J. Klir (ed.), Trends in General Systems Theory, New York 1972, p.31. 
noodzakelijke conditie van hun bestaan, het vormt tevens hun centrale probleem. De omgeving, als dat wat een systeem nooit volledig onder controle kan krijgen, is tegelijkertijd datgene wat open systemen voortdurend bedreigt. Als het veranderlijke, chaotische, onberekenbare is de omgeving ook telkens datgene waarop een open systeem zich moet instellen, waaraan het zich moet zien aan te passen op straffe van zijn eigen ondergang.

Deze verhouding tussen systeem en omgeving vormde de grondslag voor het soort verklaringen dat de na-oorlogse systeemtheorie nastreefde. ${ }^{34}$ Het gedrag van complexe systemen, zo verklaarde de bioloog Bertalanffy, kan niet met de middelen van de traditionele, empirisch-analytische wetenschap en unilineaire causaliteitsmodellen worden verklaard, maar moet begrepen worden als een resultante van de wisselwerking tussen een systeem en zijn omgeving. Daarbij kreeg de ongeving in die zin het primaat toegewezen, dat de processen die zich binnen complexe systemen afspelen, geacht werden een functionele reactie te vormen op gebeurtenissen die zich in de 'over-complexe', steeds bedreigende omgeving voordoen. Complexe systemen zoals cellen en planten, of zelfs hele maatschappijen, leken in principe beschrijfbaar als samenstelsels van "input(/throughput)/output"-functies die richtwaarden of parameters incorporeren als uitdrukkingen voor optima, of begrenzingen ('equilibrium'/ 'homeostase'/ etc.) van systeemtoestanden.

Welnu, de poging om binnen dit 'open systeem'-model het structuurbegrip te dynamiseren moest vroeg of laat op een even simpel als fundamenteel probleem stujten. Gegeven het primaat van de omgeving, kon de verandering en ontwikkeling van structuren nauwelijks anders geĭnterpreteerd worden dan als functionele, "adaptieve" reacties op de externe of interne omgeving. Maar dan volgt de simpele vraag: hoe doen systemen dat, waar halen ze het "materiaal" vandaan dat nodig is voor de opbouw van nieuwe structuren? of geredeneerd vanuit het idee dat systeemstructuren ook altijd informatiepotentialen yoorstellen: Als van de telkens gegeven systeemstructuren afhangt : welke omgevingsfactoren binnen het systeem informatieve waarde kunnen verkrijgen, hoe kan een systeem zichzelf dan die nieuwe informatie verschaffen die het nodig heeft voor de verandering of vernieuwing van zijn eigen structuren. $\mathrm{Bij}$ nedere analyse bleek telkens weer, dat de opname van externe factoren ten behoeve van de interne structuuropbouw de nog op te bouwen structuren al vooronderstelde. ${ }^{35}$ Een cirkel diende zich aan: Dynamische systemen schenen zich slechts aan hun omgeving aan te kunnen passen, op woorwaarde dat ze al aan hun omgeving waren aangepast (of de omgeving aan hen).

Ook Luhmann moest ooit met dit probleem in aan raking komen. Als bijzondere versie van een systeem/omgevingstheorie was zijn 'functioneel-structuralisme'

34. Zie voor een allgemeen overzicht: Gray/Rizzo (eds), Unity through Diversity I, New York 1973.

35. Verg. ook de 'Einleitung' van H.Haferkamp/M.Schmid bij het door hen geredigeerde Sinn, Kommunikation und soziale Differenzierung, Frankfurt/M. 1987. 
nog altijd ontwikkeld binnen het overkoepelende kader van de 'open systeem'theorie. Alhoewel met het functioneel-structuralisme een eenzijdige fixatie op systeem-interne, identiteit verlenende structuren was opgegeven, hield ook Luhmann vast aan een asymmetrische betrekking tussen systeem en omgeving waarbij het systeem zijn processen voortdurend organiseert en reorganiseert in het licht van telkens wisselende toestanden in de omgeving. ${ }^{36}$ 'Die Permanenz der Problematik', zo stipuleerde hij, 'hat ihre Wurzel im Grundgedanken der System/Umwelt-Theorie: daß alle Invarianz durch eine besondere Kombination von Systemleistungen einer anderslaufende Umwelt abgewonnen werden muß und insofern problematisch bleibt.' En in 'Funktion und Kausalitat', een van de kroonjuwelen van de 'Soziologische Aufklärung'-reeks, heet het: 'Alle funktionalistischen Analysen werden letztlich in bezug auf Stabilisierungsprobleme als Leiffäden gefuhrt'. ${ }^{37}$

De circulariteit waar we hierboven aan refereerden, als het probleem waar de dynamisering van het 'open systeem'-model bijna onvermijdelijk op moest stuiten, neemt in Luhmanns vroegere werk echter een bijzondere, men zou haast zeggen: 'actievere', vorm aan. Wanneer we systemen namelijk opvatten als 'eilandjes van gereduceerde wereldcomplexiteit' en tegelijkertijd postuleren, dat in de analyse van systemen 'complexiteitsreductie" - hetzij het door processen en structuren, dan wel door systeem-ontwikkeling als zodanig - het overkoepelende referentieprobleem dient te vormen, dan schotelen we onszelf in feite een tautologie voor: Systemen houden zichzelf als plaatselijk gerealiseerde complexiteitsreducties in stand, door complexiteit te reduceren. In een formulering van Wolfgang Schneider: 'Diese Tautologie läßt sich dahingehend paraphrasieren, daß Systeme sich durch ihre eigene Leistung der Komplexitätsreduktion selbst ermöglichen. ' Systemen maken zichzelf mogelijk! Typerend voor Luhmanns houding ten opzichte van tautologieên en paradoxen en meer in het algemeen tegenover de 'problemata" van het identiteitslogische denken, is, dat hij geen probleem zag in deze tautologie en haar ronduit accepteerde. Zij mag een cirkel zijn, zo redeneerde hij, maar daarom hoeft het nog geen 'circulus vitiosus' te zijn. ${ }^{33}$ Tijdens een voordracht gehouden in april 1975 te Amsterdam formuleerde Luhmann het probleem van de "zelfimplicatie' van, in dit geval, sociale systemen als volgt:

"Reflexionsverhältnisse findet die Soziologie an ihrem Gegenstand schon vor und nicht erst in ihrem eigenen Denken. Eine dafur adäquate Theorie muß daher selbstreferentielle

36. Verg. G. Kiss, Grundzüge und Entwicklung der Luhmannschen Systemtheorie, Stuttgart $1990, \mathrm{p} 32$.

37. N. Luhmann, "Funktion und Kausalitüt", in: Soziologivehe Aufklärung $I_{m}$ op.cit., p.27.

38. Verg. Soziale Systeme, waar Luhmann de 'zirkuläre Tautologie: Systeme können sich der Umwelt anpassen, wenn die Umwelt dem System angepaBt ist, und umgekehrt', een fruchtbaven Tautologie" moemt. (op.cit., p.56) 
Strukturen an ihrem Gegenstand aufweisen und verkraften kơnnen. Sie kann als Theorie nicht davon absehen, daß ihre Aussagen aber Systemstrukturen oder Systemprozesse sich ständig auf die Differenz von System und Umwelt beziehen müssen, die ihrerseits als Differenz nicht unabhängig gedacht werden kann von den Strukturen, die ein System ausdifferenzieren. Die Wendung von der klassischen zur modernen Systemtheorie, nămlich die Kritik der Vorstellung vom selbstgenugsamen Ganzen, das den Teilen Perfektion vermittelt,betrifft also genau den Punkt, der zur Bildung selbstreferentieller Begriffe zwingt. ${ }^{39}$

Terugblikkend kan de overgang die Luhmann aan het einde van de jaren zeventig maakt, yan het systeem/omgevings-paradigma naar de theorie van zelfreferentielle systemen, begrepen worden als de uitkomst van een langer lopende reflectie op de vraag, hoe dynamische systemen deze circulariteit organiseren en beheren en hoe ze er in slagen de telkens dreigende steriliteit van een kortgesloten tautologie te ontlopen.

\section{§. Zelfreferentiele systemen}

De breuk in zijn denken, die met het verschijnen van Soziale Systeme - Grundriß einer allgemeinen Theorie in 1984 zijn definitieve beslag kreeg, heeft Luhmann zelf geinterpreteerd als de sociologische verwerking van een tweede paradigma-wisseling binnen de algemene systeemtheorie. ${ }^{40}$ De eerste paradigma-wisseling zou de overgang betreffen van de 'klassieke', door Bertalanffy c.s. in de jaren vijftig geformuleerde systeemtheorie naar systeem/omgevingstheorieen; de tweede paradigma-wisseling voltrekt zich dan met de verbreiding van modellen en theorieèn van zelfreferentiële systemen sinds het einde van de zestiger jaren. Of het werkelijk zin heef, om op het niveau van de algemene systeemtheorie precies drie paradigma's te onderscheiden - en niet bijvoorbeeld twee, of anders vijf ${ }^{p 1}$ - is de vraag; Luhmann lijkt in deze vooral zijn persoonlijke ontwikkeling tot maatstaf te nemen. Hoe dan ook, het is de hierboven als 'tweede paradigma-wisseling' aangeduide omslag, die het aanzicht van de systeemtheorie diepgaand heeft veranderd. Voor wie in gedachte nog vertoeft bij de concepten en modellen van Von Bertalanfly of Ackoff, wie systeemsociologie nog steeds identificeert met het werk van Parsons

39. N. Luhmann, "Systemtheorie, Evolutionstheorie und Kommunikationstheorie', in: idem, Soziologische Aufklarung 2, Opladen 1982 (1e dr.1975), p.194-195.

40. Zie hiervoor het 'Zur Einfuhrung: Paradigmawechsel in der Systerntheorie', Soziale Systente Frankfurt/M. 1985, p.15 e.v.

41. Verg. o.a. H.Willke, Systemtheorie, Stuttgart 1991, p.3-7. 
of met dat van Buckley en Deutsch - voor zo iemand moet de hedendaggse zelfreferentièle systeemtheorie onherkenbaar zijn geworden:

Zelfrefentielle systemen zou men in eerste aanloop kunnen omschrijven als systemen die in staat zijn betrekkingen tot henzelf te organiseren en deze te onderscheiden van betrekkingen tot hun omgeving. ${ }^{42}$ In conoreto gat het daarbij om terugkoppelingsprocessen, om de recursieve toepassing van systeemprocessen op systeemprocessen, om kringlopen, etc. Men herkent natuurlijk het circulariteitsprobleem, $m_{\text {, }}$ beter: de poging om aan circulaire structuren een positieve, productieve betekenis toe te kennen. Dat laatste vormde althans het uitgangspunt van de pioniers van de zelfreferentiele systeemtheorie, mensen als Von Foerster, Zopf, Ahsby en Yovits, die al vroeg in de jaren zestig met modellen van 'zelf-organisatie' experimenteerden. $\mathrm{Nu}$ concentreerde de theorie van 'zelf-organiserende systemen' zich op het niveau van systeemstructuren; men onderzocht 'zelfreferentie' m.a.w. in de vorm van zichzelf structurerende structuren. Deze exclusieve betrekking op structuren is inmiddels losgelaten. Zelfreferentie, zo is de gedachte, kan op allerlei niveaus worden aangetroffen, kan alles wat binnen een systeem als eenheid functioneert, betreffen, met als gevolg dat vandaag de dag vrijwel iedere theorie die met circulaire modellen werkt tot het overkoepelende paradigma van de zelfreferentiële systeemtheorie wordt gerekend - de chaos-theorieen van Prigogine en Atlan, de 'synergetica' van Haken, de 'second order'-cybernetics van Von Foerster, de 'autopoiesis'-theorieen van Maturana en Varela, het kentheoretisch constructivisme van Von Glasersfeld en Roth, etc. ${ }^{43}$

In zijn eigen overstap naar de theorie van zelfreferentiele systemen heeft Luhmann zich aanvankelijk vooral laten leiden door de 'autopoiesis'-theorie van de Chileense biologen Maturana en Varela. ${ }^{44}$ Deze theorie was in eerste instantie geformuleerd als een antwoord op de vraag, wat levende systemen onderscheidt van niet-levende systemen. Het bijzondere van levende systemen, zo stelden Maturana en Varela, was hun autonomie in de produktie en reproduktie van hun componenten, een 'autopoiesis" (= 'zelfproduktie') die ze realiseren door systeemprocessen circulair te organiseren. ${ }^{45}$ In een wat uitgebreidere formulering: Autopoietische systemen zijn dynamische systemen die, als totaliteit beschouwd, een netwerk voorstellen van producties van componenten die a) door hun interacties op recursieve wijze het produktie-

42. Zie o.a. N. Luhmann, Soziale Systeme, op cit, p.31

43. Zie voor een overzicht in vogelvlucht: G.Roth/H:Schwegler (ed), Self-organizing systems. An interdisciplinary approach, New York 1981; P.Dumouchel/J-P.Dupuy (ed.), L'autoorganisation. De la physique au politique, Paris 1983.

44. Zie voor een algemene inleiding op het autopoiesisconcept en woor een eerste overzicht over toepassingen en discussies: M. Zeleny (ed.) Autopoiesis; $A$ Theory of the living Organization, New York 1980.

45. Verg. F.Varela/HMaturana/R. Uribe, "Autopoiesis: The organisation of living systems, its characterization and a model', in: Biosystems $5(4)$, p.187-196. Zie wan hen ook het artikel: "Mechanism and Biological Explanation", in: Philosophy of Science 29, 3 (sept. 1971) 
netwerk dat hen produceerde, regenereren, b) dit netwerk tot stand brengen als een eenheid en wel door de binnen het systeem geprefereerde interacties te specificeren en zo systeemgrenzen te conistitueren. ${ }^{46}$ Een levende cel bijwoorbeeld is een autopoietisch systeem in zoverre het netwerk van produktie- transformatie- en destructieprocessen (anabolische en katabolische processen) de componenten (macromoleculen en organellen) tot stand brengt die door hun interacties het netwerk reproduceren dat deze componenten tot stand bracht. In een wat vlakkere formulering: het gaat om systemen waarwan de processen in een kringloop zijn geschakeld die daarmee - Luhmann zou zeggen: door te 'processeren' - zichzelf als een eenheid reproduceert.

De grote aantrekkingskracht van dit model school voor Luhmamn in de vingerwijzing die het gaf voor de formulering van een theorie van zelfreferentiele systemen, die de beperkingen van de oudere "zelf-organisatie"theorieèn zou kunnen overstijgen. In principe bood de autopoiesis-theorie een model van 'zelf-constitutie middels zelfreferentie' dat, aldus Luhmann, betrekking heeft op alles wat binnen een bepaald soort systemen als 'eenheid' of "element" fungeert en niet uitsluitend op "organisatie", d.w.z. op relaties tussen de relaties van het systeem. Nog voor de publikatie van Soziale Systeme prees Luhmann de autopoiesis-theorie als volgt aan:

'Besonders die Erstreckung des Einheitskonzepts auf die Konstitution der Elemente, aus denen das System besteht, ist als innovative Theorieleistung zu werten. Im Anschluß an einen terminologischen Vorschlag von Humberto Maturana spricht man zunehmend auch von 'autopoietischen' Systernen; um diesen Theoriegewinn festzuhalten. Es geht also nicht mehr nur um 'Bestand' oder 'Bestandserhaltung', auch nicht mehr um Probleme der "Selbstorganisation", die nur die Strukturebene betreffen. Es geht um die Elemente, aus denen das System besteht. $^{.47}$

We zullen in volgende hoofdstukken nog zien, hoe deze interesse voor een geradicaliseerd model van zelfreferentie, dat ook nog de constitutie wan de meest elementaire eenheden van een systeem omvat, samenhangt met Luhmanns kritiek op subjectivistische of intentionalistische handelingstheorieenn en met zijn poging om 'handelingen' als in en door sociale systemen zelf geproduceerde eenheden te begrijpen. Hier gaat het in eerste instantie om de algemene principes achter het model van 'zelfconstitutie door zelfreferentie'. Hoezo en in welke zin hebben zelfreferentie en zelfconstitutie iets met elkaar te maken?

46. H. Maturana, 'Glossary', in: F.Benseler/P.Hejl/W.KBck (Hrsg), Autopoiesis, Communication and Society, Frankfurt/M. 1980, p.29 - in parafrase.

47. N. Luhmann, "Die Einheit des Rechtssystems', Rechtstheorie 14 (1983), p.131-132. 
We kennen het idee van een zelfverwijzing die constitutief is woor de identiteit van het 'zelf' dat naar zichzelf verwijst, natuurlijk uit de klassieke (Duitse) bewustzijnsfilosofie. ${ }^{48}$ Deze lokaliseerde, transcendentaaltheoretisch argumenterend of diallectisch, de identiteit van het denkend subject in het 'zelfbewustzijn'. Daarmee werd getracht een antwoord te geven op het door Locke geforceerde probleem, hoe een 'Ik' door de tijd heen met 'zichzelf' identiek kan blijven. Van deze beperking tot het subject trekt de zelfreferentiele systeemtheorie zich echter weinig aan. Accepteert men namelijk het idee dat 'leven' zich kenmerkt door een circulaire organisatie van anabolische en katabolische processen, dan kan men inderdaad zeggen, dat systeemprocessen voortdurend naar systeemprocessen verwijzen, oftewel dat een levend systeem op het niveau van zijn operaties voortdurend naar zichzelf verwijst. Dit, zo stelt de autopoiesis-theorie is precies de manier waarop een levend systeem zijn autonomie t.o.v. de omgeving realiseert, zichzelf als een eenheid constitueert onder uitsluiting van andere interacties, van andere mogelijke processen.

Vooralsnog is daarmee alleen toegelicht, hoe men zich de verhouding tussen zelfreferentie en zelfconstitutie op het niveau van het overkoepelend systeem kan voorstellen. De constitutie van systeeminterne componenten laat zich hiervan echter afleiden met behulp van het concept van 'indirecte zelfreferentie'. ${ }^{9}$ We kunnen namelijk zeggen, dat iedere afzonderlijke operatie binnen het systeem weliswaar naar andere operaties verwijst - iedere produktie van een systeemcomponent 'verbruikt' de uitkomst van voorafgaande productieprocessen, om zelf weer het 'materiaal' van tansluitende processen te vormen - maar dat, gegeven de circulaire structuur wan de totale organisatie; afzonderlijke operaties daardoor hun eigen heroptreden mogelijk maken. Door naar 'jets anders' te verwijzen, naar andere operaties, verwijzen de afzonderlijke operaties indirect weer naar zichzelf en dit als de vorm waarin ze ook hun eigen heroptreden mogelijk maken. Dit model kan, in de voetsporen van Luhmann, worden losgeweekt van typisch fysiologische of biologische voorstellingen, wanneer we in herinnering roepen, dat de circulaire geslotenheid en afgrenzing van autopoietische systemen tot stand word gebracht door, binnen dergelijke systemen structureel verankerde preferenties voor bepáálde voortzettingen van systeemprocessen bowen andere mogelijke voortzettingen. Niet alles kan op alles volgen. Anders geformuleerd: alleen door aan te sluiten op een systeemspecifieke operatie en aansluitingsmogelijkheden te bieden voor opvolgende systeemspecifieke operaties kan een bepaalde operatie zichzelf als een typisch tot het systeem behorende operatie realiseren. Ook hier weer het model van indirecte zelfreferentie als vorm van elementconstitutie - "Gemeint ist die Fähigkeit, sich selbst durch eine Kombination von 'self-identity' und

48. Zie voor een samenvattend overzicht: D. Henrich, 'Identitat", in: O.Marquard/K.Stierle (Hrsg.), Identität, München 1979.

49. Verg. o.a. Soziate Systeme, op.cit, p.60. 
'self-diversity' intern zu bestimmen und dabei zugleich Spielraum zu lassen für externe Mitbestimmung." ${ }^{30}$

Dit alles klinkt natuurlijk nogal abstract, maar men kan zich een intuitieve voorstelling van het achterliggende idee maken, door aan een alledaags iets als "politiek handelen" te denken. Wij zijn in het algemeen niet geneigd een handeling 'politiek' te noemen, wanneer deze niet reageert op politieke processen noch politieke handelingen uitlokt of uberhaupt iets in de politiek bewerkstelligt. Wat een handeling een politieke handeling maakt; zo zou men kunnen stellen, is het feit dat de handeling is opgenomen in een langer lopend proces, dat we op een of andere manier als een 'politiek proces' opvatten. En nü, met Luhmann, weer abstracter: alleen door zijn aansluitingswaarde ('Anschlußfähigkeit') binnen het politiek systeem kan een handeling als 'politieke handeling" een element van het politiek systeem vormen. Natuurlijk vooronderstellen politieke handelingen intenties en dus bewustzijnsprocessen en dus een functionerend biologisch systeem en dus.....etc. Natuurlijk vooronderstelt, algemener gesproken, de constitutie van elementen binnen autopoietische systemen een complexe, materiële onderbouw. Het model van 'zelfconstitutie door zelfreferentie' stelt dan ook niet dat autopoietische systemen hun eilgen fysische, chemische, biologische, etc. materialiteit produceren, maar slechts dat datgene, wat binnen dergelijke systemen als eenheid of element fungeert, zijn eigenschap een systeem-element te zijn aan het systeem ontleent. Systeem-elementen verschijnen hier als entiteiten die emergeren op basis van zelfreferentièle processen. Als zodanig kan hun betekenis en functie niet herleid worden tot de eigenschappen van hun materiële onderbouw. Luhmann:

'Entscheidend ist die Einsicht, daß Elemente, was ihre Energie/Materie-Basis betrifft, immense: Komplexität voraussetzen, aber trotzdem in Systemen alls für das jeweilige System nicht auflosbare Einheiten fungieren - also zum Beispiel als Molekule, Zellen, Vorstellungen, Handlungen. Die für das System nicht dekomponierbare Einheit eines Elements kann nur durch das System konstituiert sein; sie ergibt sich aus ihrer im System hergestellten Anschlußfahigkeit. ${ }^{\text {,s1 }}$

De door Luhmann gezochte generalisering van het autopoiesis-concept, de uitbreiding ervan tot alle 'eenheden' van een systeem, zelfs de meest elementaire, kan nu middels een simpele formule worden weergegeven: autopoietische systemen zijn systemen die de elementen waaruit ze bestaan,

50. Idem, p.393.

51. N. Luhmann, 'Die Einheit des Rechtssystems', op.cit., p.132; zie voorts Saziale Systeme, op.cit, bijvoorbeeld p.245/246. 
produceren en reproduceren middels de elementen waaruit ze bestaan. Overigens geeft Luhmann er vandaag de dag de voorkeur aan om over 'zelfreferentieel gesloten' systemen te spreken i.p.v. over 'autopoietische' systemen. Dit vanwege de wat mystieke geur die in de loop van de jaren tachtig rond de term 'autopoiesis' is komen te hangen. In feite vormen 'autopoiesis' en 'zelfreferentie' bij Luhmann twee zijden van dezelfde medaille. ${ }^{52}$ De hierboven gegeven, algemene bepaling van een autopoietisch systeem kan dan ook als volgt worden geformuleerd:

'Ein System kann man als selbstreferentiell bezeichnen, wenn es die Elemente aus denen es besteht, als Funktionseinheiten selbst konstituiert und in alle Beziehungen zwischen diesen Elementen eine Verweisung auf die Selbstkonstitution mitlaufen läßt, auf diese Weise die Selbstkonstitution also laufend reproduziert. ${ }^{, 53}$

\section{§. De autonomie van zelfreferentiële systemen: geslotenheid en temporaliteit}

Wat in vergelijking met de vroegere systeem/omgevingstheorieën naturlijk in het oog springt, is, dat de theorie van zelfreferentielle systemen niet meer van de 'openheid' van systemen uitgaat, maar van een primaire 'geslotenheid'. Deze 'geslotenheid' impliceert geenszins een terugkeer naar de 'gesloten' systeemconcepties van de $18 \mathrm{de}$ en 19 de eeuw, in reactie waarop Bertalanffy c.s. het 'open systeem'-model hadden ontwikkeld. De vroeg-moderne opvatting van 'systemen' als omvattende, in zichzelf besloten totaliteiten werd nog beheerst door het klassieke deel/geheel-probleem, d.w.z. door de vraag naar de ontologische en/of epistemologische functie en eigenaard van een 'geheel'. als de eenheid van zijn delen. De geslotenheid die de 18 de- en 19de-eeuwse systeemconcepties kenmerkt, is vervolgens een consequentie van de, met het systeembegrip verzilverde, holistische oplossing van dit probleem: de delen zijn wát ze zijn door en op grond van hun positie binnen het overkoepelende geheel. Zo definieert Lambert in zijn Fragment einer Systematologie (1787) (dus nog vóór Kants Kritik der Urtheilskraft) 'systeem' als 'den Zusammenschluß eines Vielfältigen zu einem gegliederten, in sich geschlossenen Ganzen in dem das

52. 'Der Begriff Selbtsreferenz bezeichnet die Einheit, die ein Element, ein ProzeB, ein System fur sich selbst ist', heet het al in Soziale Systeme. - 'De Begriff definiert nicht mur, er enthath auch eine Sachaussage, denn er behauptet, daß Einheit nur durch eine relationierende Operation zustandekommen karn; daB sie also zustandegebracht werden mul und nioht als: Individuum, als Substan, als Idee der eigenen Operation immer in voraus schon da ist." (Soziale Systeme, op cit., p.58.)

53. Soziale Systeme, op.cit, p.59. 
Einzelne im Verhältnis zu den anderen Teilen, seinen sowohl genau bestimmten wie auch bestimmbaren Ort eimnimt ${ }^{{ }^{54}}{ }^{4}$

De 'geslotenheid' die door de zelfreferentièle systeemtheorie op de voorgrond wordit geplaatst, staat niet meer in het teken van het deel/geheel-probleern, maar in het teken van autonomie. 'Geslotenheid' is hier eerst en vooral de geslotenheid van de circulariteit die in alle zelfreferentie huist, waarbij zelfreferentialiteit gezien wordt als de voor bepaalde systemen typische vorm van constitutic en behoud van eenheid tegenover de omgeving. Deze, door zelfreferentièle sluiting tot stand gebrachte autonomie houdt miet in, dat dergelijke systemen in geen enkel opzicht afhankelijk zouden zijn van hun omgeving. Misschien vervallen we in herhaling, maar natuurlijk geldt, dat een autopoietisch systeem, zoals bijvoorbeeld een plant, een dier, een mens of een sociaal verband, zichzelf reproduceert in een omgeving en dat het zonder die omgeving ook niet zou kunnen bestaan. "If it were not continually irritated, stimulated, disturbed and faced with changes in the environment", zo stelt Luhmann, "it would after a short time terminate its own operations, cease its autopoiesis." De autonomie van zelfreferenticel gesloten systemen houdt evenmin in, dat dergelijke systemen een volledige controle hebben over het geheel van de materiële condities en oorzaken van hun eigen bestaan als systeem. Autonoom is een systeem voorzover het zijn afhankelijkheden en onafhankelijkheden zelf kan reguleren. ${ }^{55}$ Het idee is, dat gesloten systemen weliswaar door gebeurtenissen in hun omgeving geprikkeld kunnen worden, dat de omgeving 'ruis' kan veroorzaken, kan irriteren etc., maar dat de ongeving de processen en structuurontwikkelingen binnen zulke systemen niet kan determineren. Welke gebeurtenissen of standen van zaken in de omgeving voor het systeem een aanleiding vormen om met interne veranderingen te reageren, wordt door het systeem zelf bepaald en wel op grond van intern ontwikkelde observatiemogelijkheden, beoordelingscriteria en reactie-capaciteiten. In een, door Luhmann vaak gebezigde omschrijving: De omgeving kam een zelfreferentieel gesloten systeem niet causaal beïnloeden, als dat systeem niet zelf doaraan mee werkt-

'Selbstreferentielle Systeme sind in dem Sinne geschlossene Systeme, daß sie ihre eigenen Elemente und damit auch ihre eigenen Strukturänderungen selbst produzieren. Es gibt keinen direkten Kausalzugriff der Umwelt auf das System ohne Mitwirkung des Systems. ${ }^{56}$

54. Geciteerd naar A vom der Stein, "Der Systembegriff in seiner geschichtlichen Entwicklung", in: A.Diemer (Hrsg.), System und Klassifikation in Wissenschaft whd Dakumentation, Meisenheim/Glan 1968, p.11.

55. Verg. Idem, 345 en N.Luhnann, Die soziologische Beobachtung dess Rechts, Frankfurt/M. 1985, p. 12.

56. Soziale Systeme, op.cit., p.478. 
Deze veranderde inschatting van de verhouding tussen systeem en omgeving wordt binnen de zelfreferentiële systeemtheorie tot uitdrukking gebracht middels het theorema van de 'openheid op basis van geslotenheid'. Daarmee is niet alleen een basaal kenmerk van zelfreferentieel gesloten systemen beschreven, maar tevens een centraal probleem aangekaart. Pure zelfreferentie, directe circulariteit is steriel, is informationeel leeg. (Stel je - met Roth, Luhmann of Varela - het menselijk bewustzijn eens voor als een zelfreferentieel gesloten systeem dat op grond van de circulaire organisatie van zijn processen zou blijven ronddraaien in 'ik ben ik, ben ik, ben ik...'! In dergelijke tautologieèn verstrikt, zou onze evolutionaire trots, het menselijk voorstellingsvermogen, weinig voordelen bieden.) Zelfreferentieel gesloten systemen moeten hun zelfreferentie onderbreken, zichzelf 'openen' voor informatie 'van buiten', willen ze niet aan de toevalligheid en willekeur van hun uitgangspositie ten onder gaan. En op het 'toegepaste' niveau, op het niveau van het onderzoek naar concrete systemen, is dan telkens de cruciale vraag, hoe een reeel bestaand systeem dat opereert op basis van geslotenheid, deze 'zelfonderbreking', deze openheid voor elkaar brengt.

Nu kan deze hele constellatie van "zelfreferentialiteit - circulariteit geslotenheid - autonomie - openheid op basis van geslotenheid - tautologie en onttautologisering - etc.' in principe al kant en klaar worden aangetroffen in het werk van o.a. Von Foerster, Maturana, Varela, Gordon Pask, en Joseph Glanville. ${ }^{57}$ Wat Luhmann als zijn eigen bijdrage aan de algemene theorie van zelfreferentiële systemen beschouwt, is de formulering en theoretische precisering van een bijzondere samenhang tussen de autonomie vam zelfreferentieel gesloten, autopoietische systemen en hun 'temporaliteit".

Een "getemporaliseerd" systeem is een systeem dat op een of andere manier de factor tijd weet in te voeren om het veld van eigen mogelijkheden te verruimen, om over meer mogelijke systeemtoestanden te kunnen beschikken. Een getemporaliseerd systeem, zo zouden we ook kunnen zeggen, voert tijd in om complexer te kunnen worden. Het 'temporaliseert complexiteit' en wel in die $z i n$, dat het de selectie-last die met alle complexiteit gegeven is, op de tijd afwentelt. De druk steeds scherper te moeten kiezen, wanneer het aantal mogelijke toestanden die het systeem kan aannemen, oploopt, wordt "dragelijk", hanteerbaar gemaakt door het beslisprobleem in een "na elkaar" te transformeren.

Een radicaal getemporaliseerd systeem is dan een systeem, dat zich kenmerkt door een 'vertijdelijking' van zijn basiselementen. Een radicaal getemporaliseerd systeem is m.a.w. een systeem dat op het meest basale niveau

57. Behalve door het werk van Maturana en Varela is Luhmann tevens in sterke mate beinnloed door Von Foenster. Zie van hem o. a $\mathrm{H}$. von Foerster, Observing Systems, Seaside (Cal.) 1981; zie verder mib.t. autopoiesis, zelfreferentie en autonomie: F.s. Varela, Principles of Biological Amonomie New York 1979.

58. Zie voor deze inschatting Sozicale Systeme, op.cit., p.28; idem p.78 (voetnoot 99). 
uit "gebeurtenissen" bestaat, uit elementen die met hun opkomst alweer vergaan. ${ }^{99}$ Daarbij gaat het niet om de vervanging van afgestorven of kapotte delen, ook niet om transformaties die zich in het stofwisselingsproces tussen systeem en omgeving voordoen. 'Radicale temporalisering' betreft een veel fundamenteler principe, namelijk de dwang voor een systeem zijn basiselementen aanhoudend te moeten produceren; waarbij het geheel en al is aangewezen op zijn eigen selectiecapaciteiten. Uit het geheel van mogelijke gebeurtenissen moeten ze telkens die gebeurtenissen selecteren die aansluiten op het voorafgaande en tevens aansluitingsmogelijkheden bieden voor opvolgende gebeurtenissen. Het gaat, in de woorden van Luhmann, om

"einen eigenartigen Zwang zur Autonomie, der sich daraus ergibt, daß das System in jeder, also in noch so günstiger Umwelt schlicht aufhören wörde zu existieren, wenn es die momenthaften Elemente, aus denen es besteht, nicht mit Anschlußfähigkeit ...ausstatten und so reproduzieren warde' ${ }^{, 60}$

Een systeem dat er in slaagt, zich op deze instabiele grondslag te stabiliseren, dat de aanhoudende flux van compositie en decompositie van zijn basale elementen in de greep weet te krijgen en te conditioneren, kan uiteindelijk een grotere stabiliteit en autonomie t.o.v. de omgeving ontwikkelen, volgens Luhmann, dan systemen die zijn georganiseerd op basis van duurzame elementen. Niet alleen voorkomt het 'gebeurtenis'-karakter van zijn elementen dat een radicaal getemporaliseerd systeem op dit niveau aan de omgeving 'verkleefd' zou kunnen raken; het stelt het systeem bovendien in staat om zijn selectiecapaciteit aanhoudend te benutten. Het kan voortdurend kiezen tussen mogelijke verknopingen van elementen en in het kielzog daarvan tussen mogelijke relationeringsopties en -preferenties. Juist door de instabiliteit van zijn onderbouw, door zijn ingebouwde 'onrust', kan een dergelijk systeem veel flexibeler opereren en sneller op zijn omgeving reageren.

"Chronologisch gesehen nimmt natürlich jedes Element eine gewisse Uhrzeit in Anspruch; aber die Zeitlänge, für die es als nicht weiter auflosbare Einheit behandelt wird, wird vom System selbst bestimmt; sie hat verliehenen, nicht seinshaften Charakter. Entsprechend besteht ein hinreichend stabiles System aus

59. Zis voor een fundsmentele uiteemzetting wam 'temporalisering' en 'getemporaliseerdle complexiteit' biji Luhmann: Soziale Systeme, op.cit., p.76 e.v.; zie voor een, door theoretische problemen met het klassieke handelinsgbegrip geinspireende, sociologische aanloop naar deze concepien: "Zeit und Handlung - Eine vergessene Theorie" en "Temporalstrulkturen des Handlungssystems: Zum Zusammenhang von Handlungs- und Systemtheorie", beide opgenomen in: Soziologische Aufklärung 3, Opladen 1981.

60. Soziale Systeme " op cit. p. 28. 
instabilen Elementen; es verdankt seine Stabilität sich selbst, nicht seinen Elementen; es baut sich auf einer gar nicht 'vorhandenen' Grundlage auf und ist gerade in diesem Sinne ein autopoietisches System. ${ }^{361}$

\section{§7. Voorbij structuur}

We hebben eerder gezien hoe Luhmann met zijn functioneel-structuralistische variant van het systeem/omgevingsdenken' al afscheid had genomen van het probleem van 'Bestandserhaltung' (Habermas). Niet de reproductie en stabilisering van een cruciaal geacht bestand van kernstructuren vormde nu het centrale probleem, maar - veel rumer - de aampassing van het systeem aan zijn (overcomplexe) omgeving, een aanpassing die zich 0. a. via veranderingen en ontwikkelingen op het structuumiveau kon voltrekken. Met de overgang van het systeem/omgevingsmodel naar autopoiesis, van "dynamische" systemen naar 'radicaal getemporaliseerde systemen', verliest vervolgens ook het aanpassingsbegrip zijn prominente plaats. Het algemene complexiteitsprobleem manifesteert zich nu eerst en vooral als het probleem hoe gebeurtenis op gebeurtenis kan volgen en wel als een opeenvolging van telkens systeemspecifieke gebeurtenissen. Hoe slagen autopoietische systemen er m.a.w. in, hun elementaire eenheden met een telkens selectieve aansluitingswaarde uit te rusten, zichzelf als een geordende sequentie van telkens andere, maar niet willekeurige gebeurtenissen te reproduceren - 'das Grundproblem liegt hier nicht in der Wiederholung, sondern in der Anschlußfähigkeit' ${ }^{62}$

In het kielzog van deze, men zou haast zeggen: 'internalisering' van het complexiteitsprobleem verliest ook het structuurbegrip definitief zijn "Führungsqualităt". We hebben hierboven opgemerkt, dat autopoietische systemen op het meest basale niveau uit gebeurtenissen bestaan. Wat Luhmann betreft, mag dit worden opgevat, als een uitsprtaak over de "bestaanswijze" van het soort systemen waar hij zich voor interesseert: 'Nur auf der Ebene seiner Elemente ist ein System voll konkretisiert. Nur hier gewinnt ein System zeitweise wirkliche Existenz.' Daarentegen verschijnen de structuren van een autopoietisch systeem als constellaties die complementair zijn aan de basale stroom van opeenvolgende gebeurtenissen. Autopoietische systemen ontwikkelen hun structuren in confrontatie met het grondprobleem van de relatering van gebeurtenissen door de tijd heen. Wanneer alles op alles zou kunnen volgen, wanneer ook de selectiviteit van een zich voltrekkende gebeurtenis niet kan worden benut als vingerwijzing voor de selectie van een nieuwe gebeurtenis uit het geheel van mogelijkheden, dan zou een systeem al 
snel bezwijken. Het basale proces van opeenwolgende gebeurtenissen zou niet eens op gang kunnen komen bij een dergelijk gebrek aan keuze-ondersteunende informatie ${ }^{63}$ Dit probleem van overmatige complexiteit/overmatige selectielast wordt door structuren opgevangen in de vorm van een préselectie, d.w.z. door inperking van het veld van mogelijkheden, of, nog anders geformuleerd: door een scheidslijn te trekken tussen wat wel en wat niet als een systeemconforme voortzetting van de gebeurtenisstroom geldt. Luhmann: 'Eine Struktur besteht ..., was immer sie sonst sein mag, in der Einschränkung der im System zugelassenen Relationen?' In die hoedlanigheid komt aan structuren echter niet dezelfde bestaanswijze, dezelfde concrete existentie toe alls an de elementaire gebeurtenissen van een systeem. Structuren worden in dit model niet gesitueerd op het niveau wan de elementen en hun onderlinge relaties ${ }^{64}$ - want dan zou met iedere gebeurtenis ook "structuur" verdwijnen - en ook niet opgevat als het geheel van relaties tussen relaties; structuren vormen hier een afgeleide, een secundaire realiteit die autopoietische systemen creëren in functie van hun eigen voortgang als een selectief proces ${ }^{\text {s5 }}$ Natuurlijk verschijnen autopoietische systemen altijd als gestructureerde processen. En natuurlijk zou een systeem zonder structureel bemiddelde selectiviteit geen 'systeem' zijn, niet een reductieve ordening van complexiteit -

'Insofern ist Struktur als Selektion eingeschränkter Moglichkeiten in der Konstitution qualifizierter Elemente und damit auch in der Autopoiesis vorausgesetzt; aber sie ist nicht der produzierende Faktor; nicht die Uंr-sache, sondern ist selbst

63. Men stelle zich muziek eens voor als een sequentie van opeenvolgende tonen, onder de radicale conditie dat op iedere toon iedere willekeurige andere toon zou kunnen volgen! En mu roept iemand: "speel mee'. Wat te doen? Hoe kan iemand zonder een enkele aanwijzing uit het geheel van mogelijke tonen precies die tonen selecteren, zodat voldaan wordt aan de opdracht mee te spelen? Wat geldt hier uberhaupt nogg als 'meespelen' en wat als 'toon'? Na een of twee onzekere krassen valt de strijkstok stil - muziek is te complex, de violist kan de last te moeten küezen nièt dragen (niet als nusicus!).

64. Dat was het structurbegrip van het klassieke functionalisme - verg. bijv. A.R. RadcliffeBrown, "On the Concept of Function in Social Science" American Antropologist 37 (1935). p. $397-402$.

65. Daurbij blijt Luhmann overigens wasthouden aan het wit vroeger work reeds bekende model van een gefaseerde reductie van complexiteit door "structurur" en 'proces', zij het dat deze 'strategie' wu scherper geanalyseerd wortt met het oog op de dimensie 'tijd'. Door tussen structuur en prowes te differentiëren kunnen systemen enerzijds hun 'interne' tijd van de ongeving afkoppelen en zelf conditioneren, anderzijds het risico dat daarin schuilt, opvangen door irreversibiliteit en reversibilliteit ('het ongedaan kunnen maken') over proces en structuur te verdelen. 'Strukturen halten Zeit reversibel fest, denn sie halten ein begrenztes Repertoire von Wahlmoglichkeiten offen. Man kan sie autheben oder andern oder mit ihre Hilfe Sicherheit für Anderungen in anderen Hnsichten gewinnen. Prozesse markieren dagegen die Irreversibilität der Zeit. Sie bestehen aus irreversiblen Ereignissen. '(Soziale Systeme, p.73/74) 
nichts anderes als das Eingeschränktsein der Qualităt und Verknupfbarkeit der Elemente. ${ }^{, 66}$

Structuur, zo zouden we aan deze 'ontologische relativering' kumen toevoegen, is zelf selecteerbaar, iedere gegeven structuur een door het systeem zelf tot stand gebrachte selectie uit meerdere inperkingsmogelijkheden.

We zullen in nog komende hoofdstukken, en dan met name aan de hand van 'sociale systemen', nader ingaan op Luhmanns structuurbegrip en precieser bestuderen hoe de 'zelfstructurering' van een (sociaal) systeem zich in concreto voltrekt. Hier is de meer algemene constatering van belang, dat, parallel aan de ontologische relativering van structuren, het structuurbegrip tevens zijn centrale positie binnen het conceptuele raamwerk heeft verloren, een 'tweede orde'categorie is geworden. Natuurlijk is deze dekwalificatie relatief. Het is bijvoorbeeld niet zo, dat de zelfreferentiële systeemtheorie het voortaan zonder structuurconcept(en) zou kunnen stellen. Zo schrijft Luhmann dat het struktururbegrip weliswaar zijn 'Zentralstellung' heeft verloren, maar 'Kein Systemtheoretiker wird leugnen daß komplexe Systeme Strukturen ausbilden und ohne Struktur nicht existieren könnten'. Echter: 'Der Strukturbegriff ordnet sich nun aber ein in ein vielfältiges Arrangement verschiedener Begriffe, ohne Führungsqualität $\mathrm{zu}$ beanspruchen."

De devaluatie van het structuurbegrip mag dan relatief zijn, desalniettemin heeft het een aantal theoretische en methodologische consequenties die de hele 'Gestall' van Luhmanns benadering betreffen. Precies omdat structuren nu niet meer op het niveau van de elementen en hun onderlinge rellaties worden gesitueerd, kunnen structuren ook niet langer worden begrepen als die instanties, die op een of andere manier de elementen en/of processen van het systeem. determineren. In oppositie met zowel causaal-deterministische structuuropvattingen (Marxisme, Cybernetica); als de klassiek structuralistische visie op structuren als regelsystemen die de orde achter de bonte veelheid van verschijnselen representeren, verschijnen structuren bij Luhmann als een soort. richtingwijzers. Ze geven aan in welke richting systeemconforme aansluitingen of voortzettingen van het basale proces kunnen worden gevonden, maar zonder dergelijke processen te determineren. En dat betekent, dat in principe ook altijd nonconforme, afwijkende voortzettingen van de procesgang mogelijk zijn; dat onder bepaalde voorwaarden zelfreferentieel gesloten systemen kunnen experimenteren met 'onbekende', niet voor-gestructureerde mogelijkheden en dit eventueel als aanleiding voor de bijstelling en vernieuwing van hun eigen structuren kunnen benutten.

Met dit "poststructuralisme" zijn we niet alleen mijlenver verwijderd geraakt van een technisch/technologisch begrip van 'systeem' als een soort sturingsprogramma dat processen regelt. De vraag wordt zo langzamerhand of 
er aberhaupt nog iets 'hards' is, iets dat vast en onveranderlijk is en dat in die hoedanigheid het "systemische" van systemen uitmaakt. Er doemt een beeld op van systemen als gestructureerde processen waarvoor geldt, dat alles ook anders kan zijn, niets noodzakelijk is wat het is, noch op het niveau van de elementen, noch op procesniveau, noch op het niveau van de structuren.

\section{\$. Observeren en onderscheiden}

We hebben inmiddels de term 'observeren' al vele malen gebruikt, er op vertrouwend dat de associaties die er door worden opgeroepen, de begrijpelijkheid van die tekstpassages afdoende ondersteunen. Dat dienen we nu recht te zetten. Achter de uitdrukking 'observeren' gaat bij Luhmann namelijk een epistemologische optie schuil, die ten tijde van Soziale Systeme misschien nog alls een element of deeltheorie kon worden begrepen, maar met Ökologische Kommunikation (1986) al sterker op de voorgrond treedt, om via Die Wissenschaft der Gesellschaft en Soziologische Aufklärung 5 (beide uit 1990), met de publicatie van Beobachingen der Moderne (1992) naar het centrum van zijn theoretisch project op te rukken. ${ }^{67}$ Het aanzicht van Luhmanns systeemtheorie is daardoor dermate veranderd, dat deze als een bijzondere instantie van de 'second order-cybernetics' begint te verschijnen, d.w.z. als een 'tweede orde'-theorie die zichzelf presenteert als een observatie van observerende systemen.

Als leidraad voor de 'inbouw' van het observatieconcept binnen zijn eigen theorie heeft bij Luhmann o.a. het werk van Von Foerster, de cognitie-biologie van Maturana en (bovenal) de 'differentie-logica' van George Spencer Brown gediend ${ }^{68}$ Vertrekpunt vormt het begrip 'refereren'. Een 'referentie' is een operatie die uit twee componenten bestaat, namelijk uit het maken van een onderscheid en het aanduiden of markeren van één van beide zijden van het onderscheid. Spencer Brown is plastischer wanneer hij begint met de

67. Verg in dezen ook W. Fritscher, "Romantische Bieobachtungen", in: Soziale Sysiteme 2 (1996/1), p.35.

68. Zie van George Spencer Brown met name Laws of Form, New York 1979 (1e dr. London 1969). Zie voor de systeemtheoretische appreciatie wan deze differentie-logica o: $\mathbf{a}_{2}$ : D. Baecker (Hrsg.) Kalkül der Fors, Frankfurt/M. 1993 en Idem, Probleme der Form, Frankfurt/M. 1993.

Misschien is dit ook de geeigende plaats om op de rol van Gotthard Günther te wijzen. Luhmann toont zich op vele plaatsen geintrigeerd door diens reflecties op de identiteitslogica en de daaruit voortspruitende ideeën m.b.t. een meerwaardige logica. Op cruciale momenten kiest Luhmann echter niet voor de voorstellen en oplossingen die Günther aandraagt. maar lijkt die eerder te gebruiken mls een soort 'scanner' voor zijn eigen theoretische keuzes. Zie wan Ginther met name Beiträge zur Grwndlegung einer operationsfahigen Dialektik Bd. 1 , Bd.2 "Hamburg 1976, 1979. 
aanwijzing "trek een lijn' (distinction) en 'kies éen kant van de lijn om verder te gaan' (indication). ${ }^{69}$ 'Refereren' gaat over in 'observeren' wanneer de gemaakte onderscheiding wordt gebruikt om informatie te winnen over het geîndiceerde - het is een vrouw! (en niet een man); het systeem! (en niet de omgeving); ik ben het! (en niet de ander); etc. ${ }^{70}$

Observeren bestaat dus, per definitie, uit het benutten van een differentie, waarbij de operatie 'benutten' niets anders inhoudt, dan het markeren van éen kant van de differentie als het 'veld' van aansluitende observaties. Dat is, vergeleken met meer alledaagse noties, een sterk gegeneraliseerde opvatting van 'observeren'. De consequenties zijn navenant. Om te beginnen is 'observeren' niet meer iets typisch menselijks, maar een mogelijkheid waarover veel meer soorten systemen beschikken. Een zee-egel die onderscheid kan maken tussen licht en donker en deze differentie benut voor de vaststelling dat het donker is, observeert. Bovendien moet observeren van 'waarnemen' worden onderscheiden en wel in die zin dat observeren nu niet meer exclusief gekoppeld is aan 'zintuigen', aan biologisch geconstitueerde zintuiglijkheid. Ieder systeem dat onderscheidingen benut ten behoeve van informatiewinning, observeert en dit onafhankelijk van de vraag of de daartoe vereiste capaciteit tot discrimineren biologisch verankerd is of niet. Zo kunnen volgens Luhmann ook communicatieprocessen observeren. Communicatieprocessen maken bijvoorbeeld gebruik van een onderscheid tussen het actuele gespreksthema en alle andere mogelijke thema's, om aan de hand daarvan te controleren of de inbreng van een deelnemer al of niet bijdraagt aan het gesprek - en dit alles zonder dat communicatieprocessen over zintuigen beschikken, zelfs niet over oren.

Uit Luhmanns definitie van 'observeren' volgt bovendien, dat iedere observatie, hoe 'omvattend' deze ook is (d.w.z. hoe algemeen en abstract de benutte differentie ook is), een blinde vlek heef, namelijk de observatie-operatie zelf. Wat in het observeren niet kan worden geobserveerd is de differentie en de indicatie die de observatie constitueert. Weliswaar zijn sommige systemen in staat zichzelf te observeren, hun eigen observatieproces te observeren, inclusief de eerder gehanteerde differenties, maar dit alleen op basis van nieuwe 'distinctions' en 'indications' die op hun beurt de blinde vlek van het dan actuele ("reflexieve) observeren vormen. In cen van Luhmanns roemruchte formuleringen: "[D]as Beobachten benutzt die eigene Unterscheidung als seinen

69. G. Spencer Brown, op.cit, p.3. N.b. de calculus die Spencer Brown met zijn Laws of Form presenteert, behelst een operatieve logica, het soort logica dat we van computerprogrammering kennen en geen representationele/waarheidsfunctionele logica.

70. $\mathrm{Nu}$ zou men kunnen opmerken, dat ook een operatie als "refereren' niet woor miets wordt uitgevoerd, dat normaal gesproken aan iets gerefereerd wordt ter wille van observaties en informatie-winning. "Toch will Luhmann op terminologisch niveau aan het onderseheid tussen "refereren" en "observeren" vasthouden en wel "um die Möglichkeit zu haben, Begriffe wie Systemreferenz und Selbstreterenz ohne Implikation von Beobachtungsmögliohkeiten oder Beobachtungsinteressen verwenden za kơnnen". (Soziale Systeme, op.cit., p.597.) 
blinden Fleck. Es kann nur sehen, was es mit dieser Unterscheidung sehen kann. Es kann nicht sehen, was es nicht sehen kann.' En dat geldt ook voor iedere '2e orde'-observator, ook voor het observeren van de observaties van andere systemen, en dus ook voor de systeemtheoretische observatie van observerende systemen:

'Um dies festzuhalten, kann man auch sagen, dall alles Beobachten, auch das Beobachten von Beobachtungen, auf der operativen Ebene naiv verfährt; oder mit nochmals anderen Worten: daß es in Bezug auf die eigene Referenz unkritisch vorgeht. Auch ein Beobachten von Beobachtungen von Beobachtungen ist davon nicht befreit. Insofern gibt es keine Reflexivitätshierarchien, mit denen sich das Beobachten von seinem gegenstand entfernt und sein Verhältnis zur Realitat mediatisiert: $^{\text {"71 }}$

De constructivistische implicaties van dit differentietheoretisch begrip van observatie zijn niet over het hoofd te zien. Het uitgangspunt van 'second order" cybernetics, daarin bijgestaan door de "vormen'-calculus van Spencer Brown, is precies, dat niet de werkelijkheid het observeren bepaalt (een suggestie waar een 'le orde'-observator niet aan kan ontsnappen), maar het observeren zijn eigen werkelijkheid creëert. ${ }^{72}$ Een 'observatie' is en blijft een systeeminterne operatie. Wát een systeem kan observeren, over welke informatie het beschikt of kan beschikken is dan ook afhankelijk van het systeem zelf, van de intern ontwikkelde observatiemogelijkheden en informatieverwerkingscapaciteiten. Een observerend systeem haalt, bij wijze van spreken, niet een 'stukje realiteit' uit de omgeving naar binnen; wat voor het systeem 'realiteit" is, wordt door het systeem zelf tot stand gebracht. In een formulering van Luhmann:

"The system has available only its own mode of operation and processes information using only its own operations. Everything the system determines about reality in this way remains subject to its own operations ...In the system, therefore, certainty as to

71. Idem.

72. Zo merkt Elena Esposito op: "Die Beobachtung von Beobachtungen wird erst dann interessaint, wenn man nicht won der Welt, sondern von der Beobachtung ausgeht: Die Beobachtung bestimmt den eigenen Giegenstand und nicht umgekehrt. Sie zu beobachten heilot dann, die Beobachitung selbst und die 'Welt' die sie generiert, zu betrachten und beide miteinander in Beziehung zu bringen." (E. Esposito, "Ein zweiwertiger nicht-selbstandiger Kalkal", opgenomen in D. Baecker, Ralkal der Form, op. cit, p. 96-97.) 
reality can be reached only through recursive application of its own operations to the results of its own operations..."

We zullen in het vervolg nog vaker stuiten op de constructivistische inslag die Luhmanns sociologie eigenlijk altijd al kenmerkte, maar die door zijn omarming van de ' $2 \mathrm{e}$ orde'-cybernetica nogmaals wordt versterkt en op de voorgrond geplaatst.

Ons gaat het er nu echter vooral om, de bijzondere verwevenheid van zijn latere systeemtheorie met het observatie-begrip toe te lichten, de intrinsieke relatie tussen 'observeren' als het benutten van differenties en systeemtheorie als het benutten van de specifieke differentie "systeem/omgeving". ${ }^{74}$

Welnu - , observeren, opgevat als het actualiseren van een onderscheid en het aangeven van één zijde van dat onderscheid als aanknopingspunt voor verdergaande observaties, heeft als operatie volgens Luhmann slechts zin, wanneer het zelf in een sequentie van "distinction/indication"-operaties ligt ingebed, of daar in ieder geval het startpunt van vormt: "Beobachtung ist also nie als isoliertes, vergangenheits- und zukunftloses Ereignis möglich'. ${ }^{75}$ Observaties hebben andere observaties nodig, zo zou men kunnen zeggen, om een eigen identiteit te krijgen, een onderscheidbare observatie te zijn (om dan ook de observatie van iets 'onderscheidens', van 'identiteiten' te kunnen zijn). Pas in en door de onderlinge verknoping van referenties wordt duidelijk wat het geîndiceerde, het aangeduide eigenlijk is, waarvan het zich onderscheidt, etc.

Een systeem dat observeert, vormt dus sequenties van observaties - en daarmee produceert het selectiviteit. De zich vormende sequentie van observaties onderscheidt zich van andere, ook mogelijke, maar nu niet gerealiseerde/geselecteerde sequenties. Door te observeren ontstaat m.a.w. een differentie tussen wat wel tot de operationele sequentie hoort en wat niet, tussen 'systeem' en 'omgeving'. Observeren lokt, simpelweg omdat het gebeurt, de systeem/omgeving-differentie uit, althans voor een systeem dat dit observeren

73. N. Luhmann, "Closure and Openness...", op.cit., p.344.

Dus cok wat voor een zelfreferentieel gesloten systeetn de 'omgeving' vormt, wordt door dat systeem zelf gecreeerd Natururlijk kan een buitenstaamder anders observeren dan hat systeem zelf, het geobserveerde systeem in een andere omgeving situeren dan het system zelf zou doen - en dan zien wat het systeem niet kan zien, bijvoorbeeld dat het en onderdeel uitmaakt van een materieel comtinuam, dat er zich woortdurend fysisch-causale processen tussen het systeem en zijn omgeving afspellen, etc. Het geobserveerde systeem zelf kan allteen de omgeving observeren die het zichzelf geef - Jedes selbstreferentielle System hat nur den Umweltkontakt, den es sich selbst ermöglicht, und keine Umwelt "an sich". '(Saziale Systeme, op.cit, p. 146)

74. We zoudien ook kunnen zeggen: 'systeemtheorie alls het benutten van het begrip "systeem", daar het begripsmatig observeren zich volgens Luhmann van het gewone, alledaagse (realistische) observeren onderscheidt door een specificatie van "do andere zijde" van de differentie, bijv. wanneer het observeren overgaat van de differentie risico'niet-risico naar de differentie risico/gevaat.

75. N. Luhmann, "Vorwort' bij Soziologiache Auffldarung S, Opladen 1990, p.9. 
observeert, wat natuurlijk ook in de vorm van 'zelfobservatie' kan geschieden. Luhmann:

'Die bloße Tatsache, daß er als Beobachter operiert, setzt ihn der Beobachtung mit dem Schema System/Umwelt aus. Auf der Ebene der Beobachtung zweiter Ordnung, auf der Ebene der Beobachtung von Beobachtern identifiziert man deshalb Systeme, die ihre Umwelt oder sich selbst beobachten. ${ }^{36}$

Lokt observeren als zodanig al de systeem/omgeving-differentie uit, tegelijkertijd moet men vaststellen dat het soort systemen waar Luhmann zich voor interesseert - zelfreferentieel gesloten systemen - noodzakelijkerwijs observeren en wel uitgaande van een intern gehandhaafde systeem/omgevingdifferentie! Het centrale uitgangspunt van de theorie van zelfreferentiele systemen was irmmers, dat dergelijke systemen zichzelf constitueren door zich in hun elementaire operaties op zich zelf te betrekken. Dat is slechts mogelijk wanneer een onderscheid kan worden gemaakt tussen het 'zelf' en het 'nietzelf", tussen wat tot het eigen systeem behoort en wat daarvan is uitgesloten, tot de omgeving behoort. Willen zelfreferentieel gesloten systemen zich kunnen vormen, dan moeten zij dus in staat zijn zichzelf te observeren en wel als een systeem dat zich in en door de selectiviteit van de eigen procesgang onderscheidt van de omgeving. Al hun operaties moeten begeleid gaan van een 'mee-lopende' zelfobservatie. ${ }^{77}$ In een samenvatting van Luhmann:

'Selbstbeobachtung ist demnach die Einfuhrung der System/Umwelt-Differenz in das System, das sich mit ihrer Hilfe konstituiert; und sie ist zugleich operatives Moment der Autopoiesis, weil bei der Reproduktion der Elemente gesichert sein muß, daß sie als Elemente des Systems und nicht als irgendetwas anderes reproduziert werden. ${ }^{, 78}$

Behalve als samenvatting van het voorafgaande, zouden we het bovenstaande citaat eveneens kunnen lezen als een observatietheoretische herformulering van de stelling, dat ook zelfreferentieel gesloten systemen het niet zonder omgeving kunnen stellen, slechts onder 'ecologische' voorwaarden kunnen bestaan. Autopoiesis veronderstelt zelfbeschrijving en dat veronderstelt weer dat het systeem minimaal over het systeem/omgeving-onderscheid beschikt. De constitutie van een eigen identiteit, zo zouden we kunnen zeggen,

76. Idem.

77. We herkennen hierin natuurlijk een grondfiguur van het reflexiviteitsdenken, van het model van 'zelfconstitutie door zelfreferentie' - we herkennen kortom Kant's 'Das 'Ioh denke' das alle meine Vorstellungen begleitet'.

78. Soziale Systeme, op.cit., p.63. 
vooronderstelt, dat een zelfreferentieel gesloten systeem 'omgeving' internaliseert - 'weil gerade [ihre] Operationen nicht unter der Prämisse des Solipsismus ablaufen können (man könnte auch sagen: weil alles was in ihr eine Rolle spielt, einschließlich das Selbst selbst, per Unterscheidung eingefuhrt werden muß). ${ }^{79}$

Het grote voordeel van deze observatie- of differentietheoretische beschrijving van identiteitsconstitutie is $\mathrm{nu}$, volgens Luhmann, dat het de formele structuur aan het licht brengt van een tweetal fundamentele problemen die onlosmakelijk met het ontstaan en de ontwikkeling van zelfreferentieel gesloten systemen verbonden zijn, namelijk 'tautologie' en 'paradoxie'. In abstracto kunnen we namelijk wel stellen, dat de vorming van een zelfreferentieel systeem 'omgeving" vooronderstelt; echter, een systeem dat zichzelf observeert op basis van de systeem/omgeving-differentie, observeert zijn eigen identiteit in eerste instantie slechts als een tautologie. Het is wat het is, namelijk niet zijn omgeving. ${ }^{80} \mathrm{Nu}$ levert tautologische zelfreferentie op het niveau van identiteitsconstitutie een systeem niet alleen uit aan de willekeur van een aanvangstoestand, maar bovendien volstaat één enkele negatie om deze “kortgesloten" zelfobservatie in een paradox te transformeren ${ }^{81}$ -

'Sie wird paradox wenn die Möglichkeit des Verneinens hinzu genommen wird und man die Verneinung entweder auf das referierende oder auf das referierte Selbst beziehen und zwischen diesen beiden Möglichkeiten auf Grund der Selbstreferenz, nicht entscheiden kann. Paradox werden heißt: Verlust der Bestimmbarkeit, also der Anschlußfähigkeit für weitere Operationen. ${ }^{82}$

79. Idem, p.25.

80. Verg. o.a. N. Luhmann, Die soziologische Beobachrung des Rechts, op.cit, wan dit probleom als volgt op het rechtssysteem wordt betrokken: 'Selbstreferentielle Systeme beobachiten ihre eigene Identität als Tautologie...Es gibt fur sie keine 'Kriterien' ihrer Identitat. So ist fur das Rechtssysteem Recht, was fur das Rechtssysteem Recht ist, und nur externe Beobachiter, zum Beispiel Soziologen, können dem Rechtssystem gegebenenfalls vorwerfen, dab es tober Recht disponiert, die dem Beobachter als Unrecht, zum Beispiel als Ausdruck einer Klassengesellschaft oder als mangelnde Aufklarung tber vernunttige Grunde erscheint.' (p.15)

81. Luhmanin definieert een "paradox" als een "sinvoll zugelassene Aussage, die gleichwohl zu Antinomien oder zu Unentscheidbarkeiten fulhrt'. (N. Luhmann, 'Das Erkenntnisprogramm des Konstruktivismus und die unbekannt bleibende Realität, in: Idem, Soziologische Aufklarung 5, op.cit., p.48.) In 'Paradoxie der Form" voegt hij daaraan toe, "dak man den Begriff der Paradoxio nicht über den Begriff des logischen Widerspruchs definieren kann'. (op.cit., p. 212) Daarin schuilt overigens weinig nieuws. Wormell merkte eind jaren vijftig al op: 'The paradoxes are not contradictions. They are not statements which point in two or more incompatible directions, but statements which oscillate between different direotions and fail to point in any one steady direction.' (C.P. Wormell, 'On the Pradoxes of Selfreference', in: Mind LXVII (1958), p. 271.)

82. Soziale Systeme, op.cit, p.59. 
En dàt een negatie deze zelfreferentielle cirkel binnentreedt is onvermijdelijk, is met de 'blinde vlek' die het observeren eigen is, altijd al gegeven. Een systeem dat zichzelf observeert, observeert namelijk niet deze zelfobservatie, maar zichzelf. Immers, de distinction/indication-operatie die aan deze zelf-observatie ten grondslag ligt, kan niet tegelijkertijd worden benut én geobserveerd - de observatie is zijn eigen blinde vlek. Maar dat betekent, dat zelfobservatie het observeren van een zelf is, dat precies niet kan observeren wat het op dat moment zelf is, namelijk een zichzelf observerend zelf! Compacter: Een systeem dat zichzelf observeert, observeert niet (en wel) zichzelf.

Algemener beschouwd, stelt deze paradox een bijzondere instantie voor van een "re-entry"-probleem, d.w.z. van een probleem dat ontstaat wanneer een onderscheid binnen datzelfde onderscheid weer wordt ingevoerd. Een systeem dat zichzelf observeert op basis van het systeem/omgeving-onderscheid voert een onderscheid in binnen iets (namelijk binnen zichzelf) dat deze differentie al vooronderstelt als voorwaarde van zijn eigen bestaan. Er zijn dan twee differenties in het spel, die als één en dezelfde worden behandeld (namelijk als de 'systeem/omgeving-differentie'), terwijl tegelijkertijd moet worden aangenomen dat ze niet identiek zijn. 'Sie ist dieselbe und nicht dieselbe. Sie ist dieselbe, weil der Witz des re-entry gerade darin besteht, dieselbe Unterscheidung rekursiv auf sich selbst anzuwenden; sie ist eine andere, weil sie in einen anderen, in einen bereits unterschiedenen Bereich eingesetzt wird." Een zelfreferentieel gesloten systeem, zo zouden we de zaak kumnen samenvatten, staat voor het probleem zichzelf te moeten observeren en wel in eerste instantie als de tautologie die het zelf niet is; het staat voor het probleem de willekeur van een tautologische identiteit te moeten doorbreken en aan de blokkerende, de eigen procesgang frusterende werking van paradoxaliteit te ontsnappen. Dat we deze problematiek met behulp van het begrip 'observeren' kunnen uitprepareren, is pure winst, volgens Luhmann. Het eerst nog algemeen geformuleerde probleem van de "aansluitbaarheid - hoe slagen autopoietische systemen er in gebeurtenis op gebeurtenis te laten volgen als een systeemspecifiek proces? - krijgt nu een structuur die door de theoreticus systematisch kan worden uitgebaat. We kunnen nu de vraag stellen hoe systemen er in slagen tautologieën te doorbreken en paradoxen af te bouwen. We kunnen daarbij observeren, wat het systeem zelf niet kan observeren, namelijk dat het zijn identiteit op basis van een paradox constitueert, dat de vraag naar het "zell' geen grond heeft, nooit bij het 'zelf zelf kan uitkomen, dat het systeem voor zichzelf uiteindelijk ondoorgrondelijk blijft. ${ }^{33}$ We kunnen als

83. Luhmann": 'Auf einer Ebene der Beobachtung zweiter Ordnung kamn man dan sehen und sagen...daB die Paradoxie oberhaupt nur dadurch entsteht, daB ein Beobschter versucht. Einheit und Unterschiedenheit zugleich zu beobachten. Ein Beobachter zweiter Ordnung kann also sehen, dal ein anderer Beobachter auf dieses problem auflâuf, wenn or versucht zu beobachten, wie (mit welcher Unterseheidung) er beobachtet.' (N. Luhmann, 'Die Paradoxie der Form", opgenomen in: D. Baecker, Kalkül der Form, op. cit., p. 204.) 
buitenstaander observeren hoe deze innerlijke ondoorgrondelijkheid het systeem voor verrassingen plaatst, voor het onverwachte, niet gestructureerde, chaotische, en hoe het hier in eerste instantie 'blind' mee om moet gaan, namelijk als 'ruis', als verstoring. ${ }^{84}$ We kunnen zien hoe tautologie en paradoxie als katalysatoren van systeemontwikkeling dienen, als prikkel voor de op-en uitbouw van systeemstructuren, hoe ze niet 'verbruikt' worden, maar terug keren in de oplossingen die het systeem hanteert. ${ }^{85}$ Hoe structururvorming de transformatie van tautologe en paradoxe aanvangscondities is, hun bewrerking en verwerking tot hanteerbare problemen en irritaties. ${ }^{85}$

"Zoek de paradox en gij zult vinden", zo zou Luhmanns huidige credo kunnen luiden. ${ }^{87}$ In een formulering van Walter Reese-Schafer: "Luhmanns Theorie versteht sich geradezu als Spurprogramm fur Paradoxien, Widerspruche und Tautologien, also für all das, was in der Logik als anstoßig gilt.' Maar als Luhmann zijn inschatting van de positieve, katalytische functie van paradoxen werkelijk serieus neemt, dan moet hij ook bereid zijn deze op het $2 \mathrm{e}$-orde niveau een functie toe te kennen, tautologieèn en paradoxen in het observeren van observaties toe te staan. Consequent gedacht, moeten paradoxen dan evenzeer fungeren als prikkel voor een $2 \mathrm{e}$-orde observator om zijn eigen structuren uit te bouwen, d.w.z. nieuwe differenties te ontwikkelen, deze middels

84. Op dlat inzicht berusten ook de zogeheten 'radicale" en "crisis' -therapieền. Precies omdat een gezin niet 'achter' zijn eigen zelfobservaties kan kijken, de deviantio tussen zijn zelfbeschrijving en de feitelijke gang van zaken niet in het vizier kan krijgen, stuiten de cluidingspogingen van de therapeut, al zijn inspanningen om het gezin doorzicht te geven in zijn eigen pathologie, al gauw op een muur yan zelfbegrip. Dan kan alleen een "crisis" nog uitkomst brengen. Het systeem moet op tilt, voor een moment uit zijn voegen, om ruinte to maken voor nieuwe differenties, voor nieuwe vormen van zelfobservatie en zelfbeschrijving. Zie hierover o.a. H. Willke, "Strategien der Intervention in autonome Systeme", in: D. Baecker e.a., Theorie als Passion, Frankfurt/M. 1987, pp. 333-361.

85. We kunnen bijvoorbeeld zien hoe het rechtssysteem de circulariteit van de rechtspositiviteit, namelijk dat recht is, wat volgens het recht recht is, tracht te onderbreken door systeemexteme "gronden" van het recht aan te wijzen (bijvoorbeeld "nuatuur') en vervolgens hoo de rechtstheorie, als de reflexie van het rechtssysteem op zichzelf de dan binnengehaalde paradoxen alls "brandstof" van haar eigen intellectuele traditie benut.

86. We kunnen bijvoorbeeld zien hoe hierarchische structuren gebruikt kunnen worden onn paradoxen te ontvouwen en te versnipperen. Wederom het rechtssysteem observerend" de reentry van het onderseheid recht/onrecht binnen datzelfde onderscheid, bijwoorbeeld in de vorm van de vragg of het recht was dat een rechter recht sprak dan wel onrecht en de mogelijke paradoxen die daaruit voortvloeien (zoals: recht, want onrecht), worden 0. a. hanteerbaar gemaakt door een hierarchie van lagere en hogere rechtbanken waarin na elkaar, de tijd benuttend dus, over de vonnissen van llagere instanties wordt gevonnisd. Met de irritaties over de vele beroepszaken kunnen we klaarblijklijk leven.

87. We schrijven hier miet: "Zoek de paradox en de tautologie...", omdat op geleide van Luhmanns paradoxie-concept ogk tautologieên uiteindelijk als (in pragmatisch/operatief opzicht) paradoxale constructies moeten verschijnen. In de bewering " $A$ is $A$ ' komt $A$ twee keer voor, wordt $A$ van $A$ onderscheiden en wel als vorm die tot uitdrukking moet brengen dat $A$ en $A$ niet van elkaar onderscheiden zijn. Een tautologie is zo beschouwd 'a difference that makes no difference' (en is daarom ook non-informatief in het licht van de bepaling dat informatie neerkornt op 'a differemce that makes a difference' (zie Hoofdstuk III)) 
begripsvorming te consolideren, ze met andere differenties te verknopen, etc, Luhmann zou m.a.w. bereid moeten zijn aan tautologe en paradoxale constructies binnen de systeemtheorie zelf onderdak te verlenen - "systeem: theorie' opgevat als een binnen de wetenschap zich ontwikkelend geheel van begrippen, beweringen en modellen met behulp waarvan de observatie en beschrijving van zelreferentiële (en dus: zichzelf observerende) systemen wordt gestructureerd. Daartoe is Luhmann inderdaad van harte bereid. In zijn afscheidsrede als hoogleraar van de Universiteit van Bielefeld omhelst hij de paradox zonder gềne:

"Paradoxie ist...eine Funktionsformel, ein pragmatischer Begriff fur Anstoß und Abstoß 3 in den Operationen theorieorientierter Forschung. Sie dient rein praktisch dazu, sich und anderen Schreck einzujägen, der nötig ist, wenn man den Mut gewinnen will, eine tiefgreifende Theorieänderung vorzuschlagen. ${ }^{88}$

Het gaat er, zo beschouwd, niet alleen om de paradoxen en tautologieèn te isoleren die de ontwikkeling van geobserveerde systemen aandrijven; het uitprepareren van paradoxen en aanverwanten wordt nu een constructieprincipe en ontwikkelingsmethodiek van de (observerende) theorie zelf! Of logici deze liefde voor het 'Anstößige' niet wat pervers zullen vinden, is iets waar Luhmann zich weinig aan gelegen laat liggen, zeker niet als socioloog: "Wenn das soziale Leben selbst nicht logisch sauber arbeitet, läßt sich auch eine Theorie des Sozialen nicht logisch widerspruchsfrei formulieren."

Eigenlijk is de aan Spencer Brown ontleende observatietheorie zelf al paradoxaal gebouwd - 'Begin een lijn te trekken, maak een onderscheiding' zo luidt het begin. Maar hoe kunnen we beginnen een onderscheid te maken zonder daarbij al over onderscheidingen te beschikken, bijvoorbeeld over de onderscheiding tussen onderscheiden en niet-onderschijden? Hoe kan de aanwijzing een lijn te trekken worden opgevolgd, zonder dat we over het onderscheid tussen een lijn (deze? een andere?) en een niet-lijn beschikken? Hoe kan men onderscheidsloos beginnen te onderscheiden ? $^{99}$ Luhmanns antwoord luidt: door te doen! - mak een onderscheid! Schort alle logische en kentheoretische problemen op en voer 'naief' een onderscheid in, onder aangifte van een van beide zijden van de onderscheiding. De, men zou bijna zeggen, broodnodige paradoxaliteit van een dergelijke aanwang kan worden teruggewonnen en de nairviteit afgelegd, door het aanvankelijke onderscheid opnieuw in te voeren in het observatieproces dat met het eerste onderscheid in gang is gezet. Dan kan

88. N. Luhmann, "Was ist der Fall?" und "Was steckt dahinter?", Zeitschriff fur Soziologie, 22
(1993) p.246. 89. Zie ook N. Luhmann, 'Die Paradoxie der Form', opgenomen in D. Baecker, Kalkwl der Form,
op. cit., p. 198 e.v. 
men zien wat men niet zag, de gemaakte onderscheiding onderscheiden van andere onderscheidingen, haar op bruikbaarheid, dwz. op aansluitbarrheid en herhaalbaarheid, op decomponeerbaarheid, etc. onderzoeken en de onvermijdelijke problemen van deze re-entry eventueel benutten voor een verdergaande structurering van het observatieproces.

Dit 'naief' inwoeren wan een onderscheid en het herinvoeren ervan in het, door dat onderscheid in gang gezette onderscheidingsproces, is precies wat Luhmann in zijn opus magnum, Soziale Systeme, zelf heeft gedaan. "Die folgende Ueberlegungen gehen davon aus, daß es Systeme gibt" - zo luidt de eerste zin van het eerste hoofdstuk. Systemen bestaan, klaar uit - en het vervolg van het boek buigt zich over de vraag wat de implicatie hiervan is, welk observatie- of beschrijvingsproces met deze eerste observatie in gang is gezet, wat op grond daarvan gezien kan worden, maar ook wat nu niet meer gezien kan worden, gegeven het conditionerend effect van de vaststelling dat 'systemen (niet: 'mensen', niet: 'groepen', niet: 'klassen') bestaan'. In een reactie op Danilo Zolo, die hem op grond van dit startschot van een naief, metafysisch realisme beticht $^{\text {s* }}$, stelt Luhmann dat het hier helemaal niet om een ontologische uitspraak in de klassieke zin van het woord gaat, maar om een uitgangspunt voor het creeren van 'realiteit'. De onderscheiding die het observeren stuurt is altijd een constructie van de observator, die daarvoor nergens anders te rade kan gaan dan bij zichzelf - 'Die Umwelt enthält keine Unterscheidungen. Sie enthalt keinerlei Information daruber, an hand welcher Unterscheidungen sie durch welche Systeme beobachtet wird'. ${ }^{21}$ Theorieën kunnen echter niet anders worden ontwikkeld dan door ergens te beginnen, een differentie te stellen, die dan vervolgens medle bepalend is voor wat de theorie aan realiteit, aan "wereld van referenties' voor zichzelf creerert. Wat van een theorie met een universaliteitsaanspraak dan nog verlangd kan worden, is, dat zij na verloop van tijd haar uitgangsdifferenties reflecteert, dat ze m.a.w. zichzelf beschouwt als een deel van de realiteit die zij zichzelf geeft om te beschrijven en te verklaren.

'The statement that 'autopoietic systems exist'...means nothing other than that the reality construction of the theory of autopoietic systems is built upon this assumption. It does not form "merely analytical" concepts which would introduce a difference between analytical and real facts; but through its constructs refers directly to what is reality for it And the test lies ultimately in the recursiveness, namely in the insight that this functions even when the theory is driven toward selfreference. ${ }^{92}$

90. Zie D. Zolo, "The Epistemological Status of the Theory of Autopoiesis and its Applications to the Social Sciences", in: G. "Teubner (ed.), State, Law, Eiconomy as Autopoietic Systems, Berlijin 1987.

91. Soziologische Auffliärung 5, op.cit., p. 10.

92. N. Luhmann, "Closure and Openness..", op.cit., p.347/348. 


\section{\$9. Het probleem 'complexiteit'}

Het moment is aangebroken om ons om te draaien en een probleem in ogenschouw te nemen dat tot nog toe 'gratis' achterop heeft meegereden, maar dat door zijn gewicht in verregaande mate de richting van Luhmanns theoretische ontwikkeling heeft beînvloed. Alhoewel het om een probleem gaat dat; bij wijze van spreken, al vanaf de eerste pagina van dit hoofdstuk een rol speelt, hebben we een analyse ervan moeten uitstellen - in ieder geval tot na de bespreking van de observatietheorie en haar implicaties - , precies omdat het voortdurend; in iedere episode van Luhmanns ontwikkeling een rol, zo niet een hoofdrol is blijven spelen. Het betreft het probleem 'complexiteit'. Daarmee zijn we tevens bij het punt aanbeland waarop we de systeemtheoretische grondslagen van Luhmanns project wat steviger aan de tand willen gaan voelen. Een gezonde dosis argwaan wordt al gewekt door de, misschien wat onthutsende, vaststelling dat bij Luhmann nauwelijks van een vormvast concept van 'complexiteit' kan worden gesproken. Het zou natuurlijk van meer welwillendheid getuigen, om te stellen dat op de denkweg die Luhmann heeft afgelegd, ook zijn opvattingen omtrent complexiteit zijn meegereisd. Maar hoe we het ook willen formuleren - het gaat beslist niet om een graduele ontwikkeling, maar om een opeenvolging van, in belangrijke opzichten incompatibele complexiteitsbegrippen, waarbij uiteindelijk onduidelijk blijft, welke voorstelling van complexiteit nu adequat is om als het archimedisch punt van de theorie van zelfreferentiële systemen te dienen. Op deze vraag naar een solide, en met de zelfreferentiele systeemtheorie verenigbaar concept van complexiteit zullen we in het nu volgende een antwoord proberen te geven, maar niet voordat we Luhmanns eigen concepties van complexiteit aan een kritische inspectie hebben onderworpen.

Aanvankelijk omschreef Luhmann 'complexiteit' als een eigenschap die systemen toekomt die meer dan één toestand kunnen aannemen, 'also eine Mehrheit von Möglichkeiten haben die mit ihrer Struktur vereinbar ist'. ${ }^{93} \mathrm{Nu}$ kan men zich om te beginnen al afvragen, wat we zouden moeten verstaan onder een 'gestructureerd systeem" dat niet meer dan éen toestand kan aannemen; "structuur" is bij Luhmann immers per definitie de systeeminterne conditionering van systeemmogelijkheden. Belangrijker is echter, dat dit concept van systeemcomplexiteit nog was toegesneden op het adaptiviteitsprobleem dat de 'open systeem'-theorie in de ban hield. Het complexiteitsprobleem betrof in deze constellatie voor Luhmann namelijk de vraag, of een systeem over voldoende mogelijkheden beschikt, voldoende toestanden kan aannemen om adequaat op een telkens veranderende wereld te 93. N. Luhmann, 'Soziologie als Theorie sozialer systeme', opgenomen in Soziologische
Aufklärung I, op.citu, p.116. 
kunnen reageren, een wereld of omgeving die geacht werd principieel meer toestanden te kunnen aannemen en dus per definitie 'complexer' te zijn dan het zich aanpassende systeem.

Met zijn overgang wan de systeem/omgevingstheorie naar de theorie van zelfreferentiële systemen, en dus: van het adaptiviteitsprobleem naar het probleem van de reproductie van systeemspecifieke gebeurtenissen -, moest Luhmann tevens afscheid nemen van dit idee van complexiteit als het probleem van 'requisite variety'. Eind jaren zeventig noemt hij systemen dan ook niet meer 'complex' met het oog op het geheel van mogelijke systeemtoestanden, maar wordt complexiteit betrokken op het keuzeprobleem dat zich aandient, wanneer een systeem op gronden van energetische, informationele of temporele schaarste niet meer in staat is al zijn elementen stuk voor stuk aan elkaar te relateren en dus gedwongen wordt tot selectiviteit in de relatering van zijn elementen. ${ }^{94}$ Zo heet het in Soziale Systeme:
'Als komplex wollen wir eine zusammenhängende Menge von Elementen bezeichnen, wenn auf Grund immanenter Be- schränkungen der Verknüpfungskapazität der Elemente nicht mehr jedes Element jederzeit mit jedem anderen verknupft sein kann. Der Begriff 'immanente Beschränkung' verweist auf die für das System nicht verfügbare Binnenkomplexität der Elemente, die zugleich deren 'Einheitsfăhigkeit' ermöglicht. ${ }^{.95}$

Binnen het kader van de zelfreferentiële systeemtheorie biedt deze notie van complexiteit onmiskenbaar een aantal voordelen. Zo maakt het verband, dat nu gelegd wordt tussen complexiteit en selectiedwang; het mogelijk om 'complexiteit' op te vatten als de aanduiding van een problematiek, die meer omvat dan alleen de anpassingsproblemen die door de overcomplexiteit van een omgeving worden veroorzaakt. Alhoewel de vroegere notie van complexiteit, als de eigenschap van een systeem meerdere, met zijn structuur compatibele toestanden aan te kunnen nemen, evenzeer selectiviteit impliceerde - per slot van rekening kan een systeem op ieder moment slechts éen toestand aannemen -, schuilt het probleem nu niet meer in een eventueel tekort aan mogelijke systeemtoestanden, maar in een teveel aan mogelijke procesvoortzettingen. In algemene zin kan men het probleem van complexiteit omschrijven, als de noodzaak te moeten selecteren en het daaraan inherente risico, dat met de hier en nu gemaakte selectie voor een specifieke toestand wordt gekozen, een bepaald proces in gang wordt gezet, onder uitsluiting van andere mogelijkheden - 'Komplexität..heißt Selektionszwang, Selektions-

94. Zie bijvoorbeeld: N. Luhmann, 'Handlungstheorie und Systemtheorie', opgenomen in: Soziologische Auftlarung 3, Opladen 1981, p. 55.

95. Soziale Systeme, op.cit., p.46. 
zwang heißt Kontingenz, und Kontingenz heißt Risiko' ${ }^{96}$ Met de dynamisering en intensivering echter van het idee van 'nu eenmaal noodzakelijke selectiviteit" tot de voorstelling van een permanente selectiedwang die zich met iedere systeemgebeurtenis kenbaar maakt, wordt het complexiteitsprobleem als het ware 'naar binnen geschoven', d.w.z. verbonden met het overkoepelende referentieprobleem van autopoietische systemen, namelijk de opeenvolging van gebeurtenissen als systeemspecifieke elementen. Luhmann:

${ }^{6}$ Komplexe Systeme müssen sich nicht nur an ihre Unwelt anpassen, sie mulssen sich auch an ibre eigene Komplexität anpassen... Komplexe Systeme sind mithin zur Selbstanpassung gezwungen und zwar in dem Doppelsinne einer eigenen Anpassung an die eigene Komplexitát.'

Maar welke voordelen dit concept van complexiteit ook mag bieden, er kleeft tevens een ernstig, zo niet onoverkomelijk nadeel aan. In welke zin kan nu nog van de complexiteit van de 'omgeving' of van de 'wereld" worden gesproken? Wat houdt nu nog de bewering in dat systeemgrenzen een 'complexiteitsverval" tussen een systeem en zijn omgeving markeren? Systemen in de omgeving van een systeem kunnen wel complex zijn; maar de omgeving zelf niet. $\mathrm{Er}$ is althans geen enkele reden om aan te nemen, dat de omgeving van een systeem op een of andere manier onder selectiedwang staat. ${ }^{97}$

Nu lijkt Luhmann in Soziale Systeme zelf al niet erg gerust te zijn op de theoretische draagkracht van het complexiteitsbegrip dat hem dan voor ogen zweeft. De suggestie wordt althans aan de hand gedaan, om met nog een tweede begrip van complexiteit te werken:

"Komplexität in diesem zweite Sinne ist dann ein Maß für Unbestimmbarkeit oder fur Mangel an Information. Komplexität ist, so gesehen, die Information, die dem System fehlt, um seine Umwelt (Umweltkomplexität) bzw. sich selbst (Systemkomplexitat) vollständig erfassen und beschreiben $\mathrm{zu}$ können. ${ }^{998}$

96. Idem, p.47.

97. Helmut. Willke komt op basis wan een paralelle kritiek tot de slotsom, dat 'omgeving' dan maar het best als pure 'Unordnung', als 'reine Kontingenz' kan worden begrepeni 'Die Umwelt selbst, ohne Systeme in hir, ist fur das System purer Zufall. Systemkomplexitat baut sich nicht auf in Abgrenzung von Umweltkomplexitat, also durch Reduktion, sondern in Abgrenzung von Unordnung, also durch Produktion bestimmter, nichtzufalliger Relationen.' $(H$. Willke, 'Differenzierung und Integration in Luhmanns Theorie sozialer Systeme', in: H. Ha. ferkamp/M.Sohmid (Hrsg.), Sinn, Kommwnikation und soziale Differenzierung, Frankfurt/M.
1987 , p. 258)

98. Soziale Systeme, op.cit., p.50/51. 
Als een 'ad hoc'-oplossing van het probleem, hoe we toch nog over omgevingscomplexiteit kunnen spreken, is dit al met al een weinig elegante manoeuvre. Tegelijkertijd breekt echter een belangrijk inzicht door, namelijk dat complexiteit op een of andere manier samenhangt met observeren/beschrijven. Parallel aan het toenemend gewicht van een differentie-logische observatietheorie binnen Luhmanns werk, wordt vervolgens ook deze verbinding tussen 'complexiteit' en 'observatie' conceptueel aangescherpt. In 'Haltlose Komplexität', een in 1990 gepubliceerd artikel, beschouwt Luhmann 'complexiteit' als een term die een specifiek observatieschema aanduidt, een schema dat wordt gevormd door de differentie 'complete relatering/selectieve relatering". Weliswaar blijft gelden, dat complexiteit eerst en voorall voor selectieve relatering staat, maar omdat 'selectieve relatering', volgens Luhmann, als noodzakelijk complement 'Komplettrelationierung' veronderstelt, kan het compleet/selectief-observatieschema op zich van het opschrift "komplexiteit" worden voorzien. In navolging van Spencer Brown spreekt Luhmann hier over 'complexiteit' als de naam van een Vorm, om te benadrukken dat 'complexiteit" staat voor de eenheid van een differentie die aan een bepaald type observatie/beschrijving ten grondslag ligt:

'Komplexität ist...die Einheit der Unterscheidung selbst, die das konstituiert, was dann als Komplexität bezeichnet wird. Offensichtlich bezeichnet der Begriff in dieser Fassung dann nicht mehr ein Objekt (oder eine Art von Objekten) unter anderen, sondern eine Beschreibung von Objekten mit Hilfe einer bestimmten Unterscheidung. Die Einheit des Objektes, das als komplex bezeichnet wird - sei es die Welt, sei es ein System, sei es ein Werk - wird vorausgesetzt. Sie wird mit einem bestimmten Beobachtungsinstrumentarium beobachtet mit der Folge, das man die Fragen stellen und beantworten muß: was sind die Elemente, was ist die Art ihrer Verknupfung, was ist die Form (komplett oder selektiv) ihrer Verknupfung?' ${ }^{99}$

In deze gedaante is de verbinding tussen het complexiteitsbegrip en de door Luhmann gehanteerde observatietheorie echter onhoudbaar. Wat kan een systeem er toe bewegen, om 'iets' (bijv. zijn omgeving) als een complexe eenheid te observeren? En als het slechts om één van de vele mogelijke manieren van observeren en beschrijven gaat -, waarom zou de systeemtheorie dan nu juist systemen onder het gezichtspunt van complexiteit en complexiteitsreductie willen beschrijven? Luhmann suggereert, dat dit op een of andere manier door de geobserveerde werkelijkheid zelf wordt afgedwongen -

99. N. Luhmann, "Haltlose Komplexitat", opgenomen in Sozlologische Awfklärung 5, Opladen 1990, p.62. 
'Somit ist Komplexitat zunächst die Differenz von kompletter und selektiver Verknupfbarkeit, konkret jeweils bedingt durch die empirischen Merkmale der Elemente, die mehr oder weniger Vernetzungen zulassen bzw. ausschließen'. ${ }^{100}$ Moeten we dit zo opvatten, dat complexiteit uiteindelijk een onafhankelijk 'empirisch' kenmerk van de omgeving of van de systemen die we daarin aantreffen, voorstelt? Maar voor een observatie-theoretisch geïnformeerde systeemtheorie ("second order'-cybernetica) moet nu juist gelden, dat 'realiteit" (of dit nu 'systeem" is, dan wel 'omgeving') een constructie van het observerend systeem zelf is! Wat blijft er bovendien over van de tot nog toe centrale notie 'Welt' als het overkoepelende probleem van een absolute complexiteit. Als 'de wereld" complex is op grond van de vaststelling dat we met een 'nu eenmaal empirisch gegeven' selectieve relatering van elementen te maken hebben, dan begrijpen we "wereld" in termen wan een selectiviteit vis-à-vis andere mogelijkheden, d.w.z. als een selectieve uitsnede, als systeem - en precies niet als 'Welt".

De kern van het probleem, zo kunnen we de kritiek kortsluiten, bestaat daarin, dat 'complexiteit' nu als een van de mogelijke schema's van observatie wordt ingevoerd, waardoor het complexiteitsbegrip het gevaar loopt op een veel te afgeleide (men kan ook zeggen: te hoog geaggregeerde) positie binnen het theoretisch raamwerk te belanden ${ }^{101}$ Dat dit tot spanningen moet leiden binnen een begripssystematiek die zich heeft ontwikkeld op basis van een verbinding tussen de begrippen 'systeem', 'omgeving', 'complexiteit', 'contingentie', "selectiviteit" en 'complexiteitsreductie' als haar centrale nexus, ligt voor de hand. En eigenlijk is dit opmerkelijk. De inkadering van de theorie van zelfreferentiële systemen binnen een differentie-logische observatietheorie lijkt: juist de weg vrij te maken voor een nadere precisering van het complexiteitsbegrip en van de 'quasi-transcendentale' functie die het binnen Luhmanns systeemtheorie vervult. Wat Luhmann althans op andere plaatsen omtrent observatie en zelf-observatie ten berde heeft gebracht, lijkt niet tot de conclusie te leiden dat "complexiteit" een mogelijk observatieschema temidden van andere is, maar tot de vaststelling van een inherente samenhang tussen observeren en complexiteit.

Om dit 'tegenbod' toe te lichten kunnen we gebruik maken van een voorzet die de bioloog Robert Rosen heeft gegeven. ${ }^{102}$ Complexiteit ontstaat, volgens Rosen, wanneer het om bepaalde redenen niet mogelijk is een volledige,

100. idem.

101. Op de achtergrond staan bij Luhmann inderdaad ook historisch-semantische overwegingen, i.h. b. de argwain dat de traditionele tegenoverstelling wan complexiteit en eenvoud slechts zin heeft binnen een ontologisch denkraam dat waarlijk zijn met "niet samengesteld"-zijn identificeert. Verg. 'Haltlose Komplexităt', op. cit., p. $59-61$.

102. Zie 0.a. R.Rosen; 'Complexity as a System Property', in: International Joumal of General Systems 3 (1977), p.227 - 232; idem. "The Physics of Complexity", in: R. Trappl (edl), Power, Autonomy, Utopia, New York 1986, p.35 - 42. 
absolute beschrijving van een systeem te geven en we ons dus tevreden moeten stellen met een partïele beschrijving van een systeem. Anders geformuleerd: Complexiteit ontstaat wanneer we moeten kiezen tussen op zichzelf coherente, maar telkens partiële, niet op elkaar reduceerbare beschrijvingen van een systeem. Complexiteit is, zo beschouwd, niet een intrinsieke eigenschap wan een bepaald soort systemen, maar een effect van de manier waarop een systeem wordt beschreven. Een 'beschrijver' genereert complexiteit wanneer hij om welke redenen dan ook - tijdgebrek, schaarse hulpbronnen, etc. - gedwongen is, af te zien van een complete of 'absolute' beschrijving van een systeem. Rosen:

'[C]omplexity is not an intrinsic property of systems, but rather arises from the number of ways in which we are able (or desire) to interact with a system... any system can be made to appear complex in this sense. ${ }^{103}$

In contrast hiermee is een 'simpel' systeem een systeem waar we een complete, absolute beschrijving van (kunnen) geven. Simpele systemen zijn volgens Rosen gedetermineerde systemen, in die zin, dat ze voor de beschrijver volledig voorspelbaar zijn. Kenmerkend voor wat wij als 'complexe systemen' ervaren, is daarentegen, dat de contingente selectiviteit die aan hun beschrijving ten grondslag ligt, terugkeert in de vorm van 'ruis', van 'fouten', van niet voorziene gedragingen van het systeem -:

'It is in this sense that... the failure of mechanical artifacts and social institutions can be regarded as the result of 'error'; they are uncontrollable deviations between the behavior of an abstract functional model and the behavior of a real system, with interactive capabilities not present in the model. ${ }^{\text {'104 }}$

Zoals al min of meer aangekondigd, interesseert ons aan deze conceptualiseringsstrategie het directe verband dat wordt gelegd tussen "observeren/beschrijven' en 'complexiteit'. Het nàdeel ervan, of in ieder geval het probleem dat deze opvatting van complexiteit voor een, zich van zijn constructivistische grondslag steeds bewuster wordende systeemtheorie stelt, is eveneens duidelijk. In Rosens analyse zit een asymmetrie ingebakken, die neerkomt op het idee dat complexiteit geproduceerd wordt door een (partielle) beschrijving, terwijl 'simpliciteit' verwijst naar een (volledige) beschrijving van

103. R Rosen, "Complexity as a System Property", in: International Jourmal of General Systems 3 (1977), p. 229.

104. Idem, p. 231. 
een systeem, zoals dat systeem eigenlijk is. ${ }^{105}$ Voor een dergelijke idee, dat de beschrijving van een systeem de representatie zou kunnen zijn van dat systeem 'an sich', is binnen Luhmanns zelfreferentièle systeemtheorie naturilijk geen plaats.

Nu lijkt de intrede van een observatietheoretisch constructivisme de asymmetrie tussen het beschrevene/geobserveerde en de beschrijver/observator min of meer om te draaien: niet het geobserveerde systeem is in zijn simpliciteit het gegevene; gegeven is de observator die zichzelf een werkelijkheid verschaft. Luhmann gaat echter één stap verder. De constructie van 'werkelijkheid' is tegelijkertijd de vorm waarin een observerend/beschrijvend systeem zichzelf structureert, en dus: zichzelf eerst als een selectief proces, als een systeem constitueert! Zo merkt Luhmann aan het begin van de jaren tachtig al op:

'An Identitaten differenzieren sich eigene Reaktionen des Systems in Bezug auf seine Umwelt. [-] Sie haben diese Funktion aber nicht als Naturfestes oder als widerständigen Realitătskern; sie erfullen sie nur deshalb, weil sie im System fur diese Funktion konstruiert werden'. ${ }^{106}$

Eind jaren tachtig heet het dan: 'Reality assumptions are structures of the system that uses them'. ${ }^{107} \mathrm{De}$ aanvankelijke asymmetrie is ingewisseld voor een circulaire constructie. Observator en observatum, of zo men will: beschrijver en het beschrevene constitueren elkaar wederzijds! ${ }^{108}$

Wat blijft er onder deze conditie over van het idee dat complexiteit iets te maken heeft met de contingente selectiviteit (maar niet meer: 'partialiteit') van observaties, een selectiviteit die terugkeert in de vorm van storingen, van 'ruis' en zo voor het observerende systeem tot probleem wordt? Om te beginnen moeten we er op geleide van Luhmann vanuit gaan, dat de observatie van complexiteit slechts een ' $2 \mathrm{e}$ orde'-observatie kan zijn. Op het '1e orde'-niveau kenmerkt het observeren zich als 'naief' realistisch, in die zin, dat het observerende systeem niet kan twijfelen aan wat het voor "werkelijkheid" houdt. De 'werkelijkheid" moet hier 'gegeven' zijn, precies omdat de realiteitsveronderstellingen van het observerende systeem fungeren als structuren die het observeren eerst mogelijk maken. Pas op het ' $2 \mathrm{e}$ orde'-niveau van

105. Dat deze asymmetrie ertoe leidt, dat Rosen uiteindelijk niet kan observeren, wat hij will observeren, namelijk complexiteit, wordt duidelijk aan de eindeloze regressie die volgt op de vraag of de beschrijver zelf een simpel, dan wel een complex systeem is.

106. N. Luhmann, "Identitatsgebrauch in Selbstsubstitutiven Ordnungen, besonders Gesellsehaften", opgenomen in: Idlem, Soziologische Aufklärumg 3, op.cit., p. 200.

107. N. Luhmann, "Closure and Openness. On Reality in the World of Law", in: G. Teubner (ed.), Autopoietic Law: A New Approach to Law and Society, Berlijn 1988, p. 337.

108. Verg. W. Rasch, "Theories of Complexity, Complexities of Theory: Habermas, Luhmann and the Study of Social Systems', in: German Studies Review 14 (1991), pp. 65-83, i.h.b. p. 77 
het observeren van observatieprocessen kan worden geobserveerd, dat aan de zelfstructurering van de "le orde"-observator contingent geselecteerde differentieschema's ten grondslag lagen en dat in die zin de observator ook. anders had kunnen observeren.

Op dit punt aangekomen moeten echter minstens twee mogelijke standpunten van '2e orde'-observatie van elkaar worden onderscheiden (een 'onderscheiden' dat naturlijk op zijn beurt een ' $3 \mathrm{e}$ orde'-standpunt suggereert). Zo kan de '2e orde"-observator een exteme observator zijn, bijv. de systeemtheorie, maar het kan ook het aanvankelijke systeem zijn dat zichzelf is gaan observeren, 'reflexief' is geworden. Gaan we uit van een autopoietische/zelfreferentiele systeemtheorie, dan gaan we, op geleide van Luhmann, uit van een observator die systemen observeert die per definitie zelf observeren. Voorzover de systeemtheoretische observator nu vaststelt, dat aan het observeren wan het geobserveerde systeem, contingent geselecteerde observatieschema's ten grondslag liggen, zouden we kunnen zeggen, dat de 'systeemtheoreticus' een systeem observeert dat in en door zijn observeren complexiteit genereert, een complexiteit waar het tegen aan loopt in de vorm van (interne of externe) omgevingsruis. De vraag is echter niet of een door Luhmann geïnspireerde observator 'complexiteit" kan observeren; de vraag is inhoeverre de systeemtheorie, gegeven haar eigen modellering van zelfreferentiële systemen, gedwongen is aan te nemen dat het hierbij gaat om noodzakelijkerwijs complexe systemen in een noodzakelijkerwijs complexe omgeving! Pas wanneer we op de laatste vraag een bevestigend antwoord kunnen geven, onstnappen wij zelf aan de kritiek die we eerder spuiden op Luhmanns voorstel om 'complexiteit' als een (slechts) mogelijk observatieschema op te vatten.

$\mathrm{Nu}$ beschrijft Luhmanns theorie van zelfreferentiele systemen niet simpelweg systemen die observeren, maar systemen die bovendien zichzelf observeren, waarvoor 'zelf-observatie' zelfs een noodzakelijk constitutieprincipe is. En daarmee mag de richting waarin wij een tegenbod zoeken op Luhmanns eerdere voorstel om 'complexiteit' als een mogelijk observatieschema op te vatten, duidelijk zijn. Onder de voorwaarde van een observatietheoretische herijking van de theorie van zelfreferentiele systemen, $k$ an de theoretische functie van het 'Welt'-begrip worden bezet door 'het paradoxale karakter van de zelfconstitutie van zelfreferentiële systemen'. Wat Luhmann opvoert als de 'paradox van zelfobservatie", vervult als een 'onbeslisbaarheidsproblematiek' ('das Hin-undHer-Oszillieren der Meinung') die iedere zelfobservatie zichzelf als een 'altijd al ' opgelost probleem stelt, precies de 'quasi-transcendentale' rol die het 'Welt'-begrip steeds binnen zijn werk heeft gehad. Een dergelijke interpretatie van 'Welt' lijkt bovendien ondersteuning te kunnen vinden in Luhmanns meer recente werk. Misschien kan een wat langer citaat uit 'Die Paradoxie der Form' (1993) dat inhaakt op het effect van 're-entries' van onderscheidingen binnen onderscheidingen - bijv. van het systeem/omgeving-onderscheid binnen het systeem - deze inschatting een zekere plausibiliteit verlenen: 
'Es geht um die Identität einer Differenz, um eine Unterscheidung, die sich selber in sich selber unterscheidet. Und wenn man formuliert: die sich selber in sich selber unterscheidet, könnte man auch vermuten, daß es sich um ein Symbol fur die Welt handelt. Als Paradox beobachtet, symbolisiert jede Form (i.e. een differentie genomen als eenheid - T.B.) die Welt.... Ein Paradox ist die in sich selbst enthaltene Form ohne Hinweis auf einen externen Standpunkt, von dem aus es betrachtet werden könnte. Es ist daher Anfang und Ende im einem. ${ }^{109}$

Dat is inderdaad consequent: 'Welt' heeft bij Luhmann nooit naar een observeerbaar iets verwezen. Absolute complexiteit/ absolute onbeslisbaarheid is simpelweg daarom al niet observeerbaar omdat met ieder systeem/met iedere observatie, bij voorbaat een minimale selectiviteit, een minimale reductie van complexiteit tot stand is gebracht/een beslissing is genomen. 'Inderdaad' -, een zichzelf observerend systeem kan de paradox die aan zijn zelfobservatie ten grondslag ligt niet observeren.

Maar wat abserveert Luhmann dan eigenlijk, wanneer hij zegt als externe observator de paradox te kunnen zien die het zichzelf observerende systeem niet kan zien? In ieder geval niet de paradox van zelfobservatie als een op zich gegeven iets, want dan zou hij niets zien, noch een systeem, noch een omgeving. De paradox zou op de observator Luhmann overgaan en diens observeren blokkeren - 'Die Einsicht in die Notwendigkeit von Selbstreferenzunterbrechungen entparadoxiert deshalb den Gegenstand der Beobachtung und zugleich die Beobachtung selbst'. ${ }^{110}$

Ook hier moeten we onderscheiden tussen "le orde'- en '2e orde'-observatie. Allhoewel de zelfreferentièle systeemtheorie een theorie voorstelt die structuur verleent aan de observatie van systemen die zelf observeren, is het door de systeemtheorie geleide observeren op zijn beurt wederom een 'le orde'observeren. Op dit niveau observeert het op dezelfde 'naieve' wijze als al het '1e orde'-observeren, d.w.z: het observeert de werkelijkheid die het voor zichzelf middels differenties als 'systeem/omgeving', 'structuur/proces', 'openheid/-geslotenheid', etc. creèrt als een 'gegeven werkelijkheid'. Vanuit deze positie kan de systeemtheoretische observator complexiteit ook slechts observeren als de contingente en riskante selectiviteit van de identiteit en het omgevingsontwerp die zelfreferentiele systemen voor zichzelf construeren. Op de paradox van zelfobservatie, op 'Welt' als het altijd al opgeloste probleem

109. N. Laltmanm, 'Die Pardoxie der Form', opgenomen in: D: Baecker (Hrsg), Kalkil der Form, Frankfurt/M. 1993, p. 201.

110. N. Luhmann, "Tautologie und Paradoxie in den Selbstbeschreibungen der modemen Gesellschaft', in: Zeitschrift fit Soziologie $16(1987)$, p. 172. 
van absolute complexiteit stuit de systeemtheorie pas wanneer zij reflexief wordt, wanneer ze gaat observeren hoe ze zelf observeert -: wanneer de theorie van zelfreferentiêle systemen zichzelf vanuit het standpunt van de 'second order'-cybernetica gaat observeren. Dan stuit ze namelijk op het probleem de differentie die het systeemtheoretische observeren in gang zet, namelijk de differentie systeem/omgeving, als een eenheid te moeten observeren. Die eenheid van systeem en omgeving kan ze dan nog markeren als 'Welt', maar niet zonder op de koop toe te nemen dat ze daarmee het onderscheidene als eenheid, het differente als hetzelfde wil observeren. Ze stuit, zo concludeert Luhmann n.a.v. zijn bestudering van Spencer Browns vormencalculus, op de paradox van het observeren uberhaupt, namelijk op de re-entry van het onderscheiden binnen het onderscheiden. Maar natuurlijk is die zelfobservatie tevens de observatie dat die paradoxaliteit van het observeren al is ontvouwd, namelijk door te observeren, door in actie te komen: door een onderscheid te maken, bijv. het onderscheid systeem/omgeving.

\section{$\S 10$. Ter Afsluiting}

Als een theorie die via de observatie van zelfreferentiele systemen de systeem/omgeving-differentie observeert die ook haar eigen grondslag als wetenschappelijk observatie- en beschrijvingssysteem vormt, wordt de systeemtheorie haar eigen 'metaperspectief': 'Um eine Metaperspektive handelt es sich insofern, als man nicht nur das jeweils Unterschiedene - also System auf der einen und Umwelt auf der anderen Seite - thematisiert, sondern die Unterscheidung selbst."

De reflexief geworden systeemtheoretische observator kan bovendien zien, dat de systeem/omgeving-differentie op zichzelf genomen een bijzondere instantie, een 'Anwendungsfall' van een algemenere differentie vormt, namelijk van de differentie van identiteit en differentie. Hij kan namelijk observeren, dat identiteitsconstitutie op basis wan zelfreferentie een 'zelf' veronderstelt, dat zichzelf middels het systeem/omgeving-onderscheid weet te identificeren in differentie met al het andere. Een reflexief geworden systeemtheorie kan m.a.w. vaststellen, dat voor zelfreferentiële systemen het handhaven van een differentie tussen zichzelf als systeem en de daar niet toe behorende omgeving, het handhaven van de identiteit/differentie-differentie inhoudt. Dat is de achtergrond van Luhmanns proclamatie van een nieuwe 'Leitdifferenz', die de systeem/omgeving-differentie omvat en het bovendien mogelijk maakt de cruciale functie te observeren, die de systeem/omgeving-differentie voor de geobserveerde systemen vervult - die het mogelijk maakt 'zelfconstitutie op basis van zelfreferentie' te observeren en te beschrijven. In een toelichting van Luhmann: 
'Fur die Ausarbeitung einer Theorie selbstreferentieller Systeme, die die System/Umwelt-Theorie in sich aufnimmt, ist eine neue Leitdifferenz, also ein neues Paradigma erforderlich. Hierfür bietet sich die Differenz von Identität und Differenz an. Denn Selbstreferenz kann in den aktuellen Operationen des Systems nur realisiert werden, wenn ein Selbst (sei es als Element, als Prozeß oder als System) durch es selbst identifiziert und gegen anderes different gesetzt werden kann.' ${ }^{\prime \prime \prime}$

Met de "differentie tussen identiteit en differentie" als "Leitdifferenz', als het ultieme uitgangspunt van de theoretische reconstructie van observatieprocessen en vormen van werkelijkheidsbeschrijving, rukt Luhmann niet alleen op in de richting van hedendaagse differentie-denkers als Lyotard en Derrida ${ }^{112}$ "maar stelt hij zijn systeemtheorie bovendien als concurrerende benadering op én lijn met de transcendentale (Kantiaanse) en de dialectische (Hegeliaanse) traditie. De transcendentale subjectfilosofie verwijt hij, de modus van zelfreferentiële identiteitsconstitutie op een ontoelaatbaar eenzijdige wijze in het subject (als 'zelfbewustzijn') te localiseren - 'Die Differenz von Subjekt und Objekt wird dadurch zur Prämisse aller weiteren Informationsverarbeitung'."13 Van de dialectische traditie, die zocht naar de identiteit wan identiteit en differentie, wil hij weten, waar ze die 'identiteit' als laatste eenheid en zekere grond van het denken, (zelf!) denkt te kunnen vinden - 'Fur die funktionalistische Systemtheorie genugt es, von (jeweils kontingent gewahlten) Differenzen auszugehen'." "Systeemtheorie": wordt in Luhmanns handen allengs een filosofisch programma dat zich presenteert als erfgenaarn én transformator van de filosofie in haar reflexieve gestalte, van een denken dat zich over het denken terugbuigt om zijn eigen grenzen te kunnen ontwaren en zich op geleide daarvan sinds Kant als 'kritisch' afficheert. Met de overgang naar de 'differentie van identiteit en differentie', d.w.z. met het opgewen van de speurtocht naar een laatste, eenheid stichtende en funderende identiteit en de sprong in een differentie- of observatietheoretisch constructivisme, meent de systeemtheorie nu bovendien deze 'Kritiek' over haar eigen grenzen in te kunnen lichten, het

111. Soziale Systeme, op.cit, p.26.

112. Zonder overigens enig nut te zien in een term als "postmodemisme" en zonder een radicaal relativisme als de laatste wijsheid te beschouwen. Zie voor de verhouding van Luhmanns constructivisme tot het "deconstructivisme" o.a: $\mathrm{N}$. Luhmann; "Dekonstruktion als Beobachtung zweiter Ordnung', A. Nassehi, 'Diffërend; Differance und Distinction, Zur Differenz der Differenzen bei Lyotard, Derrida und in der Formenlogik", G. Phumpen. Werber, 'Diffërance, Differenz, Literatur. Systeemtheoretische und dekonstruktivistische Lekturen" en D. Schwantz, "Zur wechselseitigen Beobachtung von Systemtheorie und Dekonstruktion', nu alle opgenomen in: H. de Berg/M. Prangel (Hrsg.), Differenzen. Systemtheorie zwisches Dekonstruktion und Konstraktivismus, Tubingen 1995.

113. Soziale Systeme, op.cit., p.594.

114. idem, p. 26 (voetnoot 19 ). 
project van de Verlichting zelf te kunnen "Verlichten". Dat is in ieder geval, wat Luhmann sinds zijn 'Antrittsworlesung' aan de universiteit van Münster in 1967, onder de titel 'Soziologische Aufklarrung", steeds voor ogen heeft gestaan.(Daarover uitgebreid: Hoofdstuk VII 'Tot Besluit')

Jürgen Habermas ziet ondertussen deze annexatie van het filosofisch erfgoed met lede ogen aan, maar hij weet zijn gezicht te bewaren:

"Mich interessiert nun, ob mit die distanziert vollzogenen Zueignung des subjektphilosophischen Erbes auch sollche Probleme des Erblasses auf die Systemtheorie ubergehen die seit Hegels Tod die erörteten Zweifel an die subjektzentrienten Vernunft als dem Prinzip der Moderne hervorgerufen haben.'

In Luhmanns ogen is de erfeniskwestie echter heel anders geregeld:

'Das Konzept der Beobachtung zweiter Ordnung ist 'autologisch' gebaut. Das heißt: es zwingt zu Ruckschllussen auf sich selber. Und genau deshalb kann es das Erbe der Vernunft für sich reklamieren und deren Firma unter der abstrakteren Bezeichnung 'Selbstreferenz' fortführen. ${ }^{\text {"115 }}$

Of dit een afdoende antwoord is op Habermas" in vragende vorm geformuleerde twijfel, of Luhmann met zijn differentie-theoretisch onderbouwde systeemtheorie niet de problemen van de klassieke "subjectfilosofie" weer binnen haalt, en dan in het bijzonder de identiteitsproblematiek, valt echter te bezien. Gerhard Wagner en Heinz Zipprian hebben, de kritiek van Habermas voortzettend, de vraag opgeworpen, wat Luhmann nu precies onder het 'zelf' verstaat dat door aan zichzelf te refereren "zichzelf" constitueert."16 Veronderstelt zelfreferentie niet, dat er al een zelf is, dat in staat moet worden geacht zichzelf te identificeren en tegenover al het "niet-zelf" af te grenzen? En stuit Luhmann daarmee niet wederom op het probleem van de klassieke (Duitse) bewustzijnsfilosofie, dat het zelf nog voor alle zelfconstitutie zichzelf als een identiteit met duurzaamheid moet kunnen veronderstellen, omdat anders de zelfreferentie in het luchtledige stoot?

In feite leveren Wagner en Zipprian hiermee de grondvorm van een kritiek die in steeds wisselende gedaantes telkens weer tegen Luhmann is ingebracht, of het nu gaat om zijn zintheorie (zie Hoofdstuk II) of om het idee van de 'autokatalyse' van sociale systemen op basis van een 'dubbele contingentie'-

115. Soziologische fuftularung 5, op.eit., p.8.

116. G. Wagner/H.Zupprian, "Identität oder Differenz? Bemerkungen zu einer Aporie in Niklas Luhmanns Theorie selbstreferentieller Systeme', in: Zeitschrift fir Soziologie 21 (1992), pp. 394-405, i.h.b. pp. 399 e.w. 
problematiek die sociale systemen zelf organiseren (zie Hoofdstuk III). In een reactie op Wagner/Zipprian heeft Luhmann tegen hun kritiek inge- bracht; dat ze in feite de categorieên 'eenheid' en 'identiteit' door elkaar halen, of wat hetzelfde is: "opereren" en "observeren" niet van elkaar onderscheiden. De eenheid van een systeem ontstaat simpelweg doordat het systeem zich van gebeurtenis tot gebeurtenis reproduceert, systeemoperaties op systeemoperaties op ... aansluiten. Anders gezegd: door te opereren onderscheidt een systeem zich vanzelf van een omgeving, ten opzichte waarvan het dan een eenheid vormt. Identiteit ontwikkelt een systeem daarentegen pas op basis van een bijzonder type operaties, namelijk op basis van 'zelf-observaties":

'Durch Operieren (und sei es referierendes Operieren) wird eine Differenz und im weiteren Verlauf die Einheit eines Systems erzeugt im Sinne eines ausdifferenzierten Operationszusammenhanges. Wenn ein solches System uber Möglichkeiten verfugt, die eigene Einheit zu bezeichnen, kann man von Identităt sprechen. ${ }^{~} 117$

Luhmanns repliek komt er dan op neer, dat in tegenstelling tot wat Wagner en Zipprian suggereren, de constitutie van systeemidentiteit geen duurzame identiteit vóóronderstelt, maar slechts de eenheid van het systeem, d.w.z. vooronderstelt dat er een systeem is dat 'loopt', dat hoe dan ook een observatieproces in gang gezet is, dat zich vervolgens over zichzelf terugbuigt, zichzelf gaat observeren

Nu mag Luhmanns weerwoord op Wagner en Zipprian eventueel bevredigen als een antwoord op de vraag hoe een eenmaal op gang gekomen systeem identiteit constitueert, het volstaat niet wanneer het idee van "zelfconstitutie door zelfreferentie" ook nog een keer van toepassing wordt geacht op de constitutie van de elementen van een systeem. Op dit meest basale niveau van systeemconstitutie lijkt de zelfreferentie slechts het "zelf" van een gebeurtenis te kunnen betreffen en niet een aan de constitutie van de elementaire eenheid van het systeem nog voorafgaande eenheid. Het lijkt althans geen zin te hebben om hier tussen 'eenheid' en 'identiteit' te differentieren. Immers, het betreft hier de constitutie van een elementaire eenheid die tegelijkertijd de constitutie van een identiteit is en moet zijn. Het gaat bij 'basale zelfreferentie' per slot van rekening niet om de constitutie van willekeurige eenheden, maar om de vorming van systeemspecifieke elementen.

Maar missohien moeten we nu preciezer worden $O p$ het niveal van de constitutie van de elementen van een autopoietisch systeem spreekt $\mathbb{L}$ lahmann

117. N. Luhnamu, 'Bemerkungen zu 'Selbstreferenz' und au 'Differenzienung' aus Anlall von Beitraigen im Heft 6, 1992, der Zeitschrift für Soziologie'; in: Zeitschrift for Soziologie 22 (1993). p. 141. 
niet van 'zelfreferentie", maar van 'indirecte zelfreferentie'. De voor een element constitutieve referentie aan zichzelf verloopt via een referentie aan iets wat het zelf niet is, namelijk aan andere elementen van het systeem. Of wat hetzelfde is: een geîsoleerde gebeurtenis kan nooit een element van een autopoietisch systeem vormen; slechts als moment van een langer lopend proces kan een gebeurtenis een element van het systeem vormen. In aansluiting op deze 'processualiteit' als conditie van (element)identiteit heeft Amin Nassehi er op gewezen, dat precies door Luhmanns conceptie van zelfreferentiele systemen als radicaal getemporaliseerde systemen het klassieke, subjectfilosofische probleem van zelfconstitutie een fundamentele wending krijgt. ${ }^{118}$ Houden we vast aan het onderscheid tussen opereren en observeren, dan kan ook op elementniveau tussen eenheid en identiteit worden onderscheiden, wanneer we, met Nassehi, accepteren dat de akt van zelfobservatie die de identiteit van een operatie of element constitueert steeds door een daarop volgende gebeurtenis/operatie voltrokken wordt. De altijd 'meelopende' zelfobservatie van een autopoietisch systeem kijkt als het ware achteruit - de 'zelfcontrole' die dergelijke systemen aan de hand van het systeem/omgevingsonderscheid uitoefenen betreft telkens de identiteit van voorafgaande gebeurtenissen. Daarmee verdwijnt de oorspronkelijke paradox van identiteitsconstitutie door zelfreferentie/zelfobservatie waar Wagner en Zipprian op wijzen niet, maar hij wordt telkens vooruitgeschoven. Nassehi:

'Man könnte also sagen, dall die Aufhebung der Paradioxie der 'Selbstbezüglichkeit' durch die Zeit nur zeitweise erfolgen kann, nämlich von Ereignis zu Ereignis. 'H19

En, zo zouden we hieraan toe kunnen: daarmee wordt tevens de katalytische functie vain de paradox van identiteitsconstitutie bewaard.

Deze hele discussie rond de zelfconstitutie van zelfreferentiële systemen wijst nogmaals op de fundamentele betekenis van het binnenbrengen van het aspect 'tijd' door Luhmann en de kwalitatieve omslag die dat inhoudt. Het gaat er niet simpelweg om dat Luhmann thet begrip 'tijd' invoert; dat doet bijv. Anthony Giddens ook. Wat als een verstrekkende theoretische innovatie kan worden gezien, en wat alszodanig ook is onderkend en bekrachtigd door de discussies die n.a.v. de publicatie van Soziale Systeme zijn gevoerd, is het feit, dat Luhmann al zijn fundamentele categorieën vanuit het perspectief van een 'radicale temporalisering' opnieuw doordacht heeft.

118. Zie A.Nassehi, 'Das Identische 'ist' das Nicht-Identische. Bemerkungen zu einer theoretischen Diskussion um Identitat und Differenz", in: Zentschrift ftr Soziologie 22 (1993), pp. 477-481.

119. Idem, p. 479. 


\section{Methodologisch Excurs: Het 'equivalentie-functionalisme.'}

We hebben in het vorige hoofdstuk vele malen begrippen als 'functioneel", 'functionalisme', 'functionele analyse', etc. gebezigd, zonder deze nader te specificeren. De overweging daarbij was eerlijk gezegd, dat een toelichting op de methodologische en epistemologische kwesties die met het denken in termen van 'functies' en 'functionaliteit' samenhangen de gang van de uiteenzetting te sterk zou onderbreken. Een 'excurs" moet nu uitkomst brengen.

Terugblikkend lijkt Luhmanns oproep tot een radicalisering van het functionele perspectief binnen de systeemtheorie als remedie tegen de kwalen van het 'structureel functionalisme' tamelijk tegendraads, gelet althans op het intellectuele klimaat van de zestiger jaren. Halverwege de jaren vijftig had de (neo-positivistische) kritiek van Hempel en Nagel het 'klassieke', van Durkheim en William Smith via Malinowski en Radcliffe-Brown op Parsons en Merton overgedragen functionalisme al een stevige crisis bezorgd. Wanneer dan Kingsley Davis, zelf ooit een gevierd functionalist, in 1959 'The Myth of Functional Analysis as a Special Method in Sociology and Anthropology' publiceert, lijkt voor velen het doek gevallen. ${ }^{134}$

Zoals de titel all aangeeft, keerde Davis zich in zijn artikel tegen het idee dat het binnen de sociologie en antropologie beleden functionalisme een zelfstandige, autonome methode zou voorstellen. De suggestie dat sociologie en antropologie in de vorm van 'functionele analyse' over een eigen, bijzondere methode beschikken, mag van een zeker nut zijn geweest in de beginfase van deze disciplines, waarin problemen van demarcatie en distantiëring t.o.v. andere, zowel wetenschappelijke als filosofisch en journalistieke 'bemoeienissen' met 'het sociale" aan de orde waren, maar, zo vervolgde Davis, aan een dergelijke afschermingsstrategie is geen behoefte meer nu beide disciplines tot de gevestigde academische orde behoren. Het ging hem er overigens niet om te ontkennen, dat onder de vlag van het functionalisme belangrijk wetenschappelijk werk was afgeleverd; bij nader toezien bleek thet echter steeds om een vorm van causale analyse en verklaring te gaan. Wat door de aanhangers van het functionalisme telkens als 'functie' wordt beschouwd, is in wezen niets anders dan een door structuren of processen veroorzaakt (causaal) effect, dat dan de bijzondere eigenschap heeft aan de integratie/stabiliteit/reproductie/etc. van een sociaal "geheel" bij te dragen. En dat het in de kern van de zaak om een causale verklaring gaat, is ook maar goed, zo meende Davis, want alleen onder die voorwaarde kunnen sociologie en antropologie tegemoet komen aan de eisen die aan iedere wetenschappelijke discipline worden gesteld, i.h.b. de eis empirische fenomenen te kunnen verklaren en voorspellen.

134. K. Dawis, "The Myth of Functional Analysis as a Special Method in Saciology and Arthropology', in: Americam Sociolgical Review, 24 (1959). pp. $757-772$. 
Met deze, gedurende de jaren zestig nog in vele toonaarden bezongen kritiek op het klassieke functionalisme kon Luhmann tot op grote hoogte instemmen. ${ }^{135}$ Eén kanttekening echter: de kritiek van Nagel, Hempel en Davis betrof niet het functionalisme per se, maar een functionalisme dat, zoals Davis inderdaad terecht constateerde, nog steeds vanuit een traditioneel, causalistisch raamwerk opereerde. Dit 'Kausalfunktionalismus', dat een functie opvat als het 'Bewirken einer Wirkung", wordt welhaast onvermijdelijk in de richting van teleologische of tautologische verklaringen gedrongen, aldus Luhmann, wanneer het zich voor de taak gesteld ziet het bestaan van specifieke functies (i.e. gegeven, als 'functioneel' bestempelde structuren of processen) te verklaren. Wil een dergelijk functionalisme zich, ondanks de causale interpretatie van een functie als het realiseren van een bepaald effect of doel, alsnog blijven onderscheiden van 'gewone' causale verklaringen van het type "A veroorzaakt B', dan dient zich als enige uitweg het idee aan dat het effect of doel van de functie die functie verklaart. Gegeven de eenduidige tijdsvector van het (moderne) causaliteitsbegrip - de oorzaak gaat per definitie aan het gevolg vooraf - lijkt een verklaring van oorzaken/functies door hun gevolgen/effecten principieel problematisch. Natuurlijk was dat ook de aanhangers van het sociaalwetenschappelijk functionalisme bekend, maar alle met het oog op deze problematiek aangevoerde hulpconstructies leiden ofwel tot tautologe verklaringen - zoals Malinowski's poging handelingsmotieven uit behoeften af te leiden - ofwel tot de constatering dat we uiteindelijk met een weliswaar complex, maar nog altijd "gewoon' netwerk van causale relaties te maken hebben - zoals bijv. bij alle cybernetische, homeostatische, equilibrium-, etc. voorstellingen van sociale systemen. ${ }^{136}$

Accepteren we Luhmanns vaststelling dat de standaardkritieken op de functionele methode terecht zijn voorzover die althans een causaal georiënteerd functionalisme betreffen, dan dienen zich twee mogelijkheden aan. Men kan zich achter de oproep seharen om de sociologie voor goed te bevrijden van de 'mythe van de functionele methode" en er een ordentelijke, causaal analyserende en verklarende wetenschap van te maken. Maar natuurlijk kan ook worden geprobeerd, het functionele denken te bevrijden uit de overheersing van het causale denken, in de hoop daarmee inderdaad een zelfstandige en voor de analyse van sociale fenomenen meer vruchtbare methode in handen te krijgen. Deze laatste optie is Lulumann in ieder geval gevolgd en wel met de radicaliteit die hem eigen is:

135. Zie voor het nu volgende eerst en vooral: N. Luhmann, 'Funktion und Kausalitat' en Idem, 'Funktionalle Methode und Systemtheorie', beide opgenomen in: N. Luhmann, Soziologische Aufklarung I; Opladen 1984, pp. 9-30, resp. pp.31-53. Nu werscheen de oorspronkelijke editie van dit eerste deel van de 'Soziologische Aufktărang'-reeks in 1970. Beide artikelen hadden echter all veel eerder het publicitaire licht gezien, respectievelijk in het Kolner Zeitschrift fizr Soziologie und Sozialpsychologie 14 (1962) en Soziale Welt 15 (1964).

136. Verg. 'Funktion und Kausalität', op.cit, p. 11-13. 


\section{'Die Funktion ist nicht eine Sonderart der Kausalbeziehung, son- dern die Kausalbeziehung ist ein Anwendungsfall funktionaler Ordnung. ${ }^{137}$}

Ter onderbouwing van deze claim bezon Luhmann zich al in zijn vroegere werk op de vraag, wat nu het bijzondere, het eigenlijk interessante is aan functionele verklaringen, zoals bijv. Malinowski die had gegeven van uiteenlopende riten en magische praktijken. Wat is, methodologisch gezien, de pointe van de vaststelling dat het uitwoeren van regendansen bijdraagt aan de sociale cohesie en integratie van een midden-Amerikaanse indianenstam? Voorzover een dergelijke waststelling zich laat staven, kan het natuurlijk om een op zichzelf fascinerend inzicht in het reilen en zeilen van een concrete sociale gemeenschap gaan. Maar wat vanuit een algemener perspectief intrigeert, of wat althans Luhmann intrigeerde, is niet zozeer de constatering dat het opvoeren van regendansen de sociale integratie van een bepaalde stam (causaal?) 'bewerkt', maar veeleer de vraag: hoe doen andere samenlevingen dat? Wat draggt bijw. in ònze maatschappij bij aan de sociale cohesie en integratie - zijn kerkdiensten of internationale voetbalcompetities in dit opzicht vergelijkbaar met regendansen? De eigenlijke pointe van een functionele analyse, aldus Luhmann, bestakat niet in het opsporen van een verborgen causale samenhang, maar in het openen en afgrenzen van een veld van vergelijkingsmogelijkheden. Het vaststellen en specificeren van een probleem, bijv. het probleem van socilale integratie, maakt in concreto zeer verschillende sociale structuren en processen onderling vergelijkbaar als mogelijke 'oplossingen'. De zin van het specificeren van dergelijke 'referentieproblemen", zo zou men ook kunnen zeggen, is niet gelegen in de verklaring van feitelijk voorkomende functionele prestaties, maar schuilt juist in de verwijzing naar andere mogelijkheden. (Omgekeerd kan in plaats van een probleem, ook een 'oplossing', d.w.z een bepaalde structuur of praktijk constant worden gehouden om daarmee een veld af te bakenen van 'problemen' die daarin vergelijkbaar zijn, dat de onderhavige structuur of praktijk hun mogelijke oplossing vormt.) Functionele analyse verschijnt zo als een comparatieve methode die zich bedient van problemen/oplossingen als gezichtspunten van vergelijking. ${ }^{138}$

Om deze visie op de functionele methode expliciet te onderscheiden van het gewraakte 'Kausalfunktionalismus', betitelde Luhmann zijn eigen concept van functionele analyse als 'Aquivalenzfunkionalismus', een functionalisme dus dat zich interesseert voor 'functionele equivalenten' - en aan die omschrijving heeft hij tot op de dag van vandaag vastgehouden.

137. Idem; p. 16.

138. Verg. ldem, p. 13 in 14; Verg ook: N. Luhman, Soziale Systeme, op cit, p. 84 e.v. 
Op basis van dit equivalentie-functionalisme is het nu ook mogelijk; zo meende Luhmann, om een functionele interpretatie van causaliteit te geven, of althans van de manier waarop het oorzaak/gevolg-denken zinwol binnen de sociologie kan worden ingepast. Het ging hem er m.a.w. niet om het nut wan causale voorstellingen op zich te betwijfelen of om het oorzakelijkheidsdenken uit de sociologie te bannen, maar om de al eerder aangekondigde 'Umkehr des Fundierungsverhaltnisses von kausaler und funktionaler Beziehung' die uiteindelijk ook de causale analyse binnen de sociale wetenschappen ten goede zou komen:

'Nachdem wir einen Funktionsbegriff gefunden haben, der unabhängig von kausalen Ordnungsbegriffen definiert werden kann, ...laßBt sich weiterhin zeigen, daß der eigentümliche Sinn kausaler Urteile besser zur Geltung kommt, wenn man die Kausalbeziehung mit Hillfe dieses Funktionsbegriffes erläutert. ${ }^{139}$

Als referentieprobleem van een functionele analyse van causaliteit diende voor Luhmann de eindeloze vertakking van oorzaak/gevolg-ketens. Niet alleen is iedere oorzaak zelf veroorzaakt door oneindig veel voorafgaande oorzaken, maar bovendien is ze op haar beurt de veroorzaker van oneindig veel toekomstige gevolgen. Betrek daarbij het gegeven dat oorzaken ook gecombineerd kunnen optreden, plus het feit dat ze als veroorzakers van specifieke gevolgen onderling inwisselbaar kunnen zijn, en het wordt duidelijk, alldus Luhmann, dat de voorstelling van causaliteit als een invariante relatie tussen een oorzaak en haar gevolg tot problemen moet leiden. Een pregnant voorbeeld daarvan meende hij te ontwaren in de problemen die binnen de sociale wetenschappen met de beruchte 'ceteris paribus'-clausule samenhangen, een techniek die inderdaad neerkomt op het uitsluiten van andere mogelijke oorzaken en/of gevolgen ten behoeve van de formele correctheid van verklaringen, maar die ten koste gaat van de empirische zeggingskracht van causale uitspraken. Van dergelijke problemen zouden we onszelf verlossen, wanneer we ons niet langer fixeren op de vaststelling van een constante relatie tussen een oorzaak en een gevolg, maar genoegen nemen met het constant houden van ofwel een 'oorzaak', ofwel een 'gevolg'. Houden we, bijv. op grond wan zijn praktisch of theoretisch belang, een gevolg constant, dan kan dat dienen als aanknopingspunt voor het zoeken naar andere mogelijke veroorzakers van dat gevolg. In het licht van een bepaald gevolg verschijnen m.a.w. uiteenlopende mogelijke oorzaken (of combinaties daarvan) als "equivalenten": Omgekeerd kan men natuurlijk ook uit de veelheid van oorzaken er één als referentiepunt selecteren en op grond daarvan een veld van mogelijke gevolgen in kaart brengen - bijv. om te zien inhoeverre sommige gevolgen (of combinaties daarvan) de veroorzaker kunnen legitimeren dan wel in diskrediet brengen. 
'Die Analyse ...konzentriert sich entweder auf die Erforschung möglicher Ursachen unter dem Leitgesichtspunkt einer Wirkung oder auf die Erforschung von Wirkungen unter dem Leitgesichtspunkt einer Ursache. Beides zugleich durchzuführen, ist unmöglich, weil jede funktionalistische Analyse einem gewählten Bezugsgesichtspunkt voraussetzt, der nicht geåndert werden kann, ohne daß die Ergebnisse sich verschieben. ${ }^{340}$

'Exclusieve" causale betrekkingen, d.w.z. causale relaties tussen slechts één oorzaak en één gevolg, verschijnen in dit perspectief als een limiet - 'Die Sinn des kausalen Beziehens liegt aber nicht darin, diesen Grenzfall zu erreichen und andere Möglichkeiten auszuschließen, sondern darin, sie zu erfassen und zu ordnen. ${ }^{141}$

Voorzover uit bovenstaande en vergelijkbare citaten kan worden opgemaakt, dat Luhmann het oorzakelijkheidsdenken van de moderne wetenschap heimelijk identificeerde met 'mono-determinisme' of 'unilineaire causaliteit', valt er op zijn functionalistische reconstructie van het oorzaak/gevolg-schema behoorlijk wat af te dingen - zeker wanneer we zijn analyse tevens zouden moeten opvatten als een kritiek op het neo-positivisme. ${ }^{142}$ Maar laten we terugkeren naar het algemene idee achter het equivalentie-functionalisme - "de relatie tussen probleem en oplossing als leidraad voor het zoeken naar functionele equivalenten" - en wel aan de hand van Luhmanns opmerking dat een probleem eigenlijk helemaal geen probleem is, als het in één keer kan worden opgelost. Het functionele analyseren wordt volgens Luhmann dan ook in beweging gehouden door het inzicht, dat een gegeven probleem door de functionele prestaties van concrete structuren weliswaar wordt bewerkt en omgevormd, maar nooit definitief opgelost:

"Probleme sind nur dann Probleme, wenn sie nicht isoliert, nicht Stuck für Stück bearbeitet und gelöst werden können. Gerade das macht ihre Problematik aus. [-] Alle Funktionsorientierung rich-

140. Idem, p. 17.

141. Idem.

142. Zie voor een in sommige opzichten zeer terechte kritiek op Luhmanns toenmalige perceptie van het causaal-nomologische denken: D. Zolo, 'Function, Meaning, Complexity: The Epistemological Premisses of Niklas Luhmann's 'Sociological Enlightenment', in: Philosophy of the Social Sciences 16 (1986), p. 11 15-127. Zolo overdrijft echter schromelijk de betekenis van zijin kritiek voor een diagnose van Luhmanns totale projekt. In een reactie op Zolo geeft Luhmann op enkele punten dan ook gemakkelijk toe. Mijn vroegste essays, zo merkt hilj op, "have been to some extent superfluous and for some aspects excessive. This is the case, for instance, of my reaction of causal laws connected with the model of monofactorial theories." Echter: 'I have not modified the central concepts I defined in these essays.' (N. Luhmann, "The Theory of Social Systems and its Epistemology: Reply to Danilo Zolo's Critical Comments', in: idem (p.129-134), p. 129.) 
tet sich deshalb auf einen unauflösbaren (nur: zerstörbaren) Zusammenhang. ${ }^{\text {143 }}$

De oorspronkelijke problematiek, zo is het idee, keert altijd weer terug, zij het getransformeerd in de negatieve, 'dysfunctionele' gevolgen die iedere gepraktiseerde 'oplossing' ook steeds met zich meebrengt. Zo kan het binnen maatschappijen altijd aanwezige confliktpotentieel worden gedempt door vormen van absolute macht, maar bijvoorbeeld ook door een splitsing en differentiatie van loyaliteiten (bijv. wanneer de loyaliteit jegens de locale gemeenschap een tegenwicht vindt in translocale verwantschapsloyaliteiten of in religieuze affiliaties). De eerste 'oplossing' voert in zijn kielzog legitimatieproblemen mee; de tweede leidt tot een verminderde flexibiliteit, ondermeer door de slagvaardigheid van processen van collectief bindende besluitvorming te ondermijnen. Iedere structureel verankerde 'oplossing' stelt m.a.w. onder een bepaald gezichtspunt zelf weer een probleem voor en kan dus op zijn beurt als referentieprobleem van een functionele analyse dienen. Het probleem/oplossing-schema laat zich op recursieve wijze toepassen, zowel in 'benedenwaartse' als in 'bovenwaartse' richting. 'Benedenwaarts' wil dan zeggen, dat een dysfunctioneel of 'negatief' effect van' een (mogelijke) oplossing in een volgende fase van analyse als referentieprobleem wordt vastgehouden, in het licht waarvan een nieuw bereik van functioneel equivalente oplossingen kan worden onderzocht. Omgekeerd kan men ook de vraag stellen, van welke 'oplossing' het uitgangsprobleem het (dystunctionele) gevolg was, on van dlaaruit op te klimmen naar een 'eerder' referentieprobleem en het daardoor ontsloten veld van functionele equivalenten.

Het grote voordeel van deze aanpak en de probleemhiërarchie ('Problemstufenordnung') die eruit resulteert, schuilt volgens Luhmann daarin, dat de onderzoeker in principe bij een willekeurig fenomeen kan beginnen en dit in de wetenschap, dat de aanvankelijk eenzijdige en abstracte bepaling van dit fenomeen als het 'referentieprobleem' van zijn analyse, door de gefaseerde uitbreiding van het probleemveld aan inhoud zal winnen en zonodig zal worden gecorrigeerd. De nadelen lijken echter ook voor de hand te liggen. We kunnen met het equivalentie functionalisme inderdaad alle kanten op - we kunnen stijgen op de probleemladder, er langs afdalen, we kunnen zijwaarts bewegen door ons op andere mogelijke oplossingen/problemen te concentrerer en de dan mogelijke vertakkingen volgen, maar dit alles zonder ooit bij een zeker houvast of definitief einde uit te komen. Kortom -, wat Luhmann als de openheid en beweeglijkheid van de functionele methode aanprijst, kan evenzogoed negatief worden geïnterpreteerd als een eindeloze regressie die hooguit uitmondt in ongebreidelde willekeur en relativisme. 
Een dergelijke kritiek, zo riposteert Luhmann, richt zich in feite tegen een functionalisme dat zich uitgeeft woor een 'zuivere", op zichzelf staande methode van vergelijken. En de kritiek zou ook met recht hém betreffen, wanneer hij van een absolute scheiding tussen methode en theorie zou uitgaan (i.p.w. een onderscheid tussen beide te maken). ${ }^{144}$ Luhmann gaat er daarentegen wel degelijk vanuit, dat het functionalisme als methode geflankeerd dient te worden door een theorie - 'theorie' niet alleen begrepen als een samenhangend geheel van analytische en beschrijwende categorieèn warvan de probleemdefinitie zich bedient, maar bovendien als "Verdichtung und Konkretisierung von Fragestellungen und Resultaten, die wir der funktionalen Methode als solcher nicht abgewinnen konnten ${ }^{145}$ Fungeert de recursieve toepassing van het probleem/oplossing-schema enerzijds als schema van theorieconstructie; anderzijds leveren relatief goed bevestigde theorieen in hun hoedanigheid van beschrijvingen en empirisch geïnformeerde modellen van de werkelijkheid, aan het functionele vergelijken houvast en oriëntatie. ${ }^{146}$ Zo kan de theorie een veld van functionele equivalenten danig inperken door erop te wijzen, dat een systeem meerdere problemen tegelijkertijd moet oplossen of door naar voren te brengen dat een specifieke functionele oplossing in uiteenlopende probleemreeksen ('A quivalenzreihe') fungeert en daarom een equivalente vervanging in concreto zeer onwaarschijnlijk is. De flankerende theorie, zo zou men kunnen zeggen, heeft precies de functie de willekeur en het relativisme van een 'reines Vergleïchen' tegen te gaan.

Deze wederzijdse implicatie van functionele methode en theorie stelt aan de theorie echter een bijzondere eis. De theorie kan nu niet meer de vorm van een deductief-axiomatisch stelsel aannemen, maar moet zelf de 'grammatica' van de probleem/oplossing-schematiek volgen, moet idealiter "die Form einer Auslegung der Probleme auf mögliche Antworten hin" aannemen. ${ }^{147}$ Precies dat, en niet een of andere bestandsproblematiek ${ }^{148}$, doet de systeemtheorie als het natuurlijk complement van de functionele methode verschijnen. De systeemtheorie reconstrueert en beschrijft immers van meet af aan haar werkelijkheid in het licht van een probleem, het alles overkoepelende probleem van een complexiteit die door systeemvorming weliswaar wordt gereduceerd, maar nooit definitief geëlimineerd. Luhmann:

'Die Eigentliche Theorieleistung, die den Einsatz funktionaler Analysen vorbereitet, liegt demnach in der Problemkonstruktion.

144. Verg, o.a. 'Funktionale Methode und Systemtheorie', op. cit., p. 37.

1145. Idem.

146. Verg. W.L. Schneider, Objektives Verstehen, Opladen 1991, p.201.

147. N. Luhmann, 'Die Praxis der Theorie', opgenomen in Soziologische Aufklärung l, op. cit., p. 260.

148. Verg. A. Gouldner, 'Reciprocity and Autonomie in Functional Theory', opgemomen in: Llewllyn/Grosz (ed.), Symposium an Sociological Theory, New York 1959, p.241-270. 
Daraus ergibt sich der Zusammenhang von funktionaler Analyse und Systemtheorie. ${ }^{.149}$

En al eerder heette het:

'Die allgemeine Systemtheorie fixiert ..nicht die in allen Systemen ausnahmslos vorzufindenden Wesensmerkmale. Sie wird vielmehr in der Sprache von Problemen und Problemlossungen formuliert, die zugleich begreiflich macht, daß es für bestimmte Probleme unterschiedliche, functional aquivalente Problemlösungen geben kann. ${ }^{\text {'150 }}$

Theorie en methode, systeemtheorie en equivalentiefunctionalisme dienen dan weliswaar van elkaar te worden onderscheiden, maar tegelijkertijd impliceert het voorafgaande, dat beide op één punt samenvallen, namelijk in de conceptie van 'Welt' als het alles overkoepelende referentieprobleem van absolute complexiteit. 'Welt' moet ook de spits van de functionalistische probleemhierarchie vormen, het punt waar we uitkomen wanneer we de probleemladder consequent in "opwaartse" richting blijven volgen. De wederzijdse implicatie van theorie en methode is uiteindelijk geworteld in een identiteit die de vorm van een probleen heeft aangenomen.

De bovenstaande uiteenzetting van het equivalentiefunctionalisme". mag, op én punt na, wolstaan als een eerste indruk van Luhmanns methodologische opvattingen. Dat punt betreft de vraag, wat nu de eigenaard is van de (sociologische) kennis waar het Luhmann om te doen is. Wat maakt het soort kennis dat door het equivalentie-finnetionalisme wordt bemiddeld dusdanig bijzonder of aantrekkelijk voor de sociale wetenschappen, dat daarbij vergeleken thet inzicht in causale samenhangen eigenlijk van een mindere orde wordt?

Wat Luhmann daar aanvankelijk zelf over te melden had, is niet altijd overtujgend. Zo meende hij nog ten tijde van 'Funktionale Methode und Systemtheorie', dat zijn equivalentiefunctionalisme bijdraagt aan de rationalisering van (praktische en theoretische) problemen. ${ }^{151}$ Het probleem is echter dat het equivalentie-functionalisme, zuiver als methode beschouwd, geen inhoudelijk criterium aanlevert voor de keuze van een concreet probleem in het licht waarvan eerst mogelijkheden met elkaar vergelijkbaar zijn - en precies die keuze van een gezichtspunt wan vergelijking, zo meende Luhmann zelf, "ist mitentscheidend fur den Stil der Rationalitat ${ }^{\prime} .{ }^{152}$ Een beroep op de flankerende functie

149. Soziale Systeme, op.cit., p. 86.

150. Idem, 33 .

151. Verg "Funktionale Methode und Systemtheorio', op.cit, p. 35

152. Idem, p.47. 
van de systeemtheorie, of eventueel van een syteemtheoretische sociologie maakt de zaak er ook niet beter op. Aan de systeemtheorie ligt geen voorstelling van rationaliteit ten grondslag. ${ }^{15.3}$ Een van haar adagia is nu juist, dat er niet zoiets als een rationaliteit 'an und fur sich' kan bestaan, maar dat over 'rationaliteit" hooguit in referentie aan een concreet systeem kan worden gesproken. In. abstracto kan een externe observator 'rationaliteit" dan nog willen afmeten aan de effecten die de inwerking van een systeem op zijn omgeving voor dat systeem zelf heeft, om op geleide daarvan bijvoorbeeld de milieuproblematiek als een teken van de irrationaliteit van de moderne maatschappij te beschouwen. Maar dat alles sluit niet uit, dat het voor een gegeven systeem dan evenzeer 'rationeel' kan zijn om mogelijkheden niet te exploreren, om het aftasten van alternatieven te blokkeren - ook latentie kan bijdragen aan een 'rationele' omgang met de omgeving.

Evenmin overtuigend was de analoge suggestie, dat het 'Erkenntnisziel' van het equivalentie-functionalisme "nicht mehr die Feststellung der unwandelbaren, sich selbst gleichenden Substanz in ihrem Wesen (betrifft), sondern die Kontrolle uber Alternativen". 154 Als "controle" hier simpelweg betekent: "het in kaart brengen van andere (dan de hier en nu gerealiseerde) mogelijkheden' - dan hebben we in feite met een tautologie te maken, aangezien dat precies de hele inhoud van het functionele vergelijken uitmaakt. Vatten we 'controle' daarentegen in meer instrumentele zin op, associëren we 'controlleren' bijv. met 'manipuleren", dan lijkt het causale denken plotseling over veel betere papieren te beschikken.

Het probleem van bovenstaande pogingen om het bijzondere karakter van het functionele weten voor het woetlicht te brengen; zo kunnen we met het gemak van de terugblik constateren, school voor een belangrijk deel daarin, dat Luhmann in zijn vroegste methodologische geschriften er nog te veel op gebrand was, om ook nog eens de superioriteit van het functionele gezichtspunt t.o.v. neo-postivistische en aanverwante causaal-analytische wetenschapstheorieên te demonstreren. ${ }^{155}$ En in zeker opzicht zijn wij Lulmmann hierin gevolgd, door de discussie aan te snijden met de vraag, welke voordelen het equivalentiefunctionalisme biedt in vergelijking met de causale analyse. Het hele idee echter, dat we door voor- en nadelen tegen elkaar af te wegen de balans tussen beide opties kunnen opmaken, veronderstelt dat we over een onafhankelijk

153. En voor een systeemtheoretische sociologie, zo zullen we nog zien, stellen noties als doelrationaliteit, waardenrationaliteit of comunicatieve rationaliteit geen grondbegrippen voor; maar mogelijke vormen van complexiteitsrectuctio warvan ontwikkelde sociale systemen gebruik kunnen maken bij hun zelfbeschrijving.

154. Idem, p. 36 .

155. In dat teken staat ook dle dikwijls terugkerende uithaal naar het substantie-ontologische identiteitsdenken, waarin het gaat om "die Feststellung der unwandelbaren, sich selbst gleichenden Substanz in ihrem Wesen" (zie boven). Lahrnanu meende namelijk (ten onrechte) dat ook het moderne causaliteitsdenken voor zijn fundering nog aàngewezen is op een substanthalistische ontologie. 
eriterium van weging beschikken, over een onbetwijfelbaar kennisideaal in het licht waarvan zowel de causale als de functionele methode op hun merites kunnen worden beoordeeld. En die veronderstelling is verre van triviaal, zo begon ook Luhmann te beseffen. Maar als dat zo is, lopen pogingen om de superioriteit van bijv. het functionalisme ten opzichte van het causale denken te demonstreren, al gauw het gevaar causale analyses af te meten aan een kennisideaal waaraan het functionele verklaren zich gecommitteerd weet, maar die voor een causaal verklarende wetenschapper of socioloog extern en wezensvreemd moeten blijven. Om die valkuil te vermijden, ligt het meer voor de hand om niet te denken in termen van onderschikking of onderlinge reductie, maar juist de contrasten tussen beide methodes te benadrukken en ze te behandelen als qualitatief verschillende methodologische paradigma"s met ieder hun eigen, onvervreembare kennisidealen.

Kijken we nu terug op Luhmanns ontwikkeling, dan kunnen we inderdaad vaststellen, dat hij al vrij snel zijn openlijk polemische houding t.o.v. de 'vorherrschenden kausalwissenschaftlichen Orientierung' liet varen, om zich meer te gaan concentreren op de verschillen tussen zijn eigen aanpak en andere vormen van (sociale) wetenschap bedrijwen. Dat heeft tevens geleid tot een precisering van zijn eigen kennisidealen, tot een scherper inzicht in de eigenaard van het functionele 'weten' - misschien moeten we zeggen: in de epistemologische basishouding van een equivalentie-functionalistische systeemtheorie. Zo opent Soziologische Aufklänung 3 (1981) met de opmerking dat binnen de sociale wetenschappen de alledaagse leefwereld ('the world taken for granted") op twee manieren tot probleem kan worden gemaakt en dat daarmee ook een tweetal verschillende theoretische intenties verbonden zijn. De ene manier van problematiseren begint met de veronderstelling van een basale onde, om vervolgens de imperfectie, het verval en de corruptie van die orde aan de kaak te stellen. Dat is, volgens Luhmann, onder meer kenmerkend voor de 'social problems'-sociologie:

'Sie fragt nicht nach den Grunden fur konformes, sondern nach den Grunden fur abweichendes Verhalten, nicht nach den Annehmlichkeiten des Stadtlebens, sondern nach den Slums. Sie zieht ihren moralischen Impetus aus den Problemen, denen sie gesunde Zustände vorzieht. ${ }^{156}$

Het andere model - en dat is het model waar Luhmann zich mee identificeert - begint er daarentegen mee de normale en vertrouwde ordening van het dagelijks leven tot iets onwaarschijnlijks en niet-normaals te verklaren, om vervolgens te laten zien hoe het onwaarschijnlijke en niet-normale waarschijn-

156. N. Luhmann, 'Vorbemerkungen zu einer Theorie sozialer Systeme', opgenomen in Soziologische Aufklarung 3, Opladen 1981, p.11. 
lijk en normaal zijn geworden. Natuurlijk is deze techniek van problematiseren niet nieuw. Een dergelijke manoevre, weg van de vraag wát iets op zichzelf beschouwd is naar de vraag hóe iets het geval kan zijn, treffen we bijv. ook bij Hobbes aan: Hoe kan zoiets waarschijnlijks als een geordend samenleven waarschijnlijk zijn, als het toch veel meer voor de hand ligt dat allen elkaar naar het leven staan. Kenmerkend voor Luhmann is hooguit de radicaliteit waarmee hij deze vorm van problematiseren tot het algemene principe van zijn functionalisme promoveerde, daarmee ook bewust aan zijn versie van een systeemtheoretische sociologie een specifieke intentie verlenend. Een wat langer citaat uit Soziale Systeme, zijn in 1984 gepubliceerde opus magnum, kan dit illustreren:

'Die Theorie deren Ausarbeitung wir beginnen ist nicht an Perfektion und Perfektionsmängeln orientiert, sondern an einem wissenschaftsspezifischen Interesse an Auflösung und Rekombination von Erfahrungsgehalten [-] Es geht nicht um ein Anerkennungs- und Heilungsinteresse, auch nicht um ein Bestandserhaltungsinteresse, sondern zunächst und vor allem um ein analytisches Interesse: um ein Durchbrechen des Scheins der Normalität.: Das methodologische Rezept hierfur lautet: Theorien zu suchen denen es gelingt, Normales fur unwahrscheinlich zu erklären. Dies kann in funktionalistischer Perspektive mit Hilfe von Problemstellungen geschehen, die es ermöglichen, normale Erfahrungsgehalte der Lebenswelt als immer schon gelungene, aber vielleicht auch anders mögliche Problemlösung. "157

Het waarschijnlijke voor onwaarschijnlijk houden! - in feite is dat de uitvergroting van een element, dat van meet af aan in Luhmanns methodologische overwegingen besloten lag. Het zoeken naar equivalente oplossingen in het licht van een gegeven probleern, het afbakenen van 'mogelijkheidsbereiken', heeft als onvermijdelijk bij-effect, dat ook de contingentie van hier en nu gerealiseerde 'oplossingen' scherper wordt uitgelicht. Het functionele vergelijken benadrukt $\mathrm{m}$.a.w. dat de vertrouwde structuren en ordeningen van het alledaagse leven als geactualiseerde mogelijkheden 'slechts' mogelijkheden zijn. Maar als het hier en nu actuele slechts een mogelijkheid onder andere mogelijkheden voorstelt, dan dringt zich onwillekeurig ook het toevallige karakter van de actualiteit op, simpelweg omdat een uitbreiding van het zicht op andere, equivalente mogelijkheden tevens onder ogen voert, dat de kans dat uit het geheel van mogelijkheden cen bepaalde mogelijkheid geselecteerd wordt, klein is. Iedere

157. Soziale Systeme, op.cit, p. 162/163. Maar vergelijk ook 'Funktionale Methode und Systemtheorie", op.cit., p.12, wast Luhmann noteert: 'Die Welt, wie sie ist und bekannt ist, muB von der Aussageebene des Unwahrscheinlichen lher rekonstraiert werden? 
gerealiseerdemogelijkheid, iedereconcretestructuurverschijntzoals 'onwaarschijnlijk'. Let wel, het gaat Luhmann niet om de constatering van de onwaarschijnlijkheid van de gegeven werkelijkheid per se, of zelfs ook maar om het vaststellen van graden van on/waarschijplijkheid. Het betreft een "Interesse an Defiguration der Fakten' terwille van kennis omtrent 'het ook anders mogelijke' - of zoals Luhmann het in 'Funktionale methode und Systemtheorie' uit 1964 al formuleerde:

'Das Seiende ist erkenntniswurdig nicht in dem Maße, als es andere Möglichkeiten ausschließt, sondem deshalb, weil es sie ordnet und mit Hilfe abstrakter Methoden zugänglich macht. ${ }^{\text {'ss }}$

En verderop heet het:

'Der Vergleich stellt das Seiende nicht als es selbst fest, sondern er fixiert abstrakte Gesichtspunkte, unter denen dem Seienden ein anderes gedanklich oder faktisch substituiert werden kann. Der Gewinn an Rationalitat besteht nicht in der Gewißheit, daß das Seiende in einigen Wesenszuigen es selbst bleibt; er besteht vielmehr in der Gewißheit, daß es unter bestimmte Voraussetzungen nicht nötig ist, daß das Seiende es selbst bleibt: ${ }^{159}$

De functionele methode wordt m.a.w. niet gedreven door de wil de gegeven werkelijkheid in zijn onveranderlijke, noodzakelijke grondstructuren te kennen, maar door een belangstelling voor 'het andere', voor het hier en nu niet-actuele en niet-geldende, maar eventueel ook mogelijke. Zoals we nog zullen zien, zal dit motief - we zouden ook kunnen zeggen - deze epistemologische basishouding -, gaandeweg Luhmanns ontwikkeling steeds sterker op de voorgrond treden, om tenslotte de vorm aan te nemen van een heuse fascinatie voor het niet-mogelijke en anders-mogelijke, voor het uitgeslotene en deviante. Uit bovenstaande citaten kumen we echter aflezen, dat dit motief als zodanig al in zijn vroegste werk aanwezig is. Voeg daarbij het plezier dat Luhmann schept in paradoxale formuleringen zoals 'onwaarschijnlijke waarschijnlijkheid' - ja, dat de techniek wan de 'ontnormalisering van het normale' precies berust op de constructie van paradoxale standen van zaken en ook alleen in die vorm prikkelt $^{160}$-, en opeens wordt niet alleen een bijzondere connectie tussen Luhmanns functionalisme en zijn (latere) theorie van zelfreferentiële systemen zichtbaar; bovendien wordt duidelijk dat de methodologische en theoretische intenties van Luhmanns project weinig of niets hebben uit te staan met rationalisme of beheersingsdenken.

158. Soziologische Aufklärung 1, op. cit, p. 36 ;

159. Idem, p. 47.

160. Verg. R. Nozilck, Philosiophical Explanation, Cambridge (Mass.) 1981, ih.b. de "Introduction'. 


\section{HOOFDSTUK II}

\section{Zin en Contingentie}

\section{$\S 1$. Inleiding}

Als het de droom van de exegeet is met relatief eenvoudige ideeên en begrippen te mogen beginnen, om daarop voorbouwend allengs complexere samenhangen en modellen te introduceren en zo stapsgewijs de lezer naar hogere abstractieniveaus te woeren, dan is het door Luhmann gebezigde begrip 'Sinn' zijn nachtmerrie. Luhmann zelf lijken uiteenzettingen over 'zin/betekenis' evenmin goed te kekomen. ${ }^{164}$ Alhoewel het een van zijn meest complexe en abstracte leerstukken betreft, heeft hij er na het richting wijzende artikel 'Sinn als Grundbegriff der Soziologie' geen zelfstandige, thematisch omvattende studie meer over gepubliceerd en dat terwijl dit artikel uit het begin van de jaren zeventig stamt, dus nog vóor de 'autopoietische Wende' is geschreven. Weliswaar zijn in de 'Soziologische Aufklärung'-reeks nadien nog opstellen verschenen die als een nadere bijdrage aan zijn zintheorie kunnen worden beschouwd ${ }^{165}$, hetgeen eveneens geldt voor passages uit bijv. Funktion der Religion (1977) en het openingsartikel van Gesellschaftsstruktur und Semantik I (1980). Echter -, het 'Sinn'-hoofdstuk uit Soziale Systeme, toch bij uitstek de gelegenheid om eens alle draden bij elkaar te trekken en de systematische samenhang tussen het zinbegrip en de theorie van zelfreferentięle systemen te demonstreren, is zonder kennis van het eerder genoemde 'Sinn als Grundbegriff der Soziologie' ook voor een welwillende, intelligente lezer(es) niet of nauwelijks te volgen.

Toch zijn er dringende redenen om de behandeling van Luhmanns zintheorie niet uit te stellen, maar er hier en nu, nog voorafgaand aan de uiteenzetting van zijn sociologie in de meer strikte betekenis van het woord, uitgebreider bij stil te staan. Johann Schulein heeft eens opgemerkt, dat het zinbegrip binnen de sociologie een "eigentumliche Zwitterstatus" bezit, "einerseits allenthalb als Grundbegriff anerkannt, praktisch ohne Bedeutung. ${ }^{166}$ Aan het werk van Luhmann kan hij daarbij nauwelijks hebben gedacht. Het zinbegrip wordt in Luhmanns meest centrale sociologische concepten, zoals "communicatie", "structuur', 'sociaal systeem' en 'maatschappij", regelrecht voorondersteld. We zouden daar bovendien aan toe kunnen voegen, dat zonder inzicht in zijn

164. "Sinn" kan in prinoipe zowel met "zin" als met "betekenis" worden vertaald. Alhoewel in engellse vertalingen van Luhmanns werk 'Sinn" meestal met "meaning" wordt weergegeven, zal ik mij doorgans aan 'zin' houdlen als de vertaling van 'Sinn".

165. Gewezen zij met narne op het artikel 'Ueber die Funktion der Negation in simikonstituierenden Systeme', opgenomen in N. Luhmann, Soziologische Aufklörung 3 , Opladen 1981.

166. J. Schülein. 'Zur Konzeptualisienung des Sinnbegriffs', in: K. Z.FS.S. 34 (1982), p. 
zintheorie, ook de werkwijze en de inzet van Luhmanns meer empirische, historisch-sociologische werk, zoals bijvoorbeeld geetaleerd in de verschillende delen van Gesellschaftsstruktur und Semantik en in Liebe als Passion, onbegrijpelijk moeten blijven. Met 'zin' lijkt definitief te zijn beslist, om wat voor een soort sociologie het Luhmann allemaal te doen is. Om de zaak in het juiste perspectief te plaatsen: met 'Sinn als Grundbegriff der Soziologie' beoogde Luhmann niet een (kennis-/cultuur-) sociologische zintheorie aan te bieden, maar de fundering te leggen voor een zintheoretische sociologie.

Wat maakt Luhmanns zin-theorie zo lastig? Op zich kan de proclamatie van 'zin' tot grondbegrip van de sociologie toch weinig opzien baren. Niet alleen is het, op enkele steunpunten van sociaal-wetenschappelijk behaviorisme na, gemeengoed geworden om 'handelen' nadrukkelijk te onderscheiden van 'gedrag" op basis van het begrip 'zin'; we kunnen ons bovendien niet goed voorstellen hoe handelingen anders met elkaar zouden samenhangen, dan op grond van hun 'zin', wat een 'rol' of 'institutie' anders zou zijn, dan een zinvol samenhangend geheel van handelingen. Voorzover de met de zin van een handeling gegeven verwijzing naar andere handelingen ook altijd selectief is, in concreto niet iedere handeling met alle andere mogelijke handelingen een 'zinsamenhang' vormt, lijkt ook de verbinding tussen 'zin' en 'systeem' niet bijzonder problematisch. Luhmanns karakterisering van sociale systemen als "zinsystemen" komt dan, in de woorden van een handelingstheoreticus als Uwe Schimank, neer op de vaststelling,

'daß sie sinnhafte Verweisungshorizonte von Handeln eingrenzen. Das Und-So-Weiter das von jedem Sinngehalt seinen Ausgang nimmt und Sequenzen aufeinander bezogenen Handlungen mobilisieren kann, schweift nicht völlig beliebig in der Totalităt aller in der Welt möglichen Sinnbezuge umher, sondern wird soweit limitiert, daß in einer sozialen Situation aufeinander abgestimmtes. Handeln verschiedener Akteure realisierbar wird. ${ }^{167}$

Wat maakt Luhmanns zinbegrip dan toch zo ingewikkeld, of in ieder geval zoveel lastiger uiteen te zetten, dan de concepties van 'zin' die we in fenomenologische/hermeneutische/Verstehende/etc. sociologieen aantreffen. Het algemene, maar daarom niet minder juiste antwoord op deze vraag zou kunnen luiden: het feit dat Luhmann, op zoek naar een zinbegrip dat noch subjectivistischindividualistisch, noch objectivistisch-collectivistisch van aard is, dat noch op

167. U. Schimank, "Gesellschaftiche Teilsysteme als Akteurfiktionen", in: K.Z.F.S.S. $40(1988,3)$, p.626. Of zoals Luhmann het zelf formulleert: "Sozialle Systeme sind sinnhaft identifizierte Systeme. Ihre Grenzen sind nicht physischer Natur... sondern sind grenzen dessen, was in Sinnzusammenhägen relevant sein kann." (N. Luhmann; 'Modeme Systemtheorien als Form gesammtgesellschaftlicher Analyse", opgenomen in: J.Habermas/N.Luhmanm, op.cit, p. 11-12. 
het bewustzijn van belevende en handelende actoren, noch op cultureel voorgegeven of anderszins collectief verankerde "dieptestructuren" kan worden gereduceerd, toch Husserls analyse van het intentionele bewustzijn als vertrekpunt neemt. Daar voegen zich natuurlijk nog andere 'problemen' bij, kwesties die vooral samenhangen met de overgang naar de theorie van zelfrefrentiële systemen en met de opmars van een differentie-logische observatie theorie. ${ }^{168}$ Die stellen een lezer echter voor minder zware beproevingen dan het feit dat Luhmann, in zijn poging om zich aan het subjectivisme van het Husserliaanse uitgangspunt te ontworstelen, precies die intuíties overboord moet zetten, die zijn publiek tot dan hadden kurnen verleiden met hem mee te gaan in zijn 'functionalisering' van Husserls fenomenologische beschrijving van het zinmatig beleven.

Met deze diagnose is meteen ook de algemene lijn van dit hoofdstuk gegeven. We zien bewust af van iedere poging tot volledigheid en concentreren ons op Luhmanns 'strategie' om via een steeds verdergaande functionalisering van het zinbegrip aan een subjectivistische zin-opvatting te ontsnappen en tegelijkertijd afstand te houden van objectivistische concepties van zin.

\section{\$2. Vertrekpunt Husserl}

Iedere functionele analyse gaat van start met de specificatie van een probleem, in het licht waarvan het functioneel te analyseren fenomeen als een 'oplossing' kan worden begrepen. Het is precies bij die, voor het verdere verloop van de functionele analyse van het verschijnsel 'zin' cruciale bepaling van het uitgangs- of "referentieprobleem", dat Luhmann aanvankelijk zwaar leunde op Husserls theorie van het intentionele bewustzijn - en dat heeft ook de betoogtrant van het richting wijzende opstel 'Sinn als Grundbegriff der Soziologie' sterk beïnvloed: ${ }^{169}$

Met de "intentionaliteit" van het bewustzijn wilde Husserl, zoals bekend, het relationele karakter van het bewustzijn onderstrepen, de typische eigenschap van mentale inhouden om altijd een bewustzijn 'van", of "omtrent iets' te zijn. Minstens zo belangrijk voor Luhmann is echter Husserls vaststelling, dat het bewustzijn in de akt van het intenderen voortdurend zichzelf transcendeert, de actuele bewustzijnsinhoud overstijgt. ${ }^{170}$ Het intentionele bewustzijn van een bepaald object is enerzijds steeds perspectivisch en dus partieel ( - bij het

168. Zie voor dit laatste punt o.a. J. Kunzler, Medien und Gesellchaft Stuttgant 1989, p. 110 e.v.

169. Luhmann beroept zich in het algemeen op thet werk van de latere Husserl; i.h.b. op Erfahrung und Urteil. Van mogelijk belang voor een zintheorie in de lijn van Luhmann, lijken mij, maast Ideen zu einer reinen Phenowenologie, Forntale und Transzerdentale Logik (1929) en naturlijk de Cartesiamische Meditationen (1931)

170. Zie woor dit en volgende o. a de 'Cartesische meditaties', $\$ 19,20$ en de Ideen zur ... $\$ 44$, p 100 e.v. 
waarnemen van "een vaas" zien we bijv. niet de achter- of onderkant van die vaas); anderzijds is het altijd een intenderen van dat object als een "transcendent' object, als iets dat telkens meer is dan wat hier en nu op perspectivische wijze geintendeerd wordt ( - in de waarneming van 'een vaas' veronderstellen we dat de hier en nu niet geobserveerde achterkant er wel is en dat we indien nodig om die vaas heen kunnen lopen om de achterkant alsnog te observeren). Dit over zichzelf heen verwijzen, deze 'immanente transcendentie' van iedere bewustzijnsakt, is volgens Husserl in en met iedere akt zelf gegeven, namelijk in zijn 'zin'. Met zijn zin of betekenis opent een bewustzijnsakt een 'horizon' van andere bewustzijnsakten, die met hùn zin of betekenis dan het oorspronkelijke, perspectivisch geîntendeerde object als het ware complementeren. De zin van de akten in de 'horizon' is dus niet willekeurig, maar 'vorgezeichnet' door de zin van de oorspronkelijke bewustzijnsakt. Daarbij maakt Husserl een onderscheid tussen een 'interne' en een 'externe' horizon. De interne horizon omvat; om kort te zijn, alle verdergaande eigenschappen van het geintendeerde object; de externe horizon omvat al het andere, alle andere mogelijk beleefbare en kenbare objecten, de 'wereld' als het geheel van voorstelbare standen van zaken. Het 'boven-zichzelf-uit-wijzen' van iedere zinmatige beleving is dus een dubbel 'Hinaus-meinen", waarbij Husserl er vamuit gaat dat de externe horizon, als dat waar het bewustzijn zich "in actu" niet op fixeert, toch mede-constitutief is voor de inhoud van de (actuele) beleving. ${ }^{171}$

Deze, door Husserl als een fenomenologische descriptie van de grondstructuren van het bewustzijnsleven gepresenteerde beschrijving van 'Sinn', wordt door Luhmann tot de formulering van een probleem geredigeerd ${ }^{172}$ Wat de fenomenologische analyse van het menselijk beleven aan het licht brengt - namelijk dat iedere beleving onophoudelijk boven zichzelf uit verwijst naar andere mogelijkheden van beleven -, stelt zowel een (evolutionair) voordeel als een probleem woor. Als een wezen dat zich, evolutionair gezien, heeft "gespecialiseerd' op de ontwikkeling van het organiseh (sub)systeem 'hersenen', is de 'mens' klaarblijkelijk in staat om naast hetgeen zich direct aan hem opdringt, ook het mogelijke, maar hier en mu niet-actuele in zijn voorstellingsvermogen vast te houden - alhoewel alles er vredig uit ziet; kan hij zich tegelijkertijd voorstellen, dat achter het volgende rotsblok een roofdier schuil gaat. Het evolutionaire voordeel van deze organisch verankerde voorstellings- of bewustzijnscapaciteit ligt voor de hand. Het 'zich-kunnen-voorstellen' van andere mogelijkheden dan de hier en nu actuele, maakt, om het in klassiekere termen uit te drukken, een kwalitatieve sprong in de stuur-capaciteiten van een systeem mogelijk, d.w.z. in het vermogen van een systeem de verhouding tot zijn omgeving (en tot zichzelf) adequaat te kunnen inrichten en beheersen. Het kan

171. Verg. Eirfahrung wand Urteil, \$8 en $\$ 33$.

172. Zie voor het nu volgende onder meer: N. Luhmann, "Sinn als Grundbegriff..,", op cit., p. 31 e.v.; idem, Soziale Systeme, op.cit, p.93 e.v. 
zijn verhouding tot de omgeving (en tot zichzelf) namelijk gaan sturen via een 'ontwerp' van zijn omgeving (en van zichzelf), dat complexer is dan de telkens actuele observatie. ${ }^{1 / 3}$ Dit mogelijke voordeel kan echter pas worden 'geïncasseerd', wanneer een fundamenteel probleem uit de weg is geruimd. Wat Husserl als de "immanente transcendentie" van bellevingsinhouden omschrijf, staat bij Luhmann tevens voor het probleem van de integratie tussen het actuele beleven en de daarin telkens aanwezige verwijzingen naar het potentiele beleven. Het cruciale probleem is, wolgens Luhmann, dat het menselijk beleven telkens een overvloed aan belevingsmogelijkheden met zich meebrengt, meer mogelijkheden dan in aansluitende belevingen geactualiseerd kunnen worden. Het menselijk beleven overspoelt zichzelf en dreigt daardoor aan een ondraagbare selectielast te bezwijken. Zijn (eveneens op organische gronden) geringe capaciteit voor informatieverwerking moet m.a.w. worden versterkt, wil de mens niet ten onder gaan aan deze zelf opgeworpen overmaat aan belevingsmogelijkheden.

Daarmee is in eerste ronde een referentieprobleem voor de functionele analyse van 'zin' afgebakend. Het komt er kortweg op neer, dat de wording van een systeem, dat in staat is, zich telkens ook andere mogelijkheden voor te stellen dan de hier en nu gerealiseerde mogelijkheid, een evolutionaire valkuil zou hebben betekend, indien het hier boven geschetste integratieprobleem niet opgelost kon worden onder behoud van deze zelfopgeworpen complexiteit als basis voor een verhoogde stuurcapaciteit. De (evolutionair gerealiseerde) oplossing voor dit probleem heet bij Luhmann: 'Sinn'.

Met Husserl gaat Luhmann er vanuit dat " $z$ in' inderdaad verschijnt in de vorm van een overschot aan verwijzingen naar andere mogelijkheden van beleven 'Etwas steht im Blickpunkt, im Zentrum der Intention, und anderes wird marginal angedeutet als Horizont für ein Und-so-weiter des Erlebens .... ${ }^{174}$ Een dergelijke beschrijving van de manier waarop 'zin' verschijnt, stapt echter gemakkelijk over het feit heen, dat ' $z$ in' in die hoedanigheid al de oplossing van een probleem behelst. Doen we een stap terug, beschouwen we zin nog vóór iedere, fenomenologisch-descriptieve bepaling zuiver functioneel, dan staat zin voor een manier van omgaan met complexiteit, en wel een omgangsvorm die "punktuellen Zugriff - geconcentreerde intentie - toelaat, maar dit telkens als een selectie die complexiteit intakt laat:

173. Het tussen haken toevoegen van de betrekking tot zichzelf (naast die tot de 'omgeving') is weliswaar stilistisch niet elegant, maar dient ter correctie/aanvalling op een anders wat al te syderwetse weergave van het concept 'sturing". Met de overgang nar de autopoietische systeemtheorie of, zo men wil, naar de theorie van zelfreferentiele systemen verschuift immers het primaat van de systeen/omgeving-verhouding naar de relatie van het systeem tot zichzelf,

174. Sosiale Systeme, op:citt., p.93. 
'Sinn fungiert als Prämisse der Erlebnisverarbeitung in einer Weise, die die Auswahl von Bewußtseinszuständen ermơglicht, dabei das jeweils nicht Gewählte aber nicht vernichtet, sonder es in der Form von Welt erhalt und zugänglich bleiben laßt. ${ }^{175}$

Het bewustzijn kan op basis van zin selectief zijn - bijv. aan reuzen denken en niet aan molens - , zonder dat daarmee bepaalde andere mogelijke voorstellingen of bewustzijnsinhouden (bijv. 'molens') definitief worden afgeschreven.

\section{§3. Negatie, actualiteit en potentialiteit}

De bijzondere eigenschap van zin, in het beleven zowel reductie (selectie) als behoud van complexiteit te bewerkstelligen, het nu-niet-geselecteerde toegankelijk te houden als bereik van aansluitende en toekomstige selecties, berust volgens Luhmann op het vermogen te negeren, i.h.b. op de 'reflexieve' en 'generaliserende" eigenschappen van negatie. ${ }^{176}$ De reflexieve eigenschap van negatie houdt in, dat de negatie altijd op zichzelf kan worden toegepast (negatie van de negatie) Dit laat het principieel toe, om de (als 'nu-niet-relevant') genegeerde belevingsmogelijkheden op een ander moment weer naar voren te halen, als een op haar beurt genegeerde negatie. Al het genegeerde verblijft in een voorlopige genegeerdheid, blijft op de achtergrond aanwezig als het latente bereik van toekomstige negaties. 'Negation ist keine Vernichtung', zo merkt Luhmann dan ook op, "sondern ein Modus der Erhaltung von Sinn'.177?

Deze reflexieve eigenschap staat in wisselwerking met het generaliserende aspect van negatie. In het negeren van de negatie, in de positieve bepaling van dat wat hier en nu van belang is, blijft al het andere onbepaald. Niet-niet-X scheert als de positieve bepaling van $\mathrm{X}$ al het andere over één kam als niet-X. Tegelijkertijd wordt het risico van een dergelijke veralgemenisering - tot het genegeerde kunnen immers ook ernstige bedreigingen behoren - dragelijk gemaakt, doordat het genegeerde middels de negatie van de negatie op ieder moment weer naar de voorgrond kan worden gehaald.

Aan de hand van de bovenstaande uiteenzetting over het 'Primat der Negativitat

175. 'Sinn als Grundbegriff...", op.cit., p. 34.

176. Bij Luhmann verschijmt het kunmen negeren als men menselijk "oer'-vermogen. In aansluiting op Baldwins genetische beschouwing van de negatie, gaat Luhmann er vanuit dat het vermogen 'gericht' (privatief en exclusief) te negeren zich ontwikkeld op basis van een daar nog voorafgaand organisch verankerd vermogen, de wisseling en instabiliteit van bellevingsinhouden gewaar te kunnen worden. Hoe dan ook - Negation scheint nicht nur dass am universellisten verwendbare Sprachsymbol zu sein, sondern darubler hinaus die Universalitath, das. heißt den Weltbezug der Lebenspraxis schlechthin zu konstituieren..." ("Ober die Funktion der Negation in sinnkonstituierenden Systemen", Soz. Aufkl.3, op. cit., p.37.

177. idem, p. 38 . 
im sinnkonstituierenden Erleben" kan nu, met Luhmann, een nadere bepaling worden gegeven van de wijze waarop de door zin bemiddelde verwerking van belevingscomplexiteit functioneert:

\begin{abstract}
'[Sinn] leistet Reduktion und Erhaltung von Komplexität dadurch, daß sie das unmittelbar gegebene evidente Erleben durchsetzt mit Verweisungen auf andere Móglichkeiten und mit reflexiven und generalisierenden Negationspotentialen und es dadurch fur riskante Selektivität ausrustet. ${ }^{178}$
\end{abstract}

Bovenstaand citaat maakt al min of meer duidelijk, welke samenhang Luhmann ziet tussen de bijzondere functionele eigenschappen van zin en de, door Husserl beschreven, globale verschijningsworm van zin. Zin 'bewaart' complexiteit in de vorm van verwijzingen naar andere belevingsmogelijkheden dan de telkens actuele belevingsinhoud. Luhmann:

'Das Phanomen Sinn erscheint in der Form eines Ueberschusses
von Verweisungen auf weitere Möglichkeiten des Erlebens und
Handelns. [-] Die Verweisung selbst aktualisiert sich als Stand-
punkt der Wirkliehkeit, aber sie bezieht nicht nur Wirkliches
(bzw. präsumptiv Wirkliches) ein, sondem auch Moggliches
(konditional Wirkliches) und Negatives (Unwirkliches, Un-
mögliches). ${ }^{179}$

Deze verwijzing van actualiteit naar (on)mogelijkheid is voor Luhmann het meest fundamentele kenmerk van zin. Zin staat altijd voor de eenheid van de differentie van actualiteit en mogelijkheid - alleen als de, in zich gedifferentieerde eenheid van het hier en nu actuele en het 'slechts' mogelijke kan zin zin zijn. Nog anders geformuleerd: de verwijzing naar andere mogelijke en niet-mogelijke belevingen(/handelingen) is constitutief voor de zin van een actuele beleving(handeling). Constitutief voor de beleving van its als een 'vaas' zijn andere mogelijke (en ook niet-mogelijke) belevingen van die vaas, de veronderstelling dat we bijwoorbeeld de nu niet zichtbare achterkant kunnen observeren, dat zij met water kan worden gevuld, dat er snijbloemen in kunnen worden geschikt, etc. ( - en ook de veronderstelling dat vazen bijwoorbeeld geen bloemen kunnen weigeren, niet zullen eisen met jenever te worden gevuld, noch tegen de komst van een huisdier zullen protesteren, ete.)

Met deze abstracte bepaling van de grondstructuur van zin als de eenheid van actualiteit en potentialiteit, lopen we echter het gevaar, op een tamelijk statisch beeld van zin uit te komen, of althans geen recht te doen aan het door en door

178. 'Sinn als Grundbegriff..,', op.cit., p. 37.

179. Soziale Systeme, op.cit., p.93. 
dynamische karakter dat, volgens Luhmann, kenmerkend is voor zin. Weliswaar heeft het zimmatig beleven alleen realiteit als een actueel beleven en is de verwijzing naar mogelijke belevingen altijd een verwijzing "vanuit" het hier en nu actuele - of zoals Luhmann in het bovenstaande citaat formuleert:" "Die Verweisung selbst aktualisiert sich als Standpunkt der Wirklichkeit...' Het zinmatig beleven is echter wezenlijk onrustig, springerig. Bewustzijnsinhouden zijn normaliter maar een korte duur beschoren; voortdurend komen voorstellingen op om weer plaats te maken voor nieuwe. Luhmann ziet in deze, ook door Husserl onder de aandacht gebrachte "beweeglijkheid van het beleven" een fundamentele eigenschap van alle op basis van zin opererende systemen, die hij aanduidt als 'basale instabiliteit'. Zin, of het nu fungeert als ordeningsmodus van psychische of van sociale systemen; heeft een 'eingebautem Zwang zur Selbständerung' met als gevolg: een 'radicale temporalisering' van zin. ${ }^{180}$ 'Zinmatig beleven' bestaat dus, op geleide van Luhmann, in de vorm van een aanhoudende stroom van opeenvolgende actualiteit/mogelijkheid-differenties. Het gaat daarbij niet zozeer om een voortdurend "verspringen" van het object van intentie - we kunnen ons tenslotte langere tijd met een 'vaas' bezig houden -, maar om een voortdurende hergroepering van actualiteit en mogelijkheid. De basale instabiliteit en de daardoor afgedwongen temporaliteit van het zinmatig beleven impliceert, dat van moment tot moment nieuwe bewustzijnsinhouden worden geactualiseerd, die precies zin hebben voorzover en omdat daarmee ook telkens een nieuwe mogelijkheidshorizon-wordt geopend. In een formulering van Luhmann, die mooi de door hem beoogde dynamisering van 'zin' (van de actualiteit/potentialiteit-differentiel) tot uitdrukking brengt:

'Sinn ist laufendes Aktualisieren von Möglichkeiten. $\mathrm{Da}$ Sinn aber nur als Differenz von gerade Aktuellem und Möglichkeitshorizon Sinn sein kann, fuhrt jede Aktualisierung immer auch $z u$ einer Virtualisierung der daraufhin anschließbaren Möglichkeiten. [-] Sinn ist somit die Einheit von Aktualisierung und Virtualisierung, von Re-Aktualisierung und Re-Virtualisierung als ein sich selbst propellierender Proze $\AA^{\circ 181}$

180. Luhmann meent dat een 'Engführung auf Bewußtsein' geen recht doet aan het algemenere fenomeen van "basale instabiliteit". Niet alleen kenmerken neurofysiologische systemen zich al door een aanhondende onrust, ook communicatieprocessen staan onder de druk voortdurend iets nieuws te berde te brengen - 'Wenn nichts zt sagen ist, mul man eben etwas erfinden. Keimenfalls darf man das, was man vorher gesagt hat, solange wiederholen, bis etwas Neues aufgenötigt wird. Dies lässt sich nicht auf Bewußtsein reduzieren; oder wern, dann ebensogut auf Neurophysiologie, usw. ... Aus diesen Granden gehen wir ohne jeden Versuch einer reduktiven 'Erklärung, von einer Grundsachwerhalt basaler Instabilität ... aus und halten fest, dab jedenfalls alle Sinnsysteme, seien es psychische oder soziale Systeme, dadurch gepragt sind.' (Soziale Systeme, op.cit, p.99.)

181. Soziale Systeme, op.cit, p.100. 


\section{$\S 4$. Identiteit}

Zin als een 'sich selbst propellierender' "een zichzelf voortstuwend proces, waarin zin voortdurend naar zin verwijst ! Men voelt al aan uit welke hoek de wind gaat waaien: 'Die Selbstbeweglichkeit des Sinngeschehens ist Autopoiesis par excellence'. ${ }^{182}$ Voor we echter zo ver zijn, woor we ons door Luhmann van de "These universeller, selbstreferentieller Formbindung allen sinnhaften Prozessierens ${ }^{183}$ laten overtuigen, moeten er eerst nog een paar behoorlijke hobbels worden genomen.

We stellen om te beginnen vast, dat Luhmann de voor zin constitutieve actualiteit/mogelijkheid-differentie primair als een 'temporeel' onderscheid invoert, d.w.z. als een onderscheid tussen het momentane en het nietmomentane. Dat mag dan de basis vormen voor een uiterst dynamische opvatting van "zin' - zimmatig beleven bestaat principieel uit gebeurtenissen, is altijd 'Sinngeschehen'; om het actualiteit/mogelijkheid-onderscheid echter als een voor het bewustzijn hanteerbare differentie overeind te kunnen houden, is een slechts temporele duiding ervan niet genoeg. Het "hier-en-nu-actuele' moet ook geìdentificeerd kunnen worden als het 'dit-en-niet-anders', het 'slechtsmogelijke" moet ook als "het-andere" begrepen kunnen worden, wil de actualiteit/mogelijkheid-differentie aan het bewustzijn als een differentie kunnen verschijnen. Nog anders geformuleerd: de actualiteit/potentialiteit-differentie kan voor het zinmatige beleven slechts een constitutieve rol vervullen op voorwaarde dat het niet alleen als een temporeel, maar ook als een inhoudelijk - Luhmann zou zeggen: 'zakelijk' — onderscheid verschijnt.

De lezer van Soziale Systeme moet zich laten welgevallen dat Luhmann deze kwestie in eerste instantie uiterst abstract aanpakt. De (re)actualisering en (re)virtualisering die het 'Sinngeschehen' kenmerkt, blijkt bij nader inzien een constante 'Neuformierung" van twee differenties in te houden. Het "verspringen" van de actualiteit/potentialiteit-differentie wordt voortdurend 'begeleid' door een 'mee-bewegende' differentie van 'identiteit en differentie':

'Die Differenz von Differenz und Identität wird gleichsam quer zur Differenz von Aktualität und Möglichkeit eingesetzt, um diese in der Operation zu kontrollieren. Das Mögliche wird als Differenz verschiedener Möglichkeiten (einschließlich derjenigen, die gerade aktualisiert ist und auf die man zurihckkommen kann) aufgefaßt, und die zu aktualisierende Móglichkeit wird dann in ihrer Identităt als dies-und-nicht- 
anderes bezeichnet. ${ }^{184}$

Nu mag dat als een reconstructie van het mechanisme dat werkzaam is in de opeenvollging van concrete bewustzijnsinhouden eventueel adequaat zijn, het vormt in al zijn abstractheid geen afdoende antwoord op het geschetste problleem. Er wordt simpelweg gesteld, dat "het mogelijke" zich telkens aandient als een gedifferentieerd geheel van mogelijkheden wamrtegenover het actuele zich als een 'dit-en-niet-anders' kenbaar maakt. Dat beantwoordt echter niet de vraag hoe het bewnistzijn over dergelijke, inhoudelijk discriminerende differenties kan beschikken. Per slot van rekening is ons beleven in de regel het beleven van een bont geschakeerd geheel, dat niettegenstaande alle afwisseling en verandering toch een zekere orde vertoont. We beleven onze omgeving als een werkelijkheid waarin zich appels, kleuren, snelheden, maatschappijtheoretici, etc. voordoen. En weliswaar kunnen appels verschillend van kleur en grootte zijn, kunnen maatschappijtheoretici Giddens, Luhmann of Habermas heten, we vertrouwen er desalniettemin op, dat appels niet plotseling overgaan in snelheden, Luhmann niet plotseling een kleur wordt, enz. Ons betekenisvol, 'zinmatig' beleven van de wereld is kortom een beleven van "identiteiten", van zaken die ondanks verschillen in tijd, plaats of context op een of andere manier hetzelfde blijven.

De vraag waar we een antwoord op zoeken, is ma.w, hoe het beleven aan identiteitsvoorstellingen komt, waarin deze (minimum)orde, deze basisstructuur is gegrondwest. We nemen daarbij de gelegenheid te baat om kort in te gaan op de verhouding tussen Luhmanns oorspronkelijk op Husserl voortbouwende conceptie van zin en zijn latere, aan Von Foerster en Spencer Brown ontleende concept van observeren.

Op het eerste gezicht lijkt 'observeren', als het maken van een onderscheid en het markeren van één zijde van dat onderscheid als het veld van aansluitende 'distinctions' en 'indications', naadlloos op het tot nog toe geschetste beeld 'van 'zinmatig beleven' aan te sluiten. Het maken van een onderscheid, het 'trekken van een lijn', lijkt dan de constitutie in te houden van een grens tussen een "binnen-" en een 'buitenhorizon", tussen het bereik van 'hier-en-nu-relevantemogelijkheden' en 'het-daarnaast-ook-nog-mogelijke', terwijl 'indication' begrepen kan worden als de 'punktuelle Zugriff' binnen het hier en nu geselecteerde bereik van mogelijkheden. Nu laat het zinmatig beleven zich inderdaad als een beleven op basis van differenties reconstrueren. Luhmann gaat er bovendien vanuit dat de evolutie van zin is uitgegaan van rudimentaire observatiecapaciteiten en dat op basis van zin opererende systemen per definitie systemen zijn die kunnen observeren. Luhmann ziet echter zelf dat simpelweg het maken van een onderscheid en het markeren van één zijde van dat onderscheid, nog geen identiteiten oplevert: '[Beobachten] erfordert noch nicht, 
daß das, was bezeichnet wird, als Identisches festgehalten wird. Man muß es nur unterscheiden können. ${ }^{\text {i8s }}$

$\mathrm{Nu}$ weten we inmiddels, dat observaties zich volgens Luhmann nooit als geîsoleerde gebeurtenissen voordoen. Observaties hebben andere observaties nodig om specificiteit te verkrijgen. Anders gezegd: observaties verschijnen altijd binnen reeksen van opeenvolgende observaties en niets sluit de mogelijkheid uit dat binnen dergelijke reeksen een zelfde observatie zich herhaalt. Weliswaar voorkomt de, als 'basale instabiliteit' aangeduide "onrust' van het beleven, dat zich reeksen van de vorm dit is een roos, die een roos is, die een roos is, die..." kunnen stabiliseren, maar het bewustzijn kan zich wel degelijk voor langere tijd op een roos concentreren; bijv. in de vorm van 'dat is een roos - dat is een roos die rood is - dat is een roos die tegen een muur opklimt - dat is een roos... - etc.' Zonder die mogelijkheid zou het evolutionaire voordeel, dat Luhmann aan een toegenomen hersencapaciteit toeschrijft, komen te vervallen. Dit voordeel gaat immers voor een belangrijk deel terug op het vermogen verschillende situaties te vergelijken met het oog op het wel/niet/anders aanwezig zijn van een bepaalde stand van zaken, op het vermogen wan het bewustzijn om bijw de reeks 'geen leeuw zichtbaar - achter die rots kan een leeuw zich hebben verscholen - etc." te vormen.

Het is nu precies deze herhaalbaarheid die bij Luhmann aan de constitutie van 'identiteiten' ten grondslag ligt. Het algemene idee is, dat door de herhaling van observaties zich generalisaties kunnen uitkristalliseren die, eenmaal vastgemaakt aan tekens of symbolen, ter beschikking blijven, 'gereactualiseerd' kunnen worden. Luhmann reconstrueert dergelijke processen van 'symbolische generalisering' aan de hand van de, aan Spencer Brown ontleende, noties 'condensatie' en 'affirmatie'. Bij herhaling van een observatie kan een observator deze twee operaties tot één 'condenseren' - men observeert een 'fietser' en observeert even later nogmaals 'dezelfde fietser'. Dezelfde sequentie $\mathrm{kan}$ echter ook in "tegenovergestelde richting" worden gelezen" - de tweede observatie als een bevestiging (affirmatie) van de eerste: het is inderdaad een "fietser". Luhmann:

"In der einen Richtung sieht man, daß sich Identitat bildet als Kondlensat einer Mehrheit von Operationen. In der anderen Richtung sieht man, daß das Konfirmieren eine zweite Operation, also eine andere Situation erfordert. ${ }^{186}$

Wanneer zich langs deze weg generalisaties vormen, betreft het dus telkens een generalisering over uiteenlopende situaties. Anders geformuleerd: het betreft

185. N. Luhmann, "Identität - was oder wie?", im: Soziologische Aufklarung 5, Opladen 1990, p.
22. 186. idem. 
generalisaties die zich in verschillend mogelijke situaties moeten kunnen 'bewijzen'. Daarmee verkrijgt de zich baan brekende 'identiteit' tevens een modaal aspect. Gekoppeld aan constant gehouden symbolen staan dergelijke 'gesymboliseerde' of 'symbolische generalisaties' niet simpelweg voor eenheden die een veelheid onder zich subsumeren, maar telkens voor een eenheid van mogelijkheden. Appels kunnen groen, rood of geel zijn, op fruitschalen of in groentebakken liggen, in winkels gekocht worden of van bomen geplukt, etc. - het blijven 'appels'. Met de observatie van de hier en nu voor mij liggende appel observeer i $\mathrm{k}$ weliswaar niet in één keer al die mogelijkheden - mijn concrete observatie van een specifieke appel stelt in feite altijd een selectie uit het geheel van mogelijke observaties van appels voor -, maar het simpele feit dat ik een "appel" observeer, impliceert wel degelijk andere mogelijkheden dan de hier en nu actuele, bijwoorbeeld dat ik iets observeer dat kan worden gegeten, weggegooid, etc.

Volgens Luhmann kunnen we dit beschouwen als een rudimentaire verklaring voor de genese van concrete zin-elementen. Wat langs deze weg ontstaat, of in ieder geval kan ontstaan, is een in uiteenlopende situaties herhaalbare, 'reactualiseerbare' zinkern plus de daarmee gegeven verwijzing naar andere rnogelijkheden - 'Das simultan prozessieren von Kondensierung und Konfirmierung erzeugt die Differenz von Aktualität und Possibilităt die wir als konstituierende Differenz des Mediums Sinn ansehen ${ }^{387}$ Door modale generaliseringen met, normaal gesproken 'talige', tekens te bezetten, worden ze voor het bewustzijn benoembaar, i.e. observeerbaar. Zin, zo zouden we samenvattend kunnen formuleren; verschijnt aan het bewustzijn in de vorm van stabiele symbolische generalisaties. Of in observatietheoretische termen: "zinmatig beleven' is een observeren op basis van symbolisch beschikbare, "modale" generaliseringen, die de grondslag vormen van differenties (bijvoorbeeld: appel/niet-appel) die in feite differenties tussen mogelijkheidsbereiken voorstellen (tussen 'appel-mogelijkheden' " en mogelijkheden die niet 'des appels' zijn).

Voor Luhmann vormt het thema 'symbolische generalisering' min of meer het sluitstuk - of beter: de 'onderkant' van zijn functionele analyse van zin. Het fungeert als het verbindingsstuk tussen de functionele analyse van zin als een ordeningsmodus en de concrete verschijningsvorm van het alledaagse beleven als een beleven dat zichzelf stuurt middels voorstellingen van identiteiten. Dat we hier de term 'onderkant' gebruiken, betekent niet, dat het geen belangrijk onderdeel van zijn zintheorie vormt. Zonder de door symbolische generalisering gevormde identiteiten zou een "zelfreferentieel processeren" van zin niet mogelijk zijn. De mogelijkheid om iets als een bepaald iets te kunnen observeren, is een voorwaarde om op dat 'iets' terug te kunnen komen - nog een keer aan een appel of een ei te kunnen denken. Luhmann spreekt in dit 
verband van de 'Notwendigkeit der Selbstsymbolisierung oder der Selbstabstraktion", die precies daaruit voortkomt, dat een zin-eenheid niet slechts momentaan beschikbaar mag zijn, maar herhaald moet kunnen worden, op een volgend moment en in andere omstandigheden. ${ }^{188}$ Let wel - Luhmann spreekt over 'Selbstsymbolisienung' en van 'Selbstabstraktion'. Symbolische generalisering is een operatie van, en door het zinmatig beleven zelf. De identiteiten waarvan het zinmatig beleven zich als zijn eenheden bedient, geeft het zinmatig beleven zichzelf - 'autopoiesis par excellence'!

Eén implicatie daarvan is op zijn minst, dat zin niet in 'taal' gegrond is en ook niet door taaltheorie(en) kan worden gereconstrueerd. Door symbolische generaliseringen wordt de vloed van belevingen als het ware "geherstructureerd" tot een opeenvolging van discrete identiteiten, maar voor deze 'digitalisering' is taal, volgens Luhmann, niet noodzakkelijk. Symbolische generaliseringen kunnen zich bijvoorbeeld ook om alledaagse geluiden, zoals het starten van auto's uitkristalliseren, of rondom gebruiksvoorwerpen als vuilnisemmers. ${ }^{189}$ Maar natuurlijk kunnen woorden en namen óók als symbool voor een generalisatie fungeren en we kunnen er - met Luhmannn - vanuit gaan, dat voor de ontwikkeling van complexe zineenheden en -structuren, taal al spoedig onontbeerlijk wordt:

'Symbolische Generalisierungen entstehen also bereits im konkreten Umgang mit Objekten und Ereignissen, sie dienen dem Vorbehalten der Wiederzugănglichkeit, und erst bei Bedarf für höherstufige" Aggregationen stellen sich auch Pauschalbezeichnungen, Typenvorstellungen und Heterogenes ubergreifende Begriffe ein. Diese können dann nur mit Hilfe von Sprache in die Sinnhafte Welt eingebaut werden. ${ }^{290}$

In deze "hulp bij symbolische generalisering" ziet Luhmann dan ook de eigenlijke functie en betekenis van taal. Niet in taal als een tekensysteem met referentiële eigenschappen - want, zo redeneert hij, "sie hat keineswegs nur, ja nicht einmal vorwiegend diese Funktion, auf etwas Vorhandenes hirizuweisen "19! Taal is ook niet exclusief een communicatiemiddel, want taal fungeert ook zonder communicatie en wel in het bewustzijn. 'Thre eigentliche Funktion liegt in der Generalisierung von Sinn mit Hilfe von Symbolen, die im Unterschied zur Bezeichnung von etwas anderem - das, was sie leisten,

188. Idem, p. 136

189. Luhmann schrijft zelf over vuilnisemmers: 'Man erkannt am Geräusch, daB die Mulleimer geleert wöden sind, Man geht heraus und kenmt unter vielen Mulleimern den seinen sofort wieder, ohne das es dazu eines Wortes, eines Namens oder gar eines Begriffs bedarf: (idem, p.136)

190. IIdem, p. $136 / 137$.

191. idem, p.137 
selbst sind. ${ }^{* 192}$

\section{§. Verwachting, Structuur en Informatie}

Het model van identiteitsworming op basis van symbolische generalisering biedt ook het antwoord op nog een ander belangrijk probleem. Luhmann kan 'zin" namelijk wel aanprijzen als dé oplossing voor het probleem van de 'overcomplexiteit' van het beleven, maar met 'zin', zuiver en alleen opgevat als eemheid van actualiteit en mogelijkheid, lijkt het complexiteitsprobleem zich slechts te hebben verschoven. "Sinn haben", wil voor Luhmann zeggen, "daß" eine der anschließbaren Möglichkeiten als Nachfolgeaktualität gewählt werden kann und gewählt werden muß, sobald das jeweils Aktuelle verblaßit, ausdünnt, seine Aktualität aus eigener Instabilităt selbst aufgibt'. ${ }^{193}$ Bedenken we dan, dat het zinmatig beleven bestaat als een aanhoudende stroom van komende en gaande voorstellingen, dat Luhmann 'zin' omschrijft als de eenheid van 'ReAktualisierung" en "Re-Virtualisierung', dan is in ieder geval duidelijk, dat het bewustzijn voortdurend onder selectiedwang staat. Op ieder moment moet weer een keuze worden gemaakt uit het geheel van verdergaande belevingsmogelijkheden dat zich met elke actuele belevingsinhoud weer aandient. Vooralsnog is het zich telkens aandienende veld van (selectie)mogelijkheden echter onbepaald en in principe oneindig groot. Of zoals Luhmann zelf schrijft:

'Sinnhafter Erlebnisverarbeitung liegt eine modale Generalisiening von Wirklichkeit zu Grunde, derzufolge alles Gegebene mit Verweisungen auf andere Möglichkeiten zur Erscheinung kommt. Durch Konstitution von Sinn wird die Unabschließbarkeit der verweisung auf andere Möglichkeiten mitkonștituiert. [-] Die modale Generalisierung van Wirklichkeit konstituiert die Welt im ganzen..." ${ }^{194}$

Als de verwijzing naar andere belevingsmogelijkheden echter "unabschließ3bar" is, indien, zoals Luhmann het zelf graag omschrijft, vanuit iedere actuele zinselectie de gehele 'wereld' bereikbaar is, dan staan we weer voor hetzelfde selectie/complexiteitsprobleem. Bij een oneindig groot en ongedifferentieerd veld van selectiemogelijkheden, wanneer alles mogelijk is - evenzogoed mogelijk! - moet het belevingsproces gaan stokken. Niet alleen ontbreekt dan iedere aanwijzing voor het maken van een bepaalde keuze, bovendien wordt het

194. N. Luhmann, Funktion der Religion, Frankfurt/M. 1977, p.75/76. 
risico dat met iedere selectie wordt genomen ondraaglijk groot.

Symbolische generaliseringen vormen nu het antwoord op dit complexiteitsprobleem, precies omdat ze een differentiatie binnen het mogelijke tot stand brengen en wel primair in termen van verwachtbaar/nietverwachtbaar. De identiteiten of 'zin-eenheden' die zich op basis van modale generalisering vormen, stellen altijd een eenheid van mogelijkheden voor niet van alle belevingsmogelijkheden, maar slechts van die mogelijkheden die 'compatibel' zijn met het hier en nu geintendeerde/geobserveerde object. Het beleven van lets is, zo beschouwd, altijd een beleven in het licht van wat men mogelijkerwijs kan verwachten van dat 'iets' - en wat men er niet van kan verwachten. Van appels verwachten we qua 'appels' bepaalde dingen wel en andere dingen niet - wel dat ze eetbaar zijn, niet dat we daardoor in zonde vervallen; wel dat ze aan bomen groeien, maar niet dat ze aan het hoofd van zoon Tell ontspruiten; etc. 'Symbolische Generalisierungen', zo formuleert Luhmann, "verdichten die Verweisungsstruktur jeden Sinnes zu Erwartungen, die anzeigen, was eine gegebene Sinnlage in Aussicht stellt. ${ }^{195}$

Door symbolische generaliseringen, zo zou men kunnen stellen, wordt het oorspronkelijke selectieprobleem verlicht en afgebouwdl doordat verwachtingen worden ingeschakeld die als een soort voor- of 'tussen'-selectie functioneren. Op het veld van toekomstige belevingsmogelijkheden wordt, om het door Husserl gebruikte beeld aan te halen, een binnen- en een buitenhorizon geprojecteerd, $\mathrm{d} w . Z$. een scheiding aangebracht tussen wat, vanuit het actuele standpunt gezien, verwachtbare, voor de hand liggende, etc. voortzettingen van het beleven zijn en wat niet, wat hier en nu niet relevant is, wat buiten de 'scoop' van de situatie ligt, etc. Daarmee verschaft het zinmatig beleven zichzelf een houvast. Het kan de selectie van 'Nachfolgeaktualitäten' gaan sturen aan de hand van het onderscheid compatibel/niet-compatibel of aansluitend/niet-aansluitend - wat natuurlijk de keuze voor "niet-compatibel', 'niet-aansluitend' niet uitsluit Door de vorming van identiteiten middels symbolische generalisering krijgen concrete zinselecties m.a.w. een 'aansluitingswaarde' die het bewustzijn kan benutten om zijn eigen selectiviteit te organiseren. ${ }^{196}$

Deze met iedere selectie van een concrete zin-inhoud eveneens geactualiseerde 'aansluitingswaarde" is niet iets, dat aan concrete zin extern is, of 'er bij komt'; het is constitutief voor de concrete identiteit van een zinselectie. We kunnen de

195. Soziale Systeme, op. cit, p, 139.

196. In "Moderne Systemtheorien als Form gesamtgesellschaftgesellschaftlicher Analyse" (oorspronkellijk 1968) schreef Luhmann al: "Durch sinnhafte Identifikationen ist es möglich, eine im einzelnen unubersehbare Fülle von Verweisungen auf andere Erlebnismỏglichkeiten zusammenzufassen und zusammenzuhalten, Eirnheit in der Fulle des Möglichen zu schaffen und sich von da aus dann selektiv an einzelnen Aspekten der Verweisungszusammenhanges zu orientieren." (Opgenomen in J.Habermas/N.Luhmann, Theorie der Gesellschaft oder Soziditechnologie, Frankfurt/M. 1971, p.12. 
verhouding 'zin' - 'Werwachting' ma.w. ook in de omgekeerde volgorde lezen: De zin van een beleving wordt gevormd door het 'in actu' gegeven ensemble van aansluitingsmogelijkheden. Luhmann:
'[J]eder bestimmte Sinn qualifiziert sich dadurch, daß er bestimmte Anschlußmöglichkeiten nahelegt und andere un- wahrscheinlich, oder schwierig oder weitlaufig macht oder (vorläufig) auuschließt. ${ }^{\times 197}$

Verwachtingen hebben dus 'structururwarde' - of om precies te zijn: zinstructuren zijn voor Luhmann verwachtingsstructuren. Ze structureren belevingsprocessen door telkens het veld van 'aansluitende' belevingsmogelijkheden in te perken, door op ieder moment belevingsmogelijkheden terzijde te schuiven ("vorlaufige Negation") als zijnde incompatibel met het hier en nu actuele belevingsproces. Daarbij stellen zinstructuren zelf selecties voor. Zin/verwachtingsstructuren zijn niet een soort substanties met duurzaamheidsgarantie - ze vormen niet het "beklijvende" tegenover het 'vliedende' -; ze worden met iedere zinselectie, met iedere identiteitsbeleving, als het ware 'mee-geselecteerd', als de afbakening van het 'en-zo-verder'. De door zin bemiddelde reductie van complexiteit voltrekt zich, zo beschouwd, langs de lijn van een 'dubbele selectiviteit', van een telkens gelijktijdige selectiviteit op procesniweau ên op structuurniveau. Enerzijds realiseert het zinmatig beleven zich altijd 'voll und konkret' als de eenmalige en dan ook unieke selectie binnen een veld van voorgestructureerde mogelijkheden; anderzijds betekent dat ook telkens structuurselectie, 'Vorauswahl', 'Sinnentwurf ins Ungewisse', een diffuus-gegeneraliseerd verwachten. Het zinmatig beleven volgt zo het spoor, dat het telkens zelf uitzet - en dat ook, wanneer het een andere richting in slaat ${ }^{198}$ ?

Aan dit onderscheid tussen structuur en proces laat zich nog een ander belangrijk onderscheid vastmaken, namelijk dat tussen 'zin' en 'informatie'. Of zoals Luhmann het ooit aan Habermas heeft voorgehouden: het onderscheid

197. Saziale Systeme, op.cit., p.94.

198. We herkennen natuurlijk het algemenere model wan de 'gefaseerde reductie wan complexiteit:' middels het "differentietren tussien structuur en proces", zoalls in het vorige hoofdstuk uiteengezet. Taegepast op "zin", leidi deze dubbele beweging tot aen opmerkelijke verthouding tussen 'het algenene" en 'het bijzondere'. Zinproeessen voltrekken zich in de vorm van concrete, unieke selecties binnen verwachtingshorizonten, waarbij elke selectie zich als een particulier "lets" realiseert, door tegelijkertijd over zijn eigen particulariteit heen naar het algemene te verwijzen, naar een gedifferentieerd veld van mogelijkheden, dat zowel het aansluitende als thet niet-aansluitende onvat - naar 'Welt'. Luhmann geeft als 'zu Grunde liegende Sachwerhalt: dab uberhaupt Sinnuberschüsse selektiv benutzt werden milssen und daB dieses 'Massen' ein Kommen ist im Sinne der Awswahl won Erwartungen. die Diskontimuitden ubergreifen und sich in diesem Sinne als Generalisientrigen bewahrem können.' (Soziale Systeme, op.cit., p.141.) 
tussen 'zin' en 'informatie' signaleert 'die Notwendigkeit, Selektionsleistungen in Struktur- und Prozeßkategorien zugleich zu analysieren'.

Batesons bekende omschrijving van 'informatie' als "a difference that makes a difference' wolgend, zouden we 'informatie" in een eerste aanloop kunnen karakteriseren als een gebeurtenis, die op een of andere manier het toekomstig gedrag van een systeem beinvloedt - ik hoor dat het zal gaan regenen en besluit een paraplu mee te nemen. Ook al verdwijnt de informatie qua concrete gebeurtenis (het 'horen' van het bericht), het is precies 'informatie' voorzover het sporen achter laat in het 'geïnformeerde' systeem. De werwachtingen tlie het systeem koesterde zijn op zijn minst veranderd - had ik al regen verwacht, dan zou het bericht, 'dat het gaat regenen', niet informatief zijn geweest.

In aansluiting op dit 'kwalitatieve' concept van informatie spreekt Luhmann over 'informatie' als een gebeurtenis die een structuureffect sonteert en dat wil, voor een beleven dat zich van zinstructuren bedient, zeggen: een gebeurtenis die verwachtingen bijstelt. Dat impliceert, dat alleen voor een systeem dat al verwachtingen koestert, een gebeurtenis informatief kan zijn:
'Als Information soll hier ein Ereignis bezeichnet werden, das Systemzustande auswahlt. Das ist nur an Hand von Strukturen möglich, die die Möglichkeiten begrenzen und vorsortieren. Information setzt also Struktur voraus, ist aber selbst keine Struktur, sondern nur das Ereignis, das den Strukturgebrauch aktualisiert." ${ }^{\prime 99}$

Zowel bij "informatie' als bij 'zin" gaat het om selectiviteit: Informatie betreft de selectiviteit van een gebeurtenis op procesniveau; zin heeft betrekking op de selectie van structuurverlenende identiteiten. Het categoriale verschil tussen beide wordt duidelijk wanneer men zich indenkt, dat een bepaalde boodschap tot vervelens toe herhaald wordt. De zim of betekenis van dat bericht verandert dan niet - het blijt het bericht 'dat het gaat regenen', of de boodschap 'dat Luhmanns zinbegrip lastig is' -, maar de informatieve waarde holt snel achteruit. Het is de tijd zelf, zo merkt Luhmann op, die er toe dwingt 'Sinn und Information zu unterscheiden, obwohl alle Sinnreproduktion aber Information lauft (und insofern auch Informationsverarbeitung heißen kann) und alle Information Sinn hat ${ }^{2}{ }^{200}$

Naast dit aan Bateson ontleende concept van informatie treffen we bij Luhmann ook een eerder kwantitatief, op Weaver en Shannon teruggaand concept van informatie. Hoe onwaarschijnlijker een gebeurtenis/observatie/beleving des te informatiever het optreden ervan. Nu heeft, zoals we nog zullen zien, een Luhmanniaanse sociologie weinig op met statistisch-kwantitatieve 
kansberekening en in feite speelt dit kwantitatieve informatiebegrip bij Luhmann dan ook alleen een rol voorzover 'on/waarschijnlijkheid" aan een van zijn beide limieten raakt. Zo viel al uit het kwalitatieve informatiebegrip op te maken, dat een gebeurtenis voor een systeem niet informatief kan zijn wanneer de waarschijnlijkheid van zijn optreden woor het systeem aan absolute zekerheid grenst. In een situatie waarin alles met even grote on/waarschijnlijk kan gebeuren, zou het optreden van een specifieke gebeurtenis echter evenmin informatief zijn en dit simpelweg vanwege het feit dat een dergelijke situatie een structuurloze situatie zou zijn, een situatie waarin het observerende/belevende systeem over geen verwachtingen zou beschikken in het licht waarvan een gebeurtenis eerst informationele kwaliteit kan verkrijgen.

\section{$\S 6$. Objectiviteit en drie-dimensionaliteit}

Een nieuw probleem dient zich al weer aan (- en hoe kan het ook anders binnen de context van een functionele analyse).

We weten nu wat het betekent, wanneer Luhmann 'zin' beschrijft als een 'Sichselbst-Prozessieren' waarin informatie 'geprocesseerd' wordt. ${ }^{201}$ Dat hij daarin een mogelijkheid ziet, om de tautologe omschrijving van zinprocessen als 'het processeren van zin' te doorbreken, of in ieder geval te 'a-symmeteriseren', laat zich raden. We kunnen ons althans voorstellen, dat een 'psychisch systeem' (i.e. een door zin gestructureerd beleven) zijn verwachtingsschema's als een soort 'scanners' inzet. Het 'niet-verwachte', de belevingen/gebeurtenissen die niet compatibel zijn met de in verwachtingsstructuren opgeslagen interpretaties van "de werkelijkheid", kunnen dan behandeld worden als informatie over die werkelijkheid. Het blijft naturlijk een 'openheid op basis van geslotenheid', maar het is op zich genomen niet ondenkbaar, dat een psychisch systeem, door zijn eigen belevingsproces middels het onderscheid zin/informatie te asymetriseren, een zekere distantie tot zichzelf verkrijgt, om vervolgens de grond van die distantie buiten zichzelf te localiseren, d.w.z informatie als informatie-uit-de-omgeving te behandelen. In een omschrijving van Luhmann:

'Information ist nur im System, nur dank dessen Selbstreferenz, nur dank dessen Auffassungsscherna möglich. Sie kann gleichwohl durch das System der Unawelt zugerechnet werden. Sie erscheint als Selektion aus einem Moglichkeitsbereich, den das System selbst entwirft und für relevant halt'; aber sie erscheint als Selektion, die nicht das System, sondern die Umwelt vollzieht. ${ }^{202}$ 
Maar laten we nu eens preciezer kijken - want woor Von Münchhausen mag het dan geen probleem zijn om zichzelf bij de haren uit het moeras te trekken, het door Luhmann ge(re)construeerde 'psychisch systeem" loopt vooralsnog eerder de kans zich de pruik wan het hoofd te rukken. De 'objectivering" van informatie vóóronderstell namelijk een 'objectivering' van de eigen. zinstructuren. Tot nog toe weten we echter niet beter, dan dat zinschema's en structuren zich in en door het zinmatig beleven zelf ontwikkelen en wel als selecties die ook anders hadden kunnen uitpakken. Het zijn contingente selecties die geen andere 'grond' hebben, dan dat ze zich bewijzen in hun functie de belevingscomplexiteit voor het bewustzijn hanteerbaar te maken. Met iedere teleurgestelde verwachting loopt het bewustzijn echter tegen die contingentie op, dringt de 'willekeurigheid' van de eigen verwachtingen zich onvermijdelijk aan hem op. Begint het beleven echter op een acute manier de contingentie van de eigen structuren te beleven, dan kan 'informatie' niet als 'beleefde werkelijkheid' worden behandeld. Bij een acuut bewustzijn van de willekeur van zijn eigen verwachtingsstructuren kan een psychisch systeem het niet-verwachte niet meer 'plaatsen'. Het 'weet' niet meer welke verwachtingen nu moet worden bijgesteld en aan welke als zijnde 'zeker'/objectief' kan worden vastgehouden. Het mist, om het zo uit te drukken, de interne coordinaten aan de hand waarvan het structuur-effecten kan alloceren.

We stuiten hiermee op een probleem, dat voor Luhmann des te belangrijker moet zijn, omdat het in feite een variant voorstelt van het soort problemen, waar de subjectfilosofische interpretaties van zin en werkelijkheid slechts aan konden ontsnappen, door een transcendentaal subject, of een aanverwante garantie van 'transsubjectiviteit' of 'objectiviteit' te postuleren. En het zijn precies die 'ontsnappingspogingen' die voor Luhmann telkens het bewijs hebben gevormd van het failliet van alle pogingen om in het kielzog van Kant, 'zin' te funderen in het kennend/zingevend subject: ${ }^{203}$ Inderdaad, funderingsstrategieèn van het Kantiaanse type leiden steeds weer tot de aanname van een transcendentaal subject, dat achter de rug van de concrete individuen om de intersubjectiviteit van zinstructuren moet garanderen. Wijs geworden weten we inmiddels, zo luidt de gangbare kritiek, dat er vanuit transcendentale subjecten geen weg meer terug voert naar het cultuurhistorisch onderzoek van betekenisstelsels en al helemaal niet naar een sociologie met empirische interesse voor interactieprocessen als locus van cultuur- en betekenisoverdracht. ${ }^{204}$

Luhmann heeft overigens nog een ander, sociaalwetenschappelijk gezien misschien interessanter argument tegen de fundering van het zinbegrip in het subjectbegrip. Wat wij vandaag de dag onder 'subject' verstaan, zo stelt hij vast $_{3}$ is een relatief jong produkt van de geschiedenis van het denken. Het

203. Zie voor dit en volgende met name N. Luhmann, "Sinn als Grundbegriff..., op.cit, p. 26 30.

204. Verg in dezen ook I. Habermas, 'Meaning of Meaning oder." Ist Sinn eine sprachunabhängige Katogorie?", opgenomen in: J. Habermas/N.Luhmann, op.cit., p.176. 
signaleert een historisch pas laat zich inzettende internalisering van het handelingsbegrip, die samenhangt met de overgang aan het einde van de middeleeuwen naar de moderne, functioneel gedifferentieerde maatschappij: De filosofische traditie heeft dit opgepakt in de vorm van een 'subject'-semantiek, die de keuze voor het 'Goede", "Schone' en 'Ware' aan de individuele persoon toerekend, dit aan hem/haar delegeert als een zelfstandig vermogen tot beslissen, waarmee tegelijkertijd de verantwoordelijkheid voor gemaakte selecties bij het individu wordt gelegd ${ }^{205}$ Wordt nu het zin-begrip, zo vervolgt Luhmann, teruggevoerd op het cultuurhistorische artefakt 'subject', dan is daarmee een geïnternaliseerd handelingsbegrip tot standaard uitgeroepen, zonder dat de historische constitutie van dit ingrijpende semantische complex zelf nog sociaalwetenschappelijk kan worden begrepen in termen van zijn maatschappelijke functie en verschijningsvorm - Artefakte eines historischen Prozesses der Begriffsprägung können ihrerseits nicht begriffen werden, wenn mann die Theorie ihnen unterwirft. Eine solche Entscheidung könnte sich selbst nicht mehr theoretisch reflektieren, sondern nur noch normativ bejahen. ${ }^{206}$ Met dit alles wil Luhmann overigens niet ontkennen, dat er een nauwe band bestaat tussen 'zin' en wat we als 'individueel bewustzijn' zouden kunnen omschrijven. Zijn voorstel is echter om de traditionele verhouding tussen 'zin': en 'subject" eerst maar eens om te draaien: "Der Sinnbegriff ist primăr, also ohne Bezug auf den Subjektbegriff zu definieren, weil dieser als sinnhaft konstituierte Identität den Sinnbegriff schon voraussetzt. ${ }^{207}$

$\mathrm{Nu}$ goed - programmatische voornemens zijn niet duur en voorzover Luhmann zich resoluut verzet tegen een apriorische gelijkstelling van zin met 'subjectieve intentie', kan hij vandaag de dag op ruime bijval rekenen. Maar voorlopig lijkt zijn conceptie van zin, als een ordeningsmodus die geworteld is in de bijzondere eigenschappen van het menselijk vermogen tot negeren, regelrecht naar de valkuil van het subjectivisme te voeren Het voltrekken van negaties kan op het eerste gezicht immers moeilijk anders worden opgevat, dan als een individuele prestatie - zeker wanneer, zoals Luhmann beweert, het vermogen te negeren een 'voor-talige' competentie is. Indien nu het veld van belevingsmogelijkheden waar iedere actuele beleving naar verwijst, telkens door individueel voltrokken negaties wordt geconstitueerd, dan is het zich in de belevingshorizon aandienende "wereldontwerp" — dat wat als "werkelijkheid" voor het psychisch systeem mogelijk is - afhankelijk van het 'subjectieve' standpunt, dat dit ene individuele bewustzijn in alle eenzaamheid inneemt. Het is echter onduidelijk, hoe een dergelijke voorstelling van het, in zijn subjectieve belevingswereld opgesloten psychisch systeem (- dat ook wat in sociaal

205. Zie 0.a. N. Luhmann, Soziale Systeme, Frankfurt/M. 1985, p. 316-317.

206. N. Luhmann, "Handungstheorie und Systemtheorie', opgenomen in: idem, Soziologische Awfklarung 3, Opladen 1981, p.59.

207. N. Lulamamn, 'Sinn als Grundbegriff,.:", op cit., p.28, 
opzicht mogelijk/verwachtbaar is, in monologe akten moet construeren!) nog in overeenstemming kan worden gebracht met Luhmanns pretentie, een 'nietsubjectivistisch" begrip van 'zin' aan de sociologie ten grondslag te leggen.

Luhmann onderkent deze problematiek natuurlijk, ziet het echter niet als het effect van zijn, men zou bijna zeggen: 'quasi-transcendentale' onderneming, maar in eerste instantie als een praktisch probleem dat zich op het niveau van het concrete beleven afspeelt:

'Die Komplexität anderer Möglichkeiten schließt es praktisch aus (oder macht es zumindest extrem unzweckmäßig), alle Möglichkeiten als subjecktive Möglichkeiten eigener Bewegung zu thematisieren... [-] Das Mögliche muß objektiviert werden, das heißt an der Sache selbst erscheinen. Es muß seine Bedingungen der Möglichkeit in einer von mir unabhängige Ordnung der Welt finden... Die Welt muß sozusagen perspektivenfrei geordnet werden. ${ }^{\text {.208 }}$

De met iedere zinmatige beleving gegeven verwijzing naar andere belevingsmogelijkheden moet volgens Luhmann dus aan het object van intentie zelf worden vastgemaakt en kunnen worden beleefd als liets dat nu eenmaal met dat object gegeven is ${ }^{209}$ Wat ik van bepaalde zaken of dingen kan verwachten, moet ik op een naïef-realistische wijze kunnen beleven als een set eigenschappen, die kenmerkend is voor een, onafhankelijk van mij bestaand deel van de werkelijkheid. Dat een vaas een achterkant heeft, moet op een of andere manier aan het 'feit" liggen dat het een vaas is en niet aan mijn gestage constructie-arbeid die $\mathrm{ik}$, om vazen heen bewegend, al observerend heb verricht.

Deze om functioneel-pragmatische redenen vereiste objectivering van zinstructuren - het is simpelweg niet handig om alles wat mogelijk is in de wereld als afhankelijk van mijn gaan en staan op te vatten - wordt volgens Luhmann tot stand gebracht, doordat het voor zin constititutieve "negeren" zich altijd voltrekt in de vorm van een 'gedifferentieerd' negeren.

Het gaat daarbij om een differentiatie in een drietal dimensies, die Luhmarn aanduidt als 'Sachdimension", 'Zeitdimension' en 'Sozialdimension'. Alle zin bestant uit een vervlechting van negatieprestaties die betrekking hebben op zowel zakelijke, als temporele en sociale aspecten of dimensies van het

208. "Simn als Grundbegriff...", op.cit., p.46/47.

209. Met Husserl zouden we kunnen zeggen: de 'akt-horizon' als de horizon wan verdere belevingsmogelijkheden, moet worden getransformeerd in een 'objecthorizon', ails het geheel wan eigenschappen die aan het object van intentie kunnen toekcomen. 
beleven. ${ }^{210}$ Deze drie dimensies vormen voor Luhmann als het ware de 'krachtlijnen' voor de decompositie van 'zin überhaupt' en keren als een universeel geldig coördinatenstelsel dan ook altijd weer terug in zijn analyse van bijzondere zin-eenheden of -complexen:

'An allem Sinn, mag er positiv oder negativ formuliert sein, sind diese drei Dimensionen zugänglich als Formen weiterer Verweisung. Die primäre Dekomposition von Sinn uberhaupt liegt dann in diesen drei Dimensionen, und alles weitere wird zur Frage ihrer Rekombination. ${ }^{211}$

Om begrijpelijk te maken, waarom deze drie-dimensionale structuur van het zinmatig beleven volgens Luhmann tot een 'perspektivenfreie' ordening van de wereld leidt, kunnen we volstaan met een korte typering van de afzonderlijke dimensies:

- Met de zakelijke dimensie van het beleven doelt Luhmann op het beleven van de wereld als een geheel van 'Sachverhalte' (die ook anders mogelijk zijn). Algemeen gesproken geldt hier als de ordeningswijze van 'zin', dingen, eigenschappen of standen van zaken te identificeren in hun onderscheidenheid: 'Sachlich erscheint Sinn im Anderssein — darin daß ein Pferd keine Kuh ist, ein Zahl kein Vergnuggen; Schnelligkeit keine Farbe ist. ${ }^{212}$

- De temporele dimensie van het beleven behelst bovenal de beleving van de wereld als een in de tijd zich realiserende mogelijkheid, de wereld als een toekomstige, huidige of voorbije werkelijkheid. 'Die Zeitdimension wird dadurch konstituiert', zo schrijft Luhmann, 'daß die Differenz von Vorher und Nachher, die an allen Ereignissen unmittelbar erfahrbar ist, auf Sonderhorizonte bezogen, nämlich in die Vergangenheit und die Zukunft hinein verlängert

210. Mathias Heidenescher suggereert, dat de keuzo voor precies deze drie dimensies is gebaseerd op de overweging, dat zinreproductie via informatie verloopt en dat informatie altijd een indoudelijk/zakelijk aspect heeft als informatie over/omtrent een bepald iets, een temporeel aspect gelet op de nieuws- of informatiewaarde en een sociaal aspect in termen wan informatileoverdracht. "Zin", als het structurele raamwerk waarbinnen informatie eerst informatio kan

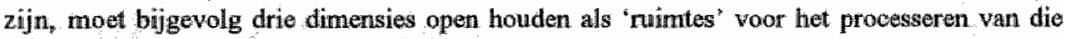
drie, an informatie inherente aspecten.

Zie M. Heidenescher, 'Zurechung als soziologische Kategorie..', Zeitschrift für Soziologie $21(1992), p .446$

211. Soziale Systeme, op.cit. p. 113/114.

Lazers/lezaressen van Luhmanns werk zullen natuurlijk gemerkl hebben, dat het onderscheid tussen zakelijke, temporele en sociale aspecten bij zijn behandeling van zeet witeenlopende zaken telkens weer opduikt, ook wanneer het onderwep van discussio op het eerste gezicht weinig met 'zin' heeft uit to staan. Dat wordt begrijpelijk wanneer men bedenkt, dat ze als de oerdimensies van de decompositie van "zin überhaupt", woor zinsystemen "Wilidimensionen" woorstellen, die niet meer opgegeven kunnen worden.

212. "Sinn als Grundbegriff...", op.cit., p.48. 
wird. ${ }^{\circ 113}$ Voor dit in de tijd zich uitstrekken van de belevingshorizon moet in het beleven zelf een onderscheid kunnen worden aangebracht tussen enerzijds het moment en de tijdsspanne van het beleven en anderzijds het moment en de tijdsspanne van het beleefde, van het object van intentie. Het moet mogelijk zijn om hier en nu aan iets te denken dat gisteren gebeurde, zonder te moeten denken dat dit een denken van gisteren is. Luhmann:

'Solche zeitliche Distanzierung von Sinn der doch aktuell vergegenwartigt wird, fungiert als erhaltende Negation und ermóglicht es dadurch die Zeitdimension als Schema einer aktuell verflagbaren Darstellung von Komplexität zu verwenden: Man kann jetzt schon im Hinblick auf einen künftig zu erreichenden Zweck die geeignete Schritte wahlen. ${ }^{214}$

- De sociale dimensie van zin komt tenslotte tot stand door de (h)erkenning van een niet-ik (Alter) alls een ander-ik (Alter Ego). Het eigen perspectief kan dan gaan verschijnen als een van de vele mogelijke perspectieven. Dat maakt tevens een uitwisseling van perspectieven, van geselecteerde belevingsopties mogelijk. Een belevend ik kan althans observeren, dat Alter vanuit een ander perspectief observeert en vervolgens besluiten, om "het perspectief van de ander" (dat natuurlijk nog steeds het produkt van zijn eigen observatie is) over te nemen. Daarmee ontlast het individuele bewustzijn zich van de taak de wereld alleen, vanuit zijn eenzame subjectieve standpunt te construeren. De herkenning van een niet-ik als een ander-, de-wereld-meebelevend-ik 'ermöglicht die Distanzierung des unerløsbar in seinem Erleben lebenden Subjekts von seinen Erlebnisinhalten. Seine Gegenstände sind auch die der andere Subjekte, haben ihre Selbständigkeit also in dem was sie allen zugänglich macht - in ihrem Sinn". ${ }^{215}$ De sociale dimensie van de zin-eenheden of "identiteiten' die het concrete beleven vullen, zo kan Luhmann dan ook stellen, bestaat bovenal uit de toegankelijkheid, uit de herkenbarheid voor de ander van een bepaald zincomplex.

De gezochte (en vereiste) 'objectivering van het mogelijke/verwachtbare' komt nit volgens Luhmann tot stand, doordat de drie zin-dimensies elkar niet alleen impliceren, maar ook wederzijds inperken en blokkeren Negaties in de ene dimensie vereisen negaties, of juist constanten in de andere dimensies. Een voorbeeld daarvan is de "eis" die de sociale dimensie van het beleven aan de temporele dimensie stelt, namelijk een synchronisatie van de beleving van, voor elkar als mede-subjecten fungerende individuen tot stand te brengen. De

213. Sozicile Systeme; op cit, p.116.

214. "Sinn als Grundbegriff...", op.eitt., p. 54.

215. Idem, p.52. 
actuele handeling van de een mag door de ander niet worden opgevat als iets dat tot zijn verleden behoort; de toekomst van Ego mag niet door een Alter Ego als een onderdeel van zijn huidige situatie worden begrepen; etc. Dergelijke vervlechtingen van negatieprestaties uit de drie verschillende dimensies leiden tot een zekere 'verstening' van zin. Wat er althans door wordt bewerkstelligd, is, dat zin-structuren niet langer willekeurig manipuleerbaar zijn. 'Zin' gaat zelf' constraints vertonen. Daardoor krijgt een psychisch systeem de indruk, aldus Luhmann, dat 'zin' iets 'objectiefs' weergeeft, dat zinstructuren iets tot uitdrukking brengen wan de manier waarop de wereld in elkaar zit. In een citaat dat tevens belangrijke delen van al het voorafgaande samenvat:

\begin{abstract}
'Sinn ist die Ordnungsform menschlichen Erlebens, die Form der Prämissen für Informationsaufnahme und bewußte Erlebnisverarbeitung, und ermöglicht die bewußte Erfassung und Reduktion hoher Komplexitat. Ein genauere Analyse die auf die sinnbildenden Leistungen des Erlebens zurackgreifen muß, führt auf ein kompliziertes Geflecht von Negationen, mit deren Hilfe sich Identitäten in einer mehrdimensionalen, sachlich, sozial und zeit]ich komplexen Welt konstituieren. Dadurch entsteht der Eindruck einer objektiven, in ihren Möglichkeiten limitierten Welt, die von der je aktuellen Erlebnisfuhrung unabhängig ist und als ihr Auswahlbereich vorgestellt werden kann. ${ }^{326}$
\end{abstract}

\title{
$\S 7$. Zin en complexiteit
}

Luhmanns model van object(iviteits)constitutie op basis van een driedimensionaal negeren, kan tot op zekere hoogte worden beschouwd als zijn alternatief voor de zogeheten 'constitutietheorie van de ervaring' die aan het einde van de zestiger jaren door Kambartel, Lorenzen en Mittelstraß was geformuleerd. De constitutie van objecten van mogelijke ervaring werd door Kambartel c.s. gekoppeld aan handelingsvelden en hun 'antropologische" functies - omvorming van de natuur, sociale organisatie, etc. Dit concept wormde ook de achtergrond van Habermas' theorie van de "kennisbelangen' en van zijn latere onderscheiding van 'instrumenteel' en 'communicatief handelen'. Met zijn alternatief voor een, aan 'Funktionskreise instrumentalen und kommunikativen Handelns" georiënteerde theorie van ervaringsconstitutie beoogde Luhmann echter geenszins processen van zinvorming voorgoed in het (individuele) beleven te parkeren. Al in zijn uiteenzetting van de driedimensionale grondstructuur van zin waren daartoe de nodige voorzorgsmaatregelen getroffen. Wat aan de drie-dimensionaliteit van zin 
namelijk opvalt, is de bijzondere positie die de 'sociale dimensie' daarin inneemt. Weliswaar geldt, dat alle drie de dimensies geacht worden even 'oorspronkelijk' te zijn, d.w.z. niet op elkaar reduceerbaar, en dat ze ieder op zich 'weltuniversale Relevanz' hebben voor de constitutie van zin. Met de sociale dimensie echter wordt de zinmatige constructie van een 'objectieve" ervaringswereld direct aan 'intersubjectiviteit' gekoppeld:

'Die soziale Dimension betrifft das, was man jeweils als 'seinesgleichen, als: 'alter Ego' annimmt, und artikuliert die Relevanz dieser Annahme fur jede Welterfahrung und Sinnfixierung....denn wenn es aberhaupt ein Alter Ego gibt, ist es, so wie das Ego auch, fur alle Gegenstände und für alle Themen relevant: ${ }^{217}$

'Objectiviteit" impliceert bij Luhmann dus 'intersubjectiviteit' - of sterker nog: de ervaring van objectiviteit, van een wereld die niet slechts het verlengstuk van mijn willekeur vormt, is slechts mogelijk als de zinmatige ervaring van een werkelijkheid die ook door anderen beleefd kan worden - ongeacht de vraag, of in werkelijkheid een ander die wereld inderdaad ook zo beleeft.

$\mathrm{Nu}$ is dat, na Mead en de latere Wittgenstein, niet een bijster originele gedachte. Deze denkfigur krijgt bij Luhmann echter een bijzondere draai, wanneer hij vervolgens postuleert, dat voor dit intersubjectieve aspect van zinconstitutie de niet-identiteit van subjecten een essentiële voorwaarde vormt. ${ }^{218}$ Of zoals Köhler met enige verbazing constateert:

'Seinen identifikatorische, 'gegenständlichen' Leistung kann der 'Simn' sogar nur unter der Bedingung gerecht werden, daß er die "Nichtidentităt der erlebende Subjekte" voraussetzt. ... Die Identităt der Gegenstände und Gegenstandsdimensionen wird also um den Preis der Nichtidentităt der Subjekte...erhalten. ${ }^{\text {*219 }}$

Dit principe van de "niet-identiteit van elkaar (mee)belevende subjecten' smijdt in feite aan twee kanten. Eerst en vooral is het gericht tegen iedere subjectfilosofische fundering van zin - dus ook tegen Husserls poging daartoe. Iedere vorm van transcendentale subjectiviteit; ieder "Einheitliches" dat wordt ingevoerd als garant van 'objectiviteit', dw.z. van de intersubjectieve overdraagbaarheid en gelding van het beleven en kennen, behelst volgens Luhmann een beroep op een instantie die juist niet 'objectief' kan beleven, 'weil ihm ein Horizont bereitgehaltener Perspektiven fehlte, die momentan nicht die

217. Soziale Systeme, op cit, p.119.

2118. Verg. "Simn alls Grundbegriff...", op.cit, p. 51 e.v.

219. J. Köhler, op.cit, p.96. 
seinen sind. Mann mußte ihm, wenn Objektivitait, ein allumfassendes, nichtselektives Erleben zuschreiben, was jede mögliche Interpretation des Begriffs Erleben sprengt' ${ }^{270}$

Deze kritiek op subjectfilosofische funderingen leidt er overigens niet toe, dat Luhmann van de weeromstuit de constitutie van zin lokaliseert in "intersubjectiviteit", in interactieve processen, of zoals hij het zelf zou uitdrukken: in sociale systemen. Al helemaal niet in "consensus'! Het principe van de niet-identiteit van, elkaar als 'mede-subjecten' belevende psychische systemen is ook tegen een Habermas gericht. De 'niet-identiteit' is principieel - op zijn minst in die zin, dat de wederzijdse exploratie van elkaars bewustzijnsleven alleen maar verder de diepte in gaat, nooit vaste bodem bereikt. $\mathbb{E} r$ is geen plaats of moment van 'samenkomen' of 'samenvallen'; belevende en handelende subjecten blijven voor elkaar uiteindelijk intransparant.

Niettegenstaande de 'weltaniversale Relevanz' van de sociale dimensie wil Luhmann de constitutie van zin dus miet in sociale processen/systemen situeren. Maar ook niet, zoals we zagen, in psychische systemen. Beide ordeningsvonmen acht hij fundamenteel voor zin, maar geen van beide 'fundamenteler'. Psychische en sociale systemen zijn even oorspronkelijk, ontstaan beide op basis van hun onderlinge 'co-evolutie':

'Die jeweils eine Systemart ist notwendige Umiwelt der jeweils andere....Personen können nicht ohne soziale Systeme entstehen und bestehen, und das gleiche gilt umgekehrt. ${ }^{221}$

'Zin' moet vervolgens worden opgevat als een verworvenheid van precies dit 'zich-aan-elkaar-optrekken'. Zin is een 'evolutionäre Errungenschaft' die in en door deze co-evolutie emergeert als het "medium' op basis waarvan psychische en sociale systemen zich eerst als zelfstandige systemen kunnen vormen. Psychische systemen (of 'persoonlijkheden' zoals Luhmann ze in zijn vroegere werk aanduidt) en sociale systemen "rekruteren zich" uit hetzelfde materiaal. We moeten volgens Luhmann dan ook uitgaan van een 'Welt konstituierenden Feld sinnhaften Erlebens und Handelns...in dem sich Persönlichkeiten und Sozialsyteme als je verschieden strukturierte Sinnzusammenhänge ausgewählten Erlebens und Handelns erst identifizieren'. ${ }^{2} 2$

Zuiver en alleen op zichzelf beschouwd, moet 'zin' dus begrepen worden als een algemene ordeningsmodus waarvan de conceptuele bepaling nog vooraf dient te gaan aan het onderscheid tussen 'psychisch' en 'sociaal'. Luhmann ervaart dit zelf als een bevrijding van het vooroordeel, dat, wanneer het om 'zin'

220. 'Sinn als Grundbegriff...', op.cit., noot 25 (p.51/52).

221. Soziale Systeme op.cit., p.92.

222. 'Sinn als Grundbegriff....', op.cit., p. $81 / 82$. 
en 'Zinconstitutie" gaat, het psychische systeem de (ontologische) voorrang zou hebben. Het zou echter van een zelfde vooringenomenheid getuigen, wanneer in plaats daarvan het sociaal systeem. geacht werd het meest fundamenteel te zijn voor zinvormingsprocessen - 'Es ist überhaupt verfehlt fur Sinn einen 'Träger' zu suchen. Sinn trägt sich selbst..."223

Alles bij elkaar genomen, impliceert dit echter, dat de functionele analyse van "zin" nu ook niet langer meer kan worden uitgevoerd met een exclusieve referentie aan het probleem van de belevingscomplexiteit. 'Zin' meet zich, op geleide van het bovenstaande, niet aan belevingscomplexiteit, noch aan handelings'complexiteit, maar aan "complexiteit uberhaupt", aan wereldcomplexiteif, aan 'Welt'. ${ }^{224}$

Met deze uitruil van belevingscomplexiteit voor "Welt' als het centrale referentieprobleem van de functionele analyse van zin, lijkt nu plotsklaps al het voorgaande op losse schroeven komen te staan. Of de critici die hierin een houvast voor hun breekijzer zien, gelijk hebben, zullen we nog nagaan. Vooralsnog kunnen we deze 'ompoling' beschouwen als een verdergaande radicalisering van Luhmanns functionele analyse van 'zin', als een nieuwe stap of 'fase', die dan ook weer nieuwe vragen en problemen oproept, in het kielzog waarvan conceptuele bijstellingen onvermijdelijk worden:

In de volgende paragrafen zullen we enkele van deze effecten nader onder de loep nemen. Maar misschien is het niet onverstandig, eerst nog een mogelijk misverstand te voorkomen. Wat in ieder geval moet worden benadrukt, is, dat zin slechts 'bestaat', realiteit heeft in de actualiteit van die gestructureerde processen die als "bewustzijn" of 'handelen/communicatie' de eigenlijke substantie van psychische en sociale systemen vormen. Zin leidt geen zwevend bestaan 'ergens daarboven' - er bestaat voor Luhmann niet zoiets als een, van bewustzijn en conmunicatie nog onderscheiden, algemeen 'zin-systeem", waarvan psychische en sociale systemen op een of andere manier (logischdeductief?) afleidbaar zouden zijn. ${ }^{225}$ Als Lyotard schrijft, dat 'naast de immense verschuiving, die van de gedachte van een Comte leidt naar die van een Luhmann, eenzelfde idee van het sociale zich [laat] raden: namelijk dat de samenleving een verenigde totaliteit is, een 'enigheid" en bovendien weet te debiteren, dat "bij de hedendaagse Duitse theoretici... de Systeemtheorie technocratisch [is]' en wel in die zin, dat 'de behoeften en de verwachtingen van individuen of groepen zijn afgestemd op de functies van het systeem, hetgeen

223. "...indem or seine eigene Reproduktion selbstreferentiell ermoglicht. Und ent die Formen dieser Reproduktion differenzieren psychische und soziale Strikturen." Soziale Systeme, op.cit., p. 141. Verg. ook: 'Sinn als Grundbegriff...', op.cit, p. 29 . 224. Verg. G. Kiss, Grundzuge und Entwicklung der Luhmanmschen Systemtheorie, Stuttgart.
1990, p. 95 .

225. Verg. G.Kneer/A Nassehi, "Verstehen des Verstehens -- Eine systemtheoretische Revision der Hermeneutiek', in: Zeitschriff fit Soziologie 20/Hft.5 (1991), p.346 e.w. 
niet meer is dan een bijkomend onderdeel van het functioneren daarvan ${ }^{226}$, dan heeft hij de zaak simpelweg niet goed begrepen (of wat even waarschijnlijk is: Luhmann niet gelezen). Het gaat evenmin om een Hegeliaans systeembegrip, om een soort 'Objektive Geist' die zich in de werelld wil realiseren. Psychische en sociale systemen zijn en blijven zelfreferentieel gesloten systemen, zijn en blijven dan ook autonoom in hun verwerking van zowel interne als externe complexiteit.

\section{§. Beleven en handelen}

Met de omschakeling van belevingscomplexiteit naar 'complexiteit uberhaupt', naar 'Welt' als referentieprobleem van de functionele analyse van zin, kan het niet anders, of ook het begrip 'beleven' moet in de revisie. In ieder geval kan 'beleven' nu miet langer doorgaan voor het proces dat het privilege heeft op zinvorming en -verwerking. Niet alleen is het sociaal systeem inmiddels opgerukt naar een positie die, als het gaat om zinconstitutie, gelijkwaardig is aan het psychisch systeem; de functie van zin heeft bovendien betrekking op zowel beleven als handelen. 'Beleven' en 'handelen' stellen beide vormen van, door zin bemiddelde complexiteitsreductie voor - zin reguleert ook de toegang tot de overmaat aan handelingsmogelijkheden.

$\mathrm{Nu}$ is 'beleven' niet hetzelfde als 'handelen' en de vraag is dan ook waarin het onderscheid tussen beide bestaat. Luhmanns antwoord hierop is niet alleen van belang, omdat het gebruik maakt van een motief dat vaker in zijn werk zal opduiken, maar ook omdat het een definitieve bezegeling lijkt van de perspectiefwisseling, die met de radicalisering van zijn analyse is ingezet:

Om te beginnen, zo stelt Luhmann vast, belichamen 'beleven' en 'handelen' allebei vormen van 'sinnhaft' gedrag. Nu behelzen zinmatige gedragingen in concreto altijd specifieke zin-selecties; het actueel gebruik van zin impliceert altijd een selectie uit meerdere mogelijkheden - we denken aan een vaas (en niet aan een appel), we geven iemand een hand (en niet een oorvijg), eto. Het onderscheid nu tussen 'beleven' en 'handelen' maakt Luhmann afhankelijk van de vraag op welk conto deze selectie moet worden bijgeschreven - hoe komt het dat we een vaas beleven, waaraan ligt het dat we een hand geven?:

'Intentionales Verhalten wird als Erleben registriert, wenn und soweit seine Selektivität nicht dem sich verhaltenden System sondern dessen Welt zugerechnet wird. Es wird als Handeln angesehen, wenn und soweit man die Selektivität des Aktes dem sich verhaltenden System 
selbst zurechnet. $22 \pi$

Het onderscheid beleven/handelen laat zich dus niet begrijpen als een onderscheid tussen twee, materieel gezilen verschillende processen. Het gaat oak niet om de vraag wie (of wat) bepaalde 'gedragingen' ten uitvoer brengt (dat kan in beide gevallen de/hetzelfde zijn), maar waar de selectiviteit van die gedragingen aan wordt toegeschreven. Wordt de selectiviteit die inherent is aan bijv. de observatie van "een vaas" aan de omgeving van de observator toegeschreven als een nu eenmal gegeven kenmerk van die omgeving, dan betreft het een "beleven" van een vaas. Wordt daarentegen de selectiviteit die inherent is aan het uitdelen van een oorvijg op het conto van de (Engelse) huisvader afgeschreven, dan betreft het een 'handeling". Het gaat kortom om attributie, om toerekeningsmechanismen en -processen.

De beslissing; of een bepaalde zinselectie nu als 'met de wereld gegeven' moet worden opgevat, of als een prestatie van het (dus handelend) systeem, heeft volgens Luhmann het karakter van een conventie en is uiteindelijk zelf contingent. Wat het ene moment als 'beleefde zin' wordt opgevat en behandeld, kan in principe op een ander tijdstip als 'handelingszin' worden aangemerkt. 'Es gibt Themen', zo schrijft Luhmann, 'bei denen es sehr langfristig vorteilhaft bleibt die Sinnverarbeitung als Erleben und nicht als Handlung zu erleben b.z.w. zu behandeln. Im prinzip kann man mithin von einer functionale Aequivalenz der Reduktionsformen Erleben und Handeln ausgehen'. ${ }^{228}$ Wat Luhmiann met deze onderlinge inwisselbaarheid van 'beleven' en 'handelen' denkt te kunnen verhelderen, is bijvoorbeeld de historische overgang van natuurrechtsdenken naar positivistische rechtsvoorstellingen. In het klassieke natururrecht werd het recht opgevat als iets dat met de wereld gegeven is, als iets dat 'van nature' aanwezig is. Dat staat tegenover een voorstelling van recht waarbij recht per definitie positief recht is, d.w.z. in het leven geroepen, afgekondigd door een wetgevend of politiek systeem.

Het onderscheid tussen 'beleven' en 'handelen' is bovendien systeemrelatief, afhankelijk van de systeemreferent die we kiezen. Wat voor het ene systeerm 'handelen' is, kan door een ander systeem 'beleefd' worden - met door alle eeuwen heen de fatale mogelijkheid van een (religieus/politiek/cultureel/erotisch/etc.) zondig, 'niet-correct', pervers beleven. Luhmann waarschuwt er met nadruk voor, het onderscheid tussen beleven en handelen niet voortijdig aan het onderscheid tussen psychische en sociale systemen te koppelen. Psychische systemen kunnen ook "handelen", d.w.z. de verantwoordelijkheid voor bepaalde zinselecties op zich nemen; sociale systemen kunnen ook 'beleven', zoals de

227. N. Lulamann, "Erleben und Handeln', opgenomen in Soziologische Aufklärung 3, op.cit., p.68/69. Vgl. ook 'Siru als Grundbegriff...' op. cit., p.77 en N. Luhmann, Fivnktion der Religion, Frankfurt/M. 1977, 1.74.

228. "Sinn als Grundbegriff..." op.cit, p. 79. 
geschiedenis van het recht bijv. laat zien, of anders wel het wetenschapssysteem, dat er immers voortdurend op uit is, de eigen selectiviteit voor 'beleven' wit te geven.

\section{\$9. Zin, Systeem en Wereld}

Psychische en sociale systemen zijn 'zinsystemen', d.w.z, systemen die zin als hun ordeningsmodus gebruiken. Tegelijkertijd geldt echter dat zin voor zijn realisatie als de zin van een handeling of beleving op systeemvorming is aangewezen. Zin realiseert zich immers altijd als een hier en nu actuele selectie binnen een voorgestructureerd veld van belevings- of handelingsmogelijkheden. Of dynamischer geformuleerd: Zin kan een concrete beleving of handeling slechts hebben alls een gebeurtenis binnen een "proces", waarbij een proces zich van een willekeurige opeenvolging van gebeurtenissen onderscheidt door zijn selectiviteit En precies dàt -, door structuurvorming tot stand gebrachte selectiviteit moemen we 'systeem'. Die systeemafhankelijkheid van zin wordt al vastgelegd, wanneer Luhmann stelt dat 'zin hebben' betekent, dat een beleving of handeling aansluiting heeft op, en aansluitingswaarde heeft voor "bepaalde" belevingen/handelingen, 'andere unwahrscheinlich, oder schwierig oder weitläufig macht oder (vorläufig) ausschließt. ${ }^{.229} \mathrm{Zin}$, zo zouden we ook kunnen zeggen, is altijd systeemspecifieke zin. Een handelaar berekent de klant een prijs en de klant denkt niet plosteling getuige te zijn van een rekenexamen; een president legt een eed af en niemand van de aanwezigen komt op het idee om terug te zwaaien; etc.

"Zin' en 'systeem', zo volgt uit het bovenstaande,-impliceren elkaar wederzijds. De relatie tussen ' $\mathrm{zin}$ ' en 'systeem' blijkt een 'wederzijdse constitutie'verhouding te zijn. ${ }^{230}$ Hier dienen we echter precies te zijn. Wat althans vermeden moet worden, is het beeld van een deel/geheel-verhouding, waarin het systeem als 'geheel' en de actuele zinselectie als 'deel' een circulair gesloten verband vormen. Juist omdat het om 'zin' gaat, ligt de zaak complexer. Dat zin een complexiteitsreductie mogelijk maakt onder behoud van complexiteit, wil zeggen, dat met iedere 'punktuelle Zugriff', met iedere belevings- of handelingsselectie weliswaar een veld van 'aansluitende' belevings- en handelingsmogelijkheden wordt 'mee-geselecteerd', maar dat tegelijkertijd het hier en nu 'niet-relevante', het 'niet-aansluitende' niet wordt vernietigd, maar in de marge behouden blijft. We kunnen bovendien telkens 'de negatie negeren', i.e. voor het in eerste instantie uitgeslotene kiezen. We kunnen per geval de grens tussen systeem en omgeving oversteken, buitenhorizon in binnenhorizon transformeren en vice versa, zij het, dat dit alles niet zonder kosten gaat, op zijn

229. Saziale Systerne, op cit., p.94.

230. Verg. H. Willke, Systemtheorie, Stuttgart 1991, p.36. 
minst tijd vergt. Dit behoud van het niet-geselecteerde als veld van toekomstig mogelijke selecties is, zoals we gezien hebben, constitutief voor zin als zodanig. De grenzen van psychische en sociale systemen zijn, om het zo uit te drukken, "doorlaatbaar" - hun grenzen zijn zingrenzen, precies voor zover ze systeem en omgeving scheiden en tegelijkertijd de omgeving voor het systeem toegankelijk houden. Wanneer Luhmann de wederzijdse constitutie van zin en systeem simpelweg als 'constitutie' aanduidt en verder over zinsystemen als 'Sinn konstituierenden Systemen' spreekt, dan doelt hij met 'Konstitution' precies op die, voor 'zin' fundamentele verhouding tussen selectiviteit en openheid:

'Gemeint ist...daß Sinn immer in abgrenzbaren Zusammenhängen auftritt und daß er zugleich uber den Zusammenhang, dem er angehört, hinausverweist: andere Möglichkeiten vorstellbar macht. [-] Was es zu verstehen und im Begriff der Konstitution zu fassen gilt, ist jenes Verhältnis einer selektiv verdichteten Ordnung zur Offenheit anderer Möglichkeiten, und zwar als ein Verhältnis des Wechselseitig-sichBedingenden, des Nur-zusammen-Möglichen. ${ }^{231}$

We zouden nu een belangrijk deel van de pointe missen, wanneer we bovenstaand citaat slechts opvatten als een op zinsystemen afgestemde formulering van het algemene principe, dat systeem en omgeving elkaar wederzijds impliceren. Voor zin-systemen figureert de systeem/omgevingverhouding-namelijk op een bijzondere manier. Zo kan een observator weliswaar vaststellen dat de omgeving van een fysisch systeem complexer is dan dat systeem zelf, maar een fysisch systeem observeert zijn omgeving niet zelf als een, op een of andere manier 'complexe' omgeving - een steen beschikt, om het zo uit te drukken, niet over een 'beeld' van zijn omgeving waarin complexiteit als zodanig is verdisconteerd. Voor zinsystemen geldt als zelfreferentiële, zichzelf observerende systemen daarentegen, dat ze "weet hebben' van complexiteit - het is telkens een beleven en handelen in het licht van andere mogelijkheden, zowel van mogelijke voortzettingen van het systeem als van andere mogelijke gebeurtenissen en standen van zaken in de omgeving. Zinsystemen ervaren m.a.w. zichzelf en hun omgeving als een telkens ook anders mogelijke selectie uit een bereik dat uiteindelijk alle mogelijkheden omvat, ook de hier nu niet actuele of relevante mogelijkheden. Zin verwijst, volgens Luhmann naar 'Welt' en wel als het noodzakelijk correlaat van zinmatig beleven en handelen:

'[D]urch das Gebrauch von Sinn wird Welt konstituiert als derjenige Gesamthorizont in dem das System sich selbst auf seine Umwelt und 
seine Umwelt auf sich selbst bezieht. ${ }^{232}$

De radicale functionalisering van het fenomeen 'zin' drijft Luhmann zo naar het bekend eindpunt. Zin constitueert 'Welt' als 'Sinneinheit der Differenz von System und Umwelt" $t^{233}$ Maar tegelijkertijd is ' $\mathrm{Zin}$ ', naar zijn functie beschouwd, reductie van 'Welt'. Beide tegelijk! In een laconieke formulering van Luhmann:

"Erst wenn Sinngrenzen die Differenz won System und Umwelt verfügbar halten, kann es Welt geben. Systeme; die Sinn konstituieren und verwenden, setzen sich damit der Welt aus. ${ }^{234}$

Dit alles mag op het eerste gezicht raadselachtig klinken, we herkennen inmiddels een, nu op zinsystemen toegesneden formulering van het probleem 'Welt'. Als noodzakelijkerwijs reflexieve, zichzelf-observerende systemen opereren psychische en sociale systemen in het licht van een paradox die zich met hun constitutie eerst formeert en wel als een op basis van contingente selecties 'altijd al' opgelost probleen. Inderdaad - de 'welthaften Konstitution. von Sinn' kan door Luhmann worden gelijkgesteld an de 'sinnhaften Konstitution von Welt'. ${ }^{235}$ Wat aan, door zin reduceerbare complexiteit mogelijk is, wordt door zin zelf geconstitueerd en gereguleerd. Zin verschijnt zo als zijn eigen mogelijkheidswoorwaarde - 'Sinn tragt' sich selbst'. ${ }^{236}$ Meer 'grondbegrip' kan 'zin' niet zijn (en verder kan de 'autopoietische' interpretatie van het 'Sinngeschehen' niet gedreven worden).

\section{$\S 10$. Ter afsluiting}

In zijn boek over de lotgevallen van het zin-begrip sedert Kant, merkt Jochen Köhler op, dat Luhmanns 'radikalisierte Funktionalismus...einer der zur Zeit wohl vielversprechendsten Versuch, dem Simbegriff eine neue diskursive Geltung zu verschaffen, [bietet]]".237 Dat is natururijk een prettige gedachte voor degene die zich door Luhmanns zintheorie heeft heen geworsteld. Het neemt echter niet weg dat Luhmanns zin-theorie van meet af aan op kritiek is gestuit. Zo heeft Habermas, al in dezelfde bundel waarin ook 'Sinn als Grundbegriff der Soziologie' verscheen, het door Luhmann gemaakte onderscheid tussen

232. N. Luhmann, Funktion der Religion, op.cit., p.22. Verg. ook: Soziale Systeme, op.cit., p.283 e. $v$.

233. Verg. Soziale Systeme, op. cit., p.283.

234. Idem.

235. Zile Idem, $\mathrm{p}_{\mathrm{n}} 105$.

236. Idem, p.141.

237. J. Köhler, Die Grenze von Sinn, München 1983, p.92. 
'beleven" en 'handelen' stevig onder handen genomen. Wat Habermas natuurlijk opviel, was, dat het 'beleven" dat Luhmann van 'handelen' onderscheidt niet meer hetzelfde 'belleven' is, als het beleven waarmee Luhmann van start was gegaan:

"Die Strategie der Einfuhrung des Grundbegriffs 'Sinn' ist bei Luhmann nicht einheitlich. Zwei Tendenzen widerstreiten einander. Einerseits neigt Luhmann dazu, die Sinnkonstitution ins Erleben zu verlagern, anderseits behauptet er Erleben und Handeln als abgeleitete und gleichrăngige Modi einer zugrundeliegenden Sinnkompetenz., 238

De achtergrond van deze tweeslachtigheid lag volgens Habermas voor de hand Het lokaliseren van zinconstitutie in het beleven biedt aanvankelijk het voordeel, om leunend op Husserl, van een niet-functionalistisch zinbegrip uit te kunnen gaan - 'So vermag er gegen den Zwang der funktionalistischen Begriffsstrategie zunächts plausibel zu machen, daß Sinn der Erhaltung der Komplexităt dient'. ${ }^{23}$ Maar, zo vervolgt Habermas, als eenmaal de zinconstitutie in de subjectieve belevingswereld is gelokaliseerd, dan wordt de intersubjectieve overdracht van middels zin gereduceerde complexiteit bijvoorbeeld het inzicht dat 'personal computers' handige type-machines zijn een probleem. Dit, inmiddels klassieke probleem stelt zich voor Luhmann in het bijzonder, aldus Habermas, daar hij benadrukt, dat communicatie geenszins een overdracht van zin behelst. Communicatie is bij hem 'gemeinsame Aktualisierung von Sinn, die mindestens einen der Teilnehmer informiert..Als Identisches fungiert in der Kommunikation indes nicht eine ubertragene, sondern eine gemeinsam zugrunde gelegte Sinnstruktur, die eine Regulierung der wechselseitigen Uberraschungen erlaubt' ${ }^{240}$

Het is nu precies deze problematiek van de intersubjectiviteit, zo meende Habermas, die ertoe noopt, op een conceptie over te schakelen, die, zoals Luhmann zelf formuleerde, 'den grundbegrifflichen Ansatz der soziologischen Theorie in den Sinnbegriff zuruckverlegt und von ihm aus Erleben und Handeln als gleichrangige, funktional aquivalente, aber verschiedenartige Reduktionsweisen ableitet'. ${ }^{241}$. Deze omschakeling gaat echter niet zonder kosten, aldus Habermas. Met deze nieuwe conceptie 'wird aus dem Begriff des erlebniskonstituierten Sinns das wesentliche Moment der Erhaltung von Komplexităt getilgt; Erleben gilt nun als eine Weise der Komplexitătsreduktion" - en niet meer, zo zouden we kunnen toevoegen, als een beleven dat aan zijn immanente transcendentie in steeds andere bewustzijnsinhouden niet kan

238. J. Habermas, "Theorie der Gesellschaft oder Sozialtechnologie", in: J.Habermas/N.Luhmann, op. cit, p.202.

239. Idem, p. 203

240. "Sirn als Grundbegriff...", op.cit., p.42/43.

241. Idem, p.79 
ontsnappen. ${ }^{242}$

We zouden Habermas op dit punt natuurlijk kunnen onderbreken met de opmerking, dat zijn 'probleem' in feite ontstaat, doordat hij de retorischdidaktische presentatie van Luhmanns zintheorie verwisselt met de logische ontwikkeling van de inhoud van het zinbegrip zelf. Het effect van Luhmanns gefaseerde, functionalistische radicalisering van het zinbegrip is nu eenmaal, dat een opstel als 'Sinn als Grundbegriff der Soziologie" weliswaar niet anders dan van voren naar achter gelezen kan worden, maar dat het van achter naar voren begrepen moet worden. Het punt dat Habermas nawr voren wilde brengen gaat echter verder dan simpelweg Luhmann te wijzen op een inconsistentie, die hem vervolgens zwaar wordt aangerekend. Wat Habermas probeerde, was Luhmann voor het blok te zetten: het "beleven" is offwel de instantie die complexiteit opwerpt, ófwell een vorm van complexiteitsreductie - maar niet allebei tegelijk! Wat Habermas, ook langs andere lijnen, telkens heeft bestreden, is het idee van 'reductie van complexiteit onder behoud van complexiteit' of zoals Luhmann het zelfs presteert te opperen: 'complexiteitsstijging door complexiteitsreductie'. 'Funktionalistischer Begriffsstrategie' moet en zal in het teken van de theoretische reconstructie van complexiteitsreductie staan; behoud van complexiteit als een 'zur Reduktion von Weltkomplexität komplementäre Leistung" willen denken, blaast, volgens Habermas, het systeemtheoretisch raamwerk uiteindelijk op. ${ }^{243}$

Vanuit tactisch oogpunt was dat nog niet zo slecht gezien van Habermas: Een sociologische systeemtheorie, die in goed vertrouwen over een model van complexiteitsreductie onder behoud of zelfs toename van complexiteit kan beschikken en dat wil zeggen: een systeemtheoretische sociologie die al via zijn grondbegrippen de sociale werkelijkheid modelleert als een realiteit die structuur (complexiteitsreductie) kan verenigen met een toename aan keuzemogelijkheden (complexiteitsstijging) en contingentie - een dergelijke sociologie laat zich niet meer zo gemakkelijk vastnagelen als 'orde-denken', als ideologische handlanger van de status quo, of als "Hochform eines technokratischen Bewußtseins, ${ }^{244}$

Misschien komt vis-à-vis de vele empirische voorbeelden, die van complexiteitsreductie onder complexiteitsbehoud en -stijging kunnen worden gegeven, Habermas" kritiek wat geforceerd over en klinkt de 'ideologiekritische' toonsoort waarin zijn polemiek met Luhmann is geschreven, enigszins gedateerd. Desalniettemin had Habermas op dat moment, d.w.z. begin jaren zeventig, wel degelijk een punt te pakken. Want Luhmann kon het betwiste principe dan wel adstrueren met uiteenlopende maatschappelijke voorbeelden, de vraag was of hij er een coherente theoretische (re)constructie

242. J. Habermas, "Theorie der Gesellschaft oder Sozialtechnologie', op.cit, p.204.

243. Zie 0.a. Habermas toegespitste kritiek in ider, p. 199 ev.

244. Verg. de 'Einleitung' bij Habermas" "Theorie der Gesellschaft oder Sozilaltechnologie", in: J. Habermas/N.Luhmann, op.cit., p.142 t/m 145. 
van kon geven. En dan moeten we constateren, dat hem dit pas jaren later op een bevredigende manier zal lukken, namelijk op basis van een zelfreferentiële systeemsociologie die, zoals we nog zullen zien, maatschappelijke complexiteit als een door sociale systemen zelf, 'endogeen' geconstitueerde complexiteit weet op te vatten. ${ }^{245} \mathrm{Er}$ valt zelfs veel te zeggen voor de these, dat het met name Luhmanns reflectie op het fenomeen "zin" is geweest, die hem in de armen van het autopoiesis-concept heeft gedreven ${ }^{246}$

De bovenstaande kritiek is niet Habermas enige tegenwerping geweest. Zo bracht hij al in zijn polemiek met Luhmann naar voren, dat zin een taalafhankelijke categorie is en dat eerst via een taalfilosofische analyse de functie en algernene betekenis van zin aan het licht kan worden gebracht. En dat standpunt zal Habermas een kleine 15 jaar later, in Der philosophische Diskurs der Moderne; nog eens herhalen. ${ }^{247}$ Het probleem met deze 'kritiek' is alleen, dat zij zo extern blijft. Het is eerder een 'tegenbod', met misschien als voordeel, dat op geleide van Habermas' voorstel 'intersubjectiviteit'/maatschappelijkheid' zonder omhaal op 'taal' kan worden teruggevoerd, terwijl Luhmann ingewikkelder toeren moet uithalen. Luhmanns positie is, op zichzelf beschouwd, echter duidelijk: Zin gaat aan taal vooraf, is een "pre-talige categorie. De evolutionaire verworvenheid die we "taal' noemen, biedt allerlei voordelen — daaraan bestaat bij Luhmann geen twijfel. Het maakt bijv. zinschema's voor het bewustzijn grijpbaar/benoembaar, het maakt een discontinuering van bewustzijnsprocessen als een opeenvolging van discrete eenheden mogelijk; het fascineert het bewustzijn en houdt zo aan communicatie deelnemende psychische systemen alert; etc. Zoals we hebben gezien, gaat Luhmann er zelfs vanuit, dat taal onontbeerlijk is voor de ontwikkeling van complexe zinschema's en structuren. Echter, "taal' is niet opgewassen tegen het complexiteitsprobleem dat met zin op tafel ligt. Taal is niet selectief genoeg. In en met taal kan teveel (je kunt er zelfs mee liegen). Luhmann: 'Die Sprache dient primär dem Offenhalten von Möglichkeiten, dem Zugänglich machen unabsehbarer Sinnkombinationen. ${ }^{248}$ Complexiteit, zo zou Luhmann zeggen, is alls referentieprobleem van zin, weliswaar iets waarover je kunt praten, maar het is miet een probleem van de taal zelf. In een formulering van Köhler, die het probleem van 'intersubjectiviteit' of 'maatschappelijkheid" schuin in het oog houdt:

'Die Funktion und der Operationsradius des 'Sinns' begrenzen die sprachlichen Möglichkeiten systematisch: der 'Sinn' deckt "prozessual' eine Fläche $a b$, die der Gesellschafstruktur koextensiv ist, weil er eben

245. Verg. W. Reese-Schäfer, Luhmann zur Einfouhrung, Hamburg 1992, p. 142.

246. Zie daarvoor T. Blom, "Zin en Systeem", in: Tijdschrift voor Saciale Wetenschappen 31
$(1986,1)$, pp. $22-53$, i.h.b. p. 49 e.

247. Verg J. Habermas, Der philosophische Diskurs der Moderne, FrankfurtM 1985, p.438 e.v.

248. "Sinn als Grundbegriff...", op.cit, p.71. 
nicht beliebig im Raum des sprachlich Möglichen vagabundiert, sondern der Unendlichkeitsstruktur der Sprache selektiv Grenzen setzt. ${ }^{249}$

De door zin opgeworpen complexiteit kan alleen door zin zelf gereduceerd worden - zin kan alleen zichzelf beteugelen. Dat was, zoals we aan het slot van de vorige paragraaf gezien hebben, precies ook het eindpunt van Luhmanns zinanalyse. Wat aan reduceerbare complexiteit mogelijk is, zo schreven we, wordt door zin zelf geconstitueerd en gereguleerd. Zin is zijn eigen mogelijkheidsvoorwaarde. Daarmee biedt Luhmann de 'linguistische' denkers een (filosofisch) compleet tegenmodel aan, dat naturlijk niet onderuit gehaald wordt, door simpelweg te blijven hameren op de fundamentele betekenis van taal voor communicatie en intersubjectiviteit.

Habermas is natuurlijk niet de enige geweest die Luhmanns zintheorie stevig bekritiseerd heeft. Van de critici die al snel op 'Sinn als Grundbegriff der Soziologie' reageerden verdienen in ieder geval Klaus Grimm en Hans Thome het te worden vermeld. ${ }^{230}$ Voor hun kritiek op Luhmanns zimbegrip geldt echter hetzelfde als voor de eerste kritiek van Habermas, namelijk dat veel ervan inmiddels verouderd is, door Luhmanns eigen ontwikkeling achterhaald. Dat voert ons weer terug naar de kritiek op het autopoiesis-concept, i.h.b. op het model van 'identiteitsconstitutie op basis van zelfreferentie'. En eigenlijk verbaast dat ook niet. De 'bottle-neck' van een niet-reductionistisch zinbegrip, van een zintheorie die noch 'subjectivistisch', noch 'objectivistisch' wil zijn, maar 'zin' wil begrijpen als een zichzelf constituerend en regulerend proces, is en blijft de vraag hoe, nog vóór alle identiteit, identiteitsvorming mogelijk is. De vorming van zinmatige identiteiten veronderstelt bij Luhmann dat op zijn minst sommige observaties geïdentificeerd kunnen worden als 'bepaalde' observaties, als observaties van een 'dit-en-niet-anders"; alleen dat maakt het mogelijk een bepaalde observatie als 'dezelfde' observatie te beleven. Maar de vraag is: hoe is die, voor het proces van symbolische generalisering noodzakelijke identificatie mogelijk.

'Genetisch' geinterpreteerd komt dit probleem neer op de vraag hoe het beleven aan zijn oorspronkelijke, primaire differentie-ervaringen komt, die dan als aanhechtingspunten voor een speeifieker differentiebewustzijn en de ontwikkeling van identiteitsvoorstellingen kunnen fungeren. Luhmann zou dan antwoorden, dat dit terug gaat op organisch verankerde capaciteiten om 'onderscheidenheid' te observeren - lichter(donkerder), warmer(koud) aangenaam(minder-aangenaam), etc. 'Sinn entzieht diesem Unterbau dann

249. J. Köhler, op.cit, p 97.

250. Zie: K. Grimm, Niklas Luhmann's 'soziologische' Aufklärung - oder das Elend der aprioristischen Sozialogie, Hamburg 1974; H. Thome, Der Versuch die Welt zu begreifer. Fragezeichen zur Systemtheorie von Niklos Lithmann, Frankfurt/M. 1973. 
Differenzen (die als Differenzen nur Sinn haben), um differenzorientierte Informationsverarbeitung za ermöglichen. ${ }^{251}$ Men zou hierop kunnen antwoorden, dat dit aan de ene kant een wel heel erg summiere toelichting is, maar dat Luhmann aan de andere kant het risico loopt de 'stop" uit zijn systeem te trekken, d.w.z. voor zijn verklaring van het fenomeen 'zin" terug te grijpen op iets dat aan zin vooraf gaat, dat zelf geen "zin" is. Luhmann zou dan zijn schouders ophalen. In vragen naar de concrete genese van een fenomeen is hij weinig geinteresseerd - iets is ontstaan, heeft zich ooit voltrokken en dat had ook niet kuinnen gebeuren. Maar nu het wel is gebeurd, wordt interessant hoe daardoor "onwaarschijnlijke waarschijnlijkheden' ontstaan.

We kunnen het probleem ook algemener opvatten en de vraag stellen, hoe, zonder voorafgaande identiteit, een zelfreferentieel processeren van zin" mogelijk is, als dat toch de identiteit van een "zelf veronderstelt, dat naar zichzelf kan verwijzen. Daarmee zijn we terug bij de discussie die we aan het eind van het vorige hoofdstuk hebben behandeld, bij de kritiek van Gerhard Wagner en Heinz Zipprian op Luhmanns algemene model van identiteitsconstitutie op basis van zelfreferentie. Wie Nassehi"s weerlegging van die kritiek niet vertrouwt, kan de inschatting van Wagner en Zipprian als leidraad nemen voor de uitwerking van een meer principiële kritiek op Luhmanns zintheorie.

We kunnen maturlijk ook ons oordeel opschorten om de boom niet aan zijn wortels, maar aan zijn vruchten te keuren. Een voorlopige balans valt dan niet slecht uit. Luhmanns zinbegrip lijkt in ieder geval de grondslag te kunnen vormen voor een sociologie, die zich niet meteen vastloopt in een dichotomisering van 'individu' en 'maatschappij', in onvruchtbaar gebleken tegenstellingen als die tussen een 'subjectivistische' en een 'objectivistische' benadering, tussen 'methodologisch individualisme' en 'methodologisch collectivisme", etc. Het draagvlak van dergelijke dichotomieen heeft altijd bestaan in een interpretatie van de verhouding individu - maatschappij als een deel/geheel-verhouding, die, eenmaal 'modern', d.w.z. anti-substantialistisch en streng relationeel opgevat, tot het methodologisch dilemma leidde, wáar de cirkel open te breken. ${ }^{252}$ Moet dat aan de kant van het individu gebeuren, dat dan als 'subject(um)' van zingeving verschijnt, of moet het primaat aan de matschappij worden toegekend, als het overkoepelende netwerk waarbinnen bijzondere betekenissen en zinvolle handelingen eerst kunnen uitkristalliseren? Als daarentegen Luhmanns zin-theorie overtuigt, dan kunnen psychische en sociale systemen begrepen worden als zichzelf structurerende, autopoietische systemen, die voor hun orde en selectiviteit geen andere grond hebben dan hun

251. Sioziale Systeme, op.cit, p.97.

252. Zie voor een uitwoeriger uiteenzetting van deze problematiek: T.Blom/T.Nijhuis; 'Ontologie en methodologie in sociologie en geschiedenis', opgenomen in: $\mathrm{Ch}$. Lorenz e. aHet historisch ateller Meppel 1990, i.h.b. p. 115 e.v., Idem, "Individualisme en collectivisme in geschiedenis en sociologie" in Tijdschrift voor sociale werenschappen 34 (1989), p. 324 . 
eigen ordeningsmodus, namelijk zin. Psychische en sociale systemen waaronder 'maatschappij" als een bijzonder sociaal systeem - staan bij Luhmann niet in een deel/geheel-verhouding tot elkaar, maar vormen voor elkaar 'systemen in de omgeving', die als autopoietische systemen noch op elkaar gereduceerd kunnen worden, noch elkaar kunnen determineren. Natuurlijk gaat het om systemen die voor elkaar een bijzondere relevantie hebben. Dat beide zich via hetzelfde medium constitueren, zich als zinsystemen uit hetzelfde basismateriaal 'rekruteren', vormt daarvoor ook de garantie. Dat bewustzijn en communicatie met elkaar in contact staan en elkaar kunnen beïnvloeden - Luhmann spreekt van interpenetratie" - is precies mogelijk omdat het beide zinsystemen zijn, omdat bijv. een talige uiting zowel voor de betrokkenen als binnen het communicatieproces ' $\mathrm{zin}$ " heeft.

Tegelijkertijd leidt dat bij Luhmann niet tot het beeld van een integratie via een overkoepelende structuur, zoals we bijv. bij Talcott Parsons kunnen aantreffen in de gedaante van een 'general action system'. 'Zin' vormt geen supersysteem 'boven' psychische en sociale systemen. Het is juist de onvrede met dit soort reductie- en integratiedenken geweest, die Luhmann al vroeg in zijn carrière tot een eigenzinnige koers inspireerde en die voor een belangrijk deel ook de drijfveer achter zijn zin-analyse vormt. ${ }^{253}$ In Luhmanns eigen woorden:

'[Die] Auflösung älterer Kompaktannahmen uber Natur und Kosmos, Naturrecht, Herrschaft oder Wertkonsens, diese Auflösung der vorausgesetzten Systematizität des Ganzen erfördert größeren analytischen Aufwand in Bezug auf das Sinnproblem; man könnte auch sagen: in Bezug auf die Probleme, die sich ergeben, wenn Komplexität sich als Sinn präsentiert. Erst mit Bezug darauf kann man dann fragen welche Unterschiede zwischen Person-zu-Person Verhältnissen und Person-zu-Sozialsystem Verhaltnissen bestehen. ${ }^{254}$

Een tweede, mogelijk belangrijk voordeel van Luhmanns conceptie van 'zin' gaat terug op zijn theorema van de 'reductie van complexiteit onder behoud, of zelfs stijging van complexiteit". Als we aanvaarden, dat de sociale werkelijkheid in de grond van de zaak een 'zin-werkelijkheid' is, en bovendien Luhmanns karakterisering van 'zin' accepteren, namelijk dat zin een ordeningsmodus voorstelt die complexiteitsreductie onder behoud of stijging van complexiteit mogelijk maakt, dan biedt dat een basis voor de theoretische reconstructie van een fenomeen, dat empirisch evident is, maar tegelijkertijd wonderbaarlijk. Het is evident, dat sociale systemen erin slagen zichzelf(1) te transformeren in systemen met een hogere "structuurdichtheid" onder een gelijktijdige toename

253. Verg. N. Luhmann, "The Theory of Social Systems and its Epistemology...", in: Phiosophy of the Social Sciences 16 (1986), p.129.

254. N. Luhmann, Gesellschaftstrukitur und Semantik Bd.2, Frankfurt 1993, p.282. 
aan keuzemogelijkheden, aan selectiedwang, aan complexiteit. De theoretische vraag is, hoe die onwaarschijnlijkheid - meer orde én meer vrijheidsgraden waarschijnlijk kan worden. Luhmanns antwoord hierop, namelijk: door zin is niet alleen van belang voor de ontwikkeling van sociale evolutietheorieën, maar vooral ook voor de formulering van een maatschappijtheorie die zich committeert aan het complexiteitsprobleem. In hoeverre Luhmann de theoretische mogelijkheden, die door zijn conceptie van ${ }^{6} \mathrm{zin}^{2}$ worden geboden, ook daadwerkelijk weet te realiseren, zullen we echter pas beoordelen aan de hand van de hoofdstukken die aan zijn algemene sociologie en maatschappijtheorie gewijd zijn. 


\section{Hoofdstuk III}

\section{EEN ONWAARSCHIJNLIJKE WAARSCHIJNLIJKHEID: COMMUNICATIE}

\section{§1. Inleiding}

$\mathrm{Na}$ 'systeem' en ' $\operatorname{zin}$ ' richten we ons met het thema van dit en het volgende hoofdstuk - 'sociale systemen' - op Luhmanns sociologische theorie. De systematische analyse en reconstructie van psychische systemen laten we aan een eventuele systeemtheoretische psychologie over. Dat betekent niet, dat we na het algemene en abstracte karakter van de vorige twee hoofdstukken nu ineens bij de concrete empirie zijn aambeland. Met 'sociale systemen' bevinden we ons niet in de Tweede Kamer, of temidden van het modeme gezinsleven, maar op een niveau van theorievorming dat betrekking heeft op de meest algemene principes van sociale systeemvorming, op de mechanismen en processen die ten grondslag liggen aan het ontstaan en de ontwikkeling van ieder mogelijk sociaal systeem. In die zin bewegen we ons in dit hoofdstuk op het abstract universaliserend niveau van het sociologisch grondslagenonderzoek. Wat we in het vervolg zullen presenteren, is een categoriaal raamwerk, een geheel van samenhangende grondbegrippen, dat vastlegt wat volgens Luhmann 'altijd al' dient te worden voorondersteld in de wetenschappelijke observatie en beschrijving van sociale fenomenen.

Van zeer algemeen naar iets minder 'zeer algemeen' dus. Wie nu denkt, daarmee ook Luhmanns zin-theorie definitief achter zich te kumnen laten, komt bedrogen uit. Zoals we in de 'Inleiding' bij het vorige hoofdstuk al beweerden, zijn Luhmanns opvattingen omtrent 'zin' van directe betekenis voor zijn meest centrale sociologische categorieên, zij het alleen al omdat de sociale werkelijkheid bij hem in wezen een "zin-" of "betekenis-werkelijkheid" voorstelt. We kunnen aan die bewering nu ook een specifiekere invulling geven: Luhmanns zin-theorie levert het vertrekpunt voor zijn theorie van sociale systemen, omdat er een theoretisch precieze bepaling van het referentieprobleem van sociale systemen uit kan worden afgeleid, i.e. van die uitsnede uit de "wereldcomplexiteit' die door sociale systemen wordt gereduceerd en onder controle gebracht. Zoals we hebben gezien, gaat Luhmann er vanuit, dat al het zinmatig beleven gedecomponeerd kan worden in de drie dimensies van "temporaliteit", "zakelijkheid" en 'socialiteit", die in en door hun onderlinge vervlechting de suggestie van 'objectiviteit' wekken. Voor de vaststelling van het complexiteitsprobleem dat als houvast of richtpunt voor de functionele analyse en reconstructie van 
sociale systemen moet dienen, is met name de 'sociale dimensie' van belang. Met de sociale dimensie van alle zin doelt Luhmann op de intersubjectieve toegankelijkheid of 'begrijpelijkheid' van concrete zinschema's en -structuren. Of als dat te "consensualistisch" geformuleerd is: 'Soziales ist... an allem Sinn zugänglich alls Problem der Gleichsinnigkeit oder Diskrepanz von Auffassungsperspektiven. ${ }^{\text {,258 }}$ De constitutie van de sociale dimensie echter, komt tot stand door de erkenning van andere "subjecten" als even oorspronkelijke bronnen van zingeving: 'Die soziale Dimension des Erlebens konstituiert sich... dadurch, daß ein Nicht-Ich als ein anderes Ich erkannt, als Träger eigener aber anderer Erlebnisse und Weltperspektiven erlebt wird. ${ }^{259}$

Voor de constitutie van de sociale dimensie - en dus ook voor de constitutie van 'objectiviteit" - is de veronderstelling van de bellevings- en duidingsvrijheid van een Alter dus essentieel. Deze, aan de ander toegemeten 'vrijheid', de veronderstelling dat zijn beleven en handelen "slechts een mogelijkheid" voorstelt en dat hij telkens ook anders zou kinnen beleven en handelen, omschrijft Luhmann in termen van een contingentie-veronderstelling. Een Ego dat een ander als een Alter-Ego beleeft en behandelt, veronderstelt echter niet alleen dat Alters belevings- en handelingsselecties contingent zijn; Ego veronderstelt bovendien dat Alter een zelfde contingentieveronderstelling jegens hem makkt! De sociale dimensie van ons beleven en handelen kenmerkt zich m. a.w. door de veronderstelling van een dubbele contingentie: ieder Ego veronderstelt dat zowel Alter als hij zelf 'vrij', niet-gedetermineerd' is in zijn selecties. ${ }^{260}$

Het is precies deze dubbele contingentie die door Luhmann als het grondprobleem van alle interactie wordt opgevat en door hem dan ook wordt aangemerkt als het ultieme referentieprobleem voor de functionele analyse van sociale systemen. Sociale systemen, zo zou men kunnen zeggen, zijn door zin bemiddelde reducties van een specifiek soort complexiteit, waarvan het bijzondere karakter is vastgelegd in het theorema van de dubbele contingentie. Praktisch gesproken gaat het om een afstemmingsprobleem: Hoe kunnen, gegeven de overmaat aan handelingsmogelijkheden, geordende interactieprocessen ontstaan, wanneer een Ego de reacties van een Alter niet door zijn eigen handelingen kan determineren, noch 'in het hoofd" van de ander kan kijken om te zien of deze op een gewenste wijze zal gaan reageren én deze onvoorspelbaar-

258. N. Luhmann, Soziale Systeme, Frankfurt/M. 1985, p.153.

259. N. Luhmann, 'Sinn als Grundbegriff der Soziologie', in: J.Habermas/N.Luhmann, Theorie der Gesellschaft oder Sazialtechnologie, Frankfurt 1975, p. 51 .

Verg. ook N. Luhmann, 'Interaktion; Organisation, Gesellschaft' en idem, 'Einfache Sozialsys-

260. In een formulering uit begin jaren zeventiglarustg $I_{s}$ Opladen 1975.

Erleben und Handeln ist darin doppelt kontingent het: "Alles auf andere Menschen bezogene. anderen Menschen abhängt, den ich als alter ent, daß es nicht nur von mir, sonidern auch vom wie mich selbst begreifen muB." "Sinn alter ego, das heilit als ebensofrei und ebenso launisch 'Soziologie als Theorie sozialer Systeme", in: Sazibegriff., op cit., p. 62-63. Verg aok (oorspr. 1970), pp. 120 e.v.) 
heid/onzekerheid zowel voor Ego als Alter geldt. Bekijken we de zaak iets formeler, dan gaat het om een dubbele selectiviteit met een circulair karakter: Ego wil zijn keuze laten afhangen van Alters mogelijke selecties en Alter wil zijn selectie laten afhangen van Ego's mogelijke selecties, terwijl beiden dit beseffen. Het probleem van deze vicieuze cirkel wordt met de term "contingentie' door Luhmann nog eens onderstreept, daar 'contingentie' in zijn vocabulaire ook altijd aan het risico van iedere selectie refereert. Socialiteit, zou men op paradoxale wijze kunnen formuleren, constitueert zich via de creatie van+ een dubbel risico, dat alle socialiteit van meet af aan dreigt te frustreren.

In het vervolg van dit hoofdstuk zullen we nagaan, op welke wijze sociale systemen dit 'dubbele contingentie'-probleem 'afbouwen', of in ieder geval dempen, om in het volgende hoofdstuk via enkele meer specifieke thema's en problemen een aantal bijzondere kenmerken en consequenties van Luhmanns oplossing voor het voetlicht te halen. Het loont echter de moeite, om eerst nog eens preciezer naar zowel de inhoudelijke als formele kanten van het "dubbele contingentie'-probleem te kijken. Niet alleen omdat we mogen verwachten, dat de structuren en mechanismen die sociale systemen kenmerken, tot op zekere hoogte dit omvattende referentieprobleem weerspiegelen; voor Luhmann geldt bovendien, dat de vraag die met het theorema van de dubbele contingentie op tafel ligt, namelijk hoe sociale orde aberhaupt mogelijk is van constitutieve betekenis is voor de sociologie als zodanig. Sociologie is als wetenschappelijke discipline 'Sozialtheorie", zo schrijtt hij, 'nicht weil das Wort 'sozial' in seinem semantischen Gehalt begrenzt ist und dieser Gehalt mit mehr oder weniger großer Unscharfe angegeben werden kann; sonder weil sie Sachverhalte auf ein Problem, nämlich auf die ungesicherte Möglichkeit von Sozialität uberhaupt bezieht'. ${ }^{261}$

\section{$\S 2$. Dubbele Contingentie}

Wie binnen een wat ruimer bestek aan 'dubbele contingentie' denkt, moet natuurlijk onwillekeurig aan Talcott Parsons denken - en vervolgens atan Thomas Hobbes en diens schildering van de natuurtoestand als een (onvermijdelijke) oorlog vàn allen tegen allen. Aan welke kritiek Parsons' sociologisch werk ook heeft bloot gestaan, zijn herformulering van 'the Hobbesian problem of order' in termen van een 'dubbele contingentie'-problematiek, vormt, om met Alan Dawe te spreken, "one of the discipline's few orthodoxies". Al in zijn eerste grote werk, The Structure of Social Action (1937), besteedt Parsons uitvoerig aandacht aan de vraag hoe een stabiele sociale orde kan ontstaan. Dicht bij Hobbes blijvend, maar tegelijkertijd gemotiveerd door een onvrede met utilitaristische maatschappijvoorstellingen, voert Parsons hier het uitgangspro-

261. N. Luhmann, Gesellschaftsstruktur and Semantik Bd. 2, Frankfurt/M. 1993, p. 195. 
bleem nog terug op een 'randomness of ends', op het chaotisch-toevallige karakter wan de doelen die door de verschillende actoren worden nagestreefd: ${ }^{262}$ Wordt het ordeprobleem echter gepercipieerd in termen van een problematische

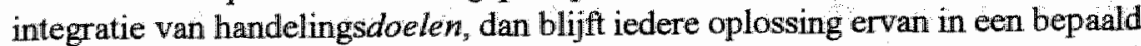
opzicht 'extern'. Wat langs deze weg namelijk uit het beeld verdwijnt, is Ego's anticipatie op de innerlijke overwegingen en subjectieve drijfveren van Alter als een moment van de handelingsbepaling. Alter blijft 'object', wordt niet een echt Alter-Ego. Men zou dit ook zo kunnen formuleren, dat met de karakterisering van het ordeprobleem in termen van een 'randomness of ends', een reflectie op de 'binnenstructuur' van interactie vrijwel onvermijdelijk de pas wordt afgesneden. ${ }^{263}$ De klassiek geworden formuleringen die Parsons later in The Social System en in het, samen met Edward Shills geschreven, Toward a General Theory of Action (beide uit 1951) aan het "sociale orde"-probleem wijdt, vormen op zijn minst in die zin een doorbraak, dat niet meer "randomness of ends', maar 'randomness of expectations' als de kem van het probleem wordt aangemerkt. Het gaat nu niet langer meer om de integratie van handelingsdoelen, maar om de onderlinge afstemming van de verwachtingen die de actoren t.o.v. elkaar koesteren. Daarmee verdiept Parsons niet alleen zijn oorspronkelijke kritiek op het utilitarisme ${ }^{264}$, maar baant hij zich tevens een weg naar de intentionele binnenstructuur van sociale interactie. Alter, voorheen slechts toerekeningspunt van klaarblijkelijke verlangens en handelingsdoelen, wordt een Alter Ego dat zich in de bepaling van zijn handelingen laat leiden door verwachtingen, i.h.b. door de verwachtingen die hij to:v. andere actoren koestert. Voor Parsons vormt dat in het vervolg een wezenlijk kenmerk van sociale interactie, in onderscheid met bijwoorbeeld de instrumentele manipulatie van fysische of biologische objecten: 'It is the fact that expectations operate on both sides of the relation between a given actor and the object of his orientation which distinguishes social interaction from orientation to nonsocial objects. ${ }^{3265}$ Daarmee is natuurlijk geen 'oplossing' gegeven voor het Hobbesiaanse ordeprobleem, maar well een richting wijzende herformulering ervan. Parsons gaat er mamelijk vamuit, dat potentiële deelnemers slechts tot sociale interactie worden gemotiveerd door het uitzicht op een positieve, d.w.z. gewenste reactie van

262. Verg. T. Parsons, The Structure of Social Action, New York 1949 (2e dr.), p. 90 e.v,

263. Verg. Habermas" "Parsons-kritiek" in: J. Habermas, Theorie des kommunikativen Handelns Bdl.2, Frankfurt/M 1982, p. 306 e.v.

264. Door de suggestie namelijk, dat de concrete gedaantes die de belangen en doelen van een actor aunnemen, precies met betrekking tot hun concreetheid worden bemiddeld door de sociale context waarin ze een rol spolen. De constitutio van de concreet-situatieve belangenconstellaties van een individuele actor vooronderstelt situatie-overstijgende, gegeneraliseerde handelingsoriërntaties in de vorm van intersubjectief geldende normen en evaluatieve criteria. (Verg: R. Munch, 'From Pure Methodological Individualism to Poor Sociological Utilitarianism", in: Canciam Journal of Sociology, 8 (1983), p.45 - 77.)

265. T. Parsons/E. Shills (ed.), Toward a General Theary of Action, New York 1962 (oorspr. Harvard 1951), p.1.5. 
Alter. Om nu van Alter een gewenste reactie te krijgen, moet Ego kunnen inschatten, welke betekenis een bepaalde handeling van zijn kant voor Alter heeft. Ego moet m.a.w. kunnen verwachten welke verwachtingen Alter omtrent het (wenselijk) gedrag van Ego koestert en welke handelingen Alter vanuit die optiek bereid is positief te sanctioneren met een handeling overeenkomstig Ego's wensen. En natuurlijk geldt deze handelingsvoorwaarde: het kunnen "verwachten van verwachtingen' - - in interactiesituaties wederzijds. Dat is wat Parsons vanaf het begin van de jaren vijftig voor de zakelijke structuur van het "dubbele contingentie'-probleem houdt:

"There is double contingency inherent in interaction. On the one hand ego's gratifications are contingent on his selections among available alternatives. But in turn, alter's reaction will be contingent on ego's selection and will result from a complementary reaction on alter's part. ${ }^{.265}$

En elders heet het:

'[S]ince the outcome of ego's action (e.g. succes in the attainment of a goal) is contingent on Alter's reaction to what ego does, ego becomes oriented... to what ego interprets to be alter's expectations relative to ego's behavior, since ego expects that alter's expectations will influence alters behavior... [T] his orientation to the expectations of the other is reciprocal or complementary. ${ }^{267}$

Tegelijkertijd is dit de formulering van een probleem. De vraag ligt immers voor de hand, hoe Ego en Alter dat eigenlijk kunnen - 'elkaars verwachtingen verwachten" - als we er vanuit gaan, dat geen van beiden in staat is gedachten te lezen. Kunnen ze dat niet, dan rijst niet alleen de vraag hoe interactie nog kan slagen, maar tenslotte ook wat de potentièle deelnemers daartoe nog kan bewegen. Als Ego niet kan weten of zijn handelingen positief dan wel negatief gesanctioneerd zullen worden, is het aangaan van interacties in feite een hachelijke zaak. Acute, onbemiddelde dubbele contingentie leidt tot een onzekerheid die, volgens Parsons, de wil tot het aangaan van interacties bij voorbaat dreigt te frustreren.

In Toward a General Theory of Action benaderen Parsons en Shills dit 'oerprobleem' van sociale orde vanuit de (transcendentale) vraag, wat er minimaal gegeven moet zijn, willen wederzijdse verwachtingen zich kunnen stabiliseren. Hun uitgangspunt is, dat een Ego en een Alter elkaars reacties over een langere periode alleen dan trefzeker kunnen anticiperen, wanneer Alters handelingsmo- 
gelijkheden in verschillende interactie-situaties 'dezelfde blijven'. Voor een Ego wil 'dezelfde blijven' zeggen, dat ze voor hem een zelfde betekenis houden, met als witeindelijke referent de positieve/negatieve sancties die Alters handelingen voor Ego inhouden. Een dergelijke constantheid van betekenis komt in feite neer op generalisering: De handeling of geste verkrijgt een boven de bijzondere, konkrete handelingssituatie telkens uit verwijzende symboolfunctie. Langs die weg ontstaat een voor Ego en Alter binnen meerdere contexten bruikbare tekentaal - "a common culture... through which their interaction is mediated ${ }^{2}{ }^{263}$ Een dergelijke gemeenschappelijke cultuur mag volgens Parsons en Shills echter niet uitsluitend begrepen worden als medium van informatieoverdracht. Wil Ego "begrepen" worden door Alter, wil Ego de juiste reacties kunnen uitlokken, dan moet hij zich houden aan de gegroeide conventies m.b.t. het gebruik van symbolen. De oplossing van het ordeprobleem in termen van een cultureel bemiddelde reciprociteit van verwachtingen impliceert m.a.w. een normering van het gedrag van de betrokkenen - Ego en Alter moeten zich 'ge-eigend' gedragen:

'It will... be a condition of stabilisation of such a system of complementary expectations not only that ego and alter should communicate, but that they should react appropriately to each other's action. A tendency toward consistent appropriateness of reaction is also a tendency toward conformity with a normative pattern. The culture is not only a set of symbols of communication but $a$ set of norms for Action. ${ }^{269}$

Laten we terugkeren naar Luhmann en wel naar diens opmerking dat de bij Parsons 'vorliegende Theoriegewinn nicht leichtfertig verspielt werden [darf]' ${ }^{270}$ Luhmanns lofprijzing is echter van korte duur. De herformulering van het Hobbesiaanse ordeprobleem in termen van een 'dubbele contingentie"problematiek mag dan een aanwinst zijn, met zijn 'oplossing' valt Parsons daarentegen terug in een 'traditionellen Theorieansatz':271 In feite is Luhmanns kritiek opgebouwd uit verschillende elementen en 'lagen', die onderling een bepaalde samenhang vertonen - en het is interessant om te zien hoe dit tegelijkertijd een articulatie van Luhmanns eigen opvattingen m.b.t. 'dubbele contingentie' inhoudt.

Luhmann bekritiseert, om te beginnen, Parsons" voorstel om de oplossing van het dubbele contingentie-probleem in een "shared symbolic system" te zoeken. Een dergelijk gemeenschappelijk systeem van symbolen is als 'oplossing" 
slechts werkzaam, zo zagen we, voorzover het tegelijkertijd een normen- en waardenconsensus voorstelt. Daarmee plaatst Parsons de oplossing van het sociale ordeprobleem niet alleen in het culturele erfgoed, dus in het verleden, maar bovendien bindt hij daarmee alle verdergaande sociale structuurontwikkeling aan de gegeven culturele codes en waarden. 'Man mag dann', zo becommentarieert Luhmann, 'soziokzalturelle Evolution immer noch als deviante Sozialisation begreifen, aber im Prinzip ist die Konstitution sozialer Systeme an einem immer schon vorhandenen kulturellen Code gebunden, obwohl sie auch dessen Entstehung und Funktion zu erklären hä̈tte". ${ }^{272}$

Dat lijkt veel op de inmiddels wat afgezaagde kritiek die Parsons voortdurend te horen heeft gekregen. (Verg. Hoofdstuk I, \& 3.) Maar het gaat Lulmmann in feite om iets anders. Ten eerste signaleert het 'wegwerken' van het 'dubbele contingentie'-probleem, naar een niet meer traceerbaar verleden, de zuiver negatieve betekenis die dubbele contingentie voor Parsons heeft. Dubbele contingentie betreft bij Parsons weliswaar een mogelijkheidsvoorwaarde van het handelen - in die zin heeft het een transcendentale status - , maar dan uitsluitend in de vorm van een negatieve probleemstelling: het is dat, wat in en door socialiteit 'altijd al' is opgelost. Dubbele contingentie staat in die zin bij hem gelijk aan non-socialiteit. Nu gaat ook Luhmann er vamuit, dat acute, onbemiddelde dubbele contingentie een soort conceptuele 'limiet' voorstelt, die, praktisch gesproken, met iedere confrontatie tussen twee actoren altijd al is doorbroken. Dubbele contingentie heeft bij Luhmann echter ook een positieve betekenis. Het is, zoals we verderop nog zullen zien, een constitutief moment van socialiteit, dat in en met iedere interactie ook weer gereproduceerd dient te worden. Het is bovendien een onophefbaar aspect van sociale interactie, gegeven het feit dat het daarin altijd gaat om een confrontatie tussen (minstens twee) zelfreferentiële, zinverwerkende systemen.

Wat Luhmann bovendien stoort, is, dat Parsons de oplossing van het dubbele contingentie-probleem zuiver en alleen in 'conformiteit' en 'consensus' zoekt, dus in de sociale dimensie. Waarom, zo vraagt Luhmann zich af, zou het probleem niet ook met behulp van tijd kunnen worden opgelost'? Alter doet gewoon iets en wacht af wat er van komt, hoe Ego er op zal reageren: 'Jeder darauf folgende Schritt ist dann im Lichte dieses Anfangs eine Handlung mit kontingenzreduzierendem Effekt - sei es nun positiv oder negativ. ${ }^{277}$ Bovendien heeft dubbelle contingentie ook een zakelijke dimensie - het heeft ook betrekking op vragen als: waar gaat het in deze situatie voor mij en de ander $\mathrm{om}_{\text {, wat }}$ is de gemeenschappelijk context waarbinnen gehandeld moet worden, wat zijn eigenlijk mijn belangen, etc. ${ }^{274}$

Wanneer je beide punten bij elkaar optelt, d.w.z. de negatieve inschatting van

272. Idem, p. 150 .

273. Idem.

274. Verg. U. Schimank, 'Gesellschaftliche Teillsysteme als Akteurfiktionen', in: K.Z.f.S.S., vol. 40 (1988,3), p.642 e.v. 
dubbele contingentie plus de eenzijdige focus op conformiteit en consensus, dan begint het er op te lijken, dat sociale orde bij Parsons identiek is met de eliminatie van het niet-aangepaste, dat klaarblijkelijk als sociaal schadelijk, als antisociaal wordt beschouwd. Dat lijkt Luhmamn een voorbarige aanname, vooral ook gezien de ervaring, dat conflicten zich dikwijls tot buitengewoon stabiele, zo niet 'over-stabiele' interactiesystemen verharden:

'Genugt es, soziale Ordnung als Boykottierung des Boykottierens zu begreifen, oder muls man nicht zu allererst wissen, wie sie" uberhaupt möglich und hinreichend wahrscheinlich ist?'275

Het problematische karakter van Parsons" oplossing van het dubbele contingentie-probleem hangt samen, zo verdiept Luhmann in een volgende stap zijn kritiek, met de manier waarop Parsons 'contingentie' definieert. ${ }^{276}$ In de grond van de zaak betekent 'contingent' bij Parsons 'afhankelijk'. Als het dáá om gaat, om "wederzijdse afhankelijkheid", dan ligt een oplossing in de lijn van wederzijdse gebondenheid, van conformiteit, van een internalisering van gemeenschappelijke waardenstelsels, inderdaad voor de hand. In aansluiting op zijn zintheorie opteert Luhmann daarentegen voor een modaaltheoretische interpretatie van 'contingentie". 'Contingent' betekent dan: niet-noodzakelijk én niet-onmogelijk - 'Der Begriff bezeichnet mithin Gegebenes (Erfahrenes, Erwartetes, Gedachtes, Phantasiertes) im Hinblick auf mögliches Anderssein; er bezeichnet Gegenstände im Horizont möglicher Abwandlungen. .277

Een handeling is voor Luhmann dus niet 'contingent' door zijn afhankelijkheid van een andere actor, maar omdat een handeling als zodanig al een zinmatige selectie voorstelt uit een geheel van andere mogelijkheden, hetgeen met de zin van een handeling als het ware wordt 'mee-gerepresenteerd'. Mutatis mutandis geldt voor het dubbel contingente karakter van sociale situaties eveneens, dat dit niet voortkomt uit een wederzijdse afhankelijkheid, maar het effect is van een confrontatie tussen autonome zinsystemen - "auch dann, wenn dadurch Abhängigkeiten erst geschaffen werden, und auch dann wenn dadurch Abhängigkeiten gerade vermieden werden sollen". 278

Wie van een modaaltheoretisch begrip van 'dubbele contingentie' uitgaat en tot zich door laat dringen dat het dubbel contingente karakter van sociale situaties resulteert uit de ontmoeting tussen (minstens twee) zelfreferentieel opererende zin-systemen, die moet, volgens Luhmann, tot de conclusie komen, dat niet alleen Parsons', maar alle 'oplossingen' van het probleem in termen van reciprociteit en wederzijdsheid uiteindelijk inadequat, want 'onder-complex'

275. Soziale Systeme, op.cit, p. 165 .

276. Verg. N. Luhmam, Soziologische Aufklärung 3, Opladen 1981, p.13.

277. Soziale Systeme, op. cit. p. 152.

278. Soziologische Anfflarung 3, op.cit, p.14. 
zijn. ledere poging om "socialiteit' (i.e. 'overwonnen' dubbele contingentie) op een basaal niveau te karakteriseren als een soort 'wederzijdsheid', leidt onherroepelijk tot een duiding van socialiteit als een betrekking tussen individuen die haar eenheid heeft in de vorm van een 'symmetrische Verklammerung des Verschiedenen". Dergelijke symmetrie-voorstellingen onderschatten, volgens Luhmann, systematisch de complexiteit van een interactie tussen zelfreferentieel gesloten en in die zin autonome (psychische) systemen. Het betreft tenslotte een betrekking tussen systemen die én voor elkaar ondoorzichtig blijven, voor elkaar 'black-boxes' voorstellen, én alle belevings- en handelingsselectiviteit zelf moeten opbrengen - welke 'trucs' ze vervolgens ook toepassen om zichzelf van die selectielast en -verantwoordlelijkheid vrij te pleiten. Nog anders geformuleerd: het gaat om een betrekking tussen minstens twee complexiteit reducerende zinsystemen die elkaars complexiteitsreducties slechts als 'informatie" kunnen behandelen en verwerken op grond van hun eigen, telkens contingente zinstructuren. Voor Luhmann wordt het dan ook 'fragwurdig wie man uberhaupt noch die Einheit einer Beziehung denken kann, die eine Mehrheit selbstreferentieller Systeme liiert. ${ }^{279}$

In dit licht sneuvelen tenslotte ook alle 'spiegel'-metaforen. Het beeld wordt te vaak gebroken om uit de weerspiegeling nog iets af te kunnen leiden. Dat is voor Luhmann ook de reden voor het échec van het Symbolisch Interactionisme van George Herbert Mead en van aanverwante stromingen die de 'spiegeling aan de ander ${ }^{3}$ als een constitutieve factor in de ontwikkeling van een interactieve orde beschouwen. Meer specifiek luidt Luhmanns (deels onterechte) kritiek op Mead, dat deze, met zijn model van een Ego dat zich, in zichzelf, aan een Alter Ego spiegelt, weliswaar dubbele contingentie binnen een Ego situeert, maar daarbij buiten beeld laat, wat aan de andere zijde gebeurt, alsof Alters ervaring van dubbele contingentie de zaak niet nog eens extra compliceert ${ }^{280}$ Het Symbolisch Interactionisme "behandelt sozusagen nur die halbierte doppelte Kontingenz und bleibt damit Handlungstheorie' ${ }^{281}$ Het probleem is nu juist, aldus Luhmann, dat dubbele contingentie zich aan beide zijden voordoet en wel zonder de garantie dat dit voor Ego en Alter hetzelfde impliceert. ${ }^{282}$ Wat deson-

279. Soziale Systeme, op cit., p. 154.

280. Wel beschouwd, had Luhmann zijn pilen beter op fenomenologisch geînspireerde vormen van interactionisme kunnen richten, op Schutz, of op Garfinkel, dan op Mead en het van hem uitgaande Symbolisch Interaktionisme. Het voor Mead centrale idee van een dialogische interactie impliceert juist wel dat er aan beide zijden onbepaaldheid wordt ervaren. Verg in deze ook: H. Haferkamp, "Autopoietisches soziales System oder konstruktives soziales Handeln?", in: H. Haferkamp/M. Schmid (Hg.), Sinw, Kommunikation wnd soziale Differenzierung, Frankfurt/M. 1987 , p.68; G. de Vries, Sociale orde, regels en de saciologie, Meppell 1977, i.h.b. Hist. 2 en 3.

281. Soziale Systeme, op cit.s, p.154.

282. Zie oak Parsons opmerking 'that each actor is both acting agent and object of orientation both to himself and to others'. (Art. 'Interaction: Social Interaction', Int Encych of the Soc. $S_{c}$, Bd.7, New York 1968, p. 436.) 
danks aan 'afgestemd handelen', aan 'selektive Akkordierungen' ontstaat, kan niet meer handelingstheoretisch worden gereconstrueerd; althans niet zolang we daaronder de poging verstaan om, hoe dan ook, de structurele kenmerken van een gerealiseerde orde terug te voeren op de motieven en handelingsintenties van de betrokkenen. Daarvoor is de zaak van meet af aan te complex - 'overcomplex' - gegeven de informatieverwerkings- en selectiecapaciteiten van de deelnemende systemen. We moeten, volgens Luhmann, dan ook afzien van jede substanzialisierte Auffassung von Individuen oder Akteuren, die als Träger bestimmter Eigenschaften die Bildung sozialer Systeme ermöglichen" ${ }^{283} \mathrm{De}$ orde die ondanks en dankzij het dubbel contingente karakter van interactieve ontmoetingen bestaat, moet een emergente orde zijn, een realiteit 'sui generis', zoals Durkheim zou zeggen, die als 'sociaal systeem' zichzelf structureert.

Met dit laatste - de zelfstructurering van sociale systemen - belanden we al bij het thema van de volgende paragrafen. Laten we echter nog eenmaal terugkeren naar Luhmanns opmerking, dat er voorzichtig moet worden omgesprongen met de door Parsons geboekte 'Theoriegewinn'. Want het is zo langzamerhand de vraag geworden, waaruit die theoretische winst nog bestaat. Volgen we Luhmann, dan bestaat het belang van Parsons' voorzet eigenlijk alleen nog daarin, dat deze met zijn formulering van het dubbele contingentieprobleem er de aandacht op heeft gevestigd, dat aan alle sociale interactie een 'reine, nicht weiter elaborierte Zirkel selbstreferentieller Bestimmung' ten grondslag ligt. ${ }^{284}$ Deze circulariteit bestaat daarin, dat een Ego, ter wille van zijn eigen handelingskeuze, op zijn minst een idee moet hebben van Alters mogelijke reacties en vice versa. Sociale processen, zo zou men ook kunnen zeggen, bouwen zich op middels een 'mutualistische' vorm van zelfreferentie, middels het in elkaar grijpen van een tweetal zelfreferenties: een sociale handeling X verkrijgt haar identiteit in en door een zelfreferentie die zich met informatie 'oplaadt' door een referentie aan handeling $Y$ in te bouwen, terwijl hetzelfde voor handeling $\mathrm{Y}$ geldt. Handelingen $\mathrm{X}$ en $\mathrm{Y}$ controleren zichzelf aan elkaar, 'tappen' elkaar als het ware af ten behoeve van hun eigen bepaling. Dit vormt een probleem, wanneer we ons een 'nul-situatie' trachten voor te stellen, d.w.z. een situatie waarin een Ego en een Alter geen enkele informatie hebben over elkaars perspectieven en handelingsmogelijkheden, het zij dan dat ze elkaar iedere handelingsmogelijkheid toevertrouwen. Acuut wordt dan het probleem dat Ego, om zijn gedrag te kunnen bepalen, moet weten hoe Alter beslist, terwijl Ego weet dat Alter slechts kan beslissen als Alter weet hoe Ego beslist. "Soziale Situationen sind daher zunächst charakterisiert durch zirkuläre Unfähigkeit zur Selbstbestimmung. ${ }^{285}$

283. Soziale Systeme, op.cit, p.155.

284. Idem, p. 149.

285. N. Luhmann, Soziologische Aufklörung 3, op.cit., p. 13. 
Luhmann wijst er telkens weer op, dat het wederzijdse karakter van deze zelfreferentie, die door het theorema van de dubbele contingentie wordt gearticuleerd in termen van een circulariteitsprobleem, ook inherent is aan interactieprocessen die we gewoonlijk "conflicten' noemen, aan de sociale strubbelingen die betrekking hebben op ontvoogding, op emancipatie uit afhankelijkheid, op verzet tegen de heersende normen- en waardenstelsels, etc. Ook 'tegenspraak' moet gecommuniceerd worden, d.w.z. in een actie/reactie-keten worden opgenomen om uberhaupt een tegenspraak te kunnen zijn. De basale circulariteit van sociale interactie laat m.a.w. de keuze voor consensus, dan wel dissensus principieel open - en ook voor dissensus geldt, dat die pas kan 'lukken', wanneer de directe zelfreferentialiteit, de steriele symmetrie van acute dubbele contingentie wordt doorbroken. Je kunt, wat Luhmann betreft, de circulaire structuur die aan sociale situaties inherent is dan ook op verschillende manieren beschrijven. Bijvoorbeeld als: "ik doe wat jij will, als jij doet wat ik wil'. Maar ook in een negatieve vorm: 'ik laat mijn gedrag niet door jou bepalen, als jij jouw gedrag niet door mij laat bepalen'.

Van belang bij dit alles is, volgens Luhmann, het inzicht dat deze basale circulariteit, dit in elkaar grijpen van een tweetal zelfreferenties telkens een nieuwe eenheid voorstelt, die als zodanig niet op één van beide deelnemers kan worden herleid. Natuurlijk kan Ego zich in het bijzonder van deze circulariteit bewust zijn en het ook concreet als een probleem ervaren; voorondersteld wordt echter steeds, dat ook Alter dubbele contingentie ervaart. Nu mag die veronderstelling zelf op een misverstand berusten - Alter heeft Ego in feite nog helemaal niet opgemerkt - - van belang is, dat die vooronderstelling gemaakt wordt, dat Ego Alters gedrag hoe dan ook observeert als een "sociale' handeling. De veronderstelling van een wederzijdse 'dubbele contingentie-ervaring' is, volgens Luhmann, als veronderstelling al werkzaam. Daarmee wordt de interactieve situatie namelijk gedefinieerd op een manier, die de 'oplossing' van het probleem van de handelingscoördinatie als het ware all in zich draagt. Of zoals Luhmann het formuleer:

'Als doppelte Kontingenz gewinnt der selbstreferentielle Zirkel sozialer Situationen eine Form, die zugleich dafür sorgt, daß die Unbestimmbarkeit in Bestimmbarkeit uberfuhrt wird; daß3 die leerlaufende reziproke Interdependenz unterbrochen wird und daß nahezu jeder Zufall als Interdependenzunterbrecher in Anspruch genommen werden kann: ${ }^{286}$

Dit 'Wonder van Bielefeld' behoeft natuurlijk enige toelichting. Om te beginnen zij er aan herinnerd, dat het menselijk gedrag voor Luhmann niet 'van nature' contingent is - een biochemicus zou daar anders over kunnen denken - en dat 
ook de interactie tussen twee, zich "gedragende' systemen niet per se "dubbel contingent" is. Het dubbele contingentie-fenomeen komt daaruit voort, dat een zinsysteem een ander systeem observeert als een autonome, niet door externe factoren gedetermineerde bron van zingeving. Het gaat, anders geformuleerd, om een attributie, een toekenning van contingentie/niet-gedetermineerdheid/'vrijheid' aan 'de ander'. Nu is er in laatste instantie niets, dat Ego tot deze attributie dwingt; Ego is even 'vrij' om anders te observeren, een ontmoeting met een Alter niet als 'dubbel contingent' te definiëren - wat natuurlijk niet kan verhinderen dat Alter de situatie wel zo wenst op te vatten. Hoe dan ook, en wat de anleiding daarvoor ook moge zijn -, als het wel gebeurt, als de interactieve situatie door een Ego gedefinieerd wordt in termen van dubbele contingentie, dan ontstaat een typische 'take-off'-situatie, een "state of conditional readiness' (Mackay). Alles wat er in een dergelijke situatie gebeurt; ledere gedraging, uiting, of geste, wordt dan namelijk als contingente selectie informatief. Precies omdat de ander wordt beleefd en behandeld als nietgedetermineerd, krijgen zijn gedragingen het karakter van selecties uit meerdere mogelijkheden; precies omdat de ander niet-voorspelbaar is, wordt alles wat hij doet informatief. 'Dubbele contingentie', zo zou men kunnen zeggen, fungeert in de ogen van Luhmann als een situatieduiding, die de selectiviteit van een gebeurtenis naar voren haalt en dit als aanknopingspunt voor de opbouw van (verwachtings)structuren. ${ }^{287}$ Nog anders geformuleerd: geobserveerd als 'dubbele contingentie' verkrijgt de zelfreferentiële cirkel, die sociale situaties kenmerkt, een vorm die het hoogst waarschijnlijk maakt, dat het onwaarschijnlijke gebeurt, namelijk dat de zuivere symmetrie wordt geasymmetriseerd, dat de pure onbepaalbaarheid van het handelen een zekere bepaaldheid verkrijgt. 'Alles', dus ook wat een deelnemer per vergissing doet, ook wat hij helemaal niet bedoelde als 'doen', verschijnt in het licht van dubbele contingentie als een informationeel relevante selectie, als mogelijk aanknopingspunt voor de opbouw van een ordenende structuur. WWat er ook gebeurt...' - dat is wat Luhmann op het oog heeft wanneer hij in het bovenstaande citaat opmerkt, 'daß nahezu jeder Zufall als Interdependenzunterbrecher in Anspruch genommen werden kann'. In een verwante formulering:

"Was Kontingenzerfahrung leistet, ist mithin die Konstitution und Enschließung von Zufall für konditionierende Funktionen im System, also die Transformation von Zufallen in Strukturaufbauwahrscheinlichkeiten. Alles weitere ist eine Frage der Selektion dessen, was sich bewährt und was für weiteres verwendbar ist. ${ }^{2288}$

287. Verg. idem, p.14.

288. Sioziale Systeme, op.eit., p. 170-171 
Dubbele contingentie als een vorm van onbepaaldheid, van complexiteit die er naar tendeert zichzelf op te lossen! Als we dan bedenken, dat Luhmann er wanuit gat dat dubbele contingentie een onvermijdelijk effect is van de poging van (minstens twee) psychische systemen met elkaar in contact te treden en dat dus alle sociale interacties, niettegenstaande hun geordendheid, het dubbel contingente grondkarakter wan socialiteit ook altijd reproduceren of regenereren, dan wordt tevens duidelijk wat we bedoelden, toen we eerder opmerkten, dat 'dubbele contingentie' bij Luhmann niet alleen een probleem, maar ook een positief moment van socialiteit voorstelt. Sociale interacties, oftewel.: sociale systemen, regenereren voortdurend dubbele contingentie als prikkel voor hun eigen structuuropbouw. Luhmann spreekt in deze van 'auto-katalyse" en van dubbele contingentie als 'auto-katalysator' van saciale systemen:

'Das Problem doppelter Kontingenz hat mithin Eigenschaften eines autokatalytischen Faktors: Es ermöglicht, ohne selbst 'verbraucht' zu werden, den Aufbau von Strukturen auf einer neuen Ordnungsebene, die durch jene Perspektive auf Perspektiven reguliert wird. Dabei ist, deshalb kann man von 'Auto'-katalyse sprechen, das problem der doppelten Kontingenz selbst Bestandteil des Systems, das sich bildet. ${ }^{289}$

En elders heet het:

'Doppelte Kontingenz ist dasjenige Problem.. dessen Aufbaufunktion gerade darin besteht, daß es nicht gelöst, nicht durch Lösung beseitigt werden kann ${ }^{\text {290 }}$

"Man staunt uber diese elegante Lösung' schrijft Max Miller, 'und kann sie dennoch einfach nicht verstehen". ${ }^{291}$ Vanuit een causaal-genetisch perspectief liggen de tegenwerpingen immers voor de hand. Hoe kan in een situatie waarin alles mogelijk is, waarin er zelfs geen onderscheid bestaat tussen waarschijnlijke en onwaarschijnlijke mogelijkheden, de (observatie van een) selectie van een specifieke mogelijkheid uberhaupt informatief zijn? Luhmann gaat er toch zelf vanuit dat informatie gearticuleerde differentie vooronderstelt! En zelfs wanneer men er vanuit gaat, dat de betrokken psychische systemen toch over relevante differentieschema's beschikken, of deze gaandeweg ontwikkelen, dan nog blijft de wraag hoe sociaal relevante differenties kunnen ontstaan, hoe zich m.a.w. uit acute dubbele contingentie sociale structuren kunnen ontwikkelen die

289. Idem, p. 170 .

290. N. Juhmann, "Interpenetration - Zum Verhältnis personaler und sozialer Systeme", in: idem, Soziologische Awfklarung 3, op.cit, p. 160.

291. M. Miller, 'Selbstreferenz, und Differenzerfahrung', in: $H$. Haferkamp/M. Schmid (Hg), op. cit, p.205. 
voor Ego én. Alter richtinggevend zijn en een onderlinge gedragsafstemming mogelijk maken. Dat veronderstelt toch op zijn minst een gemeenschappelijk perspectief op wat different is en wat niet, zij het desnoods in de vorm van een gestructureerde dissens! Zonder een of andere vorm van voorafgaande gemeenschappelijkheid, hoe minimaal ook, lijkt zich geen enkele vorm van gemeenschappelijkheid te kunnen ontwikkelen, ook niet die van het conflict. ${ }^{292}$ Deze tegenwerpingen zouden terecht zijn, wanneer het Luhmann inderdaad te doen zou zijn om de afleiding van sociale structuren uit een soort nul-situatie die we als zuivere, acute dubbele contingentie omschrijven. Maar het gaat hem in deze helemaal niet om een genetische verklaring van stabiele interactie of sociale systemen. Trouw aan zijn functionele methode probeert Lulumann inhoud te geven aan het principe van de 'ontnormalisering' van het waarschijnlijke om een overkoepelend referentieprobleem voor de theoretische analyse van sociale systemen te vinden, in het licht waarvan het onwaarschijnlijke dan als een evolutionaire waarschijnlijkheid kan worden begrepen. D.w.z: de aanname van het 'dubbele contingentie'-theorema vooronderstelt praktisch gesproken de aanname van stabiele socialiteit. (De formulering van "dubbele contingentie" als grondprobleem van de sociologie veronderstelt op zich al dat het probleem van de acute dubbele contingentie is opgelost - het veronderstelt immers op zijn minst het bestaan van een geordende maatschappij waarbinnen een wetenschapssysteem zich heeft weten te stabiliseren, dat 'sociologie' tot een van zijn disciplines rekent.) Luhmann:

'Nie treffen Personen ohne jede Voraussetzung, ohne
irgendwelche Erwartungen aufeinander, und sie konnen auch nur
an Hand von. Erwartungen Kontingenz erleben im Sinne des
'auch-anders-möglich-Seins". Aber diese Einwand bestätigt nur,
daß die Gesellschaft ein autopoietisches System ist, das sich
selbst bei seiner Reproduktion voraussetzen muß.".

Waar het Luhmann in feite om gaat, is de vraag, hoe stabiele interactieprocessen voldoende instabiliteit kunnen organiseren als voonwaarde en prikkel voor flexibiliteit en verdergaande structuurontwikkeling. Preciezer geformuleerd: Luhmann is op zoek naar een conceptueel instrumentarium met behulp waarvan een sociologisch model van zelf-instabilisering van sociale systemen kan worden opgezet, of met behulp waarvan op zijn minst kan worden geformuleerd, hoe in en door sociale interactie het "ook-anders-mogelijke" telkens wordt meegenomen, wordt gereproduceerd. En het verwarrende is, dat

292. Men herkent natuurlijk het telkens weer terugkerende probleem van Luhmanns centrale motief, namelijk het uitgangspunt te zoekem in "differentio" (van identiteit en differentie) en niet in "identiteit".

293. Soziale Systeme, op. eit, p.185. 
aan de ontwikkeling van dat model een beslissing ten grondslag ligt, die in de formulering van het 'dubbele contingentie'-theorema al doorschijnt, de beslissing namelijk om psychische systemen in de omgeving van sociale systemen te parkeren en in die zin strikt te onderscheiden tussen het psychische en sociale - dat, terwijl we weten, dat psychische en sociale systemen zich slechts in co-evolutie ontwikkelen. De voorstelling van (minstens) twee psychische systemen die zonder enige sociale bemiddeling op elkaar stuiten, i.e. de voorstelling van acute en absolute dubbele contingentie, is een fictie die, zoals we nog zullen zien, in functie staat van de sociologische conceptualisering van de emergentie van sociale systemen, als een realiteit 'sui generis'.

Geschreven uiteenzettingen gebruiken het 'na elkaar' als vorm van complexiteitsreductie. Aan die sequentiële ordening zijn, nasst alle voordelen, onvermijdelijk ook nadelen verbonden. Zo zal de aard en inzet van het 'dubbele contingentie'-probleem binnen Luhmanns sociologie pas ten volle duidelijk worden, nadat we notie hebben genomen van zijn omschrijving van de elementen en structuren van sociale systemen: Op een tweetal zaken, wil ik, ter afsluiting van deze paragraaf, echter vooruitgrijpen. Ten eerste zij gewezen op de statische schin die de keuze, om het 'dubbele contingentie'-probleem voorafgaand aan de 'positieve' reconstructie van sociale systemen te behandelen, met zich mee brengt. De indruk kan althans gewekt zijn, dat het bij 'dubbele contingentie' om een statische toestand gaat, die zich 'nu eenmaal" instelt met en door de confrontatie tussen twee psychische systemen, die vervolgens niet meer voor- of achteruit kunnen. We zullen echter nog zien, dat het Luhmann om een wezenlijk dynamische vorm van instabiliteit gaat, dat het bij dubbele contingentie om een getemporaliseerd fenomeen gaat, om een inherente eigenschap van sociale processen.

Hiermee hangt een tweede punt samen. Wat Luhmann zichzelf probeert te verschaffen met de bepaling van dubbele contingentie als "auto-katalysator" van sociale systemen, is een uitzicht op 'socialiteit' als een "freischwebend konsolidierte Realität, ein sich selbst gründendes Unternehmen'. ${ }^{294}$ De sociale orde die ondanks en dankzij het dubbele contingentieprobleem ontstat, moet telkens gedacht worden als de (zelf)articulatie of '(zelf)ontvouwing' van een circulaire grondstructurur. Als zodanig gaat het om een emergente ordening die qua ordening, d.w.z. qua selectie van selecterende structuren, "autonoom" is. Sociale systemen worden van 'onderaf' noch van 'bovenaf' gedetermineerd, zijn noch in de menselijke 'naturu' gegrond, noch gereguleerd door apriori geldende normen of waarden. De filosofische bezweringsformules 'Materie' en "Geest' zijn obsoleet geworden. ${ }^{295}$ Wat overblijft is 'processualiteit' als zodanig, is "tijd" - tijd als een medium van selectie en structuuropbouw dat weliswaar 
gebruikt, maar niet verbruikt kan worden:

'Zeit ist Asymmetrisierung von Selbtsreferenz im Hinblick auf eine Ordnung von Selektionen, und im sozialen Bereich verzeitlicht sich die doppelte Kontingenz: mit den darin spielenden Selbstreferenzen, um zu ermöglichen, daß unwahrscheinliche Ordnung so gut wie zwangsläufig entsteht, wo immer doppelte Kontingenz erfahren wird. ${ }^{2} 296$

\section{$\$ 3$ Het begrip 'communicatie': een statische analyse}

Alhoewel met 'dubbele contingentie" een typisch sociologisch grondslagenprobleem is aangesneden, hebben we er tot nog toe, zeker voorzover het Luhmann betreft, in tamelijk algemene, systeem- en informatietheoretische termen over gesproken: $\mathrm{Zo}$ beschreven we dubbele contingentie als een 'state of conditional readiness". waarin ieder toeval een aanknopingspunt kan vormen voor het zoeken naar afstemming, naar een 'match' tussen de altijd selectieve uitingen of gedragingen van minstens twee, informatieverwerkende (zin)systemen. Luhmann spreekt in dit verband over het vinden van 'selektive Akkordierungen' als 'oplossing' van acute dubbele contingentie - en de stap in een meer sociologische analyse van sociale systemen wordt' gedaan met de vraag, wat we ons bij dergelijke "Akkordierungen" moeten voorstellen. Vanuit een theoretisch gezichtspunt geformuleerd: welk begrip dient de basis-eenheid van vloeiende sociale interactie te representeren?

Gaan we bij de verschillende sociologische stromingen te raden, dan kunnen de antwoorden die op deze vraag gegeven zijn - handeling, ruil, geweld/dwang, interactie, systeem, etc. - grosso modo in een tweetal hoofdvarianten worden onderverdeeld. Enerzijds begrippen die, zoals bijvoorbeeld in de verschillende ruil- of speltheorieen, aan de gedragingen van afzonderlijke individuen refereren; anderzijds begripsstrategieen die van meet af aan op het interactionele aspect, op de aan alle socialiteit inherente 'wederzijdsheid' afsturen. Achten we de referentie aan individuele actoren nu typisch voor handelingstheorieen en identificeren we de interactionele, of trans-individuele duicling met 'communicatie', dan kunnen we (met Luhmann) de antwoorden die de sociologische traditie gegeven heeft op de vrang naar het grondbegrip van sociale interactie versimpelen tot de keuze: ofwel 'handelingen' ofwel 'communicaties'. Voor Luhmann houdt dit een serieus dilemma in, met verreikende theoretische implicaties: 


\begin{abstract}
"Wir vermuten in dieser Frage: Kommunikation oder Handlung als Letztelement, eine grundlegende Option, die den Stil der darauf aufgebauten Theorie, z.B. den Grad ihrer Abgehobenheit von Psychischem, entscheidend prägt. ${ }^{297}$
\end{abstract}

Wie zich echter herinnert, dat Luhmann het begrip 'handelen' in termen van een allocatie van selectiviteit wil begrijpen, kan vermoeden dat het pleit al bij voorbaat is beslist. Zoals we in het vorige hoofdstuk hebben gezien, spreekt Luhmann van 'handelen' (in onderscheid met "beleven') wanneer de verantwoordelijkheid voor een bepaalde interpretatie van, of omgang met de "wereld" aan een systeem wordt toegeschreven (en niet aan de omgeving). Hoe belangrijk het handelingsbegrip voor de sociologie ook mag zijn en hoe onontkoombaar in het alledaagse leven de perceptie van andermans uitingen en gedragingen als 'handelen' ook is - we komen daar nog uitgebreid op terug -, als 'aansystemen-geattribueerde-selectiviteit' kan 'handelen' niet de eenheid van de afstemming tussen meerdere, sutonoom selecterende systemen voorstellen. Als het gaat om de vraag, uit welke 'stof' sociale processen/systemen zijn opgebouwd, wat als 'oer-element' van sociale systemen fungeert, kan Luhmann, gegeven ook zijn analyse van het 'dubbele contingentie'-probleem, niet voor 'handelingen', maar nog slechts voor 'communicaties' kiezen: Sociale systemen bestaan eerst en vooral uit gebeurtenissen die we "communicaties" noemen. Waar 'bewustzijn' refereert aan de operatie-modus van psychische systemen, vormen 'communicaties' de basale operaties van een sociaal systeem: 'Der elementare, Soziales als besondere Realitat konstituierende ProzeB ist ein Kommunikationsproze $\int^{\prime}$. ${ }^{298}$

Op zichzelf beschouwd, staat bij Luhmann het begrip 'communicatie' voor de eenheid van een drietal selecties: de keuze van een informatie", de keuze deze 'mede te delen' en, aan de kant van de 'geadresseerde', de keuze om het gedrag van een ander als een mededeling te 'begrijpen', die een bepaalde informatie bevat. ${ }^{299}$ In een wat gemakkelijker formulering: Een communicatie vormt de eenheid of synthese van een mededeling ('Mitteilung'), een medegedeelde informatie ("Information') en begrip ("Verstehen").

Laat ik een nadere toelichting op deze drie componenten inleiden met te herinneren aan wat in het vorige hoofdstuk over het onderscheid tussen 'zin' en 'informatie' is opgemerkt. We zagen daar, dat alle informatieverwerking zin

297. Idem, p. 192.

298. Soziale Systeme, op.cit, p. 193.

299. Deze onschrijving van communicatie als een drie-eenheid gaat bij Luhmann in eerste instantje terug op Karl Buthtiers "Organon"-model van de taal, maar men herkent er met weinig moeite natuurlijk ook Austins (of eventueel Searles) onderscheid tussen "locutie" (Searles "propositionele inhoud"), "illocutie' en "perlocutie" in. Tegenover de belangstelling bij Bahler en Austin voor dominantie-effecten en voor de isoleerbaarbeid van de deze drie componenten in termen van afzonderlijke typen taalhandelingen, benadrakt Luhmann just hun primordiale eenheid. 
veronderstelt en dat al het zinmatig beleven en handelen ook altijd informatief is, hoe minimial ook. Het onderscheid (en de samenhang) tussen beide schuilt in het aspect "selectiviteit". ledere actualisering van zin bestaat uit het naar voren halen van wat hier en nu relevant is - "punktuelle Zugriff' - onder een gelijktijdige verwijzing naar andere mogelijkheden van beleven en handelen als horizon van het 'und-so-weiter' "Informatie' heeft betrekking op de onvermijdelijke selectiviteit van iedere actualisatie van zin, waarbij geldt dat de 'informativiteit' van de geactualiseerde selectie telkens systeemrelatief is en afhangt van de verwachtingsstructuren waarover een 'zich informerend" systeem op dat moment beschikt.

Richten we ons nu meer specifiek op 'communicatie', dan kunnen we in een eerste aanloop stellen, dat de component 'informatie' betrekking heeft op de mededelingsinhoud en wel in het licht van het geheel aan andere meedeelbare inhouden. Informatief is communicatie, zo zou men ook kunnen zeggen, qua selectiviteit van datgene wat door de actualisering van een zinselectie in een communicatie op de voorgrond geplaatst wordt ${ }^{300}$ Natuurlijk moet een zinselectie om "communicatief" te kunnen worden, om uberhaupt sociale betekenis te kunnen krijgen, nog wel worden 'medegedeeld', d.w.z. een decodeerbare gedaante aannemen. Wie een ander wil informeren moet niet alleen een voor de ander waameembaar (hoorbaar, zichtbaar, voelbaar, etc.) gedrag ten toon spreiden, maar dit gedrag bovendien gieten in standaardvormen, zich bedienen van gemeenschappelijke conventies die het voor de ander mogelijk maken het vertoonde gedrag te observeren als de selectie van specifieke diffierenties of zinschema's. Luhmann: "Codierte Ereignisse wirken im Kommunikationsprozeß als Information, nicht-codierte als Störung (Rauschen, noise). ${ }^{2.301}$

Hoewel informatie dus alleen als medegedeelde informatie een communicatief bestaan kan hebben, moet desalniettemin de component 'Mitteilung' onderscheiden worden van 'Information'. Dat kan o.a. daaraan worden afgelezen, dat bij herhaling van dezelfde mededeling de informatiewaarde van het medegedeelde afneemt. ${ }^{302}$ De 'mededeling' is niet de 'informatie', maar de herkenbare "verpakking" ervan - of beter; de mededeling is de duplicatie van de informatie in een gecodeerd medium, een 'Zweitform" zoals Luhmann het omschrijt, waaraan zich vervolgens bijzondere (bijv. perlocutieve)

300. Luhmann: 'Die Selektion, die in der Kommunikation aktualisiert wird, konstituiert uhren eigenen Horizont; sie konstituiert das, was sie wählt, schon als Selektion, nämlich alls Information. Das, was sie mitteilt, wird nicht nur ausgewailhilt, es ist selbst schon. Auswahl und wird deshalb mitgeteilt:" (Soziale Systeme, op. cit., p.1944.)

301. Soziale Systeme, op.cit, p. 197.

302. Maar natuurlijk kan het feit dat iemand zich begint te herhalen opmerkelijk zijn, een verrassende, want niet verwachte gebeurtenis vormen. Dan is het herhalingsgedrag informatief, maar niet de herhalde mededelingsinhoud. En het psychotisch raffinement van de liefde bewijst zich dan daardoor, dat hier het uitblifven vin de herthaling informatief wordt. Wie niet meer hoorbaar zwolht, moet het in ieder geval zeggen" ik hou van jou, ik hou van jou, etc. 
communicatieve functies kunnen hechten.

Zou het communicatiebegrip nu worden beperkt tot de componenten 'mededeling" en 'informatie', "communicatie' begrepen worden als een 'zweistellige Einheit', dan verzeilen we volgens Luhmann onvermijdelijk in een handelingstheoretische opvatting van communicatie. Communicatie is dan mededelingsgedrag dat "iets" meedeelt, een commumicatieproces verschijnt dan als een reeks van opeenvolgende 'mededelings'-handelingen. Nu mag dat van Luhmann, zollang we maar in de gaten houden dat dit een simplificatie voorstelt van een meer oorspronkelijke, fundamentelere verhouding. Dit inzicht dringt zich op, wanneer we ons de vraag stellen, wat überhaupt de zin van een opeenvolging van mededelingen zou zijn, waarom verschillende individuen eigenlijk moeite doen om uiting op uiting te laten volgen. Dat lijkt een vraag, waar een triviaal antwoord op kan worden gegeven: om de ander te informeren! - te informeren omtrent de gevoelens en wensen die men koestert, omtrent verwachtingen die men van de ander heef, omtrent standen van zaken in de wereld, etc. Maar dan volgt de vraag, hoe we ons dat precies moeten voorstellen - de ander/elkaar "informeren". Voor een individualistisch georienteerde handelingstheorie ligt het voor de hand om hierop antwoord te geven in de geest van het klassieke model van een informatie-overdracht tussen een "zender" en een "ontvanger'. Bij nader inzien is dat echter een onhoudbare voorstelling van zaken. In communicatie wordt althans niets 'overgedragen' in de zin van 'weggegeven', zo, alsof de 'zender' vóór de communicatie iets in zijn bezit had, dat nu het exclusief eigendom van de ontvanger is geworden. Communicatie leidt eerder tot redundantie, tot een overvloed aan "weten'. Wie hierop reageert met de tegenwerping, dat deze kritiek zich wat al te gemakkelijk richt op de beperkingen van een metafoor - de 'overdracht'-metafoor - en dat het natuurlijk $z o$ is, dat het overdragen van informatie een actieve bijdrage van de ontvanger veronderstelt, zij het in termen van decodering, zij het in termen van "Verstehen', - zo iemand speelt Luhmann precies in de kaart. Het impliceert namelijk dat yoor communicatie, opgevat als het infomeren van een ander, het 'begrijpen' aan de kant van die ander mede constitutief is; dat communicatie niet als een 'zweistellige", maar als een 'dreistellige Einheit' begrepen moet worden; als de eenheid van mededeling, informatie én begrip.

Luhmann gaat nu een stap verder. Alhoewel 'mededeling', 'informatie' en 'begrip' als 'communicatie' een onlosmakelijke eenheid vormen, dient volgens hem de analyse van deze drie-eenheid in principe uit te gaan van de component "begrijpen"/"Verstehen". ${ }^{303}$ Alle communicatie begint er volgens Luhmann namelijk mee, dat ubberhaupt 'iemand' (een informatieverwerkend systeem) een "gebeurtenis" (een gedraging/uiting) observeert als een 'tegelijkertijd' wan twee onderscheiden zaken: als "mededelingsgedrag" én als medegedeelde informatie.

303. Verg. 0.a. N. Luhmann, "Systeme verstehen Systeme", in: N.Luhmann/K.E.Schorr (Hrag.), Zwrischen Intransparanz und Verstehen, Frankfurt/M. 1986, p.94. 
'Begrijpen' is m.a.w. per definitie het observeren van Alters gedrag als de belichaming van een tweetal keuzes - voór 'mededelen' (i.p.v. 'geen mededeling doen') en voor een specifieke ('déze en niet die') informatie. Het ononderbroken geratel op een type-machine simpelweg opvatten als teken wan iets anders: de typist heeft haast - is dus nog geen begrijpen. Pas wanneer we het gehaaste getyp opvatten als een poging van de typist om zijn ijver onder de aandacht te brengen, i.e. als 'mededelingsgedrag' dat over iets specifieks wil informeren, hebben we met die bijzondere vorm van observeren te maken die we "begrijpen" noemen.

Of iets een informerende mededeling is, een 'communicatieve offerte", hangt dus in eerste instantie van het 'verstehende' systeem af, van degene die 'begrijpt" - de als 'dienstklopper' geobserveerde typist kan zich van de prins geen kwaad bewust zijn. Om terug te komen op de vorige paragraaf: het is de akt van 'Verstehen' die eerst dubbele contingentie creeert, die de situatie als 'dubbel contingent" definieert. ${ }^{304}$

$\mathrm{Nu}$ kan iemand die zich geobserveerd weet, dit onderscheid tussen mededeling en informatie overnemen en willen dat een ander zijn gedragingen inderdaad als informatieve mededelingen opvat. En natururlijk is het zo, dat wij in de alledaagse praktijk, als ervaren 'communicatoren', heel wel in stat zijn om onze uitingen als een poging tot communiceren bij de ander onder ogen te brengen. Daarvoor volstaat het al bijna om taal te gebruiken. Desalniettemin blijft voor Luhmann gelden, dat communicatie slechts op gang kan komen, wanneer de geadresseerde het gedrag van de ander inderdaad als een communicatie-aanbod wil "begrijpen", d.w.z. als een informerende mededeling. 'Die Kommunikation', zo merkt hij op, "wird sozusagen von hinten her ermöglicht, gegenläufig zum Zeitablauf des Prozesses'. ${ }^{305}$

Deze toekenning van het primaat aan de component 'Verstehen', heeft een aantal verreikende consequenties. Enkele daarvan komen al aan het licht, wanneer we stil staan bij de vraag, wat het inhoudelijk gezien betekent, 'iemands gedrag als een informerende mededeling en als medegedeelde informatie opvatten. Om met het eerste te beginnen -: het gedrag van een Alter als "mededeling' opvatten, houdt aanvankelijk niets anders in, dan het beschouwen uls een 'Selbstfestlegung' wan de ander in een situatie die in en door het 'Verstehen' tegelijkertijd als dubbel contingent wordt gedefinieerd. ${ }^{306}$ Het gedrag van Alter wordt door een 'begrijpend' Ego m.a.w: geïnterpreteerd (en benut) als een doorbreking van de onbepaalde, steriele circulariteit die aan de confrontatie tussen twee zinsystemen eigen is.

Ego vat Alters uiting bovendien op als en selectie die ter wille van zijn

304. Luhmann: 'Es ist dieser Vorgang des Sicheinlassens auf Situationen, die als Kommunikstion interpretiert werden, der Anlaß gibt zur Entstehung von 'doppelter Kontingenz', mit der dann die Autopoiesis sozialer Systeme anläuft' (Die whisserschaft der Gesellschaft, op.cit., p.19)

305. Soziale Systeme, op.cit., p.198.

306. Verg. idem, p.208. 
selectiviteit wordt medegedeeld, d.w.z. als "informatie". Een begrijpend Ego, zo zouden we kunnen zeggen, interpreteert Alters mededelingsgedrag als een (meer of minder complexe) zinselectie waarvan Ego tevens aanneemt, dat die voor Alter de context of horizon constitueert van de 'mededelenswaardigheid' van het medegedeelde. Echter, gegeven het feit dat een Ego niet 'in Alters hoofd kan kijken', dat er tussen twee zelfreferentieel gesloten psychische systemen geen uitwisseling van 'quanta' bewrustzijn kan plaats vinden, blijft Ego's poging om Alters perspectief over te nemen, diens observatieschema's en onderscheidingen te reconstrueren, in laatste instantie het karakter van een projectie, een attributie houden. Als een bijzondere vorm van observeren blijft het "inlevend verstaan" van andermans onderscheidingen en verwachtingsstructuren een operatie "binnen' het observerend systeem en dus gebonden aan Ego's eigen zin- en verwachtingsstructuren die eerst de selectiehorizon constitueren waarbinnen een gebeurtenis voor Ego uberhaupt informatief kan zijn. Informatie is en blijft altijd informatie voor het observerende systeem, voor het systeem waarvoor, om met Bateson te spreken 'the difference makes a difference:.

Dit alles heeft een tweetal belangrijke implicaties. Het betekent om te beginnen, dat Alter uiteindelijk niet kan determineren hoe Ego hem dient te begrijpen. Communicatie kan m.a.w. door Alter wel worden uitgelokt en Alter kan onder de voorwaarde van een ontwikkeld sociaal systeem bovendien zijn best doen, de communicatie in een bepaalde tichting te sturen; gegeven de autonomie van een begrijpend Ego en gegeven de, voor communicatie cruciale rol van het begrijpen", Kan Alter de communicatie echter nooit definitief onder controle krijgen. Zolang Ego' echter 'begrijpt', wordt er desalniettemin 'gecommuniceerd':

'Kommunikation liegt auch dann vor, wenn Ego die Information für unzutreffend hält, den. Wünsch, aber den sie informiert, nicht erfullen will, die Norm, auf den sie den Fall bezieht, nicht befolgen möchte. Daß Ego zwisichen Information und Mitteilung unterscheiden mu $\beta$, befahigt ihn zur Kritik und gegebenfalls zur Ablehnung. Das ândert nichts daran dal3 Kommunikation stattgefunden hat. ${ }^{3: 07}$

De roì die Luhmann aan het 'begrijpen' toekent, heeft bovendien nog een andere consequentie: Alles wat voor een Ego 'begrijpen' inhoudt, geldt als 'begrijpen', ongeacht de vraag of Alter (of een willekeurige andere observator') het eerder als een 'misverstaan', als 'onbegrip' zou willen duiden. Luhmann: "Verstehen schließ3t mehr oder weniger weitgehende Mißverständnisse als 


\section{normal ein'. ${ }^{308}$}

Allengs begint duidelijk te worden, dat de nadruk die Luhmann legt op de component "Verstehen", vooral ook een polemische strekking heeft. Al in zijn definitie en analyse van het begrip 'communicatie' probeert hij een dam op te werpen tegen iedere intentionalistische duiding van communicatie, tegen iedere duiding die er vanuit gaat, dat de inhoud en de gang van communicatieprocessen (uiteindelijk) kunnen worden teruggevoerd op wensen, motieven en opinies van de deelnemende personen ${ }^{309}$ Wat zich als "communicatie" formeert, wordt in Luhmanns perspectief immers mede geconstitueerd door de component 'begrijpen' en daarvoor geldt; a) dat ze niet wordt vastgelegd door de mededeling en b) dat ze ook dan wordt gerealiseerd, wanneer in de ogen van de mededeler het begrijpen van de ander een 'niet-begrijpen' voorstelt. "Begrijpen" is voor Luhmann nooult een duplicatie van het medegedeelde in een begrijpend bewustzijn. Het fungeert, voorzover Ego uiting geeft aan zijn begrip van het medegedeelde, binnen het communicatieproces eerst en vooral als aarknopingspunt voor verdergaande communicatie. Natuurlijk kan Alter in aansluiting op Ego's reactie 'protesteren', claimen dat hij niet goed begrepen is, etc. , maar dit weer onder de voorwaarde van communicatie, i.e. onder de voorwaarde dat ook deze informerende mededelingen 'begrepen' worden, warbij 'on-begrip' wederom niet valt uit te sluiten. Het bewustzijn trekt, om het zo uit te drukken, andere conclusies uit de communicatic, dan de communicatie. Het gebruik van taal doet hier weinig aan af. Integendeel - het feit dat Ego en Alter een gemeenschappelijk symboolsysteem benutten mag er weliswaar toe leiden, dat zij de indruk krijgen dat ze met hun woorden hetzelfde bedoelen; tegelijkertijd voorziet taal het medegedeelde echter van een immens overschot aan semantische verwijzingen, i.e. aan selectie- en interpretatiemogelijkheden, waardoor de kans op 'anders-begrijpen' dan de spreker intendeerde, alleer nog maar toeneemt. ${ }^{310}$

Dit is natuurlijk ook gericht tegen een 'intersubjectivistische", maar desalniettemin handelingstheoretische interpretatie van communicatie in de lijn van Habermas of Apel. Waar Luhmann zich telkens weer tegen afzet, is een voorstalling van communicatie als een communicatief handelen van meendere personen, dat zich in het zoeken naar afstemming en structuur bemoedigd en gedreven weet door een, weliswar 'contrafaktische', maar desalniettemin onvermijdelijke anticipatie op 'consensus', op discursief tot stand gebrachte, intersubjectieve overeenstemming. ${ }^{311}$ Volgens Luhmann is conmunicatie

308. Idem, p.196.

309. Verg N. Luhmann, 'Systeme verstehen Systeme', op.cit., p. 103.

310. Verg. W.L. Schneider, 'Hermeneutiek sozialer Systeme', in: Zeitschrift fir Sozialogre Jg.21 (Heft 6), p.422.

311. Verg. 0.a. N. Luhmann, "Was ist Kommunikation", opgenomen in: idem, Soziologische Aufklärung 6, p.118-119; idem, "Intersubjektivitatt oder Kommunikation: Unterschiedliche Ausgangspunkte soziologischer Theoriebildung", in: idem, p. 173 e.v. 
Uberhaupt niet afhankelijk van een overeenstemming inzake cognitieve of normatieve verwachtingsstructuren, noch is communicatie unt op een dergelijk 'instemmend verstaan'. Ruzies zijn ook communicaties. Communicatie leef bij hem juist van het feit dat het bewustzijnsleven wan de een niet samenvalt met dat van de ander, van intransparantie, van dubbele contingentie. Communicatie veronderstelt:

'verschiedene Situierungen, die laufend ungleiche Perspektiven und inkongruentes Wissen reproduzieren. Diesen Voraussetzungen entspricht, daß Kommunikation nicht als systemintegrierende Leistung, nicht als Herstellung von Konsens begriffen werden kann. Das würde nämlich heißen: daß sie ihre eigenen Voraussetzungen untergräbt und sich nur durch hinreichenden Milßerfolg am Leben halten kann. ${ }^{3 / 2}$

We zullen in een volgende paragraaf nog terugkomen op de, in theorievergelijkend opzicht polemische strekking van Luhmanns communicatietheorie. Ter afsluiting van deze paragraaf zij nog slechts gewezen op een ander opvallend kenmerk van Luhmamns communicatie-begrip, namelijk dat 'communicatie' door hem gedefinieerd wordt zonder (de gesproken/geschreven) 'taal' er bij te betrekken. Luhmann gaat er vanuit, dat communicatie, als een door zin bemiddeld processeren van informatie, nog aan taal vooraf gaat, zowel logisch gezien, als genetisch: Communicatie is (en blijft) ook zonder taal mogelijk - "etwa durch ein Lächeln, durch fragende Blicke, durch Kleidung; durch Abwesenheit und ganz allgemein und typisch durch Abweichen von Erwartungen, deren Bekanntsein man unterstellen kann [-], wenn es Ego gelingt, eine Differenz von Information und Mitteilung geleichwohl zu beobachten'. 313

Het wordt zo langzamerhand echter voorspelbaar - ook theoretici scheppen verwachtingsstructuren - dat na een dergelijke afwijzing van het 'sprachphilosophisch' verlangen naar het primaat van de taal, Luhmann zich zal haasten om te verzekeren, dat de 'evolutionäre Errungenschaft' taal van enorme betekenis is en onontbeerlijk voor de verdergaande opbouw van door zin bemiddelde processen en systemen, i.c. communicatie en sociale systemen. Zo provoceert de ontwikkeling van het medium 'taal' een sterkere afgrenzing en contrastering, cen 'uitdifferentiatie" ('Ausdifferenzierung'), van commumicatie t.o.v. andere gedrags- en waamemingscontexten en "[e]rst durch Ausdifferenzierung von Kammunikationsprozessen kann es zur Ausdifferenzierung sozialer Systeme kommen ${ }^{3}{ }^{3 / 4}$ Het gericht gebruik van taal maakt namelijk door 
zijn formele pregnantie op ondubbelzinnige wijze duidelijk, dat iemand wil communiceren (en niet gewoon wat geluiden uitstoot). Ego kan zich door het taalgebruik van de ander er niet of nauwelijks aan onttrekken, dat hier en nu een communicatie-aanbod wordt gedaan. In positieve zin betekent dit voor Ego ook een verlichting, i.h.b. een ontlasting van zijn observatie-capaciteiten. In plaats van voortdurend op de mogelijkheid van communicatie bedacht te moeten zijn, kan hij er op vertrouwen dat de informerende mededeling zich, als het ware, "vanzelf' aandient. Of zoals Luhmann het uitdrukt:

'Angesichts von Sprachverhalten kan Ego sich darauf verlassen, daß die Differenz (tussen mededeling en informatie -T.B.), die Kommunikation konstituiert, bereits hergestellt ist. Er kann sich entsprechend entlastet fuhlen. Seine Aufmerksamkeit ist freigestellt fur das Verstehen dessen, was gesagt wird ${ }^{\text {315 }}$

Er zij tot slot op gewezen, dat door het gebruik van taal de component 'mededeling' een typisch 'retorische' gestalte verkrijgt. De boodschap (de 'informatie.') van een talige uiting kan per slot van rekening op verschillende manieren worden "verpakt". De retorische mogelijkheden die daarin besloten liggen, laten zich met het oog op 'overreding' en 'aanname' verder ontwikkelen en perfectioneren. Het mededelingsgedrag kan langs die lijn de component 'informatie' op sleeptouw gaan nemen, deze zelfs gaan overwoekeren - in de rythmisch-hypnotiserende zang- en verteltrant waarvan de vroegste mythen en sagen zich bedienen, in de riten en ceremonieèn van de religieuze culten, in de uiterst gestileerde pleidooien en tirades van de antieke retor; etc. Dit is voor het begrip van de sociaal-culturele evolutie op zijn minst in die zin van belang, dat de ontwikkeling van taal communicatief gedrag weliswaar sterker heeft doen onderscheiden van andere gedragsvormen, maar dat het mondelinge taalgebruik tegelijkertijd de differentie tussen mededeling en informatie onder druk zet, diffuser maakt. Dat leidt bij Luhmann tot de, maatschappijtheoretisch gezien, niet onbelangrijke these, dat het bewustzijn van de differentie tussen mededeling en informatie zelf een variabele is, die, historisch gesproken, met name beïnloed is door de ontwikkeling van wat hij 'Verbreitungsmedien' noemt, d.w.Z. door de ontwikkeling van het schrift en vervolgens de boekdrukkunst. Omdat een 'lezer", i.t.t. iemand die deelneemt aan mondelinge communicatie onder aanwezigen, veel minder onder druk staat om het beweerde ter plekke aan te nemen en direct te reageren, heeft hij tijd om te reflecteren, de inhoud van het geschrevene af te wegen en eventueel te kritiseren, etc. Daarmee worden, aldus Luhmann, de mededelingsvorm en de medegedeelde inhoud sterker uit elkaar getrokken, ontwikkelt zich haast 'naturwlichsig' een scherper bewustzijn van de differentie tussen 'mededeling' en 'informatie'. Men ziet wat een pech de 
Sofisten hadden, om in een geletterde gemeenschap te moeten leven, die verdenkingen tegen de mededelingsvorm kon gaan koesteren. In een samenvatting wan Luhmann:

'Erst Schrift und Buchdruck legen es nahe, Kommunikationsprozesse anzuschließen, die nicht auf die Einheit von Mitteilung und Information, sondern gerade auf ihre Differenz reagieren: Prozesse der Wahrheitskontrolle, Prozesse der Artikulation eines Verdachtes mit anschließsender Universalisierung des Verdachts in psychoanalytischer und/oder ideologischer Richtung. Schrift und Buchdruck erzwingen also die Erfahrung der Differenz, die Kommunikation konstiturert: Sie sind in diesem genauen Sinne kommunikativere Formen der Kommunikation.' ${ }^{316}$

\section{\$4. De autopoiesis van communicatie: een dynamische analyse}

Zolang we ons nog exclusief richtten op het begrip communicatie, volstond de bepaling, dat het 'begrijpen' van andermans gedrag als een mededeling die informatief is, een noodzakelijke voorwaarde, een "sime qua non" van een communicatie vormt. Praktisch gesproken, geldt echter, dat Ego's begrijpen van Alters uiting slechts manifest (en gecontroleerd) kan worden, wanneer Ego zich op zijn beurt uit. Pas door Ego's reactie wordt m.a.w. een communicatie definitief afgesloten. In een formulering van Luhmann:

'Die Mitteilung selbst ist zunächst nur eine Selektionsofferte. Erst die Reaktion schließt die Kommunikation $a b$, und erst an ihr kann man ablesen, was als Einheit zustandegekommen ist. Eben deshalb kann Kommunikation nicht als Handiung begriffen werden; und dies auch und gerade dann nicht, wenn man nach der letzten, nicht weiter auflösbaren Einheit fragt. ${ }^{\text {.317 }}$

Nu is Alters reactie echter een nieuwe mededeling, die op zijn beurt weer om een afsluitende reactie vraagt; etc. Communicatieprocessen bestaan, zo bezien, uit zichzelf voortstuwende processen, waarin de ene uiting een 'trigger' vormt voor de volgende.

Aan dit "basismodel" verbindt Luhmann nu een drietal kenmerken, die hij, naast 'dubbele contingentie', crucial acht voor sociale systemen tuberhaupt. Wat communicatieprocessen ten eerste kenmerkt, is hun radicale temporaliteit. 
Afzonderlijke communicaties hebben zelf geen duurzaamheid. Met hun ontstaan lossen ze al weer op om plaats te maken voor nieuwe communicaties en alleen in dat proces van komen en gaan heeft een sociaal systeem een zeker bestand: Met het oog op deze doorlopende flux van ontstaan en vergaan, karakteriseert Luhmann sociale systemen dan ook als door en door getemporaliseerde systemen. Daarbij gaat het hem niet simpelweg om een uiterlijk waarneembaar feit. Zoals we in Hoofdstuk I al zagen schuilt de pointe eerder daarin, dat een getemporaliseerd systeem - dus ook een sociaal systeem - zijn selectiviteit intensiveert door zichzelf voortdurend onder selectiedwang te stellen. Dat vereist weliswaar de opbouw van een bijzonder soort structuren, die in staal zijn de daarmee sprongsgewijs toegenomen complexiteit vast te houden en tegelijkertijd te reduceren - zinstructuren! - ; op voorwaarde dat dit lukt, kan een systeem echter ook sneller op zijn (interne/externe) omgeving reageren, zijn toestand voortdurend aanpassen. Getemporaliseerde systemen zijn in die zin uiterst flexibele systemen:

"[Sie] benutzen die Zeit, um ihre kontinuierliche Selbstauflösung zu erzwingen; sie erzwingen ihre kontinuierliche Selbstauflösung, um die Selektivităt aller Selbsterneuerung sicherzustellen; und sie benutzen diese Selektivität, um die Selbsterneuerung selbst zu ermöglichen in einer Umwelt, die kontinuierlich schwankende Anforderungen stellt." ${ }^{9318}$

Een tweede, voor sociale systemen wezenlijk kenmerk duidt Lulumann aan met de term 'basale zelfreferentie'. Om een element van een sociaal systeem te kunnen zijn, moet een communicatie een 'eenheid' vormen en daartoe hebben communicaties andere communicaties nodig. Pas door een 'opvolgende" communicatie wordt manifest dat de voorafgaande communicatie (hoe dan ook) 'begrepen" is en tot een eenheid afgesloten. Of vanuit het perspectief van de deelnemers: Pas door de reactie van een andere deelnemer, kan de mededeler controleren of hij begrepen is. Daarbij is in eerste instantie niet van belang we merkten het al eerder op - of deze 'Verstehenstest' positief dan wel negatief uitvalt, of de mededeler zich correct of niet correct begrepen voelt. Vereist is slechts, dat zich een 'begrijpen' heeft voltrokken. Luhmann:

'In jedem Falle ist jede Einzelkommunikation, sonst wurde sie gar nicht vorkommen, in den Verstehensmöglichkeiten and Verstehenskontrollen eines Anschlußzusammenhanges weiterer Kommunikationen rekursiv abgesichert. Sie ist Element nur als Element eines, wie immer minimalen, wie immer ephemeren, 
Prozesses. ${ }^{2319}$

We herkennen natuurlijk het algemene idee, dat een elementaire gebeurtenis slechts 'elementair' is in en door het proces waarvoor het een 'element' is. Met de toespitsing dat het in communicatieprocessen om een bijzondere vorm van zelfreferentie gaat, namelijk om "indirecte', of zoals Luhmann het ook wel noemt: 'basale zelfreferentie', wil Luhmann onder ogen voeren, dat communicaties zich, via een betrekking op wat ze zelf niet zijn (namelijk op andere/aansluitende communicaties), wederom op zichzelf betrekken en dit als de voor hun specifieke vorm van 'zelfconstitutie' tot elementaire eenheid van een communicatieproces.

Met de karakterisering van sociale systemen als 'radicaal getemporaliseerd' en als 'zelfreferentieel' op het niveau van hun elementen, is een structuur aan het licht gebracht, die het volgens Luhmann rechtvaardigt, om sociale systemen inderdaad - als autopoietische systemen op te vatten. Dat betekent, om de geijkte formule nog eens aan te halen, dat sociale systemen beschouwd moeten worden als systemen, die de elementen waaruit ze bestaan, produceren middels de elementen waruit ze bestaan. Communicaties produceren communicaties en alleen communicaties kunnen communicaties voortbrengen. In cen op de spits gedreven formulering:

'Es gibt also keine 'bewußten Kommunikationen', so wenig wie es 'kommunikatives Denken' (Empfinden, Wahrnehmen) gibt. Oder anders gesagt: Der Mensch kann nicht kommunizieren; nur die Kommunikation kann kommunizieren',320

In een wat minder provocerende formulering: Sociale systemen stellen emergente ordeningen voor die lhun elementen niet 'kant en klaar', als geprefabriceerde bouwstenen aantreffen, maar deze met en in hun ontstaan zelf produceren.

'Dubbele contingentie' plus 'radicale temporaliteit' plus 'basale zelfreferentic' - bezinnen we ons op het combinatorisch effect van deze drie kenmerken, dan verkrijgt de 'fundamentele instabiliteit' die Luhmann aan zinsystemen in het algemeen toeschrijft (zie Hfst. III), woor sociale systemen een bijzondere inhoud. Zoals we hebben gezien, vormt 'dubbele contingentie' voor Luhmann het ultieme, overkoepelende referentie-probleem van sociale systemen, d.w.z. die uitsnede van door zin geconstitueerde 'wereldcomplexiteit' die door sociale systemen wordt gereduceerd. We hebben bovendien gezien hoe dubbele contingentie door Luhmann aanvankelijk werd ingevoerd als een effect van de

320. N. Luthann, Die Wissenschaft der Gesellschaft, Frankfurt/M, 1990, p.30/31. 
confrontatie tussen (minstens twee) informatieverwerkende zinsystemen, die elkaar in principe een onbeperkte selectievrijheid toekennen - 'Zum Unterbau, der im Theorem der doppelten Kontingenz vorausgesetzt ist, gehören hochkomplexe sinnbenutzende Systeme, die fur einander nicht durchsichtig und nicht kalkulierbar sind'.

Een dergelijke bepaling van het overkoepelende referentieprobleem van sociale systemen is echter nog te abstract om veel houvast te bieden aan een verdergaande functionele analyse. Nu verkrijgt het 'dubbele contingentie'probleem al meer inhoud door de vaststelling, dat eerst de bijzonder observatievorm 'Verstehen' een contact tussen twee psychische systemen op scherp stelt, deze situatie 'definieert' als 'dubbel contingent'. Dit is echter nog statisch gedacht. Een dynamische opvatting van dubbele contingentie dient zich daarentegen aan, wanneer we er vanuit gaan, dat, wil een communicatie een elementaire eenheid van een communicatief proces kunnen vormen, dat dan het 'begrijpen' ge-uit moet worden, op zijn beurt de vorm van een informerende mededeling moet aannemen. Daarmee wordt het "dubbele contingentie"probleem op een typische manier toegespitst. Ego is namelijk niet alleen 'vrij' voor wat betreft zijn interpretatie van het medegedeelde; hij kan n.a.v. Alters mededeling bovendien de meest uiteenlopende reacties vertonen, daarbij inbegrepen de reactie "niet-reageren'. Op zijn beurt accepteert Alter echter niet iedere reactie als een teken dat hij inderdaad begrepen is en het staat hem in principe vrij om te kiezen tussen een voortzetting van de communicatie, desnoods in de vorm van protest, en het afbreken ervan. In die zin, d.w.z. gelet op het proces-karakter van communicatie, kan men er vanuit gaan, dat wat zich onder de conditie van dubbele contingentie als emergente eenheid, i.e. als 'communicatie' telkens formeert, bijzonder broos is. 'Es handelt sich', zo merkt Luhmann op, 'um ein extrem instabile Kernstruktur, die sofort zerfällt, wenn nichts weiter geschieht". ${ }^{321}$

Dit laatste citaat calculeert de radicale temporaliteit van sociale systemen al in. Het gebeurteniskarakter van communicaties, het feit dat afzonderlijke communicaties met hun ontstaan al weer vergaan, intensiveert de hele problematiek. Het probleem: 'voortgaan, of afbreken', stelt zich niet eenmalig, maar bij voortduring. Dat is allemaal geen kwestie van onwil of bewuste sabotage van de kant van de betrokkenen Aan hun eigen vrijheid/lot overgelaten hebben de deelnemers namelijk geen enkele zekerheid omtrent de wijze waarop een communicatie-aanbod zal worden 'begrepen', of welke reactie als een teken van begrip zal worden geaccepteerd. Bedenken we bovendien, dat communicaties andere communicaties nodig hebben om de elementaire eenheden van sociale systemen te kunnen vormen, dan dient de 'fundamentele", of 'basale instabiliteit' van sociale systemen zich in zijn volle, problematische gestalte aan: Hoe kunnen sociale systemen hun autopoiesis zeker stellen, als dit 
vooronderstelt, dat communicaties in hun onderlinge opeenvolging zichzelf produceren, terwijl we van dit laatste, de opeenvolging van communicaties, nog niet eens zeker kunnen zijn?!

Deze "fundamentele instabiliteit" is in feite niets anders dan het "dubbele contingentie'-probleem in zijn reële, d.w.z. dynamische, autopoietische gedaante. Binnen sociale systemen, en onder de conditie dat het hier om communicatieprocessen gaat, verschijnt dubbele contingentie praktisch gesproken als een aansluitingsprobleem, als thet probleem hoe communicaties op communicaties kunnen volgen - hoe de autopoiesis van sociale systemen 'waarschijnlijk' kan worden. Voor de theoretische analyse van sociale systemen biedt dit voorlopig genoeg houvast: Alle verdergaande structuru- en syste emopbouw kan nu namelijk functioneel geanalyseerd worden als de, door sociale systemen zelf tot stand gebrachte (stapsgewijze of 'getrapte') oplossing van het probleem, hoe zij ondanks 'basale instabiliteit' hun autopoiesis zeker kunnen stellen. En wat Luhmanns theorie meteen weer ingewikkeld maakt, is de aanname, dat sociale systemen zichzelf moeten (re)stabiliseren onder behoud van instabiliteit. Vanuit een algemener perspectief geformuleerd: Sociale systemen moeten dubbele contingentie weliswaar indammen, maar ze hebben tegelijk de 'wanorde' of 'chaos', die dit voor hen inhoudt, nodig als (auto)katalysator van hun dynamiek en evolutie. Luhmann:

'Das soziale System muß sich entwickeln auf der Grundlage von Situationsdefinitionen, der voraussetzen, daß alle Teilnehmer immer auch anders handeln können als sie tatsächlich tun oder tun sollen oder wahrscheinlich tun werden. ${ }^{322}$

\section{§5. Reflexiviteit en reflexie}

Bij nader inzien strekt de 'fundamentele instabiliteit", die sociale systemen eigen is, zich verder uit dan het probleem, hoe communicatie op communicatie kan volgen, hoe de deelnemers aan communicatieprocessen telkens kunnen weten, welk communicatie-aanbod 'anschlußfahig' is. Het is evenzeer een probleem, hoe we communicatieprocessen kunnen afbreken, zonder er bang voor te hoeven zijn, op een later tijdstip de draad niet meer op te kunnen pakken. Nemen we niet een enorm risico, wanneer we besliuiten een liefdesverklaring (eindelijk) af te breken!

We weten inmiddels, dat, volgens Luhmann, de middelen en strategieên die garanderen, dat dergelijke problemen zich in de alledaagse praktijk nauwelijks voordoen, niet anders ontstaan kunnen zijn dan in en door communicatieprocessen zelf. Sociale systemen zijn communicatieprocessen en

322. N. Luhmanm, 'Selbstreferentielle Systeme', Manuscript Bielefeld (1986/87), 
alleen communicatieprocessen staan ter beschikking voor de opbouw en evolutie van alles wat binnen sociale systemen voorhanden is om aam stabilisatie- en reproductieproblemen het hoofd te bieden. Deze 'zelfiorganisatie' neemt al op het meest basale niveau een aanvang. Is eermaal een communicatie tot stand

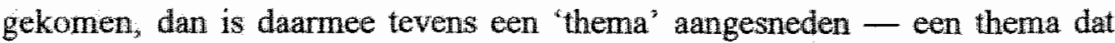
vervolgens weer kan worden verlaten, maar ook kan worden aangehouden; waardoor het an scherpte wint. De structurerende functie van communicatiethema"s ziet Luhmann op dit niveau nog daarin, dat ze mogelijke mededelingen (woor)sorteren in termen van 'wel-een-bijdrage' en 'niet-eenbijdrage' aan het thema. Zo zal de mededelling, dat Matisse (en niet Picasso!) als de grootste schilder van deze eeuw moet worden beschouwd, gewoonlijk niet als een bijdrage aan een gesprek over de kansen van het nationale voetbal-elftal worden opgevat.

Naast deze inhoudelijke, of zoals Luhmann zou zeggen: 'zakelijke' ordeningsdimensie - de communicatie gaat over een bepaald 'iets', over een bepaald fenomeen, over een bepaalde/mogelijke stand van zaken -, hebben thema's ook een temporeel aspect. Dat betreft niet alleen de ordening van mededelingen in termen van eerdere en latere bijdragen aan het thema, maar ook de "slijtage' van het thema zelf ( - een aspect dat door de moderne massamedia bijzonder scherp wordt uitgelicht):

'Themen sind alt oder neu, schon langweilig oder noch interessant, und all dies möglicherweise far verschiedene Teilnehmer in verschiedener Weise. Sie erreichen irgendwann einen Sättigungsgrad, von dem ab neue Beiträge nicht mehr zu erwarten sind. . $^{323}$

Thema's sorteren tenslotte ook in sociale zin, namelijk tussen degenen die wel kunnen of mogen bijdragen aan het gesprek en degenen die van communicatie worden uitgesloten. Zo werden tot voor kort kinderen niet geacht deel te nemen aan bepaalde, voor volwassenen gereserveerde thema's. En van de weeromstuit betitelen de $17 \mathrm{de}$ en $18 \mathrm{de}$ eeuwse verhandelingen over etiquette het als "pedanterie", wanneer men in gezelschap onderwerpen aansnijdt, waaraan niet door iedereen kan worden deelgenomen. Tegen de achtergrond van een voortschrijdende maatschappelijke differentiatie en de daaraan inherente aanwas van specialistische thema's kon de causerie schijnbaar slechts gered worden als een sociaal kunststuk. ${ }^{324}$

323. Soziale Systeme, op cit., p. 214.

324. Whe een thema anroert; moet zich bovendien laten welgevallen op zij.jn keuze to worden beoordeeld. Hijj of zij moet niet alleen zelf interesse tonen woor het ondenwerp, maar bovendien bereid zijn het gespreksthema te verdedigen als 'waardig', 'belangrijk', "amusant", ete. Thema"s hebben in die zin ook een 'bindend' effect. Wie zijn liefde verklaart, weet wat hij allemaal oproept. Uiteindelijk moet de verleider liefhebben, merkt Luhmann op, refererend aan 
In een formulering die deze drie dimensies samenvat:

'Themen dienen also sachlich-zeitlich-soziale Strukturen des Kommunikationsprozesses, und sie fungieren dabei als Generalisierungen insofern, als sie nicht festlegen, welche Beiträge wann, in welcher Reihenfolge, und durch wen erbracht werden. Auf der Ebene von Themen lassen sich deshalb Sinnbezüge aktualisieren, die an der Einzelkommunikation kaum sichtbar zu machen wären. Deshalb ist Kommunikation schließlich typisch, wenngleich nicht notwendig, ein durch Themen gesteuerter Prozeß. ${ }^{325}$

Hoe gevestigder thema's worden, des te sterker de inhoudelijke selectiviteit die er van uit gaat. Dag Østerberg heeft dit proces ooit vergeleken met een melodielijn: hoe meer de melodie zich ontwikkelt, des te waarschijnlijker worden bepaalde tonen en des te onwaarschijnlijker andere. ${ }^{326}$ Thema"s scheppen m.a.w. verwachtingen. Dat biedt de individuele actoren een eerste oriëntatiemogelijkheid. $\mathrm{Zij}$ kunnen verwachten, dat, gegeven het gespreksonderwerp, een bepaald type mededeling als 'bijdrage' geaccepteerd zal worden, op andere daarentegen niet hoeft te worden gerekend. Bovendien kunnen individueel gekoesterde verwachtingen in het communicatieproces worden ingebracht, waardoor verwachtingen voor anderen verwachtbaar worden. Dit beschouwt Luhmann als het mechanisme op basis waarvan zich sociale structuren vormen. Sociale structuren zijn 'verwachtingsverwachtingen' die de interactie ordenen door het (mededelings)gedrag van meerdere personen onderling verwachtbaar te maken. Ego kan verwachten wat Alter van hem verwachit - en vervolgens besluiten om Alters verwachtingen wel/niet te frustreren. Ego mag bovendien verwachten, dat Alter zijn verwachtingen m.b.t. tot Alters gedrag kent - om gebleken non/conformiteit eventueel negatief/positief te sanctioneren. ${ }^{327}$ Zodra door het communiceren van verwachtingen een minimale structurur is ontstaan, kan een proces in werking treden, dat tot een versterking van die structuur leidt. Binnen het communicatieproces kunnen namelijk eerdere

Adolphe van Benjamin Constant. (Verg. Soziale Systeme, op.cit., p.215.)

325. Idem, p.216.

326. Binnen de context van een Luhmann-lectuur is het aberhaupt interessant om kernis to nemeri van Osterberg's Meta-Sociological Essay, Pittsburgh 1976.

327. Verwachtingsverwachtingen kunnen op hun beurt verwacht worden. Langs deze weg ontstaan hogere orde structuren. Met en toenemende structuurcomplexiteit wordt tevens: ruimte geschapen voor manipulatie en subtielere sociale strategieën. Zo kan men werwachten, dat het alsnog accepteren van te laat ingeleverde essays, bij studenten de verwachtingsstructuur doet ontstaan, dat ook te laat ingeleverde schrijfopdrachten nog "op tijd" zijn. Daarop kat men matuurlijk anticiperen en facultaire examencommissies verzoeken om bij voorbaat maatregelen te treffen. 
communicaties als communicatiethema worden ingevoerd. Dat gebeurt bijv. wanneer een wan de deelnemers de bijdrage van een ander aan de orde stelt in termen van 'niet ter zake', 'niet wat hij verwachtte', 'niet consistent met eerdere bijdragen', etc. Deze "re-entry" van een proces in datzelfde proces, in de communicatieve praktijk vrijwel onvermijdelijk, beschourwt Luhmann als een (nieuwe) vorm van zelfreferentie, door hem aangeduid als reflexiviteit:

"Reflexiv sind Prozesse, die auch auf sich selbst angewandt werden können. Im Falle wom Kommunikation heißt dies: daß über Kommunikation kommuniziert werden kann. Man kann den Kommunikationswerlauf in der Kommunikation thematisieren, kann fragen und erläutem, wie etwas gemeint gewesen war, kann um Kommunikation bitten, Kommunikation ablehnen, Kommunikationszusammenhänge einrichten, usw. ${ }^{.328}$

Reflexieve communicatie kunnen we in de grond van de zaak beschouwen als een vorm van zelfobservatie, die sociale systemen een beeld van hun eigen procesgang verschaft. Het structuurversterkend en -opbouwend effect van deze operatie, schuilt voor een belangrijk deel in zijn explicatieve funeties. In het algemeen houdt een dergelijke communicatie over (voorafgaande) communicatie immers geen halt bij de mededeling, dat een eerdere contributie aan het communicatieproces niet was, wat men ervan verwachtte. Eerder zal degene die zich aingesproken voelt, zich verweren en proberen uit te leggen, dat de betwiste mededeling wel degelijk een zinvolle bijdrage an het thema voorstelt. Daarmee wordt, bijna onvermijdelijk, een verdergaande duiding van de inhoud en reikwijdte van het thema op gang gebracht. Wanneer dergelijke duidingen worden 'vastgehouden", hetzij door mondelinge overlevering, hetzij op schrift en opgeslagen in bibliotheken, dan vormen zich 'semantieken': intersubjectief beschikbare betekenisstelsels waaraan in communicatieprocessen gerefereerd kan worden en die deze als een semantische context begeleiden. Op basis van dergelijke, uit communicatieprocessen emergerende semantieken kunnen communicaties vloeiend worden gestart, afgebroken en weer opgenomen. De aanwezigen weten, wat er met 'bezuinigen' bedoeld wordt en kunnen afspreken, om in een volgende vergadering op dit thema terug te komen. Omdat de secundaire literatunir aan Luhmanns concept van zich rond thema"s ontwikkelende "semantieken" tot nog toe opvallend weinig aandacht besteed heeft, loont het de moeite om hier kort bij stil te staan. Niet alleen maakt dit het gemakkelijker, om in het vollgende hoofdstuk op de betekenis en functie van Luhmanns maatschappijbegrip in te gaan, maar bovendien neemt het begrip 'semantiek' bij Luhmann een aantal functies over, die vanaf Schutz tot en met 
Habermas door het 'leefwereld'-concept worden vervuld. ${ }^{329}$

In zijn meerdelige Gesellschaftsstruktur und Semantik concentreert Luhmann zich hoofdzakelijk op wat hij "gepflegter Semantik' noemt; op de 'besondere Variante der Vertextung" die, vanaf de uitvinding van het schrift, voor "ernsthafte, bewahrenswerte Kommunikation" in de arm is genomen - op 'semantiek' als het klassieke object van de ideeëngeschiedenis: ${ }^{330} \mathrm{De}$ aansluiting op Kosellecks idee van een 'historische Semantik' is daarbij niet over het hoofd te zien ${ }^{331}$ Naast deze 'gepflegter Semantik' die zich aanvankelijk in religieuze en filosofische contexten ontwikkelt, heeft er ook altijd een alledaagse semantiek bestaan - zonder dat, zou zelfs de jammerkreet van Antigone het publiek niet in het hart kunnen treffen, maar oplossen in een overmaat aan "Verstehensmöglichkeiten', in de met iedere zinselectie 'mitimplizierter Welt'. Om zinselecties sociaal verwachtbaar te houden en de mogelijkheid te garanderen dat anderen er op aan kumnen sluiten, moeten concrete, hier en nu geuite mededelingen namelijk worden ontdaan van de (over)volle verwijzingsrijkdom die met hun zin is gegeven. Zin, zo zou men ook kunnen zeggen, is sociaal slechts te 'verdragen' in een gereduceerde, gegeneraliseerde, cliché-matige vorm - slechts als getypificeerde zin. 'Ohne jeden Bezug auf Typen', zo stelt Luhmann, 'wäre Sinn wo er auftaucht, zunächst unterbestimmt, unverständlich, inkommunikabel - etwa so wie die ständig mitlaufende Icherfahrung. Er wäre immer noch aktuelle Selektion, aber unprofiliert im Hinblick auf 'was sonst'. .332

Die generaliserende typificatie achtte Schutz al kenmerkend voor wat hij vanuit fenomenologisch perspectief als de 'Lebenswelt' omschreef en in principe kan men nog verder terug, naar Weber en naar de wijze waarop hij met zijn "adequaatheidspostulaat" het ideaaltypische karakter van handelingszin trachtte te verdisconteren. Weliswaar gaat Luhmann er met het oog op de evolutie van sociale systemen vanuit, dat niet-typische zin steeds mogelijk blijft. Zodra het echter optreedt, zien we, volgens hem, telkens weer de poging om een dergelijk zingebruik te typificeren, te normaliseren, te betrekken op reeds voorhanden typificaties en zo te (re)stabiliseren. Deze 'stabiliserende normalisering', deze selectie van het nieuwe in het licht van het oude wordt nu bij uitstek bemiddeld door semantieken:

'Die Gesamtheit der fur diese Funktion benutzbaren Formen

329. Zie voor Luhmanns persoonlijke visie op het 'leefwereld'-begrip: N Luhmann, "Die Lebenswelt - nach Rucksprache mit Phänomenologen", in: Arch. f. Rechts-und Sozilatphil. 72 (1986), p. $176-194$.

330. Verg. N. Luhmann, 'Gesellschaftliche Struktur und semantische Tradition', in: idem, Gesellschaftsstruktur und Semanvik Bd.I, Frankfurt 1993, p.20.

331. Zie van Koselleck o.a. de 'Einleitung' bij: O.Brunner/W.Conze/R.Koselleck, Geschichtliche Grundbegriffe Bd.1, Stuttgart 1979 p. XIII-XXVII.

332. N. Luhmann, "Gesellschaftliche Struktur und semantische Tradition', op.cit., p.18. 
einer Gesellschaft (im Unterschied zur Gesantheit der Sinn aktualisierende Ereignisse des Erlebens und Handelns) wollen wir die Semantik einer Gesellschaft nennen, ihren semantischen Apparat, ihren Vorrat an bereitgehaltenen Sinnverarbeitungsregeln. Unter Semantik verstehen wir demnach einen höherstufig generalisierten, relativ situationsunabhängig verfugbaaren Sinn. ${ }^{* 33}$

Dat semantieken fungeren als algemene regels voor de duiding en verwerking van de zin van uitingen, is al met al weinig verwonderlijk, wanneer we bedenken dat het gaat om in taal vervatte betekenisstelsels die zich in en door, aan thema's georiënteerde communicatie ontwikkelen. Men zou de verhouding tussen een thema en zijn semantiek als een 'symbiose', eventueel als de uitkomst van een co-evolutie kunnen beschrijven. Aan de ene kant geldt, dat thema's communicatieprocessen slechts kunnen structureren in termen van bijdrage/niet-bijdrage, voorzover ze een minimale explicatie of 'semantische duiding' hebben ondergaan; aan de andere kant veronderstelt de ontwikkeling van een semantick, dat de communicatie het thema herhaalt, vaker oppakt. Die 'temporele stabiliteit' veronderstelt op zijn beurt weer, dat thema's op een of andere manier 'beschikbaar' blijwen en door de betrokkenen smel geïdentificeerd kumnen worden als 'dit' (en niet 'dat') thema - veronderstelt m.a.w. dat het thema in het door de taal gevormde magazijn van semantische mogelijkheden ligt opgeslagen en door enkele sleutelwoorden kan worden opgeroepen. Nu impliceert de herhaalbaarheid van een thema een generalisering van zowel de temporele, sociale als zakelijke dimensies van dat thema. Het impliceert immers, dat het thema op andere momenten en in andere omstandigheden, d.w.z. met andere communicatiedeelnemers kan worden aangesneden en dit met het vooruitzicht op andere bijdragen. Semantieken bemiddelen, als het ware, tussen dit gegeneraliseerde karakter van 'bewahrenswerte" thema's en de allijd concrete, specifieke bijdragen aan het thema. Ze verschaffen de context waarbinnen een uiting, niettegenstaande zijn eenmalige en unieke karakter, als een "typische" bijdrage aan (of afwijking van) het thema kan worden begrepen. Wie tijdens een discussie-bijeenkomst over 'vrouwenemancipatie' het principe van de 'positieve discriminatie' verdedigt, kan er niet alleen op vertrouwen een 'bijdrage' te leveren, maar hoeft er bovendien niet voor te vrezen, dat de vergadering niet yerder kan gaan, alvorens een diepgravend onderzoek te hebben ingesteld naar wat hij/zij er op dat moment, precies en ten volle mee bedoelt.

Luhmann gaat er daarnaast vanuit, dat iedere samenleving over een arsenaal aan 'bewahrenswerte' thema's beschikt, d.w.z. over thema's die zich hebben 'bewezen' in termen van hun communicatie-structurerende functie, hun herhaalbaarheid, het gemak waarmee ze kunnen worden aangesneden, etc. Deze 
"voorraad' aan thema's, inclusief de daarbij behorende semantieken, noemt hij "Kulltur":

'Die Themen werden nicht jeweils fallweise neu geschaffen, sind
aber anderseits auch nicht durch die Sprache, etwas als
Wortschatz, in ausreichender Pregnanz vorgegeben... Es wird
demnach ein dazwischenliegendes, Interaktion und Sprache
vermittelndes Erfordernis geben - eine Art Vorrat möglicher
Themen, die für rasche und rasch verständliche Aufnahme in
konkreten kommunikativen Prozessen bereitstehen. Wir nennen
diesen Themenvorrat Kultur und wenn es eigens für
Kommunikationszwecke aufbewahrt wird, Semantik. ${ }^{\text {,334 }}$

I.t.t. Parsons heeft het begrip "cultuur" bij Luhmann dus niet per definitie een normatieve strekking. Het gaat in de grond van de zaak om "eine Sinnfestlegung (Reduktion) die es ermöglicht, in themenbezogene Kommunikation passende und nichtpassende Beiträge oder auch korrekten bzw. inkorrekten Themengebrauch $\mathrm{zu}$ unterscheiden". ${ }^{335}$. Bij Luhmann heeft 'cultuur' bovendien een beperktere reikwijdte dan het cultuurbegrip dat we o.a. in de archeologie en culturele antropologie kunnen aantreffen en dat ook materiële voorwerpen zoals potten of grafzerken omvat. In Luhmanns visie belichamen bouwmaterialen, gebruiksvoorwerpen, sieraden, enz. slechts cuituur voorzover het bestaan van dergelijke voorwerpen het mogelijk maakt ze tot thema van communicatie te maken.

Sociale systemen - zo kunnen we na deze korte uitweiding over Luhmanns cultuurbegrip de draad weer oppakken - evolueren rondom communicatiethema's. Thema's kunnen hun ontstaan te danken hebben aan vertakkingen en afsplitsingen van eerdere thema's of gewoon aan nonconformisme. Dat roept onwillekeurig het probleem op van een onderlinge afbakening en demarcatie van thema-gestuurde communicatieprocessen, d.w.z: van uiteenlopende sociale systemen. We moeten er althans op kunnen vertrouwen, dat de vraag 'hoeveel kost dit brood", niet op een vanzelfsprekende manier voor een winkelbediende de aanleiding kan vormen voor strikt persoonlijke ontboezemingen. Op dit afgrenzingsprobleem reageren sociale systemen met een derde vorm van zelfreferentie: zelfreferentie als referentie van het systeem aan zichzelf - door Luhmann kortweg reflexie genoemd.

Zoals we hebben gezien draaide op het eerste door Luhmann onderscheiden niveau van zelfreferentie, het niveau van 'basale zelfreferentie', alles om het onderscheid tussen 'element' en 'relatie'. Het zelf was hier een element, dat in en door de verwijzing naar iets anders (een andere communicatie) weer naar

334. Soziale systeme, op.cit, p. 224.

335. Idem. 
zichzelf verwijst. Reflexiviteit, de tweede vorm van zelfreferentie, heeft daarentegen betrekking op het communicatieproces. De fundamentele differentie is hier die tussen vrcegere en latere gebeurtenissen, tussen een 'voorheen' en een 'nadien'. Het 'zelf' dat nu aan zichzelf refereert, is het door deze voorheen/nadien-differentie geconstitueerde proces. De functie van reflexiviteit is de selectiviteit wan het (communicatie)proces te versterken, middels de opbouw van structuren ("verwachtingswerwachtingen') die niet alleen aangeven 'waar', in welke richting 'aansluitende', het proces voortzettende communicatieve uitingen gevonden kunnen worden, maar die bovendien het bereik van "anschlußfahige" communicaties inperken, daarmee nogmaals voor de deelnemers het selectieprobleem verlichtend.

Op het derde niveau van zelfreferentie, dat van de 'reflexie." staat het onderscheid systeem/omgeving centraal. Het 'zelf' is hier het systeem dat naar zichzelf verwijst als iets dat zich onderscheidt van het niet-zelf, van 'omgeving'. Ook voor reflexie geldt dat het, als een operatie van een sociaal systeem, een vorm van zelfreferentie betreft, die in en door communicatieprocessen tot stand wordt gebracht. Het gaat i.h.b. om communicatieprocessen die, binnen de context van een zich ontwikkelend, d.w.z. zichzelf structurerend systeem, de explicatie van de idlentiteit van dat systeem tot inhoud hebben en dit ten opzichte van, en in contrast met andere (sub)systemen in zijn omgeving. In die zin handelt het tevens om 'uitsluiting', om het uitsluiten van die thema's, codes, structuren, etc die niet compatibel zijn met de identiteit van het eigen systeem. Wie de politiek in gaat, kan niet verwachten met zuiver esthetische argumenten veel te bereiken.

In principe kunnen sociale systemen het zonder reflexie stellen en in simpele sociale systemen, zoals kortstondige ontmoetingen - communicatie op het trottoir - is reflexie virtueel absent. Voor ook maar enigszins complexe systemen, dus voor systemen, die een hogere selectiviteit moeten organiseren, wordt reflexie echter al spoedig onontbeerlijk. De stabiliserende functie van expliciete identiteitsvoorstellingen schuilt niet alleen daarin, dat het de mogelijke deelnemers aan systeemspecifieke communicaties extra orientatiemogelijkheden biedt in termen van een algemeen beeld van wat binnen het systeem uberhaupt on/mogelijk is. Op het niveau van het systeem zelf vervullen identiteitsvoorstellingen bovendien de functie van criteria voor grensafbakening en -controle. Een complex systeem dat in zijn operaties niet voortdurend "mee-controleert" of de zich telkens aandienende proces- en structureringsmogelijkheden 'des systeems' zijn, lost al snel in zijn omgeving op. Een stam die niet middels de overdracht van mythen en rituelen over zijn eigen identiteit waakt - wij stammen af van die en die god, wij zijn daarom het mooiste/dapperste/edelste/etc. volk - loopt spoedig de kans te worden geabsorbeerd door zijn nabuurstammen.

Zelfreferentialiteit heeft een circulair, gesloten karakter - een "zelf" wijst naar zichzelf. In die zin zou men kunnen zeggen, dat de bovenstaande uitwerking van een drietal vormen van zelfreferentie voortdurend de geslotenheid van sociale 
systemen benadrikt. De centrale gedachte is althans, dat communicaties steeds op communicaties betrekking hebben en dat deze "operationele geslotenheid' de vorm is waarin sociale systemen hun autopoiesis bedrijven, zichzelf structureren en zich van hun omgeving afbakenen. Sociale systemen zijn, anders geformuleerd, gesloten voor zover het gaat om de constitutie van wat binnen en voor het systeem telkens als 'eenheid' ('communicatie", 'structuur', 'systeem") fungeent.

Sociale systemen zijn echter niet uitsluitend als 'gesloten' te karakteriseren. In communicatieprocessen wordt ook, en wel onvermijdelijk, over zaken gecommuniceerd, die niet tot het communicatieproces zelf behoren, maar tot de omgeving van het systeem. Binnen sociale systemen komt 'de omgeving' m.a.w. tot gelding in de vorm van informatie. Naast een doorgaande, operationele zelfreferentie dus ook 'alloreferentie', i.e. verwijzing naar iets dat niet tot het systeem behoort en dit als de manier waarop sociale systemen zichzelf 'onttautologiseren', hun steriele zelfverwijzing doorbreken. Natuurlijk blijft ook dit een openheid voor de omgeving op basis van geslotenheid. Sociale systemen kunnen zich slechts voor invloeden uit hun omgeving openen in een voor hen geëigende vorm: in de vorm van informatie. Bovendien prejudiciëren sociale systemen zelf, welke omgevingsfactoren in de vorm van informatie het systeem kunnen binnendringen en daar eventueel de aanleiding tot verdergaande (her)structureringsprocessen kunnen vormen. Taboes, dogma's en etiquettes zijn slechts enkele van de vele mogelijkheden die sociale systemen ter beschikking staan om elementen of delen van de omgeving buiten de communicatie te houden. Ook voor sociale systemen geldt m.a.w, het algemene theorema, dat de omgeving het systeem weliswaar kan prikkelen of irriteren, maar dat dit binnen het systeem slechts van causale invloed kan zijn, indien het systeem zelf daaraan meewerkt.

\section{\$6. Ter afsiuiting: de complexe relatie tussen bewustzijn en communicatie}

In het hierna volgende, tweede deel van het 'dubbelhoofdstuk' over sociale systemen zullen we nagaan hoe Luhmann de grondslagen van zijn sociologie op enkele punten nader specificeert, om in een afsluitende, evaluerende paragraaf een paar algemene consequenties van zijn gehele grondslagenoperatie onder de loep te nemen. Het eerste deel willen we nu afsluiten aan de hand van Luhmanns opvattingen omtrent de relatie tussen 'het psychische' en 'het sociale'. En ook met dit thema betreden we definitief het terrein van discussie en kritiek. Niets lijkt namelijk zoveel weerstand te hebben opgeroepen als Luhmanns inschatting dat psychische en sociale systemen voor elkaar 'systemen-in-de-omgeving' zijn en dat we bijgevolg ook scherp moeten onderscheiden tussen bewustzijn en communicatie als een tweetal systeemspecifieke operaties die elkaar op geen enkel moment overlappen. 
Laten we het probleem van de verhouding tussen het psychische en het sociale naar voren halen door nog eens terug te keren naar $\$ 3$ en $\$ 4$, d.w.z. de paragrafen waarin we de communicatietheoretische grondslag van Luhmanns concept van sociale systemen uiteen hebben gezet. We zagen daar, hoe Luhmann al met zijn (statische) definitie van het begrip 'communicatie" een wig plaatste tussen thet "psychische" en het "sociale". En we hebben tevens gezien, hoe met de overgang naar een dynamisch, 'autopoietisch' model van communicatie deze er defínitief in wordt gedreven. Of zoals Luhmann het zelf ziet:

'Man könnte geradezu sagen, daß das gesamte kommumikative Geschehen durch eine Beschreibung der beteiligten Mentalzustände beschrieben werden könnte - mit der einzigen Ausnahme der Autopoiesis der Kommunikation selber. Wenn es auf eine Beschreibung momentaner Zustände ankommt, wäre also ein 'psychischer Reduktionismus' oder auch ein 'methodologischer Individualismus' möglich; nicht aber wenn die autopoietische Dynamik des Kornmunikationssystems miterfaßt und miterklart werden soll. ${ }^{336}$

Interessant aan deze uitspraak is natuurlijk de manier waarop het klassieke deel/geheel-probleem, of zo men wil: de tegenstelling tussen methodologisch individualisme en methodologisch holisme, wordt getransformeerd in een temporele verhouding. Dat neemt niet weg, dat dit citaat in zeker opzicht ook irriteert. Over de gehele linie beschouwd, lijken we ons uiteindelijk met een platte tautologie te hebben ingelaten. Uit de algemene bepaling van 'autopoietisch' volgt immers per definitie, dat een autopoietisch systeem een systeem is, dat de elementen waaruit het bestaat zelf (re)produceert middels de elementen waaruit het bestaat. Autopoietische systemen zijn, anders gezegd, op het niveau van hun basale operaties 'zelfreferentieel gesloten'. Nemen we nu aan dat sociale systemen autopoietische systemen zijn en dat hun elementaire eenheden worden gevormd door communicaties, dan volgt daaruit, eo ipso, dat communicaties in en door communicatieprocessen zelf worden 'gesynthetiseerd' en als zodanig niet kunnen worden gereduceerd op de intenties, motieven of aanverwante mentale toestanden van de betrokken psychische systemen. Als autopoietische systemen zijn sociale systemen per definitie 'operationeel gesloten': alleen communicaties kunnen op communicaties volgen, alleen communicaties : kunnen communicaties controleren, tegenspreken, repareren, etc. ${ }^{377}$ Inderdaad, psychische systemen kunnen niet

336. Die Whissenschaft der Gesellschaft, op.cit., p.38-39.

337. Verg. N. Luhmanm, 'Was ist Kommunikation', opgenomen in: idem, Soziologische Aufklarning 6, Opladen 1995, p. 118. 
communiceren en sociale systemen kunnen zich nergens van bewust zijn, als geldt dat de voor hen constitutieve operaties (bewustzijn resp. communicatie) slechts binnen de eigen systeemgrenzen kunnen worden voltrokken. ${ }^{318}$

Welnu, wanneer Luhmann het tot zijn strategische maxime rekent "vor allem den nichtpsychischen Charakter sozialer Systeme zu betonen' ${ }^{339}$, dan lijkt hii zich met de bepaling van sociale systemen als autopoietische systemen, bij voorbaat al van de gewenste uitkomst te hebben verzekerd. En in dit licht begint de hele ondermeming er ineens verdacht, zo niet 'onecht' wit te zien. De critici lijken althans een punt te pakken te hebben, wanneer ze naar voren brengen, dat alle bepalingen die Luhmann aan 'communicatie' meegeeft, stuk voor stuk de uitdrukking zijn van een veel eerder genomen beslissing, namelijk de sociale werkelijkheid hoe dan ook als een realiteit 'sui generis' te willen beschouwen, voor de modellering waarvan 'zelfreferentialiteit' en 'autopoiesis' zich vervolgens als de meest geavanceerde concepten of schema's aanbieden.

$\mathrm{Nu}$ geldt voor omvattende theoretische projecten in het algemeen, dat ze doortrokken zujn van circulaire structuren. Daaraan kunnen en hoeven ze zich ook niet te onttrekken. Dat neemt niet weg, dat Luhmann wel degelijk 'onafhankelijke' argumenten aandraagt ter ondersteuning van zijn these van de operationele geslotenheid en (relatieve) autonomie van sociale systemen vis-àvis psychische systemen - argumenten die in die zin 'onathankelijk' kunnen worden genoemd, dat ze eerder van fenomenologisch descriptieve aard zijn, dan implicaties of herhalingen van het model van zelfreferentiële systeemconstitutie. Daarmee verkrijgt zijn positie in ieder geval meer substantialiteit en empirische plausibiliteit, dan we aan een al te kort gesloten cirkelredenering zouden toekennen.

Zo kan Luhmann er met een direct appel aan onze alledaagse routines en intuities op wijzen, dat het voor communicatieprocessen doorgaans helemaal niet vereist is, of zelfs maar van belang, dat de ontvanger van een communicatieve offerte, de 'begrijper', inzicht heeft in het bewustzijnsleven van de mededeler. ${ }^{340}$ Een journalist mag dan aan een voetballer vragen, wat er door hem heen ging toen hij voor het beslissende schot uithaalde, maar doorgaans vraagt niemand zich bij het lezen van de ochtendkrant af wat er cloor de journalist is heen gegaan in wiens stukje men zich nu probeert te verdiepen. Wie

338. Verg. N. Luhmann, "Wie ist Bewultsein an Kommunikation beteiligt', opgenomen in: idem, Soziologische Aufklärung 6 , op cit, p. 38.

339. Sozicle Systeme, op.cit., p. 32.

340. Vergelijik voor het voligende onder meer Luhmanns reactie op Wil Martens, gepubliceerd onder de rake en tegelijkertijd humoristische titel "Wer kennt Will Martens" in het K.Z.E.S.S. Jg.44 (1992) [.p. 139 - 142]. Voor de wolledigheid - Wil Martens had in zijn artikell "Die Autopoiesis sozialer Systeme" (K.Z.fSS. Jg.43 (1991), 625 - 646.) voorgesteld om wat Luhmann als "componenten" van én communicatie beschouwt - informatic, mededeling en begrip -, op te vatten als afzonderlijke 'elementen' op het niveau van de deeinemende organisch-psychische systemen - dit met de bedoeling Luhmanns scherpe scheiding tussen het psychische en het sociale te relativeren. 
bekommert zich om de zieleroerselen van een romanschrijver, wanneer hij zich laat meeslepen door de zieleroerselen wan de romanhelden en -heldinnen? Wie komt er bij het lezen van Teletekst of soortgelijke databestanden uberhaupt op het idee, on zich druk te maken over de bewustzijnsprocessen die zich ongetwijfeld hebben afgespeeld bij het opstellen en invoeren van de opgevraagde gegevens? En toch, zonder ook maar iets van de mededeler en zijn psychisch lewen af te weten, lezen we geinteresseerd de krant, verliezen we ons als vanzelf in een roman en zijn we al of niet tevreden over de laatste beursberichten.

Dat alles gat niet alleen op, voor wat we 'anonieme' communicatie zouden kunnen noemen, voor de communicatie tussen een Alter en een Ego die elkaar niet kennen. Ook de alledaagse communicatie onder aanwezigen kan het met een zeer hoge mate van 'psychische intransparantie' stellen. Uit eigen ervaring weet iedereen, dat het deelnemen aan een gesprek geenszins impliceert dat we onszelf voortdurend afvragen wat er 'in het hoofd' van de ander om gaat. En die 'onverschilligheid' neemt naarmate het gespreksonderwerp ingewikkelder wordt alleen maar toe. We concentreren ons normaliter op de informationele component van een uiting en niet op de mededelingscomponent, niet op de vraag waarom iemand überhaupt iets meedeelt, waarom hij niet iets anders meedeelt of waarom hij deze mededelingsvorm kiest en niet een van de talloze andere mogelijkheden. Voor zijn vrouw mag dat laatste vaak van belang zijn geweest, de meeste mensen hebben al moeite genoeg om de informationele inhoud van Einsteins uitingen te verwerken.

Tot een zelfde soort bevindingen komen we, wanneer we de zaak van de andere kant benaderen, d.w.z. niet vanuit het perspectief van de geadresseerde, van degene die 'begrijpt', maar vanuit het perspectief van degene die iets wil meedelen. Ook hier kent iedereen uit eigen ervaring het gevoel, dat hij vaak maar half, of niet begrepen wordt, dat zijn intenties lijken te worden verdraaid, dat er uiteindelijk heel iets anders van wordt gemaakt, dan was bedoeld kortom: dat het communicatieproces met zijn uiting op de loop gaat, zonder dat hij nog greep heeft op de uitkomst ervan. En dat, terwijl het naar ons eigen gevoel vaak al een behoorlijke worsteling is, om ook maar enigszins adequaat tot uitdrukking te brengen wat we denken, voelen of waamemen. Ons bewustzijnsleven ontsnapt ons bij onze pogingen erover te berichten;", het is veel te rijk om op een ook maar enigszins omvattende manier te worden verwoord. ledere gedachte, iedere voorstelling van ons bewustzijn ligt ingebed in een onmetelijk veld van associaties, is alls betekenisvolle beleving verbonden met talloze andere belevingsmogelijkheden. Wat we daarvan aan communicatie prijsgeven is slechts een uiterst magere selectie. Luhmann formuleert het fraaier:

'[S]chon bei einer geringen Aufmerksamkeit auf das, was wir selber sagen, wird uns bewußt, wie unscharf wir auswählen müssen, um sagen zu können, was man sagen kann; wie sehr das herausgelassene Wort schon nicht mehr das ist, was gedacht und 
gemeint war, and wie sehr das eigene Bewußtsein wie ein Irrlicht auf den Worten herumtanzt: sie benutzt und verspottet, sie zugleich meint und nicht meint, sie auftauchen und abtauchen läßt, sie im Moment nicht parat hat, sie eigentlich sagen will, und es dann ohne stichhaltigen Grund doch nicht tut."341

Het zijn dit soort, intuittief toegankelijke bevindingen die een zekere plausibiliteit verlenen aan Luhmanns scheiding van het psychische en het sociale, van bewustzijn en communicatie. Het gaat hem bovendien niet om een scheiding in een of andere substantiele of ruimtelijke zin. Het is de gescheidenheid van de onderscheiden selectiviteit van een tweetal processen. De ervaring, dat de communicatie telkens weer met onze woorden en bedoelingen op de loop gaat, dat wij communicatieprocessen nooit definitief onder controle krijgen, maar dat desalmiettemin communicatieprocessen een observeerbare orde en selectiviteit vertonen, wordt door Luhmann theoretisch zo verdisconteerd, dat de functie en betekenis die een uiting voor een bepaald communicatieproces heeft, in en door dat proces zelf tot stand wordt gebracht. Daarbij wordt die uiting in een samenhang van voorafgaande en mogelijk aansluitende uitingen ondergebracht, die (ondanks haar selectiviteit) voor het psychisch systeem, dat de uiting intendeerde, over-complex is. Bezien we de verhouding tussen het psychische en het sociale vanuit het sociaal systeem, dan geldt een zelfde principe. De verwijzingsrijkdom van het bewustzijnsleven is op haar beurt over-complex voor het communicatieproces, waarbij eveneens geldt dat de communicatie er nooit in slaagt de bewustzijnsprocessen van de betrokken psychische systemen in de greep te krijgen, de opeenvolging van mentale gebeurtenissen definitief te controleren."Voor sociale: systemen verschijnt deze ongrijpbaarheid van de betrokkenen als de dubbele contingentie die ze zelf - precies als communicatieprocessen! - uitlokken en die ze door de ontwikkeling van eigen structuren moeten neutraliseren. Wat Luhmann m.a.w. constateert en met concepten. als autopoiesis/zelforganisatie/zelfreferentiele geslotenheid/etc. theoretisch vast wil leggen, is, dat een en dezelfde gebeurtenis, in casu een communicatieve uiting, weliswaar van betekenis kan zijn voor zowel een psychisch als een sociaal systeem, maar dat het binnen beide systemen met andersoortige elementen - resp. met voorstellingen en communicaties - verknoopt wordt, waarbij onderscheiden selectiecriteria en mechanismen in het geding zijn:

'Die Einheit eines Einzelereignisses, eines einzelnen Gedankens oder ein einzelnen Kommunikation, kann immer nur im System unter rekursiver Vernetzung mit anderen Elementen desselben

341. N. Luhmann, "Was ist Kommunikation", opgenomen in" Soziologische Atfflarwng 6, op.cilt, p. 123. 
Systems erzeugt werden. Für jede Produktion von fur das System unauflösbaren Letztelementen, aus denen das System besteht, ist die Verweisung auf andere systemeigene Elemente und die Regulierung der Auswahl dieser Verweisung durch systemeigene Strukturen unerlaßlich: ${ }^{\text {:342 }}$

En daarmee zijn we bij het springende punt aangekomen Mogen de bevindingen en ervaringen die we 'op weg' naar een autopoietische interpretatie van 'communicatie' hebben aangestipt, intuitief nog toegankelijk zijn, op het moment dat we er bij zijn aangekomen, voltrekt zich een 'Gestaltswitch" met contra-intuitieve implicaties. Wat met het idee, dat communicatieprocessen voor zichzelf (1) de betekenis en informatieve waarde van een communicatie vaststellen namelijk wordt geforceerd, is een onderscheid tussen het 'begrijpen" van een psychisch systeem en het 'begrijpen' dat als component van een communicatie fungeert, tussen 'psychisch begrijpen" en 'communicatief' begrijpen. Een psychisch systeem kan proberen zich 'in te leven' in een ander systeem, d.w.z. voor zichzelf de onderscheidingen en zinschema's trachten te reconstrueren die aan de autopoiesis van een ander bewustzijn ten grondslag liggen. ${ }^{343}$ In die algemene zin kunnen we zeggen, dat ook psychische systemen kunnen 'verstehen'. Alleen is dat niet het 'begrijpen', waar het in communicatieprocessen op aan komt. Het communicatieve begrijpen is niet uit op het transparant maken van de betrokken psychische systemen. Het zou voor communicatieprocessen onbegonnen werk zijn voortdurend te controleren of, en hoe de deelnemers de medegedeelde informatie voor zichzelf begrijpen, met welke andere bewustzijnsinhouden de informatie wordt verknoopt, wat daarbij wordt uitgesloten, etc. Waar door aansluitende communicaties over wordt beschikt, is m.a.w. niet de belevingsstroom van een deelnemer, maar het lot dat een mededeling in het verdere verloop van de communicatie is beschoren welke interpretatie deze verkrijgt, welk communicatief belang eraan wordt gehecht en wat het binnen de communicatie aan andere communicaties bewerkstelligt of witlokt. Communicatief begrijpen komt tot stand door de aansluitingswaarde van een 'opvolgende' mededeling, met als eventuele mogelijkheid dat de "aansluiting" bestaat uit het ter discussie stellen, tegenspreken of afwijzen van de voorafgaande mededeling. "Was als Verstehen erreicht ist', zo merkt Luhmann op, 'wird daher im Kommunikationsprozeß3

342. N. Luhmann, Die Whissenschaft der Gesellschaft, op.cit, p. 30. Op pagina 37 heet het: 'Selbst wenn ... Systeme Ereignisse teilen; zum Beispiel eine sprachliche Kommunikation immer auch Ereignis in einer Mehtheit won teilnehmenden BewuBtseinen ist, andert das nichts an einer vollständigen "Trennung der Systeme, weil das Ereignis von den jeweiligen Systemen um Hinblick auf jeweils andere eigene Ereignisse anders identifiziert wird. Jedes System hat ... ein eigenes Gediachtnis und organisiert eigene Vorgriffe auf eigene anschluBfahige Operationen.'

343. Zie hierover o.a. N. Luhmann, "Systeme verstehen Systeme", in: N. Luhmann/K.E. Schorr( Hg), Zwischen Intransparanz und Verstehen. Fragen an die Pädagogik, Frankfirt/M. 1986, p. $72-117$. 
souverän entschieden und als Bedingung fürs Weitemachen bzw. für kärrende Zwischenkommunikation markiert". ${ }^{344}$

Indien echter geldt, dat het communicatieve begrijpen scherp moet worden onderscheiden van iedere vorm van psychisch begrijpen, dan kan het niet anders, of ook de componenten "mededeling' en 'informatie" moeten in een nietpsychische zin worden opgevat. We moeten althans tussen een communicatieve en een psychische betekenis van 'mededelen' en 'informatie' onderscheiden. Hoe on/zeker een communicatiedeelnemer zich voelt over de keuze van zijn woorden en welke innerlijke motieven hij heeft om uberhaupt een mededeling te doen, is vanuit het sociaal systeem beschouwd, niet per se relevant - hooguit als een bijzonder communicatiethema. Op het niveau van de communicatie geldt in eerste instantie slechts de 'Selbstfestlegung', de geobserveerde/ begrepen" selectiviteit, de symbolen/woorden die gebruikt zijn en de wijze waarop deze door opvolgende communicaties als teken voor een bepaalde informatie worden benut én vastgelegd. De component 'informatie' heeft hier geen betrekking op een meer of anders 'weten' van een communicatiedeelnemer, maar op de bijdrage die de mededeling aan het gespreksthema levert en op de manier waarop zij door volgende mededelingen als "inhoudelijke brandstof' wordt verbruikt. Informatief is een mededeling dan in termen van zijn eenmaligheid en onderscheidenheid van andere mededelingen en vervolgens in termen van zijn verrassingswaarde als bijdrage aan het gespreksonderwerp, in welke mate de mededeling het thema verrijkt, $d$ w.z. de weg vrijmaakt voor een nieuw type bijdragen, nieuwe perspectieven opent, etc. Daarmee wordt niet tegengesproken, dat een communicatie ook altijd eem verandering bij de 'ontwanger' bewerkstelligt en in die zin een psychisch systeem 'informeert", Alleen is dat niet het 'telos", het intrinsieke doel van het communicatieproces zelf. Sociale systemen hebben slechts als 'doel' hun autopoiesis zeker te stellen. Luhmann:

'Also ist das, was man traditionell als das Wesen der Kommunikation ansieht, nämlich die 'Ubertragung' von Information (Nachrichten, Bedeutungen, etc.), nur ein Nebeneffekt, den sie in ihrer psychischen Umwelt auslöst und den sie selbst mangels Zugang zu dieser Umwelt nicht kontrollieren kann. ${ }^{, 345}$

Deze, voor Luhmann principiële scheiding tussen bewustzijn en communicatie en zijn insisteren op een niet-psychische interpretatie van "mededeling", 
'informatie' en 'begrip' als componenten van communicatie ${ }^{346}$, heeft ook woor welwillende lezers telkens weer een struikelblok gevormd. ${ }^{347}$ De redenen liggen voor de hand. We weten simpelweg, dat alle communicatie betrokken deelnemers veronderstelt en voor ons zijn deze deelnemers eerst en vooral met bewustzijn begiftigde "mensen". Zonder bewustzijn, zonder de operaties van minstens twee psychische systemen loopt er aan communicatie helemaal niets. We zijn er bovendien zeker van, dat de bijdragen van de betrokkenen aan een communicatieproces - en in ieder geval die van onszelf - niet willekeurig zijn, geen "at random" selectie voorstellen, maar door het bewustzijn geselecteerde reacties zijn. (Hoe zouden we dat ook kunnen -, ons eigen bewustzijn bewust als een willekeurige opeenvolging van voorstellingen voorstellen?) We zijn er vervolgens ook van overtuigd, dat ons begrip van andermans uiting er iets toe doet; net als de intenties en motieven die ten grondslag liggen aan onze pogingen om een ander over iets te informeren. Juist als psychische systemen kunnen we ons niets voorstellen bij een communicatie die niet door onze eigen observaties en intenties wordt gedreven en gedragen; en we begrijpen al helemaal niet waarom we energie en aandacht in communicatie zouden investeren, als ons eigen toedoen er niet toe doet.

In hoeverre worden dergelijke intuities nu door Luhmann ontkend, of door zijn model van communicatie tegengesproken?

"D] a/3 menschen an Kommunikation beteiligt sind und daß ohne Menschen keine Kommunikation zustandekäme' zo schrijft Luhmann zelf; "ist kein sinnvoller Streitpunkt' ${ }^{348}$ Dat wordt al geimpliceerd door het feit, dat communicatie nog altijd het vermogen tot (zintuiglijk) waarnemen wooronderstelt - het horen van geluiden, het zien van letters, etc. Sociale systemen kunnen niet waarnemen, zijn wat dat betreft volledig aangewezen op het waarnemingsvermogen van psychische systemen. ${ }^{349}$

Geen communicatie zonder bewustzijn dus - daar is Luhmann het mee eens. Waarnemingen zijn echter mentale gebeurtenissen en geen communicaties. Natuurlijk kunnen waarnemingen de aanleiding vormen voor een communicatie. Deelnemers kunnen over hun waarnemingen berichten, masr dit slechts onder de voorwaarde van communicatie, $d . w . z$, in de worm van een informerende

346. 'Das firm die Kommunikation notwendige Verstehen', zo commentarieert Schneider, "ist ebensowenig psychologisch za begreifen, wie die Unterscheidung von Mitteilung und Irformation' (W.L. Schneider, Objektives Verstehen, Opladen 1991, p.187.)

347. Verg. naast de al eerder genoemde Martens, w. A. U. Schimank, 'Gesellschattiche Teilsysteme als Akteurtiktionen", in: K.Z.F.S.S, $40(1988,3), 619 \mathrm{ev} ;$, J. Weyer, "System und Akteur", in idem $45(1993)$, p $1-22$.

348. N. Luhmann, "Wer kennt Wil Martens.", op.cit., p.139.

349. Het neerstorten wan een vifegtaig maakt meestal een einde aan alle communicatie binnen diat vithgtuig, mar hoeft als zodanig echter de lopende conmunicatie aan boord niet te beroeren. Dat laatste kan pas gebeuren (en zat naar alle waarschijnijikheid ook gebeuren) wanneer het neerstorten wordt wargenomen door een piloot of een wan de passagiers en daar vervolgens ook melding van wordt gennankt. 
mededeling, die van een gedeelde "taal' gebruik maakt, die tijd verbruikt, die voor de ander hoorbaar of zichtbaar is, etc. Het bericht over wat is waargenomen, is niet die waarneming zelf, is niet een voorstelling van het bewustzijin, maar een communicatieve gebeurtenis, een moment van de autopoiesis van een sociaal systeem. ${ }^{350}$

Laten we bovendien in herinnering roepen wat we eerder (Hoofdstuk I) in algemene zin stelden, namelijk dat de autonomie van een autopoietisch systeem miet inhoudt, dat een dergelijk systeem in het luchtledige bestaat en op geen enkele manier afhankelijk is van andere systemen. Autopoietische systemen zijn opgenomen in een materieel continuum, waarbij andere systemen telkens als hun emergentiebasis fungeren. Over deze gronden en oorzaken van hun bestaan kunnen autopoietische systemen niet vrijelijk beschikken. Dat heeft volgens Luhmann overigens ook altijd in de lijn gelegen van het traditionele begrip van (re)produktie, "der ja noch nie bedeutet hat, daß alle notwendigen Ursachen in der Hand des Systems liegen, sondern eben nur die fur das Entstehen des Werkes, für die Autopoiesis des Systems, für die Erzeugung von Differenz notwendigen'. ${ }^{351}$ Dit alles is van meet af aan 'mee-gedacht', wanneer Luhmann opmerkt, dat sociale systernen ontstaan op grond van de ruis die psychische systemen produceren in hun pogingen met elkaar te communiceren ${ }^{332}$. 'Psychische Systeme sind als Umwelt sozialer Systeme an deren Konstitution beteiligt, sie sind Bedingung der Emergenz sozialer Systeme .... ${ }^{3,35}$

Dit laatste citaat wijst er al op, dat niettegenstaande het strikte - en voor Luhmann ook: empirische! - onderscheid tussen de operaties 'bewustzijn' en 'communicatie', psychische en sociale systemen in een bijzondere relatie tot elkaar staan. Psychische systemen behoren niet simpelweg tot de nu eenmaal gegeven systemen in de omgeving van een social systeem; ze staan in een andere relatie tot sociale systemen als bijv. organische of fysische systemen. Aan die bijzondere relatie tussen thet psychische en het sociale heeft Luhmann tot noch toe getracht inhoud te geven middels de concepten 'structurele koppeling' en 'interpenetratie'. Deze begrippen vormen bij Luhmann min of meer het complement van de these "daß Menschen nicht Teile oder Elemente sozialer Systeme sein können'.

Met de term 'structurele koppeling' wil Luhmann om te beginnen tot uitarukking brengen, dat alle communicatie corresponderende bewustzijnsprocessen veronderstelt. Preciezer geformuleerd: communicatie is slechts mogelijk onder de voorwaarde van een synchronisatie tussen psychische

350. Werg. N. Luhmann, "Wie ist BewuBtsein an Kommunikation beteiligt?", op.cit, p.45; Idem, "Was ist Kommunikation?", op cit., p.115/116.

351. N. Luhmann, "Die operative Geschlossenheit psychischer und sozialer Systeme", in: Soziologische Aufflärung 6 , op.cit., p. 28.

352. Soziale Systeme, op cit., p.292.

353. N. Luhmann, "Individuum, Individualitat, Individualismus", in: Gesellschaftsstruktur" und Sewnantik III, op, cit, p. 162. 
en communicatiewe gebeurtenissen. Synchronisatie moeten we hier letterlijk opvatten in de zin van 'gelijktijdigheid'. Nu kan er tussen gebeurtenissen die zich gelijktijdig voltrekken natuurlijk geen causale relatie bestaan - 'was gleichzeitig existiert, entzieht sich einer kausalen Beeinflussung, einer Kontrolle durch Eingriffe, durch Anreize oder durch Normen. Strukturelle Koppelungen sind auf der Ebene der Zustände, Ereignisse und Operationen schlicht gegeben - so wie der Schwerkraft bei der Bewegung der Organismen'. Middels het concept 'structurele koppeling' wil Luhmann ma.w. voorkomen, dat de meest basale relatie tussen een psychisch en een sociaal systeem als een causale relatie moet worden opgevat. Naturilijk is het voor een observator mogelijk om causale relaties op de verhouding tussen psychische en sociale systemen te projecteren, bijv. een bepaalde waarneming van een der betrokkenen als "oorzaak' van een specifieke communicatie aan te merken. Dat is in Luhmanns ogen echter al cen behoorlijke simplificatie, die als reductie van complexiteit natuurlijk functioneel kan zijn, maar tegelijkertijd buiten beschouwing laat, dat het als 'oorzaak' aangemerkte bewustzijn ook na de uiting nog present moet zijn en dat bovendien gedurende de uiting ook nog een ander psychisch systeem moet functioneren. Het model van structurele koppeling stevent in Luhmanns ogen af op een 'rijkere' interpretatie van de verhouding tussen het psychische en sociale:
'In der hier vertretene Theorieversion ist das Bewußtsein nicht weniger, sondern mehr an Kommunikation beteiligt - allerdings nicht im Sinne eines Ursachen setzenden Subjekts. Von struktureller Kopplung spricht man, um die Bedingungen der Ausdifferenzierung von Systemen auf der Basis eines fortbeste- henden Materialitätskontinuums zu beschreiben, nicht: um eine Kausalerklärung zu geben. ${ }^{354}$

Het gaat bovendien om een synchronisatie van gebeurtenissen en niet om een koppeling tussen psychische en sociale structuren. Die restrictie is min of meer gedwongen, gegeven de aanname dat het om een relatie tussen autopoietische, d.w.z. zichzelf (autonoom) organiserende en structurerende systemen gaat. De relatie tussen dergelijke, per definitie getemporaliseerde systemen kan niet gedacht worden in termen van een koppeling of 'verkleving' op het niveau van hun structuren. Positiever geforniuleerd: precies omdat de koppeling tussen psychische en sociale systemen telkens mee 'oplicht en uitdooft' met de gebeurtenissen die de elementaire eenheden van de betrokken systemen vormen, behouden deze systemen hun 'autopoietische vrijheid', d.w.z. de vrijheid (maar ook de dwang) om op ieder volgend moment nieuwe eigen gebeurtenissen/elementen te selecteren en zo de voorafgaande gebeurtenis onder te brengen in 
een systeem-eigen sequentie, met behulp van eigen structurerings- en selectieprincipes. Alhoewel een mededeling dus voor zowel een sociaal systeem als de betrokken psychische systemen tegelijkertijd van betekenis is, een 'Coereignis' produceert, blijven ze qua systemen, i.e. qua gestructureerde processen volledig gescheiden. In de woorden van Luhmann:

\begin{abstract}
"Wenn man den Zusammenhang von BewulBtseinsoperationen und Kommunikationen mit dem Begriff der strukturellen Kopplung beschreibt, heillt dies also, das die entsprechenden Systeme vollständig getrennt operieren. Es gibt keinen Einbau von Operationen des einen Systems in das andere, etwa so daß es zu einer Sequenz von Denken und Kommunizieren und weiterem Denken und Kommunizieren als Modus der Selbsttransformation ein und desselben Systems kommen könnte. ${ }^{.355}$
\end{abstract}

De vraag is natuurlijk, hoe de structurele koppeling tussen psychische en sociale systemen telkens weer, van gebeurtenis op gebeurtenis, tot stand wordt gebracht. Wat houdt een betrokken bewustzijn 'bij de les'? Hier grijpt Luhmann terug op het fenomeen taal. Taal bestaat uit pregnante akoestische of optische vormen die, wanneer ze worden waargenomen, het bewustzijn "fascineren". Juist door haar pregnantie tegen een achtergrond van akoestische of visuele ruis lijkt een psychisch systeem zich niet of slechts met moeite aan taal te kunnen onttrekken - "Sprache und Schrift faszinieren und präokkupieren das Bewußtsein und stellen dadurch sicher, das es mitzieht, obwohl die Eigendynamik des Bewußtseins dies keineswegs notwendig macht und stets Ablenkungen bereithalt. ${ }^{356}$ Daarmee wordt nogmaals de cruciale rol die Luhmann aan taal toekent, bevestigd. Zonder gesproken of geschreven taal zouden sociale systemen zich niet of nauwelijks kunnen ontwikkelen. Maar natuurlijk blijft voor hem gelden, dat taal niet een of ander supersysteem is, dat de structuren en processen van psychische en sociale systemen als het ware 'achter hun rug om' harmoniseert en op elkaar afstelt. Als symboolsysteem bemiddelt taal bij de gemeenschappelijke actualisering van meer of minder identieke zin. Maar daarmee worden psychische systemen voor elkaar nog niet transparant; het gebruik van betekenisvolle woorden legt niet vast hoe psychische systemen het medegedeelde vervolgens in hun operaties verwerken of welke structuurveranderingen er door worden uitgelokt. Door taal worden ook sociale systemen niet opeens transparant voor de deelnemende psychische systemen. In tegendeel - de semantische rijkdom van de taal levert een enorm overschot aan verwijzingsmogelijkheden die in communicatieprocessen tegelijkertijd worden bemut en afgebouwd, maar die voor een betrokken bewustzijn niet vallen te

355. N. Luhmann, 'Die operative Geschlossenheit psychischer und sozialer Systeme', op.cüt., p 32.

356. N. Lulumann, "Wie ist BewuBtsein an Kommunikation beteiligt?" "op.cit., p.41. 
averzien. Het ene woord ontlokt het andere, dat is zeker - maar niet wélk andere.

We hebben tot nog toe wooral stil gestaan bij de aard en modus van de intersystemische relatie die Luhmann met zijn concept van structurele koppeling op het oog heeft, maar nog nauwelijks bij de effecten of de functie ervan. De veronderstelde 'structurele koppeling' is kortom nog niet op het niveau van een functionele analyse gebracht. Nu zou men naturilik kunnen opmerken, dat de algemene functie van structurele koppelingen erin bestaat de kloof tussen psychische en sociale systemen te dichten en sociale systemen van hun emergentiebasis te verzekeren. Vooralsnog wordt daarmee alleen maar gewezen op de functie die het concept 'structurele koppeling' binnen de theorie vervult, of althans dient te vervullen. Het zegt bijv. nog niets over de systeeminteme effecten die door een aldus begrepen koppeling tussen het psychische en het sociale worden gesuggereerd. Dát er zulke effecten moeten zijn, volgt alleen al uit de aanname, dat het om de synchronisatie van gebeurtenisreeksen gaat die de 'substantie' van onderscheiden typen systemen vormen. Dit impliceert onder meer dat het tempo van de communicatie aangepast moet zijn aan de beweeglijkheid en het reactievermogen van psychische systemen. Er mag bijv. niet te snel worden gesproken of van thema gewisseld, te veel logische operatoren ineens op elkaar worden gestapeld, etc. Gegeven het altijd beperkte vermogen tot het waarnemen van onderscheidingen en het onderscheidene informationeel te verwerken, moeten sociale systemen bovendien al snel tot 'turn-taking' overgaan: De betrokkenen dienen 'om de beurt te spreken' — dat, terwijl ze heel goed in staat zijn tegelijkertijd door elkaar heen te schreeuwen.

Meer in het algemeen dienen we er vanuit te gaan, dat de structuren van sociale systemen tegelijkertijd de reproduktie van structurele koppelingen met psychische systemen mogelijk moeten maken. In die zin zijn sociale systemen 'altijd al' aangepast aan de beperkingen en begrenzingen wan psychische systemen. En in die zin kumnen we ook zeggen, dat het feit, dat sociale systemen structureel gekoppeld zijn met psychische systemen zich uitdrukt in specifieke structuren als vormen van 'zelfbeperking'. Anderzijds moet Luhmann er vanuit gaan, dat de aangepastheid van sociale aan psychische systemen - en vice versa - altijd beperkt is. Bij een volledige onderlinge aanpassing van sociale en psychische systemen zouden we niet meer over onderscheiden, autonome systemen kuinnen spreken. Maar dat impliceert, dat structureel gekoppelde systemen elkaar ook altijd met 'onaangepastheid' confronteren, met niet direct reduceerbare complexiteit, met "ruis" - 'mit der Folge, daß im jeweils irritierten. System strukturelle Unsicherheiten entstehen, für die dann eine Lossung gesucht werden muß, die mit der Fortsetzung der Autopoiesis des Systems - mit weiterem Denken, mit weiterem Komnunizieren - kompatibel ist $^{3}, 357$

357. N. Luhmann, 'Die operative Geschlossenheit psychischer und sozialer Systeme', op.cit. p.32. 
De functie van structurele koppelingen zouden we nu in een eerste aanloop daarin kunnen zien, dat langs deze weg systemen die voor elkaar 'systemen-inde-omgeving' zijn, elkaar onderling van ruis voorzien en dit als prikkel voor een verdergaande op- en uitbouw wan hun eigen structuren. Maar welke systemen kunnen voor een sociaal systeem op die manier omgevingssystemen zijn? Natuurlijk kan over fysische, chemische, organische, etc. systemen worden gecommuniceerd en in die zin blijft gelden, dat de 'omgeving' binnen sociale systemen 'aanwezig' is in de vorm van 'informatie'. Zoals we echter al opmerkten, kunnen sociale systemen niet 'waarnemen'; ze opereren, om het zo uit te drukken, blind - ook m.b.t. de (niet-sociale) systemen in hun omgeving. Voor alle informatie omtrent de materiële omgeving zijn sociale systemen uiteindelijk afhankelijk van de bereidheid van psychische systemen om over hun waamemingen te berichten. Al het contact dat sociale systemen met de fysische, chemische, organische, etc. omgeving hebben, wordt m.a.w. bemiddeld en gefilterd door bewustzijnssystemen. 'Das Bewu/3tsein ist der 'Raum' oder der "Phenomenbereich" zo parafraseert Luhmann de Chileense bioloog Maturana, 'in dem die Autopoiesis von Kommunikation möglich ist' ${ }^{358}$

Indien al het contact tussen sociale systemen en hun niet-sociale omgeving echter door psychische systemen wordt bemiddeld, als fysische, chemische of biologische verschijnselen nooit direct van invloed op sociale systemen kunnen zijn, dan moeten we aannemen dat de koppeling tussen psychische en sociale systemen exclusief is, dat sociale systemen alleen met psychische systemen 'structureel gekoppeld' zijn en ook alleen door het bewustzijn van de telkens betrokkenen kan worden geïriteerd. 'Gewiß kan die Kommunikation auf' physische und chemische Weise oder durch Vernichtung des Lebens beendet werden', zo schrijft Luhmann - 'Sie kan auf diese Weise aber nicht irritiert, gestört, gereizt, stimuliert, beeinflußt werden. Zur Aufnahme von Einflussen der Umwelt unter Erhaltumg der Autopoiesis des Kommunikationssystems ist die Vorfilterung durch Bewußtsein erforderlich. ${ }^{359}$

Al met al impliceert dit een extreme reductie van complexiteit. Het contact met; en de irriteerbaarheid door de externe werkelijkheid verloopt voor sociale systemen via een zeer smalle zone. De keerzijde, of her "voordeel" ervan is duidelijk. Sociale systemen kunnen zich nu geheel en al instellen op de ruis die psychische systemen veroorzaken. Door te zijn afgesloten van alle andere mogelijke vormen van intersysternische ruis en irritatie, zo zou men kunnen zeggen, worden saciale systemen des te gevoeliger voor de onaangepastheid, overcomplexiteit oftewel 'ruis' van de kant van psychische systemen. Men zou tegen deze achtergrond en met als referentieprobleem de voor autopoietische systemen noodzakelijke input van 'ruis', i.e. van extern geinduceerde storingen en prikkels, de functie van structurele koppelingen tussen psychische en sociale 
systemen, nu (met Luhmann) als volgt kunnen specificeren: Structurele koppelingen 'verdichten und steigern die Irritabilität autopoietischer Systeme, und dies dadurch, da\} andere Irritationsquellen ausgeschlossen werden".

Wat heeft Luhmann met dit 'model' van een structurele koppeling tussen psychische en sociale systemen nu precies bereikt? Het zal om te beginnen duidelijk zijn, dat binnen Luhmanns denkraam het bewustzijnsleven van communicatiedeelnemers 'er iets toe doet'. Psychische systemen doen er op zijn minst op tweecrlei wijze toe. Om te beginnen voorzien ze in wat men de energetische en informationele hulpbronnen van communicatie zou kunnen noemen. Zonder individuele warneming en zonder de psychische intenties en motieven om naar aanleiding daarvan 'zich' úberhaupt te willen 'meedelen', kunnen sociale systemen zich niet ontwikkelen. Zeker -, Luhmann houdt vast aan de autopoietische autonomie van sociale systemen, d.w.z. aan het idee dat alleen communicatie communicatie kan sturen, structureren en controleren. Maar daarin schijnt de betrokkenheid van psychische systemen nogmaals door, $z i j$ het misschien op een negatieve manier. Wie er over nadenkt, moet namelijk tot de conclusie komen, dat indien psychische systemen communicatieprocessen wél zouden kunnen controleren, dit uiteindelijk zou impliceren, dat zij elkaar zouden kunnen doorzien en controleren en dat bijgevolg de hele notie vam 'socialiteit' of van 'sociale systemen' overbodig zou zijn. We zijn weer terug bij het begin: precies het feit, dat menselijke individuen niet in elkaars hoofd kunnen kijken', woor elkaar intransparant en contingent (niet-determineerbaar) blijven, vormt als 'dubbele contingentie' de grond voor de emergentie van sociale systemen.

Het model van structurele koppeling geeft bovendien een aanwijzing, hoe de analytische capaciteit - het theoretische 'oplossingsvermogen' — kan worden benut, die wordt opgeleverd door de beslissing om psychische en sociale systemen te beschouwen als autopoietische systemen, die voor ellkaar (bijzondere) systemen-in-de-omgeving vormen. Door de verhouding tussen het psychische en sociale te denken als een relatie tussen twee typen autopoietische, zelfreferentieel gesloten (zin)systemen, wordt het in eerste aanleg mogelijk om hun onderlinge relatie veel 'complexer' te observeren (met meer theoretisch gecontroleerde onderscheidingen te beschrijven), dan mogelijk zou zijn op basis van een model dat mensen/individuen/psychische systemen tot "delen" van sociale systemen verklaart. Het concept 'structurele koppeling' biedt vervolgens een perspectief op een vorm van intersystemische beînvloeding, dat meer recht doet aan deze complexiteit, de winst aan analytische mogelijkheden beter 'bewaart', dan middels causaliteitsvoorstellingen mogelijk zou zijn.

Luhmanns functionele bepaling van structurele koppelingen werpt tenslotte ook licht op die diepzittende "common sense" intuitie, dat wij mensen, als bewust belevende en handelende wezens, het begin- en eindpunt van alle communicatie vormen. Dat heeft niet alleen te maken met wat we het 'natuurlijk' egocentrisme van psychische systemen zouden kunnen noemen, met het feit dat alle observaties van psychische systemen uiteindelijk systeeminterne operaties zijn 
en blijwen, slechts mogelijk op basis van intern - in zekere zin: "idiosyncratisch" - gehandhaafde onderscheidingen, en dat de reflexie daarop in laatste instantie het bewustzijn slechts zijn (onontkoombare) autonomie onder ogen voert. Als Luhmanns diagnose van de exclwsiviteit van de structurele koppeling tussen psychische en sociale systemen hout snijdt, dan kan een psychisch systeem dat communicatie waarneemt en observeert, inderdaad geen andere beïnvloeding ontdekken, dan die welke van hemzelf en andere, soortgelijke systemen uitgaat. Er is voor een psychisch systeem m.a.w. geen enkele grond om iets anders dan 'bewustzijn' verantwoordelijk te houden voor het turbulente karakter van communicaties, hetgeen nog eens wordt versterkt door het feit, dat het, praktisch gesproken, communicatie slechts kan observeren in de vorm van opeenvolgende handelingen, d.w.z. in de vorm van bijdragen waarvoor telkens een der deelnemers verantwoordelijk wordt gehouden.

Wanneer we de zaak in zijn geheel overzien, lijkt Luhmanns concept van structurele koppeling echter ook aan een zekere asymmetrie te lijden. We kunnen namelijk wel vaststellen, dat er zonder "bewustzijn" geen communicatie mogelijk is; het ongekeerde geldt echter niet, althans niet in die directe, we kunnen nu bijna zeggen: triviale zin. Psychische systemen hoeven niet bij communicatie betrokken te zijn om hun bewustzijnsprocessen in gang te houden. Tegelijkertijd kumnen we ons echter, zowel op empirische als op theoretische gronden, de ontwikkeling van psychische systemen niet of nauwelijks voorstellen zonder hun deelname aan communicatie. Zo beschouwd, zijn er goede redenen voor de 'omgekeerde' stelling: 'geen bewustzijn zonder communicatie'. En Luhmann zal de eerste zijn om dit te onderschrijven.

Men zou nu het door Luhmann in verschillende 'aanlopen' geformuleerde concept van 'interpenetratie' kumen opvatten als een poging, om de hierboven gesignaleerde asymmetrie bij te stellen. Dit is natuurlijk een nogal voorzichtige manier om een suggestie te berde te brengen - maar niet zonder reden. Om te beginnen voert Luhmann 'interpenetratie' nergens expliciet op als een (reparerende) aanvulling op het concept 'structurele koppeling'. Hij lijkt het eerder op te vatten als een generalisering van elementen die al in het model van structurele koppeling besloten liggen en 'interpenetratie" bovendien meer" te associëren met het specifiekere thema van de verhouding 'mens maatschappij' dan met het algemenere en abstractere probleem van de verhouding tussen psychische en sociale systemen 'tout court'. ${ }^{3610}$ Men zou in reactie hierop natuurlijk kunnen opmerken, dat de asymmetrie die in het idee van een structurele koppeling tussen psychische en sociale systemen besloten ligt, tot op zekere hoogte ook terecht is en dat een 're-symmetrisering' van deze verhouding alleen op het (historisch en cultureel) concretere niveau van de 'vermaatschappelijkte mens' gestalte kan krijgen. Hoe dan ook - er is nog een andere reden om Luhmanns concept van interpenetratie met enig voorbehoud te 
introduceren en die is, simpelweg, dat tot nog toe zijn uitweidingen erover niet bepaald de schoonheidsprijs wan de 'Verein fur theoretische Soziologie' verdienen. Het is een 'leerstuk' waaraan Luhmann her en der aandacht besteedt, maar waarvan moeilijk kan worden volgehouden, dat het op een consistente manier tot ontwikkeling is gebracht. ${ }^{361}$ Wat, meer dan een drang naar volledigheid, een korte toelichting erop kan rechtvaardigen, is, dat Luhmann het interpenetratie-concept wil benutten alls de theoretische uitvalsbasis voor een herijking van het klassieke sociologische thema van 'socialisatie'.

Zoals bekend, stamt binnen de sociologie het begrip 'interpenetratie' af van Talcott Parsons. ${ }^{362}$ Bij Parsons duidt 'interpenetratie' op een vorm van wederzijdse beînvloeding tussen handelingssystemen die elkaar gedeeltelijk "overlappen', d.w.z. ten dele dezelfde handelingen als elementen van het eigen systeem benutten. Zo kan men zich de wetgevende acties van de tweedle kamer voorstellen als elementen van zowel het politiek systeem alls van het rechtssysteem. Voor Luhmann schuilt de cnux van het interpenetratieconcept echter niet in het idee van een overlapping van systemen - én, zo zouden we eraan toe kunnen voegen, als " overlappen' per definitie het delen van elementen zou inhouden, dan kan het onmogelijk van toepassing zijn op de relatie tussen psychische en sociale systemen. Men kan bij Luhmann hooguit spreken van een "convergentie" tussen de gebeurtenissen binnen interpenetrerende systemen en daarbij bijv. denken aan het effect dat een communicatie op de betrokken psychische systemen heeft.

Laten we nu eerst het onderscheid tussen "structurele koppeling" en 'interpenetratie" iets sterker aanzetten, door te benadrukken, dat 'structurele koppeling' specifiek betrekking heeft op de gebeurtenissen die de basale elementen van de gekoppelde systemen vormen. Met 'interpenetratie' richten we ons daarentegen op de functies die interpenetrerende systemen voor elkaar hebben qua complex gestructureerde eenheden. Interpenetrerende systemen stellen wederzijds hun eigen complexiteit aan het 'partner'-systeem ter beschikking en dit ten behoeve van de structuurontwikkeling van het telkens ontvangende systeem. Luhmann:

Interpenetration kann, wenn man das Konzept der Autopoiesis zugrund legt, nicht bedeuten, daß3 Elemente der interpenetrierenden Systeme partiell identisch sind; oder in anderen Worten; daß die Systeme sich auf der Ebene ihrer Elemente überschneiden. [-] Statt dessen könnte man immer dann von Interpenetration sprechen, wenn die strukturelle Komplexität

361. Zo behnindelt Luhmann in De Wissenschaft der Gesellschaf (op cit) een aantal zaken, die hij anders met "interpenetratie" in verband brengt, direct onder de noemer 'structurele koppeling". (verg. 0.a. p. $58-59$.

362. Zie hierover o.a. D.Berkhout, De symbolische media wan de samenleving: over interpenetratie in de moderne samenleving, Utrecht 1990. 
eines Systems für den Aufbau der strakturellen Komplexität emes anderen Systems zur verfugung gestellt wird. ${ }^{363}$

De vorm waarin dit "ter beschikking stellen" geschiedt - we herkennen een motief dat al in het concept van 'structurele koppeling' is aangelegd - bestaat er in eerste instantie uit, dat het ontvangende systeem wordt opgezadeld met 'overcomplexiteit'. We zouden de functie van 'interpenetratie' wat dat betreft ook zo kunnen aangeven, dat de door interpenetratie "ter beschikking gestelde'/aan elkaar opgedrongen" complexiteit voor het ontvangende systeem altijd de belasting met overcomplexiteit betekent en dit als ruis, als prikkel voor de eigen structuuropbouw. Zo moet een psychisch systeem om uberhaupt vloeiend aan een sociaal systeem te kunnen deelnemen, zich vergewissen van de structuren van het betreffende systeem - welke verwachtingen van hem verwacht worden en welke verwachtingen hij van anderen mag verwachten. Tegelijkertijd ontgaat hem-de reikwijdte daarvan. Sociale structuren en hun dynamiek zijn voor hem steeds 'overcomplex", hetgeen wordt 'uitbetaald' in teleurgestelde verwachtingen en in de prikkel om tot dan toe gekoesterde verwachtingen bij te stellen, dan wel bijzondere vormen van omgang met teleurstellingen te ontwikkelen. Een niet gering voordeel is echter, dat het gaat om een complexiteitservaring op basis van interpenetratie. Voor een ontvangend systeem mag de complexiteit van het penetrerende systeem weliswaar "overcomplex" zijn, het is en blijft een (zij het elders) voorgestructureerde complexiteit. Interpenetratie, zo zon men kunnen zeggen, zorgt ervoor dat systemen elkaar van voldoende ruis voorzien, zonder dat de kans groot is, dat ze elkaar onder hun complexiteit bedelven. Voorzover we er bovendien vanuit mogen gaan, dat interpenetratie altijd een verhouding tussen zinsystemen betreft, kumnen we er tevens op rekenen, dat de zinschema's die in het penetrerende systeem zijn ontwikkeld, door het ontvangende systeem kunnen worden overgenomen als reeds tot stand gebrachte reducties van complexiteit.

Dit zijn en blijven naturlijk tamelijk abstracte, sterk theoretische overwegingen. Meer handen en voeten verkrijgt het misschien - en 'leertheoretisch' gesproken ook meer positieve inhoud -, wanneer we "interpenetratie" betrekken op Luhmanns beeld van "socialisatie". De socialisatie van individuele actoren veronderstelt om te beginnen de interpenetratie van psychische en sociale systemen - 'Bewußtseinssysteme

363. N, Luhmann, Gesellschaftsstraktur und Semantik 3, FrankfuntM. 1993, p. 161-162. Verg. ook N. Lahmanu, "Wie ist BewuBtsein an Kommunikation beteiligt?", op.eit, p.SI e.v. M.b.t. het Interpenetration'-hoofidstuk van Soziale Systeme (op.cit.) heeft Luhmann mij ooit mondeling toevertrouwd, dat hij er zelf niet bijster tevreden over is. En daar kan ik inkomen. 
werden durch Interpenetration mit sozialen Systemen sozialisiert. ${ }^{364}$ Wat geordende communicatieprocessen middels taal aan zich ontwikkelende psychische systemen aanbieden, is eerst en vooral 'taal' zelf. Taal niet alleen als een, op grond van grammaticale principes geordende sequentie van semantische eenheden, maar bovendien als de "opslagkamer" van telkens (cultuur-historisch) bijzondere, sociaal geproduceerde en semantisch gefixeerde zincomplexen die handelingssamenhangen en -processen als eenheid vatten; bijv. onder het gezichtspunt van typische doelen ('aanbellen', 'winkelen', 'tuin spitten"), of als pregnante gedragsschema's/persoonsmodellen ('Bohemen", "intellectueel", "skinhead'), etc. Pas door overname van dergelijke, reeds tot stand gebrachte vormen van als 'eenheid' identificeerbare ordeningen en sequenties wordt het voor psychische systemen goed mogelijk om de eigen bewustzijnsprocessen 'episodisch' te organiseren, d.w.z. in de vorm van telkens be-eindigbare sequenties te gieten - 'deren Ende nicht das Ende des Bewußtsein bedeutet, sondern mur einen mehr oder weniger sprunghaften Übergang der Autopoiesis $\mathrm{zu}$ anderen Inhalten'. ${ }^{365}$ Zonder taal en zonder de in semantieken vervatte handelings- en gedragsmodellen over te nemen, zouden, volgens Luhmann, psychische systemen geen complexe structuren kunnen ontwikkelen, niet of nauwelijks boven het niveau van gestructureerde 'waarneming' uit komen.

Echter, de vaststelling dat psychische systemen zonder het aanbod en de overname van, in en door sociale systemen tot stand gebrachte complexiteitsreducties, dus van 'elders' geproduceerde zinstructuren, zichzelf nauwelijks zouden kunnen ontwikkelen, betekent niet, dat psychische systemen door communicatieprocessen gesocialiseerd worden. De (weliswaar voorgestructureerde) overcomplexiteit die interpenetrerende systemen bij elkaar inbrengen, betekent voor het ontvangende systeem ook altijd selectiedwang. Daarbij kan een afzonderlijk psychisch systeem - en zonder door de taal te worden gehinderd (integendeel) - minimaal tussen een ja- en een nee-versie kiezen, tussen affirmatie van de aangeboden interpretatie- en handelingsmodellen en nonconformiteit. Ook nonconformiteit, ook het zich afzetten tegen geldende patronen kan de ontwikkeling van psychische structuren in gang zetten en houden. Of zoals Luhmann het formuleert:

'Die psychische Autopoiesis kann sich auch dadurch strukturieren, daß sie nicht tut was ihr gesagt wird, sondern

364. 'Wie ist BewuBtsein an Kommunikation beteiligt?', op.cit, p. 51 . Verg. daarentegen het opstel 'Individuum, Individualitat, Indiwidualismus' (opgenomen in Gesellschaftssiraktar wnd Semantik 3) waarin het Lubmann met name om de interpenetratie tussen psychische systemen en het bijzondere socialo systeem "maatschappij" lijkt to gaan. Socialisatie bestaat erin, zo schrijft hij hier, 'daßh das autopoietische Sozialsystem Gesellschaft, das auf der Basis von Kommunikation operiert, seine Eigenkomplexităt zum Autbau psychischer Systeme zur Verfugung stellt". (op,cit.; p. 162)

365. Gesellschaftsstruktur whd Semantik 3, op.oit., p. 163. 
soziale Muster konterkariert Diese Möglichkeit wird mit zunehmender psychischer Komplexität eher steigen als fallen, weil dann auch in der Negation immer noch Ordnung und Anschlufmoglichkeiten vorgegeben sind. ${ }^{366}$

We zien, en dit ter afsluiting, hoe Luhmanns poging om de wederzijdse beinvloeding tussen het psychische en het sociale op een non-causale manier te denken, deze eerder in termen van complexiteitsuitwisseling en geconditioneerde selectiviteit te begrijpen, dan in termen van onderlinge determinatie, bij een begrip van 'socialisatie' uitkomt, dat wezenlijk om 'zelfsocialisatie' draait. Psychische systemen socialiseren zichzelf, door aan communicatie deel te nemen - en alleen tegen deze achtergrond kan men vervolgens ook zeggen, dat alle communicatie een socialisatie-effect heeft. Dit idee van 'socialisatie alls zelfsocialisatie' is natuurlijk niets anders dan een bijzonder toespitsing van het algemene principe, dat autopoietische systemen slechts op hun eigen voorwaarden door hun omgeving kunnen worden beinvloed en slechts voorzover ze daar zelf aan meewerken. 


\section{Hoofdstuk IV}

\section{HANDELING, STRUCTUUR, CONFLICT}

\section{\$1. Inleiding}

Met de schildering van sociale systemen als zelfreferentieel opererende communicatieprocessen is in grote lijnen weergegeven, hoe Luhmann de theorie van autopoietische systemen probeert te (re)specificeren en te 'vertalen' in een algemeen model van geordende sociale interactie, van 'socialiteit uberhaupt'. Daarbij moet het in elkaar grijpen van een drietal vormen van zelfreferentie duidelijk maken dat de sociale werkelijkheid een zichzelf funderende onderneming is. Sociale systemen vormen, in Luhmanns woorden, een "freischwebend konsolidierte Realität'. ${ }^{371}$ Het nu volgende sluit hier op aan en wel in de vorm van enkele specificaties van Luhmanns algemene noties 'communicatie' en 'structuur'. We zullen achtereenvolgens de thema's 'handeling', 'structurele stabilisatie' en 'conflict' aan de orde stellen, met in de kantlijn hier en daar een evaluerend commentaar, om in een afsluitende paragraaf vanuit een algemener gezichtspunt ons nog eens terug te buigen over de gehele grondslagenoperatie, daarbij dus ook het vorige hoofdstuk betrekkend.

\section{§ 2. De handeling}

In retrospectief worden zaken vaak scherper zichtbaar. Dat geldt in ieder geval voor het "tactisch' belang van Luhmanns keuze voor 'communicatie" als elementaire eenheid van sociale systemen. Eerder suggereerden we al, dat niet 'handeling', maar slechts 'communicatie' de eenheid van de zelfreferentiële cirkel die aan alle interactie inherent is, kan representeren. In zijn 'drietakt'-beweging verenigt een communicatie zowel de selectiviteit van de mededeler, als die van de 'Versteher'. We kunnen daar nu aan toevoegen, dat "communicatie' tevens staat voor een procestype dat de steriele, directe zelfreferentialiteit van een dubbel contingente situatie boven zichzelf uit kan voeren, met structuur kan verrijken, daar het zelfreferentie en alloreferentie combineert. Communicatie heeft die bijzondere eigenschappen, zo preciseert 
Luhmann, "weil sie anderes und sich selbst zum Thema machen und zwischen diesen beiden Thematisierungsrichtungen thin und her pendeln kann', ${ }^{372}$

Dit alles impliceert niet, dat Luhmann de term 'handeling" definitief uit zijn sociologisch vocabulaire heeft geschrapt. In tegendeel - het handelingsbegrip blijft voor hem een onontbeerlijke categorie, die binnen zijn model een, voor sociale systemen noodzakelijke functie vertegenwoordigt. Luhmanns punt is alleen, dat 'handelingen' geen kant en klaar aantrefbare elementen vormen, die er nog slechts op wachten onderling te worden gerelateerd tot een handelingssysteem, maar eerst door communicatieprocessen worden geproduceerd. Zoals we hebben gezien, wordt in 'reflexieve communicatie" over de voorbije communicatie gecommuniceerd in termen van de bijdragen die de deelnemers aan het thema leveren. Beschouwen we dit als de manier waarop een sociaal systeem zijn eigen procesgang observeert, dan kunnen we ook zeggen, dat communicatieprocessen zichzelf observeren als een opeenvolging van themabijdragen die telkens aan een der deelnemers als diens autonome selectie wordt toegeschreven. Precies dat - aan systemen (en niet aan de omgeving) geattribueerde zinselectie - acht Luhmann kenmerkend voor 'handelingen':

'Handlungen werden durch Zurechnungsprozesse konstituiert. Sie kommen dadurch zustande, dass Selektionen, aus welchen Gründen, in welchen Kontexten und mit Hilfe welcher Semantiken ('Absicht', 'Motiv', 'Interesse') immer auf Systeme zugerechnet werden... Es kommt in der hier gewählte Begriffsbildung darauf an, daß Selektionen auf Systeme, nicht auf deren Umwelten bezogen werden und daß auf dieser Grundlage Adressaten furr weitere Kommunikation, Anschlußpunkte furr weiteres Handeln festgelegt werden, was immer als Grund dafur dient. ${ }^{373}$

Communicatieprocessen observeren zichzelf bijgevolg als processen van opeenvolgende handelingen, als handelingssystemen. Daarmee ontstaat een asymmetrie van mededeler en ontvanger, die feitelijk een simplificatie voorstelt van communicatie als de complexe eenheid van 'mededeling', 'informatie' en 'begrip'. Nu weten we inmiddels, dat 'zelfobservatie' altijd simplificatie met zich meebrengt - geen enkel systeem kan zichzelf ten volle observeren of een uitputtende zelfbeschrijving leveren. Voor communi-

372. N. Luhmann, 'Vorbemerkungen zu einer Theorie sozialer Systeme', in: Soztologische Awhlärung 3, Opladen 1981 , p.16.

373. Soziale Systeme, op.cit., p.228. (verg. ook Hoofdstuk III, "Zin en Contingentie", 9.) 
caties geldt bovendien, dat de component 'Verstehen' pas communicatief 'zichtbaar' (behandelbaar) wordt, wanneer het begrijpen zelf de vorm van een informerende mededeling heeft aangenomen, die dan vervolgens weer als een 'bijdrage' van een der betrokkenen wordt geboekt. De consequentie daarvan is, volgens Luhmann, 'daß Kommunikation nicht direkt beobachtet, sondern mur erschlossen werden kann. Um beobachtet zu werden oder um sich selbst beobachten zu können, muß ein Kommunikationssystem deshalb als Handlungssystem ausgeflaggt werden" ${ }^{374}$

Alhoewel een simplificatie, draagt de zelfobservatie van communicatieprocessen als handelingsprocessen en de asymmetrie van mededeler en ontvanger die zich daarmee instelt, bij aan de (zelf)stabilisatie van sociale systemen. De opdeling van het communicatieproces in opeenvolgende handelingen en de toewijzing van de verantwoordelijkheid daarvoor aan telkens een van de betrokken 'actoren' (terwijl geen van de betrokkenen verantwoordelijk kan worden gehouden voor het communicatieproces als zodanig!), maakt het mogelijk de informerende mededeling te ondervragen, te expliciteren, te bekritiseren, etc, een proces dat de opbouw van semantieken en complexe verwachtingsstructuren eigenlijk pas mogelijk maakt. Daarmee wordt tevens een 'intentionalisering' van handelingen uitgelokt. Psychische systemen worden ertoe uitgenodigd om de aan hen geattribueerde selectiviteit als 'handeling' te begrijpen, d.w.z. als iets waar ze zelf verantwoordelijk voor zijn en waarop ze kunnen worden aangesproken - Sie mussen sich deshalb mit vertretbaren Gründen für ihr Handeln, mit Motiven ausstatten, wenn und soweit sie damit rechnen müssen in ihrer Handlungsweise fur sich selbst oder für andere zum Problem zu werden. ${ }^{375}$

Al met al moeten we vaststellen, dat de zelfobservatie van communicatieprocessen als handelingssequenties voor sociale systemen niet alleen onvermijdelijk is, maar bovendien een noodzakelijke voorwaarde van structuurvorming en systeemontwikkeling vormt. Zolang we ons maar bewust blijven van de oorspronkelijke verhouding tussen 'communicatie" en 'handeling', bestaat er volgens Luhmann dan ook geen enkell bezwaar, om over sociale systemen als handelingssystemen te spreken, of zelfs over handelingen als elementen:

Ein soziales System konstituiert sich mithin als Handlungssystem, aber es muß dabei den kommunikativen Kontext des Handelns voraussetzen; beides also, Handlung und Kommunikation, ist notwendig und beides muß laufend zusammenwir-

374. Idem, p.226.

375. N. Luhmann, "Handlungsitheoric und Systemtheore', in: KZfS.S 30 (1978), p.217. In Die Wissenschaft der Gesiellschaft heet het, "Intention ist. nicht ein maturlich fundierter, letztlich neurophysiologischer Sachverhalt, sondern eine uber Kausalattribution laufende Kompaktidentifikation der Ursache einer Handlung...' (op.cit., p.61) 
ken, um die Reproduktion aus den Elementen der Reproduktion zu ermög-lichen. ${ }^{376}$

En tenslotte heet het:

'Auf die Frage, woraus soziale Systeme bestehen, geben wir mithin die Doppelantwort: aus Kommunikationen und aus deren Zurechnung als Handlung. Kein Moment wäre ohne das andere evolutionsfahig gewesen. ${ }^{377}$

Het behoeft nauwelijks betoog, dat Luhmann zich hiermee als socioloog een handelingsbegrip verschaft heeft, dat dwars staat op ieder subjectief-intentioneel begrip van handelen. Wat binnen een sociaal systeem als handeling fungeert, wordt niet geconstitueerd door de subjectieve intenties van de betrokken actoren, maar door het systeem zelf, en dit in functie van de voortgang en herhaalbaarheid, kortom: van de stabiliteit van communicatieprocessen. 'Was eine Einzelhandlung ist', zo onderstreept hij dit sociaal geconstrueerde karakter van handelingen, "läßt sich nur auf Grund einer sozialen Beschreibung ermitteln'. ${ }^{378}$ Oedipus wist niet wie hij doodde, maar het wordt hem door de goden (!) als een daad van vadermoord aangerekend. Luhmann is vervolgens consequent, wanneer hij opmerkt, dat ook de 'individualiteit' van de handeling niet in de subjectieve intentie gelokaliseerd moet worden. Wat de handeling individueert, zijn "principium individuationis', is de uniciteit die een handeling verkrijgt op grond van zijn eigenschap, een kortstondige gebeurtenis te zijn. Iedere gebeurtenis, en dus ook iedere handeling, heeft een minimale verrassingswaarde, is, vergeleken met het voorafgaande, hoe dan ook "nieuw'. Al het nieuwe is bijzonder, scheidt zich af van het voorbije, plaatst zichzelf apart. Het is dit "nieuw-zijn', dat volgens Luhmann de handeling zijn eenmaligheid, zijn uniciteit verleent. Daarmee zet hij zich in één en dezelfde beweging af tegen een handelingstheorie in de lijn van Parsons, waarvoor de handeling een analytische eenheid is, d.w.z. een theoretische constructie waarvan sociologen zich bedienen om greep te krijgen op de in werkelijkheid amorfe stroom van menselijke gedragingen. Handelingen zijn voor Luhmann niet slechts theoretische; en dan ook willekeurige of contingente constructen van de sociale wetenschap, maar reêl functionerende voortbrengselen van zich reëel voltrekkende communicatieprocessen. 


\section{$\$ 2.1$ Instrumentaliteit en doelrationaliteit}

Dat Luhmann geen vrede zou hebben met een intentioneel, of subjectivistisch handelingsbegrip, was natuurlijk te verwachten. En op grond van zijn opvattingen omtrent 'zin' kon eveneens worden verwacht, dat hij vervolgens niet zou uitwijken naar gedragstheoretïsche of behavioristische benaderingen. De handeling is en blijft een zinmatige eenheid. Luhmanns eigen aanpak is echter niet zonder kosten. Met de gedachte namelijk, dat de eigenaard of identiteit van een handeling door sociale systemen (dus door gestructureerde communicatieprocessen) wordt vastgelegd, verspert hij voor zichzelf de toegang tot eender welke handelingsontologie - of die nu met Aristoteles differentieert tussen 'theoria', 'praxis' en 'poiesis', of, zoals Habermas, het onderscheid tussen instrumenteel en communicatief handelen centraal stelt. Nu zijn dat ook vormen van het denken van onderscheidingen, die Luhmann met alle liefde opgeeft. Maar daarmee haalt hij zich wel de problemen op de hals, waarop een vaste en fundamenteel geachte indeling van handelingen in 'soorten' het antwoord wilde vormen. Zo lijkt het in een aantal gevallen alleszins redelijk, om ook gedrag dat niet interactief van karakter is, dat niet gericht is op een Alter Ego, als 'handelen' aan te merken. Nu meent ook Luhmann, dat het begrip 'handelen' van toepassing is op 'eenzame' situaties. De observatie van eenzaam gedrag als "handelen", parasiteert volgens hem echter op in communicatieprocessen tot stand gebrachte identificaties en beschrijvingen:

[II]n Einzelsituationen hebt sich eine Einzelhandlung aus dem Verhaltensfluß nur heraus, wenn sie an eine soziale Beschreibung erinnert. Nur so findet die Handlung ihre Einheit, ihren Anfang und ihre Ende... ${ }^{379}$

Dat klinkt allemaal nog tamelijk 'klassiek' - Schutz had dit bijvoorbeeld kunnen zeggen. Maar juist in het licht van de klassieken bevredigt dit niet of misschien is het beter om te zeggen: geeft het (nog) geen antwoord op het achterliggende probleem. Want wanneer ook het 'eenzame handelen' uiteindelijk zin en identiteit aan communicatieprocessen ontleent, rijst de vraag, hoe het gesteld is met die gedragingen, die we traditioneel ook 'handelingen' noemen, maar die hun zin en identiteit juist daaraan lijken te ontlenen, dat ze zich niet oriënteren op een Alter Ego als communicatiepartner (hooguit op zijn rol en status als lid van een collectief). Hoe zit het met de doelgerichte bewerking en omvorming van fysische, chemische, biologische, psychische of sociale systemen die tot de omgeving van het (bewerkende, omvormende) 
handelingssysteem behoren. Kortom -, waar blijven bij Luhmann categorieen als 'arbeid", of 'instrumenteel handelen'? Wat hij ook tegen mag hebben op Habermas' vertrouwen in quasi-essentialistische onderscheidingen als 'arbeid versus interactie', of 'instrumenteel versus communicatief handelen', een sociologische theorie die niet op een of andere manier een 'teleologisch' begrip van handelen kan verdisconteren, die geen conceptuele ruimte biedt aan handelingsprocessen die zich richten op de realisatie van externe doelen en zich daaraan bij hun structuuropbouw oriënteren, lijkt bij voorbaat te kort te schieten.

Nu kan men veel van Luhmann verwachten, maar niet, dat hij ook maar iets dat van sociaal-wetenschappelijke betekenis zou kunnen zijn, bewust links laat liggen; net zo min als het aannemelijk is, dat hij overgeleverde sociologische concepten met een dergelijk verregaande strekking ongemoeid zal laten. En natuurlijk ziet Luhmann zelf ook, dat het te simpel zou zijn, om de vraag naar de rol die het 'doelgerichte' of 'instrumentele' handelen in zijn theorie speelt, af te doen met de opmerking, dat doelgerichte of teleologische vormen van handelen 'bestaan' en in het conceptuele raamwerk kunnen worden opgeborgen, voorzover handelingssystemen hun eigen elementen als 'doelgericht' of 'instrumenteel' observeren en beschrijwen. Dit Jaatste moet; gegeven de hele systematiek van zijn handelingsbegrip inderdaad het geval zijn, maar tegelijkertijd lijkt dat een buitengewoon complexe, zo niet paradoxale operatie. De vraag is namelijk, onder welke voorwaarden communicatieprocessen zich ooit in zo verregaande mate hebben kunnen distantieren van de (voor hen zelf constitutieve!) fixatie op zich zelf, dat ze zichzelf niet slechts als een opeenvolging van handelingen observeren, maar daarenboven als een handelen in en met -, als een 'behandelen' van hun omgeving. Dat heeft veel weg van iemand die zijn jas binnenste buiten wil keren, terwijl hij hem aan heeft. En toch moet iets dergelijks het geval zijn, willen we vasthouden aan het adagium, dat iedere kwalificerende beschrijving van handelingen uiteindelijk voortkomt uit de zelfobservatie van communicatieprocessen. Om het perspectief nogmaals aan te geven: de observatie van een "eenzame" handeling als 'arbeid' of als 'instrumenteel handelen' moet bij Luhmann nog altijd 'parasiteren' op de observaties en beschrijvingen die door reflexieve communicaties ooit tot stand zijn gebracht.

Luhmanns behandeling van deze problematiek begint met de vaststelling, dat de zelfobservatie van communicatieprocessen (reflexiviteit) hand in hand gaat met een voordien/nadien-onderscheid. ${ }^{380}$ De ene handeling is eerder dan de andere handeling; de selectiviteit van een vroegere mededeling kan slechts

380. Zie voor thet volgende met name: $N$. Luhmann, "Temporalstrukturen des Handlungssystems: Zum zusammenhang von Handlungstheorie und Systemtheorie', in idem, Soziologische Aufklärung 3, op.cit, p.126-15l en Sioziale Systeme, op.cit., p.276 e.w. 
door een latere mededeling worden versterkt. Zonder de vorming van een dergelijke temporele reeks zou het ondervragen, bekritiseren en hernemen van voorafgaande bijdragen aan het communicatieproces in het geheel niet mogelijk zijn. Met de zelfobservatie van communicatieprocessen als handelingsreeksen ontwikkelen sociale systemen m.a.w. een systeem-interne tijd(servaring). Gegeven de irreversibiliteit van het voordien/nadien-schema impliceert dit tevens een asymmetrisering van de verhouding tot de omgeving. Een sociaal systeem dat zichzelf als een systeem-in-een-omgeving observeert ("reflexie"), moet onder druk van deze "interne tijd" zichzelf gaan beschouwen als een systeem, dat een 'vroegere'/voorbije en een 'late$\mathrm{re}^{3} /$ toekomstige omgeving heeft. De omgeving neemt, om met Luhmann te spreken, een 'Doppelform' aan.

Het idee is nu, dat een ontwikkeld sociaal systeem deze 'Doppelform' onder bepaalde omstandigheden kan gaan benutten om de eigen autonomie t.o.v. de omgeving te versterken. Het kan de 'vroegere' omgeving als initiële conditie gaan beschouwen, de 'toekomstige' omgeving als een variabele die het eventueel kan beïnvloeden. Het systeem kan zijn grenzen met de omgeving gaan onderverdelen in 'aanleveringsposten' en 'afzetpunten' - het kan, algemener geformuleerd, zijn grenzen als input/output-grenzen gaan behandelen.

Een systeem dat zich aan deze input/output-schematiek gaat oriënteren, dat een vroegere toestand van de omgeving gaat observeren als initiële conditie of voorwaarde van het eigen handelingsproces en dat met het oog op de toekomst zichzelf aan verwachtingsstructuren onderwerpt die het handelen op 'resultaten' richten, stelt zichzelf in zakelijk opzicht aan een typische beslissingsproblematiek bloot. Als een omzettingsproces van input in output moet het juist/correct/etc. handelen gaan onderscheiden van onjuist, incorrect, etc. handelen en dit met het oog op de aanvangscondities, de beoogde doelen, of met het oog op beide. De ontwikkeling van een daartoe benodigde set van criteria, regels en handelingsaanwijzingen duidt Luhmann aan met de term 'programmering':

"Wenn die Umweltlage des Systems...die Ergebniserwartungen honoriert und die Bedingungen liefert, kann das System durch Handeln eine Umsetzung von Input in Output vollziehen; es kann zumindest den eigenen Selektionsvollzug in dieser Richtung prazisieren. Das geschieht in der Form der Programmierung des Handelns.... ${ }^{381}$ 
Nu gaan beslist niet alle sociale systemen ertoe over, om hun verhouding tot de omgeving naar het model van een input/output-schema in te richten. 'Die Reduktion auf Handlung allein zwingt nicht dazu', zo merkt Luhmann op, 'sie ermöglicht es nur'. ${ }^{382}$ Systemen die dat wel doen - en dit betreft natuurlijk met name die systemen die ook wel als 'formele organisaties' te boek staan -, worden tegelijkertijd afhankelijker en onafhankelijker van hun omgeving, met als voordeel een grotere autonomie voorzover ze erin slagen hun (on)afhanklijkheden systeem-intern te reguleren. Ze worden afhankelijker van die omgevingsfactoren die hun input- en outputmogelijkheden betreffen; onafhankelijker van al het andere. Het systeem bedient zich van een verregaande complexiteitsreductie, zo zou men kumnen formuleren, die, alhoewel belast met risico's, de omgeving voor het systeem 'behandelbaar' maken:

'Es kann sich mehr Sensibilität, mehr Tiefenschärfe in der Umweltwahrnehmung und zugleich mehr Indifferenz leisten. Eins bedingt das andere. Und beides wird bedingt durch ein höheren Grad interner Autonomie... Autonomie heißt dann: wăhlen können in den Aspekten, in denen man sich auf Abhängigkeit von der Umwelt einläßt. ${ }^{383}$

Deze autonomie - ook t.o.v. andere sociale systemen! - kan nogmaals worden versterkt, als output- of resultaat-gerichte systemen erin slagen inputen output-problemen als het ware op elkaar af te wentelen, 'wenn', zoals Luhmann het formuleert, 'das System einen 'Fuhrungswechsel' von Input und Output organisieren kann'. Stel bijvoorbeeld, dat een dergelijk, teleologisch georiënteerd handelingssysteem geconfronteerd wordt met output-, of afzetproblemen. In reactie daarop, kan het natuurlijk proberen meer afzetmogelijkheden te zoeken. Een systeem echter, dat eveneens in staat is om een dergelijke afzetproblematiek om te zetten in een input-problematiek en bijvoorbeeld de oplossing zoekt in een verminderde input van omgevingsfactoren, beschikt over meer reactie-mogelijkheden, is flexibeler en is op zijn minst in die zin autonomer dat het op dit type systeem/omgevingsproblemen naar eigen preferenties kan reageren. Nu betrof ons voorbeeld toevallig een output-probleem, maar de 'Führungswechsel' kan ook de omzetting van input-problemen in een oriëntatie op output-problemen betreffen. Het centrale idee is, dat systemen die middelen bij doelen kunnen zoeken en omgekeerd ook doelen bij middelen, meer autonomie verkrijgen en zich op 
grond daarvan ook sterker kunnen "uitdifferentiëren" to.v. hun sociale/communicatieve omgeving.

Nu gaat deze laatste formulering, die onderhands het input/output-schema inwisselt voor een doel/middelen-schematiek, eigenlijk al een stap te ver. Luhmann gaat er namelijk vanuit, dat het doel/middel-schema - 'wobei die Zwecke die Wahl der Mittel und die Mittel die Wahl der Zwecke begrenzen" ${ }^{384}$ - de klassieke semantische vorm is waarin ontwikkelde input/output-systemen die mogelijkheid, om tussen input- en output-oriëntatie te kunnen kiezen, intern representeren. Dat is al met al een verstrekkende these, die op zichzelf belangrijk genoeg is, om onze nogal uitvoerige behandeling van Luhmanns reconstructie van 'instrumenteel' handelen, van 'teleologische' handelingssystemen te rechtvaardigen. De implicatie ervan is namelijk, dat, voorzover we het doel/middel-schema al identificeren met een bepaalde vorm van rationaliteit, dit een rationaliteitsopvatting of -semantiek betreft die een specifiek soort handelingssystemen ontwikkelt ter wille van een interne representatie van de verhouding tot de omgeving. 'Doelrationaliteit" is echter niet een principe of regulatief dat constitutief is voor de samenhang van een 'geïnstrumentaliseerd' handelingssysteem en dus ook niet voor de zin van de afzonderlijke handelingen die er de elementen van vormen. In een formulering van Luhmann zelf:

'Man muß bei der Analyse von Handlungssytemen deutlich unterscheiden zwischen dem Rationalitälsschema von Zweck unid Mittel und dem Zusammenhang oder Interdependenz der einzelnen Handlungen. Es ist...nicht das Zweck/Mittel-Schema, das den Zusammenhang der Handlungen vermittelt (was ja heißen mußte: daß ohne Orientierung an Zweck und Mittel keine Interdependenz zwischen Handlungen möglich wäre). Daher ist es auch nicht das Zweck/Mittel-Schema, das den Sinn der Einzelhandlung letztlich bestimmt, oder verständlich macht, oder entscheidbar macht. Der Sinn des Handelns ergibt sich immer schon aus der Verweisung auf andere Handlungen oder auf sonstige Ereignisse. 385

Dit slaat; om te beginnen, de bodem weg onder Webers these van het 'occidentale rationalisme' en onder aanverwante diagnoses van het ontwikkelingsproces dat heeft geleid tot het ontstaan van de moderne (westerse) maatschappij, voorzover deze 'doelrationaliteit' constitutief achten voor typisch 'moderne' handelingsconstellaties. Luhmanns inschatting van de

384. Soziale Systeme, op.cit., p.279.

385. N. Luhmann, 'Temporalstrukturen des Handllungssystems', op.cit., p.130/131. 
functie en betekenis van het doel/middel-schema keert zich echter evenzeer tegen al dat soort voorstellingen van 'sociale systemen' en 'systeemrationaliteit', die systemische samenhangen uiteindelijk identificeren met een handelingsintegratie die gestuurd wordt door een 'logica' van de doelrationaliteit, die dan vervolgens functionalistisch wordt geïnterpreteerd, d.w.z. betrokken op overlevings- of stabliseringsproblemen waar sociale systemen mee te kampen zouden hebben. Wanneer bijv. Habermas over 'systemischen Mechanismen' spreekt, die 'einen von Normen und Werten weitgehend abgehängten sozialen Verkehr (steuern)' en daarmee doelt op 'jene Subsysteme zweckrationalen Wirtschafts- und Verwaltungshandelns'; haakt Luhmann definitief af. ${ }^{386}$

\section{\$2.2. Voorbij Weber, voorbij Schutz}

Laten we ter afsluiting van deze paragraaf terugkeren naar het algemene concept 'handelen', zoals dat door Luhmann wordt aangeboden - en wel aan de hand van een suggestie die al vrij vroeg, vanuit een kritische optiek, door Johannes Berger op tafel is gelegd, maar nu weer door commentatoren als Matthias Heidenescher, Georg Kneer, Armin Nassehi en Wolfgang Schneider wordt opgepakt, deze keer vanuit een welwillend-positieve houding. ${ }^{187}$ Het betreft de suggestie, dat Luhmanns theorie van sociale systemen in feite een voortzetting en verdere uitwerking zou vormen van denkmotieven, die al aanwezig zijn in Webers 'verstehende' sociologie en in de, op Schutz voortbouwende, fenomenologische sociologie. Zo plaatst Heidenescher het attributie-mechanisme op de voorgrond, als het mechanisme dat bij Luhmann constitutief is voor de emergentie van de zin-eenheid "handeling', om er vervolgens op te wijzen, dat een dergelijke attributie ook een centrale rol speelt bij Weber en Schutz. Inderdaad gaat achter Webers principe van de 'Sinnadäquanz' de voorstelling schuil, dat de handelingen van een actor voor een toeschouwer slechts zin kunnen hebben, voorzover de toeschouwer deze kan onderbrengen in een voor hem begrijpelijke zinsamenhang, die hij vervolgens aan de actor attribueert als diens handelingsmotief. Een dergelijke attributie van 'motieven' steunt, volgens Weber, op cultureel ingesleten duidingsschema's, die de geobserveerde handelingssamenhang typificeren.

386. Zie I. Habermas, Theorie des kammunikativen Handelns Bd.2, Frankfurt/M. 1982, p.230.

387. Verg: J. Berger, 'Autopoiesis: Wie 'systemisch' ist die Theorie sozialer Systeme", in: H.Haferkamp/M.Schmid (Hrsg.), Sinn, Kommumikation und soziale Differenzierung, Frankfurl/M. 1987; G.Kneer/A.Nassehi, "Verstehen des Verstehens - Eine systemtheoretische Revision der Hermeneutik', in: Zeitschriff fur Soziologie, Jg. 20 (1991), p.341 - 356; M.Heidenescher, "Zurechnung als soziologische Kategorie - Zul Luhmanns Verstandnis. von Handlung als Systemleistung,, in: Zeilschrift fir Soziologie, Jg.21 (1992), p.440. 455; W.L. Schneider," Hermeneutik sozialer Systeme - Konvergenzen zwischen Systemtheorie und philosophischer Hermeneutik', in: idem, p.420 - 439 . 
M.a.w. - in de intersubjectiviteit, in het zinmatig begrijpen van de handelingen van de ander functioneert bij Weber het 'sociale' als een zelfstandig moment tegenover de particulariteit en subjectiviteit van de concreet-actuele handelingssituatie, en dit op basis van een attributie. Soortgellijks kan men opmerken m.b.t. Schutz' concept wan 'objectieve zin'. Ook voor Schutz geldt, dat sociaal-cultureel bemiddelde en in die zin 'objectieve'/' intersubjectief geldende' duidingsschemata de interpretatie van het handelen leiden en dit in de vorm van een subsumptie van het eenmalige en particuliere onder het typische en algemene.

De gedachte, dat de zinmatige identificatie van handelingen steunt op sociaal of communicatief geproduceerde observatie- en duidingschema's, zo zou men kunnen concluderen, is al met all niets nieuws. Voorzover de bovengenoemde commentatoren met het oog hierop de afstand tussen Luhmanns theorie van sociale systemen en de klassieke sociologie proberen te relativeren, ook wanneer het gaat om benaderingen die niet tot de 'collectivistische', Durkheimiaanse traditie behoren, lijkt dat alleszins redelijk. Het is echter weinig vruchtbaar om de diepgaande verschillen, die eveneens bestaan, volledig glad te strijken ter wille van een 'normalisering' van het Luhmanniaanse project. Zo gaat Webers, in wezen methodologische, postulaat van de zin-adequaatheid terug op een theoretisch construetie-probleem, dat samenhangt met zijn uitgangspunt, dat de eenheid van de entiteit 'handeling' is gegrond in de subjectieve betekenis. Weber voert, zuiver en alleen gelet op zijn begripssystematiek, de handeling in als een 'pre-sociale' gegevenheid, het sociale handelen vervolgens als een bijzondere (door de intentionele gerichtheid op het handelen van een ander bepaalde) vorm daarvan, om zich tenslotte geconfronteerd te zien met het probleem van de intersubjectieve toegang tot de zin van handelingen. Zoals we hebben gezien, geldt voor Luhmann daarentegen, dat handelingen pas geconstitueerd worden door communicatieprocessen. Het probleem van de intersubjectieve toegang tot de zin van handelingen wordt op die manier door Luhmann van meet af aan gepositioneerd als een probleem, dat in en door communicatieprocessen zelf moet worden verwerkt - om pas secundair te verschijnen als het methodologisch probleem van een empirisch-hermeneutische sociologie. En we hebben inmiddels ook gezien welke kosten dat met zich mee brengt: Luhmann kan zich niet van een (ideaaltypische, analytisch geconstrueerde) handelingstypologie bedienen, maar moet op een veel omslachtiger en uiteindelijk empirische wijze de sociale constructie van handelingstypen reconstrueren.

Diepgaande verschillen bestaan ook tussen Schutz en Luhmann. Weliswaar bekritiseert Schutz in Webers sociologie, dat daarin de gegevenheid van intersubjectief geldende typificaties en duidingsschema's op een 'naïeve" wijze wordt verondersteld en zou men op geleide hiervan geneigd kunnen zijn aan Schutz een radicaler "constructivistisch" bewustzijn van de "sinnhafte Aufbau der sozialen Welt" toe te kennen. Tegelijkertijd geldt echter, dat bij 
Schutz een handeling de uiting is van een monadisch bewustzijn, dat ook de handelingen van een Alter Ego slechts kan begrijpen/verstaan op basis van ooit aangeleerde, geïndividualiseerde voorstellingen en duidingsmodi, zonder dat dit gecompenseerd wordt door een model van niet-subjectieve, uit sociale interactie emergerende vormen van observatie en zin-explicatie. Precies dit laatste - en wel in de vorm van de zelfobservatie van sociale systemen middels zelfreferentiêle, 'reflexieve' communicatie - is echter beslissend voor Luhmanns begrip van "handelen" en kwalificeert ook in verregaande mate Luhmanns verwerping van de traditionele oppositie van 'handeling' en 'systeem' ${ }^{388}$ Als daarentegen Heidenescher zijn observatie van een doorgaande lijn in het werk van Weber, Schutz en Luhmann kracht wil bijzetten door erop te wijzen, dat ook de Verstehende en de Fenomenologische sociologie van hun kant nooit een dualiteit van handeling en systeem hebben gekend, dan lijkt dat de zaak eerder te verwarren, dan te verhelderen. Niet alleen ontkent deze grote unificatie de handelingstheoretische/intentionalistische uitvalsbasis van Weber en Schutz; het miskent bovendien, dat Luhmanns conceptie van 'systeem' en 'handeling' als twee zijden van dezelfde medaille mogelijk wordt gemaakt door een zeer specifiek model, namelijk door een model van sociale systemen als zelfreferentieel georganiseerde communicatieprocessen.

\section{\$3. Structuur}

Systemen die 'zin' benutten als ordeningsmodus zijn 'radicaal getemporaliseerde' systemen - en alleen radicaal getemporaliseerde systemen kunnen, zoals we hebben gezien, zin als ordeningsmodus benutten, kunnen zinsystemen zijn. Deze radicale temporaliteit, d.w.z. het gegeven dat ze op hun meest basale niveau uit gebeurtenissen bestaan, moeten zinsystemen op structuurniveau opvangen met een al even dynamische structuurvorm, die het mogelijk moet maken, de telkens actuele gebeurtenissen 'op te spannen' in een tijdsraam van voorbije en toekomstige gebeurtenissen en zo iedere gebeurtenis onder te brengen in de selectiviteit van een 'proces'. Die bijzondere structuurvorm wordt geconstitueerd door 'verwachtingen'; de structuren van zinsystemen zijn, zoals we in een eerder hoofdstuk al zagen, verwachtingsstructuren. Het specifieke voordeel van verwachtingen is, dat ze een temporele oriëntatie combineren met een uiterst flexibele presentie. Ze kunnen als het ware naar behoeve worden

388. Verg. o.a. N. Luhmann, "Handlungstheorie und Systemtheorie', opgenomen in: Soziologische Aufklärung 3, Opladen 1981, p.50-67. 
ingeschakeld, om aan het hier en nu gebeurende, richting te geven. In een formulering van Luhmann:

'Strukturen gibt es nur alls jeweils gegenwärtige; sie durchgreifen die Zeit nur im Zeithorizont der Gegenwart, die gegenwărtige Zukunft mit der gegenwärtige Vergangenheit integrierend. Eine klunftige Enttäuschung von Erwartungen bedeutet also nicht, daß es keine Struktur gewesen war. ${ }^{589}$

Sociale relevantie krijgen verwachtingen pas, wanneer ze op hun beurt verwachtbaar worden. De structuren van sociale systemen worden, zoals we gezien hebben, dan ook gevormd door 'verwachtingsverwachtingen". Luhmann gaat er vanuit 'daß die Möglichkeit zu Handeln sich uberhaupt erst aus der Art und Weise ergibt, wie Handlungszusammenhänge über Erwartung von Erwartungen koordiniert sind ${ }^{390}$ We hebben tevens, zij het nog tamelijk globaal, gezien welke functies hij aan sociale structuren toekent. Als 'Einschränkungen der im System zugelassenen Relationen' fungeren structuren als een soort wegwijzers van het sociale verkeer, die aangeven wáar, in welke richting "aansluitende" handelingen gevonden kunnen worden. Stabiele "verwachtingsverwachtingen' maken het voor de sociale actoren aantrekkelijk, om zich op een bepaalde manier te gedragen, daar ze voorspelbaarheid suggereren en za het probleem van de handelingsoriëntatie versoepelen. Sociale structuren 'verleiden'. Verleiden! - niet(!) 'determineren'. Het zou slechts zin kunnen hebben, om van een 'structurele determinatie' van handelingen of communicaties te spreken, indien structuren relaties tussen dergelijke systeemelementen zouden voorstellen. Sociale structuren, opgevat als verwachtings-verwachtingen, 'existeren' echter niet op hetzelfde niveau als de elementen van een sociaal systeem, maar vormen een daaraan complementaire realiteit.

Kijken we er vanuit een theorie-vergelijkend perspectief naar, dan staat het door Luhmann gepresenteerde begrip 'structuur' dus haaks op een structuurbegrip, dat, in de lijn van Lévi-Strauss of Althusser, refereert aan relaties tussen relaties, en, als het zou kunnen, nog 'haakser' op Braudels omschrijving van 'structuur' als een patroon van duurzame relaties tussen de elementen van een systeem. Luhmann karakteriseert zijn eigen onderneming dan ook wel als 'post-structuralistisch', mede om aan te geven, dat bij hem het structuurbegrip weliswaar nog steeds een belangrijke rol speelt, maar zijn 'Führungsqualităt' verloren heeft. In de analyse van sociale systemen staat niet langer het probleem van de stabiliteit en instandhouding van 
systeemidentiteit verlenende structuren centraal, maar het probleem van de reproduktie van communicaties als kortstondige gebeurtenissen:

\begin{abstract}
'Wir schränken deshalb den Strukturbegriff auf andere Weise ein: nicht als ein Stabilitätstypus besonderer Art, sondern durch seine Funktion, die autopoietische Reproduktion des Systems von Ereignis zu Ereignis zu ermöglichen. Für soziale Systeme kann man dies durch das Theorem der doppelten Kontingenz präzisieren. Die Selektion von Einschränkungen gewinnt nur dann Strukturwert, wenn sie Reproduktion unter der Bedingung von doppelter Kontingenz ermöglicht. ${ }^{391}$
\end{abstract}

Een belangrijke voorwaarde voor het functioneren van structuren als richtingwijzers van het communicatieproces, is hun relatieve invariantie. Verwachtingsverwachtingen moeten inhoudelijk gezilen over langere tijd 'dezelfde' blijven. En daarmee ligt een centraal probleem van Luhmanns structuurtheorie op tafel. Want ook wanneer we aannemen, dat sociale structuren een niet-subjectieve, op basis van communicatie emergerende realiteit voorstellen, dan blijft vooralsnog gelden, dat voor de sociale actoren 'verwachtingsverwachtingen' gewoon een bepaald soort verwachtingen zijn en wel verwachtingen die met name betrekking hebben op de handelingen van anderen. Anders geformuleerd: vanuit de handeling verschijnen sociale structuren als 'dat wat aan andere handelingen verwachtbaar is'.

$\mathrm{Nu}$ weet een ieder uit eigen ervaring, dat verwachtingen soms worden teleurgesteld, ook verwachtingen omtrent het gedrag van andere actoren. Met deze ervaring dringt zich onherroepelijk ook de contingentie van al het verwachten aan ons op. Verwachtingsstructuren stellen ons weliswaar in staat de naaste toekomst te sonderen, maar dit op een wijze die telkens ook anders had gekund. Met het vertrouwen op onze verwachtingen nemen we m.a.w. een risico: andere dan de verwachte gebeurtenissen kunnen intreden. Dit, aan alle ervaring van contingentie inherente risico-bewustzijn moet op een of andere wijze worden geneutraliseerd, wil het de opbouw en instandhouding van sociale structuren niet voortdurend ondermijnen.

$\mathrm{Nu}$ bestaat één mogelijkheid om verwachtingen te stabiliseren er uit, een verwachting of een set verwachtingen te projecteren op zaken die zelf geen gebeurtenissen zijn en in die hoedanigheid, als 'ding', ook niet in strikte zin 'verwachtbaar' zijn, niet het risico van niet-gebeuren met zich meebrengen. Van de leunstoel bij het raam verwachten we bepaalde zaken en andere niet, omdàt het nu eenmaal een leunstoel is - en naar we aannemen: blijft (een veronderstelling of 'projectie' die natuurlijk niet uitsluit dat die leunstoel ons 
op zekere dag alsnog een onaangename verrassing bezorgt). Ongetwijfeld wordt een groot deel van onze verwachtingen t.a.v. de ervaarbare werkelijkheid op deze, men zou haast zeggen: 'substantialistische" manier geordend en gestabiliseerd. Tot op zekere hoogte is het zelfs mogelijk, om verwachtingen omtrent het handelen van een ander te stabiliseren, door deze te betrekken op het ding 'mens' en erop te vertrouwen, dat het typisch menselijk is, om op een bepaalde manier te handelen. Een dergelijke strategie verzaakt echter al snel, wanneer sociale systemen complexer gaan worden en, zoals in de moderne maatschappij, de sociale omgeving ook steeds complexer wordt. De overmaat an handelingsmogelijkheden, het voortdurend overschakelen van het ene maatschappelijke subsysteem naar het andere, plus de graad van specificiteit die socialle subsystemen in een maatschappij als de onze hebben ontwikkeld, maken de 'dingvorm' ontoereikend als manier om gedragsverwachtingen invariant te houden. In plaats van 'de mens' (of: de adellijke/de gelovige/de rationele/de moreel autonome/de innerlijke onbestemde/etc. mens) fungeren in de moderne samenleving 'personen', 'rollen', 'programma's' en 'waarden' als ankers voor de zakelijke identificatie van gedragsverwachtingen.

Met de term 'persoon', of de uitdrukking 'een persoon zijn', doelt Luhmann niet op een psychische realiteit, niet op een set bijzondere eigenschappen van een psychisch systeem, maar op een sociaal construct. De persoon' is een (in en door communicatieprocessen gecreẽerd) identificatiepunt van gedragsverwachtingen. Het gaat, anders gezegd, om een geündividualiseerde attributie van een bepaald gedragsrepertoir en dit in functie van de ordening en stabilisering van de verwachtingen die ta.v. de handelingen van een specifieke 'persoon' worden gekoesterd. Natuurlijk kunnen concrete individuen de aan hen gerichte gedragsverwachtingen overnemen; en 'een persoon zijn' wil zeggen, dat men middels communicatief en lichamelijk gedrag verwachtingen oproept en aan zich bindt - zowel verwachtingen van anderen, als eigen verwachtingen. 'Personen sind Konstrukte eines Beobachters', zo formuleert Luhmann, 'die den Menschen auferlegt, ja ihnen als Eigenkonstruktion zugemutet werden'. ${ }^{392}$

Gaat het bij de constructie van 'personen' nog om gedragsverwachtingen die aan concrete, individuele actoren zijn gericht, met de ontwikkeling van 'rollen' ontstaan 'anonieme' identificaties van samenhangende gedragsverwachtingen. In die zin vertegenwoordigt de 'rol' een abstracter gezichtspunt dan de persoon. Tegelijkertijd is de set van onderling samenhangende verwachtingen, die de rol vormt, normaal gesproken minder 392. N. Luhmann, 'Sozialsystem Familie', opgenomen in: Soziologische Aufklarung 5 ,
Opladen 1990, p.200. 
omvattend, dan wat de persoon aan verwachtingen met zich mee torst. Luhmann:

'Eine Rolle ist zwar noch dem Umfang nach auf das zugeschnitten, was ein Einzelmensch leisten kann, ist aber gegenuber der individuellen Person sowohl spezieller als auch allgemeiner gefaßt. Es geht immer nur um einen Ausschnitt des Verhaltens eines Menschen, der als Rolle erwartet wird, anderseits um eine Einheit, die von vielen und auswechselbaren Menschen wahrgenommen werden kann. ${ }^{393}$

Onder een "programma" verstaat Luhmann "ein Komplex von Bedingungen der Richtigkeit (und das heißt: der sozialen Abnehmbarkeit) des Verhaltens'. ${ }^{394}$ In Soziale Systeme lijkt Luhmann bij het begrip 'programma' vooral aan (formele) organisatie en planning te denken. We zullen in thet volgende hoofdstuk echter zien, dat 'programma' binnen de context van zijn maatschappijtheorie een wijdere strekking krijgt, wanneer het wordt gekoppeld aan een model van functionele differentiatie op basis van 'codering'. Hoe dan ook -, specifiek voor programma's is, dat ze i.t.t. rollen het gedrag van meerdere personen coördineren en verwachtbaar maken. Daarbij kan men denken aan tamelijk concrete zaken, zoals het werkplan dat een aannemer opstelt bij de bouw van een huis, maar bijv. ook aan de afstemming van het handelen binnen het rechtssysteem voorzover dat het predikaat 'juridisch' verdient.

Om adequaat te kunnen functioneren moeten programma's dikwijls zeer complex en tegelijk veranderlijk, aanpasbaar zijn. Dat voert natuurlijk de contingentie van programma's onder ogen. Waarden verlichten, volgens Luhmann, de communicatie over deze contingentie, voorzover men er vanuit mag gaan, dat bij alle verandering, aanpassing, of zelfs opheffing van een programma, een aantal uitgangspunten onomstreden blijven. In abstracto zou men 'waarden' kumnen omschrijven als algemene, tot symbolen gestolde preferenties. Luhmann benadrukt echter, dat op grond van 'waarden' bepaalde handelingstrajecten of programma's weliswaar eerder te verwachten zijn dan andere, maar dat waarden, i.t.t. programma's, geen criteria van correct/juist handelen voorstellen. Natuurlijk kunnen afzonderlijke handelingen onder het gezichtspunt van waarden worden beschouwd, maar omdat praktisch gesproken iedere handeling zowel positief als negatief geëvalueerd kan worden, afhankelijk van de waarde die men prefereert, volgt uit het 
bestaan van waarden uiteindelijk niets $\mathrm{m}$. b.t. de juistheid van een handeling Luhmann:

'Das wird oft ubersehen, oft wohl auch bewußt vertuscht. Wollte man aus Wertungen Informationen über richtiges Handeln gewinnen, müßte man eine logische Rangordnung, zum Beispiel Transitivität des Verhältnisses einer Vielzahl von Werten voraussetzen." 395

Personen, rollen, programma's en waarden dienen de inhoudelijke, of "zakelijke" identificatie van gedragsverwachtingen. Luhmann gaat er overigens vanuit, dat de differentiatie en functie-specifieke ontwikkeling van deze structuurcomponenten een typisch modern fenomeen is. Daarbij komt met name aan rollen en programma's de functie toe een, historisch gezien, steeds meer toegenomen handelingscomplexiteit sociaal verdraagbaar te houden, d.W.Z als een geordend geheel van handelingsmogelijkheden verwachtbaar te maken. Rond de persoon kan dan, in contrast met de eisen die het rolgedrag stelt, een sterkere individualisering op gang komen, terwijl door de immense verbreiding van formele organisatievormen over allerhande maatschappelijke terreinen en het daardoor navenant toegenomen belang van programma's als het gaat om de coördinatie van supra-individuele handelingssamenhangen, de ruimte wordt geschapen voor een verdergaande ideologisering van waarden, Volgens Luhmann spelen onder die historische voorwaarde 'personen' en waarden 'übergreifend zusammen, um die Grundlagen des gesellschaftlichen Zusammenlebens zu symbolisieren, während Rollen und Programme die Erfordenisse der Komplexität zur Geltung bringen:" ${ }^{396}$ Dat impliceent overigens ook, dat veranderingen in het waardensysteem van een maatschappij, zolang dit althans niet een 'Umwertung aller Werte' betreft, een minder diepgrijpende aangelegenheild is, dan dikwijls wordt aangenomen. Door de 'uitdifferentiatie' van waarden als bijzondere structuurcomponenten kunnen zich op dit niveau enerzijds gemakkelijker en sneller ontwikkelingen en transformaties voordoen - het waardensysteem sleurt niet de hele structuurlast met zich mee; anderzijds, en dat is de keerzijde van de functionele verzelfstandiging van de waardensfeer, kunnen de meer concrete, op complexiteit georiënteerde structuurniveaus die door rollen en progamma's worden gevormd, zich in verregaande mate immuniseren tegen waardentransformaties. Luhmann: 
'Man kann vermuten, daß Werte und Personen neue Arten von Symbiosen suchen - und dabei das mehr oder weniger außer Acht lassen, was auf der Ebene der Rollen und Programme die Komplexität der Gesellschaft trägt. Allem Wertwandel und allem neu betonten Individualismus zum Trotz bleiben Rollen und Programme durch Komplexitătserfordernisse in die Gesellschaft eingebunden., ${ }^{397}$

Dat we, eenmaal op het niveau van de analyse van sociale structuren beland, gemakkelijk in maatschappijtheoretische diagnoses verzeilen, is weinig verwonderlijk. Het structuurbegrip 'vraagt' bij wijze van spreken om een meer concrete situering, zij het desnoods binnen de context van algemeen maatschappelijke ontwikkelingen. Per slot van rekening identificeren we in de praktijk een sociaal systeem altijd aan de hand van zijn concrete en telkens bijzondere structuren - een gezin aan de hand van zijn betrokkenheid op ("volledige') personen, een groothandelsorganisatie aan zijn statutair vastgelegde rollenstructuur en programmatische doelstellingen, een gegeven rechtssysteem aan zijn specifieke programma"s, etc. We hebben echter ons aanvankelijke probleem: de stabilisering van gedragsverwachtingen als voorwaarde voor de ontwikkeling en het functioneren van complexe sociale structuren -, nog maar ten dele beantwoord. Op basis van personen, rollen, programma's en waarden mag het dan mogelijk zijn om gedragsverwachtingen te coördineren en in zakelijk opzicht te identificeren als telkens begrensde (en dus ook specificeerbare) verwachtingssamenhangen, de vraag blijft, hoe sociale structuren in temporeel opzicht stabiliteit kunnen verkrijgen, gegeven het feit dat we nu en dan worden teleurgesteld in onze verwachtingen omtrent andermans gedrag. Luhmanns behandeling van dit probleem, hoe sociale structuren door de tijd heen een zekere eenvormigheid en constantheid kunnen verkrijgen, is eigenlijk interessanter - misschien moeten we zeggen: origineler — dan zijjn differentiërende analyse van sociale structuren in termen van personen, rollen programma's en waarden. Uitgangspunt is de, op zichzelf weinig schokkende gedachte, dat wanneer een verwachting niet wordt ingelost, er in principe op twee manieren kan worden gereageerd. De ene mogelijkheid is, dat men zich bereid toont van de teleurstelling te leren en die ervaring gebruikt om de aanvankelijke verwachting bij te stellen. Een andere mogelijkheid die open staat, is om aan de eigen verwachting vast te houden en, hoe dan ook, een rectificatie van het verloop van de gebeurtenissen te eisen. Het idee is nu, dat verwachtingen aan (temporele) stabiliteit winnen, wanneer in de verwachting zelf al is opgenomen, hoe op teleurstellingen 
gereageerd zal worden. ${ }^{398}$ Luhmann spreekt in dit verband van een tweetal verwachtingsmodi, wan een cognitieve en van een normatieve stilering van werwachtingen. Cognitief gestileerde verwachtingen, of simpelweg: cognities, maken een anticipatie op gebeurtenissen in termen van weten/nietweten mogelijk. Als niet gebeurt wat werd verwacht, dan hield de verwachting een 'niet-weten' in. Ook verwachtingen ta.v. het gedrag van andere actoren kunnen cognitief van aard zijn: Op grond van de veronderstelling, dat winstmaximalisatie een algemene preferentie inhoudt, verwachtte ik, dat hij op mijn aanbod in zou gaan - hij sloeg het af. Op grond van een uitgebreid psychologisch onderzoek, verwachtte ik dat hij voet bij stuk zou houden - hij gaf toe. Normatief gestileerde verwachtingen, of simpelweg: normen, differentiëren gebeurtenissen onder het gezichtspunt conform/deviant. Als niet gebeurt wat normatief werd verwacht, heeft de deviant genoegdoening te verschaffen en daarmee de verwachting te (her)bevestigen als juist en correct.

Cognitieve en normatieve stileringen van gedragsverwachtingen fungeren, zo beschouwd, als een buffer of schokdemper tussen ("verwachtings')teleurstellingen en de sociale structuur die de concrete verwachting suggereerde. Degene die in zijn verwachting wordt teleurgesteld, bevindt zich niet plotseling in een soort niemandsland, maar weet 'uit de aard der verwachting' wat hem te doen staat. Deze temporele stabiliseringsfunctie veronderstelt echter, dat de modalisering van specifieke verwachtingscomplexen in termen van aanpasbaar/cognitief en nietaanpasbaar/normatief, is losgekoppeld van individuele willekeur. Alleen wanneer in structuurvormingsprocessen zelf wordt voorbeschikt, wat als cognitie en wat als norm zal worden behandeld, kunnen de verschillende strategieên om met teleurstellingen om te gaan, de schijn van "objectiviteit" verkrijgen. Die objectiviteit wil eigenlijk niets anders zeggen, dan dat de aansprakelijkheid voor de keuze van een bepaalde verwerkingsvorm op het sociale systeem wordt afgewenteld, en dit ter ontlasting van het individu. Als niet gebeurt wat op grond van een norm mocht worden verwacht, staat niet degene die de verwachting koesterde voor schut als iemand die niet weet hoe de wereld in elkaar zit, maar de deviant, die ter bevestiging van de norm genoegdoening moet verschaffen - desnoods in de vorm van een ontkenning van zijn deviantie, desnoods door te liegen.

Met zijn normbegrip, ingevoerd op een "theoretisch sekundärer, abgeleiteter Stelle', zet Luhmann zich bewust af tegen de Durkheimiaans-Parsoniaanse traditie, waarin normativiteit als het uiteindelijke fundament van alle sociale orde wordt opgevat. ${ }^{399}$ Luhmann wil, bij wijze van spreken, nog achter het

398. Zie voor dit en volgende: Saziale Systeme, op.cit., p.436 e.v.

399. Verg. idem, p. 444 e.v. 
normconcept kunnen kijken, om dit te ondervragen op de functie die het kan vervullen in een analyse die de temporaliteit wan sociale systemen central stelt en de onderlinge aansluiting van communicaties als het overkoepelende referentieprobleem beschouwt. Daarmee wordt natuurlijk niet de empirische bevinding tegengesproken, dat alle samenlevingen tot nog toe een hoge mate van gedragsnormering laten zien, noch wordt gesuggereerd, dat sociale systemen het zonder normen zouden kunnen stellen. Het interessante van Luhmanns conceptualiseringsstrategie is veeleer, dat deze uitnodigt, om de balans tussen cognitieve en normatieve stileringen van gedragsverwachtingen te beschouwen als een variabele van verschillende systeemtypen en sociaalculturele ontwikkelingsniveaus. Het lokt vragen uit als: onder welke voorwaarden kunnen 'normen' in 'cognities" worden getransformeerd (en vice versa); welke aanpassingsproblemen levert een dergelijke ompoling binnen een maatschappelijk subsysteem voor omringende sociale systemen op; wat zijn, structureel en semantisch gezien, de maatschappelijke begeleidingsverschijnselen van dit soort processen; etc. Zo heeft Rudolph Stichweh, als promovendus van Luhmann, op grond van uitgebreid historisch onderzoek laten zien, dat de overgang van een normatieve omgang met het corpus van overgeleverde waarheden naar een cognitieve instelling tegenover waarheid claimende uitspraken, als een cruciale factor in het ontstaan van de moderne wetenschap moet worden aangemerkt. Terwijl tot in de $18 \mathrm{de}$ eeuw het bedrijven van wetenschap werd beschouwd als het bewaren en doorgeven yan een encyclopedisch bestand aan onbetwijfelbare, ware inzichten, dat nu en dan met nieuwe kennis werd verrijkt, is de huidige wetenschap principieel 'hypothesen"-wetenschap. Door beweringen in de vorm van hypothesen te gieten, wordt expliciet gemaakt, dat van meet af aan met de weerlegging ervan rekening wordt gehouden. De hypothese anticipeert erop, zo zou men kunnen zeggen, dat het in de bewering voorspelde ook niet kan gebeuren. Tegelijkertijd heeft het moderne wetenschapsonderzoek laten zien, dat ook een, op de produktie van cognitieve uitspraken toegespitst wetenschapssysteem het niet zonder de conserverend-stabiliserende functie van normering kan stellen, zelfs niet op het niveau van zijn theorieen en methoden: de "hard core" van een onderzoeksprogramma wordt niet bij de eerste de beste anomalie opgegeven. Al met al illustreert dit een algemener punt, en wel de dynamische balans tussen normativiteit en cognitiviteit die sociale systemen eigen is, de voortdurende tegenkoppeling van veranderlijkheid en onveranderlijkheid, van gestructureerde instabiliteiten en stabiliteiten.

Ter afsluiting werpen we nog een korte blik op wat voorbij deze hele grondslagenoperatie ligt. De vraag dringt zich namelijk op, in hoeverre Luhmanns duiding van cognities en normen zich cultuurfilosofisch laat verbreden. Tekent $z i c h$ in de moderne geschiedenis een overgang af naar een maatschappij die in haar sociale structuren een hoge leercapaciteit heeft 
gerealiseerd als basis voor de omgang met extreem complexe handelingssituaties, d.w.z. met situaties waarin onwaarschijnlijk veel handelingsmogelijkheden open staan? Vormt dit de achtergrond van de veel beklaagde "ontmoralisering" en verzakelijking van de samenleving? Zijn, om gecondenseerde verwijzingen te gebruiken, de 'sexuele revolutie', de 'vrouwenemancipatie', de strijd om abortus of het getouwtrek rond euthanasie (sterven als "handeling") te begrijpen als stadia of momenten in de ompoling van normatief gestileerde verwachtingen t.a.v. seksualiteit, vrouwelijk gedrag, de omgang met leven en dood, etc. naar cognitieve verwachtingsmodi, die teleurgestelde verwachtingen niet afwentelen op de deviant, maar verdergaande leerprocessen m.b.t. menselijke gedragsmogelijkheden stimuleren? Toegegeven -, dat zijn vooralsnog uiterst speculatieve vragen. Wat er in doorklinkt; is echter de suggestie, dat in Luhmanns conceptie van sociale structuren een alternatief ligt besloten voor wat Weber met zijn rationaliseringsthese aan de orde wilde stellen, voor het nog in Parsons cultuurbeschouwingen voortlevende onderscheid tussen 'Gemeinschaft' en 'Gesellschaft', of voor Habermas" dichotomie van leefwereld en systeem.

\section{\$ 4. Conftict}

De manier waarop we tot nog toe over "communicatie" hebben gesproken, zou de indruk kunnen wekken, dat het om tamelijk gladlopende processen handelt, die zich zelfs over 'wanbegrip' heen kunnen zetten. Het is echter een weinig realistische voorstelling van zaken, wanneer communicatieprocessen simpelweg worden opgevat, als een '(mis/)begrijpen' van een medegedeelde informatie, dat slechts manifest kan worden, indien het zelf de vorm van een informerende mededeling aanneemt, hetgeen weer om een 'begrijpen' vraagt, enz., enz. Wat daarbij op de achtergrond raakt, is de, aan alle communicatie inherente mogelijkheid van discursiviteit, van tegenspraak. ${ }^{400}$ Zoals we eerder stelden, is informatie per definitie een gebeurtenis, die (hoe minimaal ook) verwachtingen schept of bijstelt, di:w.z. een 'structuur-effect' heeft. Iemand die een communicatie-aanbod 'begrijpt' kan echter op tweeërlei wijze met de medegedeelde informatie omgaan. Hij kan de daarin tot uitdrukking komende selectiviteit aanvaarden en overnemen als een conditie of 'premisse' van zijn verdere beleven en handelen; maar hij kan het in de mededeling vervatte selectievoorstel natuurlijk ook afwijzen. Deze keuze tussen accepteren of afwijzen is van een andere orde dan de selectiviteit die inherent is aan het begrijpen van een mededeling. We kunnen de mededeling,

400. Zie voor het volgende 0.a. Sozlale Systeme, op cit., p. 203 e.v. 
dat er geen wezenlijk onderscheid tussen literatuur en filosofie bestaat heel goed (goed/fout) begrijpen, maar dat tegelijkertijd grote onzin vinden en er in de eigen praktijk (als schrijver!) ook geen gehoor aan willen geven. Waar we dan echter verder mee moeten leven, is de wetenschap, dat er mensen zijn die dwaze dingen denken - dat is het onvermijdelijk structuureffect, waar ook degene die de boodschap niet accepteert, aan moet geloven.

In de praktijk spelen dus altijd vier keuzemomenten een rol. Naast de selectiviteit van het 'mededelen', de 'informatie" en het 'begrijpen', ook nog de keuze tussen accepteren of afwijzen. Men zou nu kunnen zeggen, dat een communicatie sociaal werkzaam wordt, 'lukt', wanneer de communicatieve offerte door de aangesprokene niet alleen wordt begrepen, maar bovendien wordt geaccepteerd. ${ }^{401}$ Hier dienen we echter precies te zijn. Om te beginnen, moet het idee worden vermeden, dat communicatie als zodanig op acceptatie, op het 'lukken' van communicatie uit zou zijn, als zou dat haar immanente telos zijn. De enige toespitsing die communicatie met zich meebrengt, is een toespitsing van de sociale situatie op de keuze acceptatie/afwijzing. (Maar natuurijik zou de wens tot communiceren sterk afnemen, wanneer men in de alledaagse praktijk niet in voldoende mate op acceptatie of bereidheid tot acceptatie kan rekenen.)

Ten tweede dient te worden benadrukt, dat de keuze tussen acceptatie en afwijzing niet een keuze inhoudt voor communiceren of niet-communiceren. Acceptatie en afwijzing stellen beide 'aansluitingen' op voorafgaande communicaties voor en op beide kan wórden aangesloten - en alleen wanneer dăt niet gebeurt, breekt de communicatie af. In die zin volstaat de eenheid van mededeling, informatie en begrip voor de constitutie van communicatie en heeft de differentie acceptatie/afwijzing in eerste instantie betrekking op de vorm waarin het communicatieproces wordt voortgezet. In een formulering van Luhmann:

"[D]ie Frage, ob jemand die mitgeteilte Information als Prämisse seines eigenen Verhalten übernimmt oder nicht stellt sich nur im Hinblick auf weiteres Geschehen...Zur Kommunikation gehört, daß sie eine soziale Situation schafft; die solche Anschlußentscheidungen erwarten läßt. Es ist intendierter Effekt, eine derart zugespitzte, aber offene Lage zu schaffen, und die Kommunikation kann Pressionselemente in sich aufnehmen, die den Empfänger mehr in Richtung auf Annahme als in Richtung auf Ablehnung drängen. ${ }^{402}$ 
Deze thematiek van acceptatie en afwijzing, van het slagen en misllukken van communicatie speelt, zoals we nog zullen zien, een belangrijke rol in Luh manns maatschappijtheorie, met name waar het gaat om de rol en functie van de zogeheten 'symbolisch gegeneraliseerde media'. Binnen de context van dit hoofdstuk blijvend, biedt het echter de mogelijkheid om een onderwerp aan de orde te stellen, dat enkele bijzondere consequenties van Luhmanns grondslagenoperatie aan het licht kan brengen. Het betreft hier het thema "conflicten".

Onder een 'conflict' verstaat Luhmann 'die operative Verselbständigung eines Widerspruchs durch Kommunikation. Ein Konflikt liegt also nur dann vor, wenn Erwartungen kommuniziert werden und das Nichtakzeptieren der Kommunikation rilckkommuniziert wird. ${ }^{403}$ De grond, of kern van ieder conflict is dus een communicatieve gebeurtenis: de manifeste uiting van een "nee', de openlijke afwijzing van een aangeboden zinselectie. Daarmee ontstalat de bijzondere eenheid die Luhmann 'Widerspruch'/tegenspraak noemt. Een 'tegenspraak' is een synthese van twee communicaties, die zijn eenheid ontleent aan een directe, kort gesloten vorm van (basale) zelfreferentie: de gecommuniceerde afwijzing bevat in zichzelf de afgewezen mededeling, zij het in genegeerde vorm. 'Tegenspraken' staan dus niet 'dwars' op het communicatieproces, zijn niet extern aan sociale systemen, maar vormen, zo beschouwd, een bijzondere instantie van communicatie als een zelfreferentieel proces.

$\mathrm{Nu}$ vormt het strikt logisch gezien nog geen tegenspraak, wanneer een persoon $p$ ' $A$ ' beweert en persoon $q$ daarop reageert met een afwijzing van ' $A$ ', net zo min als er sprake is van een logische contradictie, wanneer een koper slechts bereid is om de helft van het bedrag te betalen, dat de verkoper voor zijn waar will hebben. Het 'widersprilchliche', contradictoire karakter van communicatieve tegenspraken wordt eigenlijk pas manifest wanneer we letten op de verwachtingen die in het geding zijn, of deze nu betrekking hebben op het gedrag van een ander, of op een willekeurige toestand in de wereld, of op beide. (Zo wordt met de mededeling 'doe de deur dicht', zowell de verwachting uitgesproken, dat de ander bereid is bevelen te volgen, als de "verwachting", dat er een deur is die kan worden gesloten.) Met de communicatie van een 'nee' (- "doe zelf de deur dicht'/"de deur kan niet dicht') wordt een alternatief, zo niet concurrerend verwachtingspatroon in het veld gebracht. Als het al zin heeft, om binnen Luhmanns concept van 'tegenspraak' een (formeel) logische dimensie te situeren, dan slechts voorzover dit betrekking heeft op mogelijke contradicties tussen verwachtingen, d.w.z. voorzover de betreffende verwachtingspatronen 
eigenschappen of gedragingen aan objecten toekennen die niet tegelijkertijd kunnen gelden.

Belangrijker dan de formeel-logische aspecten van Luhmann concept van 'tegenspraak' lijken vooraleerst de consequenties van het voorafgaande. Luhmann gaat er om te beginnen vanuit, dat tegenspraken bestaan in de vorm van reële gebeurtenissen - wat vanuit een (traditioneel) logisch gezichtspunt "non-sense" is - maar onderkent vervolgens, dat de identificatie en articulatie van een tegenspraak qua tegenspraak het bestaan van concrete verwachtingen, i.e. structuren vooronderstelt en wel als een soort matrix van observatie en herkenning. M.a.w., pas in en door een referentie aan structuren kan een communicatieve gebeurtenis de vorm van een "tegenspraak" aannemen - het woordje 'nee' en zijn synoniemen zijn daarvoor niet genoeg. In een formulering van Luhmann:

'Widersprüche kommen nur im zusammenwirken von Struktur und Ereignis zustande. Sie setzen eine strukturelle Vermittlung der Selbstreferenz des Ereignisses voraus. Nur durch Umleitung ibres Sinnes über strukturiertes Anderes können Ereignisse sich selbst Widersprechen... Alle Formen widerspruchsvoller Kommunikation laufen uber eigens hierfur ausgewählten Sinn, und diese Auswahl orientiert sich an der Strukturselektionen sozialer Systeme: ${ }^{\text {404 }}$

Tegenspraken veronderstellen dus structuren - maar tegelijkertijd ondermijnen tegenspraken structuren, zowel op psychisch als op sociaal niveau: De veronderstelde (intersubjectieve) gelding van bepaalde 'werwachtingsverwachtingen' blijkt niet te kloppen en nu wordt onzeker, aan welke verwachtingen tegemoet zal worden gekomen. 'Widerspruche', zo merkt Luhmann op, "destabilisieren ein System, und sie machen dies an der Unsicherheit des Erwartens erkennbar'. ${ }^{405}$ We hebben echter gezegd dat de tegenspraak een bijzondere vorm van communicatie is, en dat ook op de afwijzing van selectievoorstellen kan worden aangesloten. Tegenspraken stellen, zo beschouwd, een bijzondere vorm van autopoietische reproduktie wan sociale systemen voor, die ook dan nog kan opereren, wanneer de structuren van het systeem buiten werking raken. Tegenspraken nemen als het ware de plaats in van structuren en maken dan alsnog 'aansluitend' handelen mogelijk. ${ }^{406}$ 
Willen we een terminologisch onderscheid maken tussen 'conflicten' en 'tegenspraken' - Luhmann doet dat zelf nauwelijks -, dan kunnen we het 'conflict' beschouwen als de systemische, gestructureerde vorm die een spontaan zich aandienende tegenspraak kan aannemen. Conflicten zijn geordende communicatieprocessen, i.e. sociale systemen die zich ontwikkelen in de schoot van andere sociale systemen - huwelijken, internationale betrekkingen, universitaire organisaties, etc. - , daar als het ware op 'parasiteren'. In abstracto zou men kunnen zeggen, dat de 'autokatalyse' van conflicten wordt aangedreven door een negatieve versie van dubbele contingentie, die we eerder omschreven in de trant van: 'Als jij niet doet, wat ik wil, dan doe ik niet, wat jij will. Meer in concreto bedienen conflicten zich van een typisch integratie- en structureringsprincipe, door Luhmann aangeduid als het 'Gesichtspunkt der Gegnerschaft', en dat we ook zouden kunnen omschrijven als het principe van het 'overkoepelend antagonisme'. Het gaat in ieder geval om het verschijnsel, dat in een zich ontwikkelend conflict de betrokken partijen de neiging vertonen, om al het handelen, hoe heterogeen van aanleg en motief ook, in een negatieve versie van het dubbele contingenti $\mathrm{e}^{3}$-bewustzijn te dopen, d.w.z. iedere gebeurtenis of handeling betekenis te geven in termen van het nut of (liever) de schade die deze de tegenstander oplevert. Dat is natuurlijk een extreme reductie van de mogelijke zin van handelingen, die leidt tot een bijzonder hoge graad van integratie tussen de commitments van psychische systemen enerzijds en de inhoud en vorm van het conflict anderzijds. Conflicten vertonen dan ook de neiging zich te ontwikkelen tot buitengewoon stabiele, zo niet "overstabiele" systemen. In die 'Integrationskraft ersten Ranges' schuilt met name ook het probleem van conflicten, in hun tendens om alle observatie-capaciteiten en alle energie-bronnen van het 'gastheer'-systeem te absorberen en uiterst eenzijjigheid op éến programmatisch doel te richten. In een commentaar van Luhimann:

'Jeder kann alle Möglichkeiten aktualisieren, die den anderen benachteiligen, und je mehr dies geschieht, um so mehr ist es plausibel. Das System erreicht zu hohe Interdependenz: ein Wort gibt das andere, jede Aktivitat muß und kann mit irgendwelchen anderen beantwortet werden. Die destruktive Kraft des Konflikts liegt nicht in ihm selbst und erst recht nicht in den Schaden an Reputation, Handlungspotential, Wohlstand oder Leben, die er den Beteiligten zufügt; sie liegt in dem Verhälthis zum System, in dem der Konflikt Anlaß und Ausgang gefunden hatte. ${ }^{407}$ 
Dat Luhmann het eigenlijke probleem van conflicten lokaliseert in hun neiging tot overmatige stabiliteit, zo niet tot 'monomanie' en niet primair in hun destabiliserende werking, brengt in feite een algemener principe van zijn systeemtheorie tot uitdrukking, het idee namelijk dat een zeer hoge mate van stabiliteit, of zelfs volledige interdependentie tussen de elementen van een systeem eerder een probleem dan een voordeel inhoudt. Te sterk geïntegreerde systemen neigen er volgens hem toe, 'onverschillig' te worden t.o.v. hun omgeving, hun sensibiliteit voor externe prikkels en ruis te verliezen, "weil im voraus festgelegt ist, in welchem Sinne sie Materialien und Informationen verwenden' ${ }^{408}$ Systemen hebben, zo beschouwd, een zekere mate van instabiliteit nodig; ze moeten naast hun stabiliteit ook instabiliteit reproduceren. Vertaald naar sociale systemen impliceert dit principe onder meer, dat 'verwachtingsverwachtingen' niet te sterk mogen "vastroesten', dat er ook voldoende 'verwachtings-onzekerheid' moet worden gereproduceerd, d.w.z. voldoende onzekerheid met betrekking tot de aansluitingswaarde van een handeling. Voorzover tegenspraken en conflicten dàt precies doen, voorzover ze de dubbele contingentie die aan alle sociale systemen ten grondslag ligt opnieuw naar voren halen en articuleren, vervullen ze dus ook een nuttige functie. Zonder tegenspraken en conflicten zouden de flexibiliteit en leercapaciteiten van een sociaal systeem al snel afnemen en zou uiteindelijk ook de maatschappelijke evolutie sterk worden geremd.

Luhmanns theorie van sociale conflicten kan tot op zekere hoogte worden beschouwd als een exemplarische analyse van deze rol en functie van 'instabiliteiten'. Zijn uitgangspunt is, dat tegenspraken en conflicten afwijkingen van gegeven sociale structuren aan het licht brengen en zo de mogelijkheid bieden deze devianties te elimineren. De mogelijkheid! Als de zelfreproductie van sociale systemen zich in een telkens veranderende omgeving afspeelt, moeten ook interne veranderingen, i.e. afwijkingen van de status quo mogelijk zijn. Tegenspraken en conflicten zijn dus niet iets 'slechts", ook niet per definitie iets 'goeds' - Luhmann vergelijkt ze eerder met "alarmsignalen' en beschouwt ze in die hoedanigheid als componenten van een (sociaal) immuunsysieem. Of dit een gelukkige woordkeuze is, valt te betwijfelen. De analogie die Luhmann tussen biologische immunnsystemen en tegenspraken ziet, betreft in ieder geval een tweetal zaken. Net als pijn zijn tegenspraken direct observeerbaar; ze fungeren als de antennes of voelsprieten van een speciaal daartoe ingericht 'apparaat' dat het systeem "scannt" op afwijkingen. Bovendien maken tegenspraken het, net als pijn, mogelijk om zonder diepergaande kennis van de oorzaken te reageren. Het feit dat wordt tegengesproken, dat middels de communicatie van een 'nee' 
een zinselectie expliciet wordt afgewezen, volstaat op zichzelf, om een reactie uit te lokken. Luhmann:

'Es genugt die Charakterisierung, die darin liegt, daß etwas in die semantische Figur des Widerspruchs aufgenommen wird. Eben deshalb kann man von einem Immunsystem sprechen und die Lehre von den Widersprüchen einer Immunologie zuordnen denn auch Immunsysteme operieren ohne Kognition, ohne Umweltkenntnis. ohne Analyse der Störfaktoren auf Grund einer bloßen Diskrimination als nicht dazugehörig. ${ }^{* 409}$

Welke heuristische voordelen een vergelijking van tegenspraken met de alarmsignalen van een immuunsysteem ook mag opleveren, op dit algemene niveau blijft het een tamelijk abstract concept. Het wordt spannender, wanneer Luhmann zich de vraag stelt, welke maatschappelijke subsystemen de rol van immuunsysteem in de moderne maatschappij vervullen en in antwoord daarop onder meer naar het rechtssysteem en naar de zogeheten 'sociale bewegingen' verwijst. We beperken ons hier, en dan nog vrij summier, tot het rechtssysteem.

Maatschappijtheoretisch gesproken, bestaat bij Luhmann de algemene functie van het rechtssysteem uit het screenen, articuleren en preventief testen van de generalîseerbaarheid van sociaal relevante, normatieve verwachtingen en dit met het oog op mogelijke conflictsituaties. Anders geformuleerd: het rechtssysteem dient die "verwachtingswerwachtingen" uit te sorteren, die op dusdanige acceptatie of geldingskracht kunnen rekenen, dat ze als het kader voor de beslechting wan conflicten kunnen dienen. In die zin zou het te kort schieten om moderne rechtssystemen uitsluitend als immuunsystemen, i.e. als 'scanners' van afwijkingen te karakteriseren. Het is echter geenszins de functie van het recht, om er voor te zorgen, dat alles zoveel mogelijk rechtmatig verloopt - dat zou simpel zijn: gewoon alles toestaan. Het is evenmin de functie van het recht zoveel mogelijk conflicten uit te bannen. Het rechtssysteem bemiddelt weliswaar in conflicten en natuurlijk dient via het (straf)recht 'al te verregaand' non-conform gedrag preventief te worden bezworen, maar in feite heeft de ontwikkeling van het recht tot een vergroting van de kansen op conflicten geleid. Een tweetal mechanismen zijn daarvoor met name van belang geweest. Ten eerste het, in alle ontwikkelde rechtssystemen verankerde verbod op de fysieke beslechting van tegenspraak door 'gewone', niet speciaal daartoe bevoegde individuen. Dat vermindert voor de betrokkenen in aanzienlijke mate het risico van tegenspreken. Juist 
de monopolisering van het fysiek geweld door de overheid en de preventieve werking die in deze van het recht uitgaat, heeft de bereidheid tot het aangaan van conflicten dus doen toenemen. Ten tweede garanderen de principes van de rechtsgelijkheid en de vrijheid van de rechtstoegang (in combinatie met de positiviteit van het recht en de ontwikkeling van de rechtsstaat), dat het communiceren van (normatieve) verwachtingen ook in geval van tegenspraak kan worden voortgezet, desnoods tot voor de rechterstoel.

Het is al met al niet de intentie van het recht om conflicten te genereren, maar een effect. Door simpelweg te functioneren, zo zou men kunnen zeggen, verzorgt het rechtssysteem de maatschappij met een aanhoudende stroom van conflicten, etableert het zichzelf als 'immuunsysteem'. Met een knipoog naar Von Clausewitz:

\begin{abstract}
'Das Recht dient der Fortsetzung der Kommunikation mit anderen Mitteln. E's ist gesellschaftsadäquat nicht nur dann, wenn es die vorkommenden Konflikte erfaßt, sondern erst eigentlich dann, wenn es hinreichend viele Konflikte erzeugen und für deren Behandlung hinreichende eigene Komplexität zur Verfugung stellen kann. ${ }^{\times 10}$
\end{abstract}

In het volgende hoofdstuk zullen we nog uitgebreider op het rechtssysteem terugkomen. Wat we hierboven, hoe summier ook, over tegenspraken en conflicten hebben opgemerkt, mag echter volstaan, om enkele, meer allgemene consequenties van Luhmanns positie in een theorie-vergelijkend perspectief onder ogen te voeren.

Luhmann gaat er zelf vanuit, dat zijn omschrijving van 'tegenspraak' en 'conflict' de basis kan vormen voor een empirische sociologie van sociale conflicten. Zijn conflict-begrip is naar zijn mening immers auf einen präzise und empirisch faßbaren Kommunikationsvorgang bezogen: auf ein kommuniziertes 'Nein', das eine vorherige Kommunikation beantwortet" " 11 Een dergelijk sociologie van conflicten zou niet alleen de 'logica" van sociale immutunsystemen verder moeten uitwerken, maar ook moeten bestuderen hoe het komt, dat de immense produktie van tegenspraken in de alledaagse praktijk niet voortdurend tot serieuze, of zelfs 'maatschappelijke' conflicten leidt. Naast het onderzoek naar de mechanismen die sociale systemen of de maatschappij van 'voldoende' tegenspraken en conflicten voorzien, moet m.a.w. ook empirisch worden onderzocht welke sociale mechanismen conflicten kanaliseren en dempen - en in het geval van daadwerkelijke 
conflicten: welke mechanismen en strategieën effectief bijdragen aan de beslechting of 'verdamping' van conflicten.

We spreken hier welbewust van een (systeemtheoretische) sociologie van conflicten, in de zin van een specialistische deel-discipline binnen de sociologie, en niet wan een 'conflictsociologie", zoals bijv. door Ralf Dahrendorf is uitgedragen. Voor Luhmann zijn conflicten, sociaal gezien, niet fundamenteler of van een meer primordiale betekenis dan vormen van coopperatie. Het Hobbesiaanse orde-probleem wordt door hem niet als een 'conflict-problematiek' aan de sociologie ten grondslag gelegd, maar als een (dubbele) contingentie-problematiek die nog aan alle mogelijkheden van conflict en coöperatie voorafgaat. Weliswaar hebben conflicten en hun destabiliserende effecten voor Luhmann ook een positieve functie, maar zonder enig uitzicht op acceptatie van communicatieve offertes, zonder enige overname van selectievoorstellen en zonder een minimale vorm van coöperatie kunnen sociale systemen zich evenmin ontwikkelen. Bovendien geldt voor Luhmann dat tegenspraak en conflict niet de enige bronnen of katalysatoren van systeemdynamiek en -verandering voorstellen. Wanneer we over de "verandering van een sociaal systeem" spreken, dan hebben we het in feite altijd over veranderingen op het niveau van de systeemstructuren - waar zou 'verandering' anders betrekking op kunnen hebben, gegeven de aanname dat we met systemen te maken hebben die basaliter uit gebeurtenissen bestaain en we ons bij de verandering van een gebeurtenis weinig voor kunnen stellen? Behalve door tegenspraken en conflicten, künnen structuurveranderingen echter ook door doelgerichte planning in gang worden gezet, bijv. binnen de context wan formele organisatie, of eerder 'morphogenetisch' van aard zijn. Onder 'morphogenese' verstaat Luhmann een vorm, of eigenlijk een 'mechanisme' van structuurontwikkeling, dat bestaat uit de (re)activering van tot dan toe onderdrukte mogelijkheden. Bij sociale systemen gaat het dan met name om het toelaten van mogelijkheden waarnaar door de zin van handelingen of communicaties in principe al werd verwezen, maar die tot dan toe, zij het door interne, zij het door externe condities, niet of nauwelijks werden uitgetest. In een formulering van Luhmann:

'Die Morphogenese ergibt sich wicht aus Anpassungszwângen, und ihr ausbleiben füht auch nicht zu Konflikten. Sie entwickelt sich auf freiem Terrain. [-] Sie setzt Systeme voraus, deren Möglichkeiten weitestgehend inhibiert sind, deren Sinnverweisungen zum Beispiel durch die zur Reproduktion benötigten Erwartungsstrukturen nur sehr begrenzt ausgenutzt werden. In solchen Fällen kann das Verhältnis von Aktivierung und Inhibierung durch evolutionäre Variation geändert werden, so daß inhibierte 
Möglichkeiten abweichend von Strukturen gelegentlich desinhibiert, also re-aktiviert werden können. ${ }^{\text {412 }}$

Voorbeelden van dergelijke, morphogenetische structuurontwikkelingen zijn er legio. Men kan bijwoorbeeld denken aan de wijze waarop de toename van mobiliteit en van privaat beschikbare vrije tijd structuurontwikkelingen binnen het moderne gezinsleven in gang gezet hebben, of althans hebben bijgedragen aan de veranderingen inzake de verwachtingen die gezinsleden jegens elkaar koesteren. Een ander bekend voorbeeld is de veranderde houding in het Westen t.o.v. ziekten en de geheel andersoortige verwachtingen die men, vergeleken met vroegere tijden, ta.v. de medische stand koestert. Dat een ziekte niet meer wordt beschouwd als een noodlot, of als een straf Gods, maar als een 'mankement' dat in principe kan en moet worden verholpen, is een niet-geïntendeerd en ook niet door conflicten uitgelokt effect van de explosieve ontwikkeling van het medisch kunnen.

Belangrijker dan de afstand die Luhmann wil bewaren tot conflictsociologieën met theoretische universaliteitsaanspraken, is in theorievergelijkend perspectief misschien nog wel het volgende. Zoals we gezien hebben, zijn 'tegenspraken' bij Luhmann communicatieve gebeurtenissen, düe zich voordoen wanneer, middels de communicatie van een 'nee', een voorafgaand communicatie-aanbod wordt afgewezen. Luhmann gaat, zoals hij zelf zegt, uit van de "These einer ausschließlich kommunikativen (dann aber Bewußtsein mehr oder weniger provozierenden) Existenz der Widersprüche des sozialen Systems". ${ }^{413}$ Bedenken we nu, dat Luhmann er bovendien vanuit gaat, dat de structuren van een sociaal systeem een, aan het basale communicatieproces complementaire realiteit voorstellen, dan impliceert dit, dat er binnen het raamwerk van zijn theorie geen sprake kan zijn van zo iets als 'structurele tegenspraken'. Zoals we eerder zagen, veronderstelt de vorming van tegenspraken weliswaar structuren, maar het spreken over tegenspraken op structuurniveau, in de zin van relatief duurzame structuren die tegenspraken bevatten en deze tegenspraken dan ook een zekere permanentie verlenen, moet bij Luhmann betekenisloos blijven. Dat is een forse consequentie. Het impliceert een scherpe scheidslijn tussen al die, structureel georiënteerde theorieên - het Marxisme natuurlijk voorop -, die de drijfkracht achter de dynamiek en verandering van sociale systemen lokalliseren in structureel aangelegde antagonismen en tegenspraken. De door Marx voor het kapitalisme structureel geachte tegenstelling tussen loonarbeid en kapital is voor Luhmann net zo min een "tegenspraak", als bijvoorbeeld de behoefte van het economisch systeem aan 
zowel spaarders als aan consumenten. Dat impliceert eveneens, dat conflicten, ook als het gaat om "maatschappelijke conflicten', bij Luhmann niet 'structureel aangelegd' kunnen zijn, maar telkens een culminatie voorstellen van vooraleerst locaal en ad hoc gecommuniceerde tegenspraken, die zich vervolgens stabiliseren en zich als het ware 'doorstructureren' tot ontwikkelde sociale systemen.

Parallel aan deze afwijzing van het idee van "structurele tegenspraken' en van 'structureel aangelegde conflicten' kan er bij Luhmann ook niet zo iets als een "klasse-conflict" bestaan, althans niet in de zin van een mogelijk ook latent, sluimerend, maar desalniettemin de hele maatschappij doordringend conflict tussen een tweetal, in abstracto bestaande sociale groepen. Gegeven Luhmanns insistentie op het 'empirische', observeerbare karakter van conflicten, kunnen conflicten uberhaupt niet latent zijn. "Eine allgemeine Widerspruchslage, ein Interessengegensatz, eine Wechselseitige Schädigung', zo schrijft hij, 'ist noch kein Konflikt'. ${ }^{414}$

$\mathrm{Nu}$ zou dit laatste citaat de indruk kunnen wekken, dat het al met al om een terminologisch kwestie draait en dat we in een onvruchtbaar woordenspel verzeild zijn geraakt. Luhmann erkent immers het bestaan van belangentegenstellingen en spreekt bovendien over "Widerspruchsiage", d.w.z. over een situatie waarin het optreden van tegenspraken waarschijnlijk is. En het is bovendien niet aannemelijk, zo zouden we hier nog aan toe kunnen voegen, dat zich met betrekking tot de structuren van sociale systemen geen problemen voordoen. Dat zou immers betekenen, dat structuren niet voor een doorgaande functionele analyse in aanmerking komen, hetgeen door Luhmanns eigen werk de facto wordt tegengesproken.

$\mathrm{Nu}$ is het natuurlijk waar, dat Luhmann de term 'tegenspraak' op een specifieke wijze gebruikt; en het kan heel goed zijn dat voor die gevallen waarin Luhmann over een belangentegenstelling spreekt, een ander de term 'tegenspraak' zou willen reserveren. Wie op grond daarvan echter denkt dat het in wezen om een terminologische 'stuivertje wisselen' gaat, mist een belangrijke, niet oninteressante pointe van Luhmanns conceptualiseringsstrategie. Bondig geformuleerd, komt die neer op de poging, een "realistisch" concept van tegenspraak te redden! Wat het van Hegel en Marx uitgaande denken over 'maatschappelijke tegenspraken', als tegenspraken in en van de maatschappij, zich telkens heeft moeten laten welgevallen, is de nuchter-ironische, "logische" kritiek, dat beschrijvingen en theorieèn tegenspraken kunnen bevatten - wat op zichzelf al ernstig genoeg is maar de te beschrijven werkelijkheid zelf niet. Zou de werkelijkheid zelf tegen de regels van de logica zondigen, dan zou, formeel gezien, van een correcte beschrijving van de werkelijkheid iedere andere, willekeurige uit- 
spraak op een geldige manier kunnen worden afgeleid en zou, zo besluit de kritiek, wetenschappelijke kennis uberhaupt niet mogelijk zijn. Luhmann gaat hier tot op zekere hoogte in mee, voorzover ook hij ervan uit gaat, dat tegenspraken enkel en alleen voor een observator/beschrijver kunnen bestaan. Luhmann:

'Widersprüche gibt es nur fur Beobachter eines Systems (eingeschlossen: Selbstbeobachtung des Systems), denn nur Beobachter können Unterscheidungen einführen und mit Hilfe von Unterscheidungen Widersprüche feststellen. Für Beobachter wird der Widerspruch als Ereignis des je eigenen Systems aktuell. Ohne solche Aktualisierung hat der Widerspruch in Sinnsystemen keine Realität, nämlich keine Bedeutung und erst recht kein alarmierende Funktion. ${ }^{3} 1 \mathrm{~s}$

Met dit citaat is de theoretische judo-truc eigenlijk al verraden. Sociale systemen kunnen als communicatieprocessen zichzelf observeren en wel in de vorm van reflexieve communicatie. Tegenspraken kunnen ma:w. voor een sociaal systeem realiteit hebben als actuele, communicatieve gebeurtenissen van het systeem zelf. Deze poging een realistisch concept van tegenspraken voor de sociologie te redden, heeft een, inmiddels bekende, prijs. Communicatieprocessen kunnen zichzelf observeren, structuren niet.

\section{\$5. Ter afsluiting}

De ironie wil, dat waar de klassieke systeemsociologie telkens is verweten 'de mens' te degraderen tot een marionet die danst naar de trekken van "het systeem', Luhmanns beslissing om het psychische en het sociale als twee onafhankelijke domeinen op te vatten, bij veel critici in vergelijkbaar slechte aarde is gevallen. Wat we Luhmanns 'theoretisch antihumanisme' zouden kunnen noemen, is door sommigen zelfs als een normatief anti-humanisme geduid, als zou zijn theorie een inhumane, of zelfs anti-humane strekking hebben. ${ }^{416}$ Luhmanns antwoord typeert hem:

415. Idem, p.507.

416. Verg. o.a. H. Grunberger, 'Dehumanisierung der Gesellschaft und Verabschiedung staatlicher Souveranitat: das politische System in der Gesellschaftstheorie Nikdas Luhmanns', in: Fetscher/Munkler (Hrsg), Pipers Handbuch der politischen Ideen Bd. 5, Munchen 1987, p. 624, zie ook: T. Schøfthaler, 'Soziologie als "interaktionsfreier Kommunikation - Niklas Luhmanns leidenschafthicher Antihumanismus", in: Das Argument 15 (1985), p. $372-384$.

Habermas is in deze minder kortzichtig (of minder kortzichtig gewordent?); verg. J. Habermas, Der philosophische Diskurs der Moderme, Frankfurt/M. 1985, p. 435 e.v. 
"Gewonnen wird mit der Unterscheidung von System und Umwelt aber die Möglichkeit, den Menschen als Teil der gesellschaftlichen Umwelt zugleich komplexer und ungebundener zu begreifen, als dies möglich walre, wenn er als Teil der Gesellschaft aufgefaßt werden mußte; denn Umwelt ist im Vergleich zum System eben derjenige Bereich der Unterscheidung, der höhere Komplexitat und geringeres Geordnetsein aufweist. Dem Menschen werden so höhere Freiheiten zu seiner Umwelt konzediert.... ${ }^{247}$

Voor Luhmann bestaan er, naast alle argumenten die we al eerder zijn tegen gekomen, bovendien maatschappijtheoretische redenen, om het individu/de mens/het psychisch systeem/etc. buiten de maatschappij te sluiten en in de omgeving van sociale systemen te plaatsen. Zo meent hij, dat in premoderne, gestratificeerde maatschappijen - men denke bijv. aan de middeleeuwse samenleving - de individualisering van de enkeling tot stand komt door sociale inclusie, d.w.z. door opgenomen te zijjn in een familie of soortgelijke groep en daarmee toe te behoren aan een bepaalde sociale laag, kaste of stand Pas door lid van de maatschappij te zijn, wordt men hier een met rechten en plichten uitgerust, bij naam en toenaam genoemd, concreet gekend 'individu'. 'Moderne' individualiteit wordt volgens Luhmann echter daardoor aangemoedigd én afgedwongen, dat een individueel persoon voortdurend aan verschillende maatschappelijke systemen moet deelnemen, zonder dat er één subsysteem is, dat hem de kans biedt zich met de maatschappij als zodanig te identificeren, zich via een collectieve identiteit een persoonlijke identiteit te verschaffen. ${ }^{418}$ Het 'individu' of de 'geïndividualiseerde persoon' wordt in de moderne, functioneel gedifferentieerde maatschappij m.a.w geconstitueerd door exclusie. ${ }^{419}$ Wil een theorie van de moderne maatschappij ('object'-)adequaat zijn, zo zou men nu kunnen zeggen, dan moet ze deze sociale exclusie van het individu

417. Soziale Systeme, op cit., p. 289.

418. Luhmann: 'Die Einzelperson kann nicht mehr einem und nur einem gesellschaftlichen Teilsystem angehören. [-] Da die Gesellschaft aber nichts anderes ist als die Gesamtheit ihrer intemen System/Umwelt-Verhaltnisse und nicht selbst in sich selbst als Ganzes nochmals vorkommen kann, bietet sie dem Einzelnen keinen Ort mehr, wo er als "gesellschaftliches Wesen' existieren kann. Er kann nur außerhalb der Gesellschaft leben, nur als System eigener Art in der Umwelt der Gesellschaft sich reproduzieren, wobei fir ihn die Gesellschaft eine dazu notwendige Umweit ist. Das Individuum kann nicht mehr durch Inklusion, sondern mur noch durch Exklusion definiert werden." ( Gesellschaftsstruktur und Semantik, op.cit., p.158.)

419. Zie woor een veel uitgebreidere toellichting: $N$. Luhmann, Individuum, Individuallitat, Individualismus", opgenomen in Gesellschafisstruktur und Semantik Bd. 3, op.cit., p.149 259. 
van meet af aan in haar grondbegrippen en beschrijvingsmodellen verdisconteren. Of zoals Luhmann het formuleert:

'Will man die Systemanalyse begrifflich auf diese neue Lage
einstellen (so daß sie ihrerseits dann zur Sellbstbeschreibung
der modernen Gesellschaft beitragen kann), dann muß sie das,
was der Einzelmensch an Leben und an Bewußtsein
reproduziert, als jeweils eigenes, autonomes,
selbstreferentielles System behandeln können.' 420

De tegenwerping, dat deze 'object-adequaatheid' slechts schijn is, ligt voor de hand. Men kan hooguit willen beweren, dat de theorie 'zich aan zichzelf' controleert, haar grondslagen aan een daarop voortbouwende maatschappijtheorie en vice versa. Per slot van rekening gaat Luhmann er zelf vanuit, dat een theorie wan de moderne maatschappij in wezen een zelfobservatie van die maatschappij voorstelt, die wordt ondernomen vanuit een bijzonder subsysteem, namelijk 'wetenschap', en wel op basis van specifieke onderscheidingen en observatieschema's die niet ergens 'daarbuiten' worden aangetroffen, maar door dat systeem zelf moeten worden geconstrueerd, zonder dat het kan claimen in een dermate geprivilegieerde positie te verkeren, dat zijn (sociologische) observatie van de maatschappij de enig juiste of geldige zou zijn. Ook een beschrijving van de moderne maatschappij als 'functioneel gedifferentieerd', inclusief de observatie dat 'individualiteit' zich hier via uitsluiting constitueert, is in die zin een 'constructie' en in principe ook anders mogelijk.

De constatering, dat de veronderstelde adequaatheid van de theorie vis-à-vis haar 'object' in feite berust op een circulaire 'zelfbevestiging', is natuurlijk correct. De vraag is alleen in hoeverre dit een tegenwerping is. Als kentheoretisch constructivist zou Luhmanns reactie althans moeten zijn, dat iedere 'fundering' van een theorie uiteindelijk een 'zelf-fundering?' voorstelt en dat andere vormen van fundering binnen de wetenschap ook njet mogelijk zijn. De kwestie is eerder of in deze de zelfreferentiele toepassing van de theorie op de theorie ver genoeg is doorgedreven. Idealiter zou een sociologische theorie haar eigen voorkomen als sociaal produkt moeten kunnen verklaren en aan die 'zelfverklaring' dan ook haar basisonderscheidingen en theorie-technische principes moeten spiegelen. In het onderhavige geval zou dit betekenen, dat er een verband gelegd wordt tussen aan de ene kant het feit dat sociologische theorieën een (disciplinair) produkt zijn van het maatschappelijk subsysteem 'wetenschap' en aan de andere kant de 
beslissing om mensen niet als delen of elementen wan sociale systemen te beschouwen.

Op een dergelijke verklaring lijkt Luhmann inderdaad aan te sturen met zijn hypothese, dat er een samenhang bestaat tussen de ontwikkeling van het maatschappelijk subsysteem 'wetenschap" en de hoge mate wan autonomie en zelfsturing die de wetenschap daarmee bereikt enerzijds, en wat hij als een bijzonder kenmerk van de moderne wetenschap beschouwt anderzijds, namelijk de letterlijk 'tot in het onvoorstelbare' toegenomen capaciteit tot onderscheiden, tot het oplossen van grotere eenheden in steeds kleinere eenheden. ${ }^{421}$ Deze steeds sterker toegenomen drang tot analyse en deconstructie, heeft er onder meer toe geleid, ' $\mathrm{daB}$ die Formel Mensch nur noch ein Einheitsbegriff oder ein Rahmenbegriff fur unübersehbare Komplexitat ist, aber nicht mehr ein Gegenstand, uber den man direct Aussagen formulieren kann" " ${ }^{422}$ Wat ooit 'mens' was, verschijnt binnen de wetenschap als een uiterst complexe compilatie van fysische, chemische, organische en psychische systemen. Dan kan men zich inderdaad afvragen, wat uberhaupt nog bedoeld wordt met de frase dat 'de mens deel of element van de maatschappij is". Rekenen wij ook het organisch systeem, het lichaam, tot die mens en moeten we bijgevolg aannemen dat een gebeurtenis In de dikke darm ook altijd een maatschappelijke gebeurtenis is, want een gebeurtenis in/van de maatschappij? Of stellen we ons er mee tevreden om de mens' met het psychisch systeem te identificeren, maar houden we er well aan vast, dat wanneer door ziekte of ongeval een psychisch systeem uitvalt, ook een deel van de maatschappij verdwijnt?

Maar ook de sociologie zelf heeft zich, vanaf haar vestiging als wetenschappelijke discipline niet kunnen onttrekken aan de drang naar een steeds verdergaande analyse en deconstructie. De structuur-eenheden waar de eerste generaties sociologen nog mee rekenden - de institutie, de rol, de norm en tenslotte ook de 'persoon' als toerekeningspunt van handelingen zijin uiteindelijk opgelost in gedragsverwachtingen en gereconstrueerd als verwachtingscollages. Daarbij tekende zich tegelijkertijd een sociologische deconstructie, of zo men wil: een 'decentrering' van het subject af en wel als het effect van een abstractieproces dat, op basis van een relationistische duiding van het sociologisch object, eerst een verdergaande sociologische analyse mogelijk maakte. (Man kann) es als eine Grundrichtung der modernen Wissenschaft bezeichnen "zo schreef Georg Simmel al in 1900, 'daß sie die Erscheinungen nicht mehr durch und als besondere Substanzen, sondern als Bewegungen versteht, deren Träger gleichsam immer weiter und

421. Zie: N. Luhmann, 'Die Soziologie und der Mensch', opgenomen iun: Saziologische Aufklarnung 6, op.cit, p.267.

422. Idem, p. 269. 
weiter ins Eigenschaftslose abrucken; dass sie die den Dingen anhängende Qualitäten als quantitatieve, also relative Bestimmungen auszudrücken sucht; . dass sie auf das an sich seiende Wesen der Dinge verzichtet und sich mit der Feststellung der Beziehungen begnügt... ${ }^{, 23}$ Daarbij was voor Simmel tevens duiclelijk - natuurlijk had hij Marx in de rug - dat het, vanuit het oogpunt van een wetenschappelijke sociologie geen zin heeft, om over mensen als delen of elementen van de maatschappij te spreken. De maatschappij bestaat voor de socioloog niet uit individuen, aldus Simmel, maar uit de (vormen van) wisselwerkingen tussen individuen. ${ }^{424}$ Durkheim zit daar in zijn Règles niet ver vanaf, wanneer hij de uitdrukking 'maatschappij' opvat als een aanduiding voor het geordende geheel van relaties tussen individuen. En Weber sluit zich daarbij aan, wanneer hij 'Gesellschaft' definieert als 'Inbegriff' van de 'allgemeinen Strukturformen menschlicher Gemeinschaften' 425

Of men Luhmanns suggestie, dat zijn aanpak samenhangt met de wetenschappelijkheid van de sociologie, nu wel of niet acceptabel vindt, terugblikkend op de geschiedenis van de sociologie kan men zich in ieder geval afvragen, wat al met al toch het probleem is, dat veel critici met zijn principiële scheiding van het psychische en het sociale hebben? In feite lijkt Luhmann weinig anders te doen, dan consequent een lijn door te trekken die altijd al in de sociologie lag besloten. '[W]enn unter Humanismus eine Semantik verstanden wird, die alles, auch die Gesellschaft auf die Einheit und Perfektion des Menschen bezieht ${ }^{t}$, dan is Luhmanns positie inderdaad radicaal anti-humanistisch. ${ }^{426}$ Mar wat is daaraan, binnen de context van de hedendaagse sociologie, problematisch? Dat 'de mens' niet meer de maatstaf van de maatschappij vormt? Maar laten we wel wezen - als onder 'mens' hier het concrete, alledaagse individu wordt verstaan, dan kunnen we alleen verzuchten: 'gelukkig'. De autonomie en vrijheid die Luhmann aan individuele psychische systemen toeschrijft, omvat ook hun vrijheid om zich onredelijk en inhumaan te gedragen. Als hier 'de mens' echter een symbool

423. Georg Simmel, Philosophie des Geldes, Berlijn 1977 (oorspr. 1900), p.63-64

424. Zo schrijft Simmel, de grondslag van de "formale Soziologie" leggend: "Uit het alleem ruimtelijk naast- elkaar of in de tijd na-elkaar van de mensen is pas een maatschappij ontstaan wanneer deze levende inhouden de vorm verkrijgen wan wederzijdse belnvloeding als de een op de ander inwerkt - dixect of via een derde. Als er dus een wetenschap van - alleen - de maatschappij moet zijn, dan kan zij alleen deze wisselwerkingen, deze soorten en vormen wan de vermaatschappelijking willen onderzoeken. Want al het andere dat zich verder nog in de "malschappij" bevindt, dat door haar en in thaar kader gerealiseerd wordt, is niet zelf maatschappij, maar alleen een inhoud.' (G. Simmel, "Het probleem an de sociologiex, opgenomen in: Een keuze uit het werk van Georg Simmel, Deventer 1976, p.6.)

425. M. Weber, Wirtschaft und Gesellschaft, p.212

426. 'Die operative Geschlossenheit psychischer und sozialer Systeme', op.cit., p. 36. 
is voor een bijzondere set van meer of minder samenhangende waarden, dan is er geen reëel probleem. Luhmanns theorie laat althans de mogelijkheid, dat een maatschappij aan humanistische idealen een belangrijke plaats toekent binnen haar waardensfeer, volledig open. Het laatste echter wat we van een ook maar enigszins kritische sociologie kunnen verlangen, is dat zij zich bij voorbaat committeert aan de, historisch gezien contingente waarden en idealen van de maatschappij waarbinnen zij opereert.

Luhmanns 'theoretisch antihumanisme' bezorgt zijn lezers ongemak - dat is duidelijk; maar misschien heeft dit, voorzover het althans zijn sociologisch geschoolde lezers betreft, uiteindelijk weinig met moreel-ethische of politieke overwegingen te maken. Wil Martens zou de spijker wel eens eerder op de kop kunnen slaan met zijn suggestie, dat het al of niet kunnen accepteren van de manier waarop Luhmann een scheiding aanbrengt tussen psychische en sociale systemen, samenhangt met de beelden en idealen die wij koesteren omtrent de aard en de mogelijke rol van sociologische kennis. ${ }^{427}$ Actortheorieèn, of die nu eerder speltheoretisch, dan wel intentionalistisch van aard zijn, suggereren de mogelijkheid van sociale interventie, van gerichte gedragsverandering en sturing en dit op basis van een manipulatie van handelingscontexten. Een dergelijke 'praxis" (progressief) of "instrumentaliteit" (conservatief-technocratisch) is Luhmanns theorie ten enenmale vreemd. Martens diagnosticeert de grond daarvan correct:

'Psychische und soziale Systeme haben ihre je eigenen Zusammenhänge und Entwicklungen und lassen keine einfache Steuerung zu. Dabei wird jeder Steuerungsversuch in ein Kommunikationssystem aufgenommen, das selbst uber die Wahrnehmung der und die Anschlüsse an die steverende Kommunikation entscheidet. Eine einfache Änderung des Kontextes ist, wegen der Eigenständigkeit des Sozialen, ausgeschlossen. ${ }^{3} 428$

Wat dit uiteindelijk betekent voor de politiek, of algemener: voor de mogelijkheid om gericht maatschappelijke hervormingen door te voeren, zullen we in volgende hoofdstukken onder de loep nemen. Hier gaat het vooraleerst om de vaststelling dat Luhmann al in zijn grondbegrippen en modellen op een type theorie afstevent, dat inderdaad - men zou haast zeggen: uit de aard der zaak - geen directe aanwijzingen voor interventie en sturing oplevert. Waar Luhmann zich als theoreticus mee engageert, is het

427. Zie W. Martens, "Die Autopoiesis sozialer Systeme", in $K Z f S S . S .43$ (19.91), p.626. Verg. voor het volgende ook W. Reese-Schafer, Luhmann zur Eimführung, Hamburg 1992, p. 169
e.w.

428. W. Martens, op.cit., p.626. 
probleem van maatschappelijke complexiteit. Wat hij met de grondslagen van zijn sociologie voorbereidt, is, anders gezegd, een theorie die sociale complexiteit kan beschrijven en analyseren. En dit 'onder behoud van complexiteit"!, oftewel: op een miet-reductionistische wijze en met in achtneming van alle contingentie die onvermijdelijk met complexiteit verbonden is. Vanuit die optiek worden causale en causaal-genetische principes en modellen van secundair belang, hooguit interessant als bijzondere, binnen een specifieke context meer of minder functionele vormen van complexiteitsreductie. Een dergelijk perspectief op 'causaliteit' moet onherroepelijk in conflict komen met een instrumentalistische/activistische oriëntatie binnen de sociologie, onafhankelijk van de vraag of deze sociale sturing/interventie/'praxis' de emancipatie van het individu of de mensheid moet dienen, dan wel de locale overheid. Binnen het kader van een bewust interventionistische of 'praktische' sociale wetenschap moeten causale voorstellingen wel centraal staan, zij het alleen al als zakelijke grond van de verwachting, dat gericht ingrijpen in, en vormgeven aan sociale samenhangen reěel mogelijk is. Tegen deze achtergrond kunnen we instemmen met Heidenescher, wanneer hij vaststelt:

'Zunächst einmal kann man sagen, daß viele Kritiken an der Intention der Theorie autopoietischer Systeme vorbei argumentieren. Anstatt auf Interessen und Einflußpotentiale zu rekurrieren, muß ein Handlungsbegriff, der für Bedingungen von Komplexitătsreduktion entworfen ist, abstrakter ansetzen und verfolgt eine ganz andere Absicht als die Analyse 'kausalgenetischer' Erklärungsansä̈tze:, ${ }^{, 429}$

Van de weeromstuit is en blijft een kritiek interessant die Johannes Berger al n.a.v. de publikatie van Soziale Systeme heeft gespuid en die vrijwel diametraal tegenover actor- en handelingstheoretisch geïnspireerde kritieken staat. De lijn van Bergers commentaar wordt al duidelijk aan de titel die hij zijn kritiek mee gaf: "Autopoiesis: Wie "systemisch" ist die Theorie sozialer Systeme?'. ${ }^{430}$ Het antwoord luidde: te weinig. Met de overgang van het systeem/omgeving-paradigma naar de autopoiesistheorie heeft zich in Luhmanns werk een 'fenomenologisering" doorgezet, aldus Berger, die de systeemtheoretische sociologie van haar tanden heeft beroofd. Wat overblijft is een 'systemtheoretisch umformulierte Handlungstheorie', een soort

429. M. Heidenescher, 'Zurechnung als soziologische Kategorie', in: Zeitschrift für Shoziologie 21 (1992), p. 451.

430. Opgenomen in: H.Haferkamp/M.Schmid (Hg), Sinn, Kommunikarion and soziale Differenzierung, Frankfurt/M. 1987, p. $129-152$ 
'kybernetische Phänomenologie'. ${ }^{431}$ Wat Berger met name stoorde, was de inperking en afzwakking van het structuurbegrip die daarvan het gevolg was - 'Wie im handlungstheoretischen mainstream werden auch bei Luhmann die Strukturen sozialer Systeme als generalisierte Verhaltenserwartungen definiert' ${ }^{432}$ Een dergelijk structuurbegrip is in de ogen van marxisten, structuralisten en functioneel-structuralisten niet gewoon ' $z w a k$ ', het is te zwak. Het idee dat sociale structuren 'materieel' gezien uit gedragsverwachtingen bestaan, ondermijnt niet alleen in verregaande mate de voorstelling van 'latente' structuren " met zijn grondbegrippen haalt Luhmann bovendien in eén beweging een streep door ieder concept van 'dieptestructuren' of van 'structurele tegenspraken' als verklaringsprincipes van maatschappelijke 'oppervlakteverschijnselen' of sociaal-historische dynamiek.

Bergers diagnose van Luhmanns theorie is in deze natuurlijk correct. We hebben er zelf al opgewezen, dat Luhmann niets kan aanvangen met een voorstelling van 'structurele tegenspraken' en met een eventueel statistisch structuurbegrip, dat refereert aan de verdeling van eigenschappen over een bepaald geheel en de correlaties tussen dergelijke distributies (men denke aan inkomensverdelingen, inkomensverdelingen in relatie tot 'gender', etc.) heeft hij ook weinig op - Man muß... vorsichtig sein mit dem Begriff 'latente Struktur'. Wenn statistischer Artefakte bzw. Zusammenhänge gemeint sind, sollte man es bei dem Hinweis darauf belassen. ${ }^{434}$ Of Luhmanns sociologie indirect toch compensatie biedt voor noties als 'dieptestructuur' of 'structureel aangelegde maatschappelijke tegenspraken' is een vraag die eigenlijk pas op het niveau van zijn maatschappijtheorie kan worden beantwoord en die we voor het moment nog voor ons uit moeten schuiven. We kunnen hier nog slechts een keer herhalen, wat we in feite al eerder naar voren hebben gebracht: een sociologie die de complexiteit en contingentie van de sociale werkelijkheid centraal stelt, kan niet terugvallen op een uiteindelijke reductiebasis - niet op actoren en handelingen, niet op dieptestructuren en hun eventuele tegenspraken.

431. Berger: "Lulumanns systemtheoretischer Ansatz teilt mit der soziologische Fllandlungstheorie die Reduktion sozialer Tatsachen auf kommunizierte Tatsachen.' (Idem, p. 149 (noot 1 )

432. Idem, $p_{i} 138$.

433. Luhmann meent uberhaupt, dat de sociologie het werschijnsel 'latentie' schromelijk heeft overdreven, zeker als het over de modeme maatschappij gaat. In een maatschappij die zich dominant aan "functionaliteit" orienteert, kan wolgens hem de functie van latenties niet onopgemerkt blijven. Maar daarmee begint latentie te verschrompelen, daar het een functioneel vereiste van latente structuren en functies is, dat hun latentie latent blijft. Verg. Soziale Systeme, op.cit., p.463 e.v.

434. Soziale Systeme, op cit., p.399. 


\section{Hoofdstuk V}

\section{EVOLUTIE EN DIFFERENTIATIE: GRONDSLAGEN VAN DE MAATSCHAPPIJTHEORIE}

\section{$\$ .1$ Inleiding}

Een algemene theorie van sociale systemen is nog geen theorie die refereert aan sociale samenhangen in hun telkens bijzondere, concrete verschijningsvorm. Zoals we in het vorige hoofdstuk al opmerkten, beweegt Luhmann zich met zijn 'Grundriß einer allgemeinen Theorie' - de ondertitel van Soziale Systeme op het abstracte niveau van het sociologisch grondslagenonderzoek. Voor Walter Reese-Schaffer gaat het in dit boek ook eigenlijk niet om 'theorie', maar veeleer om een "systematisch reflektierendes Kompendium der begrifflichen Grundentscheidungen und Grunddefinitionen' van Luhmanns sociologische denken. ${ }^{455}$ Rene König sprak met thet oog op dergelijke ondernemingen ooit van 'Kategoniensysteme' met als functie 'die systematische Definition und transzendentale Deskription der Wirklichkeitsdimension, in der alle mogliche Gegenstände beheimatet sind, deren Untersuchung sich die Soziologie widmet". ${ }^{436}$ Maar hoe men Soziale Systeme ook wrenst te karakteriseren, en welke eisen men aan een 'echte' theorie meent te moeten stellen -, wat aan onze uiteenzetting van Luhmanns werk vooralsnog (in grote lijnen) ontbreekt, is het intermedièrend begrippenapparaat met behulp waarvan concrete sociale systemen methodisch kumnen worden beschreven en geanalyseerd, zowel met het oog op hun specifieke functies en kenmerken in vergelijking met andere sociale systemen, als met het oog op het altijd 'historische' karakter van hun bijzondere verschijningsvorm. En dat laatste wil voor de socioloog Luhmann eerst en vooral zeggen: met het oog op de historische bijzonderheid van een sociaal systeem als uitkomst van een proces van maatschappelijke evolutie.

In dit hoofdstuk zullen we ons vooral concentreren op die begrippen en modellen die bemiddelen tussen het grondslagenonderzoek van Soziale Systeme en de empirische beschrijving van "maatschappijen", i.h.b. van de 'moderne",

435. W, Reese-Schafer, Lwhmann zur Einfihrung, Hamburg 199., p.101.

436. R. Kônig "Grundiagenprobleme der soziologische Forschungsmethoden (Modelle, Theorien, Kategorien)', in: F.Kamenberg/H.Albert (Hrsg), Sozialwissenschaft und Gesellschaftsgestaltung, Berlijn 1963, p.36. 
Westerse maatschappij. Daarmee nemen we van meet af aan een zekere eenzijdigheid in de reconstructie van Luhmanns werk voor lief. Die eenzijdigheid mag alleen al daaruit blijken, dat bij Luhmann zélf de eerste opstap naar een meer historisch-empirische analyse van sociale fenomen wordt gevormd door een onderverdeling van 'sociale systemen' (als algemene soortnaam) in drie primai$\mathrm{re}_{\text {, }}$ onderling niet reduceerbare typen van sociale systeemvorming: naast "maatschappij', en qua theorieconstructie op hetzelfde niveau, staan 'organisatie' en 'interactie'. ${ }^{137}$ Het schema op deze pagina situeert deze drie systeemtypes binnen een algemene, taxonomische classificatie van systemen en daaraan gerelateerde niveaus van theorievorming. ${ }^{438}$

nivera van theorievoming:

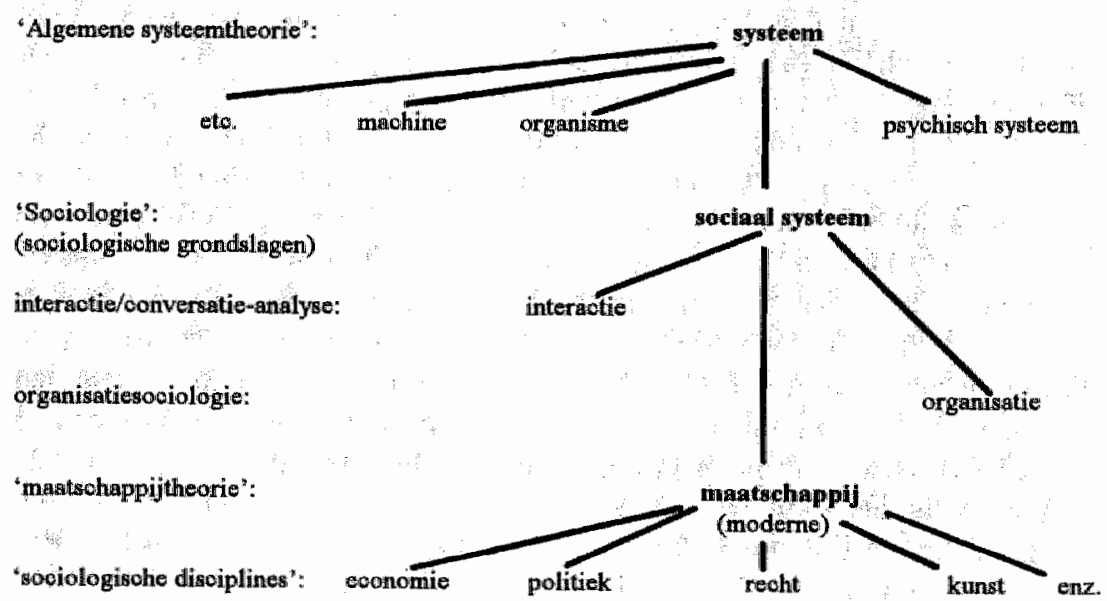

437. In Sioziale Systeme merkt Luhmann op: 'In allen sozialen Verhattisisen, unter allen Umstifriden, komt es zu einer Differemz von Gesellschaft und Interaktion; aber nicht alle Gesellschaften kennen organisierte Sozialsysteme.... Auf der nachsten Ebene der Theoriekonkiretisierung hatte man aber gleichwohl Gesellschaftssysteme; Organisationssysteme und Interaktionssysteme $2 u$ unterscheiden und entsprechende. Theorien getrennt zu entwiokeln, weil diese drei Sonderformen der Bildung sozialer Systeme (das heibi: des Umingangs mit doppelter Kontingenz) nicht aufeinander reduzierbar sind.' (N. Luhmann, Soziale Systeme, Frankfurt/M. 1985, p.551 (noot 1))

438. Verg. Luhmanns eigen schema in Soziale Systeme (op.cit) op p.16. 
Ter afsluiting van deze 'Inleiding' willen we benadrukken, dat het in dit en het hierna volgend hoofdstuk vooral zal gaan om de descriptieve en daarop aansiütende diagnostische aspecten van Luhmanns maatschappijtheorie. Normatieve en eventueel maatschappijkritische kwesties zullen in het slothoofdstuk centraal staan. Anticiperend op een overbekende, maar voor sommigen nog steedls niet afgezaagde tegenwerping, willen we hier al volmondig bekennen dat - inderdaad - descriptie en prescriptie nooit volledig te scheiden zijn (enz.). Voorlopig zullen we onze handen echter nog vol hebben aan de reconstructie wan, en kritiek op, de modelmatige, beschrijvende en empirisch-diagnostische elementen van Luhmanns analyse van de modeme maatschappij. Dit ter vóórbereiding van een discussie over de merites van Luhmanns sociologie en matschappijtheorie.

\section{$\S 2$ Interactie, organisatie, maatschappij}

Alhoewel het in dit hoofdstuk vooral om de algemene uitgangspunten van Luhmanns maatschappijtheorie zal gaan, ontkomen we er niet aan, kort stil te staan bij de systeemvormen 'interactie' en "organisatie' en hun beider verhouding tot 'maatschappij'. Dit niet alleen terwille van een beter begrip van wat Luhmann onder 'maatschappijen' verstaat, maar bovendien omdat, zoals we in het volgende hoofdstuk nog zullen zien, een belangrijke kritiek op Luhmanns maatschappijtheorie precies betrekking heeft op de manier waarop hij "interactie', 'organisatie' en 'maatschappij' onderling afbakent en met elkaar verbindt.

\section{$\$ 2.1$ Interactie}

Met het systeemtype 'interactie' lijken we nog tamelijk direct aan te sluiten bij Luhmanns algemene analyse van sociale systemen Zo zijn interacties - in zijn vroegere werk spreekt Luhmann ook wel over "einfache Sozialsysteme" - per definitie thematisch georienteerde, zichzelf structurerende communicatiesystemen. Het definierende en specificerende criterium van interacties, datgene waardoor ze zich van anderssoortige sociale systemen onderscheiden, wordt gevormd door het principe van de "aanwezigheid". "Aanwezigheid', zo zou men ook kunnen zeggen, is het voor interacties constitutieve selectie- en afgrenzingscriterium - 'Sie schließen alles ein was als anwesend behandelt werden kamm, und können gegebenenfalls unter Anwesenden daruber entscheiden, was als anwesend zu behandeln ist und was nicht'. ${ }^{439}$

439. N. Luhmann, Saziale Systeme; op.cit, p.560; verg. (voor dit en het nu volgende) o.a.: N. Luhmann, "Interaktion, Organisation, Gesellschaft", in. Soziologisch Alufhlarung 2, op.cit, p. 10 e.v.; Idem, 'Einfache Sozialsysteme"; in idem, p.21-39. 
Uit dit Luhmann-citaat blijkt al, dat het bij 'aanwezigheid' als afgrenzingscriterium van interacties niet gaat om aanwezigheid in een zuiver fysiek-ruimtelijke betekenis. De verschillende gezelschappen in een restaurant mogen dicht op elkaar zitten, ze vormen daarmee nog niet eén groot interactiesysteem. Wie 'aanwezig' zijn en ook als zodanig in de interactie mogen (en moeten!) figureren, wordt door de gezelschappen/interactiesystemen vastgesteld. Dat een naburig tafelgesprek woord voor woord kan worden verstaan, betekent geenszins, dat men er zich ongevraagd in kan mengen. Als autopoietische communicatiesystemen constitueren interacties m. a w. hun eigen grenzen. ${ }^{40}$

Dit alles neemt niet weg, dat het aspect 'ruimtelijke nabijheid' wel degelijk een rol speelt. Aanwezig-zijn impliceert bij Luhmann ook altijd (op een of andere manier) 'waarneembaar-zijn'. Interaktiesystemen ontstaan, zo schrijft hij, doordat "Anwesende sich wechselseitig wahmemen" ${ }^{441}$ Weliswaar geldt, dat 'waarnemen' primair een vorm van psychische informatieverwerking voorstelt, het verkrijgt echter een sociale dimensie wanneer psychische systemen van elkaar waarnemen, dat ze elkaar onderling waarnemen - wanneer het waamemen, om het zo uit te drukken, in dubbele contingentie wordt gedoopt en dan als (auto)katalysator van 'interactie" gaat functioneren. Dit reflexief worden van de waarneming is onder aanwezigen vrijwel onvermijdelijk. ${ }^{442}$ Typisch voor wat Luhmann 'interacties' noemt, is dan ook hun dubbelspoor van expliciete, verbale communicatie en een wederzijdse waarneming die selectief de "lichamen" van de deelnemers aftast op mogelijke betekenissen en informatie. ${ }^{443}$ Daarmee wordt natuurlijk een al oud inzicht verdisconteerd, namelijk dat het in alledaagse conversaties niet alleen gaat om wat verbaal wordt uitgedrukt, maar ook om "de

440. Heiko Hausendorf, zelf afkomstig uit het empirisch conversatie-onderzoek, heeft gewezen op enkele frappante (methodologische) paralellen tussen Luhmanns interactie-sociologie en Goffmans "conversatie-analyse":

"Luhmanns und auch Goffmans Oberlegungen zielen auf die Konstitution eines eigenständigen Gegenstandes sozialer Natur. Entsprechend mul schon die Amuesertheit von Personen als ein genuin soziales Phänomen bestimmt werden. Anwesenheit kann anders gesagt nicht als physikalisch gegelben, sondem mu B als sozial (wieder)hergestellt betrachtet wenden. Die Amnahme der sozialeri (Wieder)Herstellung von Anwesenheit konstituiert den Gegenstand Interaktion."

H. Hausendorf, 'Das Gesprach als selbstreferentielles System - Ein Beitrag zum empirischen Konstruktivismus der ethnomethodologischen Konversationsanalyse", in: Zeitschriff fiur Soziologie, Jg.2 (Heft 2), p.86.

441. "Interakition, Organisation, Gesellschaft", op.cit, p.10.

442. Mon vergelijke Paul Watzlawicks theorema van het "niet-niet-kunnen-communiceren" (P. WatzlawickJJ.H.Beavin/D.D.Jackson, Pragmatics of Human Communication: a Study of Interactional Patterns, Pathologies and Paradoxes, New York 1967.

443. Interessant worden dan 'border line'-gewallen, zoals telefoongesprekken onder intimi (i.t.t. 'zakelijke', grotendeels 'anonieme' oommunicatie). Typisch is hier de owermatige gevoeligheid voor intonatie, stembuiging en klankkleur als substitunt voor de waameming van het hiohamamsedrag - en bekend de riis en inritaties die dit oplevert Moest de duivel van het huwelijksaltaar wegblijven, via de telefoon neemt hij wraak. 
taal van het lichaam' - dat in gesprekken onder aanwezigen op meerdere niveaus tegelijk wordt 'gecommuniceerd'.

Van dit dubbelspoor van verbale communicatie en waarneming profiteren interacties door de typische voordelen van beide contactvormen afwisselend te benutten. ${ }^{444}$ Een voordeel van het menselijk waamemen is bijv, dat het ook visa-vis complexe (visuele, auditieve, etc.) structuren een hoog tempo van informatieverwerking mogelijk maakt. Communicatieprocessen zijn door hun sequentiele structuur qua informatieverwerking altijd veel trager. Daar staat tegenover, dat communicatie in principe veel selectiever is dan thet waarnemen met zijn relatief geringe analyse-scherpte.

Een ander voordeel van 'waarnemen' is, dat deelnemers aan een interactieproces voor hun waarnemingen geen verantwoording hoeven af te leggen. Hun waarnemingen worden hun niet als eigen selecties, i.e. als 'handelingen' toegerekend; alle (natuurlijk onontkoombare) selectiviteit van het waarnemen wordt op het conto van de omgeving afgeschreven. Dat mag voor een buitenstaander (of Sigmund Freud) een weinig waarachtige veronderstelling zijn, het effect van een sociaal gepraktizeerde 'ontoerekeningsvatbaarheid' en dus: 'nietkritiseerbaarheid' van het waarnemen, is, dat de deelnemers erop gaan vertrouwen, dat de andere aanwezigen dezelfde waamemingen hebben als zij, i.h.b. dat zij dezelfde mededelingen op dezelfde manier waamemen. En tenslotte biedt het wederzijds waamemen de bijzondere mogelijkheid strategisch om te gaan met het lichaam als drager van betekenis en langs die lijn, door 'indirecte communicatiex, de expliciete communicatie 'bij te kleuren'.

Precies door de vervlechting van communicatie en waarneming, is volgens Luhmann 'innerhalb von Interaktionssystemen eine Intensivierung der Kommunikation möglich, fär die es außerhallb von Interaktion keine Aquivalente gibt" "45 Daar staat onvermijdelijk een aantal beperkingen en nadelen tegenover. $\mathrm{Om}$ te beginnen beperkt het aanwezigheids/waarneembaarheidscriterium de reikwijdte van interacties in termen van deelnemers. Interacties kunnen een bepaald deelnemersaantal niet overschrijden. Bovendien hindert de thematisch georienteerde, sequentiële structuur van interactionele communicatie - de deelnemers spreken "na elkaar', leveren 'om beurten' hun bijdrage aan het gespreksthema, moeten thema's afkappen om een nieuw onderwerp aan te kunnen snijden - bij de opbouw van 'synchrone' complexiteit, d.w.z. van een interne, paralel gehandhaafde differentiatie in subsystemen. Kenmerkend voor interactiesystemen is, anders gezegd, dat ze nauwelijks of geen ruimte laten voor de ontwikkeling van simultaan opererende subsystemen. ${ }^{446}$ Extra bemoeilijkt wordt de ontwikkeling van interne of 'structurele' complexiteit, doordat interac-

444. Verg. voor het volgende o.a. Soziale Systeme, op.cit, p.561 e.v., en "Einfache Sozialsysteme", op.cit., p. 23 e.v.

445. Soziale Systeme, op.cit., p. 563 .

446. Verg. Idem, p.566. 
tiesystemen sterk op hun eigen 'geschiedenis' leunen als houvast voor selectiviteit en zelfconditionering. Daarbij gaat het echter om "nog herinnerde' geschiedenis, om 'gegenwärtige Vergangenheit', om geschiedenis voorzover ze niet al weer is vergeten. ${ }^{47}$ Nu is 'vergeten' produktief in die zin, dat het bijdraagt aan de openheid van een systeem voor innovatie - en de belangrijkste functie van het geheugen is misschien ook wel het vergeten. Tegelijkertijd is een dergelijke strategie weinig bevorderlijk voor de ontwikkeling van structurele, of 'synchrone' complexiteit. Veeleer versterkt het de neiging tot "diachroniciteit", d.w.z. tot een geleding 'in de tijd', tot een differentiatie van het systeem in opeenvolgende 'episodes'. Interactiesystemen, zo zou men kunnen samenvatten, zijn beweeglijk en in potentie innovatief, maar structureel gezien slecht uitgerust voor de ontwikkeling wan interne complexiteit.

\section{\$2.2 Organisatie}

Voor een moderne wereldburger zal Luhmanns vaststelling, dat 'organisatie' een systeemvorm voorstelt waarin de aan interacties inherente beperkingen kunnen worden overstegen, weinig verrassend zijn. Opmerkelijker is Luhmanns omschrijwing van wat een 'organisatie' op zichzelf beschouwd eigenlijk voorstelt. Met 'organisatie' doelt hij eerst en vooral op een bijzonder type sociaal systeem, dat zijn specificiteit daaraan ontleent, dat het op element-niveau bestaat uit communicatieve gebeurtenissen die door hem als 'beslissingen' worden aangeduid. 'Organisationssysteme sind soziale Systeme', zo noteert Luhmann begin jaren tachtig, "die aus Entscheidungen bestehen und Entscheidungen wechselseitig miteinander verknupfen' ${ }^{\prime 48}$ Een radicaal autopoietische definitie van 'organisatie' laat dan niet lang meer op zich wachten. Die luidt, dat 'organisierte Sozialsysteme" begrepen moeten worden als systemen "die aus Entscheidungen bestehen und die Entscheidungen, aus denen sie bestehen, durch die Entscheidungen aus denen sie bestehen, selbst anfertigen' ${ }^{449}$

Als een omschrijving van 'organisatie' klinkt deze variant op de geijkte formulering van 'autopoiese' natuurlijk rijkelijk abstract. In Luhmanns ogen is een hoog-abstract uitgangspunt echter nodig, om niet bij voorbaat in finalistische, instrumentalistische of rationalistische concepties te vervallen. Wat hij zoekt, is een begrip van 'organisatie' 'ohne Bezug auf Ziele und Mittel, ohne Bezug auf Optimierung, ohne Bezug auf die relative Leistungsiberlegenheit formaler Hierarchie". ${ }^{450}$ De autopoietische definitie van organisaties als beslissingsystemen biedt daarop een uitzicht, voor zover hiermee een selectie- of contingentiet-

447. Zie: 'Einfuche Sozialsysteme', op.cit., p.27.

448. N. Luhmann, 'Organisation und Entscheidung', in: Soziologische Aufklarung 3, Opladen 1981, p $339 / 340$.

449. N. Luhmann, "Organisation', in: W.Kupper/G.Ortmann (Hrsg.), Rationalität, Macht und Spiele in Organisationen; Opladen 1988, p.166.

450. N. Luhmann, 'Organisation", op.cit., p.165. 
heoretisch gezichtspunt onder het denken over organisaties wordt geschoven, op basis waarvan vervolgens "doel/middel-rationaliteit", "hiërarchie", planning", etc. als bijzondere (maar niet noodzakelijke) vormen van de conditionering van selecties kunnen worden begrepen. De veronderstelling, dat bimmen organisaties beslissingen het aanknopingspunt en de "brandstof" voor" andere beslissingen vormen, is bij Luhmann namelijk gekoppeld aan het idee, dat beslissingen telkens contingenties transformeren:

'Vor der Entscheïdung gibt es mehrere mögliche Entscheidungen, also einen begrenzten Raum von offenen Möglichkeiten. Nach der Entscheidung gibt es die dieselbe Kontingenz in fixierte Form: die Entscheidung wäre möglich gewesen, sie ist jetzt selbst kontingent. ${ }^{3451}$

Natuurlijk wordt er ook buiten organisaties 'beslist'. Wat echter specifiek is voor organisaties, namelijk de ontwikkeling van een recursief netwerk van beslissingen, bewerkstelligt, dat met iedere beslissing een contingentiespeelruimte voor latere beslissingen wordt geopend én afgebakend. Anders geformuleerd: binnen organisaties fungeren beslissingen als premissen voor nog komende beslissingen, zonder dat dit als zodanig al een 'finalisering", een beweging richting een einddoel impliceert. Luhmann:

'Entscheidungen schränken sich wechselseitig ein, bereiten sich wechselseitig vor, setzen einander unter Druck, entlasten einander, ohne daff all dies als Zweck/Mittel-Verhaltnis begriffen werden könnte. Deshalb ersetzt man den Zweckbegriff durch den allgemeineren Begriff der Entscheidungspremisse. ${ }^{452}$

De pointe van Luhmanns benadering is nu niet, dat organisaties geen doelrationeel gedrag zouden kunnen vertonen, of dat 'planning' een waanidee zou zijn. Verschillende vormen van sturing en finalisering behoren onder bepaalde omstandigheden (episode-vorming, hierarchisering) tot de mogelijkkheden van een organisatie, zij het onder de conditie van een overkoepelende recursiviteit die altijd weer 'strange loops' of 'tumbling hierarchies' ${ }^{\text {s53 }}$ met zich meebrengt, i.e. vormen van 'resymmetrisering" die bewerkstelligen dat beslissingen op het hoogste niveau in feite het resultaat zijn van 'ondergeschikte' beslissingen, en vice versa. Luhmanns pointe is veeleer, dat organisaties niet op zichzelf al een bepaalde vorm van rationaliteit belichamen - het immens toegenomen belang

451. Idem, p. 170.

452. N. Luhmann, 'Organisation und Entscheidung', op.cit., p.342.

453. Zile hiervoor: D. Hofstadter Gödel, Escher, Bach - an eternal golden braid, New York 1980. 
van organisaties binnen de moderne maatschappij impliceert niet 'per se" dat onze matschappij op een of andere manier rationeler (doelrationeler?) is geworden. Dat is niet alleen tegen een Weber gericht, maar ook tegen Habermas' suggestie, dat de kapitalistische organisatie van de economie wordt gekenmerkt door een 'formele ${ }^{3}$ rationaliteit. ${ }^{454}$

Het meest contra-intuitieve aan Luhmanns omschrijving van organisaties is misschien nog wel zijn vaststelling, dat deze uit een zeer specifiek soort communicaties bestaan, namelijk uit beslissingen, onder uitsluiting van alle andere mogelijke wormen van communicatie. Dat lijkt zowvel een te beperkte, als een te ruime opvatting. "Te beperkt; amdat iedereen weet dat "binnen" organisaties over allerhande zaken, ook zeer alledaagse, wordt gecommuniceerd, zonder dat dit voor een organisatie voortdurend de relevantie van 'beslissingen' heeft, te ruim, omdat iedere handeling of communicatie een selectie voorstelt en in die zin per definitie de uitdrukking van een beslissing lijkt te zijn.

Orn met het laatste te beginnen - : Luhmann gaat er vanuit, dat (inderdaad) iedere handeling een selectie voorstelt, maar dat de perceptie van een handeling als 'beslissing' die selectiviteit precies naar voren haalt en als het ware 'meethematiseert". ${ }^{455}$ Wordt een handeling als beslissing gepercipieerd, dan wordt niet alleen de, door de selectiviteit van die handeling geconstitueerde zin begrepen, maar wordt die handeling tevens 'beoordeeld' als een kenze uit verschillende alternatieven. Aangezien: "beoordelen', algemeen gesproken, neerkomt op het vaststellen van conformiteit/deviantie in het licht van gegeven (cognitieve en/of normatieve) verwachtingen, kunnen we ook zeggen, dat handelen 'beslissen' wordt, wanneer het handelen onder de druk van verwachtingen komt te staan en de actor daarop reageert - of in ieder geval moet toestaan, dat anderen hem, eventueel retrospectief, zijn handeling als beslissing aanrekenen. ${ }^{456}$.

'Beslissen', als handelen onder verwachtingsdruk, treffen we, zoals gezegd, ook buiten organisaties aan. Voor de vorming van organisaties is een vereiste, dat er voldoende 'reflexiviteit' in opeenvolgende beslissingen wordt ingebouwd, dat er m.a.w. in afdoende mate over beslissingen beslist gaat worden. Praktisch gesproken komt dat neer op een differentiatie tussen niveaus van beslissingen die het mogelijk maakt, dat sommige beslissingen 'formeel' beslissen over de premissen (condities, criteria en thematische inhoud) van andere beslissingen. Langs die weg kunnen organisaties zich gaan 'programmeren', d.w.z.. regels en criteria opstellen die vastleggen; wat onder welke omstandigheden een correcte (d.w.z. "conforme") beslissing voorstelt. Natuurlijk heeft het reflexieve of

454. Verg. o.a. N. Luhmann, Die Wirtschaft der Gesellschaft, Frankfuart/M. 1988, p.297.

455. In 'Organisation und Entscheidung', heet het: 'Im Unterschied zu einfachen Hlandlungen thematisieren Entscheidungen ihre eigene Kantingenz... Was als Einheit einer Eintscheidung (und in Organisation: als Systemelement) fungiert, ist mithin die gerichtete Relation zwischen Alternativen.' (Op,cit, p.338.)

456. Zie idem, p.278-281. 
'parasitaire' beslissen ook betrekking op de "opbouw' van een organisatie in termen wan wijzingsbevoegdheden, dus op de vraag welke beslissingen van wie bindend zijn voor welke andere beslissingen. Met dit alles ontwikkelt zich de structuur van een organisatie als een netwerk van normatieve verwachtingen dat meer en meer handelingen onder verwachtings- en beoordelingsdruk stelt en zo beslissingssamenhangen in voldoende mate "verdicht - voldoende althans om de autopoiesis van het beslissen in gang te houden: En mocht het zo zijn, dat er ad hoc een tekort aan beslissingen optreedt, dan worden ze, zo merkt Luhmann op, desnoods retrospectief vastgesteld:

'Entscheidungen brauchen, um Entscheidungen sein zu können, andere Entscheidungen; und wenn sie als solche, was Bewulßtseinslage und Kommunikation betriff, nicht aufzufinden sind, werden sie fingiert. Dadurch werden auch Unterlassungen zu Entscheidungen, und Nullwerte gewinnen Kausalitat... Diese Nichtentscheidungen können unversehens zu Entscheidungen werden, wenn spätere Entscheidungen darauf angewiesen sind. ${ }^{45 \pi}$

Naast beslissingen inzake handelingsprogramma's en de opbouw van de organisatie in termen van posities en bevoegdheden, wordt een derde, en voor organisaties minstens zo belangrijk terrein van reflexieve beslissingen gevormd door de vraag, wie lid is van de organisatie en onder welke condities. Van formele organisatie' is eigenlijk pas sprake wanneer, zoals Luhmann het noemt, 'Mitgliedschaftsregeln' zijn ontwikkeld en gestabiliseerd die het lidmaatschap binden aan het volgen van de, binnen de organisatie (wederom per beslissing) geldende regels. Onderscheiden organisaties zich van andersoortige sociale systemen als 'beslissingssystemen', ze bakenen onderling hun grenzen af middels de regulering van het lidmaatschap.

De beslissing, van een actor om, al of niet tegen een geldelijke beloning, lid te worden van een formeel georganiseerd systeem is tegelijkertijd 'eine Entscheidung zum Akzeptieren von Entscheidungsprämissen, inclusive Bedingungen der legitimen Änderung oder Respezifikation. solcher Entscheidungspramissen'. ${ }^{458}$ Via formele organisatie kan ma.w de contingentie of 'willekeurigheid' van de disposities en gedragsmotieven van verschillende individuele actoren worden getransformeerd in een gegeneraliseerde motivatie en dispositie om het eigen handelen te laten specificeren door (eveneens contingent geldende) regels en wijzingsbevoegdheden - en dit 'unabhängig davon, ob für jede Einzelhandlung

457. N. Luhmann, Sozialogie des Risikos, Berlijn 1991, p. 203.

45:8. N. Luhmann, Soziologie des Risikos, op.cit, p.202. 
natarlich gewachsene Motive oder moralischer Konsens beschafft werden können'. ${ }^{\text {ts }}$.

Nog afgezien van de vraag in hoeverre dat functioneel zou zijn, slaagt geen enkelle organisatie er in; om ál het gedrag van haar leden formeel te organiseren. De formele organisatie betreft altijd een selectie van handelingen en handelingsaspecten en het is slechts binnen dit formeel georganiseerde bereik; dat al het handelen onder een "georganiseerde verwachtingsdruk' staat en als "beslissen" versehijnt. In die zin zou men ook kunnen zeggen, dat het in bureaucratieên om een 'georganiseerd verwachten van beslissingen' gaat en dit als grondslag voor de afbakening van 'officieel", 'dienstdoend' gedrag. ${ }^{460}$ Daarnaast "bestaan" organisaties ook altijd uit "alledaagse' interacties - of indien 'bestaan' in deze een verwarrende uitdrukking is: het als 'beslissen" voor organisaties relevante gedrag is altijd omgeven door een wolk van communicaties die buiten de scope van de organisatie vallen. "Auf den Bildschirm der Organisation", zo vult Andre Kieserling aan, "erseheint die Interaktion daraufhin als Vollzug von Arbeit oder als Programmdurchfuhrung... also unter selektiv abstrahierten Gesichtspunkten, die immer nur einen Teil dessen erfassen und reduktiv ordnen können, was unter den jeweils Anwesenden an Sinn kondensiert', ${ }^{461}$

Dit alles neemt niet weg, dat door formele organisatie de grenzen die aan de uitbreiding en complexiteit van interacties gesteld zijn, verregaand kunnen worden overschreden. Om te beginnen geldt voor organisaties als gelaagde en recursieve netwerken wan beslissingen niet het principe wan de aanwezigheid/waarneembaarheid. Veel kan, en wordt ook schriftelijk afgedaan. Bovendien kunnen organisaties door conditionering van het lidmatschap en door hierarchisering een handelingscapaciteit opbouwen, die in de vorm van een beslissing van weinigen of zelfs een enkeling uiteindelijk de gehele organisatie kan binden. Dat vormt niet alleen een 'backing' voor de in quantitatieve zin welhaast ongebreidelde groeicapaciteit van organisaties, maar garandeert ook bij verregaande interne differentiatie een zekere samenhang en integriteit van de organisatie als geheel. De opbouw van een ge-unificeerde handelingscapaciteit, of anders geformuleerd: de ontwikkeling van organisaties tot "quasi-" of 'macro-actoren', vergemakkelijk daarnaast een via beslissingsprogramma's gecontroleerde intput/output-oriëntatie (verg. hoofdstuk V, \& 1.) waar de interne differentiatie bij kan aanknopen. Daarbij geldt, dat waar interactiesystemen zich bij de keuze van thema's sterk laten leiden door hun eigen geschiedenis (door een voorkeur voor 'beproefde' thema's), organisaties gemakkelijker en gerichter hun reflexiviteit kunnen inzetten in de vorm van een beslissen over de thematieken van beslissingsprocessen. Daarmee maken organisaties zich nog niet los

459. Verg. 0.at. N. Luhmann, "Interaktion, Organisation, Gesellschaft', op cit, p 12.

460. N. Lahmann, Die Wirtschaft der Gesellschaff, op oit., p.389 e.v.

461. A. Kieserling, 'Interaktion in Organisationen', in: K.Damman/D. Grunow/K. P.Japp (Hrsg), Die Verwaltung des politischen Systems, Opladen 1994, pi 171. 
van hun eigen geschiedenis als een geschiedenis van elkaar conditionerende beslissingen; het opent echter wel de weg voor een functionele omgang met beslissingthematieken, hetgeen weer als het gezichtspunt voor een functionele differentiatie en inrichting van de organisatie kan fungeren. In aansluiting op Luhmann, heeft Hans Geser 'organisaties" min of meer samenvattend gekarakteriseerd als -

'durch Entscheidungen konstituierte und gesteuerte Sozialsysteme... die weitgehender als andere Kollektive ihre Entstehung einem expliziten Entscheidungsakt ("Grindung") verdanken, ihre inneren Strukturparameter, Zielsetzungen und Handlungsprogramme mittels autoritativer Entscheidungen in Geltung setzen und dauerhaft in der Lage bleiben ihre täglichen Handlungsabläufe... durch laufende Entscheidungsarbeit zu steuern. ${ }^{962}$

In feite zijn formele organisaties een laat produkt van de sociale evolutie: Weliswaar treffen we vormen van 'organisatie' ook in hoogculturen, zoals het Romeinse Rijk, aan en dan met name rondom religieuze, militaire of commerciele ondernemingen, pas in de modeme, "functioneel gedifferentieerde" maatschappij verkrijgt de formele organisatie echter zijn definitieve vorm en zijn alles, ook het alledaagse leven, doordringende inwloed. Dat doet natuurlijk een bijzondere samenhang vermoeden tussen de grondstructuren en -problemen van de moderne maatschappij en de algemeen-maatschappelijke functie(s) van organisaties. Het is precies op dit punt, dat zich in Luhmanns werk een leemte openbaart. Zeker -, Luhmann ziet zelf dat de formele organisatie een typisch modern fenomeen is en hij geeft ook aan onder welke historische condities de 'georganiseerdheid van de maatschappij]' eerst de vorm kon aannemen die wij inmiddels gewoon vinden. Zo wijst hij op de voorwaarde van een ontwikkelde monetaire economie - 'Wer Organisation braucht, braucht Geld' ${ }^{463}$ Bovendien gaat hij er in historisch perspectief vanuit, dat eerst met het typisch westEuropese staatsontwikkelingsproces zich een voldoende 'organisatiedichtheid" ontwikkelde on als katalysator van organisatievorming te gaan fungeren 'Burokratien lieben Burokratien'. En tenslotte heeft hij oog voor het feit, dat de "formaliteit" van formele organisaties voor een belangrijk deel daarin schuilt, dât de conditionering van het lidmaatschap zich niet meer aan stand en afkomst meet en in die zin samenhangt met een cultureel ontwikkelingsproces dat we met Talcott Parsons zouden kunnen omschrijven als een opwaardering binnen 'de moderne' van het 'performance"-perspectief' ten koste van ascriptieve gezichtspunten. We zullen een op aantal van deze punten verderop nog terugko-

462. H.Geser, 'Gesellschaftliche Folgeprobleme und Grenzen des Wachstums formaler Organisationen", in: Zeitschrift fur Soziologie, Jg. 11. (1982), p.113/114.

463. N. Luhmann, Die Wirtschaft der Gesellschaft, op.cit., p.307. 
men, Luhmann dan proberen te herinneren aan zijn eigen constateringen en deel-analyses. Vooruitlopend op die discussies; willen we hier echter al opmerken, dat Luhmanns analyse van het 'moderne' karakter van formele organisaties, of zo men wil: van de moderne maatschappij als een 'organisatiemaatschappij", uiteindelijk empirisch-descriptief van aard blijft: Wat ontbreekt, is een algemeen theoretisch model van de verhouding (formele) organisatie - (moderne) maatschappij. En dát, zo zal blijken, heeft uiteindelijk repercussies voor Luhmanns kritische diagnose van de structuren en problemen van de huidige maatschappij.

\section{\$2.3 Maatsehappij}

Wat Luhmann ook van Marxisten, Frankfurters en andere 'Alt-Europäer' mag doen onderscheiden, hij lijkt Duitser genoeg om althans één centrale veronderstelling met hen te delen: Of filosofisch, of sociologisch van aard -, het denken over socialiteit kan niet zonder een totaliteitsconceptie: 'Es muß in der Soziologie einen Begriff geben fur die Einheit der Gesamtheit des Sozialen". ${ }^{464}$ Als zodanig, als totaliserende categorie heeft in zijn werk altijd het begrip 'maatschappij" gefungeerd: 'Gesellschaft ist das umfassende Sozialsystem das alles Soziale in sich einschließt und infolgedessen keine soziale Umwelt kennt'. ${ }^{465}$

Aan die totaliteitsfunctie heeft ook de 'autopoietische Wende" in Luhmanns denken niets veranderd, wel echter aan de inhoud van het begrip 'maatschappij'. In het kielzog van een groeiende nadruk op het gebeurtenis- en proceskarakter van sociale systemen (ten koste van een denken in termen van structuren) en overeenkomstig Luhmanns keuze voor 'communicaties' (i.p.v. 'handelingen') als hun elementaire eenheden, verschijnt nu ook 'maatschappij" primair als een communicatief gebeuren. Werd 'maatschappij' voorheen begrepen als een eerste, overkoepelende 'pre-selectie' die de maatschappelijke subsystemen van een 'gedomesticeerde' (sociale) omgeving voorziet - als 'dasjenige Sozialsystem $_{x}$ das im Voraussetzungslosen soziale Komplexität regelt, da 3 heißt den Horizont des Möglichen und Erwartbaren definiert und letzte grundlegende Reduktionen einrichtet' - en dus primair als een structuurbegrip, na de autopoietische ommezwaai vormt 'maatschappij' eerst en vooral het inbegrip van alle, op elkaar aansluitbare communicaties. Zo definieert Luhmann in Ökologische Kommunikation uit 1986 'maatschappij' als 'das umfassende soziale System aller aufeinander Bezug nelmenden Kommunikationen... Die Ge-

464. Soziale Systeme, op. cit. p.555.

465. Idem; verg. echter ook een vroeg artikell als "Gesellschaft', opgenomen in Soziologische Auffilarwing $l_{\mathrm{B}}$ Opladen 1970, i.h.b. p.114-115. Dat een dergelijke 'eenheidswoorstelling' van de matschappij moch noodzakelijk, noch triviaal is, kan men bijw. ann het werk van Pierre Bourdieu aflezen, voor wie de maatschappij geen totaliteit 'uit én stuk' voorstelt, maar een losse koppeling van relatief autonome speelwelden. Zie voor een algemeen overzicht: Chr. Lloyd, Explanation in Social History, Oxford 1986. 
sellischaft besteht aus nichts anderem als aus Kommunikationen, und durch die laufende Reproduktion von Kommunikation durch Kommunikation grenzt sie sich gegen eine Umwelt andersartiger Systeme $a b^{\text {? }}{ }^{466}$

Alhoewel vooralsnog tamelijk formeel en abstract, valt aan deze definitie toch al het een en ander af te lezen. Om te beginnen heeft het begrip 'maatschappij' bij Luhmann geen territoriale strekking, noch heef het betrekking op personen of sociale groepen en al helemaal niet op politieke of 'statelijke' georganiseerdheid. Als er al een 'ruimtelijk' aspect aan 'maatschappij' kan worden ontwaard, dan betreft dit de bereikbaarheid van potentiële adressaten van communicatie, een communicatieve bereikbaarheid die onder specifieke historische condities een globaal karakter kan verkrijgen. De 'wereldmaatschappij', in wezen een $18 \mathrm{de}$ eeuwse rechts- en politiek filosofische speculatie, is volgens Luhmann in de $20 \mathrm{e}$ eeuw realiteit geworden:

'Die moderne, funktional differenzierte Gesellschaft ist unausweichlich Weltgesellschaft. Regionale, staatlich-politische Binnendifferenzierungen der Weltgesellschaft dienen eher dazu, die Grundmerkmale dieses Gesellschaftstypus durch Konkurrenz und Entwicklungsvergleich zu steigern. ${ }^{3467}$

Belangrijker misschien is de, door Luhmanns definitie van 'maatschappij" geïmpliceerde, "absolute geslotenheid" van maatschappijen, hetgeen volgens hem ook het specificum van dit sociaal systeem uitmaakt. Kunnen interacties en organisaties communicatieve betrekkingen met hun omgeving aangaan, voor het systeem 'maatschappij' is dit per definitie onmogelijk. De maatschappij kan niet met een 'omgeving" communiceren, kan op het niveau van haar eigen operaties niet met iets anders, dan met zichzelf in contact treden, simpelweg omdat ze zich met iedere communicatie zelf uitbreidt. Natuurlijk kan binnen de maatschappij over een (fysische, chemische, biologische; etc.) omgeving gecommuniceerd worden en natuurlijk heeft de maatsehappij als systeem ook een omgeving waartegen ze zich afgrenst. Die grens wordt geconstitueerd door het onderscheid communicatie/niet-communicatie - en precies met het oog daarop en niet in een of andere hiërarchische zin, kan van de maatschappij dan ook gesproken worden als het 'urnfassende Sozialsystem das alles Soziale in sich einschließt und infolgedessen keine soziale Umwelt kennt. [-] Gesellschaft

466. N. Luhmann, Okologische Kommumikation, Opladen 1986, p.24.

467. N. Luhmann, 'Gesellschaftsstrukturelle Bedingungen und Folgeprobleme des naturwissenschaftich-technischen Fortschritts", in: Idem, Soziologische Aujklarumg *, Opladen 1987, p.61. Zie hierover ook R. Stichweh, "Zur Theorie der Weltgesellschaft', in: Soziale Systeme 1 (1995), p.29- 47. 
betreibt Kommunikation und was immer Kommunikation betreibt; ist Gesellschaft'. 468

Dit alles blijft, nog steeds, rijkelijk abstract. In een eerste aanloop kan aan Luhmanns maatschappijbegrip echter al meer inhoud worden gegeven, door in te gaan op zijn modellering van de relatie 'interactie' - 'maatschappij'. We hebben eerder gezien, en wel aan de hand van een algemene, schematische classificatie van systeemtypen, dat 'interactie', 'organisatie' en 'maatschappij" binnen het formele bestek van een owerkoepelende "theorie-architectuur' op gelijk niveau staan. Desalniettemin wordt door Luhmann aan de verhouding tussen 'interactie' en 'maatschappij' een bijzondere betekenis toegekend. Dat heeft o.a. daarmee te maken, dat organisaties, historisch gezien een bijzondere verschijning voorstellen. Volgens Luhmann komt het echter altijd en overal waar vain socialiteit sprake is, tot een differentiatie tussen interactie en maatschappij, die, hoe minimaal ook en hoe 'interaktionsnah' sommige archaïsche maatschappijen ook gebouwd mogen zijn, een onontbeerlijk aanknopingspunt voor het sociale evolutieproces vormt. ${ }^{469}$ ?

Laten we beginnen met vast te stellen, dat het in de verhouding tussen interactie en maatschappij on een differentie gaat Dat impliceert bij Luhmann per definitie, dat 'maatschappij' niet simpelweg mag worden opgevat als de optelsom of het aggregaat van alle (mogelijke) interacties. Uit de definitie van 'maatschappij' volgt bovendien, dat interactiesystemen (als communicatieprocessen) altijd een realisatie van maatschappij voorstellen — en dus kan de maatschappij niet als de "omgeving' van interacties worden opgevat, net zo min als interacties de omgeving van de maatschappij vormen. De differentie interactie/maatschappij heeft bij Luhmann eerst en vooral een temporele strekking die onderscheidingen zoals 'duurzaamheid/vluchtigheid' en 'synchroon/diachroon' omvat. We hebben eerder gezien, dat de principes en mechanismen die voor interacties constitutief zijn, tevens de ontwikkeling van een synchrone differentiatie, van structurele complexiteit in verregaande mate verhinderen. Interacties, zo formuleerden we, kenmerken zich door een 'geleding in de tijd', differentieren zich diachroon middels de vorming van 'episodes'. Die 'episodes' kunnen elkaar in de tijd aaneengesloten opvolgen, bijv. door wisseling van thema's of opname van nieuwe "aanwezigen", maar ook de vorm aannemen van communicatieprocessen die worden opgestart, afgebroken, op een later tijdstip weer opgenomen, weer beëindigd, etc. Een dergelijke diachrone geleding is voor de maatschappij, als het systeem dat alle communicatie omvat, niet mogelijk. Kenmerkend voor maatschappijen is hun synchrone differentiatie, zij het desnoods in de minimale vorm van parallel verlopende interacties. Voor de maatschappij verschijnen interacties dan als episodes van haar zelfreproductie

468. Soziale Systeme, op cit. p.555.

469. leder concreet social systeem, zo merkt Luahmann op, wordt mede bepaald door de nietidentiteit van 'interactie" en 'maatschappij'. (Soziale Systeme, op.cit., p. 552. 


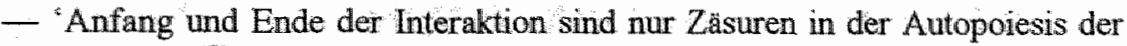
Gesellschaft' ${ }^{470}$ Voor interacties verschijnt de maatschappij daarentegen als een ononderbroken, doorgaande communicatiesamenhang, die de afżonderlijke interacties bij voortduring en schijnbaar moeiteloos voorziet van geldende zinschema's, beproefde thema's en stabiele verwachtingsstructuren en waarvan de duurzaamheid garandeert, dat interacties kunnen worden afgebroken, om op een later tijdstip weer te worden opgestart - 'Die Gesellschaft garantiert die sinnhaft-selbstreferentielle Geschlossenheit des kommunikativen Geschehens, also fur jede Interaktion auch Beginnbarkeit, Beendbarkeit und Anschlußfshangkeit ihrer Kommunikation'. ${ }^{471}$

Naast een temporele strekking heeft de differentie interactie/maatschappij bij Luhmann ook een sociale en een zakelijke dimensie. Zo hebben de deelnemers aan interacties gewoonlijk ook verplichtingen elders, hetgeen met de ontwikkeling en het complexer worden van een samenleving alleen nog maar toeneemt. Dergelijke verplichtingen kunnen door afzonderlijke interacties niet telkens 'ad hoc' worden georganiseerd en versehijnen dan ook als een invloed van buitenaf, als een maatschappelijk gegeven. In sociaal opzicht verschijnt de maatschappij binnen interacties m.a.w. als een diffuus netwerk van verplichtingen, als een complexe rollenstruetuur die, in en door interactiesystemen zelf, niet of nauwelijks kan worden gecontroleerd. Dat brengt ook vrijheden met zich mee. Met bestaande of gefingeerde verplichtingen jegens anderen elders kan men zich verontschuldigen voor de hier en nu zich aandienende verplichtingen. 'Die Differenz von Gesellschaft und Interaktion", zo merkt Luhmann op, transformiert Bindung in Freiheit'. ${ }^{472}$.

De zakelijke," inhoudelijke' dimensie van het onderscheid interactie/maatschappij hebben we indirect al aangesneden en betreft met name de ordening en selectie van de thema's van interactieve conversaties. Interactiesystemen zijn niet gebonden aan één thema, kunnen normaal gesproken uit een heel scala van concrete onderwerpen kiezen. In die zin kiezen interacties hun thema's concreet én contingent. Luhmann spreekt in deze echter van een 'gearticuleerde' contingentie in onderscheid met 'radicale' contingentie, om de indruk te vermijden, dat alles altijd mogelijk is. Een gezelschap dat op de koningin wacht, kan na 5 minuten niet voorstellen om maar vast te gaan eten. De contingentie van de thema-keuze betreft m.a.w. een 'maatschappelijk', en niet eerst door de lopende interactie voorgestructureerd veld van mogelijke onderwerpen. En alleen door die 'pre-selectie' kunnen interacties die beweeglijke selectiviteit opbrengen die hen kenmerkt. 
'Die Interaktion muß eigene Ereignishaftigkeit leisten, muß sich selbst temporallisieren, sich selbst ubberraschen können; aber sie kann dies nur, wenn sie durch hinreichende Strukturvorgaben zu raschem; pausenlosen Prozessieren und zur Selbstselektion von eigener Struktur und eigener Geschichte befähigt wird. ${ }^{373}$

Het is van belang, onder ogen te blijven zien, dat de differentie interactie/maatschappij bij Luhmann niet een 'slechts' analytisch onderscheid voorstelt, met een zuiver theoretische betekenis, maar door hem realistisch wordt opgevat. Het betreft m.a.w. een scheiding tussen twee feitelijk opererende systemen. Natuurlijk zijn en blijven interactie en maatschappij ("structureel") aan elkaar gekoppeld $_{j}$ en men zou kunnen zeggen, dat precies in deze terugkoppeling de functionele voordelen van hun differentie naar voren treedt. De differentiatie van interactie en maatschappij impliceert namelijk ook een zekere zelfstandigheid en profilering van synchrone en diachrone differentiatie als een tweetal algemene differentiatieprincipes - of zoals Luhmann het formuleert:

'Die Unterschiede in der systemtypischen Binnendifferenzierung beleuchten zugleich den Sinn der Differenzierung von Gesellschaft und Interaktion: sie ermöglicht das Ineinandergreifen von synchroner und diachroner Differenzierung. ${ }^{, 474}$

De met 'maatschappij' gegeven voordlelen van synchrone differentiatie betreffen met name duurzaamheid/stabiliteit en structurele complexiteit. Interactiesystemen benutten dit, algemeen gesproken, in de vorm van een "nu eenmaal gegeven' 'Strukturvorgabe'. Maatschappijen profiteren op hun beurt van de veranderlijkheid en vluchtigheid die eigen is aan het, door interacties belichaamde principe van diachrone differentiatie. Op het niveau van haar interacties kan de matschappij experimenteren met nieuwe thema's en semantieken, met innovatieve zinstructuren, zonder direct beducht te hoeven zijn voor lange termijn effecten bij eventuele mislukkingen of ontsporingen. In de vorm van kortstondige episodes kan de maatschappij zich gerust de risico's permitteren die aan alle vernieuwing en afwijking inherent zijn. Zonder dit "riesige Versuchsfeld" en zonder de 'gesellschaftliche Belanglosigkeit des Aufhörens der allermeisten Interaktionen' zou, zo merkt Luhmann op, van maatschappelijke ontwikkeling geen sprake zijn - "auch insoweit ist also die Gesellschaft selbst auf eine Differenz von Gesellschaft und Interaktion angewiesen". ${ }^{73}$ 


\section{$\$ 2.4$ Problemen met het begrip 'maatschappij'}

Adorno heeft ooit opgemerkt, dat het begrij 'maatschappij' zich niet laat definiëren, maar slechts in en door een maatschappijtheorie kan worden ontvouwd. ${ }^{476}$ Op deze plaats klinkt dat bijna als een waarschuwing: beschouw de algemene en abstracte definitie die Luhmann van "maatschappij" geeft als een voorlopige markering en schort een kritische evaluatie op totdat duidelijk is geworden waar deze bij de analyse van concrete maatschappijen toe leidt. Het lijkt echter teveel gevraagd, om niet nu al - en onvermijdelijk vooruitlopend op nog komende discussies en kritieken - in te gaan op een probleem, dat zich, met de uiteenzetting van Luhmanns sociologische grondslagen nog vers in het geheugen, min of meer vanzelf opdringt. Het betreft, simpel geformuleerd, de status wan 'maatschappij' als 'sociaal systeem'.

Een sociaal systeem bestaat uit communicaties, uit communicaties die op elkaar aansluiten en in dat aansluiten zichzelf vormen tot de elementaire eenheden van een bepaald sociaal systeem. Dat is, zoals hebben gezien, de "basale autopoiesis" waarop alle verdergaande ontwikkeling van een sociaal systeem als eenheid 'uitrust'. In hoeverre kan nu de maatschappij als totaliteit van op elkaar aansluitende communicaties een sociaal systeem worden genoemd? In welke zin vormt dit reusachtige complex van naast en na elkaar verlopende communicatieprocessen een eenheid, op grond waarvan we vandaag de dag zelfs van een "wereldmaatschappij" kunnen spreken? Niet, zo zagen we eerder, als de optelsom van alle hier en nu zich voltrekkende communicatieprocessen. 'Die Einheit des Gesellschaftssystems' kan nergens anders in bestaan, zo merkt Luhmann op, dan in haar "selbstrefrentielle Geschlossenheit. Gesellschaft ist das autopoietische Sozialsystem par excellence". ${ }^{477}$ Dat klinkt bekend. Had Luhmann in de context van een abstract-functionele omschrijving van zin als alomvattend ordeningsmedium, de 'selbstbeweglichkeit des Sinngeschehens' niet eveneens als 'Autopoiesis par excellence' gekaraktiseerd! Op dit niveau van analyse werd 'zin' aangesproken als 'Weltbegriff', d.w.z. in zijn functie de wereld te constitueren als een ononderbroken zinmatige verwijzingssamenhang die vanuit ieder punt, vanuit iedere zinervaring kan worden ontsloten. Daarbij signaleerde de term "Welt', dat het niet gaat om 'die bloße Summe aller Möglichkeiten, sinnhaften Verweisungen nachzuvollziehen', maar om 'die Einheit dieser Möglichkeiten'. 478 Wat betekent het nu, dat Luhmann het eveneens noodzakelijk acht, "daß der Gesellschaftsbegriff analog zum Weltbegriff gebildet wird: sich selbst und alle anderen Sozialsysteme enthaltend' ? $^{479}$ Impliceert dit, dat we 'maatschappij' als een beperkte, namelijk

476. Th. Adomo, 'Gesellschaft', in: Soziologische Schriften I, Frankfunt/M. 1979, p.9-19 (i.h.b. p. $12 \cdot 13)$

477. Soziale Systeme, p.555.

478. Idem, p. 106.

479. Idem,p. 594 . 
'sociale' zin-kosmos moeten opvatten, als eenheid van het sociaal uberhaupt mogelijke? Maar dan stuiten we op het probleem, dat 'maatschappij' geen systeem kan zijn - net zo min (om de analogie af te maken) als 'zin' een systeem is, wanneer het wordt gedacht als het medium dat de wereld van mogellike belevingen eerst 'opspant'. 'Wereld' is zelf nooit systeem; alle systeemvorming is systeemvorming 'binnen' de wereld - wat eigenlijk een merkwaardige formulering is, als we bedenken, dat 'wereld' de zelf niet observeerbare, paradoxale eenheid van de differentie systeem/omgeving voorstelt. En indien 'maatschappij' als een 'Weltbegriff' moet worden behandeld - , van welke differentie vormt het dan de eenheid? Van de differentie maatschappij/interactie? - zodat de theorie van meet af aan opereert 'vanuit' een paradox!

Voor diegene op wie dit analyse-en discussieniveau wat al te metafysisch overkomt, zou het probleem waar we hier op stuiten, ook als volgt kunnen worden geformuleerd: Een sociaal systeem heeft concrete realiteit in de feitelijke aaneensluiting van opeenvolgende communicatieve gebeurtenissen. Niet in wat structureel gezien mogelijk was, wiet in zijn contrafacticiteit, niet in wat eventueel ook had kunnen gebeuren, maar nu eenmaal niet gebeurde. Dat is een onvermijdelijke consequentie van Luhmanns autopoietische ommekeer en van het daarmee beleden 'denken in gebeurtenissen'. Maar hoe zouden we ons de moderne 'maatschappij' of zelfs de 'wereldmaatschappij' anders als een "eenheid' kunnen voorstellen, dan op de voorwaarde dat de maatschappij nietalleen bestaat uit op elkaar aansluitende, maar ook uit mogelijk aansluitende, voor elkaar mogelijk bereikbare communicaties! Dan wordt de (theoretische) status van 'maatschappij' als een autopoietisch sociaal systeem echter ambivalent.

Interessant is in deze de poging van Helmut Willke om aan dit probleem een positieve draai te geven. "Maatschappij” definieert hij expliciet als 'der umfassende Zusammenhang der aufeinander beziehbaren und fureinander relevanten Kommunikationen". ${ }^{480}$ De reeds gesignaleerde ambivalentie van een dergelijke omschrijving wordt door Willke, vervolgens als een pluspunt aangemerkt, ondat daarmee al in de definitie van "maatschappij' het onderscheid tussen "real existierender und möglicher Gesellschaft" wordt verdisconteerd:

"Damit ist auch in die Definition won Gesellschaft der sie kennzeichnende Aspekt des Hypothetischen aufgenommen; denn...aufgrund der gesteigerten Formen der Abstraktion und Generalisierung [erscheint in der Moderne] vieles aufeinander beziehbar, was in der faktischen Operationsweise von realen Gesellschaften nicht notwendigerweis gelingt.'

480. H. Willke, Systemtheorie entwickelter Gesellschaften, München 1989, p.29. 
Interessant is eveneens, dat Willke er inmiddels achter is gekomen, dat hij alleen trouw Luhmanniaan kan blijven én kan vasthouden aan het, in zijn ogen potentieel kritische onderscheid tussen reele en hypothetische maatschappij, door terug te keren naar Luhmanns vroegere, pre-autopoietisehe opvattingen. ${ }^{435}$ Inhoudelijk gezien, is dat overigens niet zo bevreemdend. We hebben eerder al opgemerkt, dat in Luhmanns vroegere werk een maatschappijbegrip figureerde dat sterker het structurele aspect benadrukte, dan het procesmatige - met als evident voordeel, dat op het niveau van structuren, begrepen als "begrenzingen van selectiemogelijkheden', alle plaats is voor contrafacticiteit, voor het 'eventueel ook mogelijke'. Een 'vroegere' definitie van 'maatschappij', een die nog stamt uit de zogeheten Habermas/Luhmann-discussie, kan het punt illustreren:

'Gesellschaft ist...jenes Sozialsystem, das letzte, grundlegende Reduktionen institutionalisiert. Gesellschaft schafft damit die Voraussetzungen, an die andere Sozialsysteme anknüpen können. Gesellschaft - das ist dasjenige Sozialsystem, dessen Strukturen darüber entscheiden, wie hohe Komplexität der Mensch aushalten, das heißt in sinvolles Erleben und Handeln umsetzen kann. ${ }^{4}{ }^{482}$

Men zou nu kunnen opmerken, dat bovenstaand citaat eigenlijk min of meer weergeeft, hoe Luhmann vandaag de dag de betekenis van 'maatschappij' voor interactiesystemen inschat. De vraag wordt dan echter, of de term 'maatschappij' niet inwisselbaar wordt voor de term 'cultuur' en of we met "maatschappij" dan niet gewoon doelen op een meer of minder geordend complex van sterk gegeneraliseerde betekenisstelsels die door interacties telkens zowel worden gespecificeerd als gereproduceerd: Deze suggestie wordt gevoed door een tweetal overwegingen. Ten eerste gat het bij sociale structuren altijd om zin-structuren en het is vooralsnog niet in te zien waarom dalt woor 'maatschappelijke' structuren anders zou zijn. We kunnen sociale structuren weliswaar nader karakteriseren als 'verwachtingsverwachtingen', als werwachtingen die via communicatie intersubjectief verwachtbaar zijn geworden; dat neemt niet weg dat het uiteindelijk meer of minder complexe zinschema's zijn, die de "stof" vormen waaruit ze bestaan.

Een tweede overweging vertrekt vanuit het theorema van de 'zelfreferentiele geslotenheid' van autopoietische systemen. Daarmee wordt immers gestipuleerd, dat alle voor dergelijke systemen relevante structuren in en door die systemen zelf worden georganiseerd. Indien we er nu, met Luhmann, vanuit

481. Verg. een meer recent opstel als: H. Willke, "Staat und Gesellschaft", in: K.Damman/D.Grunow/K.P.Japp (Hrsig.), Die Verwaltung des politischen Systems, Opladen 1994, p. 13 29.

482. J. Habermas/N. Luhmann, op.cit., p.16. 
moeten gaan, dat ook interactiesystemen en organisaties autopoietische systemen zijn, dan dient ook voor deze systemen te gelden, dat zij hun structuren niet kant en klaar aantreffen, maar dat zij zichzelf structureren en dit in aanpassing aan de voorwaarden en criteria die de specificiteit van hun eigen operaties uitmaken. Dat zou echter inhouden, dat de complexiteitsreducerende prestaties die maatschappelijke structuren geacht worden te leveren (zie bovenstaand citaat), slechts realiteit kunnen hebben in de vorm van semantische differenties die interactiesystemen (en organisaties) zelf produceren. Zo beschouwd, zou aan 'maatschappij' slechts een virtueel bestaan toekomen, namelijk in de vorm van door interacties en organisaties activeerbare (en dan te specificeren) betekenisstelsels. Al met al wordt het dan minder verrassend wanneer we bij de autopoietisch omgezwaaide Luhmann ook 'culturalistische" interpretaties van 'maatschappij' kunnen aantreffen:

'Interaktionssysteme können und müssen laufend aufgegeben und neu begonnen werden. Das macht eine übergreifende Semantik, eine Kultur erforderlich, die diesen Vorgang in Richtung anf Wahrscheinliches und Bewährtes steuert. Insofern wirkt die Gesellschaft selektiv auf das, was als Interaktion vorkommt, ohne dadurch Widersprechendes und Abweichendes sicher auszuschließen, ${ }^{\text {48, }}$

We verkeren nu nog niet in de positie om de hierboven aangesneden problemen met Luhmanns maatschappijbegrip op te lossen of om definitief voor een bepaalde optie te kiezen. Voor een gerichte aanpak moet, om met Adorno te spreken, Luhmanns maatschappijtheorie eerst nog worden 'ontvouwd", ook in descriptieve en diagnostische zin. Hier zij er nog slechts op gewezen, dat het om meer gaat, dan om conceptuele scherpslijperij of een neurotische hang naar eenduidigheid en consistentie. Wat er op het spel staat, is de vraag in welke zin de maatschappij bij Luhmann een "eenheid" vormt en bijgevolg, wat we onder de 'identiteit' van een maatschappij moeten verstaan - en indien er meerdere identiteiten mogelijk zijn: wat zou, om met Habermas te spreken, een 'vernunftige Identital' kunnen zijn? Op het spel staan m.a.w. de mogelijkheidsvoorwaarden van mogelijke vormen van maatschappijkritiek.

\section{§3. Maatschappij en Evolutie}

Tot nog toe, hebben wij de differentie tussen interactie en maatschappij min of meer als een statisch gegeven behandeld. In feite vormt deze differentie bij Luhmann een variabele van het sociale evolutieproces. Met de toename van de 
maatschappelijke complexiteit die volgens hem kenmerkend is voor de sociale evolutie, treden ook interactie en maatschappij steeds verder uit elkaar. ${ }^{484}$ Overigens verraadt deze formulering al, dat de sociale evolutie bij Luhmann de worm aanneemt van een $d u b b e l$ differentiatieproces: naast de differentiatie van interactie en maatschappij ook nog een toenemende differentiatie van de maatschappij zelf. ${ }^{485}$ Dit proces van maatschappelijke differentiatie heef, bezien vanuit het perspectief van een sociaal evolutionaire 'ontwikkelingslogica' (Habermas), een gefaseerd karakter, waarbij iedere 'fase' een bepaald maatschappijtype, een zelfstandige 'maatschappijvorm' voorstelt. Een algemeen kenmerk van deze opeenvolging van maatschappijtypen, is, volgens Luhmann, dat met de overgang naar een nieuwe maatschappijvorm telkens ook een drempel wordt overschreden m.b.t. de maatschappelijke capaciteit tot complexiteitsstijging. Het 'sprongsgewijze' karakter wan de maatschappelijke evolutie heeft, zo zou men ook kunnen zeggen, betrekking op een vergroting van het potentieel voor sociale complexiteit.

In zijn karakterisering van deze opeenvolgende maatschappijtypen grijpt Luhmann terug op het inmiddels klassieke sociologische onderscheid tussen segmentaire, hierrarchisch-stratificatorische en functionele differentiatie. Segmentaire differentiatie wordt dan geacht de voor archaïsche maatschappijen typische differentiatiemodus te zijn en komt neer op een splitsing van het sociale geheel in gelijksoortige eenheden (clans, stammen, etc.) van gelijke rang. Hoogculturen kenmerken zich door stratificatie, d.w.z: dóor een opdeling van de maatschappij in sociale lagen en rangen die onderling een hiërarchisch verband vormen, eventueel in combinatie met een tegenstelling tussen centrum (stad) en periferie (platteland). Functionele differentiatie tenslotte is kenmerkend voor de moderne maatschappij en kan in algemene zin worden omschreven als een opdeling van de maatschappij in afzonderlijke, relatief onafhankelijke deelgebieden of 'subsystemen' (zoals het recht, de economie, de politiek, etc.) die 'gespecialiseerd' zijn in de vervulling van een specifieke maatschappelijke taak of 'functie'. Het is overigens van belang om er op te wijzen, dat het bij deze (evolutietheoretische) classificatie van historische maatschappijen telkens gaat om de vraag, welk differentiatieprincipe voor de betreffende maatschappij de dominante differentiatiemodus vormt. In principe moeten binnen een concrete maatschappij steeds meerdere differentiatiemiveaus worden

484. Of zoals Luhmann formuleert: "Die Differenz von Gesellschaftssystem und Interaktionssystemen ist offenbar ihrerseits Resultat einer historischen Entwicklung. Sie setzit sich selbst in rudimentärer Form voraus und vermag dann sich selbst als Differenz zu steigem. (Soziale Systeme, op.cit, p.576)

485. Verg. in deze ook Jürgen Habermas die de sociale volutie als een 'Differenzierungsvorgang zweiter Ordmung" begrijpt: "System und Lebenswelt differenzieren sich, indem die Komplexiltăt des eimen und die Rationalitat der anderen wächst, nicht nur jeweils als System und als Lebenswelt - beide differenzienen stch gleichzeitig auch voneiriander. (J. Habermas, Theorie des kcommanikativen Handelms Bd. 2, Frankfurt/M. 1982, p. 230.) 
onderscheiden ${ }^{486}$ Zo stelt de opsplitsing van de middeleeuwse stand van "vrije boeren" in familiale eenheden een vorm van segmentaire differentiatie voor binnen de context van een overkoepelende hiërarchische stratificatie. Een ander voor de hand liggend woorbeeld is het ruime gebruik dat binnen functioneel gedifferentieerde maatschappijen van hiërarchische structurering wordt gemaakt.

Dit is allemaal nog bekend sociologisch gedachtengoed en men zou tegen deze achtergrond bijna vergeten, dat voor Luhmann, gegeven zijn definitie van 'maatschappij', alle maatschappelijke differentiatie zich noodzakelijkerwijs moet voltrekken in de vorm van een differentiatie van communicatie(processen), met als enig 'voertuig' de communicatie zelf. Over welk, door differentiatie gevormd maatschappelijk subsysteem we ook spreken, '[es] existiert nur in Kommunikation (bzw. psychologisch gesehen: in Aussicht auf Kommunikation): ${ }^{487}$

Kijken we, met dit in ons achterhoofd, naar maatschappelijke differentiatieprocessen vanuit het macroscopisch perspectief van een sociale evolutietheorie, d.w.z met het oog op de gefaseerde ontwikkeling van steeds complexere maatschappijvormen, dan valt, volgens Lulmmann, om te beginnen de bijzondere rol op die de zgh. 'verbreidingsmedia' spelen. Onder 'verbreidingsmedia' schaart hij al die zaken en technieken die het bereik van communicaties vergroten, die, zoals het schrift, de boekdrukkunst of radio en televisie, er toe bijdragen dat een communicatieve offerte aan meer 'ontvangers' kan worden geadresseerd, dan de hier en nu toevallig aanwezigen. De empirische (hypo)these is nu, dat de overgang van de archailsche maatschappij naar de hiërarchisch gestratificeerde maatschappij en vervolgens naar de moderne, functioneel gedifferentieerde maatschappij in aanvang telkens een reactie is geweest op ontwikkelingen die zich rond verbreidingsmedia voordeden. Zo ziet Luhmann de evolutionaire overgang van de archaische matschappij naar de hiërarchisch gestratificeerde, hoog-culturele maatschappij als een 'antwoord' op de uitvinding van het schrift - een 'beproefd' antwoord en wel in die zin, dat hoog-culturen een oplossing bieden voor de problemen die zich met de invoering van het schrift voordoen, onder behoud van de enorme voordelen die het tegelijkertijd oplevert.

De theoretische andyse en reconstructie van deze samenhang tussen de ontwikkeling van verbreidingsmedia en de maatschappelijke evolutie, start, naar goed functionalistisch gebruik, bij de problemen die door een plotselinge

486. Zie hierover o.a.: R. Mayntz, "Funktionelle Feilsysteme in der Theorie sozialer Differenzierung"; in: R. Mayntz ua., Differenzierung und Verselbständigung - Zur Entwokking gesellschaftlicher Teilsysteme, Frankfurt/M. 1988, p. II-45.

487. N. Luhmann, 'Die Einheit des Rechtssystems', in: Rechtstheorie 14 (1983), p.ll35. 
'schaalvergroting' van communicatieprocessen ontstaan. ${ }^{488}$ Voor het op gang komen van een communicatieproces, is het namelijk niet voldoende, dat een of meerdere toehoorders worden bereikt; een mededeler moet er tevens vanuit kunnen gaan, dat de inhoud van zijn mededelingen min of meer begrepen wordt, zoals hij deze zelf begrijpt. Wordt die veronderstelling al te sterk ondermijnd, dan neemt ook de neiging tot het actief aangaan van communicatieve betrekkingen af. We hebben bovendien gezien, dat voor het 'Iukken' van communicatie meer nodig is, dan alleen een begrijpen aan de kant van de geadresseerde. Communicatie lukt, is sociaal effectief, zo schreven we, wanneer diegene aan wie de mededeling gericht is, de daarin vervatte selecties niet alleen begrijpt, maar tevens accepteert en overneemt als premissen van zijn verdere beleven en handelen. In Luhmanns eigen woorden:

'Mit kommunikativen 'Erfolg' meine ich daß der Empfänger den selektiven Inhalt der Kommunikation (die Information) als Prämisse des eigenen Verhaltens ubernimmt, also an die Selektion weitere Selektionen anschließt und sie dadurch in ihrer Selktivität verstärkt. ${ }^{\text {489 }}$

In archaische maatschappijen met hun geringe differentie tussen interactie en maatschappij - die 'interaktionsnah' gevormd zijn, zoals Luhmann het uitdrukt — wordt aan de voorwaarden van 'begrijpelijkheid' en 'accepteerbaarheid' op een welhaast "natuurlijke", leefwereld-achtige manier voldaan. De begrijpelijkheid van communicatieve handelingen wordt hier in afdoende mate gegarandeerd door het gebruik van een gemeenschappelijke taal en door de mogelijkheid van directe mondelinge navraag en toelichting. De persoonlijke bekendheid met de ander, het weten van, en het vertrouwen in zijn kennis, kundes en sociale status, dekken daamaast het probleem van de acceptatie van door anderen tot stand gebrachte selecties/complexiteitsreducties af. De segmentaire differentiatiemodus is tegelijkertijd ook uitdrukking van de begrenzingen die inherent zijn aan een dergelijke, door een gedeelde leefwereld bemiddelde "waarschijnlijkheid" van communicatie. De schaal van communicatieve processen en hun wertakkingen kan de sfeer van verwantschap en persoonlijke bekendheid maar weinig overschrijden. En natuurlijk correspondeert dit alles met het feit, dat in archaische matschappijen de communicatie vrijwel uitsluitend mondeling van aard is, dus voortdurend de vorm van communicatie onder aanwezigen moet aannemen.

488. Zie voor het nu volgende o.a. N. Luhmann, 'Einführende Bemerkungen zu einer Theorie symbolisch generalisierter Kommunikationsmedien', in: Soziologische Aufklirung 2, Opladen 1975 , p.170-192; Idem, Soziale Systeme, op.cit., p.580 e.w.; W.L. Schneider, Objektives Verstehen, Opladien 1991 , p.190 e.v.

489. N. Luhmann, 'Die Unwahrscheinlichkeit der Konmunikation', in: Idemi, Soziologische Aufflaruing 3, Opladen 1981, p. 26/27. 
Deze constellatie wordt door de uitvinding van het schrift onder druk gezet. Met het schrift neemt immers de kans op anonieme communicatie, dw.z. communicatie onder niet-aanwezigen toe. Aangezien ook anonieme communicatie een realisatie van 'maatschappij' voorstelt ${ }_{\text {" }}$ zou dit een verdergaande differentiatie van interactie en maatschappij inhouden. Nu biedt een grotere distantie t.o.w. de mechanismen en structuren die interactiesystemen kenmerken, het systeem 'maatschappij' weliswaar de mogelijkheid complexer te worden, maar dit slechts op woorwaarde dat op een of andere manier de begrijpelijkheid en acceptatie van communicatieve offertes waarschijnlijk blijft, ook wanneer de schriftelijke communicatie buiten de sfeer van de directe, persoonlijke bekendheid treedt, niet meer gedekt wordt door de vanzelfsprekendheid van een gedeelde leefwereld en de motivationele controlemechanismen waar de interactie onder aanwezigen op terug kan vallen. Niet alleen wordt onzeker of, bij gebrek aan de mogelijkheid van directe navraag en toelichting, de onbekenden tot wie men zich schriftelijk wenst te richten, de medegedeelde informatie zullen begrijpen zoals het de auteur voor ogen stond; anonieme communicatie drijft bovendien de aspecten 'begrijpen' en 'accepteren' uit elkaar. Het bindingseffect van interactionele, persoonlijke communicatie wordt namelijk zowel door de bekendheid met de ander bewerkstelligd, inclusief de sociaal-psychologische mechamismen die daarop inhaken, als door het hoge tempo van actie en reactie. Bij schriftelijke communicatie valt dit grotendeels weg. Men leest een tekst, hoeft niet direct te reageren en heeft dus tijd - tijd om na te denken, voor afweging, voor twijfel. Men kan een tekst begrijpen en toch vraagtekens plaatsen achter de 'juistheid" of 'waarheid' van het gelezene, het definitief terzijde schuiven of zijn oordeel opschorten. De geschreven tekst kan misschien nog een tijdlang zijn magie bewaren, maar lokt dan onvermijdelijk reflexiviteit en kritiek uit. En waarom zou iemand eigenlijk de letters willen lezen die zijn neergeschreven door iemand die hij niet kent, en wiens mening voor hem geen directe persoonlijke betekenis heeft? Waarom een bevel opgevolgd, dat door een vreemideling in naam van een andere onbekende van een kleitablet of stuk perkament wordt voorgelezen?

Kortom - de mogelijkheden die de uitvinding van het schrift biedt, kunnen slechts ten volle worden benut, wanneer zich; ter compensatie van persoonlijke nabijheid en vertrouwdheid, structuren ontwikkelen, die begrijpelijkheid en acceptatie alsnog waarschijnlijk maken. Een zekere uniformering van de taal binnen een maatschappelijk relevant territorium biedt enig soelaas, maar niet voldoende. De evolutionair gezien beslissende stap, waarmee tevens de overgang van de archaïsche naar de hoog-culturele maatschappijvorm wordt ingezet, bestaat volgens Luhmann in de ontwikkeling van zogeheten 'symbolisch gegeneraliseerde communicatiemedia':

"Die Grunde für die Annahme von Selektionsofferten müssen auf abstraktere Basis rekonstruiert werden, sie müssen auf 
Kommunikation mit Unbekannten eingestellt sein und die Verquikung mit einem archaischen Ethos des Sozialbindung unter Nahestehenden abstreifen. Das ist der historische Ausgangspunkt fur die Ausdifferenzierung besonderer symbolisch generalisierter Kommunikationsmedien., ${ }^{490}$

Zoals bekend, is de theorie van de symbolisch gegeneraliseerde media een van de klassieke leerstukken die Talcott Parsons de sociologie heeft nagelaten. Jan Künzler heeft er echter terecht op gewezen, dat Luhmanns revisies van Parsons' oorspronkelijke mediatheorie dermate ingrijpend zijn geweest, dat vandaag de dag 'zwei vôllig heterogene Theorien vorliegen', ${ }^{491}$ Zo leidde Parsons de (maatschappelijke) media - 'geld", 'macht", 'invloed' en 'waardebinding' deductief af uit de noodzaak van intersystemische ruilrelaties tussen de AGLLvormig uitgedifferentieerde subsystemen (economie, politiek, communale gemeenschap en cultuur) van het algemene sociaal systeem (maatschappij). Een dergelijke, axiomatisch-analytische aampak wordt door Luhmann ten enenmale van de hand gewezen. De ontwikkeling van symbolisch gegeneraliseerde media is in zijn visie een historisch contingent gegeven en moet bovendien gezien worden in relatie tot concrete, geïnstitutionaliseerde structuren, zoals de markt, politieke organisatievormen, het wetenschapsbedrijf, etc. ${ }^{492}$ Dat leidt er niet alleen toe, dat Luhmann meer en andere media onderscheidt - in ieder geval: waarheid, geld, liefde, macht en kunst ${ }^{49 .}$-, maar dat hij bovendien niet, zoals Parsons, onder druk staat, om de verschillende media strikt isomorf te begrijpen, d.w.z. voor ieder kenmerk van bijv. het medium geld een equivalent in de andere media te vinden ${ }^{494}$

Het meest beslissende onderscheid met Parsons - de consequenties ervan zullen we verderop nog onder ogen zien - schuilt misschien wel daarin, dat Luhmann de functie van symbolisch gegeneraliseerde media niet meer toespitst op de onderlinge titwisseling en convertibiliteit van de 'prestaties' die door functionele subsystemen worden geleverd, maar op het probleem van de overdracht en acceptatie van in communicatieve offertes aangeboden selecties. De algemene functie van symbolisch gegeneraliseerde communicatiemedia, zo

490. N. Luhmann, Einfuhrende Bemerkungen zu einer Theorie symbolisch generaltsierter Kommunikationsmedien', op.cit., p. 173.

491. J. Kunzler, Medien und Gesellschaft - Die Medienkonzepte von Talcort Parsons. Jurgen Habermas und Niklas Luhmanm, Sturtgart 1989, p. 71. Bij Künzler houdt dit tevenss een vermaning aan het adres wan Mabermas in, voorzover deze meent, dat zijn kritiek op Parsons' mediatheorie volstaat, om "von einer detaillierteren Beschäftigung mit Luhmamns Version dispendiert zu sein'. (Idem, p.72)

492. Verg. ook $\mathrm{D}$. Berkhout, De symbalische media van de samenlewing : over interpenerratie in de moderne samenleving, Utrecht 1990,159 e.v.

493. Kunzler voegt daar nog 'recht' problematisch is, zeker voor wat betreft het recht. Zie I Kanzler, op.cit., o.a. p. $100 / 101$.

494. Verg, Kunzler, op.cit., p.91. 
merkt Luhmann op, bestaat er in 'reduzierte Komplexitât ubertragbar zu machen und fur Anschlußfähigkeit auch in hochkontingente Situationen zu sorgen... ${ }^{495}$ Een voor de hand liggend voorbeeld vormt het fenomeen 'macht". 'Macht' draagt er zorg voor, dat iets waarschijnlijk wordt, wat op het eerste gezicht buitengewoon onwaarschijnlijk lijkt, namelijk dat iemand de in een aanwijzing of 'bevel' vervatte selecties accepteert als premissen van zijn verdere handelen, ook al komt hem dat, om welke reden dan ook, niet gelegen.

In het vervolg van onze korte schets van Luhmarns mediatheorie zullen we ons voornamelijk op 'macht' en 'geld" richten. Niet alleen is hun bemiddelende rol bij de acceptatie van aangeboden selecties tamelijk evident, maar bovendien kunnen aan 'geld' en 'macht' de belangrijkste kenmerken van 'symbolisch gegeneraliseerde communicatiemedia' zonder veel omhaal worden afgelezen. Inzichtelijk is, om te beginnen, dat dergellijke media een institutionele inbedding behoeven Zo veronderstelt 'geld' als algemeen medium van (economische) communicatie de markt en het institurt "eigendom?: Het communicatiemedium 'macht', door Luhmann primair als 'politieke' macht begrepen, veronderstelt daarentegen een 'staat', hetgeen minimaal wil zeggen: een hièrarchische organisatie van ambten - 'Politisch ist macht... sofern sie zur Deckung kollektiv bindender Entscheidungen eingesetzt werden kann, und die Frage wer und wer nicht dazu befugt ist wird durch das Innehaben von Staatsämtern definiert." 496

Aan 'geld' en 'politieke macht' kan bovendien vrij simpel worden toegelicht, waarom het, voluit geschreven, over symbolisch gegeneraliseerde media van communicatie gaat. Weliswaar zijn in moderne maatschappijen de domeinen waarbinnen geld en politieke macht als medium bruikbaar zijn, (veelal juridisch) afgegrensd - politieke macht kan niet collectief bindend voorschrijven wat 'waar' of 'mooi' is; met geld mag niet de gewenste rechterlijke beslissing worden gekocht - , binnen hun domeinen zijn communicatiemedia echter algemeen toepasbaar, onathankelijk van de naar tijd en plaats telkens veranderlijke omstandigheden. Het maakt het geld niet uit of het om knollen of citroenen gaat, of de (ver)koper edelman, bedelman of Rockefeller is. Voor het geld verschijnt alles als koopwaar, iedere concrete persoon als een mogelijke koper of verkoper. Geld vormt als de "universele waar' (Marx) de eenheid van een uiterst veelvormig domein. Hetzelfde geldt yoor politieke macht. Wie politieke machtsposities bekleedt, 'beschikt' daarmee over een vermogen, dat in zeer uiteenlopende omstandigheden, met het oog op verschillende doelen en vis à vis allerhande 'onmachtigen' inzetbaar is.

Een dergelijke generalisering, het onder én noemer brengen van het veelvormige, vereist symbolisering. De opkomst van het papiergeld vormt 495. N. Luhmann, "Einfuhrende Bemerkungen zu einer "Theorie symbolisch generalisierter
Kommunikationsmedien', op cit, p.174.

496. Oekologische Kommunikation, op.cit., p. 169. 
daarvan een tastbare instantie: Het papier dat als materièle drager van een symbolische waarde fungeert, is zelf nauwelijks iets waard. Ook politieke macht. leidt als medium van communicatie slechts een symbolisch bestaan, heeft slechts 'realiteit" in de vorm een ritueel omklede 'bestempeling' van sommige beslissingen als (colleetief) 'bindend'. 'Politieke macht' moet als symbolisch gegeneraliseerd medium dan ook principieel onderscheiden worden van "geweld'. Geweld in de zin van fysieke bedreiging vormt weliswaar een soort 'dekking" voor het functioneren van macht als symbolisch medium, maar dit slechts op voorwaarde dat het niet hoeft te worden ingezet: Waar geweld wordt ingezet, treedt al spoedig een inflatie op van macht als communicatiemedium.

Waar wij zo juist spraken over geweld als een soort 'rugdekking" van macht als communicatiemedium, spreekt Luhmann over geweld als een "symbiotisch mechanisme". Symbiotische mechanismen, zoals fysiek geweld - maar ook: behoeftebevrediging, waarneming, seks - reguleren de verhouding tussen communicatieprocessen en hun fysisch-organische omgeving, die sociale systemen eerst en vooral gegeven is in de vorm van de lichamelijkheid van betrokken actoren. Anders geformuleerd: symbiotische mechanismen brengen de fysisch-organische omgeving van sociale systemen via de belevingswereld van psychische systemen in een communicatief behandelbare vorm. De koppeling van een communicatiemedium aan een (telkens specifiek) symbiotisch mechanisme - macht aan fysiek geweld, geld an behoeftebevrediging, waarheid aan waarneming, liefde aan seks, etc. - dempt de risico's die aan een toenemende generalisering, en dus symbolisering van een communicatiemedium verbonden zijn, indem sie die organischen Bedingungen zu einer Sicherheitsgmundlage machen.Die Kapazität der Medien, die Akzeptanz von Selektionen zu motivieren, verdankt sie vor allem dieser Sicherheitsleistung der symbiotischen Mechanismen."

De ontwikkeling van symbolisch gegeneraliseerde media, zo kunnen we naar ons uitgangsprobleem terugkeren, maakt een toename van niet-interactionele, anonieme communicatie behandelbaar, door te garanderen, dat door "vreemden" tot stand gebrachte selecties (wensen, behoeften, observaties) in voldoende mate acceptatie vinden bij degenen an wie die selecties in de vorm van communicatieve offertes zijn gericht. Een heerser hoeft niet door al zijn onderdanen persoonlijk te worden gekend; om toch op uitvoering van zijn wensen en bevelen te kunnen rekenen. Natuurlijk is dit een abstracte, ideaaltypische voorstelling van zaken. Zo moet, historisch gezien; de ontwikkeling van macht, geld, waarheid, etc. tot communicatiemedia eerder begrepen worden in termen van een toenemende generalisering en symbolisering, van een verdergaande differentiatie tussen een medium en zijn symbiotisch mechanisme en van een allengs zich aftekenende toespitsing van ieder medium op een specifiek communicatief deelbereik en de daardoor behartigde matschappelijke functie. 
Niet alleen geldt, dat "politieke' macht aanvankelijk sterk gekoppeld was aan de beschikking over fysieke geweldsmiddelen, mar bovendien was lange tijd de grens tussen macht, geld en waarheid vaag en daarmee hun zelfstandigheid als medium onvolledig ( - "liefde" en "kunst" treffen we als communicatiemedia uberhaupt pas in de moderne maatschappij aan). De ware heerser werd geacht zowel de meest machtige te zijn, als de waarheid in pacht te hebben en over grote rijkdommen te beschikken. Kenmerkend voor hoogculturen is daarnaast de maatschappelijke dominantie van macht to. $\mathrm{v}$. de andere media. Dit thangt ten nauwste samen met de voordelen van het, aan macht als medium inherente principe van hièrarchisering. Men zou dit ook zo kunnen formuleren, dat met de ontwikkeling van macht als symbolisch gegeneraliseerd medium de maatschappij hiërarchie ontdekt" - niet het fenomeen van een rangorde, niet onder- en bovenschikking op zichzelf, maar hiërarchie als een wijder toepasbaar strueturerings- en organisatieprincipe dat een sprongsgewijze toename in de sturingscapaciteit van een sociaal systeem mogelijk maakt bij een relatief geringe toename van de daartoe benodigde 'communicatieve energie', d.w.z. bij een relatief spaarzame uitbreiding van de communicatieketens en contacten. In die zin kan men spreken van een dieperliggende samenhang tussen politiek 'centrisme' en hièrarchische stratificatie als een tweetal belangrijke kenmerken van hoogeulturen, zonder dat dit overigens impliceert dat het door maatschappelijke stratificatie tot stand gebracht sociale rangenonderscheid samenvalt met politieke machtsposities en -relaties.

Is de sociale stratificatie eenmaal tot ontwikkeling gekomen, dan kan daar weer een mechanisme op aansluiten, dat eerder op het probleem van de 'begrijpelijkheid' van communicatie onder toenemende anonymisering reageert, dan op het acceptatieprobleem. De 'sociale lagen' worden in dat geval benut als maatschappelijke loci voor een 'recontextualisering' van de taal in de vorm van standsgebonden semantieken. Een bekend voorbeeld van deze 'schichtsspezifische Kommunikation' is de zogeheten 'hoofse' liefdessemantiek die zich in Europa vanaf de 11 de eeuw ontwikkelt in het kielzog van een toenemende drang tot distinctie bij een zich aristocratiserende maatschappelijke bovenlaag. ${ }^{498}$

In feite komen de symbolisch gegeneraliseerde cormmunicatiemedia, volgens Luhmann, pas in de moderne maatschappij volledig tot ontwikkeling. Eerst onder moderne condities verzelfstandigt de symbolische realiteit van de communicatiemedia zich definitief t.o.v. de symbiotische mechanismen die hun 'dekking' verlenen (met alle bijbehorende problemen van mediale inflatie en deflatie); eerst dan verzelfstandigen media als politieke macht, geld, waarheid,

498. Verg. in deze o.a. N. Luhmann, "Interaktion in Oberschichten: Zur Transformation ihrer Semantik im 17. und 18. Jahirhundert; opgenomen in: Idem, Gesellschafisstruktur und Semantik Bd.1,Frankfurt/M. 1993, p.72-162. En natuurlijk ook: N. Luhmann, Liebe als Passion, Frankfurt/M. 1982. 
etc. zich ook definitief t.o. $\mathrm{x}$. elkaar, zonder nog een onderlinge hierrarchie te vormen. Deze 'zuivering' van de communicatiemedia gaat band in hand met een, vanaf de $16 \mathrm{de} / 17 \mathrm{de}$ eeuw aan impuls winnende transformatie van hiërarchische stratificatie naar functionele differentiatie als de maatschappelijk dominante differentiatiemodus. Lulmann omschrijft deze 'Katastrofe der Neuzeit" als een "Umkippen des Formtypus der gesellschaftlichen Differenzierung von vertikaler Stratifikation in horizontale funktionale Differenzierung' en beschouwt dit als de historische uitkomst van een, zowel in de tijd als qua geografische ruimte diffuus en verstrooid proces van maatschappelijke herstructurering, dat reageert op de ruis, die wederom het gevolg is van een innovatie binnen de verbreidingsmedia, namelijk de uitvinding van de boekdrukkunst. ${ }^{499}$

De effecten (én problemen) van een door boekdrukkunst mogelijk gemaakte, grootschalige verspreiding van geschriften, liggen binnen het Luhmanniaans analysekader voor de hand: een sprongsgewijze toename van het aandeel aan anonieme communicatie binnen de maatschappij - één tekst kan in principe a an honderd, duizend, of nog meer lezers tegelijkertijd worden gericht -, met als keerzijde, dat de begrijpelijkheid en acceptatiegraad van de anonieme communicatie opnieuw in gevaar komt. Deze problematiek wordt aan het begin van de nieuwe tijd des te urgenter, daar de verbeteringen die zich dan op het gebied van vervoer en transport (scheepvaartl) voordoen, in aanleg ook de geografische en dus culturele distantie tussen een 'zender" en zijn 'ontvangers' vergroot. Het gaat m.a.w. niet alleen om een kwantitatieve uitbreiding van de potentiêle deelnemers aan anonieme communicatie, maar bovendien on de mogelijkheid van een ruimtelijke verlenging van communicatieketens die dan op het probleem van de regionaliteit van 'Verstehenskontexte' stuit; op het probleem datt 'the world taken for granted' voor een Venetiaan uit de l6de eeuw een andere is, dan voor zijn Londense tijdgenoten. Is de woorliggende tekst een loflied op een machthebber, een politiek filosofisch geschrift, een theologisch traktaat?" Is de waarheid of morele correctheid van de neergeschreven zinnen van belang, of gaat het om de bevalligheid van woordkeus en constructie??

We stuiten daarmee op dezelfde probleemfiguur die zich eerder bij de uitvinding van het schrift voordeed: De in aanleg gegeven mogelijkheden van schaalvergroting, van 'uitbreiding' van de maatschappij als het omvattende systeem van communicatie en de kansen op diversificatie en complexiteitsstijging die dit biedt, kunnen sleehts ten volle worden benut, wanmeer tegelijkertijd een structurele oplossing wordt gevonden voor de problemen die dit oproept m.b.t de begrijpelijkheid en acceptatie van nietinteractionele communicatie. Alleen het gewicht van beide problemen lijkt nu verschoven en wel in de richting van het aspect "begrijpelijkheid". Wat althans

499. N. Luhmann, "Distinctions directrices" - Ober Codienung von Semantieken und Systemen", in: Idem. Soziologische Aufklarung 4, Opladen 1987, p.19. 
nieuw is, wat de evolutionaire sprong uitmaakt in de 'Europese' oplossing van de problemen die zich met de boekdrukkunst aandienen, heeft betrekking op de oplossing die uiteindelijk wordt gevonden voor een toenemende contingentie van het 'begrijpen', een contingentie of 'teveel-aan-mogelijkheden" die het gevolg is van een uit elkaar drijven van de alledaagse leefwerelden die, tot dan toc, voor de communicatiedeelnemers de context wan hun begrijpen van informatieve mededelingen had gevormd. In tegenstelling tot bijv. het keizerlijke China, waar de techniek van het drukken van teksten al eerder bekend was, wordt in Europa niet teruggegrepen op het beproefde recept van een standsgebonden recontextualisering (en compartimentalisering) van communicatie. In plaats daarvan wordt een begrenzing van interpretatie- en duidingsmogelijkheden gevonden op een abstracter niveau, namelijk in de vorm van een 'horizontale" differentiatie van betekenisvelden ("Sinnprovinzen") die zich middels specifieke codes en semantieken van elkaar afgrenzen. Dergelijke betekenisvelden of zincontexten hebben zich in sommige, maar niet in alle gevallen rond symbolisch gegeneraliseerde media van communicatie uitgekristalliseerd Van belang is echter, dat de ontwikkelingsmogelijkheden van deze betekenisvelden en hun kansen op duurzaamheid en stabiliteit afhangen van de vraag of de communicatieprocessen waarvoor ze de context vormen, die ze als het ware 'kanaliseren', erin slagen een specifieke maatschappelijke functie te usurperen. Vanuit het perspectief van de maatschappij verschijnt de recontextualisering van de communicatie in de vorm vam afzonderijke zin- of betekenisvelden dan ook als een, van sociale lagen en standen onafhankelijke differentiatie van de maatschappij in functionele subsystemen, of kortweg: 'functiesystemen'.

De ontwikkeling van maatschappelijke functiesystemen, zoals het economisch, het politiek, het wetenschapssysteem, etc. tot onathankelijke, zichzelf via specifieke codes en bijzondere semantieken afgrenzende communicatieve deelgebiedlen, vormt tevens het kader voor wat we hierboven omschreven als een verdergaande 'zuivering' van de symbolisch gegeneraliseerde media. Deze 'zuivering' betrof zowel een verzelfstandiging van de communicatiemedia t.o.v. elkaar, als ook een versterkte generalisering en symbolisering ${ }^{500}$ Het eerste aspect verschijnt nu als een contextuele 'specificatie' waarbij een bijzonder functiesysteem telkens als context fungeert: Met het tweede aspect, hun sterkere generalisering en symbolisering, reageren de communicatiemedia op een complexiteitsstijging, die precies mogelijk wordt gemaakt door de overgang van hiesrarchische stratificatie naar functionele differentiatie als de maatschappelijk dominante differentiatiemodus Verzelfstandigt zich bijv. het economisch bereik t:o.v. matschappelijke deelgebieden, dan opent dit de poort voor een commercialisering of het tot 'waar' worden (Marx) van goederen en diensten, die voorheen om religieuze, morele of politieke redenen niet als marktwaar 
konden verschijnen. Deze toename en diversificatie van waren (i.e. van keuzemogelijkheden, van 'economische' complexiteit) heeft alleen zin, wanneer tegelijkertijd het geld, als bemiddelingsinstantie, algemener kan worden aangewend. Zoals we eerder zagen, impliceert een sterkere generalisering van het medium geld voor Luhmann tevens een versterking van het symbolisch karakter van geld. Men zou ook kunnen zeggen, dat functionele differentiatie hand in gaat met een "abstracter" worden van de communicatiemedia en dit orm te benadrukken, dat onder 'moderne' condities deze media zich definitief van hun symbiotische mechanismen gaan onderscheiden.

We zullen in de volgende paragrafen nog uitwoerig ingaan op de grondstructuren en basale kenmerken van de moderne, functioneel gedifferentieerde maatschappij en dan ook preciezer analyseren wat Luhmann onder, nu in het voorbijgaan aangestipte zaken als 'functie/functionele differentiatie', 'code/codering", 'functionele autonomie', etc. verstaat. Ter afsluiting van deze paragraaf loont het echter de moeite om nog eens terug te blikken op het evolutietheoretische raamwerk, dat aan het voorafgaande ten grondslag heeft gelegen. Want niet alleen beschouwt Luhmann de (neodarwinistische) evolutietheorie als een van de 'pijlers' van zijn denken ${ }^{501}$, maar bovendien bestaat er naar zijn idee een intrinsieke 'link' tussen 'evolutie" en 'maatschappij". Wat er in het proces van sociale evolutie daadwerkelijk "evolueert" zijn niet de sociale systemen 'interactie' en 'organisatie', maar uiteindelijk slechts het systeem 'maatschappij' - Nur auf der Ebene des Gesellschaftssystem und seiner Subsysteme ist Evolution möglich, das heißt einen Änderung von Strukturen durch Variation, Selektion und Restabilisierung'. ${ }^{502}$ En dat is, in omgekeerde blikrichting, voor Luhmann op zichzelf al genoeg reden om vast te houden aan het project van een maatschappijtheorie als de enige sociologische ondememing die onvattend genoeg is om de mogelijkheidsvoorwaarden van de sociale evolutie adequat te kunnen reflecteren:

'In der Soziologie ist nicht selten behauptet worden, daß man auf Begriff und Theorie der Gesellschaft verzichten könne. Wurde man das tun, dann würde man auch die Ebene aufgeben, auf der allein Evolution angemessen diskutiert werden kann. ${ }^{.503}$

501. En dat al ten tijde van zijn discussie met Habermas - verg o.a. N. Luhmann, "Systemtheoretische Argumentationen. Eine Entgegnung auf Jurgen Habermas", in: J.Habermass N.Lukmann, op.cit; p.366 e ev.

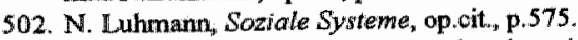

503. N. Luhmann, 'Moderne Systemtheorien als Form gesammtgesellschaftlicher Analyse', in: J.Habermas/N.Luhmann, op.cit, p.20/21. Zie ook: N. Luhmann, 'Die Weltgesellschaft', opgenomen in: Soziologische Aufklarung 2, op.cit., p.61. 
Vanuit een functionalistisch, zich aan referentieproblemen oriënterend perspectief zou 'evolutie' in zeer algemene termen kunnen worden omschreven als het proces dat onwaarschijnlijkheden transformeert in warschijnlijkheden (om eens niét in termen van (wereld)complexiteit en complexiteitsreductie, wat naturilijk hetzelfde is, te spreken). Dat geldt ook voor de "sociale evolutie" en het laat zich inmiddels raden welke 'onwaarschijnlijkheid', volgens Luhmanm, door het sociale evolutieproces een waarschijnlijkheid wordt: "Kommunikation ist unwahrscheinlich. Sie ist unwahrscheinlich, obwohll wie sie jeden Tag erleben, praktizieren und ohne sie nicht leben wirden. ${ }^{504}$ Of zoals Wolfgang Schneider het formuleert:

"Die Evolution der Gesellschaft findet ihre Finhrung im Problem der Unwahrscheinlichkeit von Kommunikation, das seinerseits als Spezifikation des universellen Problems der Reduktion von Komplexitat zu begreifen ist. ${ }^{-50.5}$

We hebben hierboven al min of meer gezien waaruit die onwaarschijnlijkheid van communicatie bestaat. Om te beginnen is het al onwaarschijnlijk dat iemand begrijpt, wat een ander bedoelt - 'Sinn kann nur kontextgebunden werstanden werden, und als Kontext fungiert für jeden zunächst einmal das, was sein eigenes Gedächtnis bereitstellt', ${ }^{506}$ Onwaarschijnlijk is bovendien, dat een communicatie meer personen bereikt dan de toevallig aanwezigen. En tenslotte is onwaarschijnlijk dat een medegedeelde selectie ook geaccepteerd wordt, dat communicatie sociaal 'succesvol' is:

Natuurlijk gaat het hier om theoretisch geconstrueerde onwaarschijnlijkheden, om 'onwaarschijnlijkheid' als het referentieprobleem van een evolutionairfunctionele analyse van het systeem maatschappij en niet om een probleem van de alledaagse communicatieve praktijk. De sociaal-culturele evolutie moet juist begrepen worden als een 'Umformung und Erweiterung der Chancen für aussichtsreiche Kommunikation' ${ }^{507}$ Wat met de functionele reconstructie van communicatie in termen van een drietal onwaarschijnlijkheden echter zichtbaar kan worden gemáakt, is een typische conditioneringsrelatie, die licht kan werpen op het sprongsgewijze karakter van de sociale evolutie. Het probleem is namelijk, dat de drie door Luhmann gesignaleerde "onwaarschijnlijkheden" niet één voor één, na elkaar kunnen worden afgehandeld en in waarschijnlijkheden getransformeerd. Als "drempels" van communicatie versterken ze elkaar en limiteren ze wederkerig mogelijke oplossingen en innovaties. Is een van de drempels overschreden, dan begint een andere onwaarschijnlijkheid op te

504. N. Luhmann, 'Die Unwahrscheinlichkeit der Kommunikation', opgenomen in: Idem, Soziologische Aufklarung 3, op.cit., p.26.

505. W.L. Schneider, Objektives Verstehen, Opladen 1991, p.195.

506. N. Lahmann, 'Die Unwahrscheinlichkeit der Kommunikation', op.cit., p.26.

507. Idlem, p.27. 
spelen, de 'evolutionaire Führung' op zich te nemen. Is bijv. door de ontwikkeling van een gemeenschappelijke taal - Die Sprache ist darauf spezialisiert den Eindruck des ubereinstimmenden Verstehens als Basis weiteren Kommunizierens verfügbar zu machen ${ }^{\text {,50 }}$ — de onwaarschijnlijkheid van het begrijpen getransformeerd in een alledaagse waarschijnlijkheid, dan dient zich aanstonds het probleem van de bereikbaarheid aan als hindernis voor een verdergaande ontwikkeling van het systeem "maatschappij". Worden door de uitvinding van het schrift of de boekdrukkunst de grenzen van de communicatieve bereikbaarheid significant verlegd, dan begint, zoals we gezien hebben, de onwaarschijnlijkheid van acceptatie of van begrijpelijkheid zich naar de voorgrond te dringen. Luhmann spreekt in deze zelfs van een 'Gesetz wachsender wechselseitiger Belastungen': terwijl de drie vormen van onwaarschijnijjkheid elkaar versterken, limiteren probleemoplossingen in de ene dimensie de mogelijkheden in de andere dimensies. ${ }^{509}$

Deze typische conditioneringverhouding tussen een drietal dimensies van communicatieve onwaarschijnlijkheid kan gedeeltelijk verklaren, waarom de sociaal culturele evolutie niet een gradueel proces voorstelt, maar gefaseerd en eerder sprongsgewijs verloopt. Het gaat telkens om een 'totaalpakket'. Wil een kwalitatief nieuwe oplossing voor problemen in een specifieke dimensie zich kunnen doorzetten, dan moet de maatschappij over de gehele linie een 'Gestaltswitch' ondergaan. Of een maatschappij zich langs die lijnen transformeert, een evolutionaire sprong maakt, is contingent. Niets dwingt een maatschappij ertoe om bijv. de kamsen die de uitvinding van de boekdrukkunst biedt op schaalvergroting en complexiteitsstijging, daadwerkelijk te benutten en zich daar structureel op in te stellen. Zo was ook de opkomst in West-Europa van de functioneel gedifferentieerde maatschappij geenszins noodzakelijk. Dát deze maatschappijvorm tot ontwikkeling komt; is bij Luhmann eerder te begrijpen als de, wederom contingente uitkomst van een maatschappelijk proces van 'trial and error'. Daarbij bedient de sociale evolutie zich van een constellatie die in en door het sociale evolutieproces zelf tot stand wordt gebracht, namelijk de differentiatie tussen maatschappij en interactie. Hoe verder maatschappij en interactie uit elkaar zijn getreden, des te irrelevanter wordt voor de maatschappij het beëindigen van de meeste interacties. In de vorm van interacties beschikt de maatschappelijke communicatie m. a.w. over de mogelijkheid te experimenteren met nieuwe thema's, non-conventionele bijdragen, semantische innovaties, kortom: met 'mutaties', zonder dat het mislukken daarvan een ernstig risico oplevert. Luhmann spreekt met het oog hierop over het "riesige Versuchsfeld' dat door het geheel van interacties wordt gevormd, over de 'basale Anarchie' die daarmee gegeven is en over interacties als 'das Spielmaterial fur gesellschaftliche Evolution'. Samenvattend: 
"Im Bereich sozialer Systeme wird die Einnahme von relativ unwahrscheinlichen Positionen dadurch erleichtert; daß das Risiko auf Interaktionssysteme verteilt wird. Interaktionen mussen ohnehin aufhören, also kann man sie auch zum Experimentieren benutzen... Es steht zunächst nur die Autopoiesis der Interaktion, nicht auch die Autopoiesis der Gesellschaft auf dem Spiel. ${ }^{\text {s10 }}$

Met het idee dat de maatschappelijke evolutie zich van het innovatieve potentieel van interacties bedient, is al min of meer een sociologische invulling gegeven aan 'variatie', als een van de drie evolutionaire mechanismen (naast "selectie' en 'retentie") die door de neo-dlarwinistische evolutietheorie worden onderscheiden. Uiteindelijk berust dit innovatorisch potentieel op de taal en de daarmee gegeven mogelijkheden wan gerichte negatie, van expliciete deviantie en tegenspraak. ${ }^{511}$ Negatief geformuleerd, zou men kunnen zeggen, dat taal niet selectief genoeg is, dat de taal altijd meer voorstelbaar maakt, dan als ordening, als reductie van complexiteit kan worden gehandhaafd. Positief geinterpreteerd, garandeert deze 'Weltadăquatheit' van de taal de mogelijkheid om middels talige communicatie de door verwachtingsstructuren gestabiliseerde, selectieve zinordeningen telkens te transcenderen.

Selectie, het tweede evolutionaire mechanisme, voltrekt zich in feite al wanneer thematische of semantische vernieuwingen zich 'bewijzen' in termen van hun herhaalbaarheid en aansluitingswaarde binnen interacties - als 'Interaktionstabilităt des Unwahrscheinlichen', zoals Luhmann het uitdrukt. ${ }^{512}$ Met de ontwikkeling van hoog-culturen beginnen echter de symbolisch gegeneraliseerde communicatiemedia maatschappelijk aan gewicht te winnen als selectiemechanismen en wel op grond van hun functie de overdraagbaarheid en acceptatie van selecties en dus ook nieuwe, innovatieve selecties te reguleren. Luhmann:

'Kommunikationsmedien dienen insofern selektiven Funktionen, als sie regulieren, welche Reduktionen des Erlebens bzw. Handelns in sozialen Systemen ubertragbar gemacht werden und welche anderen, obgleich sprachlich möglich, an ihrer Nichtübertragbarkeit in sozialen Systemen scheiteren. Ihr Selektionsprinzip ist intersubjektiver Erfolg der Sinnbildung:

510. Soziale Systeme, op cit, p.591.

511. Verg. N. Luhmann, "Evolution und Geschichte" opgenomen in: Soziologische Awfklärung 2, Opladen 1975, p.151 e.v.

512. Soziale Systeme, op.cit, p.591.

513. J.Habermas/N.Luhmann, op.cit., p. 366. 
De retentie-, ofte wel 'restabiliseringsfunctie" tenslotte wordt in sociaal evolutionair perspectief door maatschappelijke differentiatie waargenomen 'erst sie sichert ubber den kommunikativen Erfolg hinaus die Reproduzierbarkeit von Problemlösungen unter sich ändernder Unweltbedingungen'. ${ }^{54}$ Aan deze inschatting van de sociaal evolutionaire betekenis van maatschappelijke systeemdifferentiatie ligt echter een specifieke veronderstelling ten grondslag, het idee namelijk, dat de differentiatie van de maatschappij niet simpelweg een opdeling of opsplitsing van de maatschappij voorstelt, maar neerkomt op een herhaling van het systeem/omgeving-onderscheid binnen de maatschappij als het overkoepelende systeem. Maatschappelijke differentiatie is, zo bezien, ook altijd een proces van (sub)systeemvorming met als functie de ordening en stabilisering van nieuwe opties en handelingsmogelijkheden:
'Systembildungen leisten ihren spezifischen Beitrag zur Evolution dadurch, daß sie die Kompatibilităt und Repro- duzierbarkeit von Problemlosungen gewährleisten. Sie machen Problemlosungen vom Zufall ihres Auftreten unabhängig - was nicht ausschließt, Zufall selbst als stabilisierbare Problemlösung zu verwenden. ${ }^{315}$

Ook in deze speelt volgens Luhmann de differentie tussen interactie en maatschappij weer een bijzondere rol. Zoals bij een verdergaande differentiatie van interactie en maatschappij, interactiesystemen als het ware worden 'bevrijd' van 'gesellschaftlich durchgehende Normalitätserwartungen', zo geldt omgekeerd, dat de maatschappij kan differentiëren, i.e. subsystemen kan vormen, zonder daarbij te zijn aangewezen op de concrete kenmerken en kwaliteiten van feitelijke interacties - 'sie entwickelt sich durch einziehen neuer System/Umwelt-Relevanzen in das Gesellschaftssystem und nicht durch Aufsuchen und Sortieren passender Interaktionen' ${ }^{516}$ Welbeschouwd komt dit er op neer, dat maatschappelijke differentiatie tevens de verankering van variatiemogelijkheden dient, voorzover door de vorming van subsystemen relatief stabiele contexten worden geschapen, die noch afhankelijk zijn van, noch interveniëren in de 'afwijkende', non-conventionele interacties die binnen die contexten mogelijk zijn. Al met al tekent zich een beeld af wan maatschappelijke evolutie als een proces van toenemende differentiatie, waarbij

514. N. Lahmann, 'Evolution und Geschichte', op.cit., p.15.1.

515. J.Habermas/N.Luhmann, op.cit, p. 367.

516. Soziale Systeme, op,cit, p.574. Dat desalniettemin een onderscheid kan worden geobserveerd tussen bijw . handelingen die tot het politiek system en handelingen die tot het economisch systeem behoren, is, volgens: Luhmann, 'dem Zugriff der Abstraktion auf den konkreten Vollzug zu danken und ist nicht der Grund der Differenzierung'. (Idem) We zullen op deze en soortgelijke constateringen nog terug komen in de context van een discussie inzake de empirische demarcatie wan functiesystemen. 
de evolutionaire trias die dit proces in gang houdt - variatie, selectie en retentie - zelf het subject wan een differentiatieproces wordt, en wel in die zin, dat gaandeweg de matschappelijke evolutie deze drie evolutionaire mechanismen zich ten opzichte van elkaar beginnen te profileren en te verzelfstandigen.

Vergelijken we tot slot Luhmanns model van sociale evolutie met andere, meer kJassieke benaderingen, dan valt op dat het anders zo prominente principe van 'aanpassing-aan-de-omgeving" ofte wel "adaptatie' sterk naar de achtergrond gedrongen is. Parsons bijv. zag de eigenlijke evolutionaire betekenis van de ontwikkeling van sociale stratificatie in de, vergeleken met zuivere verwantschapssystemen, verhoogde dirigeerbaarheid van menselijke en nietmenselijke hulpbronnen en dit als een instantie van het algemenere principe van 'adaptive upgrading', van een vergroting van de controle van de maatschappij over haar verschillende omgevingen. "Growth in ability to control their environments is', aldus Parsons, 'the explanation of societal evolution'. ${ }^{517}$ Voor Luhmann daarentegen gaat het bij de evolutionaire overgang van de segmentaire naar de hiërarchisch-gestratifficeerde maatschappijvorm niet primair om een aanpassing aan een externe omgeving, maar eerder om een aanpassing van de maatschappij aan zichzelf, aan een endogeen veroorzaakte onrust. ${ }^{518}$ Anders gesteld: het schrift is niet het probleem; de uitvinding van het schrift biedt alleen mogelijkheden. Het is slechts bij het benutten van die mogelijkheden, dat de maatschappij op problemen stuit, maar die zijn van maatschappelijke, want communicatie-interne aard. Gebeurtenissen in de omgeving kunnen weliswaar een prikkel tot verandering vormen, maar dit slechts op de voorwarden van de maatschappij zelf.

Dat Luhmann een strikt adaptionistisch concept van evolutie afwijst ligt natuurlijk in de lijn van zijn autopoietische interpretatie van sociale systemen en meer in het bijzonder van zijn conceptie van 'maatschappij' als een systeem dat op het niveau van zijn operaties uberhaupt niet met zijn omgeving kan interageren. De grens tussen de maatschappij en haar omgeving wordt gevormd door de differentie cornmunicatie/niet-communicatie en dat is niet een grens die op adaptieve kwesties wijst Maatschappijen zijn geen adaptieve systemen, maar evoluerende systemen. Of in een wat cryptische formulering van Luhmann: "Furs Uberleben genügt Evolution". ${ }^{519}$ Precies het omgekeerde geldt voor interactiesystemen. Interacties worden niet gekenmerkt door evolutie, maar door een dwang tot aanpassing aan de condities van hun sociale omgeving, hetgeen binnen interacties tot uiting komt in de vorm van verplichtingen, die de interactiedeelnemers met hun andere rollen elders zijn aangegaan.

517. T. Parsons(/J. Toby), The Exolutiom of Socieves, Englewood Cliffs 1977, p.11.

518. Verg. Ni Iahmann, Okologische Kommumikation, Opladen 1986, p.36.

519. Soriale Systeme, op. cit., p.645. 
Met dit alles geeft Luhmann natunrlijk ook het idee op, dat de sociale evolutie tot een steeds "betere" aanpassing van de maatschappij aan haar psychische, organische en fysische omgevingen leidt, als ware dit het verborgen 'telos' van de socialle evolutie. Men zou hooguit kunnen zeggen, dat de sociale evolutie globaal gezien tot een stijging van maatschappelijke complexiteit leidt, maar dit niet als haar doel en onder inachtneming van het empirisch constateerbare feit, dat die complexiteitsstijging beslist niet alle niveaus en deelgebieden van het sociale leven betreft. Belangrijker, met name voor de analyse van de moderne 'hoog-complexe' maatschappij, is de constatering dat de sociale evolutie eerst en vooral betrekking heeft op de ontwikkeling van verschillende vormen of schema's van differentiatie en dat dárrvan afhankelijk is welke complexiteit een maatschappij kan bereiken en in welke vorm ze die genereert. Luhmann:

'Der...wichtigste Gesichtspunkt betrifft die Form, in der das Gesellschaftssystem intern in Teilsysteme differenziert wird. Vom Schema dieser Differenzierung hăngt es $a b$, welche Komplexităt das Kommunikationssystem der Gesellschaft erreichen...kann. Die moderne Gesellschaft ist nicht einfach nur komplexer und differenzierter als altere Gesellschaftssysteme; sie ist dadurch ausgezeichnet, daß sie durch eine andere Form der Differenzierung höhere Komplexität erzeugt. ${ }^{520}$

\section{$\S 4$. Grondstructuren van de modeme, functioneel gedifferentieerde maat- schappij}

De observatie dat de eigentijdse maatschappij, vergeleken met eerdere maatschappijformaties, in sterke mate gedifferentieerd is en dat precies daarin voor een belangrijk deel ook haar "moderniteit" schuilt, was al voor de kerkvaders van de sociologie een gemeenplaats. Men hoeft slechts aan het werk van Herbert Spencer, Emile Durkheim, Ferdinand Tönnies, of Georg Simmel te denken - en wie wil kan verder teruggaan in de tijd: naar Marx, de Fysiokraten of zelfs naar de Schotse moraalfilosofen Smith en Ferguson. De naoorlogse sociologie, Parsons woorop, lijkt wat dit betreft weinig nieuws te brengen. Zeker -, Durkheims idee dat het proces van maatschappelijke differentiatie het schema van een verdergaande arbeidsdeling volgt, is opgegeven en weinig sociologen zullen vandaag de dag organistische metaforen zo ver 'oprekken' als Spencer heeft gedaan. Over de gehele linie beschouwd, leeft de sociologie echter nog steeds met (en van) het idee, dat de moderne maatschappij een uiterst

520. N. Luhmann, 'Gesellschaftsstrukturelle Bedingungen und Folgeprobleme des naturwissemschaftlich-technischen Fonschritts", opgenomen in: Sozlologische Aufklärung 4, Opladen 1987, p.52. 
complexe maatschappij is en dat die complexiteit samenhangt met een, in welke vorm dan ook, ver doorgedreven differentiatie van de maatschappij. Dat geldt voor Giddens, Habermas, Bourdieu en het lijkt evenzogoed voor Luhmann te gelden. Op één punt na.

Wat met de suggestie, dat we eigenlijk niet weel méér observeren dan de grote maatschappijtheoretici en sociologen op wiens schouders wij zitten, gemakkelijk over het hoofd wordt gezien is een, op het eerste gezicht tamelijk formeel punt, dat binnen de context van Luhmanns maatschappijtheorie echter van wezenlijk belang is. In de grond van de zaak heeft de 'klassieke' sociologie differentiatie altijd begrepen als een opsplitsing van een geheel in steeds kleinere delen, als een steeds verder gaande 'partitionering'. Dat is, we hebben het al eerder aangestipt, voor Luhmann een onacceptabele voorstelling wan zaken. De differentiatie van een sociaal systeem in subsystemen kan, precies omdat het om een autopoietisch systeem gaat, niet simpelweg bestaan uit een verdergaande interne geleding, maar moet de vorm aannemen van een herhaling van het systeem/omgeving-onderscheid binnen het differentiërende systeem. Het heeft, anders gezegd, voor Luhmann alleen maar zin om over de vorming van sociale of maatschappelijke subsystemen te spreken, wanneer we ons daarbij de vorming van autopoietische (sub)systemen binnen een autopoietisch systeem voorstellen. Aan dit, integratietheoretisch gezien, versirekkende punt, geeft Luhmann terminologisch nadruk, door niet meer de term 'differentiatie' te gebruiken, maar te spreken van 'uitdifferentiatie'("Ausdifferenzierung") wanneer het om matschappelijke differentiatieprocessen gaat. ${ }^{521}$ Ons bewust van het neologisme, zullen wij Luhmann in dit taalgebruik volgen.

De maatschappij die ons in het vervolg bijzonder zal interesseren, de 'moderne' maatschappij, ontstaat, zo kunnen we nu zeggen, door de uitdifferentiatie van functiesystemen. Dat lijkt, na aftrek van het systeemtheoretisch Bargoens, een overzichtelijke bewering. In werkelijkheid liggen er echter twee cruciale veronderstellingen an ten grondslag, waarvan de consequenties ons nog uitgebreid bezig zullen houden. De eerste veronderstelling ligt al besloten in het gebruik van de term 'functiesysteem" ('Funktionssystem'). Daarmee wil Luhmann namelijk beklemtoond zien, dat het gaat om de ontwikkeling van matschappelijke subsystemen die op een exclusieve wijze precies éen maatschappelijk functie vervullen. Substitutie of owername van functie door een ander systeem acht hij uitgesloten:

"Kein Funktionssystem kann für ein anderes einspringen, keines kann ein anderes ersetzen oder auch nur entlasten. Politik kann nicht für Wirtschaft substituiert werden, Wirtschaft nicht für

521. Verg. R. Mayntz, 'Funktionelle 'Teilsysteme in der 'Theorie sozialer Differenzierung', in RMayntz (e:a.), Differenzierung und Werselbstandigung - Zur Entwicklung gesellschafticher Teilsysteme, Frankfurt/M. 1988, p.19. 
Wissenschaft, Wissenschaft nicht für Recht oder für Religion, Religion nicht für Politik, usw. in allen denkbaren Intersystemrelationen. ${ }^{.522}$

Met de formulering "uitdifferentiatie van functiesystemen" wordt bovendien geimpliceerd, dat het gaat om een proces dat leidt tot de vorming van autonome subsystemen die niet meer in een hiërarchisch verband kunnen worden ondergebracht. Het gaat, anders gezegd, om een 'horizontale' differentiatie die uitsluit dat er één subsysteem een dominante, geprivilegieerde positie inneemt. 'Autonomie' betekent in deze overigens niet dat uitgedifferentieerde functiesystemen in geen enkele opzicht afhankelijk zouden zijn van hun omgeving, of dat ze zonder de prestaties van andere functiesystemen zouden kunnen voortbestaan. ${ }^{523}$ Zo is het rechtssysteem wel degelijk afhankelijk van scholing als een output-prestatie van het onderwijssysteem; het economisch systeem zou zonder het contract recht en zonder juridische regulering van de markt en het geldwezen niet kumnen functioneren; etc. Kortom, de autonomie die Luhmann aan functiesystemen toekent, impliceert niet, dat dergelijke systemen de controle hebben over álle materiële condities en oorzaken van hun eigen bestaan als systeem. Autonoom is een systeem voorzover het zijn afhankelijkheden en zijn onafhankelijkheden zelf kan reguleren. We herkennen natuurlijk het concept van "autopoietische autonomie", de autonomie die zelfreferentieel gesloten systemen kenmerkt:

'Funktionssysteme werden als selbstreferentielle Systeme ausdifferenziert, denn nur so läßt sich ihre gesellschaftliche Autonomie verwirklichen. ${ }^{9524}$

Al met al verschijnt daarmee de ontwikkeling van de moderne maatschappij als een proces, waarin thematisch min of meer samenhangende communicatieprocessen zichzelf (1 - hoe kan het anders) in recursieve banen beginnen te dwingen, met als uitkomst, dat op (functie)systeemspecifieke communicaties nog slechts door (functie)systeemspecifieke communicaties kan worden aangesloten. De operaties van een uitgedifferentieerd functiesysteem betrekken zich m. a. w. enkel en alleen op de uitkomsten van eigen, voor afgaande operaties. Zo consolideert bijvoorbeeld het wetenschapssysteem zich als een functiesysteem precies in die mate waarin wetenschappelijke communicatie

\$22. N. Luhmann, Okologische Kommunikation, op, cit, p.207.

523. Let wel, Luhmann mailkt een onderscheid twissen de functie van een maatschappelijk subsysteem en zijn "prestaties". Functies vervullen subsystemen ten behoeve van de maatschappij als het totaalsysteem; prestaties leveren subsystemen aan elkaar; dus aan andere maatschappelijke functiesystemen.

524. N. Luhmann, Die soziologische Beobachtung dest Rechts, Frankfurt/M, 1985, p.12 
wetenschappelijke communicatie bewerkt en uitlokt, politieke uitingen daarentegen als 'niet-aansluitbaar' terzijde worden geschoven; etc.

\section{$\$ 4.1$ Codering}

De vraag die met de these dat functiesystemen zich als zelfreferentieel gesloten systemen uitdifferentièren, op tafel ligt, is natuurlijk hoe operationele geslotenheid op het niveau van maatschappelijke subsystemen tot stand wordt gebracht. Hoe onderscheiden bijv. rechtscommunicaties zich (qua communicatiesf) van politieke, economische of religieuze communicaties en wel op een dermate exclusieve wijze, dat alle "andere", niet-juridische communicatie naar de omgeving van het rechtssysteem wordt verbannen? Voor een dergelijke geslotenheid (eigenlijk: 'zelfsluiting') biedt de thematische organisatie van communicatieprocessen geen voldoende houvast. Weliswaar blijft binnen functiesystemen de structurerende functie van thema"s volop behouden, maar thema's kunnen niet zichzelf op een eenduidige wijze indelen als specifiek voor; of exclusief behorend tot, én bepaald maatschappelijk subsysteem. Het eten van aardappels kan zowel binnen een gezin tot discussie leiden, bepaalde sectoren van de economie zorgen bereiden, als een kunstzinnig thema voorstellen.

Luhmanns antwoord op de vraag hoe de zelfreferentiële sluiting van functiesystemen tot stand komt, luidt: eerst en vooral door codering:

"Codierung ist die technisch wirksamste und folgenreichste Form der Ausdifferenzierung von Funktionssystemen. [-] Meine These ist, daß Codes ....im Laufe der gesellschaftlichen Evolution entstehen und daß, wenn sie in Operation gesetzt werden, die Tendenz besteht entsprechende Systeme auszudifferenzieren'. ${ }^{525}$

In afwijking van het alledaagse, met 'translatie' of 'vertaling' geassocieerde gebruik van woorden als 'code" en 'codering', hanteert Luhmann de term 'code' als aanduiding voor binaire schema's die worden gevormd door een positieve en een dearop betrokken negatieve 'waarde'. Voorbeelden van zulke binaire schema's zijn waar/onwaar, betalen/niet-betalen, transcendent/immanent, of recht/onrecht. Historisch gezien - 'im Laufe der gesellschaftliche Evolution" - treedt de maratschappelijke relevantie en functie van dergelijke schema's voor het eerst aan het licht in, en door de ontwikkeling van symbolisch gegeneraliseerde media van communicatie. Zo gaat Luhmann er bijvoorbeeld vanuit, dat de (primaire) codle van het politiek systeem, gevormd door het binaire schema macht/onmacht, ontstaan is rond het medium '(politieke) macht' en de politiek-organisatorische inbedding daarvan in een 'staat'. Het medium 
"macht", zo merkten we in de vorige paragraaf al op, dient ter uitwoering van collectief bindende beslissingen. Wie in deze wel en wie niet beslissingsbevoegd is, hangt af van de vraag, wie welk staatsambt bekleedt. Deze toespitsing van het medium macht op beslissingen en de koppeling daarvan aan een hiërarchie van staatsambten treedt naar buiten in de vorm van een differentie: het gaat om het bezetten of niet-bezetten van een machtspositie, om meer of minder macht, uiteindelijk om macht/onmacht. "Die Stellenstruktur des Staates', zo merkt Luhmann op, 'dient als Code der Politik, aber als einheitlicher Code der gesammien Politik" ${ }^{526}$

Dergelijke eerste, zich rond communicatiemedia ontwikkelende vormen van binaire schematisering treffen we in alle hoogculturen aan. Luhmann zelf wijst expliciet op processen van 'proto-codering' in de Griekse oudheid 'und zwar in Form einer deutlichen Differenzierung von logisch-epistemologischen, politisch-ethischen, freundschaftsbezogene und okonomische Semantiken'. ${ }^{27}$ De uitdrukking 'proto-codering' geeft echter al aan, dat we hier nog met vroege vormen van codering te maken hebben en niet met die ontwikkelde, van communicatiemedia losgekoppelde vorm die in de modeme tijd 'drager' van het proces van functionele differentiatie wordt en die het dan mogelijk maakt, dat functiesystemen uitdifferentiëren die niet over een 'eigen' medium beschikken, zoals bijv. de gezondheidszorg en het rechtssysteem ${ }^{528}$

Van 'codering' in de eigenlijke, of misschien moeten we zeggen: in de "moderne" zin van het woord is bij Luhmann pas sprake, wanneer een binair schema als 'Leitdifferenz' van een bepaald bereik van communicatie functioneert, d.w.z. als het onderscheid dat an alle verdergaande informatieverwerking binnen het sub- of functiesysteem ten grondslag ligt - als 'the difference that makes all the difference'. In een wat langere formulering van Luhmann:

'Differenzen sind Informationspotentiale, sind Möglichkeiten uber etwas als 'dies und nichts anderes' zu kommunizieren, und Informationsverarbeitung kann dann als Erzeugung von

526. N. Luthmann, Okologgische Kommunikation, op.cilt, p.170.

\$27. Idem, p.87.

528. Verg. N. Luhmann, Die Wirtschof der Gesellschaft, Frankfurt/M. 1988, p.304.

Jan Künzler heeft er op gewezen dat het cade begrip bij Luhmann zelf een ontwikkeling heeft doorgemaakt. Begreep Luhmann 'codering” ganwankelijk nog sterk vanuit het perspectief van zijn mediatheorie, later ontwikkelt hij; in het kielzog van zijn 'tutopoietische Wende', een min of meer zelfstandige coderingstheorie - zelfstandig op zijn minst in die zin, dat coderingsverschijnselen nu onafhankelijk van de mediatisering van een maatschappelijk deelbereik worden geanalyseerd. Het verschil is im artikelen uitgednukt het verschil tussen het opstel 'Einfthrende Bemerkungen zu iner Theorie symbolisch generalisierter Kommunikationsmedien' uit 1975 (Soziologische Aufklärung' 2) en het artikel "Distinctions Directrices". Uber Codierung von. Semantieken und Systemen" uit 1987 (Soziologische Aufklärwng 4). (Kunzlers eerder negatieve inschatting van deze ontwikkeling is te vinden op $\mathrm{p}$. 88 e.v. van zijn Medien und Gesellsehaft (Stuttgant 1989)) 
Differenzen durch Differenzen begriffen werden...In jedem Falle entsteht Information erst durch eine Unterscheidung, die ad hoc gewählt, aber auch, wie die Unterscheidung von wahr und unwahr, einem Gesamtbereich der Informationsverarbeitung zugrundegelegt werden kann. Wenn dies der Fall ist, wollen wir von Leitdifferenzen sprechen. ${ }^{529}$

Willke spreekt in dit verband van een 'Engfuhrung', een 'kanalisering' van de betekenisstroom van communicaties: binnen een gecodeerd systeem heeft 'iets" (een gebeurtenis, een handeling, etc.) uiteindelijk slechts betekenis in termen van de positieve of de negatieve waarde van de code en ook alleen door een betrekking op een van beide codewaarden kunnen mededelingen binnen het systeen over dat 'iets" informeren en aansluitingswaarde krijgen. ${ }^{530} \mathrm{Zo}$ geldt, volgens Luhmann, dat het moderne wetenschapssysteem alle gecommuniceerde informatie behandelt en verwerkt in het perspectief van de vaststelling 'waar/onwaar' als de woor het wetensehapssysteem specifieke binaire code. Voor het rechtssysteem, gecodeerd door het schema recht/onrecht, geldt daarentegen dat het zich telkens oriënteert aan de vraag "is iets "recht" (op grond van het recht) of is het "onrecht"?'. De elementaire operaties van het gecodeerde rechtssysteem onderscheiden zich m.a.w. als 'rechtscommunicaties" van alle andere mogelijke communicaties door hun oriëntatie op de differentie recht/onrecht als fundamentele premisse van de verwerking en verdere behandeling van eerdere mededelingen.

Als "Leitdifferenz", als "abstrakte und universell verwendbare Unterscheidungen' hebben codes onvermijdelijk een totaliserend effect. ${ }^{531}$ Zo geldt voor het rechtssysteem dat alles wat zich voordoet, alles waarover gesproken kan worden en waaraan kan worden gerefereerd, zich voordoet als iets dat een juridische betekenis of status heeft. Door codering universaliseert het rechtssysteem m.a.w. zijn relevantiebereik: Alles kan juridisch relevant worden - huwelijksperikelen, doping, elektriciteit, etc. En wat niet als zodanig kan worden geobserveerd kan simpelweg niet worden geobserveerd, kan niet op het 'beeldscherm' van het rechtssysteem verschijnen. Of on deze 'idiosyncrasie' van functiesystemen iets welwillender te formuleren:

'Ein codiertes System ist... in gewisser Weise sich selbst ausgeliefert, und das heißt for allem. daß es keine Grunde finden kann, seine Code nicht anzuwenden - ein politisch attraktives Thema nicht aufzugreifen, eine Krankheit nicht zu heilen, eine

529. N. Luhmiann, "Distinotions directrices", Sozlologische Awhlarung 4, op.cit, p.15-16.

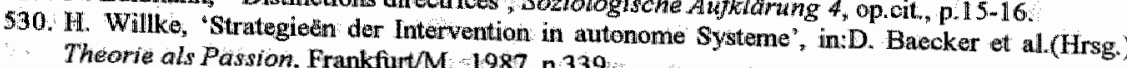

531. N: Luhmann, Soziologie des Risikos, Berlin 1991, p.88. Vergelijk ook: Okologische
Kommunikation, op.cit, p.78 -79 
Rechtsfrage, wenn sie schon als solche auftaucht nicht im Hinblick auf Recht und Unrecht zu durchleuchten. ${ }^{5532}$

Natuurlijk kunnen verschillende functiesystemen zich richten op gebeurtenissen die voor een derde observator identiek zijn, een en dezelfde gebeurtenis vormen, bijvoorbeeld een vliegtuigongeluk. Het neerstorten van een vliegtuig heeft echter voor het rechtssysteem een andere betekenis en andere consequenties, dan voor het wetenschapssysteem, voor de economie of voor een bepaald gezin. Voor het recht gaat het niet om een persoonlijke tragedie, maar bijvoorbeeld on de vraag of het vliegtuig had mogen opstijgen, of de piloot gerechtigd was om te viliegen, wie in deze onrechtmatig gehandeld heeft en wat de eventuele rechtsgevolgen (smartegeld, erfenis, etc.) zijn. Voor het economisch systeem gaat het daarentegen om een winst/werlies-rekening, om de effecten ervan op de betalingsbalans van een bepaalde vervoersmaatschappij, voor het wetenschapssysteem eerder om de vaststelling van meteorologische, metallurchische, radiografische, etc. (on)waarheden. 'Unterschiedliche Codes', zo vat Luhmann dit samen, "fuhren zu einer unterschiedlichen Qualifizierung von Informationen weil sie den Informationswert der Information auf unterschiedliche Selektionshorizonte beziehen: ${ }^{533}$

Het zou nu kunnen toeschijnen, dat het hele concept van codering weinig meer is dan een ingewikkelde omweg om bij een trivialiteit uit te komen, namelijk dat de politiek politiek belangrijk vindt, het wetenschapssysteem geinteresseerd is in wetenschappelijke vragen, de kunstwereld door kunst geboeid wordt, etc. ${ }^{534}$ Het punt is echter dat codes slechts als basis van functionele differentiatie kunnen fungeren - en zoals we gezien hebben gèldt voor Luhmann, dat codering de meest effectieve en effectvolle modus van functionele differentiatie voorstelt - indien ze aan bepaalde voorwaarden voldoen.

$\mathrm{Om}$ te beginnen moeten codes tegemoet komen aan de eis van strikte tweewaardigheid, d.w.z.: negatie van de positieve waarde van de code levert automatisch de negatieve waarde van de code op en vice versa. ${ }^{\text {5.9 }}$ Bijvoorbeeld: Niet-recht is onrecht en niet-onrecht is recht. Een derde waarde is uitgesloten. In dit perspectief kan het modeme recht bij het processeren van informatie dus niet kiezen tussen bijv. recht/onrecht/politiek opportunn (het zij dan om de prijs van een regressieve dedifferentiatie, van een ontmanteling van het rechtssysteem als autonoom functiesysteem zoals in de $20 \mathrm{e}$ eeuw onder totalitaire regines telkens weer is gebeurd). Deze strikte binariteit behelst een extreme redactie

532. N. Luhmann, Soziologie des Risikos, Berlijn 1991, p.89.

533. N. Lulmann, "Distinctions directrices", op.eit., p.21

534. Men zou op dit verwijt natuurlijk kunnen reageren met de opmerking, dat het juist de vaag is hoe deze 'trivialiteit' heeft kunnen ontstaan, er en passant op wijzend dat het ten tijde van Galileî nog geenszins triviaal was dat de wetenschap zich slechts voor wetenschappelijks vragen diende te interesseren.

535. Luhmann spreekt in deze van 'Technizierung' en van de 'Technizität' van een code. 
van complexiteit, met als voordeel tijdsbesparing door een vergemakkelijking van de overgang tussen de codewaarden - als het niet onrecht is, weet men wat het wel is. En de vraag wordt dan, hoe de nooit uit te sluiten "uitgesloten derde" zich alsnog binnen het systeem kenbaar maakt.

Een tweede voorwaarde van matschappelijke differentiatie op basis van codes is, dat ze als semantische doubletten voldoende distantie hebben t.o.v. alledaagse meningen en reacties, in het bijzonder to.v. de moraal en ethische semantieken. Voorondersteld is m. a.w. dat een gecodeerd functiesysteem zelf de controle heeft over de keuze/negatie van de codewaarden en zich daarbij niet laat sturen door bijvoorbeeld een moreel geinspireerde preferentie voor (normaal gesproken) de positieve codewaarde:

'Die Ausdifferenzierung binär codierter Funktionssysteme eliminiert für sie systemexterne Entscheidungskriterien, und das gilt auch angesichts von aktuellen Versuchen, solche Kriterien unter dem Pseudonym "Ethik" erneut ins Gespräch zu bringen. ${ }^{536}$

Zo kon het funktiesysteem 'wetenschap' zich slechts ontwikkelen onder de voorwaarde dat het vaststellen van waarheid niet per sé achtenswaardiger is dan het vaststellen van onwaarheid - slechts als 'hypothesenwetenschap'! Luhmann: 'Die Funktionssysteme codieren sich auf einer Ebene höherer Amoralität. ${ }^{538}$

Deze bevrijding uit de alledaagsheid en de moraal betekent, om ons bij het rechtssysteem te houden, onder meer dat het onderscheid recht/onrecht niet moet worden geïnterpreteerd in termen van rechtvaardigheid en onrechtvaardigheid. Het gaat in het recht niet om de vaststelling van (on)rechtvaardigheid - waar het de leek/buitenstaander heel wel om kan gaan - maar orn wat volgens het recht recht is (of onrecht). En natuurlijk betekent de ontmoralisering van het recht ook, dat de vaststelling 'onrecht' niet automatisch een morele veroordeling inhoudt Men kan een rechtszaak aanspannen met het risico deze te verliezen, maar zonder dat het verlies noodzakelijk met zich meebrengt dat men als persoon in achting daalt.

Een middels codering tot stand gebrachte distantie tussen een systeem en zijn 'buitenwereld', impliceert nog niet, dat er tussen de positieve en de negatieve waarde van een code een zuivere symmetrie moet bestaan. In de praktijk is het tenslotte handiger om in je recht te staan. En Thomas Sprat dicteert: 'To the Royal Society it will be at any time almost as acceptable to be confuted, as to discover'. 'Almost' $\mid$ - een niet te negeren preferentie, zoals Luhmann opmerkt,

536. N. Luhmann, Soziologie des Risikos; Berlijn 1991 , p. 89

537. Hetgeen voior een traditie die zichzelf begreep alls schathewaarder van een overgeleverd corpus a an gegarandecrdo kennis en zijn voornaamste activiteit begreep als de systematisering daarvan, an hoogst onwaarschijnlijke (en dlan ook omstreden) gedachte was:

538. "Distinotions directrices" "op.cit., p.25 
voor de vaststelling van waarheden. Dergelijke asymmetrische verdelingen van preferenties over de code-waarden hebben typisch de functie om op de code betrelkking hebbende beslissingsproblemen te versoepelen, i.h.b. patstellingen te doorbreken. Als schuld niet bewezen kan worden, wordt 'onschuldig' aangenomen (ook al kan de onschuld evenmin worden bewezen). Zuiver symmetrische differenties zijn, zo Luhmann, te arm aan informatie, geven daarmee te weinig richting aan de op hen gebaseerde operaties. ${ }^{519}$ Dat normaliter de positieve codewaarde geprefereerd wordt, hangt samen met de hogere aansluitingswaarde van 'positieve' selecties binnen het systeem en dus met zijn reproductiemogelijkheden (waar de duivel natuurlijk een andere mening over kan hebben). Met ware uitspraken kan men meer aanvangen dan met onware; recht biedt meer voortzettingsmogelijkheden dan onrecht; wie in de regering zit beschikt over meer politieke mogelijkheden, dan een lid van de oppositie; etc.

\section{$\$ 4.2$ Programmering}

We hebben reeds gewezen op de totaliserende werking van codes: door codering ontstaan 'Weltkonstruktionen mit Universalitätsanspruch'. Tegelijkertijd fungeren codes als duplicatieregels: Alles kan recht of onrecht zijn, waar of onwaar zijn, bijdragen aan machtsuitbreiding of deze in de weg staan, etc.

'Die Realităt die nach Maßgabe des Codes behandelt wird ist nur einmal vorhanden. Sie wird gleichwohl fiktief dupliziert, so daß jede Bewertung sich ihr Komplement suchen und sich in ihrem Gegenteil spiegeln kann."540

Wélke codewaarde wordt toegekend aan gebeurtenissen of standen van zaken, dat bepaalt het systeem zelf. De gebeurtenissen en standen van zaken die in de vorm van informatie binnen een funktiesysteem circuleren, zijn niet door hun 'natuur', of een of andere 'essentie' op éen bepaalde codewaarde vastgelegd, noch door morele apriori's. Het doden van een medemens is niet uit de arard der zaak zelf onrechtmatig en wordt in oorlogssituaties zelfs aangemoedigd; een bewering is voor het moderne wetenschapssysteem niet (on)waar omdat die op grond van ethische, religieuze, of esthetische overtuigingen (on)waar moet zijn. De wereld is ma:w. Wat ze is, maar door codering van communicatie over de wereld kan alles als contingent worden behandeld - het is mogelijk dat een medemens doden onrecht is, maar niet noodzakelijk. Binaire codering "ver-

539. werg. 0.a. "Distinotions directrices", op.cit., p. 17 e.v.

540. N. Luhmann, Oekologische Kommunikation, op.cit, p.77 
absoluteert' contingentie, zoals Luhmann het uitdrukt - 'Alles was ist oder nicht ist, erscheint danach als weder notwendig noch unmöglich" ${ }^{541}$

De constitutie van contingentie door codering is tegelijkertijd de constitutie van keuzevrijheid voor het systeem. De keerzijde ervan is, dat gecodeerde systemen zichzelf opzadelen met een verhoogde sellectiedruk. Zo reproduceert het rechtssysteem zich als een opeenvolging van rechtscommunicaties onder de voortdurende dwang (uiteindelijk) te moeten beslissen of iets recht dan wel onrecht is, zonder daarbij te kunnen rekenen op externe, reeds buiten het systeem beschikbare selectiecriteria. De eigen code biedt in deze evenmin soelaas. Als code van het rechtssysteem bevat de differentie recht/onrecht geen aanwijzing, dat het (per definitie? altijd?) om 'recht' gaat, net zo min als "waarheid' een criterium van zichzelf is. Of om het van een andere zijde te belichten: functiesystemen mogen weliswaar preferentie-asymmetrieen ontwikkelen, de positieve code is niet per definitie en in alle gevallen te prefereren. Het vaststellen van onrecht/onwaarheid/onmacht/etc. kan onder bepaalde omstandigheden net zo belangrijk zijn als de vaststelling van het tegendeel. ${ }^{542}$ Uitdifferentiatie op basis van codering, zo mag men hieruit concluderen, veronderstelt de ontwikkeling van een set regels en criteria op basis waarvan een systeem beslissingen over de toewijzing van codewaarden kan sturen (en dit als antwoord op een complexiteitsprobleem dat door codering zelf in het leven wordt geroepen). De uitdifferentiatie van een funktiesysteem kan, anders geformuleerd, slechts lukken op voorwaarde dat het systeem zijn keuzegedrag vis-ávis de twee codewaarden weet te "programmeren". Zo fungeren in het wetenschapssysteem methoden en theorieen als programmals, als aanwijzingen en criteria voor het vaststellen van (on)waarheid. Het rechtssysteem wordt in Luhmanns visie daarentegen geprogrammeerd door "Verfassungen, Gesetze, Verordnungen, Gerichtsentscheidungen mit offizieller Präjudizwirkung und vor allem: Verträge; kurz: das gesamte positive Recht'.

\section{$\$ 4.3$ Codering en programmering}

Benadrukt dient te worden dat code en programma elkaars noodzakelijke complement vormen. Gezamenlijk (en slechts gezamenlijk) maken ze de reproduktie van een functiesysteem mogelijk en wel als een systeem dat gesloten is en op basis van deze geslotenheid open is. Door codering ontstaat operationele geslotenheid. Zoals we weten, houdt die 'geslotenheid' niets anders in, dan dat de gebeurtenissen die de (re/productieve) elementen van een systeem vormen, onophoudelijk naar elementen van datzelfde systeem verwijzen en dit als voorwaarde van hun constitutie tot element van dat systeem. Zo geldt voor

541. 'Distinctions directrices', op.cit., p.14. Verg ook N. Luhmann. "Die Codierung des Rechtssystems', in: Rechtstheorie 17 (1986), p. 1771-172.

542. verg. o.a. 'Distinctions directrices', op cit., p. 15 e.v. 
sociale systemen, dat de communicaties waaruit ze bestaan voortdurend naar andere communicaties verwijzen en dat ze zich ook alleen daardoor als communicaties kunnen manifesteren. Middels codering van sociale systemen wordt nu bereikt dat alleen gekwalificeerde communicaties op elkaar kunnen volgen en de informationele 'brandstof' voor nieuwe, systeemtypische communicaties vormen. Die kwalificatie ontlenen communicaties aan de systeemspecifieke code die als 'Leitdifferenz' de selectiehorizon opent én afgrenst, waarbinnen mededelingen eerst als bijzondere selecties, d.w.z. als 'informaties' verschijnen, waarop volgende mededelingen weer kunnen aansluiten. In de vorige paragraaf hebben we over de ontwikkeling van functiesystemen gesproken in termen van een 'recontextualisering' van communicatieprocessen en dit als reactie op een, door de boekdrukkunst toegenomen anonimisering en globalisering van de maatschappij. We weten nu, dat deze recontextualisering van de maatschappelijke communicatie volgens Luhmann eerst en vooral door codering tot stand wordt gebracht. Misschien wordt door de term 'recontextualisering' alleen beeldender een typisch effect van codering naar voren gebracht, namelijk dat qua teken- of woordgebruik dezelfde mededelingen in verschillende functiesystemen verschillende informaties bevatten, dat - om de zaak op de spits te drijven - functiesystemen dus welhaast systematisch doof voor elkaar moeten zijn, elkaar niet kunnen verstaan.

Terwijl functiesystemen zich sluiten door codering, 'openen' ze zichzelf door programmering. Via programmals, i.e. regels en criteria die vastleggen wat een correcte manier van beslissen is inzake de toewijzing van codewaardes, maakt het systeem zichzelf gevoelig voor systeemexterne factoren - 'und sei es tiber ein störendes Rauschen, das nur durch eine Modifikation der Programme zu beheben ist". Zo leggen de programma's van het rechtssysteem (wetter, jurisprudentie e.d.) bijvoorbeeld vast welke, aan het recht als zodanig externe omstandigheden en factoren bij de behandeling van een concrete zaak moeten worden betrokken en op welke wijze deze in de uiteindelijke beslissing dienen te worden verdisconteerd - "wie schoot er/was de dader toerekeningsvatbaar/was er sprake van woorbedachte rade/etc?".

Maar niet alleen reguleren de programma's van een functiesysteem welke informatie omtrent externe factoren en gebeurtenissen intern relevantie verkrijgt en als zodanig ook verdisconteerd moet worden; via programmering kunnen bovendien de opties en belangen van andere functiesystemen binnendringen. Zo kunnen zaken als 'politieke opportuniteit', 'economische rentabiliteit', 'sociale rust', etc., opties dus die door de binaire code van het rechtssysteem als basale keuzemogelijkheden worden uitgesloten, via wetgeving, ministeriële richtlijnen, rechters-recht, etc. alsnog binnen het rechtssysteem tot gelding worden gebracht. De 'uitgesloten derde' keert via programmering terug - maar natuurlijk weer onder de voorwaarden van het systeem zelf, in vormen die met de systeemintern ontwikkelde structuren van informatieverwerking compatibel zijn. 
Programma's kunnen bovendien veranderen. Dit vermogen tot verandering komt programma's toe, volgens Luhmann, "weil sie nur Gesichtspunkten des Richtigen anbieten und durch keinerlei absolut Richtiges gedeckt sein können". Men zou dit ook zo kunnen formuleren, dat functiesystemen op het niveau van hun programma's kunnen 'leren'. Alleen op dit niveau! - de code van een functiesysteem kan niet veranderen. Een andere, of veranderde code levert per definitie een ander functiesysteem op. Bỉnnen Luhmanns concept van functionele differentiatie is m.a.w. de identiteit van een functiesysteem gekoppeld aan zijn code en niet aan zijn functie. De uitdifferentiatie van een functiesysteem komt in Luhmanns perspectief uberhaupt niet tot stand door een fixatie op zijn functie, maar door codering. Een functiesysteem vervult zijn functie simpelweg door zich als een gecodeerd communicatieproces te reproduceren - het rechtssysteem neemt zijn functie - "die Absicherung von Erwartungen gegen eine möglicherweise anders ausfallende Zukunft ${ }^{543}$ waar, door rechtscommunicatie op rechtscommunicatie te laten volgen. Het hoeft zijn functie niet te 'bedoelen'. Weliswaar ontwikkelen functiesystemen bijna dwangmatig zelfbeschrijvingen, reflexieve semantieken die aan het systeem in kwestie al snel specifieke prestaties en een algemene mantschappelijke functie toeschrijven, zij het alleen al ter legitimatie van de eigen

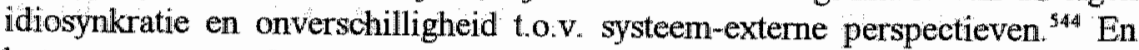
het mag eventueel zo zijn, dat een dergelijke 'reflexive Überhohung' van de eigen code en programma's binnen een functiesysteem de vorm van een waardensemantiek aanneemt, waarmee het systeem zichzelf verplicht tot het nastreven van bepaalde doelen; de sequentie "functie $=$ doel $=$ waarde" is in Luhmanns ogen echter een al te simplistische voorstelling van zaken, als het gaat om de uitdifferentiatie van functiesystemen:

'Funktionen werden systemintern nicht einfach durch Werte abgebildet, sie werden vielmehr durch zweiwertige, technisierte, binäre Codes bedient, die einen Kontingenzraum offenhalten in dem zwangsläufig alles zur Selektion wird und dann erst zur Wertbildung Anlaß gibt. So tritt denn auch die Semantik der Werte in ihrer heutigen Form erst in der Mitte des 19. Jahrhunderts auf, längst nachden die die grofen Funktionscodes ihre Systeme unter Kontingenzdruck gesetzt haben. ${ }^{* 545}$

543. N. Luhmann, "Positivitat als Selbstbestimmtheit des Rechts", in: Rechtstheorie 19 (1988), p. 25. lets uitgebreider geformuleerd: de fiunctie van het rechtssysteem betreft de formulering en stabilisering van gegeneraliseerde, conflictbestendige (en dus 'normitieve') verwachtingen. Het rechtssysteem dient dus niet ter vermijding wan comflicten! De uitdifferentatie van het rechtssysteem leidt eender tot een vergroting van de kansen op conflicten. 544. Verg. U. Schimank, "Gesellschaftliche Teilsysteme als Akteurfiktionen', in: KZJSS 40 (1988),
p.628 e.v.

545. 'Distinctions directrices', op.cit, p. 20 . 


\section{§ 5. Ter afsluiting: de sociologische beschrijving van zelfbeschrijuing}

We zullen in het volgende hoofdstuk nader bezien wat Luhnanns algemene maatschappijtheorie oplevert, wanneer deze wordt benut als het raamwerk voor een diagnose van de moderne samenleving. Dat zal tevens de aanleiding vormen voor een kritische evaluatie die, terugblikkend, ook de centrale uitgangspuntem van dit hoofdstuk zal omvatten. In plaats van nu een soort 'tussentijdse' conclusie aan te bieden, willen we de ruimte die daarmee wordt bespaard, gebruiken, om 'ter afsluiting' van het voorafgaande op een interessante 'toepassing' van Luhmanns maatschappijtheorie te wijzen. Die toepassing betreft een typisch gezichtspunt, zo niet een 'techniek' voor de sociologische analyse van al die zelfbeschrijvingen of 'reflexietheorieën' die binnen functiesystemen worden ontwikkeld met het oog op de vaststelling/fundering van hun eigen eenheid en identiteit. We blijven trouw aan het systeem dat ons telkens als "woorbeeldig voorbeeld' heeft gediend, het rechtssysteem, en zullen. ons in het nu volgende dan ook bepalen tot het recht en zijn zelfbeschrijving. ${ }^{546}$ Laten we om te beginnen vaststellen, dat binnen het rechtssysteem uiteenlopende beschrijvingen van het recht kunnen worden aangetroffen, die we, gegeven de redelijke mate van hun systematisering, als rechtswetenschappelijke theorieen zouden kunnen aanduiden. Te denken valt daarbij aan de rechtsdogmatiek, aan heuristieken van rechtsvinding, an rechtsrhetoriek, aan een algemene begripsleer, ete. Dergelijke, binnen de context van de alledaagse rechtspraktijk en het juridisch onderwijs ontwikkelde en "vertekste" produkten van juridische zelfobservatie, onderscheiden zich van die zelfbeschrijvingen die de eenheid en identiteit van het rechtssysteem binnen het rechtssysteem reflecteren en die traditioneel onder de noemer 'rechtsfilosofie' werden opgeborgen, maar vandaag de dag ook wel met de term (algemene) 'rechtstheorie' worden aangeduid. Bij deze rechtstheoretische zelfbeschrijvingen gaat het niet om bijdragen aan de consistentie van de juridische begripssystematiek, noch om een discursieve afweging van de veralgemeniseerbaarheid van rechtsprincipes of beslissingsregels, maar, zoals Luhmann het formuleert ${ }_{x}$ om 'Darstellung von Einheit, Funktion, Autonomic und auch Indifferenz des Rechtssystems'. ${ }^{47}$

Een tweede vaststelling - - de sociologische observatie van het rechtssysteem, 'rechtssociologie' kortom, moet worden onderscheiden van de zelfbeschrijvingen die we in het vervolg als 'rechtstheorie(ên)' zullen aanduiden. Een rechtssociologie levert een externe beschrijving van het

546. Zie voor een analyse van het reflexiviteitsprobleem binnen de wetenschap en van de manier waarop dit door toedoen van sociaal constnutivisten als Ashmore en Woolgar tot een controverse is opgeblazen: T.Blom, "Een constructivistische radicalisering van het social constructivisme', in: Kermis en Methode 19 (1995) , p.160-181.

5.7. N. Luhmann, Das Recht der Gesellschaft, GrankfurtM. 1993, p.499. 
rechtssysteem, zich daarbij oriënterend aan de code waar/onwaar en aan de methoden en theorieen van de sociologie als een wetenschappelijke discipline. Dit "externe' karakter van de rechtssociologie wordt in eerste instantie betaald met een "Versagen vor der Komplexität und der Intransparanz des Rechts". Daar staat een belangrijk voordeel tegenover. Als een vorm van zelfbeschrijving vervult de rechtstheorie namelijk een functie binnen en voor het rechtssysteem en committeert zich daarmee aan de code en de programma's van het recht. Luhmann:

"Selbstbeschreibungen beachten Beschränkungen die sich aus ihrer Zugehörigkeit zu dem beschriebenen System ergeben. Eine Selbstbeschreibung des Rechtssystems kann zum Beispiel nicht bestreiten, daß 3 das System berechtigt ist, zwischen Recht und Unrecht zu unterscheiden oder daß man sich auf "geltende" Normen einzulassen hat. ${ }^{5548}$

$\mathrm{Nu}$ moet de rechtssociologie weliswaar iedere aanspraak op een juridisch 'beter-weten' opgeven, 'sie kann sich aber auch von operativen Verantwortungen im Rechtssystem, von Systemtreue, von Hilfsangeboten und Nützlichkeiten aller Art entlasten'. ${ }^{549}$ De rechtssociologie heeft, om het zo uit te drukken, haar handen vrij. Ze kan het zich permitteren, posities in te nemen die voor de rechtstheorie op grond van haar verankering en functie binnen het rechtssysteem onbereikbaar zijn. Vanuit die externe posities kan de rechtssociologie dan wel niet meer "zien' dan de rechtstheorie, maar wel andere zaken. Zo kan de rechtssocioloog zien, dat de rechtstheorie 'leeft' van een paradox en wel door deze voortdurend te verbergen, door deze niet te zien.

$\mathrm{Nu}$ hebben we eerder al uiteengezet hoe, volgens Luhmann, zelfobservatie en beschrijving onvermijdelijk paradoxen produceert (zie hoofdstuk 1 \& $\$$.). Die paradoxaliteit kan op verschillende manieren worden beschreven, bijwoorbeeld in termen van een systeem, dat om zichzelf te kunnen identificeren het systeem/omgeving-onderscheid moet hanteren, daarmee de ongeving, als datgene wat principieel niet tot het systeem behoort, dat is buitengesloten, een plaats binnen het systeem gevend - als 'relevante niet-relevantie' bemuttend. De tautologe en paradoxale effecten van zelfobservatie komen, algemener gesproken, voort uit een "re-entry", uit de herinvoering van een onderscheid binnen datzelfde onderscheid.

Binnen functiesystemen neemt deze re-entry de bijzondere vorm aan van een toepassing van de systeernspecifieke code op zichzelf. Begrijpen we, om naar ons voorbeeld terug te keren, de rechtstheorie als een poging de eenheid en identiteit van het rechtssysteem te beschrijven en dit mede ter legitimatie van de

548. Idem, p. 498.

549. N. Luhmann, Die soziologische Beobachtung des Rechns, Frankfurt/M. 1985, p.19. 
'onverschilligheid' van het recht t.o.v. andere 'Leitdifferenzen' en functionele perspectieven, dan begrijpen we, met Luhmann, de rechtstheorie als een poging om op een of andere manier een grond te leveren voor het bestaan van het rechtssysteem als een bijzonder functiesysteem. In die zin kunnen we zeggen dat het bij rechtsfilosofie en rechtstheorie om een 'fundering' van het recht gaat. Op geleide van Luhmann moeten we echter tevens aannemen, dat het rechtssysteem, nog voór alle zelfbeschrijving, zijn eenheid realiseert, zichzelf 'fundeert', door zichzelf als een gecodeerde communicatiesamenhang te reproduceren. De 'bestaansgrond of "reden' van het recht is simpelweg zijn code - en niet, zoals we eerder al opmerkten, zijn functie. Nu kan de rechtstheorie natuurlijk de vraag naar de grond van de code recht/onrecht willen stellen, maar als een interne beschrijving van het rechtssysteem kan ze dat slechts, op basis van. diezelfde code, d.w.z. als een zelfbeschrijving die zich wederom oriënteert aan de differentie recht/onrecht als de 'Leitdifferenz' van het rechtssysteem. Voor de rechtstheorie moet de funderingsvraag m.a.w. uitlepen op de vraag of de invoering en het gebruik van de code recht/onrecht wel 'recht' (of "onrecht') is. In de Talmoed wordt verhaald van een rabbi die zijn studenten een vraag voorlegde en toen enkelen van hen reageerden, complimenteerde hij ze met hun antwoord. Een paar andere studenten leek het gegeven antwoord echter niet correct en opperden een alternatieve oplossing. Ook zij kregen van de rabbi gelijk. Toen daarop weer anderen protesterend de wraag stelden hoe beide antwoorden correct konden zijn, gegeven het feit dat het om tegengestelde standpunten ging, kregen ook zij gelijk. Die 'derde vraag' keert binnen de context van de zelfbeschrijving van het recht weer terug en wel als de vraag "how can we rightly or wrongly differentiate the right and the wrong. .50 Eigenlijk wordt deze re-entry van de code van het recht binnen zichzelf al geimpliceerd door het totaliserende karakter van codering, door de universaliteitsaanspraak die er vanuit gaat en die in principe niets buitensluit, ook niet zichzelf. Voor de rechtstheorie zou dit echter betekenen, dat ze ofwel in tautologieen als 'recht want recht', of 'onrecht want onrecht' vervalt, ofwel verstrikt raakt in paradoxen van het type 'recht want onrecht'. of 'onrecht want recht". Beide, zowel tautologie als paradox, moet de zelfobservatie van het recht voor zichzelf onzichtbaar maken - tautologieèn leveren de zelfobservatie uit aan zuivere willekeur; aan de toevalligheid van een aanvangsconditie; paradoxen blokkeren het proces van zelfobservatie, omdat er geen aanwijzing kan worden gevonden voor het kiezen (of negeren) van één zijde van de differentie. Liegt de Kretenzer die beweert dat alle Kretenzers liegen, of is die bewering onwaar?? Luhmann:

550. N. Luhmann, "The Third Question: The Creative Use of Paradoxes in Law and Legal History", in: Jourmal of Law and Society 15 (1988), pit 154. 
'Obwohl die Selbstreferenz des Rechtssystems, wenn sie beobachtet und beschrieben wird, darauf hinausläuft, darf das System selbst weder Tautologie noch Paradoxie zulassen. Weder Beliebigkeit noch Blockierung der Operationen sind im System zulässige Strukturen. Im System muß deshalb ein Diskurs über das System gefuhrt werden, der einen heimlichen Bezug zu Tautologie und Paradoxie hat, zugleich diesen Bezug aber verschweigt und uber Sinnsetzungen die Ergiebigkeit der Operationen garantiert.

Luhmanns idee is nu, dat de paradoxen (en tautologieën) die uit de toepassing van de code op de code voortkomen, weliswaar voor het recht verborgen moeten blijven terwille van een ongestoorde, voor het rechtssysteem informatieve zelfbeschrijving, maar niet voor een rechtssocioloog. De rechtssociologie kan de tautologie en paradoxie die het heimelijk fundament van de rechtstheorie vormen, gerust observeren omdat het niet háár tautologie is en zij als externe observator niet gedwongen is terwille van haar eigen voortzetting de paradoxie door een onmogelijke keuze te beslechten. De claim is vervolgens, dat het inzicht in de tautologe/paradoxale grondstructuur van de rechtstheorie én in het gegeven, dat deze voor de zelfbeschrijving van het recht verborgen moet blijven, een aanknopingspunt biedt voor een idee-historische reconstructie van de ontwikkeling van de rechtsfilosofie en de huidige rechtstheoretische debatten. De geschiedenis van de rechtsfilosofische reflexie laat zich lezen "als Geschichte der Bemuhungen um Enttautologisierung und Entparadoxalisierung des Rechts'. ${ }^{552}$

Het moet Luhmann worden nagegeven, dat hij het niet bij een interessant suggestie heeft gelaten, maar deze claim handen en voeten heeft gegeven met een nog steeds groeiend aantal op de rechtsfilosofie en -theorie toegesneden idee-historische studies. ${ }^{553}$ Het is hier niet de plaats om deze idee-historische reconstructies na te lopen. Maar misschien is de hint al genoeg om toch met andere ogen naar het vroeg-moderne idee van 'natuurrechten" te knjken, als rechten waarvan de erkenning, bijv. in de visie van Hobbes, niet afhangen van de erkenning van complementaire verplichtingen, als rechten dus die nog voor al het recht, nog voor het onderscheid recht/onrecht gelden. Op de tautologie van de fundering van het recht in een 'socisal contract' is al dikwijls gewezen, maar minder vaak op de 19 de eeuws maskering van de rechtsparadox met

551. N. Luhmann, Die soziologische Beobachtung des Rechts, Frankfurt/M. 1985, p.17.

552. Idem.

553. Zie nasast het zojuist genoemde "The Third Question', o.a. N. Luhmann, Ausdifferenzienung' des Rechts, Frankfurt/M. 2981; Idem, Die soziologische Beobachtung des Rechts, Frankfurt/M. 1985; Idem, Dos Recht der Gesellschaft, Frankfurt/M. 1993, ihb. de hooldstukken 4,6 en 11 ., en natuurlijk ook de op het recht betrokken studies die in de reeks Gesellschaftsstruktur und Semantik zijn verschenen. 
behulp van een toekomst waarn geen onrecht meer zal bestaan - "the splendid future of divine mankind, the future of freedom and equality, the future of emancipation and democratic constitutions, or the future of the greatest happiness of the greatest number of people, and finally as the future if the communist society as the new state of nature...' De blik wordt van het onrecht van het (bestaande) recht weggeleid naar een toekomst waarin alleen nog recht zal bestaan - en daar kunnen tautologie en paradox rustig thun gang gaan, want de toekomst is denkbaar, maar niet observeerbaar. De toekomst als het grote excuus 'for all the misdeeds of the new industrial society..., for the law which the society itself produces according to a calculus of interest" ${ }^{554}$

Het antwoord op 'de derde vraag', zo zouden we ter afsluiting kunnen generaliseren, is altijd de poging om een fundament onder de idiosyncratie van het (functie)systeem te leggen, of plastischer: te storten -, waarin ook de geheimen van het systeem kunnen verdwijnen - 'We need this basement as the rule without exception; that is, as the exception to the rule that there are no rules without exception. We need it as the paradox. ${ }^{555}$ 


\section{Hoofdstuk VI}

\section{DE MODERNE MAATSCHAPPIJ: DIAGNOSE EN KRITIEK}

\section{§. Inleiding}

Met concepten als 'maatschappij", "uitdifferentiatie', 'functiesysteem", 'symbolisch gegeneraliseerde communicatiemedia' en 'codering' beschikken we zo langzamerhand over de belangrujkste bouwstenen van Luhmanns theorie aangaande de moderne, functioneel gedifferentieerde maatschappij. Als datgene wat een brug moet slaan tussen de algemene grondslagen van een bijzonder type sociologie en haar empirie, is en blijft deze maatschappijtheorie een observatieen beschrijvingsapparaat en is het niet zelf een empirisch-concrete, statistischsociologische beschrijving van (historisch) bijzondere maatschappelijke fenomenen. De toevoeging "statistisch" is misschien wat misplaatst, want statistisch onderzoek is beslist niet Luhmanns grote liefde. Wanneer zijn beschouwingen omtrent de moderne maatschappij empirisch en concreet worden, nemen deze eerder de vorm aan van een kennissociologie, van een 'Wissenssoziologie der modernen Gesellschaft', zoals de ondertitel van de verschillende delen uit de reeks Gesellschaftsstruktur und Semantik steeds luidt. Men zou eventueel ook van een cultuursociologische operationalisering kunnen spreken, aangezien in Luhmanns empirische en historische studies het object vam onderzoek eerst en vooral door 'semantieken' wordt gevormd, bijv. door tijdssemantieken, risico-semantieken, natuurconcepties, rechtvaardigheidsvoorstellingen, liefdessemantieken, 'conservatief/progressief' -schematiseringen, etc. Hoe dan ook - in Luhmanns "kennissociologie van de modeme maatschappij" gaat het in ieder geval niet om de reductie van sociaal voorhanden weten op de intenties van individuele actoren en evenmin om een 'klassiek' type kennissociologie dat ideeên herleidt tot belangen ('interesses') of tot de sociale gebondenheid en positionering van personen of groepen. Het gaat, anders gezegd, noch om social-psychologie, noch om ideologiekritiek, noch om de heropstanding van Karl Mannheim. Immers, de historisch gegeven semantieken waarop Luhmann zich in zijn empirische studies concentreert, stellen vanuit een algemeen theoretisch perspectief telkens interpretaties en afgrenzingen van thema's voor die in en door sociale systemen worden 
voortgebracht en wel in functie van hun eigen autopoiesis (Verg. Hfst. III, \& 5.) ${ }^{561}$

Dat in Luhmanns empirische en historisch-sociologische studies zijn algemene maatschappijtheorie een belangrijke rol blijft spelen, blijkt onder meer uit het feit dat hij geen genoegen neemt met een zuiver ideeanhistorische benadering, zoals bijv. door Koselleck, Conze en Brunner in het lexicon Historische Grindbegriffe is uitgedragen. Wat daaraan ontbreekt, aldus Luhmann, is een model of theorie van de samenhang tussen begripshistorische en sociaalstructurele ontwikkelingen. Het is niet toevallig, zo redeneert hij, dat verschillende semantische ontwikkelingen die aan het einde van de Middeleeuwen op gang komen, in de 2 de helft van de 18 de eeuw - Kosellecks 'Sattelzeit' - culmineren in een algemene en tot op zekere hoogte onomkeerbare, cultuurhistorische omslag. Het suggereert een bepaald patroon dat het kader van de zuiver historische analyse overstijgt. Om wetenschappelijk vat te krijgen op dat patroon, moet 'een historiserende benadering worden gecomplementeerd met een functionalistisch perspectief - of zoals Luhmann het eigenlijk ziet: de oorspronkelijke samenhang tussen de historische en de functionele beschouwing moet in ere worden hersteld -

"Historismus und Funktionalismus entstehen gleichzeitig und hängen zusammen. Der Funktionalismus garantiert dem Historismus die Nichtbeliebigkeit der Variation. ${ }^{562}$

De meest algemene strekking van "functionaliseren" is bij Luhmann het betrekken van een fenomeen op een probleem, en zoals we in het 'Excurs' over zijn equivalentie-functionalisme hebben gezien, dient theorievorming er volgens hem toe om dit 'problematiseren' in banen te leiden, van systematische aanknopingspunten te voorzien. Dit laatste is precies de functie die Luhmann aan zijn maatschappijtheorie toekent als het gaat on de sociologische analyse en duiding van semantische, of zo men will: van culturele ontwikkelingen. Daarbij vertrekt hij vanuit de (hypo)these, dat er een correlatie of co-variantie bestaat tussen de in semantieken neergeslagen, cultureel beschikbare kennisbestanden en de ontwikkeling en stabilisatie van maatschappelijke structuren. Het gaat Luhmann hierbij overigens niet om causale relaties, zo, alsof de dominante maatschappelijke structuren de ontwikkeling van het telkens beschikbare ideeëngoed zouden determineren - of juist omgekeerd: dat semantische

561. Dat wil overigens niet zegger, dat groepen of sociale lagen er helemaal niets toe doen. Zo wezen we er eerder all eens op, dat de "hoofse liefde" een typisch aan do adel geboncten liefdessemantiek voorstelt. Volgens Luhmann kunnen worm en inhoud van dergelijke groepsof klasse-specifieke semantieken echter niet herleid worden tot "objectieve" belangen of klasseposities.

562. N. Luhmann, 'Gesellschafliche Struktur und semantische Tradition' in: Idem, Gesellschafisstruktur tind Semanitik, Frankfurt/M. 1993, p.9. 
innovaties de ontwikkeling wan maatschappelijke structuren zouden bepalen. 'Uns genugen fur die Formulienung der Problemstellung schwächere, voraussetzungsärmere Begriffe wie Kompatibilităt, Grenzen der Kompatibilität, Korrelation' - zo schrijft hij. 'Gemeint ist damit zunächst nur, daß Ideengut im Verhältnis zur Gesellschaft, die es benutzt, nicht beliebig variieren kann, ${ }^{563}$

De empirische operationalisering van Luhmanns algemene maatschappijtheorie, zo zouden we het bovenstaande kunnen samenvatten, neemt bij hem niet de vorm aan van een politiek-economische of anderszins als structureel of structuralistisch te kwalificeren analyse, ook niet die van een groeps- of klassentheoretische interpretatie wan maatschappelijke processen en strueturen, maar de 'culturaiistische' vorm van semantiek-onderzoek. Zo treffen we een empirisch inhoudswolle analyse van het "moderniseringsproces" o.a. aan in Liebe als Passion en in de opstellen die Luhmann gepubliceerd heeft onder de (reeks)titel Gesellschaftsstruktur und Semantik - Studien zur Wissenssoziologie der modernen Gesellschaft. Wie zich eerder interesseert voor concrete analyses van de huidige maatschappij, is aangewezen op boeken als Okologische Kommunikation of Soziologie des Risikos.

Misschien klinkt een dergelijke samenvatting van de verhouding tussen Iuhmanns 'maatschappijtheorie" en zijn "empirie" wat al te braaf, of in ieder geval te neutraal. Met name zijn meer op hedendaagse fenomenen, zoals de milieuproblematiek of het risico van grootschalige technologie georienteerde studies behelzen ook telkens een diagnose van de moderne maatschappij, stellen, in de woorden van Walter Reese-Schäfer, ook steeds een 'politischsoziologische Gegenwartsdiagnostik' voor. En uit deze 'tijdsdiagnoses' spreekt niet een onverdeeld optimisme over een goede afloop. Zo beschouwt Luhmann de milieuproblematiek als 'ein sich heute dramatisch zuspitzendes Problem' dat de samenleving zichzelf aandoet, alls een 'ökologische Selbstgefährdung des Gesellschaftssystems' die wezenlijk samenhangt met de grondstructuur van de moderne maatschappij. Dat is geen op zichzelf staande, geisoleerde uiting van pessimisme, maar een toespitsing van een algemener motief. Over een bredere linie beschouwd, rijst uit Luhmamns analyses van de huidige samenleving het beeld op van een maatschappij die zich op een uiterst riskant pad heeft begeven, waarbij de risico's niet zozeer van buitenaf komen, maar van binnenuit worden gegenereerd.

In feite vindt dit 'onbestende pessimisme' (dat overigens nog geen morele of politieke veroordeling wan de moderne, Westerse samenleving inhoudt) zijn aanleg in de algemene uitgangspunten en modellen van Luhmanns overkoepelende maatschappijtheorie. Met concepten als 'functionele uitdifferentiatie', 'functiesystemen', 'codering', etc. heeft Luhmann, om de bekende metafoor nog eens aan te halem, zichzelf een bril op gezet die nu ook zijn empirie in specifieke tinten kleurt. In het nu volgende zullen we ons eerst 
een preciezer beeld verschaffen van die diagnostische impact van Luhmanns algemene maatschappijtheorie, voorzover deze althans betrekking heeft op de moderne, functioneel gedifferentieerde maatschappij. We zien m. a.w. af van een samenvatting/uiteenzetting van Luhmanns meer empirische werk en concentreren ons in plaats daarvan op het algemene raamwerk dat ook het kader vormde van de kritische tijdsdiagnoses die Luhmann in geschriften als Okologische Kommunikation en Soziologie des Risikos heeft gepresenteerd. Dat mag vervolgens als achtergrond dienen voor een eerste ronde van discussie en kritiek waarin een specifieker thema centraal staat, namelijk een door velen aan Luhmanns maatschappijtheorie toegeschreven pessimisme met betrekking tot de mogelijkheden van 'politieke sturing'. Dat zal tevens de gelegenheid bieden om ons nog eens te buigen over de 'leemte' die we in het vorige hoofdstuk al constateerden en daar bekritiseerden als het 'ontbreken hinnen Luhmanns werk van een algemeen theoretisch model van de verhouding (formele) organisaties en (moderne) maatschappij (Hfst.V, § 2.2.). Problemen rondt de operationalisering en demarcatie van "functiesystemen" vormen dan de aanleiding voor een tweede discussieronde die eveneens zal terugvoeren naar een in het vorige hoofdstuk al aangesneden probleem, namelijk Luhmanns omschrijving van 'maatschappij' als een autopoietisch sociaal systeem (Idem, § 2.4.). De balans van deze discussies zullen we definitief opmaken in de slotparagraaf van dit hoofdstuk:

\$ 2. De diagnose van de moderne maatschappij: redundantieverlies, positivering en heterar-chie

Wanneer we observeren hoe Luhmann observeent, dan lijken de differenties en schema's die de structuur van zijn maatschappijtheorie vormen, zo te zijn gemodelieerd, dat bepaalde kenmerken van de noderne maatschappij in het bijzonder worden uitvergroot. In het onderstaande zullen we deze kenmerken en bijbehorende constellaties onder een drietal steekwoorden behandelen, namelijk als 'redundantieverlies', "positivering' en 'heterarchie'. En inderdaad-, naast alle waardering, zo niet 'respect' die Luhmann heeft voor de complexiteit, en d.w.z: voor de keuzemogelijkheden en vrijheidsgraden die de moderne maatschappij realiseert, verwijzen deze drie steekwoorden naar structuren en tendensen die in hun onderlinge samenhang een typisch en dan ook problematisch syndroom vormen.

\section{\$2.1. Redundantieverlies}

Zowel Luhmanns optimisme als pessimisme liggen voor een belangrijk deel reeds besloten in de veronderstelling, dat de moderne maatschappij tot ontwikkeling komt door het 'uitdifferentiëren van functiesystemen'. Daarmee wordt, om te beginnen, naar voren gehaald, dat de opkomst van de moderne 
maatschappij hand in hand is gegaan met de afbraak van 'multifunctionele' inrichtingen, zoals de familiehuishouding, het middeleeuwse hof en de traditionele moral, en dit ten gunste van de vorming wan "functiesystemen"; d.w.z. subsystemen die exclusief en zonder substitutiemogelijkheden precies één maatschappelijke functie behartigen. Dit verlies aan intersystemische substitutiemogelijkheden is in Luhmanns ogen een onvermijdelijk effect van de universaliteitsaanspraak die elk gecodeerd systeem voor zijn eigen perspectief verheft: alleen binnen een functiesysteem (intrasystemiseh) is een uitwisseling van functionele equivalenten mogelijk, maar functiesystemen kunnen niet voor elkaar inspringen. Het rechtssysteem kan bijvoorbeeld niet het perspectief (d.w.z. de code) van het wetenschapssysteem als een oorspronkelijk, primair gezichtspunt overnemen; het kan hooguit op basis van de eigen code proberen om wetenschappelijke communicatie te observeren.

Het negatieve aspect van dit "Verzicht auf Substituierbarkeit" omschrijft Luhmann als 'Verzicht auf Redundanz', als redundantieverlies. Welke voordelen het principe van functionele differentiatie ook mag bieden, het wordt betaald met een verlies aan mogelijkheden om storingen binnen een bepaald functiesysteem, of zelfs uitval van een specifieke maatschappelijke functie, elders, in andere maatschappelijke subsystemen op te vangen. "Redundantie", d.w.z: overschot aan functioneel equivalente mogelijkheden, fungeert ook altijd als een soort buffer, als een 'ingebouwde' extra zekerheid Zo beschouwd, is 'Verzicht auf Substituierbarkeit', als 'Verzicht auf Redundanz', uiteindelijk een 'Verzicht auf Sicherheit durch Redundanz' ${ }^{564}$ Het risico dat de moderne maatschappij met het opgeven van intersystemische substitutiemogelijkheden aangaat, wordt vervolgens meer tastbaar, wanneer tevens moet worden vastgesteld, dat functionele differentiatie zowel de autonomie van de uitgedifferentieerde subsystemen versterkt, als hun onderlinge afhankelijkheden. In een formulering van Luhmann:

'Die strukturell aufgezwungene Nichtsubstituierbarkeit der Funktions-systeme schließt Interdependenzen der vielfältigste Art nicht aus. [-] Die Nichtsubstituierbarkeit der Funktionen (= Substitutionsregelung durch Funktionen) wird vielmehr durch zunehmende Interdependenzen kompensiert. Gerade weil die Funktionssysteme einander nicht ersetzen können, begünstigen und belasten sie sich wechselseitig. ${ }^{.565}$

De autonomie van een systeem, we hebben het al vaker geconstateerd, impliceert bij Luhmann niet een volledige onafhankelijkheid van zijn omgeving,

564. Verg o.a. N. Luhmann, Die soziologische Beobachtung des Rechts, Frankfurt/M. 1985, p.12 e.v.

565. N. Luhmann, Okologische Kommunikation, op cit., p. 208. 
of absolute controle over de voorwaarden waaronder het systeem kan bestaan Zo bepaalt 'de economie' (als autopoietisch functiesysteem) weliswar zelf hoe het op politieke besluiten of op ontwikkelingen in het onderwijssysteen reageert, zonder collectief bindende beslissingen, of zonder scholing kan het economisch systeem niet functioneren. En soortgelijks geldt voor de onderlinge afhankelijkheden van het recht, de politiek, de wetenschap, de gezondheidszorg, het kunstsysteem, etc. Het risico van functionele differentiatie en van het daaraan inherente 'redundantieverlies', zo zouden we kunnen samenvatten, is, dat de maatschappij, als totalsamenhang, weerloos wordt tegen de desintegrerende effecten van storingen in één van haar subsystemen.

Als belangrijkste compensatie voor het redundantieverlies op het niveau van de maatschappij ziet Luhmann de toegenomen substitutiemogelijkheden bimnen de afzonderlijke functiesystemen. ${ }^{566}$ Die toename hangt direct samen met het principe van codering als basis van uitdifferentiatie. Codering universaliseert het relevantiebereik van functiesystemen, zoals we eerder opmerkten, hetgeen betaald wordt met een zekere blindheid, met onverschilligheid voor perspectieven die niet 'des systems' zijn, met 'idiosynkratie'. In termen van een algemene systeemtheorie zou men ook, en misschien met een meer positieve bijklank, kunnen spreken van een verhoging van (intra-systemische) complexiteit door een middels codering tot stand gebrachte (verregaande) reductie van complexiteit. Het "positieve" daarvan is dan, dat finctiesystemen binnen hun eigen domein vrijer en beweeglijker worden, over meer mogelijkheden gaan beschikken - ook over meer mogelijkheden om functioneel equivalente oplossingen voor problemen te organiseren en in te zetten ter vervanging of ondersteuning van structuren of mechanismen die niet meer voldoen. Voorbeelden daarvan liggen voor het oprapen - men hoeft slechts te denken aan de differentiatie van het middelbaar onderwijs, aan de ontwikkeling van nieuwe vormen van recht zoals het 'milieurecht', of aan de wereldwijde reallocaties van arbeid en/of kapitaal.

\section{\$2.2. Positivering}

Voor functiesystemen heef de, door codering bereikte winst aan dynamiek en flexibiliteit ook een keerzijde. Als het principe dat aan functiesystemen hoge vrijheidsgraden toestaat, tendeert binaire codering naar een verabsolutering van contingentie. Alles, zo schreven we, kan voor het rechtssysteem recht of onrecht zijn, voor het wetenschapssysteem waar of onwaar, enz., zonder dat het recht of de wetenschap of enig ander functiesysteem bij de toewijzing van éen van beide codewaarden kan terugvallen op bij voorbaat gegeven, extern voorhanden apriori's of essenties. Toename van contingentie is toename van selectiedruk en functiesystemen kumnen die slechts met eigen middelen, op basis van eigen 
structuren opvangen: door programmering, bijv. door wetten en jurisprudentie, door theorieên en methodes, door constitutionele procedures en verkiezingen, etc. Programmas zijn echter zelf selecties, zijn zelf sets van beslissingsregels en -criteria die door het betreffende functiesysteem ook anders hadden kunnen worden georganiseerd. Programma's zijn m.a.w. zelf contingent functiesystemen reduceren (open) contingentie middels (gearticuleerde) contingentie. De ervaring van deze 'programmatische' contingentie dringt zich al op door de veranderlijkheid van programma's binnen thet onbeweeglijke kader van de code. De observatie van dit contingente karakkter van, voor de samenleving centrale regelstructuren zoals het recht, de politieke (democratische) constitutie of wetenschappelijk-technologische programma's, wordt vervolgens onvermijdelijk, wanneer functiesystemen zelfbeschrijvingen, gaan ontwikkelen, bijvoorbeeld in de vorm van rechts-, democratie- of wetenschapstheorieern, terwille van een interne oriëntatie bij (of 'conditionering' van) de selectie tussen mogelijke programma's. Dit 'herkennen' van contingentie komt, zij het aarzelend, al in de 17 de/18de eeuw op gang, om in de 2 de helft van de $19 \mathrm{de}$ onder de titels 'positiviteit' en 'positivering' een "onttoverde" wereld achter te laten:

'Man denke an die Ablösung des Naturrechts durch das positive Recht, an den demokratischen Wechsel der Regierungen, an den nur noch hypothetischen Charakter der Geltung von Theorieën, an die Möglichkeiten der freien Wahl des Ehepartners und nicht zuletzt an all das, was man als 'Entscheidungen des Marktes' (wer oder was immer das sei) erfăhrt und zunehmender Kritik aussetzt. ${ }^{\text {567 }}$

'Positiviteit' of 'positivering van sociale structuren' vertoont als aanduiding van een tweede algemeen kenmerk van de moderne maatschappij in feite verschillende facetten. Het benadrukt om te beginnen, dat het recht, de wetenschap, de kunst, de regels van de politiek, etc. die de moderne maatschappij zichzelf geeft, geen andere grond hebben dan het recht, de wetensehap, de kunst of de politiek zelf. Anders geformuleerd: er zijn voor rechtsregels of wetenschappelijke theorieèn geen andere redenen of 'fundamenten', dan hun fumctie in de autopoietische reproduktie van het rechtssysteem c.q. het wetenschapssysteem. Recht, wetenschap, kunst, religie, enz. funderen zichzelf. De leer van het 'rechtspositivisme' is, zo beschouwd, niets anders dan een (19de eeuwse) verwoording van het inzicht, dat recht recht vooronderstelt. De positiviteit van het recht is zijn autopoiesis, zo noteert 
Luhmann. ${ }^{568}$ Wat er aan natuurrechtsdenken dan nog resteert, verschijnt als een poging om in de interne, rechtstheoretische reflectie op het rechtssysteem, die circulariteit van het recht te doorbreken, te asymmetriseren door interne rechtsprincipes te externaliseren en zo als 'fundament' en 'ijkmaat' aan de veranderlijkheid van rechtsprogramma's te onttrekken. Een 2de orde observator, de socioloog Luhmann bijvoorbeeld, kan als 'buitenstaander" echter observeren, dat het recht zichzèlf "bewijst" en wel door de zelfreferentielle operatiemodus van het recht in gang te houden en deze geslotenheid tegelijkertijd te openen voor externe ruis en prikkels, voor 'informatie' omtrent de omgeving.

De observatie en beschrijving van het contingente karakter van het recht, van esthetiek, van wetenschappelijke theorieen en methoden, van de staatkundige inrichting, etc. is natuurlijk ook de ontdekking, dat "de geldende werkelijkheid" slechts een mogelijkheid is, dat de structuren die het sociale leven en de omgang met de psychische en fysisch-organische condities van socialiteit reguleren, er in principe ook anders uit kunnen zien. Met toenemende reflexiviteit verschijnen steeds meer delen van een voorheen 'natuurlijke" of 'door-god-gegeven" werkelijkheid als een mogelijke selectie, als uitdrukking van een keuzemoment. Dat vormt de achtergrond van een tweede facet van 'positiviteit', namelijk "maakbaarheid". Het aan functionele differentiatie inherente principe van positivering of 'zelffundering' leidt onvermijdelijk tot de communicatie van maakbaarheid - maakbaarheid van de samenleving door recht en politiek, van de natuur door wetenschap en technologie, van de mens door scholing en medische of psychische ingrepen,etc. De maatsehappelijke betekenis van dit 'maakbaarheidșdiscours' wordt niet alleen zichtbaar aan het cultureel diepgrijpende 'project van de Verlichting' of aan de opkomst van een nieuwe revolutie-semantiek, maar ook aan wat men de 'lijdenskwaliteit" van het "nietmaakbare' zou kunnen noemen. een lijden aan oorlog, armoede of ziektes als het 'nog-niet-gecontroleerde' in het licht van een principieel geachte (en geeiste) controleerbaarheid. ${ }^{569}$

Onvermijdelijk zet zich dan echter het inzicht door, dat ook maakbaarheid geen "grond" heeft: Aan de keuze van bijv. de wetgever om de juridische blauwdruk van het contract dat we 'huwelijk' noemen, langs patriarchale en niet langs matriarchale lijnen in te richten; blijft hoe dan ook een zekere willekeur kleven. Dat plaatst de gerealiseerde maatschappelijke ordeningen onder een verhoogde legitimatiedruk, die in westerse samenlevingen o.a. wordt opgevangen door een toenemende juridische formalisering en proceduralisering van besluitvormingsprocessen - 'Legitimation durch Verfahren'. En Helmut Willke wijst

568. N.Luhunann, 'Die Einheil des Rechtssytems', Rechtstheorie 14 (1983) p.136; verg. verder: Idem, Die soziologische Beobachtung des Rechts, Frankfurt/M. 1985, p.15 e.v., en Idem, 'Positivität als Selbstbestimmtheit des Rechts', Rechtstheorie 19 (1988), p. 11 - 27.

569. Verg. Habermas" 'Exkurs zu Fortschritt und Ausbeutung'; in zijn Zur Rekonstriktion des Historischen Materiatismus, Frankfurt/M. 1976, p.180 e.v. 
daamaast terecht op de 'normative Kraft des Faktischen' en de 'faktische Kraft des Normativen' in deze:

\begin{abstract}
"Immer noch ist es einfacher, den status quo zu belassen, als Änderungen durchzusetzen. Immer noch mussen sich Innovationen eigens legitimieren, obwohl aberdeutlich ist, dafl durch die unvermeidliche Veränderung von Kontextbedingungen jeder status quo kontinuierlich veraltet und antiquiert wird ${ }^{370}$
\end{abstract}

Ook bij wat men als een 'afdoende' legitimatie van geldende ordeningen zou kunnen beschouwen, kan een functioneel gedifferentieerde maatschappij zich echter niet onttrekken aan de 'voorlopigheid' van haar programmas en structuren. De gelding van een wet of van een wetenschappelijke theorie heeft steeds een woorlopig karakter en kan altijd weer herroepen worden. Onder de titel 'hypothetisering' van de maatschappij kunnen we dit 'blijvend voorbehoud', naast 'zelffundering' en 'maakbaarheid' als een derde facet van de positivering van functiesystemen beschouwen. ${ }^{571}$

Met "hypothetisering" wordt in deze minimaal aangegeven, dat de moderne maatschappij zich moet reproduceren op basis van regelstructuren die in toenemende mate "onder voorbehoud' gelden, in het licht van een mogelijk 'niet-gelden' gelden, d.w.z: de maatschappij moet haar autopoiesis voortzetten middels regels waarvan de juistheid/correctheid/nuttigheid/zin-volheid/etc. structureel en systematisch wordt betwijfeld. Of vanuit het niveau van de maatschappelijke subsystemen beschouwd: functiesystemen moeten hun regelstructuren zelf "maken" en de fundering darvan in hun eigen autopoiesis zoeken, zonder dat een 'lukkende' zelffindering een functiesysteem zekerheid kan verschaffen omtrent de 'geldigheid' van zijn programmas en structuren.

Beschouwen we 'zelffundering", 'maakbaarheid' en 'hypothetisering' nu als samenhangende facetten van een toenemende positivering, dan dringt zich het beeld op van een maatschappij die onder het gewicht van haar eigen contingenties begint door te buigen, wan een samenleving die oog in oog met haar ongebreidelde keuzemogelijkheden verlant dreigt te raken door het besef, dat de selectiviteit en dus het risico van iedere afzonderlijke mogelijkheid navenant is toegenomen. Willke spreekt met het oog hierop van een 'zunehmend paradoxes Verhaltnis zwischen der prinzipiellen Kontingenz aller Zustande einerseits und der Selbstblockierung komplexer Systeme gerade aufgrund der überwältigenden Komplexităt ihrer Möglichkeiten.

570. H. Willke, System theorie entwickelter Gesellschaften, Munchen $1989, \mathrm{p}_{4} 41$.

571. Verg. H. Willke, op.vit., p. 27 e.v. 
Man könnte auch sagen: je mehr möglich ist, desto weniger geht, oder präziser: weil so viel möglich ist, geht so wenig. ${ }^{572}$

En elders heet het:

'Positivierung der Regelstruktur erzeugt mit einem Obermaß an Kontingenz und hypothetischer Realität eine neuartige Riskiertheit entwickelter Gesellschaften und insgesamt die Gefahr, daß diese die Kontrolle über sich verlieren." ${ }^{.573}$

Met dit alles wordt niet tegengesproken, dat ook pre-moderne maatschappijen hun eigen complexiteit bezitten, dat de historisch concrete structuren van archaissche maatschappijen en hoog-culturen eveneens contingente selecties voorstellen en in die zin een risico belichamen. Wat echter met 'redundantieverlies' en 'positivering', als termen die naar typisch moderne constellaties en kenmerken verwijzen, wordt benadrukt, is, dat onder de condities van functionele differentiatie maatschappelijke complexiteit een bijzondere, en in bepaalde opzichten ook buitengewoon problematische vorm aanneemt. Verlies aan redundantie, aan substitutiemogelijkheden op algemeen maatschappelijk niveau wordt inderdaad gecompenseerd op het niveau van de functiesystemen, maar, zoals Luhmann opmerkt, 'das Problem liegt nur darin, daß dies nur auf der Ebene der Teilsysteme geschehen kann' ${ }^{574}$ In het kieizog van een algehele positivering van 'geldende werkelijkheid' kan zich onder de vaandels van 'planning', 'sturing', 'doelrationele organisatie", etc. binnen functiesystemen weliswaar een oriëntatie aan 'maakbaarheid' breed gaan maken; daarmee plaatst het handelen zich echter tegelijkertijd onder een verhoogde selectiedruk die als een toegenomen risicobewustzijn de maatschappij parten gaat spelen. Daarbij voegt zich nog een derde, algemeen kenmerk van de moderne maatschappij, dat als 'polycontexturaliteit' of 'heterarchie' kan worden aangeduid.

\section{§. 2.3. Heterarchie}

We hebben er al eerder op gewezen, dat Luhmann het proces van functionele differentiatie beschouwt als de vorming van autopoietische systemen binnen het autopoietisch systeem "maatschappij': Dat dit geschiedt op basis van codering, wil onder meer zeggen, dat functiesystemen zich van hun matschappelijke omgeving affgrenzen middels hun 'Leitdifferenz', d.w.z. op basis van een specifiek perspectief dat eerst de horizon opspant waarbinnen selecties kunnen

572. H. Willke, op cit, p.4l.

573. Idem, p.55.

\$74. Ökologische Kommunikation, op.cit., p.210. 
verschijnen als voor het betreffende functiesysteem relevante, verwerkbare "informatie'. Ook hier blijft echter gelden - en daarop wordt geanticipeerd door het postulaat dat 'maatschappij", formeel gesproken, als een "Weltbegriff' moet worden opgevat - dat systeem en omgeving tezamen de totaliteit vormen, dat de eenheid van de differentie functiesysteem/"maatschappelijke omgeving" de maatschappij als totaalsamenhang reconstrueert - "Jede Differenz von System und Umwelt, beides zusammengenommen, rekonstruiert die Einheit des Gesamtsystems". ${ }^{575}$ Door uitdifferentiatie, zo zou men kunnen zeggen, herhaalt of "vermenigvuldigt" de maatschappij zich in zichzelf. Met iedere 'Leitdifferenz', met iedere geslaagde codering komt de maatschappij in zichzelf voor, zij het telkens vanuit het specifieke perspectief van het gecodeerde functiesysteem. Daarop is de term 'polycontexturaliteit' toegesneden: 'maatschappij' is telkens voorhanden, "bestaat' steeds als datgene wat vanuit de politiek, de economie, de wetenschap, het recht, etc. als totaalsamenhang van het sociale zichtbaar wordt. Of wat in wezen op hetzelfde neerkomt: functioneel gedifferentieerde maatschappijen zijn 'polycentrisch' van aard, kennen evenzoveel 'centra' als zij functiesystemen tellen.

Met 'typeringen als 'polycontextureel' en 'polycentrisch' wordt tevens vastgesteld, dat moderne maatschappijen zich kenmerken door 'heterarchie'. Er is geen eenduidig maatschappelijk centrum meer, geen bijzonder functiesysteem dat het privilege toekont de maatschappelijke totaliteit meer en beter te representeren, dan alle andere functiesystemen. Luhmann:

\begin{abstract}
'Solange die Gesellschaft nach Zentrum/Peripherie oder nach einer Rangordnung differenziert war, konnten zumindest Positionen fixiert werden, in denen es konkurrenzlos möglich ist, die Einheit des Systems zu 'repräsentieren'... Die Übergang zu funktionaler Differenzierung zerstört diese Möglichkeit, indem er es vielen Funktionssystemen überläßt, die Einheit der Gesellschaft durch jeweils ihre Teilsystem/Umwelt-Differenz zu repräsentieren, und sie untereinander einer Konkurrenz aussetzt, für die es keinen übergeordneten Standpunkt der Superrepräsentation gibt. ${ }^{.576}$
\end{abstract}

Ook het politieke systeem kan vandaag de dag niet meer worden geacht de maatschappelijke wijsheid in pacht te hebben en een overkoepelend "bonum commune' te doorgronden. Voor het politieke systeem zelf, kan het eigen perspectief weliswaar een geprivilegieerd positie innemen, maar dat geldt dwangmatig voor ieder afzonderlijk functiesysteem. Wat op het "beeldscherm" van de afzonderlijke subsystemen kan verschijnen, is immers afhankelijk van de

575. N. Luhmann, 'Die Theorie gesellschafticher Differenzienung', Ms. Bielefeld (1989), p.4.

576. Okologische Komuvilkation, op.cit., p. 216. 
quasi-transcendentale werking van hun codes en van de daarop voortbouwende differenties en observatieschema's. Interactiesystemen kunnen onder modeme condities evenmin nog als bron van overkoepelende, de maatschappij als geheel orientatie verlenende gezjchtspunten dienen. Daarvoor is, volgens Luhmann, de moderne maatschappij te complex geworden en de afstand tussen interactie? en 'maatschappij' te groot -

'Keine Interaktion, wie immer hochgestellt die beteiligten Personen sein mögen, kann in Anspruch nehmen repräsentativ zu sein fur Gesellschaft. Es gibt infolgedessen keine 'gute Gesellschaft' mehr. ${ }^{.577}$

Functionele differentiatie, zo kunnen we samenvatten, is onvermijdelijk een vorm van 'horizontale' differentiatie die afrekent met 'hierarchie?. als een primair principe van maatschappelijke differentiatie. Voor de afzonderlijke functiesystemen maakt dit een verregaande ontketening van hun eigen potenties mogelijk. Wat kan het recht nog daaraan hinderen haar eigen rationaliteit te volgen, deze te ontplooien en juridisch hoogontwikkelde, specialistische rechtsconstructies te produceren? Wat kan de economie, kunst of wetenschap 'verbieden' hun eigen logica en competenties absolunt te stellen en die steeds verder te verfijinen en uit te bouwen? Vanuit het universaliserend perspectief van de functiesystemen zelf is er geen reden tot een beteugeling - of zoals Luhmann deze 'ontremming' inschat:

'Ausdifferenzierte Funktionssysteme' sind, bisher jedenfalls, so entwickelt, daß sie ihr eigenes Wachstum nicht selbst kontrollieren können. In die jeweilige Funktionsperspektiven ist ein Steigerungsaspekt eingebaut...im Prinzip gibt es keine funktionsspezifische Grunde, ein bessere Erfullung der Funktion nicht zu wollen: keine paddagogische Grinde, von mehr Bemühungen um bessere Erziehung eines größeren Teiles der Bevölkerung abzusehen... ${ }^{578}$

\section{§ 2.4. Redundantieverlies, positivering, heterarchie}

Beschouwen we redundantieverlies, positivering en heterarchie in hun onderlinge samenhang, dan tekent zich een typisch, 'modern' syndroom af. Niet alleen brengt de welhaast onbegrensde produktie van opties en keuzemo-

577. Soziale Systeme, op. cit., p.585.

578. N. Luhmann, "Gesellschaftsstrukturelle Bedingungen und Folgeprobleme des naturwissenschaftlich-technischen Fortschritts', in: Soziologische Auflalarung 4, Opladen 1987, p. 57. 
gelijkheden binnen de afzonderlijke functiesystemen met zich mee, dat iedere daadwerkelijke keuze een bijzonder hoge selectiviteit belichaamt; bovendien intensiveert functionele differentiatie, als de maatschappelijke vorm waaronder opties worden gegenereerd en keuzes gemaakt, het risico-karakter van alleselectiviteit. Wat als 'risico' op het beeldscherm van een maatschappelijk functiesysteem kan verschijnen, welke neveneffecten van mogelijke opties en outputs in ogenschouw worden genomen en gescreend op hun eventueel schadelijke gevolgen woor de maatschappelijke omgeving, is namelijk afhankelijk van de systeemspecifieke (en dus beperkte) observatiemiddelen en beoordelingscriteria. Zo kan voor het economisch systeem de produktie van bepaalde waren (CFK's, pesticiden, abortuspillen, onco-muizen, geavanceerde wapensystemen, etc.) uiterst rationeel zijn, terwijl de gezondheidszorg of de politiek zich voor de eventuele nadelen daarvan geplaatst ziet. In de moderne maatschappij zijn de beslissingsrisico's m.a.w. niet alleen toegenomen, maar bovendien worden ze slechts ten dele daar opgevangen en afgehandeld, waar ze worden aangegaan. Bij gebrek aan een coördinerend en controlerend maatschappelijk centrum wordt een deel van de risico-last op de omgeving van de betrokken subsystemen afgewenteld, op andere functiesystemen afgeschoven of op de individuele burgers, zonder dat er een garantie bestaat dat deze de voor hen 'exotische' problemen kunnen opvangen en verwerken. En dat, terwijl bij een toenemend redundantieverlies een storing in één van de functiesystemen direct repercussies heeft voor de reproduktie van de malschappij als totaalsamenhang. Wat Luhmann als eventuele compensatie voor redundantieverlies ziet, namelijk een complexer worden van de functiesystemen zelf, kan deze hele problematiek slechts intensiveren. Luhmann ziet dit natuurlijk ook:

"Gerade weil die Funktionssysteme einander nicht ersetzen können, begunstigen und belasten sie sich wechselseitig. Gerade ihre Unersetzlichkeit zwingt zum laufenden Verschieben der Probleme von einem ins andere System. Gerade dadurch kommt es zu jener Steigerumg von Independenzen und Interdependenzen, von Unabhängigkeiten und Abhängigkeiten zugleich, deren operativer und struktureller Ausgleich die einzelne Systeme zu immenser, unkontrollierbarer Eigenkomplexität aufbläht. ${ }^{579}$

Precies datgene wat de basis van het 'succes' van de westerse maatschappij vormt, zo zouden we het bovenstaande kunnen samenvatten, namelijk haar differentiatie in functiesystemen en de daardoor uitgelokte, explosieve ontwikkeling van politieke, technische, wetenschappelijke, juridische, economische, kunstzinnige, etc. competenties en rationaliteitsvormen, dreigt zich tegen diezelfde matschappij te keren. Er is geen maatschappelijk centrum 
meer aanwijsbaar, dat de ongebreidelde, idiosyncratische dynamiek van de afzonderlijke deelgebieden zou kunnen coördineren tot een samenhangend geheel, geen overkoepelend gezichtspunt meer dat het 'machtig particularisme' (Mayntz) van de functiesystemen aan banden zou kunnen leggen - althans niet in een vorm die aanspraak kan maken op algemene geldingskracht. Dat wetenschappers of filosofen dit bij herhaling constateren en beklagen, kan daaraan weinig verhelpen. Het wetenschapssysteem is een functiesysteem naast de andere functiesystemen en niets dwingt de politiek, de economie of de kunst zich aan een "beter-weten' van de wetenschap te onderwerpen. Luhmann:

'Die wissenschaft produziert im Blick auf ihre eigene Funktion für andere Funktionssysteme nur Uberschüsse an Selektionsmöglichkeiten, die nach deren Kriterien benutzt oder beiseite gelassen werden können. ${ }^{558}$

Willke spreekt, doelend op het probleem van de onderlinge integratie van functiesystemen, over een 'grundlegende Widerspruch zwischen der hochgetriebenen Rationalität der gesellschaftichen Teilsysteme und der immer risikoreicheren Irrationalitat des Ganzen von Gesellschaft' en diagnostiseert moderne maatschappijen als 'drifting societies'(Etzioni), d.w.z: als maatschappijen die vanwege een gebrek aan controle over hun eigen mogelijkheden en vrijheidsgraden de kans op een zelf gekozen ontwikkeling voorbij laten gaan, terwijl ze zich tegelijkertijd bloot stellen aan de risico's van een ongecontroleerde produktie van handelingsopties. ${ }^{581}$

'Entwickelte Gesellschaften stoßen an die Grenzen der Kontrolle ihrer eigenen Potentialitat. Sie uberfluten sich mit Möglichkeiten, deren Implikationen nicht kontrollierbar, häufig sogar nicht einmal abzusehen sind. ${ }^{582}$

En elders heet het:

"So ergibt sich insgesamt das Bild, daß die Verlagerung des Schwerpunktes gesellschaftlicher Ordnung auf das Prinzip funktionaler Differenzierung eine Spezifizierung der "Rationalitat? der Teilsysteme, eine Steigerung der Optionenvielfalt, sowie eine Steigerung der problematischen Außenwirkungen ('Externalitäten") der Operationsweise der spezialisierten

\footnotetext{
580. N. Luhmann, 'Gesellschaftsstrukturelle Biedingungen und Folgeprobleme des

581. Verg. $H$. Willke, Systemtheorie entwickelter Gesellschaften, Dynamik und Rishanz moderiner gesellschaflicher Selbstorganisation, Weinheim 1989, p.98 en 99.

582. Idem, p.98.
} 
Teilsysteme mit sich bringt. Die Gesellschaft insgesamt wird in einer noch kaum begriffenen Weise leistungsfahiger, dynamischer, reicher an Möglichkeiten und hochspezialiserte Optionen, komplexer und unübersichtlicher - und eben zugleich in völlig neuer Weise anfallig und selbstgefahordet. ${ }^{383}$

\section{§ 3. Kritiek (I): De sturingsdiscussie.}

De discussie over de grenzen van de welvaarts-, c.q. verzorgingsstaat en de toespitsing daarvan in termen van een regulerings- of sturingscrisis heeft ongetwijfeld bijgedragen aan een sinds de jaren tachtig sterk toegenomen belangstelling voor Luhmanns werk, niet alleen in Duitsland en Italié, maar recentelijk ook in de Spaanstalige en Angelsaksische wereld. Per slot van rekening lijkt Luhmanns these van de zelfreferentiele geslotenheid van functiesystemen een stevig theoretisch fundament te leveren voor de inmiddels wijdverbreide twijfel aan het vermogen van de overheid, om via het recht de maatschappelijke ontwikkelingen gericht te sturen. Zijn model van functionele differentiatie leidt immers tot een beschrijving van de moderne maatschappij alls een samenhang van subsystemen die in zoverre autonoom zijn, dat ze onderling elkaars processen en structuurontwikkelingen niet kumnen determineren. Dus ook het rechtssysteem laat zich niet zonder meer als sturingsmechanisme door de politiek gebruiken, net zo min als de overige maatschappelijke functiesystemen aan de leiband van het recht lopen.

Opvallend is, dat waar Habermas er begin jaren zeventig nog alles aan had gedaan om Luhmann voor het oog van 'die Linke" als rechts-conservatief te kijk te stellen, de Duitse sociologen en politicologen die zich in de jaren tachtig voor Luhmanns werk beginnen te interesseren juist van sociaal-democratische snit zijn. Zonder in een radicale anti-sturingsideologie te vervallen, lijken Teubner, Willke, Ronge, Japp, Ladeur en Bendel Luhmanns sturingspessimisme als een vorm van (maatschappij)kritiek te beschouwen, die in ieder geval opruiming houdt onder inmiddels verstarde dogma's van het planningssocialisme en al te simpele progressief/conservatief-schematiseringen. Van deze nieuwe generatie (hele of halve) Luhmannianen is het duo Teubner/Willke waarschijnlijk het meest bekend geworden; althans wanneer het gaat om de zogeheten "sturingsdiscissie". $\$$. Onder de banier van het "reflexieve recht", hebben

583. Idem, p.38.

584. Tot hun velle individuele en gemeenschappelijke publicaties behoren o.a.: G. Teubner, Recht al's autopoietisches System, Frankfurt/M. 1989; H. Willke, Entzanberung des Staates. Uberlegwngen zu einer sozietalen Steterungstheorie, Konigstein/Ts $1983 ; \mathrm{H}$. Willke, Ironie des Staates. Grundtinien einer Theorie des Staates polyzentrischer Gesellschaft, Frankfurt/M. 1992; G. Teubner/H.Willke, "Kontext und Autonomie: Gesellschaftliche 
Teubner en Willke de door Luhmann gepresenteerde diagnose van de moderne maatschappij als een polycentrische, heterarchische samenhang van functiesystemen, rechtstheoretisch en politicologisch uitgediept, om vervolgens een alternatief te suggereren voor de traditionele, 'dirigistische' sturingsconcepten en -modellen.

Hun concept van 'context-sturing' vertrekt vanuit Luhmanns bespiegelingen omtrent systemische 'reflexie' als een mogelijke basis voor 'rationaliteit' op het niveau van de maatschappelijke functiesystemen. Zoals we eerder zagen, impliceert "reflexie", als de vorm warrin zinsystemen hun eigen identiteit vis-àvis hun omgeving observeren, een 're-entry' van de systeem/omgevingsdifferentie binnen het systeem. Op zichzelf leidt dat nog niet tot meer rationaliteit. In plaats van deze differentie echter te benutten voor een observatie wan de eigen identiteit, kan een ontwikkeld systeem ook de 'andere' zijde van de differentie (i.e. 'omgeving') markeren, om op basis daarvan zichzelf als een systeem in de omgeving van andere systemen te observeren. Van 'rationaliteit' zouden we nu kunnen spreken, wanneer een systeem beide zijden van de differentie op elkaar weet te betrekken, hetgeen praktisch gesproken wil zeggen: waneer een systeem in staat is te verdisconteren, dat zijn uitwerking op de omgeving ook altijd een boemerang-effect heeft. Luhmann: [D] as System [muß] seine Einwirkungen auf die Umwelt an den Rückwirkungen auf es selbst kontrollieren, wenn es sich rational verhalten will. Ein System, das uber sein Umwelt verfugt, verfugt im Endeffekt über sich selbst'. ${ }^{\text {s85 }}$

Reflexie zou aldus een correctiemechanisme kunnen vormen voor onverschilligheid to.v de omgeving, voor een te ver doorgeslagen idiosyncrasie van een systeem, voorzover het althans een zelfbeperking van systemen met het oog op de functionele vereisten van andere systemen impliceert. Een aldus benutte, 'rationaliserende' reflexie impliceert echter nog geenszins, dat de systemen in de omgeving nu plotseling transparant worden. Hoeveel energie een systeem ook in het 'Verstehen' van de systemen in zijn omgeving stopt, d.w.z: hoezeer een systeem ook tracht om op basis van zijn eigen(l) differenties te observeren welke differenties ten grondslag liggen aan de autopoiesis van het geobserveerde systeem, uiteindelijk, zo weten ook gezinstherapeuten, stuit al het Verstehen op een onophefbare intransparantie, op een grens die als het ware de autopoietische autonomie van het geobserveerde systeem belichaamt.

Het door Teubner en Willke gepropageerde model van "context sturing" gaat er nu vanuit; dat deze intransparantie/autonomie wordt erkend en gerespecteerd. Natuurlijk zien ook Teubner en Willke dat zuivere 'zelfsturing' op het niveau

Steuerung durch reflexives Recht", in: Zeitschrift fur Soztologie 1984, p.4-35. Imteressant is overigens, dat met mame Willke aanvankellijk nog geprobeerd heeft, om een synthese tot stand te brengen tussen het denken van Habermas en dat van Luhmann. Een echo daarwan is nog bespeurbaar bij Walter Reese-Schäfer.

585. Idem, p.642. Verg. ook Okologitohe Kommunikation, op.cit, Hfst.XX 'Zur Rationalitat okologischer Kommunikation', p. 249 e.v. 
van de functiesystemen geen oplossing biedt voor de centrifugale, desintegratieve tendensen die aan functionele differentiatie inherent zijn. Als premisse van alle interventie en sturing moet volgens hen echter gelden, dat het te sturen systeem zelf een probleemdruk percipieert die dermate sterk is, dat het daarop zelf met veranderingen wil reageren. Maar ook dan heeft een autoritair, dirigistisch ingrijpen van de politiek geen zin; het leidt hooguit tot afweerreacties, eventueel zelfs tot haperingen in de autopoiesis van een functiesysteem en functie-uitval. Wat Teubner en Willke onder de vlag van het 'reflexieve recht' als sturingsinstrument aanbevelen, gaat er daarentegen vanuit, dat het recht slechts als een 'eingeladene Eindringling' de functie van een katalysator voor (systeem-eigen) veranderingen kan vervullen. In concreto denken zij daarbij aan de wettelijke instelling en regulering van die instituties en onderhandelingsfora die kenmerkend zijn voor wat in Nederland bekend staat als de 'overleg-economie' - die, ruimer geformuleerd; typisch zijn voor een 'onderhandelingsmaatschappij'. Een langs die (neo-corporatistische) lijn opererend politiek systeem ziet er van af, om direct en beslissend in te grijpen in maatschappelijke conflicten, gebruikt zijn wetgevende competenties daarentegen om raden en fora in te richten, waarbinnen de verschillende maatschappelijke deelsystemen de last die ze van elkaar ervaren, onder behoud van hun autonomie kunnen uitdiepen en reguleren. In Nederland denken we daarbij al snel aan het geïnstitutionaliseerde overleg tussen werkgevers, werknemers en de overheid, of tussen de medische wereld, de ziekenfondsen, eventueel patiëntenverenigingen en de overheid, etc. Politieke sturing via het recht wordt door Teubner en Willke dan begrepen als een 'Konditionierung der Selbststeuerung', waarbij het conditionerende element gelegen is in het terugdringen van verzelfstandigingstendenzen en de hoop is gevestigd op een verdergaande. 'rationalisering' van de functiesystemen door ze een van overheidswege georganiseerde 'spiegel' voor te houden, d.w.z: door ze met zachte hand te dwingen te observeren hoe ze door andere functiesystemen worden geobserveerd. ${ }^{586}$

Op dit model van 'context-sturing' middels 'reflexief recht' is van verschillende kanten kritiek geleverd. Zo is er bij herhaling op gewezen, dat het vermogen tot zelfsturing van de functiesystemen een collectieve handelingscapaciteit veronderstelt, die door Teubner en Willke niet, of althans niet voldoende wordt toegelicht, terwijl duidelijk is, dat binnen het ramwerk van Luhmanns theorie functiesystemen niet als macro-actoren kunnen worden voorgesteld. ${ }^{587}$

586. Zie voor een soort 'samenwatting' van het bovenstaande: H.Willke, Systemtheorie entwickelter Gesellschaftem, Munchen 1989, p.5.7-60.

587. Verg. o.a. N.Luhmann, Die Wintschaft der Gesellschaff, FrankfurtM. 1988, p.321; Idem, Soziologte des Risikos, op.cit, p.172. Zie voor 'critici" a. U. Schimank, "Politische Steuerung in der Organisationsgesellschaft, in: W. Zapf (Hg) Die Modernisienung moderner Gesellschaften, FrankrutM: 1992, p.505-517; J. Weyer, "System und Akteur', in: KZifSS 45 (1993), p. 1-22. 
Daarnaast is er, o.a. door Renate Mayntz, op gewezen, dat er binnen het model van context-sturing geen ruimte is voor de rol en effecten van reel bestaande, ongelijke verdelingen van macht en invloed over de verschillende functiesystemen. ${ }^{588}$ Klaus Bendel probeert daarentegen, min of meer met Luhmann in de hand, het autopoietisch-gesloten karakter van functiesystemen te relativeren, om daarmee de angel te trekken uit de (re)constructie wan een sturingsprobleem die eerst zin en richting geeft aan de voorstellen van Teubner en Willke. ${ }^{589}$ Niet alleen geldt, volgens Bendel, dat functiesystemen elkaar nodig hebben om niet in hun eigen contingenties te verdrinken, maar bovendien moeten we er vamuit gaan dat, analoog aan de emergentie van sociale systemen uit de dubbel contingente ontmoeting tussen twee psychische systemen, ook uit de 'interferentie' tussen functiesystemen zelfstandige communicatiesystemen van een hogere orde emergeren, door hem aangeduid als 'intersystemische Diskursen'.

'Die strukturell bedingte Eigenselektivität dieses abergreifende Kommunika-tionszusammenhangs... impliziert vielmehr ein autonomes Operations-potential der Gesellschaft, mit dem diese auf die Entwicklungsrichtung der Funktionsbereiche zurthckwirkt und ihren Reproduktionsimperativen im Rahmen intersystemische Diskurse Geltung verschafft. ${ }^{390}$

Als we met Bendel mogen aannemen dat de moderne maatschappij uit zichzelf en wel in de vorm van 'intersystemische' discoursen een tegenwicht biedt aan het particularisme van haar functiesystemen, dan betekent dat inderdaad een behoorlijke relativering van de sturingsproblematiek en is de door Teubner en Willke voorgestane context-sturing eerder een reconstructie van een beinvloedings- en conditioneringssamenhang die zich als het ware "vanzelf" insteit. Eind jaren tachtig - om precies te zijn: op 12 september 1988 - lijkt de door Luhmanns maatschappijtheorie geïnspireerde sturingsdiscussie op een ontknoping af te stevenen. Alhoewel Luhmann zelf altijd de nodige afstand had

Of deze kritiek onversweden kan worden gehandhaafd, is twijfelachtig. Zo rekent Teubner wel degelijk met en op een via 'organisatie" en 'zelfbinding' tot stand gebrachte collectieve handelingscapaciteit Zie bijv. G. Teubner, 'Hyperzylklus in Recht und Organisation. Zum Verhaltnis von Sellostheobachtung, Selbstkonstitution und Autopoiese', in: H.Haferkamp/M.Schmid ( $\mathrm{Hg}_{\mathrm{g}}$ ), Simm, Kommunikation und soziale Differenzierung,

Frankfurt/M.1987, p.89-129, i.h.b. p.113 e.v.
588. Zie R. Mayntr, "Politische Steuerung und gesellschaftiche Steuerungsprobleme Ammerkungen zu einem theoretischen Paradigma", in: Jahrbuch zur Staats- und werwaitungswissenschaft 1 (1987), p.89-110.

589. Zie voor het nu volgende: KBendel, "Funktionale Differenzieung und gesellschaftliche Rationalitat', in: Zeitschr.f. Soziologie 22 (1993), p. $261 \cdot 278$.

590. Idem, p.274. 
gehouden tot Teubners en Willkes voorstellingen omtrent "reflexief recht" ${ }^{\text {s91 }}$, is hij dan persoonlijk uitgenodigd om te Darmstadt, op het congres van de "Deutscher Vereinigung für politische Wissenschaft" in het krijt te treden tegen Fritz Scharpf, een van de leidende figuren binnen de Duitse politicologie. Scharpf opent zijn polemiek met de constatering, dat Luhmanns denken over politieke sturing zich in de woorbije jaren nogal eenzijdig heeft ontwikkeld. ${ }^{592}$ Weegt Luhmann in zijn Politische Theore im Wohlfahrtsstaat uit 1981 nog de voor- en nadelen af van zowel expansieve als restrictieve opvattingen van politiek, in Okologische Kommunikation (1986) treedt Luhmanns sturingspessimisme al sterker op de voorgrond, om in Die Wirtschaft der Gesellschaft uit 1988 definitief te verharden, aldus Scharpf. En dan volgt een in wezen empirische tegenwerping:

'Wenn Luhmann recht hätte, dan mußite man sich zuallererst daraber wundern, daß in funktional differenzierten Gesellschaften doch so vieles einigermaßen befriedigend funktioniert - und zwar nicht nur innerhalb der einzelnen Funktionssysteme, sondern auch im Verhalltnis zwischen diesen und der staatlich werfaßten Politik: Die Wirtschaft bietet trotz aller Proteste bleifreies Benzin an, wenn die Umweltpolitik das so vorschreibt; das Bildungssystem hat in Realktion auf politische Interventionen die neue Mathematik eingefluhrt und dann wieder abgeschafft.... 593

$\mathrm{Nu}$ had de congresorganisatie kunnen weten, dat Luhmann (trouw aan de autopoiesis van zijn eigen theorie??) zich zelden of nooit door 'externe' omstandigheden tot discussies op het scherpst van de snede laat verleiden en al helemaal niet door een overvolle zaal. Alsof hij er plezier in schept hooggespannen verwachtingen te frustreren, begint Luhmann zijn "repliek" met te melden, dat hij zelf er niet aan twijfelt, dat pogingen tot sturing effect hebben - 'Steuerungbemühungen haben selbstverständlich Effekte'. ${ }^{594}$ Om daar vervolgens enigszins obligaat aan toe te voegen, dat sturing echter nooit alles tegelijk kan veranderen en soms meer, soms minder bewerkstelligt, dan in de bedoeling lag. De rest van zijn 'Diskussionsbeitrag' besteedt hij aan een

591. Zile bijv: N. Luhmann, "Einige Probleme mit 'reflexivem Recht" in: Zeitschrift für Rechtssoziologie 6 (1985), p.I - 18; verg. ook I. Maus, "Perspektiven reflexiven Rechts" im. Kontext gegenwatitiger Deregulierungstendenzen", in: Kritische Justiz 1986, p. 390 405, i.h.b. p. 391 .

592. Verg. voor dit en volgende: F.W. Scharpf, 'Politische Steuenung und politische Institutionen', in: Politisches Verteliahresschrift 30 (1989), p.10-21.

593. Idemm p.12.

594. N. Inuhmann, 'Politische Steuerung: ein Diskussionsbeitrag', in: Pol. Viertelfh 30 (1989), p.4. Verg. in deze ook V. Ronge, 'Politische Steuenung - innerhalb und auBerhalb der Systemitheorie', in.: K. Dammann/D.Gnunow/K.P.Japp (Hrsg.), Die Verwallong des politischen Systems, Opladen 1994, p. 57. 
eonceptuele verheldering en precisering van wat er met 'sturing" wetenschappelijk gezien bedoeld kan worden - 'wovon uberhaupt die Rede sein soll'. En dan blijkt al snel, dat Luhmann onder 'sturing' iets anders verstaat, dan het toegestroomde publiek, Scharpf incluis, en lijkt de hele bodem onder de discussie te zijn weggeslagen. Volgens Luhmann moet 'sturing' namelijk begrepen worden als 'terugdringen van differentie', als 'het afzwakken, zo niet opheffen van verschillen'. Een dergelijk concept van 'sturing' laat weliswaar nog ruimte voor teleologische benaderingen, voor 'Zweckorientierung", voorzover het 'doel' gedacht kan worden als het 'verschil' met de situatie die ontstaat wanneer men niets zou doen, maar het grote voordeel schuilt er volgens Luhmann in, dat 'doel-oriëntatie' nu als een bijzonder geval van een algemener principe kan worden begrepen en we ons dus los kunnen maken van de beperkingen van een teleologisch sturings- begrip. ${ }^{595}$ Enkele jaren later terugkijkend op de hele discussie schrijft Luhmann:

'Wenn ich mich kritisch zu Steuerungstheorien der üblichen Art äußere, so liegt dem die (wohl nicht unberechtigte) Annahme zu Grunde, daß diese Theorien mit Steuerung die Bestimmung von Systemzustănden meinen. Daß kybernetische Steuerungen im Hinblick auf spezifische Differenzen möglich sind und massenhaft vorkommen, sollte damit nicht bestritten sein. ${ }^{596}$

Olie op de golven, of een afleidingsmanoeuvre? In ieder geval heeft niet iedereen aan de Darmstadter-discussie het gevoel overgehouden, dat Luhmann op de kern van de zaak was ingegaan, laat staan dat hij de discussie had" beslecht. Zo blijft Rottleutner opponeren tegen de klakkeloze aanname van "the Myth of a Regulatory Crisis" - "especially as put forward in West Germany by Luhmann, Teubner and Willke':

'There has been no attempt to prove it by giving a comprehensive picture of the approaches and results of research on the efficacy of law or of implementation and evaluation research. Instead the rellative succes of the theories of reflexive law or 'autopoietic' law (..) in the academic field is attributable to a certain atmosphere in which political clichés constitute a "plausibility structure' within which assumptions about the litigation flood or regulation flood, as well as about regulatory crisis and deregulation, can easily be framed. ${ }^{597}$

595. Zie Idem, p. 5.

596. N. Luhmann, "Steuerung durch Recht? Einige klarstellende Bemerkungen', in: Zeitschr. ff" Rechtssoziologie 12 (1991), p. 144.

597. H. Rottleuthner, "The Limits of Law - The Myth of a Regulatory Crisis", in: International Jowrmal af Saciology of Law 17 (1989), p.274. 
Degene die zich nog het sterkst is blijven verzetten tegen alles wat binnen discussies over de "crisis van de welvaartsstaat" naar Luhmann zweemt, is misschien wel de politiek-econoom Peter Nahamowitz. ${ }^{598}$ Het kader van waaruit Nahamowitz ageert wordt gevormd door het concept wan het 'georganiseerde kapitalisme'. Daarin laat zich - Nahamowitz legt er eer in, openlijk zijn kaarten te tonen - de "Austro-marxistische" traditie herkennen, gemengd met een flinke scheut Keynes. Politiek-ideologisch gesproken, komt dit neer op de "eis", dat de overheid het kapitalistisch economisch systeem met zijn ingebouwde anarchische tendensen voortdurend moet blijven bijsturen en dit in de veronderstelling, dat 'zu wirksamen und umfassenden Organisationsmaßnahmen unter allen gesellschaftlichen Teilsystemen und sozialen Institutionen einzig der Staat im stande (ist) ${ }^{3599}$ Tegen die achtergrond wordt Nahamowitz er niet moe van, de propagandisten van het 'reflexieve recht' onder de neus te wrijven, dat ze in feite een wat verlate golf voorstellen van het neoliberale/neo-conservatieve tij dat al halverwege de jaren zeventig op kwam. En Luhmanns sturingspessimisme is in Wahrheit nichts anderes als die Wiederauflage des liberalen Interventionstabus in neuem theoretischem Gewand. ${ }^{6000}$ $\mathrm{Nu}$ maken dergelijke vormen van politiek geëngageerde ideologiekritiek halverwege de jaren tachtig weinig indruk meer binnen de geïnstitutionaliseerde sociologie, zij het alleen al omdat ze bij een reflexieve toepassing op zichzelf direct hun pointe verliezen. Dat heeft Nahamowitz zelf ook begrepen en zijn afkeer van al het Luhmanniaans geinspireerde sturingspessimisme dan ook ondersteund met een vracht aan empirisch materiaal, waaruit zou moeten blijken, dat politieke sturing en regulering van (met name) het economisch systeem niet alleen mogelijk is, maar bovendien op een "akzeptabler Wirksamkeit' kan rekenen. De vraag is alleen, waar dit in de context van een theoretisch opgeladen sturingsdiscussie toe leidt. Niet alleen kunnen de theoretici van het 'reflexieve recht' op hun eigen 'empirie' wijzen ${ }^{601}$, het getuigt bovendien van naĭviteit om in discussies met door de wol geverfde constructivisten te verwachten, dat empirische data voetstoots zullen worden erkend als van alle sturingstheorieën en -modellen onafhankelijke gegevens, die

598. Zie van hem o.a. P. Nahamowitz, 'Reflexives Recht': Das unmögliche Ideal eines postinterventionistischen Stewerungskonzept', in: Zeitschrift fitr Rechtssoziologie 6 (1985), p.2944. Idem, Effektivitht wirtschattsrechtlicher Steuerung - Ein Beitrag zur AutopoiesisDebatte', in: Kritische Jkstiz (1987), p.411 433, Idem, Autopoiesis oder ökonomisoher Staatsinterventionismus", in: Zeitschr, Rechtssoz. 9 (1988), p. 36-73, Idem "Autopoietische Rechtstheorie: mit dem baldigen Ableben ist zu rechnen", in: idem 11 (1990), p.137-160.

Mar vergelijk ook: H.F.P. Jetswant, "The Conference on Reflexive Law and the Regulatory Crisis", in Zeitschryf fur Rechtssoziologie 1983, en I. Nocke "Autopoiesis Redrtssoziologie in selisamen Schleifen", in: Kritische Justiz 1986, p. 363 -389.

599. P. Nahamowitz, "Autopoiesis oder okonomischer Statsinterventionismus", op cit, p.38.

600. Idem, p.42 en P. Naharnowitz, "Reflexives Recht", op.cit., p.32.

601. Bijwoorbeeld op het werk wan F. Traxl en G. Volmuba - zie wan hen o. a: 'Selbststeuerung alls funktionales Aequivalent zum Recht?', im: Zeitschrift fitr Soziologie 16 (1987), p.3-15. 
de discussie op een objectieve, dwingende wijze kunnen beslissen. Empirische argumenten blijven in deze onmachtig, wanneer ze niet verbonden kunnen worden met een kritiek op de grondslagen van Luhmanns denken. Anders geformuleerd: empirische tegenwerpingen tegen een 'Luhmanniaans" sturingspessimisme winnen aan kracht, wanneer plausibel kan worden gemaakt, dat het daarin tot uitdrukking komende gebrek aan realiteitsbesef in feite een onvermijdelijke consequentie is van de theoretische beslissingen en conceptualiseringstrategiečn die aan de autopoietische systeemsociologie, annex maatschappijtheorie, thberhaupt ten grondslag liggen.

Natuurlijk is door de critici van het 'reflexief recht' en van de systeemtheoretische diagnose van de "sturingserisis" naar een dergelijke argumentatiefiguur gezocht. ${ }^{602}$ De discussie overziend, kunnen (minimaal) drie pogingen om een empirisch geinspireerd ongenoegen om te zetten in een meer theoretische kritiek, worden onderscheiden. Om te beginnen hebben Nahamowitz, Joachim Nocke en tot op zekere hoogte ook Walter Kargl de theoretische wortel van al het kwaad in het autopoiesis-concept op zich gezocht. ${ }^{603}$ Dat is in zoverre triviaal, als uit Luhmanns "autopoietische" differentiatietheorie niet alleen volgt, dat de modeme maatschappij onderhevig is aan centrifugale, desintegratieve krachten, maar bovendien, en wel dwingend, dat het politiek systeem de processen binnen de andere functiesystemen niet gericht kan sturen of 'determineren' en dat 'regulering": uiteindelijk slechts als 'zelfregulering' kan lukken. Nu kunnen bovengenoemde critici er inderdaad op wijzen dat Luhmann yóór zijn 'autopoietische Wende' maatschappelijke stabiliserings- en sturingsmogelijkheden optimistischer inschatte, dan daarna. ${ }^{604}$ De tegenkritiek, dat daarmee de zaak wordt omgedraaid, ligt echter voor de hand. Voor Willke of Ronge schuilt de aantrekkingskracht van Luhmanns "autopoietische' differentiatietheorie nu juist daarin, dat het een theoretisch gestuurde observatie en beschrijving mogelijk maakt van een probleemcomplex dat zich hoe dan ook binnen de maatschappij kenbaar maakt.

602. Bijw. door Nahamowitz, die grag zijn planken van wat dikker hout zaagt: "Das gesellschaftspolitische Defizit der Systemtheorie hat allerdings seinen methodischen und daher tiefsitzende Grund. Das kategoriale System erhebt den Anspruch, als allgemeine Theorie sozialer Systeme sowohl fur personale Interaktionen als auch Organisationen und Gesellschaftssysteme gleicherweise aussagekräftig zu sein. Es üst nicht verwunderliclia, daB eine Theorie wielche Skatrunden, Kegelvereine, multinationale Konzerne sowie das Gesellschaftssystem als Ganzes mittels einer prinziptell identischen Begrifflichkeit analysiert, den Kontakt zu den Alarmsignalen der gesellischaftlichen Bodenstation verliert. ( $P$. Nahamowitz, "Reflexives Recht', op.cit., p.35.)

603. Verg. van de nog niet geciteerde Kargl o.a.: W. Kargl, "Kommunikation kommuniziert? -Kritik des Rechissoziologischen Autopoiesebegriff's', in: Rechsstheorje 21 (1990), p.352-373; Idem, 'Gesellschat ohne Subjekte oder Subjekte ohne Gesellschaft? - Kritik der rechtssoziologische Autopoiese-Kritik", Zeitschrift für Rechtssoziolagie 12 (1991), p.120141.

604. Verg. bijv. N. Luhmann, "Die Weltgesellschaft", opgenonen in: Soziologische Awfklarung 2 , Opladen 1975, p.51-72, en Idem, 'Evolution und Geschichte', in idem, P.150-170. 
Voor Scharpf, die toch al enige distantie tot Nahamowitz wil bewaren, zit het probleem niet zozeer in Luhmanns omarming van het autopoiesis-concept, als wel in zijn beslissing om 'communicaties" i.p.v. 'handelingen' of "actoren' tot de elementaire eenheden van sociale systemen te verklaren. Proberen we de empirisch gemotiveerde twijfell aan de uitkomsten van Luhmanns maatschappijtheorie terug te voeren op de premissen die aan zijn sociologie ten grondslag liggen, zo schrijft Scharpf, 'dann erscheint die Fokussierung auf "autopoietische" - sich selbst reproduzierende - Systeme vielleicht sogar als weniger folgenreich dann die Beschränkung auf Kommunikationssysteme ${ }^{9605}$ Wehiswaar beschikt Luhmann over de categorie "handelen", maar dat is, gedacht als het produlkt wan de simplificerende zelfobservatie van communicatie-processen, een 'subjectloos' handelen. Scharpf gaat er daarentegen vanuit, dat 'politische Steuerung als Chance der zielstrebigen Selbstveränderung des Gemeinwesens sich ohne Rthckgriff auf Subjekte politischen Handelns nicht konzipieren [lä3t]. ${ }^{606}$

Net als de eerder aangehaalde kritiek van Nahamowitz, Nocke en Kargl treft ook de kritiek van Scharpf op een triviale wijze zijn doel - 'triviaal' in die zin, dat er natuurlijk een onloochenbaar verband bestaat tussen het uitgangspunt dat sociale systemen worden geconstitueerd door communicatieprocessen en Luhmanns bedenkingen tegen het idee dat de politieke sturing van functiesystemen begrepen kan worden volgens het model van een intentionele (micro/macro-) actor die op strategische wijze vooropgestelde doelen tracht te realiseren. Het probleem dat men met beide kritieken kan hebben, is alleen, dat we nu wel erg snel terug zijn bij 'af': Wie het autopoiesisconcept of de communicatietheoretische interpretatie van sociale systemen afwijst, wijst natuurlijk Luhmanns sociologie integraal af. $\mathrm{Nu}$ kunnen daar allerlei goede redenen voor bestaan. De vraag is echter of een integrale afwijzing van Luhmanns sociologie, zuiver en alleen op grond van de onvrede die men kan hebben met de positie(s) die Luhmann en zijn volgelingen in de sturingsdiscussie innemen, niet veel weg heeft van het bekende badwater waar nog een kind in zat.

Minder rigoreus is in ieder geval een derde, eveneens naar aanleiding van de sturingsdiscussie geuite kritiek op Luhmanns benadering. We treffen deze ook bij Scharpf aan en wel in de vorm van het verwijt, dat Luhmann bij zijn analyse

605. F. Scharpf, op cit, p. 12 .

606. Idem. Scharpf deelt overigens Luhmanns scepsis ten aanzien van het analytisch potentieel van actor-theoriean inzake maatschappelijke sturingsproblemen voorzover het theorieen betreft, die van concrete, afzonderlijke individuen en hun intenties vitgaan. De hele problematiek komt, volgens Scharpf, echter in een ander dagticht te staan, wanneer we ons op constellaties van strategisch handelende, collectieve of "corporatieve" actoren richten en de oriëntatie op particuliere sturingsintenties en hum on/bedoelde gevolgen vervangen door speltheoretische analyses. 
van sturings- en reguleringsproblemen overmatig de nadrik legt op het aspect van functionele differentiatie. ${ }^{607}$ 'Politieke sturing' betreft bij Luhmann eerst en vooral een relatie of 'interactie' tussen uitgedifferentieerde, voor elkaar intransparant geworden functiesystemen. Problematisch aan dit "primaat van het maatschappijsysteem' is niet zozeer, wat Bendel Luhmann verwijt, namelijk dat niet inzichtelijk wordt gemaakt, waarom functiesystemen elkaar tuberhaupt trachten te beînvloeden ${ }^{608}$, het probleem is veeleer dat dit niet het juiste niveau van analyse is, wanneer het om politieke sturing gaat! Wel beschouwd, betreft sturing een relatie tussen uiteenlopende vormen van georgamiseerde communicatie, de poging om middels 'staatkundig' georgamiseerde communicatie het gedrag van andere organisaties te beïnvloeden. Politieke sturing, zo zou men ook kunnen formuleren, betreft de poging om middels in wetten en decreten neergeslagen, collectief bindende beslissingen het beslisgedrag van bijv. economische, of wetenschappelijke organisaties te beïnvloeden, maar richt zich niet direct op de basale operaties van een functiesysteem zelf: Of zoals Uwe Schimank het op grond van zijn empirisch onderzoek naar de problemen en mogelijkheden van een politieke sturing van het door Duitse onderzoeksinstituten verrichte werk verwoordt: 'Der primåre Zugriffspunkt forschungspolitischer Steuerung sind nicht Forschungshand-lungen; sondern Forschungseinrichtungen - also formale Organisationen" ${ }^{609}$

Deze derde (en voorlopig laatste) kritiek komt positief geformuleerd neer op het voorstel, om in de analyse van sturingsmogelijkheden/-problemen het primaat niet langer te leggen bij het systeem "maatschappij" en zijn subsystemen, maar politieke sturing eerst en vooral te beschouwen als een verschijnsel of probleem dat de verhoudingen tussen organisaties betreft, waarbij 'maatschappij' als een typisch gestructureerde, conditionerende context verschijnt. Natuurlijk plaatst ook dit voorstel de sturingsdiscussie in een ander daglicht, dan waarin Luhmann, Willke of Teubner het zien ${ }^{610}$ Het impliceert echter geenszins een

607. Verg F. Scharpf, op.cit., p.15. Zie verder o.a. R. Mayntz, 'Differenzierung und Verselbstandigung - zur Entwicklung gesellschafticher Teilsysteme" in R. Mayntz

e.a, Differenzierung und Verselbständigung Zur Entwicklung gesellschaflicher Teilsysteme, Frankfurt/M. 1988 p.11-45, i.h.b. p.37; B. Rosewitz/U.Schimank, "Verselbstàndigung und politische Steuerbarkeit", in: idem, p.295-329, i.h.b. p. 317 e.v.

608. Zie K. Bendel, op, cit, pi:270:

609. U. Schimank, "Politische Steuerung in der Organisationsgesellschaft - am Beispiel der Forschungspolititi", in: W/2apf (Hg) Die Modernisierung moderner Gesellschaftem, Frankfünt/M. 1992, p.506.

610. Alhoewel - recenteliijk is ook Willke, zich afzettend tegen Habermas' idee dat in laatste instantie slechts interactionele communicatie de bron van cen 'vemunftige Identitat' kan wormen, tot de conclusie gekomen, dat het probleem van de rationele inrichting en wormgeving van de samenleving in de relatie tussen 'organisatie" en 'maatschappij" ligt: "Die wichtigste Hindemisse auf dem Weg zu einer vernanftigeren Identität gegenwärtiger Gesellschaften liegen nicht auf der Ebene personaller Interaktion, sondern auf der Ebenen der Interaktion von Organisationen und Funktionssystemen." (H. Willke, 'Staat und Gesellschaft', in: Damman/Grunow/Japp (Hrsg.), Die Venwaltung des politischen Systems, Opladen 1994, p.25) 
integrale verwerping van Luhmanns sociologie. We kumnen er om te beginnen aan vasthouden, dat 'organisaties' autopoietische systemen voorstellen die emergeren als zelfreferentieel gesloten netwerken van beslissingen. 'Beslissingen' zijn en blijven in deze optiek 'communicaties' en dat volstaat ook om tegemoet te komen aan de o.a. door Scharpf en Schimank verlangde modellering van handelingscapabele macro-actoren. Functiesystemen kumen we ons inderdaad niet als handelingsbekwame eenheden voorstellen; organisaties kunnen echter door 'zelfbinding' een ge-unificeerde handelingscapaciteit ontwikkelen, zich als hiërarchisch gestructureerde 'actor-systemen' profileren. De erkenning van dit laatste, inclusief de al eerder gedane constatering, dat de ontwikkeling van organisaties tot 'macro-actoren een via beslissingsprogramma's gecontroleerde intput/output-oriëntatie vergemakkelijkt (zie Hfst.4, \& 2.1), impliceert nog niet een heimelijke terugkeer naar intentionalistische, handelingstheoretische benaderingen. ${ }^{\text {sI }}$

Het is ook niet zo, dat nu plotseling de hele sturingsproblematiek is verdampt, als zouden economische, juridische, wetenschappelijke, etc. organisaties als was in de handen van de politiek zijn. Ook organisaties zijn zelfreferentieel gesloten, en op grond daarvan "autonome' systemen die telkens hun eigen, locale 'logica" volgen. Houden we er nu aan vast, dat die autopoietische geslotenheid van organisaties tevens de basis van hun 'openheid' vormt, dan komen we uit op een positie die in grote lijnen overeenstemt met het zowel theoretisch als empirisch onderzoek dat zogeheten 'neo-institutionalisten' als Schimank en Johannes Weyer naar sturingsvraagstukken hebben gedaan. ${ }^{612}$ De consequentie daarvan is wel, dat een Luhmanniaans geïnspireerd sturingspessimisme gerelativeerd dient te worden.

Misschien is het bovenstaande te defensief van toon en komt de behandeling van de kritiek, dat Luhmanns inschatting van de sturingsproblematiek op een negatieve wijze gedirigeerd wordt door zijn theorie van de functioneel gedifferentieerde maatschappij, teveel over als een 'redden-wat-er-nog-teredden-valt". Benaderen we de sturingsdiscussie echter niet vanuit Luhmanns maatschappijtheorie, maar vanuit zijn organisatiesociologie, dan valt er, met

611. Misschien kan het geen kwasd om er nog eens op te wijzen, dat alhowel Luhmann weinig brood ziet in teleologische denkfiguren en "doelrationaliteit" woor hem geen sociologisch grondbegrip kan zijn, zowel zijn algemene sociologie als zijn organisatietheorie wel degelijk ruimte laat voor viteenlopende vormen wan doel-oriëntatie. Voor Luhmann is het punt niet, dat actoren of sociale systemen geen doelen zouden kunnen nastreven, maar dat een theorie en i.h.b. een sturingstheorie die dat als vertrekpunt neemt, niet complex genoeg gebouwd is on de complexe sociale werkelijktheid to beschrijven - "Wer einen Zweck in die Welt setzt, mulk dann mit dem Zweck gegen die Welt spielen - und das kann nicht gut gehen oder jedenfalls nicht so wie er denkt" (N. Luhmann, Die Wirtschaft der Gesellschaft, Frankturt/M. 1988, p.330.)

612. Verg. van: Uwe Schimank, naast de eerder geciteerde werken, ook: 'Gesellschaftliche Teillsysteme als: Akteurfiktionen', in: KZ/SS 40 (1988), p.619 e.v. Zie ook: J.Weyer, "System und Akteur", in idem 45 (1993), p.1-22. 
Luhmann in de hand, eigenlijk veel te zeggen voor het voorstel om sturingsproblemen eerst en vooral te analyseren in termen van een beüvloeding van organisaties door organisaties ${ }^{633}$ Zonder hier een alternatief sturingsmodel te presenteren, willen we slechts op de volgende zaken wijzen:

- Luhmann stelt zelf wast, dat organisaties een maatschappelijk milieu veronderstellen waarin beslissingen en beslissingscapaciteit in raime mate aanwezig zijn - "Entscheiden in der Organisation wird fur sich selbst nur plausibel, wenn es Entscheidungsprozesse auch in der Umwelt voraussetzen kann, so daß die Systemgrenze nicht nur als Trennlinie 'fungiert, sondern zugleich als Zuordnungsregel für Entscheidungszusammenhänge. ${ }^{.614}$ Niet alleen voorziet de politiek-bestuurlijke organisatie die we 'overheid' of 'staat' noemen in een belangrijk quanturn aan observeerbare beslissingen, maar bovendien zijn de moderne overheidsburokratieën voor hun eigen functioneren aangewezen op "beslissingen" in hun omgeving - "die Organisationsmechanismen des Rechtssystems und der Wohlfahrtsbürokratie rasten nur ein, wenn sie davon ausgehen können, das ihre Klienten entscheiden. ${ }^{615}$ In die zin kunnen we uitgaan van een symbiotische relatie tussen het overheidsapparaat en andere maatschappelijke 'beslis'-systemen.

- Alloewel organisaties normaliter binnen de context van specifieke functiesystemen ontstaan en zich middels hun programma's daar ook aan conmitteren, d.w.Z. primair economische, juridische, wetenschappelijke, medische, etc. organisaties zijn, kunnen we er vanuit gaan, dat ze, abstract beschouwd, dezelfde 'taal' spreken, de taal van 'beslissingen'. ${ }^{616}$ Bovendien zijn hiërarchische organisaties bekend met de 'grammatica' van collectief bindende beslissingen, als datgene wat hun een ge-unificeerde handelingscapaciteit verleent. In die zin kunnen we er vanuit gaan, dat in weerwil van de affiniteit die normaliter bestaat tussen een organisatie en een specifiek functiesysteem, tussen organisaties onderling niet een zelfde informationele/observationele kloof bestaat als tussen gecodeerde functiesystemen. Organisaties zijn, anders gezegd,

613. Daarmee zilj niet verhuld, dat Luhmann zelf weinigg op heefl met een dergelijke omschakeling van perspectief De keren dat ik zelf aanwezig ben geweest bij gesprekken en discussies met Luhmann hierover, is zijn tegenwerping steeds geweest, dat het belang van organisaties niet moet worden overdreven. Voorzower ik zelf kan nagaan, bestaan de enig beschikbare "notullen" hieromtrent uit een door André Kieserling en Georg Krilcken opgetekende 'Seminardiskussion' (Universituit Bielefeld, Febr. 1994), als manuscript verkrijgbaar ander de titel 'Die Wissenschaft der Gesellschaft: Fragen an Niklas Luhmann'.

614. N. Luhmann, "Organisation und Entscheidung"; opgenomen in Soziologische Alwflarung 3, Opladen 1981, p.361; zie ook: N. Luhmann, Die Wirtschaft der Gesellschaft Frankfurt/M. 1988, met daarin op p 289 de opmerking: 'Burokratien lieben Burokratien oder setzen sive in ihrer Umwelt einfach vorans.'

615. N. Luhmiann, "Organisation und Entscheidung,", op.cit, p. 360.

616. Verg. N. Luhmann, "Organisation im Wirtschaftssystem", in: Soziologische Aufkldirung 3, op.cit., p.392. 
uberhaupt gevoelig voor beslissingen, hetgeen resonantie woor andere, dan de eigen opties forceert.

- Zoals de politiek (via het recht op belastingheffing) macht transformeert in geld, transformeren organisaties (via 'budgetierten Stellen') geld in macht ("Weisungsunterworfenheit"). Zonder deze mogelijkheid kunnen modeme organisaties niet functioneren - "Wer Organisation braucht, braucht Geld' ${ }^{617}$ ? Zo beschouwd, zijn alle organisaties direct of indirect aan het economisch systeem als de 'thuisbasis' van het medium 'geld' gekoppeld, spreken alle organisaties ook altijd de, door de differentie betalen/niet-betalen gecodeerde taal van de economie. 'Alles Handeln in Organisationen ist zugleich Handeln im Wirtschaftssystem und, als solches Handeln im Gesellschaftssystem. Wirtschaft und Gesellschaft sind fur die Organisationen Zusammenhảnge, die das Organisationssystem und dessen Umwelt abergreifen. ${ }^{618} \mathrm{Nu}$ heeft Luhmann zelf ooit gesuggereerd dat 'geld' als schaarse bron een correctief voor de verzelfstandiging van functiesystemen zou kunnen vormen ${ }^{619}$ Daar is o.a. door Rosewitz en Schimank tegenin gebracht, dat aangezien geld slechts een kwantitatieve invloed heeft op het gedrag van functiesystemen, maar niet inhoudelijk discrimineert tussen gewenste en ongewenste vormen van functiespecifieke autonomie, dit ons weinig verder helpt als het gaat om het probleem van de negatieve effecten die verzelfstandigde functiesystemen op hun omgeving hebben ${ }^{620}$ Die kritiek blijft voor een deel overeind, wanneer we van het niveau van functiesystemen afdalen naar organisaties - de overheid kan met geld per slot wan rekening wel onderzoeksactiviteiten stimuleren, maar geen nieuwe wetenschappelijke 'waarheden' afdwingen op de door haar gewenste terreinen. Desalniettemin geldt voor organisaties in verhevigde mate, dat ze gevoelig zijn voor beslissingen die hun beschikking over geld beïnvloeden, een gevoeligheid war politieke beslissingen inzake subsidies, belastingheffing of juridische strafbaarstelling gericht op in kunnen spelen.

Al met al lijkt de eenzijdige nadruk die Luhmann in zijn analyse van politieke sturingsmogelijkheden legt op het systeem 'maatschappij' en zijn structuren, ten koste van een organisatietheoretische benadering, een misgreep. Dat is als algemene uitkomst van de sturingsdiscussie een welhaast onoverkomelijke conciusie. Er is vooralsnog echter geen reden om aan te nemen, dat deze misgreep en het daarop stoelende sturingspessimisme noodzakelijk volgt uit de

617. N. Luhmann, Die Wirtschaft der Gesellschaft, op.cit, p.307.

618. Idem, p.308.

619. Mehr Geld ist die kategorische Optativ dieser Gesellschaft, gerade weil alle Erhaltungs- und Steigenungsanspriche damit in Gang gehalten werden können; und weniger Geld ist zugleich dlas einzige Regulativ, das auf der Ebene symbolischer Kommunikation die Grenzen des Erreichbaren ... representiert." (N. Luhnann, "Amspruchsinflation im Krankheitssystem" P. Herder-Dorneich/A,Schuller (Hrsg), Die Anspruchsspirale - Schioksal oder Systemidefekt?, Stuttgart 1983, p.39.)

620. Rosewitz/Schimank, op.cit., p.302. 
centrale premissen van een Luhmanniaanse sociologie. Eerder lijkt zich een omissie te wreken die we al in het vorig hoofdstuk aan de orde hebben gesteld en daar kritiseerden als het ontbreken bij Luhmann van een algemeen theoretisch model van de verhouding (formele) organisatie - (moderne) maatschappif . Interessant genoeg biedt de bovenstaande kritiek en discussie voldoende aanknopingspunten om deze leemte in leder geval ten dele op te vullen. We herinneren er om te beginnen aan, dat volgens Luhmann organisaties normaliter gerelateerd kunnen worden aan een specifiek maatschappelijk functiesysteem, waar ze zich via hun programma's als het ware toe 'bekennen'. In Luhmanns eigen woorden:

\begin{abstract}
Normalerweise sind Organisationen der modernen Gesellschaft auf jeweils eines der gesellschaftlichen Funktionssysteme spezialisiert: Industrie-unternehmen und Banken auf die Wirtschaft, Kirchen auf das Religionssystem, Schulen auf das Exziehungssystem, politische Parteien und Interessenvertretungen auf das politische System. ${ }^{3621}$
\end{abstract}

We kunnen echter tegelijkertijd vaststellen, dat het in organisaties nooit alleen en uitsluitend om één vorm van functioneel gespecialiseerde communicatie gaat. Als complexe, gelaagde systemen van beslissingen dirigeren ontwikkelde organisaties niet alleen economische, maar bijvoorbeeld ook juridische, wetenschappelijke, technische, etc. handelingen. Een bedrijf als Philips "organiseert', anders gezegd, niet alleen economische communicatie, maar matuurlijk ook communicatie die tot het finctiesysteem 'wetenschap' behoort, of tot het recht, of tot het gezondheidssysteem. Fritz Scharpf heeft met het oog hierop van een gedwongen 'veel-taligheid' gesproken:

'Organisationen können es sich also nicht leisten, nur eine einzige Funktionssprache zu sprechen - sie müssen multilinguale Kommunikationskompetenz erwerben und je nach Bedarf zwischen Funktionslogiken wechseln können. Deshalb gibt es in Unternehmen Rechtsabteilungen; deshalb haben große Forschungsorganisationen nicht nur einen wissenschaftlichen, sondern auch ein kaufmänmischen Geschaftsführer... ${ }^{622}$

Zo beschouwd, fungeren organisaties als maatschappelijke "ruimtes' voor de wisselwerking, of zo men wil, "interpenetratie" tussen functiesystemen, begrepen als gecodeerde communicatieprocessen. Daammee wordt niet ontkend,

621. N. Luhmann, "Zwischen Gesellschaft und Organisation - Zur Situation der Universitaten", opgenomen in: Soziologische Aufklärung 4, Opladen 1987, p.205.

622. F. Scharpf, op:cit., p.16. 
dat de juridische afdeling wan een onderneming zich eerst en vooral -aan de differentie recht/ourecht orienteert, net zoals een wetenschappelijke divisie slechts "wetenschappelijk" kan zijn op voorwaarde dat de daarin ondergebrachte communicatieprocessen zich aan de Leitdifferenz van het wetenschapssysteem orienteren. In die zin, zo zou men kunnen zeggen, herhaalt het particularisme van de functiesystemen zich binnen de organisatie. Tegelijkertijd gaat het hier echter om een 'langszij' leiden van communicatieprocessen onder het gezichtspunt van een overkoepelend, programmatisch verankerd primat van het functiesysteen waarin de organisatie zichzelf lokaliseert. Tegenover de heterarchie op het niveau van de functiesystemen kunnen organisaties hiërarchie inzetten, om de interpenetratie tussen functiesystemen te kanaliseren en in het licht van programmatische doelstellingen te conditioneren. Organisaties die daar niet in slagen, kunnen simpelweg niet overleven.

Tegen deze achtergrond zouden we als hypothese kunnen formuleren, dat de opkomst en algehele verbreiding van (formele) organisaties die zo kenmerkend zijn voor de modeme tijd, een functionele noodzaak voorstelt, uitgaande van de veronderstelling, dat maatschappelijk gezien het moderniseringsproces eerst en vooral een proces van functionele differentiatie is geweest. Als een kanalisering van de wisselwerking en afstemming tussen gecodeerde communicatieprocessen dempt 'organisatie' de destabiliseringstendenzen die typisch zijn voor functioneel gedifferentieerde maatschappijen. Organisaties neutraliseren, het "particularisme' van de functiesystemen, een eigengereidheid die zonder breideling de integriteit van de moderne maatschappij van meet af aan zou ondermijnen. Met deze, vooralsnog zeer algemene hypothese springen we bewust in het gat, dat Luhmann heeft achtergelaten als het gaat on de verhouding tussen zijn organisatiesociologie en zijn maatschappijtheorie. De vraag is echter, of hiermee niet ook een ander probleem gereactiveerd wordt, namelijk de eveneens eerder gesignaleerde kwestie, in hoeverre Luhmanns voorstelling van 'maatschappij" als een zelfstandig sociaal systeem adequaat is. Kunnen we ons de door organisaties telkens locaal bemiddelde integratie van gespecialiseerde communicatieprocessen voorstellen als een verhouding tussen autopoietisch opererende sociale systemen, waarbij een specifiek type sociale systemen, namelijk organisaties, de interpenetratie tussen geheel andersoortige sociale systemen, namelijk functiesystemen, forceert? Met deze vraag bevinden we ons al halverwege de volgende paragraaf.

\section{\$4. Kritiek (II): de demarcatie van functiesystemen}

Van buitenaf bezien heeft de sturingsdiscussie de vorm gehad van een empirisch geinspireerd ongenoegen met een, door Luhmanns maatschappijtheorie gesuggereerd sturingspessimisme, een ongenoegen dat zich als een corrosief zuur 'naar binnen' heeft gevreten. Een zelfde beeld dringt zich op naar aanleiding van discussies rond de empirische demarcatie van 
functiesystemen. ${ }^{623}$ Nog in de context van de sturingsdiscussie had Nahamowitz al naar voren gebracht, dat als Luhmann meent, dat het economisch systeem zich overal daar bevindt, waar betalingen geschieden en dit ongeacht het doel terwille waarvan geld wordt overhandigd, dat dan de hele sturingsdiscussie onzinnig wordt, omdat nu iedere 'afgrenzing' ontbreekt, die als blokkade van sturing zou kunnen functioneren. ${ }^{624}$ Betaald wordt er immers in iedere uithoek van de maatschappij (en met weloverwogen gierigheid) - aan de overheid, door de overheid, in de kerk en door de kerk; voor kunst en met kunst, etc. Soortgelijks geldt in een gejuridificeerde samenleving ook woor het techt - en wie zou de alomaanwezigheid van macht willen ontkennen. ${ }^{625}$ Parallel daaraan heeft Renate Mayntz geopperd, dat indien alle betalingen - 'ob sie nun im Rahmen von Tauschprozessen in der Wirtschaft, als Spende von Gläubigen in einer religiösen Kultgemeinschaft oder aber in der Wissenschaft von einer Stiftung an einen Forscher geleistet werden' - per definitie tot het economisch systeem behoren, Luhmanns theorie, analytisch gezien, natuurlijk prachtig eenduidig wordt, maar dit op kosten van "đas Selbstverständnis des Gläubigen, der Stiftung und des Forschers, was den Sinn ihrer Handlungen angeht" ${ }^{626}$ Voor de kerkgangers hoort het tenslotte iets uit te maken of ze hun geld aan de koster of aan een tollenaar geven.

Kritiek in de lijn van Nahamowitz zou Luhmann waarschijnlijk pareren met de opmerking, dat dit alleen een probleem voorstelt voor onverbeterlijke "ontologen" die zich functiesystemen niet anders kunnen voorstellen, dan als naar tijd en ruimte netjes afgegrensde verzamelingen van voorgesorteerde handelingen. En op Mayntz zou Luhmann ongetwijfeld antwoorden. dat hij als socioloog niet erg onder de indruk is van een theoretische "Vergewaltigung" (Mayntz) van de subjectieve zin die individuele actoren aan hun handelingen geven. Daarmee is echter het meer algemene probleem van een empirische operationalisering van functiesystemen nog niet van tafel geveegd. Men zou eventueel nog kunnen accepteren, dat met een bepaling als "communicatie-diezich-richt-op-de-code-waar/onwaar' op theoretisch-modelmatig niveau een halarscherp onderscheid is aangebracht tussen het wetenschapssysteem en alles wat daarvan de omgeving vormt; in concreto stelt zich echter de vraag of we moeten accepteren, dat de aanmaning aan de getuige van een misdrijf on de waarheid te spreken, een wetenschappelijke communicatie voorstelt, simpelweg omdat hier de on/waarheid van uitspraken in het geding is. Geldt een gesprek in.

623. Verg. voor het nu volgende T.Blom/L.Timmermans, "Recht is Recht is Recht is....". in: Recht en Kritiek 19 (1993), p.48-78, i.h.b. p.68-72

624. Zie P. Nahamowitz, 'Effektivität wirtschaftsrechithicher Steuerung', in: Kritische Justuz $(1987), p .430$.

625. Verg. W. Kargl. :Kommunikation Kommuniziert - Kritik der rechtssoziologischen Autopoiesebegriffs", in: Rechtsheorie 21 (1990), p.352-373, i.h.b. p.365-367.

626. R. Mayntz, 'Funktionelle Teilsysteme in der Theorie sozialer Differenzierung', in: R.Mayntz e.a., op.cit., p. 30 
de kroeg over het onrecht dat iemand door zijn ex-vrouw is aangedaan, als een 'rechtscommunicatie", een "elementaire operatie van het rechtssysteem'? Zijn TV-documentaires over prominente politici zelf politieke communicaties? Behoren de colleges die aan een medische faculteit worden gegeven tot het onderwijs-, wetenschaps- of gezondheidssysteem? Dat we hier met een serieus probleem te maken hebben, mag o.a. daaruit blijken, dat wanneer Luhmann zelf op demarcatieproblemen stuit, zijn behandeling ervan bepaald niet uitblinkt door vastberadenheid. Als voorbeeld kan zijn worsteling met de afgrenzing van het rechtssysteem dienen.

Aanvankelijk ging Luhmann er vanuit; dat birnen het relevantiebereik van het rechtssysteem een kembestand moet worden onderscheiden, gevormd door 'handelingen met rechtsgevolgen'. De these luidde vervolgens, dat handelingen "nur dann die Qualität einer Elementareinheit des_Rechtssystems erhalten können, wenn sie die Rechtslage ändern' ${ }^{627}$ De zelfreproduktie van het recht voltrekt zich, zo beschouwd, als een voortdurende rechtsverandering - 'als Ubertragung der Qualität normativer Geltung auf partiell neue Erwartungen ${ }^{\text {628. }}$. Daarmee is weliswaar een empirisch operationaliseerbaar afbakeningscriterium geleverd, maar de prijs is hoog. Allerlei vormen van juridische consultatie, overleg of onderhandelen die we normaal gesproken als rechtscommunicaties zouden opvatten, of in ieder geval als handelingen die typisch tot het rechtssysteem behoren, worden nu buitengesloten op grond van de overweging dat ze niet (of niet direct) de rechtstoestand veranderen. Het lijkt tamelijk verregaand om bijvoorbeeld het optreden van een advocaat voor de rechtbank, of onderhandelingen over eventuele schikkingen niet tot het rechtssysteem te rekenen; zolang het niet een verandering van de rechtstoestand tot gevolg heeft. In een artikel uit 1986, getiteld 'Die Codierung des Rechtssystems' lijkt Luhmanns blik te zijn verruimd. Nu heet het, dat (gecommuniceerde) rechtsaanspraken op een empirisch eenduidige wijze tot het rechtssysteem kunnen worden gerekend. "Von Operationen im Rechtssystem wird man immer dann sprechen können, wenn es um Rechtsbehauptungen (claims, Geltungsansprüche) geht; sei es, daß sie direkt aufgestellt werden; sei es dal3 ihre Möglichkeit vorbereitet wird; etwa durch Formulierung eines Vertrages oder durch Einholung von Rechtsauskunft. ${ }^{\times 29}$ Kortom, wanneer binnen de context van het rechtssysteem gecommuniceerd wordt gaat het altijd om de voorbereiding, het opstellen, het verhelderen van rechtsaanspraken, het beslissen daarover, etc. In een meer algemene formulering heet het "daß der Code ausschließlich dem prozessieren won Rechtsbehauptungen dient ${ }^{1630}$.

627. N. Luhmann, "Die Einheit des Rechtssystems", in: Rechtstheorie 14 (1983). p.136.

628. idem

629. N. Luhmanm, "Die Codlerung des Rechtssystems", in: Rechtstheorie 17 (1986), p.179

630. idem 
Deze benadering heeft als consequentie, dat ook pogingen om (een toekomstig vaststellen van) onrecht te voorkomen, als elementaire operaties van het rechtssysteem dienen te worden aangemerkt. En inderdaad gaat Luhmann er nu zelf van uit, dat bijvoorbeeld een oproep tot burgerlijke ongehoorzaamheid verhinder dat de overheid onrecht begaat! - eveneens als het stellen van een rechtsaanspraak moet worden beschouwd. Daaraan laat zich echter ook het probleem van deze aanpak aflezen. De grenzen van het rechtssysteem lijken nu enorm te worden opgerekt. ${ }^{631}$ Is iedere oproep tot burgerlijke ongehoorzaamheid een elementaire operatie van het rechtssysteem? Is iedere publieklijk verheven aanspraak op een bepaald recht een rechtscommunicatie? Mag bijvoorbeeld de claim op een basisinkomen daarvoor doorgaan?

In een recenter artikel schoteit Luhmann nog een andere optie voor. ${ }^{632}$ Bij de beschrijwing van het rechtssysteem, zo wordt geopperd, gaat het om een tweetal zaken, namelijk om 'beschikking' ('Verfügung') en 'argumentatie'. Van "beschikking" is sprake wanneer door wetgeving, gerechtelijke uitspraken, verdragen, testamenten, etc. de 'rechtstoestand' verandert, d.w.z. een wijziging optreedt in wat tot dan toe juridische geldigheid had: 'Tagtaglich vollzieht das Rechtssystem eine Unmenge von Verfügungen gleichzeitig, es verändert also unaufhörlich, ähnlich wie ein Gehim den eigenen Zustand, von dem es im nächsten Moment auszugehen hat, und weicht damit von Moment zu Moment von der Umwelt ab. ${ }^{633}$ In onderscheid met zijn vroegere positie, waarin als de eigenlijke eenheden van het rechtssysteem die gebeurtenissen/handelingen werden aangemerkt die de rechtstoestand veranderen ('handelingen met rechtsgevolgen'), wordt er nu vanuit gegaan dat het rechtssysteem zich niet uitsluitend als samenhang van 'beschikkingen" laat observeren en beschrijven: 'Es hat auch mit undisponiert anfallende Tatbestände zu tun und benutzt vor allem die Operationsform der Argumentation"634 Middels 'argumentatie', bijv. in de vorm van de rechterlijke motiveringsplicht, van requisitoir of pleidooi, controleert het systeem de wijze waarop het over de codewaarden recht/onrecht disponeert. En voor de rechtstheorie (niet noodzakelijkerwijs voor de rechtssociologie) gaat het daarbij om de vraag of er voor de vaststelling dat iets 'recht' is, of juist 'onrecht", goede gronden bestaan.

Deze korte schets van een drietal opties inzake de empirische demarcatie van het rechtssysteem mag volstaan, om te demonstreren hoe weinig trefzeker Luhmann is, wanneer hij zelf voor het probleem wordt gesteld, een functiesysteem op een concrete, operationaliseerbare manier van andere, voor het betreffende functiessysteem irrelevante communicatieprocessen af te grenzen. En eigenlijk is dit weinig verwonderlijk. Wat hier in de gedaante van

631. Verg. in deze o.a. de kritiek van W. Kargl, Gesellschaft ohne Subjekte oder Subjekte ohne Gesellschaft", in: Zeitschriff far Rechsssoziologie 12 (1991), p.120-141, i.h. p. 365 e.w.

632. Het betreft: $\mathbb{N}$. Luhmann, 'Die Geltung des Rechts", in: Rechtstheorie $22(1991)$, p. 273-286

633. Idem, p. $282 / 283$

634. Idem,p. 283 
een methodologisch probleem aan de oppervlakte komt, is in feite de uitdrukking van een tweeslachtigheid die al in de modelmatige uitgangspunten van Luhmanns maatschappijtheorie is ingebouwd. Het demarcatieprobleem komt bij Luhmann daaruit voort, dat hij er vanuit gaat (a) dat codering het dominante mechanisme van de uitdifferentiatie en grensafbakening van functiesystemen vormt en tegelijkertijd vasthoudt aan het idee (b) dat functiesystemen sociale systemen voorstellen.

- ad a) We hebben over een wliegtuigongeluk al eens opgemerkt; dat cen dergelijke gebeurtenis voor het rechtssysteem een andere betekenis en andere consequenties heeft, dan voor het wetenschapssysteem, voor de economie of voor een bepaald gezin. Het vliegtuigongeluk 'is' voor de verschillende functiesystemen steeds iets anders en dit als resultaat van de telkens systeemspecifieke, code-gestuurde vorm van observatie en informatieverwerking. Deze "poly-realiteit' heeft, on het zo uit te drukken, een typische 'binnenkant": funktionele differentiatie leidt niet tot de vorming van regionen die zich in "dingmatige" (ontologische) zin wan elkaar onderscheiden, leidt niet tot tijdruimtelijk identificeerbare verzamelingen of reeksen van woorgesorteerde gebeurtenissen/-communicaties/handelingen/etc. ${ }^{635}$ Het gaat bij funktionele differentiatie om het uitdifferentieren van Leitdifferenzen" als "Informationspotentiale', als 'Möglichkeiten aber etwas als 'dies und nichts anderes' zu kommunizieren und Informationsverarbeitung kann dann als Erzeugung von Differenzen durch Differenzen begriffen werden'. ${ }^{636}$ Functionele differentiatie, zo zou men ook kunnen zeggen, wordt bij Luhmann niet verankerd in onderscheidingen op het basale niveau van communicaties als de elementaire eenheden van systeemproduktie en -reproduktie, maar primair in differentiële codes die semantische onderscheidingen voorstellen. Daarin, in het feit dat het niet om een differentiatie van zijnsregionen gaat, die næar tijd en ruimte gezien exclusief zijn, maar om een differentiatie van semantische differenties ligt volgens Luhmann precies ook het voordeel van een maatschappelijke differentiatie op basis van codering: "Operationsketten können blitzschnell von Reclitscode zum politischen Code, wom Wissenschaftscode zum Wirtschaftscode umschalten, usw. ". ${ }^{67}$ Wat communicatieprocessen daartoe nodig hebben, is slechts de negatie van de hier en nu actuele 'Leitdifferenz' en de selectie van een nieuwe differentie als geziehtspunt van informatieverwerking. Functiesystemen verschijnen zo, als rond centrale differenties opgebouwde 'semantische velden' (Kneer/Nassehi), of om een wat oudere uitdrukking te gebruiken: als "Sinnprovinzen" (Schutz), waarvan lopende communicatieprocessen zich ter eigen situering en oriëntatie kunnen bedienen, zoals ze zich ook in ruime mate

635. Verg. N. Luhmann, Okologische Kommunikation, Opladen 1986, p.86.

636. N. Luhmann, 'Distinctions directrices', opgenomen in: Soziologische Aufklorung 4 Opladen 1987 , p. $15 / 16$.

637. N.Luhmann, Ökologische Konmumikation, Opladen 1986, p.87. 
- en 'blitzschnell' - uit de culturele voorraadkast van thema"s kunnen bedienen. ${ }^{638}$

- ad b) Luhmann gaat er tevens vanuit, dat functiesystemen zich als autopoietische subsystemen van de maatschappij uitdifferentiëren. Als zodanig bestaan functiesystemen uit zichzelf structurerende reeksen van opeenvolgende, "aansluitende" gebeurtenissen - en of we die nu als communicaties of als handelingen beschrijven, gebeurtenissen kunnen we ons niet anders voorstellen dan als naar tijd en ruimte eenduidig gelokaliseerde en identificeerbare entiteiten. Als sociale systemen, zo moeten we concluderen, emergeren functiesystemen wel degelijk als onderscheiden, zichzelf organiserende 'zijnsregionen'. En net zoals 'interacties' en 'organisaties' als spatio-temporeel gelokaliseerde processen empirisch identificeerbaar zijn, roept ook de interpretatie van functiesystemen als autopoietische sociale-systemen onvermijdelijk de vraag op naar hun empirische demarcaties.

Als historisch geronnen 'Sinnprovinzen" of "orientatiesystemen", zo kunnen we het bovenstaande samenvatten, is Luhmanns conceptie van functiesystemen nog wel verenigbaar met zijn vroegere, meer 'structurele' opvatting van sociale systemen, maar niet met het idee, dat functiesystemen middels codering als autopoietische sociale systemen uitdifferentiëren. Het dilemma dat zich hiermee aftekent, lijkt duidelijk: We geven ofwel een autopoietische interpretatie van sociale systemen op, ofwel Luhmanns model van functionele differentiatie.

Eveneens vertrekkend vanuit het demarcatieprobleem, en op min of meer parallelle gronden heeft Bela Pokol in een interessante bijdrage aan het debat voorgesteld om bij de empirische operationalisering van functiesystem uit te gaan van de "professionelle Institutionensysteme" als de institutioneelorganisatorische kern van de uitgedifferentieerde maatschappelijke subsystemen. ${ }^{699}$ Daarbij kunnen we er op rekenen, aldus Pokol, dat dergelijke subsystemen via recruterings-, socialiserings- en sanctioneringsmechanismen het verschil tussen henzelf en alledaagse, of onder andere gezichtspunten

638. In Die Wirtschaff der Gesellschaft lijkt Luhnam deze zienswijze er bij de lezer min of meer in te willen hameren, wanneer hij er bij herhaling op wijst, dat het voor de atbakening er autonomie van functiesystemen slechts nodig is om te kunnen onderscheiden, in en galerie bijvoorbeeld tussen de schoonheid van een kunstwerk en de prifs arvan. In een algemenere formulering: 'Es ist wichtig festzuhalten, dalB Unterscheidungsvermbgen verlangt ist und daB es nicht beliebig sondern strukturell vorgeregelt ist., um welche Unterscheidungen wich handelt. Dile Struktur des operativ erforderlichen Unterseheidungsvermögens kann mithin als Indikator fur die Striktur gesellschaftlicher Differenzienung benutzt werdien. "En even verder:"Noch einmal: Wer hier nicht unterscheiden kann, kann sich in der hautigen Gesellschaft nicht adäquat orientieren. "(Die Wirtschaft der Gesellschaft, $\mathrm{p}, 321$ en p. 322.

639. Zie B. Pokol, 'Professionelle Institutionensystemen oder Teilsysteme der Gesellschaft?', in: Zeilschrift für Soziologie 5 (1990), p.329-344. 
gespecialiseerde communicaties zelf owereind houden en via symbolen en rituele passages kracht bij zetten ${ }^{640}$ :

'Die strukturelle Differenzierung der gesellschaftichen Subsysteme ist also auf die Ebene der professionellen Institutionensysteme einzuengen. Nur so können Sozialstrukturen zustandekommen, die die einzelnen Differenzierungen zwangsläufig aufrechterhalten. ${ }^{\text {64 } 41}$

In termen van het hierboven geschetste dilemma is dit natururlijk een keuze voor de tweede hoorn, yoor het opgeven van Luhmanns model van functionele differentiatie. Met het idee immers, dat functiesystemen hun grenzen en dus zichzelf reproduceren via het professioneel-organisatorisch complex en de daarin verankerde recruterings- en socialiseringsmechanismen, staat Luhmanns hele concept van 'functiesystemen' als uitgedifferentieerde subsystemen van de 'maatschappij' ernstig op de tocht, en daarmee zijn hele maatschappijtheorie. De consequentie die Pokol trekt is dan ook,

'daß die Systemebene 'Gesellschaft' aufzulosen und neben der Kategorie der professionellen Institutionensysteme (als eingeengte Form der fruheren Kategorie des gesellschaftichen Teilsystems) die des Alltagslebens einzuführen ist. Die evolutionäre Ausdifferenzierung dieser Systeme kann damn nicht mehr als Ausdifferenzierung voneinander, sondern als Hervorhebung dieser spezifisch-spezialisierten Kommunikationsbereiche aus der diffusen Alltagswelt thematisiert werden. ${ }^{2642}$

Wij willen hier op een minder radicale optie wijzen, op een alternatief waarvoor binnen Luhmanns werk aanknopingspunten bestaan en waarmee we in ieder geval uitzicht houden op een algemene maatschappijtheorie. Als vertrekpunt kan daarbij de vaststelling dienen, dat we in de moderne maatschappij met een drietal, onderling niet reduceerbare, systemisch gestructureerde communicatie-

640. Zo watakt het rechtssysteem via regulering van de toegang tot het professioneel-organisatorisch complex en middels institutioneel verankerde controles op de operaties daarbinnen voorteirend over de juridisch-rechtelijke kwaliteit van zijn eigen handelingen. Niet alleen geldt, dat slechts diegenen toegang tot de professie verkrijgen die (gereguleerde) bewijzen van hun kennuss wan het recht kunnen overleggen, bovendien zien rechters, procureurs en adwacatenordes er op toe, dat leden van de professie daadwerkelijk op specialistische wijze geinvolveerd zijn in de juridisch-rechtelijke beslissingsprocessen waar zo officieel bif betrokken zijn. (Verg. "T.Blon/L Timmermans, "Recht is Recht is Recht is..." in: Recht ey" Kritiek 19 (11993), i.h.to p.68 e.v)

641. B. Pokol, op.cit, p.335.

642. Idem, p.334. 
processen te maken hebben, te weten: 'interactie", 'organisatie' en "anonieme' of 'gemedieerde communicatie'. Lulhmanns autopoietische interpretatie van 'interactie" en 'organisatie' nemen we daarbij grosso modo over. Met 'gemedieerde communicatie' - men denke bijv. aan de gecomputeriseerde, wereldwijde aan- en verkoop van aandelen via beurzen, of aan wetenschappelijke publicaties - doelen we op wat Luhmann aanduidt als 'anonieme' communicatie, met de toevoeging, dat bij gebrek aan de afstemmingsmechanismes waarover interacties onder 'aanwezigen' beschikken (zie Hfst. $V$, $\$ 2.1$ ), gemedieerde communicaties 'organisatie' parasitair benutten terwille van hun stabilisering als autopoietische sociale systemen. Zo geldt voor wetenschappelijke publicaties, dat ze slechts wetenschappelijke publicaties kúnnen zijn, voorzover ze een onderdeel vormen van een bepaalde stroom van (via citatie) op elkaar reagerende, 'aansluitende' wetenschappelijke publicaties - en dat veronderstelt, naast het gedrukte schrift als "medium", tevens 'organisaties" in de vorm van wetenschappelijke instituten, bibliotheken, uitgeverijen, tijdschriftredacties, etc.

In tegenstelling tot de drie zojuist onderscheiden sociale systemen vatten we functiesystemen niet op als systemisch gestructureerde communicatieprocessen, maar als rond centrale differenties of 'codes' ontwikkelde en op maatschappelijke functies gespecialiseerde betekenisstelsels. In die hoedanigheid dienen functiesystemen eerst en vooral de algemene sociale 'situering' of 'typificatie' van concrete, bijzondere communicaties. De achterliggende gedachte daarbij is, dat functiesystemen, begrepen als gespecialiseerde "semantische velden", op een specifieke manier inspelen op het feit, dat locale handelingsconstellaties steeds zijn opgenomen in algemenere structuren, hun zin mede ontlenen aan gegeneraliseerde en generalisenende conventies, normen, rollen, instituties, etc. Anders gezegd: sociale systemen realiseren zichzelf steeds onder een dubbel gezichtspunt, namelijk als de hier en nu concrete opeenvolging van communicaties én als onderdeel van een wijdere, "maatschappelijke" zinsamenhang.

Dit, in wezen klassiek-sociologische inzicht kunnen we ook formuleren met behulp van de termen 'zin', "contingentie', 'selectie' en 'complexiteit". Vasthoudend aan de gedachte, dat sociale systemen uit spatio-temporeel identificeerbare communicatieprocessen bestaan, zeggen we dan, dat de zin van concrete communicaties altijd een tweetal dimensies van contingentie omspant. De ene, locaal-situatieve dimensie betreft de zin van particuliere handelingen als selectief aansluitende 'reacties' op voorafgaande handelingen en dit in een omgeving die primair wordt gevormd door psychische systemen en hun waarnemingen. De andere, abstract-algemene dimensie betreft de, boven de concrete situatie uit verwijzende zin van communicaties en de daarin tot uitdrukking komende selectiviteit van het communicatieproces als een bepaald type communicatie naast of i.p.v. andere mogelijke, zinmatig samenhangende communicatieprocessen. 
Functiesystemen, zo kunnen we nu nader specificeren, dienen middels typificatie de reductie van de complexiteit die zich in de abstract-algemene dimensie aandient als een in eerste instantie open bereik van zinmatig mogelijke communicatie- of handelingsprocessen. De zaak van de andere kant benaderend, zouden we ook kunnen zeggen, dat (alle drie de) sociale systemen het abstract-allgemene karakter van functiesystemen benutten ter compensatie van de locale contingenties die ze als spatio-temporeel gesitueerde systemen op ieder moment (re)produceren, of om het bijzondere voordeel daarvan vis-à-vis 'alledaagse', niet functioneel gespecificeerde communicatie naar voren te halen: door zichzelf in de context van een functiesysteem te plaatsen en daarmee een preselectie van de hier en nu relevante contingentiebereiken over te nemen, kunnen sociale systemen hun locale contingenties doen toenemen.

Tegen deze achtergrond laten zich bijvoorbeeld de 'laboratorium studies' van Latour/Woolgar, Karin Knorr en Michael Lynch in een 'omgekeerde richting' lezen. Noodgedwongen voorbijgaand aan de empirische rijkdom van deze studies kunnen we als hun grote 'ontdekking' het inzicht aanmerken, dat de concrete, locale praktijken van het wetenschapsbedriif, zoals die in onderzoekslaboratoria worden aangetroffen, in hoge mate worden gekenmerkt door een 'situationeel opportumisme?. ${ }^{643}$ De handelingen van individuele onderzoekers, hun verknoping met het onderzoek van anderen en met de aanwezige onderzoeksapparatuur, de plannen en projecten die ze opstellen, de instrumenten die wordt aangeschaft - dat alles, zo luidde de boodschap van de 'Laboratorium studies', wordt sterk beïnvloed en gestuurd door contingente locale omstandigheden. Misschien niet voor de 'ingewijden', maar vergeleken met het denken over wetenschap (en techniek) dat zich nog sterk oriënteerde aan normerende wetenschapstheorieën en dat de vooruitgang in de wetenschap bij voorkeur verklaarde uit methodologische disciplinering, $\mathrm{kan}$ inderdaad van een belangrijke 'ontdekking' worden gesproken. Tegelijkertijd geldt echter, en daarin bestaat de pointe van ons 'tegenlezen', dat laboratoria en aanverwante onderzoekslocaties kunnen 'functioneren' en zichzelf in de tijd reproduceren, omdat de interacties, de organisatorische beslissingen en de output aan publicaties die tezamen de sociale realiteit van het onderzoeksinstituut vormen, in een algemener en veralgemeniserend kader zijn opgenomen, dat we kunnen omschrijven als 'het bedrijven van wetenschap", het 'functiesysteem wetenschap' of simpeler: als het 'wetenschapssysteem'. Wat we eerder als het 'situationeel opportunisme' van de 'wetenschappelijke werkvloer' aanduidden en dat zich empirisch gezien voordoet als een tamelijk chaotische, door 'ad hoc'-reacties en contingente motieven gesturde opeenstapeling van

643. Zie voor dit en het nu volgende: U. Schimank, Gesellschattliche Teilsysteme als Aktenrfiktionen: in KZFSS 40 (1988), p.619-639. Schimanik, aan wie ik de werwijzing naar de 'Iaboratorium studies' ontleen en die vanuit zijn 'actor-theoretische' perspectief do laboratorium studies in de 'gangbare' richting leest, spreekt over concrete sociale situaties beeldend als "Brutstatte fur Kontingenzen" (op.cit., p.631). 
gebeurtenissen, is verdraagbaar en kan bovendien toenemen, precies op grond van de complexiteit reducerende functie van het overkoepelende maatschappelijke subsysteem warbinnen de sociale systemen die het onderzoeksinstituut vormen zichzelf situeren.

De structuren of 'mechanismen' waarvan sociale systemen zich middels de selectie van een functiesysteem bedienen om hun locale contingenties op te vangen en te compenseren, hebben we eerder leren kennen als "codering"; 'programmering', 'semantieken' en de uit reflexieve zelfobservatie emergerende 'meta-beschrijvingen' en '-theonieên'. Deze mechanismen fungeren niet alleen als compensatoren van de 'zakelijke' en 'sociale' contingenties die actuele communicatieprocessen kenmerken - over de waargenomen uitkomst wan een experiment kan op allerhande wijze worden bericht; de persoonlijke achtergronden, wetenschappelijke opleidingen en verwachtingen van de aanwezigen kunnen zeer verschillend zijn; enz. - maar hebben ook betrekking op de temporele dimensie, d.w.z. op de verknoping van qua tijd en ruimte uiteenlopende handelingsprocessen. Zo moet de output van een onderzoeksinstituut om aan te kunnen sfuiten op, en aansluitbaar te zijn voor elders verricht onderzoek in een vorm worden gebracht - de 'publikatie' - waaruit de contingenties die in de concrete onderzoekssituatie speelden voor het overgrote deel zijn verdwenen. Het werken aan een publikatie is zuiveringsarbeid zuivering zowel in de zin van "wegzuiveren" van wat officieel niet relevant is als in de zin van sublimeren, opschonen en aanpassen. Deze zuivering voltrekt zich niet willekeurig, maar wordt gedirigeerd door de "regels vam het spel", door de officiële methodologie en de daarin vervatte normen en criteria waaraan een publikatie moet voldoen - in Luhmanniaanse termen: door de codespecifieke programma's van het wetenschapssysteem. Bovendien hebben, naast en ondanks alle contingenties die de werkvloer kenmerken, de eisen waaraan toekomstige publicaties moeten voldoen, ook een constitutieve betekenis voor de concrete inrichting van het onderzoek - de leiding schaft gestandaardiseerde apparaten en vloeistoffen aan; men neemt : specifiek gekwalificeerde medewerkers in dienst, etc. Al met al induceert de officiele methodologie een enorme opruiming van zakelijke en temporele contingenties. En de traditionele wetenschapsgeschiedenis loopt daar nog eens achteraan, om alle locale geschiedenissen glad te strijken en sociale contingenties te herleiden op grote namen en genieën.

Wat we hier aan de hand wan het wetenschapsbedrijf hebben hebben opgemerkt omtrent de complexiteit dempende en generaliserende betekenis van functiesystemen geldt ook voor andere deelgebieden van de maatschappij ook de aankoop van een brood voltrekt zich enerzijds als een concrete, temidden van zakelijke, sociale en temporele contingenties gesitueerde gebeurtenis, anderzijds als een instantie van het economisch systeem. Met dit alles wordt overigens niet beweerd, dat communicatieprocessen zichzelf per definitie 'functioneel' specificeren - voor vluchtige communicatie kan de algemeen structurerende functie van het aangesneden thema volstaan. De these die wij 
hier presenteren, is echter, dat sociale systemen door zichzelf aan functiesystemen te committeren, hun situatieve contingenties kunnen laten toenemen, daarmee hun locale complexiteit én hun innovatieve vermogens. Met het oog op deze laatste, evolutietheoretisch relevante aanname kunnen we de zaak ook algemener formuleren en er vanuit gaan, dat de differentiatie van maatschappelijke subsystemen uberhaupt tot functie heeft een kader te vormen voor een (mogelijke) complexiteitsstijging op het niveau van sociale systemen - dus ongeacht de vraag, of de vorming van subsystemen zich als een proces van functionele differentiatie voltrekt of de gestalte aanneemt van bijv. een hiërarchische stratificatie.

Voor sociale systemen zijn functiesystemen, om ons daartoe te beperken, observeerbaar als semantische structuren en semantieken, d.w.z. als voor communicatieprocessen beschikbare beschrijvingen van de identiteit, zin of legitiem doel van een maatschappelijk subsysteem, van de (verwachtings)verwachtingen en programma's die daar gelden, etc. Tegelijkertijd kan de (re)produktie van een functiesysteem zich op niets anders verlaten dan op de communicatieprocessen die zich telkens aan het betreffende functiesysteem oriënteren. Een dergelijke vaststelling beweegt zich niet ver buiten de lijn die Luhmann volgt, wanneer hij $\mathrm{m}$ b.t. de verhouding interactie/maatschappij schrijft:

'Die Gesellschaft ist jedoch ihrerseits Resultat von Interaktionen. Sie ist keine Instanz, die unabhängig von dem was sie seligiert eingerichtet ist. (-) Insofern kann man festhalten: Die Gesellschaft seligiert die Interaktionen, die Interaktionen seligieren die Gesellschaft. ${ }^{2644}$

Maar natuurlijk staat dit alles ook niet ver af van Giddens' structuratietheorie, zij het dat wij hier opereren onder het motto "keeping the subject out" en het principe van 'reflexive monitoring' van toepassing achten op sociale systemen, d.w.z. op communicatieprocessen i.p.v. op de handelingen van individuele actoren. $^{645}$

Wij hebben het hierboven in grove lijnen geschetste amendement op Luhmanns matschappijtheorie geïntroduceerd met de opmerking, dat het om een minder radicale optie zou gaan, dan bijv. door Bèla Pokol wordt voorgesteld en dit in de hoop uitzicht te houden op een algemene maatschappijtheorie. Zeker - de suggestie om functiesystemen niet langer als autopoietische sociale systemen op te vatten, maar als "semantische velden" of zo men wil: als culturele systemen, leidt in bepaalde punten tot verregaande modificaties van Luhmanns

644. Soziale Systeme, p $588-589$.

645. Onder 'reflexive monitoring' verstant Giddens de, voor de zin van een handeling constitutieve "controle" van die handeling aan wat de actor weet omtrent de condities en gevolgen van die handeling. Verg. A Giddens, The Consequences of Modernity, Stanford 1990, p.36 e.v. 
maatschappijtheorie, in het bijzonder, zoals we in de slotparagraaf nog zullen zien, waar het zijn concept van 'maatschappij" betreft. Desalniettemin menen we, dat voor het door ons voorgestelde alternatief aanknopingspunten binnen Luhmanns werk zelf bestaan. Niet alleen levert het een gezichtspunt op voor de interpretatieve omgang met passages die bimnen de context van Luhmanns algemene maatschappijtheorie ambivalent zijn - zoals bijv. de eerder geciteerde, 'culturalistische' omschrijvingen van 'maatschappij' -; de modellering van functionele differentiatie als een proces van semantische/culturele differentiatie strookt bovendien met de kennis-, of zo men wil: cultuursociologische methodiek die Luhmann zelf volgt in zijn meer empirische analyses van het moderniseringsproces en de moderne maatschappij. De belangrijkste verbinding met Luhmanns sociologie schuilt evenwel daarin, dat het door ons gesuggereerde alternatief betrokken blijt op het centrale motief van zijn denken: het probleem "contingentie/complexiteit'.

\section{$\S 5$ Ter afsluiting}

Zonder de argumenten daarvoor te herhalen, kumnen we uit dit en het voorafgaande hoofdstuk een tweetal belangrijke, kritische conclusies destilleren. Die luiden:

1) $\mathrm{Bij}$ Luhmann ontbreekt een algemene, systematische theorie aangaande de relatie tussen "formele organisatie' en de "moderne maatschappij". Dit wreekt zich in een eenzijdig-abstracte, weinig realistische lokalisering van politieke sturingsproblemen, met als uitkomst een overdreven 'sturingspessimisme'.

2) Luhmanns model van functionele differentiatie middels codering staat op gespannen voet met zijn karakterisering van functiesystemen als autopoietische handelings - of communicatiesystemen Dit uit zich o.a in de problemen die zich voordoen bij de empirische operationalisering van functiesystemen en hun grenzen.

Met deze twee kritieken worden Luhmanns algemene maatschappijtheorie en zijn diagnostische bevindingen inzake de huidige samenleving geenszins integraal naar de prullenbak verwezen. Ook niet als het om politieke sturing gaat. Al laat zich een overdreven sturingspessimisme relativeren op grond van de overweging dat 'sturing' primair een relatie tussen organisaties betreft, Luhmanns coderingsprincipe blijf desalniettemin een relevant gezichtspunt, wanneer het gaat om de afweging van verschillende sturingsmodellen. Interessant en vruchtbaar blijft ook het observatietheoretische kader, dat Luhmann aanbiedt voor de sociologische analyse van de ontwikkeling en structurele problematiek van 'reflexie-theorieën', zoals rechtstheorieën, kennisen wetenschapstheorieën, etc. We herinneren hier slechts aan wat we ter afsluiting van het vorige hoofdstuk ten berde hebben gebracht. Bovendien lijkt Luhmanns inschatting van de maatschappelijke betekenis van "verbreidingmedia' in het licht van zijn analyse wan een drietal structureel 
gegeven communicatiedrempels - 'bereik", 'begrijpelijkheid' en 'acceptatie" - (zie Hoofdstuk V, \$3) een bruikbaar kader te bieden voor een reflexie op de mogelijke effecten van een om zich heen grijpende informatisering van de samenleving, van digitale snelwegen en aanverwante, wereldomspannende informatienetwerken. Of om op nog een ander, niet eerder aangesneden onderwerp te wijzen: Luhmanns diagnose, dat de modeme maatschappij wordt gekenmerkt door "redundantieverlies", terwijl tegelijkertijd de interdependenties tussen de maatschappelijke subsystemen of deelgebieden toenemen, kan tevens licht werpen op de structurele achtergronden van de zogeheten 'nieuwe vormen van uitsluiting". Wie eenmal de boot mist, blijft de boot missen - wie bijv. geen lagere of middelbare scholing heeft genoten, of wie in de toekomst een computer-analfabeet blijkt te zijn, heeft niet alleen grote kans ook buiten het economisch systeem te worden gesloten, maar mist langs die weg bovendien al gauw de aansluiting op andere maatschappelijke netwerken of subsystemen.

Tegelijkertijd valt echter niet te ontkennen, dat naast alle interessante en prikkelende elementen die Luhmanns analyse van de moderne maatschappij bevat, met name de hierboven als tweede genoemde kritiek; en i.h.b. de alternatieve duiding van functiesystemen die wij op grond daarvan hebben voorgesteld, verreikende consequenties heeft, zowel wan conceptueeltheoretische als van beschrijvend-diagnostische aard. Om slechts het kernprobleem te noemen: geven we het idee op, dat functiesystemen als autopoietische communicatiesystemen kunnen worden geconceptualiseerd, dan geven we onvermijdelijk ook Luhmanns idee van de 'maatschappij' als een bijzonder sociaal systeem op. Per slot van rekening percipieert Luhmann, zoals we hebben gezien, het proces van functionele (uit)differentiatie als een herhaling van de maatschappij binnen de maatsehappij. En precies dat model van differentiatie verleent als de folie van een bijzondere integratieproblematiek aan zijn tijdsdiagnostische verkenningen een specifieke kleur.

Met dit afscheid van Luhmanns maatschappijbegrip is tevens tegemoet gekomen aan het voorheen op analytische en conceptuele overwegingen gebaseerd vermoeden, dat de definitie van "maatschappij" als het omvattend sociaal systeem op anomalieën uitloopt (zie Hoofdstuk V, \& 2.4). Op Luhmanns vraag waar sociale evolutietheorieên of modellen van maatschappelijke differentiatie dan nog betrekking op hebben, kunnen we nog slechts antwoorden: op 'cultuur' als het geheel wan intersubjectief toegankelijke thema's en semantieken waaruit alle communicatie terwille van haar zelfstructurering put. Op Habermas' vraag: "Konnen komplexe Gesellschaften eine vernulinftige Identität ausbilden?" zouden we van de weeromstuit met een tegenvraag willen reageren: op basis wan welke voorstelling van socialiteit kan een 'vernikftige' sociologie worden ontwikkeld. Met die vraag betreden we echter al het terrein van ons slothoofdstuk. 


\section{Hoofdstuk VII}

\section{TOT BESLUIT}

- Normativiteit en Rede -

\section{$\S 1$. Inleiding}

Er ligt nog steeds een probleem op tafel. Met enig kunst en vliegwerk hebben we het tot nog toe voor ons uit kunnen schuiven, maar geduldige critici zullen er ongetwijfeld op hebben toegezien dat het uiteindelijk niet onder tafel verdwijnt: Niet ten onrechte. Wie het zich permitteert om in een kritische samenspraak met het werk van Niklas Luhmann, hardop na te denken over een "verniumfige" sociologie, zal zich vervolgens ook de vraag moeten laten welgevallen, wat de normatieve, zo niet 'politieke' inhoud van een dergelijk project vornt. Per slot van rekening is in de modeme tijd de filosofische ere-titel "verntunftig" altijd gereserveerd geweest voor een denken dat zich niet uitput in de analyse en reconstructie van onze aanspraken op theoretisch-descriptieve kennis. 'Vernunft' heeft ook steeds verwezen naar een verbinding van het theoretische weten met de esthetisch-expressieve en praktisch-normatieve dimensies van het menselijk bestaan.

$\mathrm{Nu}$ kan een ieder die ook maar enigszins vertrouwd is met zijn werk weten, dat het een buitengewoon hachelijke zaak is om Luhmann normatieve oordelen of een politieke positie in de schoenen te schuiven. Tegenstellingen als die tussen conservatief/progressief worden door hem onbarmhartig gedeconstrueerd als reacties op de Franse Revolutie die gedurende de 19 de en eerste helf van de $20 \mathrm{e}$ eeuw nog een politiek-structurerende functie konden vervullen, maar in een tijdperk waarin techniekkritiek en verlangen naar kleinschaligheid zich als progressieve standpunten kumnen afficheren, obsoleet zijn geworden ${ }^{646}$ En weinig fijnzinnig wordt Habermas aangewreven, dat het etiketteren van concurrerende maatschappijtheorieën als "affirmatief" "conformistisch", "conservatief" of zelfs "neo-conservatief" meer en meer het stagneren van de eigen theorieontwikkeling moet compenseren. ${ }^{647}$ Deze allergie voor politiek-normatieve oordelen heeft Luhmann overigens niet alleen opgelopen aan het 'Besserwissen' en de 'Humorlosigkeit' die naar zijn mening het 'Frankfurter. Wissenschaftsland-

646. Verg. 0.a. N.Luhmann, 'Ich sehe was, was Du nicht siehst', in: Idem, Soziologische Auffelörung 5, Opladen 1990, pp. 228-234.

647. N. Luhmann, "Am Ende der kritischen Soziologie', in: Zentschrift fitr Sozjologie 20 (1991), p. 149. 
schaft' kenmerken ${ }^{648}$ Met ethiek en moraal heeft Luhmann altijd slechts op veilige afstand van doen willen hebben -

"es [handelt] sıch um einen hochinfektiösen Gegenstand, den man nur mit Handschuhen und mit möglichst sterilen Instrumenten anfassen sollte. Sonst infiziert man sich selbst mit Moral und setzt das, was als wissenschaftliche Untersuchung begonnen hatte, einer moralischen Verwendung aus. ${ }^{649}$

Natururlijk kan een socioloog niet de ogen sluiten voor het factum 'moraal', ook in Bielefeld niet. Voor Luhmann gaat het dan om een multifunctionele inrichting die de toewijzing wan achting en verachting aan personen weliswaar middels een orièntatie op de code goed/slecht reguleert en zich in die zin als een functiesysteem gedraagt, maar waarvan de mogelijkheden tot een verdergaande functionele specialisatie en autonomie beperkt zijn. Dat onder moderne condities de maatschappelijke betekenis van het moraalsysteem sterk is afgenomen, bevestigt voor Luhmann slechts, dat moraal niet het meest oorspronkelijke, primaire bindmiddel van het menselijk samenlleven is:

Nur bei oberflächlicher und zudem einseitiger Betrachtungsweise erscheint Moral als Bindemittel, das die Menschen in der Gesellschaft hält Moral stößt auch $a b$, verfeindet auch und erschwert die Lösung von Konflikten - eine Erfahrung auf die man unter anderem mit der Trennung von Recht und Moral reagiert hat: ${ }^{650}$

De maatschappij is geen 'moreel feit' - 'en gelukkig maar', kan Luhmann niet nalaten daaraan toe te voegen ${ }^{651}$ Bovendien weigert hij te accepteren, dat achter

648. In het betreffende interview met Heidi Renk en Mareo Bruns voegt Luhmann daar aan toe, dat hem met name ook het "direkte Verhăttnis zu den Dingen, dieses Dafür-oder-Dagegen" irriteert: 'Ein leise Distanz mag auch einfach eine Geschmacksfrage sein." (Opgenomen in D. Baecker/G. Stanitzek (Hrsg), Niklas Lwhmann. Archimedes und wir. Interviews, Berlijn 1987, p. 117.

649. N. Luhmann, 'Ethik als Reflexionstheorie der Moral', in: Idem, Gesellschaftsstruktur und Semantik 3 , Frankfurt/M., 1993, p. 359. Zie voor Luhmanns opvattingen omtrent moraxil en ethiek voorts o. a. N.Luhmann, 'Soziologie der Moral', in N.Luhmann' st. Pfürner (Hrsg.), Theorietechnik und Moral, Frankfurt/M 1978, pp. 8116, N. Luhmans, Durkheim on Morality and the Division of Labor', in: Idem, The Differentiation of Soctety, New York 1982, pp. 3-19; Idem, Soziale Systeme, Frankfurt 1985, pp. 317 e.v.";

650. Saziale Systeme, op.cit., p. 318.

651. Luhmann: 'Moral ist ein riskantes Unternehmen. Wer moralisiert, laBt sich auf ein $\mathbb{R}$ isiko ein und wird bei Widerstand sich leicht in der Lage finden nach starkeren Mitteln stuchen zu mussen oder an Selbstachtung einzubüßen...[D]ie Erfahroingen, die Europa seit dem Hochmittelalter mit religiös aufgezogenen Aufständen und Unterdrückungen, thit den Schrecken der Inguisition, mit Kriegen um moralisch verbindliche Wahiheiten und mit aus Empörung entstandenen Revolten gemacht hat, sollten eigentlich beim Stichwort Moral immer gleich 
de moraal als een gecodeerd systeem een universeel geldige of antropologisch noodzakelijke ethische substantie schuil zou gaan. Of zoals Sighard Neckle en Jürgen Wolff het formuleren: "the concept of morality is not related by Luhmann to universalizable norms of the right way to live or the advancement of wellbeing, and also not to the question of justice. Morality determines itself solely through the difference good/bad or good/evil, which is to say, it is not identifiable as the good and the valuable: ${ }^{952}$

Meent Luhmann al te moeten waarschuwen voor de polemische effecten van moraalsystemen - Moral hat soweit sie sich nicht im Selbstverständlichen aufhält und hier fast unnötig ist, eine Tendenz Streit zu erzeugen oder aus Streit zu entstehen und den Streit dann zu verschärfen' ${ }^{-653}$-; van ethiek, begrepen als een vooral door filosofen bedreven 'Reflexionstheorie' van de moraal, moet hij in het algemeen nog minder hebben. Alle filosofische virtuositeit ten spijt hebben ethici hun ogen altijd stijf dicht gehouden voor het eigenlijke probleem van alle moraal, dat het namelijk wel eens immoreel zou kunnen zijn om de wereld onder een moreel gezichtspunt te beleven en te behandelen. Anderen hebben ze een "selbstverschuldete Unmundigkeit" verweten, zo vaart Luhmann uit, maar als zelfbenoemde fundeerders van de moraal hebben de filosofenethici nooit de moed gehad te waarschuwen voor moraal, nooit de gedachte aangedurfd dat het onderscheid tussen het goede en het kwade zelf wel eens een kwaad zou kunnen zijn.

Nu kan natuurlijk worden tegengeworpen, dat Luhmann zich dan wel publiekelijk mag uitspreken tegen iedere moralisering/politisering/ideologisering/etc. van het maatschappelijk en i.h.b. van het sociologisch debat, maar dat het nog maar de vraag is in hoeverre hij daar zelf aan weet te ontkomen. Een van de tactieken die we dan ook telkens weer tegenkomen bij diegenen die zich (net als wij) geroepen voelen de normatieve drijfveren, of anders wel de politieke ideologie van Luhmann aan de kaak te stellen, is het uitziften van her en der door zijn werk verspreide uitspraken die zouden getuigen van morele of politieke 'commitments'. Vanzelfsprekend zijn die te vinden, al valt uit het diffuse, soms weinig coherente karakter daarvan niet veel op te maken. Nu eens toont Luhmann zich bezorgd over de broze stabiliteit van de moderne maatschappij, zoals in Okologische Kommumikation of Soziologie des Risikos, dan weer hecht hij er aan te benadrukken, niet geinteresseerd te zijn in een legitimatie van de bestaande maatschappelijke systemen en hun functies en dat zijn beschrijving daarvan geen normatieve aanbeveling inhoudt. ${ }^{654}$ En in Archimedes und wir, de door Dirk Baecker en Georg Stanitzeck gebundelde interviews met Luhmann heet het:

dieses Problem vor Augen fuhren." ("Ethik als Reflexionsthieorie der Moral", op.cit., p.370. 652. S. Neckel/J. Wolf, "The Fascination of Amorality: Luhmann's Theory of Morality and its Resonances among German Intellectuals', in: Theory. Culnure \& Society 11 (1994), p. 78

653. "Ethik als Reflexionstheorie der Moral", op.cit, p. 370.

654. Vergelijk bijw, de derde druk van zijn Legitimatian durch Verfähren, Berlijn 1978, p. 6. 


\begin{abstract}
'Ich finde, daß unsere Gesellschaft mehr positive und mehr negative Eigenschaften hat als jede fruhere Gesellschaft zuvor. Es ist heute also zugleich besser und schlechter. Das kann man viel zutreffender als ublich beschreiben, aber nicht zu einer Gesamturteil aufaddieren."6ss
\end{abstract}

Wie op dergelijke uitspraken afgaat, komt uit op evaluaties als 'Habermas ist in der Theorie konservativer, in der Politik emanzipationsorientierter als Luhmann" ${ }^{656}$ En de lezer vraagt zich vertwijfeld af, welk superieur inzicht achter een dergelijke constatering schuil gaat.

Wij willen in dit 'Tot Besluit' een andere weg bewandelen - een die weliswaar omslachtiger is dan een opsomming van 'teveel zeggende" citaten, maar daarentegen de gelegenheid biedt om in contact met de oorspronkelijke motieven van Luhmanns denken, de normatieve inzet van zijn werk aan het licht te brengen. Dat zal het bovendien mogelijk maken om vanuit een zekere distantie Luhmanns project te situeren in het social-filosofisch debat dat vandaag de dag onder de titel 'Modernen versus Postmodernen' wordt gevoerd, maar dat natuurlijk al vanaf het moment dat de Verlichting de Romantiek als 'haar andere zijde' in het leven riep, het geestelijk en culturele leven van het 'moderne' tijdperk gedomineerd heeft.

\title{
§ 2. Verlichting van Verlichting
}

Op 25 januari 1967 hield Luhmann te Münster zijn eerste Antrittsvorlessung en wel ter gelegenheid van zijn ambtsaanvaarding als professor aan de WilhelmsUniversität. De 'Ausarbeitung' van die rede onder de aanhef 'Soziologische Aufklärung' is het titelopstel geworden van de bekende, nog steeds uitbreidende reeks van gebundelde artikelen, waarvan Luhmann zal blijven volhouden, dat deze 'unbeirtt an dem Titel Aufklärung fest halt' .657

In het opstel 'Soziologische Aufklärung' schetst Luhmann als een soort raamwerk voor de bepaling van zijn eigen positie ${ }^{658}$ een ontwikkeling die in de $18 \mathrm{de}$

655. D. Baecker/G. Stanizek (Hrsg), Niklas Luhmann. Archimedes wnd wir. Interviews, Berlijn 1987, p. 139. En in een volgend interview heet het Weil mir gar keine andere Gesellschatt vorschwobt als die, die wir haben, will ich auch die vielen positiven Seiten unseres Systems. aufzeigen. Es geht also nicht um Ablehnung oder Zustimmung zu diester Gesellschaft, sondern um ein besseress Varstandnis ihrer sitrukturellen Risiken, ihrer Selbstgefahrdungen, ihrer evolutionären Unwahrscheinlichkeit.", Idem, p. 155.

656. W. Reese-Schafer, Luhmamn zur Einfihrung, Hamburg 1992, p.151.

657. Alls parafrase wan de eerste zin wan het "Vorwort' bij Soziologische Aufklärung 3 (Opladen 1981, p. 5.)

658. En zo moet de vluchtige sohets van het proces van de Verlichting die Luhmann in dit artikel presenteert ook gelezen worden. Voor uitgewerkte idee-historische analyses moet men te rade gaan bij de verschillende delen van Gestellschaftsstruktur und Semamtik. 
eeuw begint als 'Vernunftaufklärung', zich dan in de 19 de eeuw als 'entlarversde Aufklärung' voortzet, om aan het begin van de 2 de eeuw de vorm van een "soziologische Aufklärung' aan te nemen. Dat we telkens van 'Verhichting" kunnen spreken, is volgens hem daarin gegrond, dat niettegenstaande alle verschillen en discontinuiteiten, het in de onderscheiden fasen steeds is gegaan om een observatie en beschrijving van de gegeven "werkelijkheid" in het licht van complexiteit, d.w.z met het oog op de toegang tot het "evenzeer-mogelijke": "Aufklärung ist der geschichtliche Prozeß der sich bemüt, die Moglichkeiten der Welt dem Erleben und Handeln als Sinn zugänglich zu machen. ${ }^{.659}$

Ons interesseert hier nu eerst de overgang van een 'entlarvende Aufklarung' naar een 'soziologische Aufklärung'. Met 'entlarvende', of 'kritisch onthullende' Verlichting doelt Luhmann op de verdenking die het denken gedurende de 19 de eeuw tegen zichzelf begint te koesteren - de verdenking slechts "ideologie' te zijn, een uitdrukking te vormen van persoonlijke of groepsgebonden belangen, of van sociale gepositioneerdheid uberhaupt. ${ }^{660}$ Marx of Nietzsche kunnen voor zichzelf dan nog wel claimen vanuit het "ware klassestandpunt" of op basis van een 'hogere wil' te denken, maar met dergelijke voorbehouden heeft een eenmaal op gang gekomen 'Entlarvung' gemakkelijk spel. Voor iédere observatie of beschrijving van de werkelijkheid kan een dubbele bodem worden gezocht en gevonden. Langs die weg ontdekt de radicaal onthullende Verlichting het sociaal contingente karakter van alles wat kan worden beweerd of gefingeerd, van alles wat als 'werkelijkheid' kan worden geobserveerd, beschreven en gecommuniceerd. Waar zij de vinger op legt, is m.a.w., dat alle zinen betekenisgeving wordt gedragen door een sociale context, die wederom kan worden beschreven en benoemd als een niet-noodzakelijk, contingent produkt van de menselijke geschiedenis. ${ }^{661}$

Daarmee nadert de Verlichting, volgens Luhmann, echter het punt, waarop zij zichzelf en haar maatschappelijke omgeving overvraagt. Zoveel contingentie, zoveel 'toevalligheid' en "willekeur' is in ongereduceerde vorm niet verdraagbaar. Als 'Verlichting' de poging inhoudt, op een betekenisvolle wijze de ogen te openen voor andere dan de hier en nu gerealiseerde mogelijkheden (van bijv. wetenschap, politiek of kritiek bedrijven), dan impliceert dat naast' 'Erfassung' ook altijd reductie van complexiteit. In een 'onbegrensde" wereld waar op voorhand iedere bewering mogelijk is en even (on)waarschijnlijk, kumnen beweringen over die wereld niet meer informatief zijn, noch voor het beleven en handelen

659. N. Luhmann, 'Soziologische Aufklärung', in: Idem, Sozialogische Aufklärung, Opladen 1984 ( 5 de dr.), p. 74.

660. Zie m.b.t. deze "entlarvende Aufklarung' o.a het opstel van Hans-Georg Gadamer, 'Die Grundlagen des zwanzigsten Jahrhunderts", opgenomen in: Adorno/Anton/Dien, Aspekre der Modernirürr, Göttingen 1965.

661. Zie mb.t. deze problematiek ook het wit dezelfde periode als Shoziologische Aufklärung" stammende: N. Luhmann, "Wahrheit und Ideologie', opgenomen in. Idem, Soz. Awfkl. I, op.cit., pp. 54-65. 
een oriènterende waarde hebben - 'Eine Steigerung der in der Welt erfaßbaren Möglichkeiten wird sinnlos, wenn nicht zugleich entsprechend wirkungsvolle Mechanismen der Reduktion von Komplexität entwickelt werden" ${ }^{6.62}$

Deze overmaat aan mogelijke voorstellingen en handelingen is volgens Luhmann precies het probleem in confrontatie waarmee de sociologie aan het begin van de 2de eeuw zich ontwikkelt en dat ze voor zichzelf vastlegt in de voor het sociologisch denken constitutieve vraagstelling: hoe is (gegeven alle contingentie/dubbele contingentie) sociale orde mogelijk. Luhmann:

"Soziologie konstituiert sich durch die Art, wie sie der abrutschenden, universell werdenden Entlarvingsaufklärung einen Gegenhalt bietet; letztlich durch die Art wie sie der unfäßlichen Komplexităt einer sozial kontingenter Welt entgegenarbeitet. ${ }^{2663}$

'Soziologische Aufklärung' moet dan begrepen worden als de poging het niettoevallige, gestructureerde karakter van de sociale werkelijkheid aan het licht te brengen - als de poging de Verlichting 'in te lichten' over de grenzen van het proces van Verlichting, als 'Abklärung der Aufklärung'. Meer in concreto zou de sociologie duidelijk moeten maken, dat de variatiemogelijkheden van de maatschappelijke contexten die alle sociaal relevante (d.w.z. voor anderen toegankelijke) zin- of betekenisgeving dragen, in actu telkens begrensd zijn. Slechts door onderscheid te kunnen maken tussen het waarschijnlijke en het onwaarschijnlijke, d.w.z. door inzicht te bieden in de selectiviteit die in en door de evolutie van sociale systemen zelf tot stand wordt gebracht, kan de sociologie aan de zelfverzekerdheid van het denken en handelen bijdragen. Of zoals Luhmann zich de oorspronkelijke uitdaging aan de grondleggers van de sociologie voor de geest haalt:

'Große Theorie ist jetzt nur noch möglich als Vorschlag zur Losung dieses Problems - nicht mehr als eine immer mehr entlarvende Aufklärung, sondern als Durchblick auf Grenzen der Aufklärung, als Abklärung der Aufklärung: ${ }^{\text {'564 }}$

Die "große Theorie" is er gekomen, maar heeft volgens Luhmann van meet af aan een typisch kenmerk gehad. Onder de indruk van haar eigen probleemstelling zette de opkomende sociologie al haar conceptuele en theoretische middelen in ter wille van een reductionistische behandeling van het contingentiepro-

662. 'Soziologische Aufklärung", op.cit, p.73.

663. Idem, p. 69. Vergelijk bovendien het opstel "Wie ist soziale Ordnung möglich?" in: $\mathbb{N}$. Luhmann, Gesellschaftsstruktur und Semantik Bd 3, FrankfurcM 1993, pp. 195-286.

664. 'Soziologische Aufklärung', op.cit., p. 68. 
bleem. ${ }^{655}$ Bij Max Weber neemt dit reductionisme de vorm aan van een individualistisch subjectivisme, bij Durkheim de vorm van een collectivistisch objectivisme. Maar daarmee verviel de sociologische Verlichting in een nieuwe eenzijdigheid. In haar zoektocht naar een dieper liggende 'simpliciteit' die als reductiebasis voor de "uiterlijke" of "oppervlakte"-complexiteit van het maatschappelijk leven kan dienen, verloor de sociologie de mogelijkheid om complexiteit als complexiteit te denken, $d$.w.z complexiteit niet als de ontoereikende uitdrukking of oppervlakteverschijning van een 'achterliggende', "simpele" dieptestructuur te beschouwen, maar als een oorspronkelijk, niet redueeerbaar kenmerk van socialiteit. Ze zag de mogelijkheid over het hoofd, contingentie en selectie, wanorde en structuur in hun onderlinge samenhang te denken. De ontoereikendheid van zowel de Weberiaanse/handelingstheoretische/-intentionalistische als de Durkheimiaanse/structuralistische/objectivistische traditie 'besteht darin', zo formuleert Luhmann in 1967, 'daß ihr. Problem nicht ihre Theorie wird'. 666

"Het probleem van de complexiteit/contingentie van al het sociale tot immanent onderdeel van de sociologische theorie maken' - dat postulaat wormt in essentie Luhmanns vertrekpunt en markeert misschien wel de meest wezenlijke breuk tussen de overgeleverde, "klassieke" sociologie en zijn eigen project. De vraag is alleen hoe dat kan, hoe een probleem een theorie kan zijn. Een probleem is geen mogelijk ware bewering omtrent de werkelijkheid en laat zich evenmin begrijpen als een axioma of theorema binnen de logisch-deductieve structuur die traditioneel geacht wordt kenmerkend te zijn voor echte theorieèn. En natuurlijk zag ook Luhmann, dat 'Welt' als het overkoepelende referentieprobleem een axiomatisering niet toelaat, daar dit een voortijdige en in wezen arbitraire reductie zou impliceren van de ultieme complexiteit die door het 'Welt'-begrip wordt aangeduid. Maar in plaats van 'problemen' te couperen naar het model van een traditionele theorie-opvatting, kan men natuurlijk ook proberen 'theorie" te schikken naar de eigenaard van (complexiteits)problemen en de systematiek van een theoretisch stelsel trachten te begrijpen in termen van een ontvouwing en differentiatie van een overkoepelend uitgangsprobleem. Dat laatste was althans Luhmanns optie:

Eine Theorie die sich Erfassung und Reduktion von Komplexitait zum Ziel setzt, muß sich als nicht axiomatisierbar erkennen, muß daher aus der Sprache der Axiome und ihre Konsequenzen in die Sprache der Probleme und ihre Lösungen tubersetzt und in thre

665. Vergelijk in dezen ook de kritiek yan Roberto Mangabeira Unger op de klassieke sociologie, in: R.M. Unger, Social Theory" its Situation and its Task, New York 1987, i.h.b. p. 145 e.v. Zie voorts S.N. Eisenstadt/M. Curelaru, The Form of Sociology - Paradigms and Crises New York 1976, i.h.b. p. 15 e.v. en p. 55 e.v.

666. Idem, p.69. 
Aussageformen und Erkenntniszielen entsprechend umstrukturiert werden: ${ }^{5667}$

Ten tijde van 'Soziologische Aufklärung' meende Luhmann dat voor deze overgang van een axiomatische naar een probleemgeoriënteerde theorie nog twee stappen moesten worden gezet. Op methodologisch niveau diende de functionele analyse te worden bewrijd van iedere binding aan (nomollogische) causaliteitsvoorstellingen en worden getransformeerd in een zuiver "equivalentie-functionalisme', in een methode die systematisch oplossingen vergelijkt in het licht van problemen en problemen in het hicht van hun oplossingen. Op theoretisch niveau, d.w.z. op het niveau van de systematische beschrijving en modellering van de sociale werkelijkheid zou het 'structureel functionalisme' (Parsons) moeten worden vervangen door een 'functioneel structuralisme' dat geen apriori "bestandsproblemen" meer accepteert, maar daarentegen alle structuren, ja zelfs systeenvorming op zich, analyseert als mogelijke oplossingen in het licht van de "wereldcomplexiteit" als het overkoepelende referentieprobleem. Uit de wisselwerking tussen equivalentie-functionalisme en functioneel structuralisme zou dan een sociologie moeten ontstaan die denkt in termen van problemen en hun oplossingen en die haar algemeenheid als theorie daaraan ontleent, dat zij ongelijke situaties of verschijnselen vergelijkbaar maakt en wel als mogelijke antwoorden op hetzelfde probleem. Daarmee zou het project van de Verlichting, met 'Erfassung' en 'Reduktion' van complexiteit als centraal motief; in een nieuwe gedaante kunnen worden voortgezet:

'So kann die theoretisch-vergleichende Problemanalyse das Handeln mit Substitutionsmöglichkeiten ausstatten und ihm dadurch eine Sicherheit bieten, die nicht auf der Verlaßßlichkeit festgestellten Seins sondern auf der Verfugbarkeit anderer Móglichkeiten beruht. ${ }^{3668}$

We hebben in een eerder hoofdstuk van dit boek gezien hoe een aan alle systeem/omgeving-theorieen inherente problematiek uiteindelijk ook Luhmann er toe dwong afscheid te nemen van zijn functioneel structuralisme en om te zien naar een nieuw model of paradigma, in casu de theorie van zelfreferentielle systemen. Daar hoeven we nu niet meer op terug te komen. Hier zij er nog slechts op gewezen dat met Luhmanns 'autopoietische Wende" ook de perceptie van het type problemen waartoe een ontketende Verlichting leidt, veranderde (en wel moest veranderen). Vanuit het perspectief van een functionalistisch geradicaliseerde systeem/omgeving-theorie zou het proces van maatschappelijke Verlichting, voorzover dit inderdaad gelijk staat aan een toename van 
handelingsmogelijkheden, de greep van de maatschappij op haar (nog altijd complexere) omgeving versterken. Toename van systeemcomplexiteit, zo luidde de gedachte, betekent dat een systeem met meer mogelijke toestanden op turbulenties in de omgeving kan reageren en komt er effectief op neer, dat een systeem steeds meer omgevingscomplexiteit kan beheersen: De schaduwzijde daarvan zou echter zijn, dat bij een sterke toename van handelingsmogelijkheden het door sociale systemen (alls zinsystemen) bemiddelde vermogen tot complexiteitsverwerking onder druk komt te staan. Dit probleem zou daarin tot uiting komen, dat het steeds moeilijker wordt om binnen een saciaal systeem de selectiviteit van eerdere of parallel verlopende handelingen te benutten als een aanwijzing voor, of ter versterking van de selectiviteit van tegelijkertijd of later te voltrekken handelingen. Toenemende maatschappelijke complexiteit, zo zou men ook kunnen formuleren, impliceert een stijging van de contingentie van iedere afzonderlijke handeling en overvraagt uiteindelijk de selectie- en ordeningscapaciteit van de voorhanden zinschema's en -structuren. Vanuit dit diagnostisch perspectief kon Iuhmann nog spreken van een 'Innenproblematik groß3er Systeme' als de vorm waarin de grenzen van de Verlichting merkbaar worden en als remedie hopen op 'eine effektive Steigerung des menschlichen Potentials zur Erfassung und Reduktion von Komplexität. Es geht um die Fähïgkeit, viele Möglichkeiten sinngemäß zu berucksichtigen und doch rasch zu handeln: um Verhaltnisse zwischen sachlicher und sozialer Vielfältigkeit und Zeitknappheit, die optimiert werden müssen. ${ }^{1669}$

Deze inschatting van 'het maatschappelijk probleem van de Verlichting' kan na Luhmanns autopoietische ommekeer en de nadruk die daarmee op de geslotenheid van sociale systemen is komen te liggen, niet langer correct zijn. De vorm waarin het proces van Verlichting, begrepen als een toenemend vermogen 'die Komplexität der Welt zu erfassen und zu reduzieren' zich in de moderne maatschappij heeft gerealiseerd, is die van de functionele differentiatie. Het medium waarvan de Verlichting zich bedient, zo zouden we in navolging van Luhmann moeten aannemen, wordt eerst en vooral gevormd door uitgedifferentieerde, gespecialiseerde functiesystemen. Zoals we in het vorige hoofdstuk hebben gezien, worden de grenzen waar deze 'Verlichting' op stuit, niet zozeer merkbaar als een 'Innenproblematik großer Systeme', maar veeleer in de vorm van 'externe' afstemmingsproblemen tussen de functiesystemen. Niet een teveel aan contingentie binnen de functiesystemen vormt de keerzijde van het moderniseringsproces, maar de overmatige identificatie van de functiesystemen met hun eigen codes en de onverschilligheid die dit met zich meebrengt voor andere dan de systeemeigen perspectieven. 


\section{\$3. Complexiteit en normativiteit: de 'politiek' van Luhmanns project}

Luhmann als Verlichter?! - het zal menigeen onwaarschijnlijk in de oren klinken. Zijn concentratie op het probleem van de maatschappelijke complexiteit is voor velen, daarin voorgegaan door Habermas, eerder een teken van politieke apathie, van resignatic en conformisme geweest.

Een dergelijk type kritiek is tot op zekere hoogte begrijpelijk als het spiegeleffect van de gedachte, of in ieder geval van de hoop, dat een onderliggende (of juist alles overkoepelende) simpliciteit niet alleen als een verklaringsbasis van de veelvormige maatschappelijke verschijnselen kan dienen, maar tevens als maatstaf, als criterium van de ware, eigenlijke, wenselijke maatschappij. ${ }^{670} \mathrm{Het}$ is echter precies de grote zoektocht naar een dieper- of 'achterliggende' simpliciteit waaraan de 'oppervlakte-complexiteit' van de maatschappij normatiefkritisch kan worden gemeten, dit verlangen naar een laatste, ware eenheid in het licht waarvan ongewenste maatschappelijke ontwikkelingen kunnen worden begrepen als 'devianties' van de humane, "vernünftige" samenleving, dat Luhmann keer op keer bespot als 'alteuropäisch'. 'Alteuropaisch' - dat is de poging van de traditionele filosofie om laatste, definitieve eenheden of 'identiteiten" aan het licht te brengen, waarin alle maatschappelijke differenties uiteindelijk worden 'aufgehoben', in het bijzonder de differentie tussen wat de maatschappij 'waarlijk' kan zijn, maar nog niet is ${ }^{\text {"71 }}$ "Vernünftige' identiteit als ware verzoening - of zoals Detlef Pollack het 'oud-Europese denken' waar Luhmann zich vrolijk over maakt, samenvat:

'Ob die alteuropäischen Denker nun nach der prästabilisierten Harmonie, nach der Vernunt in der Geschichte, nach einem allgemein-verbindlichen Recht der Natur, nach der Authebung der Geschichte in einer klassenlosen Gesellschaft oder nach der Konstutionsbedingungen der herrschaftsfreien Diskurses suchen, in jedem Fall geht es ihnen darum, Letztgrößen zu konstruieren in denen die gesellschaftlichen Differenzen, die Differenz zwischen Individum und Gesellschaft, zwischen Subjekt und Objekt,

670. Het mu volgende matkt dankbaar gebruik wan de vergelijking die William Rasch heeft getrokken tussen de normatieve consequenties van Habermas" project en dat van Luhmann W.Rasch, "Theories of Complexity, Complexities of Theory: Habermas, Luhmarin and the Study of Social Systems", in: German Srudies Review 14 (1991), pp. 65-83.

671. Verg. N. Luhmann "Tautologie und Paradoxie in den Selbstbeschreibungen der modernen Gesellschaft, in: Zeitschrift für Soziologie 16 (1987), pp. 161-174. Maar verg. ook Jürgen Hahermas' opstel 'Das Zeitbewulitsein der Moderne und ihre Bedlurfnis nach Selbstvergewisserung" in: J. Habermas, Der philosophische Diskurs der Moderne, Frankfurt/M. 1985, pp. 934 en bovendien E. Fink, Alles und Nichts, Den Haag 1959, pp. 20 e.w. 
Besonderen und Allgemeinen aufgehoben sind und in denen das Ganze, das Wahre, das Gute representiert wird. ${ }^{1672}$

Typisch voor de moderne maatschappij, zo meent Luhmann, is nu juist dat 'das Ganze und Allgemeine nicht mehr das Eigentliche sein kann: ${ }^{673}$ De dialectische maatschappijtheorie is als laatste grote poging dit te negeren en wast te houden aan een totaliteitsvoorstelling, zij het als "Vorschein', geeindigd in een negatieve dialectiek, in ... resignatie.

De vraag dringt zich echter op wararin volgens Luhmann 'das Eigentliche' dan wél schuilt, als dat niet meer de kwaliteit van het algemene of universele kan hebben, niet meer door de voorstelling van een primitieve grootheid of laatste eenheid kan worden gerepresenteerd? Het antwoord daarop kan in ieder geval niet luiden, dat er helemaal niets 'eigenlijks' bestaat. Of het nu gaat om een 'progressieve', 'linkse' of 'revolutionaire' beweging, dan wel om het uithangbord van een in feite conservatieve 'Gegenaufklärung', 'Verlichting' heeft hoe dan ook een politiek-historische 'vector', een 'stootrichting' die wordt geinspireerd door een voorstelling van wat het maatschappelijk verband eigenlijk inhoudt. Ook een als 'Abklärung der Aufklärung' begrepen Verlichting moet een motief hebben, moet de Verlichting die ze ter ziele wil dragen op zijn minst als een oneigenlijke omgang met het probleem van de maatschappelijke complexiteit en contingentie aan de kaak kunnen stellen.

In principe kennen we Luhmanns antwoord op de hierboven gestelde vraag al. We zijn het eerder tegengekomen in de context van een epistemologisch gekleurde discussie over identiteitsconstitutie op basis van zelfreferentie (zie het "Ter afsluiting" van Hoofdstuk I). Abstract geformuleerd luidt het antwoord: Het eigenlijke ligt in het differente, in de onvermijdelijke keerzijde die met iedere vaststelling van identiteit wordt ge(re)produceerd als fonds van 'het telkens ook anders mogelijke' - in de differentie van identiteit en differentie. Of in de lapidaire formulering van Armin Nassehi: 'Das Identische 'ist' das NichtIdentische?. ${ }^{674}$ "Maar hoe abstract ook, de normatieve en politieke consequenties van dit antwoord liggen voor de hand. Als niet 'identiteit' maar 'differentie" het laatste woord heef, als iedere identiteitsvoorstelling zich uiteindelijk laat "deconstrueren" als een 'slechts mogelijke' zijde van een differentie, als ieder beeld van een verzoening tussen mens en natuor, tussen mens en mens, of tussen mens en maatschappij, een telkens ook anders mogelijke voorstelling van de "goede maatschappij" inhoudt, dan lijkt ook iedere vorm van politiek-norma-

672. D. Pollack, 'Bestanderhaltung oder Kritik oder: Weder Bestanderhaltung noch Kritik - Die Intention der Systemtheorie Niklas Luhmanns;, in: Deutsche Zeitschrff fuir Philosophie. 1991, p. 96.

673. N. Luhmann, "Grundwerte als Zivilreligion" " in Saziologische Aufflarung 3, Opladen 1981, p. 303.

674. A. Nassehi, 'Das Identilisches "ist" das. Nioht-Identische - Bemerkungen zu einer theoretischen Diskussion um Identitat und Differenz", in: Zeitschriff für Soziologite 22 (1993) pp. 477-481. 
tieve kritiek haar intellectuele zelfverzekerdheid en overtuigingskracht te verliezen.

Dat er voor Luhmann geen definitieve en onaantastbare matstaf van maatschappijkritiek kan bestaan, wordt in feite al geimpliceerd door zijn oorspronkellike uitgangspunt, namelijk dat de verhouding systeem/omgeving niet begrepen moet worden als een soort contradictie, of als een constellatie die "in laatste instantie' op een van beide polen kan worden gereduceerd, maar als een differentie die alleen kan bestaan in en door de wederzijdse, of zo men wil: 'circulai$\mathrm{re}^{y}$ implicatie van systeem en omgeving. ${ }^{675}$ Dat verbiedt als het ware de gedachte dat er een eenduidige factor of set factoren zou bestaan, zij het in de omgeving, zij het binnen het systeem, die als vaste, noodzakelijke ijkmaat van het systeem zou kunnen fungeren. Alle vaste maten of grootheden worden uiteindelijk relatief in het licht van de contingente selectiviteit van de grens die eerst systeem en omgeving constitueert. Om Detlef Pollack nogmaals te citeren:

'Mit der Konstitution einer weder nach außen hin ubersteigbaren noch auf einen Pol reduzierbaren System/Umwelt-Zirkularität wendet sich Luhmann gegen die Behauptung systemunabhängiger Letztwerte wie Substanz, Gott, Sein oder Ding an sich als auch gegen die Hypostasierung won systemabhängigen Größen wie Subjekt, Freiheit, Gerechtigkeit, Gleichheit oder Solidaritat zu unhinterfragbaren Letztgrößen. Die Behauptung ihrer Letztgăltigkeit beruht nâmlich stets auf der Behauptung ihrer Unverfuggbarkeit, weswegen Luhmann von auf Unklahrheit beruhenden Notwendigkeitspostulaten auf kontingente, das heißt immer auch anders mögliche Bestimmtheiten umschaltet. ${ }^{2676}$

De derikfiguur van een maatschappij die 'niet is, wat ze is' (nog miet is, wat ze zou kunnen en moeten zijn), kan voor Luhmann niets anders zijn dan het paradoxale effect van een zelfbeschrijving en wel van een zichzelf als "progressief afficherende beschrijving van de maatschappij binnen de maatschappij, maar zal nooit vaste bodem onder de voeten verkrijgen in de vorm van noodzakelijke, onbetwijfelbare 'Letztgrôße'. Dat betekent niet, dat Luhmann automatisch in het conservatieve kamp terecht komt, waarvoor (de tautologie) geldt, dat "de maatschappij is wat ze is" en bijgevolg iedere deviantie van het hier en nu geldende slecht/onwenselijk/illegitiem/etc. is. De normatieve crux van Luhmanns sociologische Verlichting, of filosofischer geformuleerd: van het idee dat 'het eigenlijke' schuilt in de differentie van identiteit en differentie, bestaat

675. Verg wat dit betreft nog steeds: N. Luhmann; "Systemtheoretische Argumentatiomen. Eine Entgegnung auf Jurgen Habermas", in: J.Habermas/N.Lulimarim, Theorie der Gesellschaft oder Sozialtechnologie, Frankfurt/M.. 1975, p. $297 \mathrm{ew}$.

676. D. Pollack, op.cit, p. 97. 
precies in wat we zouden kunnen omschrijven als een "ontmoralisering" van "deviantie".

Luhmann wijst er telkens op dat "deviantie" - zowel het afwijken van de hier en nu geldende structuren, als de ontwikkeling van structuren die niet overeenstemmen met identiteitverlenende zelbeschrijvingen - niet alleen een "normaal" kenmerk van complexe systemen voorstelt, maar bovendien een operationeel vereiste van de autopoiesis, of "zelfconstitutie" van sociale systemen vormt. Het idee, dat sociale systemen complexiteit moeten reduceren onder behoud van complexiteit, dat hun autopoietische reproduktie niet alleen om een beheersing van dubbele contingentie vraagt, maar tevens de reproduktie ervan vereist als 'autokatalysator' van hun eigen ontwikkeling, komt neer op de gedachte, dat sociale systemen op ieder moment hun capaciteit tot deviantie moeten reproduceren. Deviantie, zo zouden we ook kunnen stellen, is bij Luhmann niet het afwijken van een 'normatief-controlerende' simpliciteit, maar een constitutief moment van de complexiteit van al het sociale.

Het is precies in deze "ontmoralisering van het deviante" dat de "politieke" inhoud van Luhmanns sociologie begint door te schijnen. Nu duikt de term 'politiek' in zeer verschillende contexten en definitorische gedaantes op - en Luhmann zelf dringt erop aan de uitdrukking politiek' toch vooral te beperken tot analyses en beschrijvingen van het politiek systeem als een specifiek, maatschappelijk functiesysteem. Gaan we er echter vanuit, dat voorzover wetenschappelijke of intellectuele inspanningen een 'politiek' karakter hebben, dit minimaal betrekking heeft op de inschatting en beoordeling van het sociaal deviante, het maatschappelijk non-conforme, dan beschikken we over een algemeen gezichtspunt op basis waarvan betekenis kan worden gegeven aan het idee dat social wetenschappelijke theorieen over "een politiek" beschikken overigens zonder daarmee in strikte zin politieke theorie of zelfs politicologie te zijn. 'Politiek' is een sociologie dan in het licht van de differentie 'conform/deviant' ("normaal/afwijkend") - of wat in wezen hetzelfde is; de politieke 'vector' van een sociologische denkstijl of maatschappijtheorie wordt bepaald door de wijze waarop het sociale complexiteit vat en verwerkt. In dit licht laat de politieke betekenis van Luhmanns project zich opeens heel anders beoordelen dan gangbaar. Zo heeft Rasch erop gewezen, dat devianties vanuit een Luhmanniaans perspectief als een soort experimenten moeten worden beschouwd, die niet bij voorbat positief of negatief zijn, maar die zich al of niet bewijzen in termen van hun "aansluitingswaande", hun herhaalbaarheid en de mogelijkheid van hun structurele stabilisering. ${ }^{677}$ Maar dat is nog steeds niet war wij op doelen, wanneer we over "de politiek" van Luhmanns theorie spreken. Wat aan.

677. Over Habermas' ambivalente houding t.o.v: de complexiteit van de moderne maatschappij, merkt Rasch datentegen op, dat dit uiteindelijk een restrictieve impact heef: "Habermas's model of communicative action, which attempts to deal with error even before it happens, night be seen as a prescriptive model to restrict communicative action.' (W.Rasch, op.cit., $p$. 79.) 
zijn denken een radicale - men zou bijna zeggen: 'progressieve' - politiek verleent, is de realisatie, dat voor een hoog-complexe maatschappij het probleem van deviantie onder meer schuilt in het probleem van mogelijk onvoldoende deviantie! Dat laatste is het probleem van een maatschappij die, onder de (in)druk van haar eigen complexiteit, niet meer (of niet afdoende) met zichzelf, en dat wil zeggen. met de structuren die deze complexiteit garanderen experimenteert Dat is het probleem van een samenleving die tegenspraken en conflicten moraliseert, die communicatieprocessen in de richting van politieke, culturele, esthetische, etc. 'correctheid" dirigeert, die, om met Luhmann te spreken, de programma"s die zich als reductie- en selectiemechanismen hebben bewezen, normativeert en zelfs in de marges van haar centrale bereiken geen "anti-programmering" duldt, geen eco-anarchistische anti-politiek binnen de politiek verdraagt, geen post-modern estheticisme binnen de wetenschap, geen positieve of negatieve discriminatie binnen het recht.

Daarmee tekenen de normatieve contouren van Luhmanns project zich in ieder geval scherper af, dan door de wel vaker gehoorde verzekering dat zijn sociologie een kritische inslag heeft, daar deze de gegeven maatschappelijke structuren steeds analyseert in het licht van andere mogelijkheden. Zo meent bijvoorbeeld Grunmann: 'To show both that things are possible the way they are and that they could be otherwise gives the theory critical potential. ${ }^{378}$ Dat is een wel erg bleke vaststelling. Maar leveren onze bevindingen in concreto meer op? In antwoord hierop zou men o.a. de suggestie op tafel kunnen leggen, dat Luhmanns sociologie begrepen kan worden als de "politieke theorie' van een pluriforme, "inherent onrustige" samenleving die etnische, nationale of culturele fixaties afwijst, maar evenmin heil ziet in trans- of supraculturele harmonisaties of verzoeningen. De reactie op deze inschatting is natuurlijk voorspelbaar: Welke tastbare aanwijzingen of richtlijnen levert dit alles op voor een politiek die zich gesteld ziet voor de concrete problemen van de moderne samenleving? Is de praktisch-politieke wijsheid van Luhmanns sociologie uiteindelijke gelegen in een 'anything goes'?

$\mathrm{Nu}$ is, om te beginnen, Luhmann helemaal niet van mening dat 'alles kan'. Sociale systemen beschouwt hij als 'structuurgedetermineerde systemen', d.w.z. het zijn systemen die hun eigen veranderlijkheid en ontwikkeling conditioneren middels hun eigen geschiedenis, die zichzelf 'in het spoor houden' met behulp vani structuren die telkens het veranderlijke, maar hier en nu actuele resultaat vormen van het ontwikkelingsproces dat het systeem heeft doorgemaakt. 'Komplexe Systeme', zo houdt Luhmann een ontremde Verlichting voor, "sind no. $90 / 7$, Florenoe, p. 38. 
immanent historische, durch ihre eigene Selektionsgeschichte konditionierte Systeme'.679

Maar misschien is het in deze context belangrijker om nogmaals te herinneren aan de, in zekere zin pessimistische uitkomst van Luhmanns analyse van de moderne, functioneel gedifferentieerdle maatschappij, i.h.b. aan zijn vaststelling dat die differentiatiemodus onvermijdelijk met zich meebrengt dat er geen unieke, boven alle twijfel en concurrentie verheven posities meer kunnen bestaan vanwaaruit de maatschappelijke totaliteit in haar eenheid zou kunnen worden geobserveerd. Geen enkel maatschappelijk subsysteem - ook de wetenschap niet, ook de sociologie niet - kan claimen op basis van zijn specifieke code, vanuit zijn bijzondere perspectief een geprivilegieerde toegang tot de ware identiteit van de maatschappij te hebben en een algemeen verplichtend "bonum commune" te kunnen vaststellen. Luhmanns sociologie is zich ervan bewust, zo zou men ook kunnen zeggen, dat zij de maatschappelijke wijsheid niet in pacht heeft en ook nooit zal kunnen hebben. Voor Luhmann bestaat er geen enkele reden om aan te nemen dat hij als socioloog, of desnoods als sociaal filosoof, beter zou weten wat er in de praktische politiek zou moeten gebeuren, dan bijvoorbeeld een politicus. Ook de sociologie beschikt niet over een slechts voor ingewijden toegankelijk 'Geheimwissen' dat inzicht verschaft in onbetwijfelbare maximen van politiek handelen of maatschappijkritiek. De klassieke praktische filosofie kon zichzelf nog als instructief voor het alledaagse handelen begrijpen op grond van de overweging dat filosoof en actor in een en dezelfde werkelijkheid leven en allebei deel hebben aan een gemeenschappelijke Rede. Die veronderstelling van een dubbele homogeniteit van theoretisch denken en praktisch handelen is definitief achterhaald, ingeruild voor een sceptische sociologie die beseft dat haar werkelijkheid niet de werkelijkheid van de alledaagse actor is en dat 'soziologische Vernunt' waarschijnlijk niet de Vernunft van politici of kunstenaars is.

Nu goed - , sinds de aardbeving van Lissabon weten we dan, dat we niet in de beste van alle mogelijke werelden leven, waarin het nog aanwezige kwaad in wezen 'zijnsuitval' (stérèsis) voorstelt, een corruptie van de perfectie die door de filosofische rede kan worden doorzien. We leven daarentegen, zoals Luhmann zelf ook steeds heeft gemeend, in een wereld vol betere mogelijkheden. ${ }^{680}$ Heeft Luhmann daar niets aan bij te dragen; heeft de sociologie uberhaupt geen praktische betekenis? Als onder dit laatste de vraag wordt verstaan of het

679. N. Luhmatn, "Haltlose Komplexitat", opgenomen in: Saztologische Alufklarung 5, Opladen 1990 , p.66. Verg. ook het "Vorwort" bij deze bundel, i.h.b. p. 11. En al ten tijde van Luhmanns discussie met Habermas heette het: "Man könnte ... die Erzeagung von Möglichkeiten, wie Generalisierung schlechthin als strukturabhängige Leistung zu begreifen versuchen und whirde in den Systemstrukturen zugleich die jeweils maßgebenden Bedingungen der Moglichkeit lokalisieren.' (N. Luhmann, 'Systemtheoretische Argumentationen', op. cit., p.315.

680. Zie N. Luhmann, 'Systemtheoretische Argumentationen. Eine Emtgegnung auf Jurgen Habermas', op eit, p.297. 
sociologisch discours op een of andere manier van invloed is op andere vormen en praktijken wan maatschappelijke communicatie, dan is het antwoord (een door velen betreurd) ' $\mathrm{ja}$ ". Een Luhmanniaanse sociologie kan zich echter niet opmaken om instruerend en belerend de maatschappij het 'goede pad' te wijzen. Maar ze kan anderzijds meer dan de maatschappij telkens ook andere mogelijkheden voorspiegelen. Ze kan het mogelijke, maar hier en nu uitgeslotene te hulp snellen met haar typische techniek van de ontnormalisering van het vertrouwde en waarschijnlijke, bijvoorbeeld door steeds weer de 'onmogelijke', want paradoxale grondstructuur van sociale systemen aan het licht te brengen. Zo kan $z e$, als een van de vormen waarin de maatschappij zichzelf observeert en beschrijt, op bestudeerde wijze, als 'kunstvorm' (en niet als een klassieke kunstleer), zelf de deviant zijn die het denken en de communicatie over de eigenaard en identiteit van maatschappij aanhoudend van onrust en ambivalentie voorziet. Wolfgang Fritscher verwoordt het fraaier:

'Soziologie solle sich (auf dem Wege des Re-entry) in gesellschaftliche Kommunikation eimmischen - nicht steuernd, sonder als die Kunst der Parodierung von Gesellschaft. 681

Misschien is met 'parodie" wel een van de belangrijkste kritische functies van een Luhmanniaanse sociologie benoemd, namelijk 'de maatschappij op een irriterende manier onder ogen te voeren wat ze zichzelf permitteert, wanneer ze zich zelfbeschrijvingen in de vorm van sociologie permitteert. ${ }^{682}$

\section{§4. Seculiere Romantiek}

Sociologie als 'Parodiëring' van de maatschappij? - nogmaals: wat heeft dat met Verlichting uit te staan?

Met het projeet van de historische Verlichting dat naar zijn inhoud was gericht op de emancipatie van de mens uit blinde traditie en vooroordelen en dat zijn hoop had gevestigd op een aan allen gemeenschappelijke Rede als wetgever van een nieuwe maatschappij, met de 18de eeuwse 'Vernunftaufklarung' kortom, heeft Luhmanns sociologie inderdaad weinig affiniteit. Een teken aan de wand was natuurlijk al zijn eigenzinnige, historisch gezien abstracte bepaling van Verlichting als "Erweiterung des menschlichen Vermögens, die Komplexităt der Welt zu erfassen und zu reduzieren". ${ }^{683}$ En wie vanuit een ideeën-historisch perspectief Luhmanns voorliefde voor differentie, voor paradoxie, voor 'het

681. W. Fritscher, 'Romantische Beobachtungen. Niklas Luhmanns soziologische Aufklärung als modeme soziologische Romantik, in Soziale Sysreme 1/96, p. 45.

682. As parafrase van Luhmanns omschrijving van de maxtsehappelijke functie van het Constractivisme - Ni Luhmann, Soziologische Aufhlärung 5; op.cit, p. 58.

683. "Soziologische Autklärung", op cit, p.67. 
andere ${ }^{x}$ en deviante, voor het logisch aanstootgevende, het subversieve, etc. in ogenschouw neernt, die weet zeker dat we ons niet meer aan de zijde van de Verlichting bevinden met haar identiteitsdenken, met haar hang naar verzoening, consensus, rationeel gefundeerde orde, logische consistentie, etc. ${ }^{684}$ Luhmanns Verlichting is Verlichting aan de zijde van de Romamtiek, is inderdaad Verlichting die de Verlichting wil Verlichten, die de Verlichting haar grenzen wijst - 'abklärt' - zonder daarmee in een conservatief anti-modernisme te vervallen. ${ }^{685}$ Of zoals Fritscher al in de subtitel van zijn eerder geciteerde opstel "Romantische Beobachtungen" constateert: Luhmanns "soziologische Aufklärung ${ }^{3}$ is sociologische Romantiek. ${ }^{686}$ Onder de condities van een sceptische wetenschap kan het dan alleen nog gaan om een alledaags geworden, geseculariseerde Romantiek. "Welt" vormt nog steeds thet correlaat van het "eindeloos doorverwijzen" dat al het zinmatig beleven en handelen eigen is, maar het oneindige, het 'All', heeft voor de sociologie zijn transcendente, goddelijke status verloren en daarmee is ook de "Sehnsucht" naar het Absolute verdwenen. Wat is gebleven, is ironie. Ironie niet in socratische zin, ook niet alleen als literaire stijlvorm, maar als typisch romantische methode, als een techniek van destabilisatie van gegeven gremzen, van 'ontgrenzing', van het doorzeven van het vertrouwde en waarschijnlijke met onwaarschijnlijkheid, als bewuste creatie van ambivalentie. ${ }^{687}$

Kijken we nu nog eens terug op de weg die Luhmann vanaf 'Soziologische Aufklärung' heeft afgelegd, dan wordt zichtbaar dat zijn. methodologische en theorietechnische overwegingen van meet af aan in het teken van een Romantische ironje hebben gestaan. "Het normale voor onwaarschijnlijk houden" — dat was al het motto van zijn equivalentie-functionalisme in naam waarvan 'kontrafaktische Abstraktionen' tot vruchtbare methodologische middelen werden verklaard. ${ }^{688}$ En nog in Soziale Systeme heet het:

'Es geht nicht um ein Anerkennungs- und Heilungsinteresse, auch nicht um ein Bestandserhaltungsinteresse, sonderi zunächst und vor allem um ein analytisches Interesse: um ein Durch-

684. Interessant in deze is nog steeds het artikel van Alan Dawe, "The "Two Sociologies." in: British Journal af Sociology Vol. XXI, 2 (1970), pp. 207 e.v.

685. Dat wordt zelfs door een criticus als Danilo Zolo erkend: Luthmanns 'soziologische Aufklärung" kwalificeert hij als "a courageous effort, in the name of critical reason, to free social knowledge from scientistio prejudice and from subservience to the rhetorical tradition of "old European humanism". (D. Zolo, 'Function, Meaning Complexity: The Epistemological Premisses of Niklas Luhmann's "Sociological Enlightenment', in: Philosophy of the Social Sciencest, $16(1986)$, p. 127.

686. W. Fritsclier, op.cit.; zie voor het tiu wolgende i.h.b. p.42-45.

687. Zie over Romantiek als 'tegenbeweging /" counter-culture', als subversieve techniek van "ontgrenzing" die zich telkens weer bedient van het dubbelzinnige en ambivalente, o: $\mathrm{a}$ : $\mathrm{B}$. Martin, A Saciology of Contemporary Cultural Change, Oxford 1981.

688. Verg. het opstel "Vorbenerkungen zu diner Theorie sozialer Systeme', in: N.Luhmann, Soziologische Aufldarurig 3, op.cit. 
brechen des Scheins der Normalität... Das methodologische Rezept hierfur lautet: Theorien zu suchen denen es gelingt. Normales fur unwahrscheinlich zu erklaren. Dies kann in funktionalistischer Perspektive mit Hilfe von Problernstellungen geschehen, die es ermöglichen, normale Erfahrungsgehalte der Lebenswelt als immer schon gelungene, aber vielleicht auch anders mögliche Problemlösung darzustellen. ${ }^{7689}$

Met het toenemend belang van een differentielogische (Spencer Brown) observatietheorie (Bateson, V. Foerster) begint vanaf de tweede helft van de jaren tachtig de nadruk allengs te verschuiven naar de reconstructie van paradoxale structuren en dat wil tevens zeggen: het observeren van de maatschappij opzadelen met ambivalenties en onbeslisbaarheid, om de observator (eventueel de maatschappij als 'zelfobservator') uiteindelijk onder ogen te voeren dat de selectiviteit van zijn observaties (of: heersende voorstellingen omtrent de identiteit van de moderne maatschappij) van eenzelfde willekeur en non-rationaliteit zijn als het ondanks alle paradoxie toch normale en waarschijnlijke functioneren van de samenleving.

Zijn we nu al met al bij een eigengereide variant van het Postmodernisme uitgekomen - ook al wil Luhmann daar zelf niets van weten? Hebben Erdmenger en Fach simpelweg gelijk, wanneer ze Luhmanns theorie omschrijven als de 'sociologische algemene noemer waarop het filosofisch Postmodernisme kan worden gereduceerd' $7^{690}$

Ja en nee.

Ja, voorzover de wijze waarop Luhmann het "oud-Europese" denken de wacht aan zegt, sterke parallellen vertoont met de Postmoderne kritiek op het totalitaire karakter van de 'grote vertellingen' die aan de 'Vernunftaufklärung' zijn ontsproten. Luhmann zelf zal hooguit geneigd zijn termen als 'totalitair' te reserweren voor politiek-maatschappelijke ideologieën en daarop gebaseerde stromingen, en (in de lijn van Karl Bracher) de daarvoor kenmerkende, pathologische hang naar identiteitsvoorstellingen benadrukken ${ }^{691}$ Of zoals hij in navolging van Marcel Gauchet opmerkt: Een grondtrek van het totalitarisme is precies de poging te negeren, desnoods met geweld, dat de representatie van de eenheid van het matschappelijk systeem binnen dat systeen een nieuwe

689. N. Luhmann, Soziale Systeme, Frankfurt 1985, p.162/63. Verg. bovendien Idem, p. 83 e.v.

690. Zje K.Erdmenger/W.Fach, "Von Wilden und Wichten. Ein Versuch uber den postmodernen Kleingeist', in: Zeitschrift fir Soziologie 17 (1988), pp. 365-373, i.h.b. p. 372.

691. Varg. 0.a. K. D. Bracher, Zeit der Ideologien-Eine Geschichte politischen Denkens im 20. Jahishundert, Munchen 1985. Voor het totalitarisme kenmerkende identiteitsvoorstellingen zijn volgens Bracher o.a. de identiteit van leider en volk, van partij en staat, van staat en maatschappij - met een navenante opheffing van het onderscheid tussen de publieke en de private sfeer. 
differentie produceert. ${ }^{692}$ Misschien kunnen we nog een stap verder gaan en met Neckel en Wolf constateren, dat "there is scarcely a key phrase of postmodem philosophy for which Luhmann"s systems theory would not already offer a scientific explanation." ${ }^{693}$ Inderdaad, Luhmanns sociologie geeft in grote lijnen een verklaring voor het 'Postmoderne bewustzijn' en wel als een enigszins verlate, achter de 'Zeit' aanlopende en dan natuurlijk wat geëxalteerde 'Geist' die er achter is gekomen, dat een van de grondkenmerken van de modeme maatschappij is gelegen in de telkens slechts locale, zo niet idiosyncratische gelding van uiteenlopende rationaliteitsvormen en werkelijkheidsbeschouwingen.

We zouden natuurlijk nog op een andere overeenkomst tussen Luhmann en de Postmodernen kunnen wijzen, namelijk op hun gemeenschappelijke preferentie voor 'differentie' boven 'identiteit'. Maar daarmee zijn we tevens bij een belangrijk onderscheid aangekomen. 1.tt. de Postmodernen brengt Luhmanns voorkeur voor het differente geen afwijzing van identiteit met zich mee, geen argwanend agonisme (Lyotard). Als Luhmann sociale systemen als stnuctuurgedetermineerde systemen karakteriseert en over zichzelf nadrukkelijk zegt: 'Ich denke primär historisch" van het hier en nu telkens geldende en vaste, niet als het eeuwig onveranderlijke, maar als datgene in het licht waarvan het mogelijke eerst als mogelijkheid kan verschijnen. Luhmann is geen radicaal possibilist voor wie geldt, dat alles wat mogelijk is, tegelijkertijd en met eenzelfde waarschijnlijkheid mogelijk is. We hadden inderdaad in een andere wereld kunnen leven, maar wat in deze wereld mogelijk is, is slechts mogelijk op basis van het hier en nu actuele. Of zoals Fritscher Luhmanns, in vergelijking met bijv. Derrida, strenge ironie inschat:

'Nicht ungebundenes Ironisieren und Parodieren, statt dessen: reflexives Nutzen von Paradoxien. Nicht bloß asthetisches Spielen mit postmoderner Weltenpluralitat, statt dessen Ernst. Also: aufgeklärte/aufklärende romantische Ironie. ${ }^{: 695}$

692. Verg. N. Luhmann, Okologische Kommumikation, Opladen 1986, p.47. Zie wan M. Gauchet, 'L" experience totalitaire et la pensée de la politique', in: Esprit (juli/augustus) 1976, p. 3-28.

693. S.Neckel/J. Wolf, op.cit., p. 72.

694. Zie N Luhmann, "Ich denke primär historisch' Religionssoziologische Perspektiven" (interview met Detlef Pollack), in: Dewtsche Zeitschriff for Philosophie 39 (1991/9), pp. 937. 956 i.h.b. p. 940 .

695. W. Fritscher, op.cit., p. 45. 


\section{$\$ 5$ Ter afsluiting: 'Vernünftige Soziologie'}

Onze zoektocht naar de normatieve, zo niet kritische impuls van Luhmanns werk nadert zijn einde. Laten we ter afsluiting nog eens terugkeren naar een thema dat we in de 'Inleiding' van dit hoofdstuk hebben aangesneden, het thema van een "vernüftige Soziologie": Kunnen we in goeden gemoede beweren dat Luhmann, als een soort alternatief voor Habermas' vraag naar de "vernünftige Identitat' van de modeme maatschappij, de contouren van een 'vernünftige Soziologie' heeft weten te schetsen?

Als de 'Vernunftigkeit' van een theorie gelegen zou zijn in haar bekenning tot het "bonim commune", in de keuze voor het moreel juiste en politiek gewenste, dan is Luhmanns project beslist niet 'verntunftig' - maar Luhmann heeft volstrekt gelijk, wanneer hij een dergelijke optie van een onvoorstelbare nailviteit vindt getuigen. Het is vanuit een filosofie-historisch perspectief echter even naîf om te veronderstellen dat het idee van 'Vernunftigkeit' tot een dergelijke, moralistische affirmatie kan worden gereduceerd. Op zijn minst vanaf Kant, en i.h.b. sinds Hegel, is de idee van 'Vernunft/Vernunftigkeit' in een veel bredere zin betrokken geweest op de vraag naar de fundeerbaarheid van een samenhang tussen de verschillende dimensies van het moderne bestaan, een fundering die niet in het laatst de samenhang tussen onze theoretisch-cognitieve en onze praktisch-morele omgang met de wereld betrof. Als we nu (voorzichtig genoeg) van een 'samenhang' blijven spreken, en niet van 'eenheid' of 'identiteit', laat zich dan binnen Luhmanns project een vergelijkbare funderingssamenhang aanwijzen? Kan, anders geformuleerd, de 'differentie van identiteit en differentie' worden begrepen als een 'gefundeerde/funderende' samenhang van beschrijvende theorie en voorschrijvende normativiteit, van descriptie en prescriptie?

De voortekenen zijn wederom niet erg gunstig. Immers, Luhmann deelt met het relativisme dat het handelskenmerk van de hedendaagse filosofie is geworden een binnen deze context tamelijk cruciale intuitie. Want of dit relativisme zich nu afficheert als 'post-structuralisme", 'Postmodernisme', of algemener als 'antifunderingsdenken', de grondslag ervan blijft in wezen dezelfde: een alles doordringend besef van de contingentie, de niet-noodzakelijkheid, het "ookanders-mogelijke', niet alleen van wetenschap en techniek, maar ook van onze maatschappelijke instituties en cultureel bemiddelde, normatieve idealen. Voor niets lijkt meer een dwingende reden te kunnen worden gegeven; alle waarheden en waarden schijnen als uitkomst van een contingente historische configuratie slechts een locale, mar verder willekeurige gelding te hebben.

Dit 'fílosofisch' contingentiebewustzijn krijgt bij Luhmann echter een typische, zo niet beslissende wending. De basale contingentie van onze duiding van de wereld dienen we volgens hem niet langer uit te geven voor de bodemloze willekeurigheid van al onze opvattingen, maar moet worden gerdentificeerd als het vertrekpunt, ja als mogelijkheidsvoorwaarde van al ons kennen, inclusief 
ons 'Wetenschappelijk' kennen. ${ }^{6 \%}$ Wat Luhmann in zijn discussies met constructivistische wetenschapsonderzoekers herhaaldelijk naar voren heeft gebracht, is, dat zolang sociaal constructivisten vaststellen, dat het wetenschappelijk kennen niet gegrond is in een onafhankelijk van het wetenschappelijk kennen bestaande 'natural world"697 en het daar verder bij laten, zij al met al weinig nieuws te melden hebben ${ }^{698}$ Een dergelijk constructivisme is, aldus Luhmann, niet meer (maar ook niet minder) dan een nieuwe editie van een kentheoretisch scepticisme dat zich gedragen weet door een probleemfiguur die in feite al zo oud is als Descartes' 'harde' onderscheid tussen 'res cogitans' en "res extensa", tussen een kennend subject en een te kennen object. Op het moment dat Descartes subject en object ontologisch uit elkaar drijft, d.w.z. het kennen en het gekende onderscheiden zijnsregionen toewijst, stelt zich natuurlijk het probleem hoe het kennen alsnog over die kloof heen kan springen: Hoe kan het kennen vaststellen dat er iets bestaat, dat onafhankelijk is van het kennen, wanneer geldt dat iedere vaststelling daarvan kenprestaties vooronderstelt en dus slechts in afhankelijkheid van het kennen gekend kan worden? ${ }^{699}$ of in een, door de taalfilosofische kritiek op het kentheoretisch realisme geinspireerde formulering: Hoe kunnen we vaststellen dat taal, of een talige beschrijving, aan een objectief bestaande, buiten de taal gelegen werkelijkheid refereert, indien die vaststelling wederom het gebruik van taal veronderstelt, namelijk in de vorm van een beschrijving zou moeten geschieden. ${ }^{700}$

Een definitief afscheid van dit in wezen nog steeds 'traditionele', of zo men wil: Kantiaanse, scepticisme wordt volgens Luhmann pas genomen, wanneer we eén stap verder gaan - wanneer we de vraag "Hoe is kennis mogelijk, gegeven de veronderstelling dat het kennen geen van zichzelf onafhankelijke toegang tot een 'externe', vam het kennen onafhankelijke realiteit heeft?' achter ons laten en vaststellen: kennen is voor een kennend systeem mogelijk omdat het zich van

696. Verg. 0.a. N. Luhnam, Enkenntnis als Konstruktion, Bern 1988, p. 8 ev. In zeker opzicht herinnert de beweging die door Luhmann wordt gemaakt aan de wijze waarop Grotius, daarin o.a. gewolgd door Hobbes, het sombere scepticisme van Lipsius en Montaigne overwint, namelijk door de grondslag ervan: de constatering dat de mens uiteindelijk gedreven word: door cen niets ontziend egoïsme - - orn te zetten in een "natuurrecht" op zelfbehoud en daarin het uitgangspunt wan cen nieuwe ethiek en politiek te vinden. De stap die door Luhmana wordt gezet, is in zoverre vergelijkbaar als nu eveneens een probleem in een vertrekpunt wordt getransformeerd.

697. Zo schrijf Harry Collins: "The naturall world has a small or non-existent role in the construction of scientific knowledge:' (H.M. Collins, 'Stages in the Empirical Programme of Relativism', in: Social Sudies of Science 11 (1981), p.3.

698. Zie woor dit en het nu volgende, nast het reeds geciterde Erkenntwis als Konwtruktion en Die Wissenschaft der Gesellschaft (Frankfurt 1990), wooral ook het "Vorwort' bij Sozlollogisishe Aufklärung 5 (Opladen 1990) en de daarin opgenomen opstellen 'Identität - was oder wie?' en 'Das Erkenntnisprogramm des Konstruktivismus und die unbekanuntbleibende Reallitatt.'

699. Verg. N. Luhmann, Erkemintris als Konstruktion, op:cit., p.8.

700. Verg. H. Putnam, Reatism and Reason, Cambridge 1983, i.h.b. de datrin opgenomen opstellen 'Models and reality', 'Reference and truth' en 'Why there isn't a ready-made world". 
vaststellen: kennen is woor een kennend systeem mogelijk omdät het zich van een buitenwereld of omgeving afsluit. ${ }^{701}$ Alleen systemen die zich van hun omgeving kunnen afsluiten, die externe determinatie kunnen afweren, kunnen ook kennen. Een systeem dat voortdurend reageert op gebeurtenissen in zijn omgeving, dat niet anders kan dan "mee-vibreren", is uberhaupt niet in staat om intern die complexe structuren op te bouwen die wij met kennen associèren. Pas een systeem dat zijn causale relaties met de omgeving weet te onderbreken, dat zich afkoppelt, dat voor het overgrote deel alleen nog op zichzelf, op zijn eigen, contingent geselecteerde aanvangstoestanden reageert, kan zijn interne complexiteit, zijn interne combinatiemogelijkheden vrijmaken en aanwenden voor de opbouw van cognitieve structuren zoals we die in een hoog ontwikkelde vorm bij het menselijk brein en ook in de modeme wetenschap aantreffen ${ }^{702}$

Dit idee van 'afkoppeling', van contingente selectiviteit als uitgangspunt en mogelijkheidsvoorwaarde van al het kennen, een idee waarvoor Luhmann zich in zijn kentheoretische uitwijdingen herhaaldelijk beroept op hersenbiologisch en -fysiologisch onderzoek, vormt natuurlijk een direct correlaat van zijn maatschappijtheorie, van de gedachte dat fumctiesystemen zich slechts alls gesloten systemen kunnen uitdifferentiëren. ${ }^{703}$ Ook het moderne wetenschapssysteen heeft zich slechts op voorwaarde van 'slwiting' kunnen formeren, door zich af te koppelen van zijn omgeving - en dat wil in eerste instantie zeggen: van zijn maatschappelijke ongeving, van religie, politiek, moraal, etc. Meer in het algemeen is Luhmann van mening dat hetgeen wij "weten" ("Wissen") noemen, of dit nu het alledaagse of het wetenschappelijke weten betreft, nooit het 'bezit' is van individuen of psychische systemen, maar altijd refereert aan maatschappelijk geproduceerde en gestabiliseerde cognitieve verwachtingsstructuren -

"Wir behandeln Wissen, und damit auch Wissenschaft, in der Systemreferenz eines sozialen Systems, und zwar die Ge-

701. Verg. o.a. N. Luhmann, Erkenntnis als Ronstruktion, op.cit., p.51 em Idem, Soziologiwche Awhilarung 5, op.cit., p. 37.

702. Dit alles wil niet zeggen, dat een kennend systeem zonder omgeving bestato, of zou kunnen bestaan. Natuurlijk kan het centrale zenuwstelsel niet zonder een fysische, chemische en biologische ongeving bestaan. En natuurlijk kan het moderne wetenschapssysteem niet zonder een economische, politieke, pedagogische, etc. omgeving bestaan en evenmin zonder wetentschappers en laboratoria. Afkoppeling, sluiting impliceert evennin, dat er geen enkele beinvloedingarelatie tussen een kennend systeern en zijn omgeving zou bestaan. De kllap op het oog heeft inderdaad ists to maken met de gewaarwording van sterretjes. Sluiting, en de autonomie die een systeem daarmee bereikt, wil zeggen, dat het systeem zelf bepaalt op welke prikkels, ruis of irritaties het reageert en hóe het dat doet Om de geijkte formule te parafraseren: een keninend systeem is slechts gevoelig voor die zaken watar het zichzelf gevoelig voor maakt. Maar natuurlijk kan men systemen van buitenaf vernietigen, bijwoorbeeld door kogels, of door een ministerievan onderwijs:

703. Verg. o.a. N. Luhmann, "Das Erkennthisprogtamm des Konstruktivismus und die unbekannt bleibende Realitat', op. cit., p.57. 
sellschaft. Die basale Operation, un die es sich handelin wird, ist also allemal Kommunikation - und weder Leben, noch Bewußtsein. ${ }^{\text {704 }}$

En even verder heet het:

'Wissen ist mithin das Sediment einer Unzahl von Kommunikationen, die kognitive Erwartungen benutzt und markiert hatten und mit ihren Resultaten reaktualisierbar sind. ${ }^{705}$

De 'naturalisering' of 're-empirisering' van de ken- en wetenschapstheorie die al via de biologische wetenschappen en de 'cognitive sciences' baan brak, neemt bij Luhmann dus de vorm aan van een sociologische naturalisering. En eigenlijk is hij er ook van overtuigd, dat een radicalisering van het naturalistische programma uiteindelijk bij een sociologie van de kennis moet uitkomen: 'Das Quinesche Programm der 'naturalisierten Epistemologie' muß um Soziologie ergänzt werden; ja es leistet erst so eigentlich, was es verspricht". ${ }^{706}$

Ons interesseert hier eerst en vooral de vraag welk licht een dergelijke 'sociologische naturalisering' van de ken- en wetenschapstheorie kan werpen op de vraag naar de 'Vernünftigkeit' van een Luhmanniaanse sociologie. Vanuit een meer algemeen perspectief moeten we in ieder geval vaststellen, dat indien 'sluiting' in de vorm van een circulaire organisatie van cognitieve operaties het sine qua non van kennisverwerving vormt, dat er dan ook voor het wetenschappelijk (en sociologisch) kennen geen externe, van de wetenschap onafhankelijke gronden kunnen bestaan. Dat betekent nog niet, dat er voor wetenschappelijke kennis helemaal geen grond zou bestaan. Het wetenschappelijke kennen vindt zijn grond in zichzelf, wetenschap fundeert zichzelf in de recursieve opeenvolging van wetenschappelijke operaties! Of om het in eerste instantie tautologe karakter van deze zelffundering op de voorgrond te plaatsen: wetenschappelijke kennis is wat het wetenschappelijke kennen voor wetenschappelijke kennis houdt. ${ }^{707}$

$\mathrm{Nu}$ bieden tatitologe, circulaire constructies als het om (zelf)fundering gaat beslist een aantal voordelen. Ze stoppen bijwoorbeeld het vragen naar verdere, 'diepere' gronden, naar de gronden wan gronden, door de funderingsvraag en het funderende antwoord zo op elkaar te betrekken, dat al nia enkele malen zowel de vraag, als het antwoord, als de vraag n.a.v. het antwoord, als het

704. N. Luthmann, Die Wissenschaft der Gesellschaft, op,cit, p. 133.

705. Idem, p.139.

706. N. Luhmann, 'Das Erkenntmisprogramm des Konstruktivismus und die unbekannt bleibende Realitut', in: Soziologische Auflarung 5, op.cit., p.54. Verg ook: Idem, Erkenntwis als Kanstruktion, op cit., p. 24.

707. Verg. o.a. Soziale Systemse, op. cit., p.648. 
antwoord daarop, als.... - voorspelbaar worden. Uiteindelijk kunnen we er op vertrouwen dat de kerk aan het kerkplein ligt en het kerkplein bij de kerk ligt, een vertrouwen dat wordt uitbetaald in de ervaring van zekerheid. Het nadeel van circulaire constructies, of in ieder geval van 'tekort' gesloten tautologieën is eveneens evident: ze zijn informationeel 'leeg", slechts geconditioneerd door een zuiver contingente aanwang. (Men zou haast zeggen: ze zijn op een willekeurige wijze per definitie 'waar'.) En de voor de hand liggende vraag wordt dan hoe de wetenschap er in slaagt die directe circulariteit te doorbreken, de aanvankelijke tautologie te "ontvouwen' (of: de waarheid van de tautologie minder willekeurig te maken).

Luhmanns antwoord op deze vraag is inmiddels voorspellbaar: de oorspronkelijke tautologie komt in beweging, verkrijgt een eerste structuur door 'externalisering", door de zelfreferentie om te leiden via (allo)referenties aan wat het zelfreferentieel gesloten systeem niet als een eigen operatie observeert, door de aanvankelijke zelfreferentie te onderbreken met referenties aan zaken dlie het kennen van zichzelf weet te onderscheiden als zijnde geen kennisverwervings-operaties. Natuurlijk blijft gelden, dat de observatie van iets als 'extern', als 'niet tot het kennende systeem behorend' slechts mogelijk is op basis van een differentie tussen 'zelf" en "niet-zelf', een differentie die het kennend systeem/de wetenschap niet 'ergens daarbuiten' aantreft, maar zelf moet construeren. In die zin is ook Luhmann principieel - "van meet af aan" constructivist. Zijn con-structivisme verkrijgt vervolgens een "radicaal" karakter, voorzover voor hem tevens geldt, dat de constructie van een "exteme realiteit' precies de vorm is waarin het kennen zichzelf structuur verschaft, zich eerst als een kennend systeem constitueert - 'Reality assumptions are structures of the system that uses them". ${ }^{708}$ Observator en observatum, de beschrijver en het beschrevene, of in een meer klassieke terminologie: subject en object constitueren elkaar wederzijds! $!^{709}$ Wetenschap, zo zou men ook kunnen zeggen, constitueert zichzelf op basis van indirecte zelfreferentie. Het wetenschapssysteem verwijst naar zichzelf in en door een verwijzing naar een zelf geconstrueerde 'externe' werkelijkheid en dit als de vorm waarin het zichzelf van structuur woorziet, zichzelf constitueert als systeem:

Op het eerste gezicht lijken we met deze transformatie van de tautologie "kennis is wat het kennen voor kennen houdt" in een "wederzijdse constitutieverhouding tussen het kemnen en het gekende', alleen nog maar verder wan huis te zijn geraakt. De cirkel blijkt beide kanten op te kunnen draaien. een perfecte, maar daarmee ook non-informatieve symmetrie. Bij nader inzien moeten we echter constateren, dat pas deze vaststelling van een wederzijdse constitutie van het

708. N. Luhmann, "Closure and Openess. On Reality in the World of Law", in: G. Teubner, Autopoietic Law A New Approach to Law and Society, Berlijn 1988, p.337. Zie wooral ook $\mathrm{N}$. Luhmainn; "Tautologie und Paradoxie in den Selbstbeschreibungen der modemen Gesellschaft" op, eit, p. 171 e.v.

709. Verg. W. Rasch, op.cit, p. 77. 
kennen en het gekende, van het beschrijven en het beschrevene, het mogelijk maakt de zelffundering van het wetenschappelijk kennen als de 'zelfontvouwing' van een oorspronkelijke, zelfreferentiele circulariteit te begrijpen. De "dubbele circulariteit" die in deze wederzijdsheid ligt besloten kan worden benut als het aanknopingspunt van een tweetal vragen die ieder voor zich in een specifieke asymmetrie resulteren. De ene vraag, die we hier met een schuin oog op de geschiedenis van de filosofie, de 'ontologische' vraag zullen noemen, luidt: aan welke voonwaarden moet de (wetenschappelijk) te kennen werkelijkheid voldoen, gegeven de wijze waarop wij aannemen die werkelijkheid (wetenschappelijk) te kennen. ${ }^{710}$ De "epistemologische" vraag luidt dan: aan welke voorwaarden moet het (wetenschappelijk) kennen voldoen wil het de werkelijk kunnen kennen zoals die werkelijk is. Natuurlijk kan de vragende vorm niet verhullen, dat we hier nog steeds met circulaire constellaties van doen hebben, en een verhulling daarvan is ook niet de bedoeling. Het punt is daarentegen, dat langs deze weg de oorspronkelijke circulariteit met een tweetal asymmetrieèn wordt "verrijkt" (zoals Luhmann zou zeggen). In het ene geval worden de (historische gezien contingente) methodologische en epistemologische veronderstellingen, of meer sociologisch geformuleerd: de normatieve structuren van het kennend systeem constant gehouden en dit terwille van een versterking van de selectiviteit van een (allo-referentiëel) beschrijven dat zich geconfronteerd ziet met een "overmaat aan beschrijvingsmogelijkheden. In het andere geval wordt datgene wat zich in en door recursieve beschrijvingsoperaties an 'werkelijkheid' heeft uitgekristalliseerd, i.e. de hier en nu geldende, maar veranderlijke cognitieve structuren van het systeem, probleemloos voorondersteld en dit terwille van de zelfobservatie en zelfbeschrijving van een systeem dat zichzelf als een 'kennend' systeem identificeert, zichzelf maw, onderscheidt van een observeren en beschrijven dat slechts in 'menen' (doxa) of in kunstzininige expressie resulteert. (Het circulaire karakter van beide vormen van 'asymmetrisering' keert overigens terug in een (dikwijls indirecte, latente) "controle'-functie die zich tegengesteld aan de 'conditionerings-" of "selectie'functie beweegt. Zo 'controlleert' de vraag, aan welke (structurele) voorwarden de werkelijkheid moet voldoen, willen we deze kunnen kennen zoals we menen die te (moeten) kennen, tegelijkertijd of de binnen het systeem vigerende methoden- en kennisidealen een coherente constructie/beschrijving van wat het systeem voor zichzelf als "werkelijkheid" moet scheppen, uberhaupt wel toelaat.)

710. De karakterisering van deze vraagstelling als "ontologisch" komt owerigens niet uit de luctat vallen, maar herinnert aan een centrale drijfveer van de traditionele ontologie, Zo omschrijf John Randall de kern van Aristoteles" 'eerste filosofie' als 'an analysis of the fundamental characteristics any existent thing must possess, if it is to be and to be known, a set of ultimate distinctions to be used in making existential subject-matter intelligible ${ }^{x}$. (J.H. Randall Jr. Artstorle (New York 1960), p. 109.) 
De transformatie van een dubbele, perfect symmetrische circulariteit in twee afzonderlijke, zich door een tegengesteld asymmetrie-effect van elkaar onderscheidende cirkels, zo zouden we het bovenstaande in abstracte, maar ook simpeler vorm kunnen samenvatten, leidt tot een differentiatie van wat in de tautologie "kennis is wat het kennen voor kennis houdt", slechts als diffuse eenheid aantrefbaar is, de eenheid namelijk van het cognitieve en het normatieve, van descriptie en prescriptie. De 'zelf-ontvouwing' van het kennen (de zelfconstitutie van het kennende systeem "wetenschap'), zo zouden we in het post-Hegeliaans jargon van Luhmann kunnen formuleren, neemt de vorm aan van een eenheid (van descriptie en prescriptie) die zich differentieert van de differenties waar ze zelf de eenheid van vormt - van differentie van identiteit en differentie.

Het is natuurlijk verleidelijk om op dit punt gekomen definitieve conclusies aangaande de "Vernünftigkeit" van een Luhmanniaanse sociologie te trekken. Maar laten we bovenstaande, in wezen kentheoretische bevindingen eerst nog eens controleren aan de hand van de relatie tussen de descriptieve en prescriptieve veronderstellingen van Luhmanns sociologie in engere zin. Wat impliceert een op basis van zijn sociologie voltrokken 'sociologische naturalisering' van de kentheorie voor Luhmanns sociologie zelf?

Gegeven de 'zelf-implicatieve'; of zoals Luhmann zou zeggen: 'autologische" consequenties van zijn kennistheorie, moet ook voor een Luhmanniaanse sociologie gelden dat deze slechts mogelijk is op voorwaarde van 'sluiting', van afkoppeling van de omgeving, van 'niet-gedetermineerd-zijn' door iets anders dan de eigen ontwikkeling als wetenschappelijke discipline. Ook voor een systeemtheoretische sociologie moet m.a.w gelden, dat de contingentie van een aanvankelijke selectiviteit haar mogelijkheidsvoorwaarde vormt. $\mathrm{Nu}$ is er inderdaad niets dat er toe dwingt, ook de 'omgeving' niet, de systeem/omgeving-differentie als 'Leitdifferenz' van de observatie/beschrijving van de wereld te nemen. Opmerkelijk is alleen, dat met de systeem/omgeving-differentie een contingentieveronderstelling wordt gemaakt jegens 'de werkelijkheid'. die met behulp wan die (contingente) differentie wordt geobserveerd en beschreven. En die contingentieveronderstelling wordt des te pregnanter, wanneer Luhmann sociale systemen - het eigenlijke object van zijn sociologie - kenmerkt als zichzelf structurerende, maar in wezen contingente 'oplossingen' van een 'dubbele contingentie'-problematiek. De contingente constructie van een systeem theoretische sociologie gaat bij Luhmann ma.w. (willens en wetens) van start met een zelfde contingentieveronderstelling t.a.w. haar 'object', de sociale werkelijkheid die zij wil observeren en beschrijven en waarin zij als onderdeel van het wetemschapssysteem zelf rerugkeert.

Daarmee belanden we niet alleen bij het bekende criterium van reflexiviteit dat stelt, dat de sociologie haar eigen ontstaan en voorkomen in de sociale werkelijkheid moet kunnen beschrijven en verklaren met dezelfde middelen als waarmee ze gelijksoortige, maar andere sociale verschijnselen beschrijft en verklaart - en in die zin haar theorie(ën) dus toetst aan de mogelijkheid 
zichzelf (als 'sociologisch object") te verklaren. De zaak ligt veel specifieker. We zjjn uitgekomen bij een kentheoretisch zelfbewuste sociologie die:

a) een basale contingentie van de sociale systemen (inclusief het wetenschapssysteem) moet postuleren als mogelijkheidswoonwaarde om zichzelf als een wetenschappelijk kennen te kunnen begrijpen;

b) tegelijkertijd een bijzonder kennisideaal moet postuleren, namelijk: kennis die de complexiteit en contingentie van het gekende op een nietreductionistische manier verdisconteert - en dit als mogelijkheidsvoorwaarde van de observatie en beschrijving van 'het' sociale' als een werkelijkheid die precies wordt gekenmerkt door een basale, voor het werkelijkheidsdomein (en dus ook voor zichzelf als sociologie) constitutieve contingentie.

M.a.w. Luhmanns specifieke kennisideaal fundeert zichzelf in, en controlleert zichzelf aan, grondstructuren (of: 'domain assumptions') die een, door dat ideaal geleid kennen projecteert op een werkelijkheid die het zichzelf als (cognitieve) structuur geeft. Wat we eerder als de 'normatieve impuls' of als "de politiek' van Luhmanns theorie omschreven, zijn commitment aan het differente en deviante, verschijnt nu niet langer als een onvermijdelijk effect van een nu eenmaal gemaakte (maar ook anders mogelijke) keuze voor een typische modellering van de sociale werkelijkheid, en in die zin als 'toevallig'; het dient zich aan als een mogelijkheidsvoorwaarde van het theoretisch project als zodanig. Luhmanns project van een systeemtheoretische sociologie, zo zouden we ook kunnen zeggen, sluit zich in zichzelf op: gegeven de door dit project zelf in gang gezette sociologische naturalisering van de epistemologie én gegeven de observatietheoretische/constructivistische epistemologisering van die sociologie, kunnen de normatieve drijfveren van dit project, voor dit project zelf niet meer ter discussie staan. De theorie fundeert haar descriptieve pretenties in een specifieke normativiteit, zonder daarbij nog ruimte te laten voor contingente keuzes. Welke affiniteiten er met het Postmodeme bewustzijn ook mogen bestaan - $\rightarrow$ eenmaal de theorie binnen gestapt, eenmaal de grondslagen van Luhmanns theorie van sociale systemen geaccepteerd, is er voor een grenzeloos relativisme geen plaats meer.

Langs deze weg stuiten we tevens op de blinde vlek van Luhmanns project en op de paradox die daarmee aan het oog wordt onttrokken. De keuze voor een radicaal contingentietheoretische benadering van de sociale realiteit kan voor de theorie zelf geen contingente keuze meer zijn. Dat impliceert o.a.; dat zij haar eigen, specifieke normativiteit niet meer als een normatieve keuze kan begrijpen. Of om het soort paradoxen waartoe deze funderende, tautologe identiteit van kennisideaal en gekende werkelijkheid leidt, in termen van 'de politiek' van Luhmanns sociologie te formuleren: zijn sociologie doet precies zelf wat ze wil voorkomen - ze sluit theorieèn die devianties willen uitsluiten uit als deviante theorieẻn. Wat dan nog ten gunste van een Luhmanniaanse sociologie kan worden opgemerkt, is, dat deze binnen haar eigen raamwerk op 
een beargumenteerde wijze vrede kan hebben met het besef, dat omvattende theoretische projecten onvermijdelijk op paradoxen gefundeerd zijn. ${ }^{711}$

Laten we nu terugkeren naar omze uitgangsvraag: inhoeverre kan Luhmanns sociologie als een 'vernünftige' sociologie worden begrepen. 'Vernünftigkeit', zo stelden we eerder al vast, heeft minimaal betrekking op de wijze waarop normativiteit en descriptiviteit op elkaar worden betrokken. Het bovenstaande overziend, zouden we daar nu aan toe kunnen voegen: én van elkaar onderscheiden blijven. ${ }^{712}$ 'Vernunftig' is dan een sociologie die de circulaire, zelffunderende en identiteitverlenende eenheid van normativiteit en descriptiviteit, van kennisideaal en gekende werkelijkheid, weet te onderscheiden van die zelfgecreerde werkelijkheid als dat wat ze in cognitieve zin will beschrijven. Vernunftig is een sociologie, zo zouden we ook kunnen formuleren, woorzover ze in staat is de differentie tussen de identiteit van de normatief/cognitief-differentie en het daardoor gediffentieerde overeind te houden en dit ter fundering van zichzelf als een niet-normatieve, cognitiefbeschrijvende wetenschap van de sociale werkelijkheid.

Tegen een dergelijke, op 'differentie' afgestemde invulling van het idee van een 'redelijke sociologie' zou kunnen worden ingebracht, dat deze bij voorbaat is toegesneden op een 'Romantische sociologie'. En de beantwoording van de vraag, inhoeverre Luhmanns sociologie als een 'vernunftige sociologie' kan worden bestempeld, zou op die manier wel erg voorspelbaar worden. Maar let wel - het gaat er nu niet om, het onszelf gemakkelijk te maken of om van Luhmann op de valreep nog een held van de Rede te maken. We zijn aan het einde gekomen van een immanent opererend onderzoek naar de nomativiteit en mogelijke 'Vernunftigkeit' van het Luhmanniaanse project - inderdaad naar de vraag wat onder de intellectuele condities van een dergelijk project nog als 'Redelijkheid' kan worden begrepen. En verder kunnen we ook niet gaan, tenzij we in de herhaling van het detail willen vervallen. Wat de voorafgaande bespiegelingen daarnaast nog bieden, is slechts een aanwijzing voor het op nietwillkeurige, systematische wijze bedrijven van een externe kritiek op Luhmanns sociologie en maatschappijtheorie. Die aanwijzing luidt dan: stel je op aan de zijde van een niet-Romantische Verlichting en reconstrueer van daaruit en met behulp van de intellectuele middelen die aan de oorspronkelijke Verlichting eigen zijn, het Luhmanniaanse project. Op de keper beschouwd, hebben we in de voorafgaande alinea's al van deze aanwijzing gebruik gemaakt. We hebben

711. En de techniek om daarmee om te gaan ligt al klaar, namelijk te onderscheiden tussen le- en 2 -ordle observatie/beschrijving, bijv. tussen de beschrijving van een 'exteme werkelijkheid' en de epistemologische zelfbeschrijving als een beschrijven van dit beschurijven, en dit in het besef dat 2 e-orde observaties tegelijkertijd le-orde observaties zijn.

712. En we menen zo over "Vernunft' to kunnen spreken in herinnering aan bijv, Kants associatie van "Vernunft" met "Ideeën", begrepen als transcendentale regulativa die zin verlenen aan de inspanningen van het "Verstand', aan de wil de wereld wetenschappelijk te kennen, maar die tegelijkertijd wan het wetenschappelijk kennen principieel onderscheiden moeten worden. 
althans de techniek van logische reconstructie en consistentie gebruikt om een laatste, Luhmanns denken funderende identiteit aan het licht te brengen, waarvan we vervolgens vaststelden dat deze zijn blinde vlek vonmde. Daarmee is niet nog even snel de Verlichting zalig gesproken - die heeft haar eigen blinde wlekken en met de uiteenzetting van Luhmanns "sociologische Verlichting' hebben we daar al uitvoerig bij stil gestaan. Het zou echter een interessante onderneming kunnen zijn, om de kritiek van Habermas op Luhmann eens met Habermas' kritiek op Adomo te vergelijken. Als de differentie Verlichting/Romantiek een vruchtbare spiegellijn oplevert, dan lijkt althans Adorno met zijn 'Romantiek aan de zijde van de Verlichting', en niet Habermas, het grote spiegelbeeld van Luhmanns 'verlichtende Romantiek' te zijn. ${ }^{73}$ Maar dat zijn suggesties voor een geheel ander boek dan het nu voorliggende.

713. En des te interessanter Luhmanns weigering tot dusverre om zijn verhouding tot Hegel systematisch to expliciteren en uit te diepen. Naar eigen zeggen zou hem dat veel to veel opslorpen. 



\section{LITERATUURLIST}

Adomo, Th. Soziologische Schriften. Vol. 1. Frankfurt/M, 1979.

Baecker, D., ed. Kalkiul der Form. Frankfurt/M., 1993.

Baecker, D., ed. Probleme der Form. Frankfurt/M., 1993.

Baecker, D., ed. Theorie als Passion. Frankfurt/M., 1987.

Baecker, D., and G. Stanitzek, eds. Niklas Luhmann. Archimedes una' wir. Interviews. Berlijn, 1987.

Bednarz, J. 'Functional Method and Phenomenology: the View of Niklas Luhmann.' Human Studies 7 (1984): 343-362.

Bendel, K. 'Funktionale Differenzierung und gesellschaftliche Rationalität.' Zeitschrift für Soziologie 22 (1993): 261-278.

Benseler, F., P. Hejl, and W. Köck, eds. Autopoiesis, Communication and Society. Frankfurt/M, 1980.

Berg, H. de, and M. Prangel, eds. Differenzen. Systemiheorie zwischen Dekonstruktion und Konstruktivismus. Tübingen, 1995.

Berkhout, D. De symbolische media van de samenleving: over interpenetratie in de moderne samenleving. Utrecht, 1990.

Bertalanify, L. von. "General System Theory.' General Systemtheory I I (1956): $1-10$.

Blanke, T. 'Kritik der systemfunktionalen Interpretation der Demonstrationsfreiheit.' Kritische Justiz 20 (1987): 157-165.

Blom, T. 'De zelforganisatie van de sociale werkelijkheid.' Kennis \& Methode 12 (1988): 236-255.

Blom, T. 'Een constructivistische radicalisering van het sociaal constructivisme.' Kennis en Methode 19 (1995): 160-180.

Blom, T. 'Zin en Systeem.' Tijdschrift voor Sociale Wetenschappen 31, 1 (1986): 22-53.

Blom, T., and T. Nijhuis. 'Individualisme en collectivisme in geschiedenis en sociologie.' Tijdschrift voor sociale wetenschappen 34 (1989): 3-24.

Blon, T, and L.M.A. Timmermans. "Recht is Recht is Recht is..." Recht en Kritiek 19.(1993): 48-78.

Boulding, K. 'General System Theory-The Skeleton of Science.' General Systemtheory I 1 (1956): 11-17.

Bracher, K.D. Zeit der Ideologien-Eine Geschichte politischen Denkens im 20 Jahrhundert. Munchen, 1985.

Brunner, O., W. Conze, and R. Koselleck. Geschichtliche Grundbegriffe Bd.1. Stuttgart, 1979.

Buckley, W. Sociology and Modern Systems Theory. Englewood Cliffs, 1967. Collins, H.M. 'Stages in the Empirical Programme of Relativism.' Social Studies of Science 11 (1981): 3-10.

Damman, K., D. Grunow, and K. Japp. Die Venwaltung der Politischen Systems.Opladen, 1994. 
Davis, K. "The Myth of Functional Analysis as a Special Method in Sociology and Anthropology." American Sociological Review 24 (1959): 757-772.

Dawe, A. "The Two Sociologies." British Journal of Sociology XXI, 2 (1970): 207-281.

Diemer, A, ed. System und Klassificationin Wissenschaft und Documentation. Meisenheim/Glan, 1968.

Dumouchel, $\mathrm{P}_{\text {, }}$ and J. P. Dupuis, eds. L'Autoorganisation. De la physique au politique, Parijs, 1983.

Eisenstadt, S.N., and M. Curelaru. The Form of Sociology-Paradigms and Crises. New York, 1976.

Erdmenger, K, and W. Fach. 'Von Wilden und Wichten. Ein Versuch uber den postmodernen Kleingeist.' Zeitschrift für Soziologie 17 (1988): 365-373.

Fink, E. Alles und Nichis. Den Haag, 1959.

Foerster, H. von. Observing Systems. Seaside (Cal), 1981.

Frankenberg, G. 'Der Ernst im Recht.' Kritische Justiz 20 (1987): 281-307.

Fritscher, W. 'Romantische Beobachtungen.' Soziale Systeme 2 (1996): 35-51.

Gauchet, M. 'L'Experience totalitaire et la pensée de la politique." Esprit juli/augustus (1976): 3-28.

Geser, H. 'Gesellschaftliche Folgeprobleme und Grenzen des Wachstums formaler Organisationen.' Zeitschrift für Soziologie 11 (1982): 113-114.

Giddens, A. The consequences of Modernity. Stanford, 1990.

Gotthard, G. Beiträge zur Grundlegung einer operationsfähigen Dialektik, Bd. I, Bd. 2. Hamburg, 1976, 1979.

Gouldner, A. The Coming Crisis of Western Sociology. London, 1971.

Gouldner, A. 'Reciprocity and Autonomie in Functional Theory." In Symposium on Sociological Theory, edited by L. Grosz. New York, 1959.

Gray, W., and N.D. Rizzo, eds. Unity through Diversity I. New York, 1973.

Grimm, K. Niklas Luhmann's 'soziologische' Aufklärung - oder das Elend der aprioristischen Soziologie. Hamburg, 1974.

Grosz, L., ed. Sympositum on Sociological Theory. New York, 1959.

Grunberger, H. 'Dehumanisienung der Gesellschaft und Verabschiedung staatlicher Souveränitat: das politische System in der Gesellschaftstheorie Niklas Luhmanns.' In Pipers Handbuch der politischen Ideen Bd.5, edited by Fetscher and Munkler. Munchen, 1987.

Grunmann, R. Luhmann Consenvative, Luhmann Progressive, EUI Working Paper, LAW no. 90/7. Florence, 1990.

Habermas, J. Der philosophische Diskurs der Moderne. Frankfurt/M., 1985.

Habermas, J. Theorie des Kommunikativen Handelns Bd.2. Frankfurt/M., 1982.

Habermas, J. Zur Rekonstruktion des Historischen Materialismus. Frankfurt/M., 1976.

Habermas, J., and N. Luhmann. Theorie der Gesellschaft oder Sozialtechnologie. Frankfurt/M., 1975. 
Haferkamp, F, and M. Schmid, eds. Sinn, Kommunikation und soziale Differenzierung. Frankfurt/M. 1987.

Hausendorf, H. 'Das Gespräch als selbstreferentielles System-ein Beitrag zum empirischen Konstruktivismus der ethnomethodologischen Konversationsanalyse.' Zeitschrift für Soziologie 21 (1992): 83-95.

Heidenescher, M. 'Zurechnung als soziologischer Kategorie- Zu Luhmanns Verständnis von Handlung als Systemleistung.' Zeitschrift fur Soziologie 21 (1992): 440-455.

Henrich, D. 'Identităt.' In Identität, edited by O. Marquard and K. Stierle. Munchen, 1979.

Herder-Dorneich, P., and A. Schuller, eds. Die Anspruchsspirale-Schichsal oder Systemdefekt? Stuttgart, 1983.

Husserl, E. Cartesianische Meditationen. Den Haag, 1963.

Husserl, E. Formale und Transzendentale Logik. Den Haag, 1974.

Husserl, E. Ideeẽn zu einer reinen Phenomenologie. Den Haag, 1976.

Ietswaart, H.F.P. "The Conference on Reflexive Law and the Regulatory Crisis.' Zeitschrift für Rechtssoziologie 4 (1983).

Kargl, W. 'Gesellschaft ohne Subjekte oder Subjekte ohne Gesellschaft? - Kritik der rechtssoziologische Autopoiese-Kritik.' Zeitschrift für Rechtssoziologie 12 (1991): 120-141.

Kargl, W. 'Kommunikation kommuniziert? - Kritik des Rechtssoziologischen Autopoiesebegriffs." Rechtstheorie 21 (1990): 352-373.

Karrenberg, F, and H. Albert, eds. Sozialwissenschaft und Gesellschaftsgestaltung. Berlijn, 1963.

Kiss, G. Grundzüge und Entwicklung der Luhmannschen Systemtheorie. Stuttgart, 1990.

Klir, G.J., ed. Trends in General Systems Theory. New York, 1972.

Kneer, G., and A. Nassehi. "Verstehen des Verstehens- Eine systemtheoretische Revision der Hermeneutik' 'Zeitschrift für Soziologie 20, 5 (1991).

Köhler, J. Die Grenze von Sinn. München, 1983.

Krawietz, W., and M. Welker. Kritik der Theorie sozialer Systeme. Frankfurt/M., 1992.

Künzler, J. Medien und Gesellschaft-Die Medienkonzepte von Talcott Parsons, Jürgen Habermas und Niklas Luhmarn. Stuttgart, 1989.

Küpper, W., and G. Ortmann, eds. Rationalität, Macht und Spiele in Organisationen. Opladen, 1988.

Lloyd, Chr. Explanation in Social History. Oxford, 1986.

Lorenz, Ch. e.a., ed. Het historisch atelier. Meppel, 1990.

Luhmann, N. 'Am Ende der kritischen Soziologie.' Zeitschrift fur Soziologie 20 (1991): 147-152.

Luhmann, N. 'Bemerkungen zu 'Selbstreferenz' und zu 'Differenzierung' aus Anlaß von Beiträgen im Heft 6, 1992, der Zeitschrift fur Soziologie.' Zeitschrift fuir Soziologie 22 (1993b): 141-144. 
Luhmann, N. Beobachtung den Moderne. Opladen, 1992.

Luhmann, N. 'Closure and Openness: On Reality on the World of Law.' In Autopoietic Law: A new Approach to Law and Society, edited by Teubner. Berlijn, $1988 \mathrm{~b}$.

Luhmann, N. Das Recht der Gesellschaft. Frankfurt/M, 1993.

Luhmann, N. 'Die Codienung des Rechtssystems." Rechtstheorie 17 (1986): $171-203$.

Luhmann, N. 'Die Einheit des Rechtssystems.' Rechtstheorie 14 (1983): 129-154.

Luhmann, N. 'Die Geltung des Rechts.' Rechtstheorie 22 (1991): 273-286.

Luhmann, N. 'Die Lebenswelt-nach Rucksprache mit Phänomenologen.' $A r$ chiv für Rechts-und Sozialphilosophie 72 (1986): 176-194.

Luhmann, N. Die soziologische Beobachtung des Rechts. Frankfurt/M., 1986.

Luhmann, N. Die Wirtschaft der Gesellschaft. Frankfurt/M, 1988.

Luhmann, N. Die Wissenschaft der Gesellschaft, 1990.

Luhmann, N. The Differentiation of Society. New York, 1982.

Luhmann, N. 'Einige Probleme mit "reflexivem Recht'.' Zeitschrift für Rechtssoziologie $6(1985): 1-18$.

Luhmann, N. Erkenntnis als Konstruktion. Beri, 1988.

Luhmann, N. Furktion der Religion. Frankfurt/M., 1977.

Luhmann, N. Gesellschaftsstruktur und Semantik Bd.1. Frankfurt/M., 1993.

Luhmann, N. Gesellschaftsstriktur und Semantik, Bd 3. Frankfurt/M.; 1993.

Luhmann, N. Gesellschaftsstruktur und Semantik, Bd.2. Frankfurt/M., 1993.

Luhmann, N. 'Handlungstheorie und Systemtheorie.' Kölner Zeitschrift für Soziologie und Sozialpsychologie 30 (1978). 211-227.

Luhmann, N. 'Ich denke primär historisch'. Religionssoziologische Perspektiven (interview met Detlef Pollack).' Deutsche Zeitschrift fur Philosophie 39 (1991): 937-956.

Luhmann, N. Legitimation durch Verfahren. Berlijn, 1978.

Luhmann, N. Liebe als Passion. Frankfurt/M, 1982.

Luhmann, N. "Neuere Entwicklungen in der Systemtheorie.' Merkur 42 (1988): 292-300.

Luhmann, N. Ökologische Kommunikation. Opladen, 1986.

Luhmann, N. 'Politische Steuerung: eine Diskussionsbeitrag.' Politisches Vierteljahiresschrift 30 (1989): 4-9.

Luhmann, N. 'Positivitat als Selbstbestimmtheit des Rechts.' Rechtstheorie 19 (1988): 11-27.

Luhmann, N. Soziale Systeme. Frankfurt/M., 1985.

Luhmann, N: 'Soziologie der Moral.' In Theorietechnik und Moral, edited by N. Luhmann and St.H. Pfurtner. Frankfurt, 1978.

Luhmann, N. Soziologie des Risikos. Berlijn, 1991.

Luhmann, N. Soziologische Aufklärung 1. Opladen, 1984.

Luhmann, N. Soziologische Aufklärung 2. Opladen, 1982. 
Luhmann, N. Soziologische Aufklärung 3. Opladen, 1989.

Luhmann, N. Soziologische Aufklärung 3. Opladen, 1981.

Luhmann, N. Soziologische Aufklärung 4. Opladen, 1987.

Luhmann, N. Soziologische Aufklärung 5. Opladen, 1990.

Luhmann, N. Soziologische Aufflärung 6. Opladen, 1995.

Luhmann, N. 'Steuerung durch Recht? Einige klarstellende Bemerkungen." Zeitschrift für Rechtssoziologie 12 (1991): 142-146.

Luhmann, $\mathrm{N}$. 'Tautologie und Paradoxie in den Selbstbeschreibungen der modernen Gesellschaft.' Zeitschrift für Soziologie 14 (1987): 161-174.

Luhmann, N. 'The Theory of Social Systems and its Epistemology: Reply to Danilo Zolo's Critical Comments.' Philosophy of the Social Sciences 16 (1986): 129-134.

Luhmann, $\mathbb{N}$. 'The Third Question: The Creative Use of Paradoxes in Law and Legal History.' Journal of Law and Society 15 (1988a): 153-165.

Luhmann, N. "Ueber systemtheoretische Grundlagen der Gesellschaftstheorie." Deutsche Zeitschrift für Philosophie 38 (1990): 277-284.

Luhmann, N. 'Was ist der Fall?' und 'Was steckt dahinter?'.' Zeitschrift für Soziologie 22 (1993a): 244-260.

Luhmann, N. 'Wer kennt Wil Martens.' Kölner Zeitschrift für Soziologie und Sozialpsychologie 44 (1992): 139-142.

Luhmann, N., and St. Pfurtner, eds. Theorietechnik und Moral. Frankfurt/M., 1978.

Luhmann, N., and K.E. Schorr, eds. Zwischen Intransparanz und Verstehen. Frankfurt/M., 1986.

Lyotard, J-F. Het Postmoderne Weren. Kampen, 1987.

Martens, W. 'Die Autopoiesis sozialer Systeme.' Kolmer Zeitschrift für Soziologie und Sozialpsychologie 43 (1991): 625-646.

Martin, B. A Sociology of Contemporary Cultural Change. Oxford, 1981.

Maturana, $\mathrm{H}$. 'Glossary.' In Autopoiesis, Communication and Society, edited by F. Benseler, P. Hejl and W. Köck. Frankfurt/M, 1980.

Maturana, H., and F. Varela. "Autopoiesis and Cognition-The Realization of the Living.' Boston Studies in The Philosophy of Science 42 (1980).

Maus, I. 'Perspektiven 'reflexiven Rechts' im Kontext gegenwartiger Deregulierungstendenzen.' Kritische Justiz 19 (1986): 390-405.

Mayntz, $\mathrm{R}$ 'Differenzierung und Verselbständigung - zur Entwicklung gesellschaftlicher Teilsysteme. " In Differenzierung und Verselbständigung - Zur Entwicklung gesellschaftlicher Teilsysteme, edited by R. Mayntz. Frankfurt/M., 1988.

Mayntz, R. 'Politische Steuerung und gesellschaftiche SteuerungsproblemeAnmerkungen zu einem theoretischen Paradigma." Jahrbuch zur Staats-und Verwaltungswissenschaft 1 (1987): 89-1 10.

Miller, M. 'Selbstreferenz und Differenzerfahrung.' In Sinn, Kommunikation und soziale Differenzierung, edited by F. Haferkamp and M. Schmid. Frank- 
furt/M, 1987.

Munch, R. "From Pure Methodological Individualism to Poor Sociological Utilitarism. 'Canadian Journal of Sociology 8 (1983): 45-77.

Nahamowitz, P. "Autopoiesis oder okkonomischer Staatsinterventionismus." Zeitschrift für Rechtssoziologie 9 (1988): 36-73.

Nahamowitz, P. 'Autopoietische Rechtstheorie: mit dem baldigen Ableben ist zu rechnen.' Zeitschrift für Rechtssoziologie 11 (1990): 137-160.

Nahamowitz, P. 'Effektivität wirtschaftsrechtlicher Steuerung - Ein Beitrag zur Autopoiesis-Debatte.' Kritische Justiz 20 (1987): 411-433.

Nahamowitz, P. Reflexives Recht': Das unmögliche Ideal eines post-interventionistischen Steuerungskonzept.' Zeitschrift für Rechtssozialogie 6 (1985): $29-44$.

Nassehi, A. 'Das Identische 'ist' das Nicht-Identische. Bemerkungen zu einer theoretischen Diskussion um Identität und Differenz.' Zeitschrift für Soziologie 22 (1993): $477-481$.

Neckel, S., and J. Wolf. 'The Fascination of Amorality: Luhmanns Theory of Morality and its Resonance among German Intellectuals.' Theory, Culture and Society 11 (1994): 69-99.

Nijhuis, T. Structuur en contingentie - Over de grenzen van het sociaal-wetenschappelijk verkilaringsideaal in de Duitse geschiedschrijving: Assen, 1996.

Nocke, J. 'Autopoiesis - Rechtssoziologie in seltsamen Schleifen.' Kritische Justiz ? (1986): 363-389.

Nozick, R. Philosophical Explanation. Cambridge, Ma, 1981.

Osterberg, D. Metasociological Essay. Pittsburgh, 1976.

Parsons, T. The Evolution of Societies. Edited by J. Toby. Englewood Cliffs, 1977.

Parsons, T. 'Interaction: Social Interaction.' In Int. Encycl. of the Social Science, Bd.7. New York, 1968.

Parsons, T. The Structure of Social Action. New York, 1949.

Parsons, T., and E. Shills, eds. Toward a General Theory of Action. New York, 1962.

Podak, K. 'Without subject, without reason.' Thesis Eleven 13 (1986): 54-66.

Pokol, B. 'Professionelle Institutionensystemen oder Teilsysteme der Gesellschaft?' Zeitschrift für Soziologie 5 (1990): 329-344.

Pollack, D. 'Bestanderhaltung oder Kritik oder: Weder Bestanderhaltung noch Kritik- Die Intention der Systemtheorie Niklas Luhmanns.' Deutsche Zeitschrift fur Philosophie 39 (1991): 95-99.

Putnam, H. Realism and Reason. Cambridge, 1983.

Radcliffe-Brown, A.R. 'On the Concept of Function in Social Science.' American Antropologist 37 (1935): 397-402.

Radder, H. 'Experiment, Technology, Knowledge and Power.' Social Studies of Science 16 (1986): 663-683.

Randall, J.H. Aristotle. New York, 1960. 
Rasch, W. 'Theories of Complexity, Complexities of Theory: Habemas, Luhmann and the Study of Social Systems.' German Studies Review 14 (1991): $65-83$.

Reese-Schäfer, W. Luhmann zur Einfuhrung. Hamburg, 1992.

Ronge, V. "Politische Steuerung-innerhalb und ausserhalb der Systemtheorie." In Die Verwaltung des Politischen Systems, edited by K. Damman, D. Grunow and K.P. Japp. Opladen, 1994.

Rosen, R. 'Conplexity as a System Property.' International Journal of General Systems 3 (1977): 227-232.

Rosewitz, B., and Schimank. U. 'Verselbständigung und politische Steuerbarkeit." In 'Differenzierung und Verselbständigung - Zü" Entwicklung gesellschaftlicher Teilsysteme, edited by R. Mayntz. Frankfurt/M., 1988.

Roth, G., and H. Schwegler, eds. Self-Organizing Systems. An interdisciplinary Approach. New York, 1981.

Rottleuthner, $\mathrm{H}$. 'The limits of Law-The Myth of a Regulatory Crisis.' International Joumal of Sociology of Law 17 (1989): 273-285.

Scharpf, F. 'Politische Steuerung und politische Institutionen.' Politisches Vierteljahresschrift 30 (1989): 10-21.

Schimank, U. 'Der mangelnde Akteurbezug systemtheoretischer Erklärungen gesellschaftlicher Differenzienung." Zeitschrift für Soziologie 14 (1985): $421-434$.

Schimank, U. 'Gesellschaftliche Teilsysteme als Akteursfiktionen." Kölner" Zeitschrift für Soziologie und Sozialpsychologie 40 (1988): 619-639.

Schimank, U: 'Politische Steuerung in der Oranisationsgesellschaft - am Beispiel der Forschungspolitik".' In Die Modemisierung moderner Gesell-schaften, edited by W. Zapf. Frankfurt/M., 1992.

Schneider, W.L. 'Hermeneutik sozialer Systeme-Konvergenzen zwischen systemtheorie und philosophischer Hermeneutik. Zeitschrift für Soziologie 21, 6 (1992): 420-439.

Schneider, W.L. Objektives Verstehen. Opladen, 1991.

Schöfthaler, T. 'Soziologie als 'Interaktionsfreier' Kommunikation - Niklas Luhmanns leidenschaftlicher Antihumanismus.' Das Argument 15 (1985): $372-384$.

Schulein, J. 'Zur Konzeptualisierung des Sinnbegriffs.' Kölner Zeitung fur Soziologie und Sozialpsychologie 34 (1982): 649-664.

Simmel, G. Een keuze uit het werk van Georg Simmel. Deventer, 1976.

Simmel, G. Philosophie des Geldes. Berlijn, 1977.

Spencer Brown, G. Laws of Form. New York, 1979.

Steffen, H., ed. Aspekte der Modernität. Göttingen, 1965.

Stichweh, R. 'Zur Theorie der Weltgesellschaft.' Soziale Systeme 1 (1995): 29-47.

Teubner, G. Autopoietic Low: A new Approach to Law and Society. Berlijn, 1988. 
Teubner, G. Recht als autopoietisches System. Frankfurt/M, 1989.

Teubner, G., ed. State, Law, Economy as Autopoietic Systems. Berlijn, 1987.

Teubner, G., and H. Willke. 'Kontext und Autonomie: Gesellschaftliche Steuerung durch reflexives Recht.' Zeitschrift fiur Rechtssoziologie 5 (1984): 4-35.

Thome, H. Der Versuch die Welt zu begreifen. Fragezeichen zur Systemtheorie von Niklas Luhmann. Frankfurt/M., 1973.

Trappl, R, ed: Power, Autonomy, Utopia. New York, 1986.

Traxl, $\mathrm{F}$, and $\mathrm{G}$. Vobruba. 'Selbssteuerung als funktionales Aequivalent zum Recht?' Zeitschrift für Soziologie 16 (1987): 3-15.

Turk, K. Handlungssysteme. Opladen, 1978 (Hrsg.).

Unger, RM. Social Theory: its Situation and its Task: New York, 1987.

Varela, F., H. Maturana, and R. Uribe. 'Autopoiesis: The Organisation of living systems, its characterization and a model.' Biosystems 5, 4 (1971): 187- 196.

Varela, F.J. Principles of Biological Autonomie. New York, 1979.

Vries, G. de. Sociale orde, regels en de sociologie. Meppel, 1977.

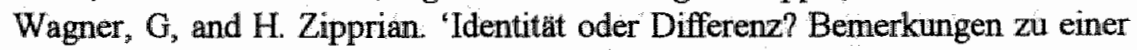
Aporie in Niklas Luhmanns Theorie selbstreferentieller Systeme.' Zeitschrift für Soziologie 21 (1992): 394-405.

Weber, M. Wirtschaft und Gesellschaft. Thäbingen; 1980.

Weyer, J. "System und Akteur." Kölner Zeitschrift für Soziologie und Soziopsychologie 45 (1993): 1-22.

Willke, H. Entzauberung des Staates. Uberlegungen zu einer sozietalen Steueringstheorie. Königstein/Ts, 1983.

Willke, $\mathrm{H}_{.}$Ironie des Staates. Grundlinien einer Theorie des Staates polyzentrischer Gesellschaft. FrankfürtM., 1992.

Willke, H. "Strategien der Intervention in autonome Systeme." In Theorie als Passion, edited by D. Baecker. Frankfurt/M., 1987.

Willke, H. Systemtheorie. Stuttgart, 1991.

Willke, H. Systemtheorie entwickelter Gesellschaften, Dynamik und Riskanz moderner gesellschaftlicher Selbstorganisation. Weinheim, 1989.

Wormell, C.P. 'On the Paradoxes of Selfreference.' Mind LXVII (1958): 267-271.

Zapf, W., ed. Die Modemisierung moderner Gesellschaften. Frankfurt/M., 1992.

Zeleny, M., ed. Autopoiesis: A Theory of the living Organisation. New York, 1980.

Zolo, D. "The Epistemological Status of the Theory of Autopoiesis and its Applications to teh Social Sciences.' In State, Law, Economy as Autopoietic Systems, edited by G. Teubner. Berlijn, 1987.

Zolo, D. 'Function, Meaning, Complexity: The Epistemological Premisses of Niklas Luhmann's Sociological Enightenment.'Philosophy of the Social Sciences 16 (1986): 115-127. 


\section{SUMMARY}

Complexity and Contingency - a Critical Introduction to the Sociology of
Niklas Luhmann (T. Blom)

This thesis is an introduction to and a critical survey of the sociology of Niklas Luhmann, with an emphasis on its basic tenets and the theory of (modern) society based upon it.

Any thorough study of Luhmann's theoretical endeavours requires an account of the general systems theany that has formed their encompassing framework. Therefore the first chapter opens with a survey of its presuppositions and startingpoints. Actually, considering the fact that through the years the general systemstheoretical lay-out of Luhmann's enterprise has developed and changed, it is more accurate to speak of the systems theories which have served as the successive frameworks of Luhmannian sociology. In reconstructing this development, the focus will first be on a decisive change, which Luhmann himself considers to be a real "paradigm-switch", viz. the transition from (a specific version of the theory of 'open systems" to the theory of 'autopoietic', or "selfreferential systems'. This transition has provided Luhmann with the 'logical' instruments and theoretical models enabling him to conceive of "the social" as a free-floating, self-sustaining, dynamic reality. In the wake of this paradigm-change a specific tenet, viz. the theory of 'observation', has become of major importance, ultimately occupying a central place in the theoretical edifice. As a result, Luhmann's more recent work is to be considered a particular application or instance of the so-called "second order'-cybernetics, essentially a theory of the observation of observing systems, with radical constructivistic implications. At the same time this rather 'natural', if not obvious, merging of the theory of selfreferential systems with a constructivist theory of observation, poses a serious problem. As it turns out, one of the most central concepts of Luhmann's entire enterprise, the concept of 'complexity', does not fit in with these more recent theoretical developments, at least not as they are defined and dealt with by Luhmann so far. Following up a critical discussion of this problem an adjusted concept of "complexity" is suggested.

After an exploration of the general systemstheoretical premisses of Luhmann's, the next three chapters turn to those categories that, in order to establish a systemstheoretical sociology, should bring about a sociological (re)specification of the general startingpoints and models involved. Special attention is paid to the concept of "meaning" ("Sinn'). Within the context of a Luhmannian sociology, it is meaning which figures as a, if not the fundamental category ('Grundbegriff'); moreover it gives Luhmann's work a very distinctive quality, unexpectedly blending phenomenological (Husserl) and herneneutic motives with an originally non-intentionalistic, anti-individalistic or 'structural' approach. This 'blend' or synthesis is arrived at by a radical functionalist interpreta- 
tion of 'meaning' as a special and highly potential mode of reducing complexity. Notwithstandig this functionalism and the anti-intentionalistic/anti-psychological flavour that pervades all his work, Luhmann's sociology is and remains a sociology based on "meaning", a sociology that is which takes "meaning" as the inevitable medium of all interaction and social structure. It is, in effect, a sociology designed for the empirical study of structures of meaning ('Semantiken'), considered as the always historical and variable means by which societies organise and structure themselves.

Following the chapter dedicated to Luhmann's concept of meaning, all those principles and concepts - e.g. 'double contingency", 'reflexivity', "reflexion', 'communication', 'social system', 'structure', 'cognition", 'norm', 'action', "conflict', etc. - are explored which, together with "meaning", form the categorial system of his sociology proper. First the crucial function is shown of Luhmann's concept of 'communication' in the sociological translation and specification of general, systemstheoretical models. It is explained in which sense the interpretation of "communication" or "communicationprocesses' as the substance of social systems leads to a picture of social systems as autopoietic/selfreferential systems, i.e. as radically temporalized systems which produce and reproduce the elements (events called "communications") they consist of, by and out of the elements they consist of. This sociological translation and reconstruction of the theory of selfreferential systems forms the basis of Luhmann's claim to have developed a sociology which is neither individualistic nor collectivistic. To put it differently, Luhmann's sociology does not lean on subjectivist or objectivist reductions; instead it stresses the selfstructuring capacities as well as the self-destabilizing capacities of social systems, taking the ordered reproduction of dis-order for a normal and inevitable feature of social processes. Against this background and still at the abstract level of the foundation of a 'grand theory' the adjoining chapter considers some consequences and extensions of this, already rather complex theoretical fabric, e.g. Luhmanns theory of conflict, his re-interpretation of teleological, instrumental action and some cultural-diagnostic implications of his distinction between 'normatively' and 'cognitively' styled social structures.

Although whenever possible Luhmann's progtamm is compared with the suggestions and aspirations of other theoretical sociologists, the main thrust of the critical and evaluative sections of these chapters is a defense of Luhmann's positions against attacks inspired by a typical consequence of his approach, viz. the decision to regard humans/individuals/psychic systems as systems in the environment of social systems and not as elements of the social systems themselves. After the general groundwork of his sociology has been exposed, the chapters $V$ and VI concentrate on Luhmann's theory of society; particularly his theory of modern society. For Luhmann a theory of society (agaim) has to function as a general framework in its own right, giving theoretical hold to, and at the same time methodically integrating, empirical research on the level of sociological subdisciplines, such as the saciology of religion, of art, of law, etc. The general 
assumptions and organising principles of Luhmann's theory of society are described in the first of the two chapters dedicated to this subject. Besides a short glance at Luhmann's theory of (face-to-face) interaction and his sociology of organisations, this survey includes the concept of 'society' as such, the theory of societal evolution and its principles, the concept of 'symbolically generalised media of communication' and Luhmann's rather specific model of functional differentiation as a 'code'-based phenomenon.

The following, "complementary" chapter VI focusses more specifically on Luhmann's diagnosis of modern, Western society. First it is shown that (and why) Luhmann's general model of functional differentiation implies a rather pessimistic picture of modern society. In Luhmann's view modern society is unable to counter the threat that originates in the form of complexity this type of society has taken on, a danger that can be summarised as the growing opposition between the highly developed potentials and specialized rationalities of the societal subsystems on the one hand and the ever-increasing irrationality and unmanagable drift of modern society taken as a whole on the other. Next, two more specific issues are discussed, viz. the problem how the political system can control other societal subsystems and the problem of an empirical identification/delimitation of functionally differentiated subsystems. As an outcome of these discussions two, rather serious objections are formulated: 1) Within his towering theoretical edifice there is a remarkable gap between the theory of organisations and the theory of modern society/modernisation, not only foreclosing a systematic analysis of the "modernity' of formal organization and its function within a functionally differentiated society, but also leading to an unnecessarily sceptic/pessimistic outlook on how the modern state can excercise control 2) The problems regarding the empirical delimitation of societal subsystems stem from an untenable interpretation of the process of functional differentiation as a code-based differentiation of society into social systems, the later being defined as structured processes of communication or action. It is argued that the model of 'coding' (and 'programming') can only lead to the assumption that functional differentiation takes the form of a differentiation of 'provinces of meaning' (Schutz). This leads us back to and strengthens a conjecture raised in the preceding chapter, that, as it is, Luhmann's concept of 'society' cannot stand the test of criticism.

The final chapter of this book confronts one of the most puzzling questions posed by any comprehensive reading of Luhmann's work, viz. the question concerning the normative, if not 'political' commitment of his sociology. Taking Luhmann's concept of 'sociological Enlightenment' as a key, it is argued that the normative commitment of the Luhmannian project lays hidden in the "demoralisation of deviancy' inherent to it. Luhmann's sociology is 'political' to the extent that it calls to attention that in our modern, highly complex society the problem of deviancy lurks, among other things, in the problem of possibly insufficient deviancy. This normative stance is closely linked up with a specific idea of what constitutes 'sociological Reason' (or: a rational-reasonable 
sociology). To sum up the outcome of this reconstruction of the underlying concept of "Reason': Reasonable is any sociology that is able to distinghuish the circular, self-founding unity of epistemological normativity and theory-loaded description from the self-constructed reality as the reality it wishes to describe cognitively.

Viewed from a distance, and in terms of the history of Ideas, this concept of rationality, and in fact the whole idea of a "sociological Enlightenment", is tributary to, if not rooted in, Romantic philosophy. Essentially Luhmann's sociology is a secularized, sociological Romanticism (Fritscher). Or to paraphrase Adorno's famous dictum: Luhmann! - that is 'halbierte Romantik', Romanticism that has abandoned all "Sehnsucht", but clings to irony as an indispensable source of travesty, as a method of showing the impropability of the propable. 